\title{
Industrial Cogeneration
} Optimization Program

\section{MASTER}

Volume II

Appendix A: Conceptual Designs and Preliminary Equipment Specifications

Appendix B: Characterization of Cogeneration Systems (Near-Term Technology)

Appendix C: Optimized Cogeneration Systems

January 1980

Prepared for:

U.S. Department of Energy

Office of Industrial Programs

Conservation and Solar Energy

Washington D.C. 20585

Under Contract No. EM-78-C-01-5310

ADL Reference C-82467 


\section{DISCLAIMER}

This report was prepared as an account of work sponsored by an agency of the United States Government. Neither the United States Government nor any agency Thereof, nor any of their employees, makes any warranty, express or implied, or assumes any legal liability or responsibility for the accuracy, completeness, or usefulness of any information, apparatus, product, or process disclosed, or represents that its use would not infringe privately owned rights. Reference herein to any specific commercial product, process, or service by trade name, trademark, manufacturer, or otherwise does not necessarily constitute or imply its endorsement, recommendation, or favoring by the United States Government or any agency thereof. The views and opinions of authors expressed herein do not necessarily state or reflect those of the United States Government or any agency thereof. 


\section{DISCLAIMER}

Portions of this document may be illegible in electronic image products. Images are produced from the best available original document. 


\section{NOTICE}

This report was prepared as an account of work sponsored by the United States Government. Neither the United States nor the United States Department of Energy, nor any of their employees, makes any warranty, express or implied, or assumes any legal liability or responsibility for the accuracy, completeness, or usefulness of any information, apparatus, product, or process disclosed, or represents that its use would not infringe privately owned rights. Reference herein to any specific commercial product, process, or service by trade name, mark, manufacturer, or otherwise, does not necessarily constitute ur iuply its endorsement, resemmpniation, or favoring by the United States Government or any agency thereof. The views and opinions of authors expressed herein do not necessarily state or reflect those of the United States Government or any agency thereof.

Available from:

National Technical Information Service (NTIS) U.S. Department of Comerce 5285 Port Royal Road Springfield, Virginia 22161

Price: Printed copy: $\$$ A 14 Microfiche: $\$ 3.00$ AOI 


\section{Industrial Cogeneration Optimization Program}

Volume II

Appendix A: Conceptual Designs and Preliminary Equipment Specifications

Appendix B: Characterization of Cogeneration Systems (Near-Term Technology)

Appendix C: Optimized Cogeneration Systems

January 1980

Prepared by:

Westinghouse Electric Corporation

Gibbs \& Hill, Inc.

Contract No. EM-78-C-01-5310

ADL Reference C-82467

Prepared for:

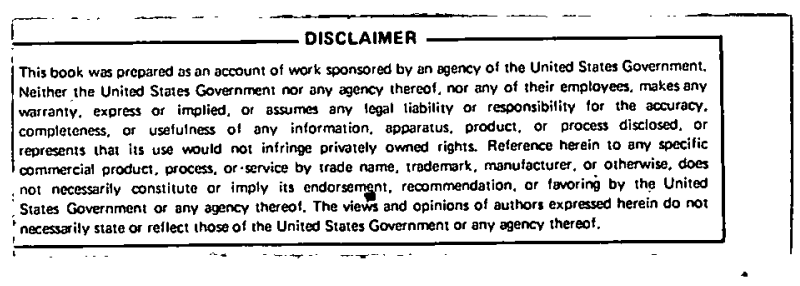

U.S. Department of Energy

Office of Industrial Programs

Conservation and Solar Energy 
LIST OF TABLES

LIST OF FIGURES

APPENDIX A: CONCEPTUAL DESIGNS AND PRELIMINARY

EQUIPMENT SPECIFICATIONS .

$A-1$

APPENDIX B: CHARACTERIZATION OF COGENERATION SYSTEMS

(NEAR-TERM TECHNOLOGY)

$\mathrm{B}-1$

B1: Limitations on Fuel Utilization in Energy

Conversion Subsystems for Cogeneration

Applications

B-1

B2: Analysis of Boiler Blowdown Requirements and

Thermodynamic Losses due to Blowdown

$B-5$

B3: Relationship Among Performance Criteria for

Cogeneration Systems

$B-11$

B4: Characterization of Coal-Fired Steam Energy

Conversion Subsystem with FGD

B-14

B5: Characterization of 0il-Fired Gas Turbine

Conversion with Waste Heat'Boiler Energy

Subsystem

B6: Characterization of Oil-Fired Combined-Cycle

Energy Conversion Subsystem

B7: Characterization of Diesel Engine with Waste

Heat Boiler Energy Conversion Subsystem

B-34

B8: Characterization of Coal-Fired Closed-Cycle

Gas Turbine Energy Conversion Subsystem with

Flue Gas Desulfurization

B9: Characterization of Coal-Fired Indirectly Heated

Open-Cycle Gas Turbine with Flue Gas Desulfurization B-45

B10: Thermal Energy Storage System Characterization B-48

1. Introduction

B-48

2. Packed Bed Storage

B-48

3. Fluid Bed Heat Exchanger with Packed Bed Storage

B-53

4. Moving Bed Exchanger/Storage

B- 56

5. Combined Fluid and Rock Thermal Storage、

B-60 
Page:

B10: Thermal Energy Storage System Characterization (cont)

6. Steam Accumulators

7. Comparison of the Thermal Energy Storage Techniques.

B11: Characterization of Bottoming Cycles for Cogeneration Applications

B12: Basis for Capita1 Equipment Costs

1. Fired Power Steam Generators

2. HRSG's and Waste Heat Boilers

3. Steam Turbine/Generators

$\mathrm{B}-91$

4.. Gas Turbine/Generators

B-92

5: Flue Gas Desulfurization

B-95

6. Organic Cycles

B-95

7. Process Steam Boilers

APPENDIX C: OPTIMIZED COGENERATION SYSTEMS

C1: Introduction

C2: Background

c-1

C3: Air Separation Plant/Cluster Chemical Complex

C-2

C4: Brewery

C-19

C5: Soybean Oil Plant

$C-37$

C6: Large Capacity Petroleum Refinery

C-53

C7. : Medium Capacity Petroleum Refinery

C-71

C8: Writing Paper Mill

$\mathrm{c}-83$

C9: Kraft Paper Mill

C-98

C10: Textile Finishing Mil1

C-115

C11: Integrated Textile Mil1 
TABLE NO.

Page

A2-1 AGRI-CHEM PLANT COGENERATION FACILITY PRELIMINARY

A3-1 BREWERY PLANT COGENERATION FACILITY' PRELIMINARY SPECIFICATIONS OF MAJOR COMPONENTS

A4-1 AIR SEPARATION PLANT COGENERATION FACILITY PRELIMINARY SPECIFICATIONS OF MAJOR COMPONENTS :

A5-1 LARGE REFINERY "B" COGENERATION FACILITY PRELIMINARY SPECIFICATIONS OF MAJOR COMPONENTS

A6-1 WRITING PAPER MILL COGENERATION FACILITY PRELIMINARY SPECIFICATIONS OF MAJOR COMPONENTS

A7-1 INTEGRATED TEXTILE MILL COGENERATION FACILITY

PRELIMINARY SPECIFICATIONS OF MAJOR COMPONENTS

A8-1

KRAFT PAPER MILL COGENERATION FACILITY PRELIMINARY SPECIFICATIONS OF MAJOR COMPONENTS

A9-1.

B1-1

B10-1

B10-2

B10-3

TEXTILE FINISHING MILL COGENERATION" FACILITY

PRELIMINARY SPECIFICATIONS OF MAJOR COMPONENTS

THERMAL LOSSES FROM PRODUCTS OF COMBUSTION

STORAGE COASTDOWN

PACKED BED STORAGE CHARACTERIZATION

FLUIDIZED HEAT EXCHANGER/PACKED BED STORAGE

CHARACTERIZATION

B10-4

MOVING BED EXCHANGER/PACKED BED STORAGE

CHARACTERIZATION

MDAC COMBINED FLUID/ROCK STORAGE SYSTEM CHARACTERIZATION

B10-5

B10-6

B10-7

B10-8

VARIABLE PRESSURE STEAM ACCUMULATOR REQUIREMENTS

CONSTANT PRES.SURE ACCUMULATOR CHARACTERIZATION

COMPARISON OF DESIGN REQUIREMENTS FOR THERMAL ENNERGY

STORAGE SYSTEMS

B11-1

B11-2

BI1-3

B11-4

FLOORINOL-85 SATURATED LIQUID AND SATURATED VAPOR

PROPERTIES

AMMONIA SATURATED LIQUID AND SATURATED VAPOR PROPERTIES

METHANOL SATURATED LIQUID AND SATURATED VAPOR PROPERTIES

EFFECT OF PLANT CAPACITY ON THE RATIO OF PLANT POWER TO

C3-1

THERMAL INPUT FOR THE WORKING FLUIDS

STATEPOINTS FOR ENERGY UTILIZATION SUBSYSTEM IN AIR

SEPARATION PLANT

C3-2

STATEPOINTS FOR CONVERSION SUBSYSTEM IN AIR SEPARATION

PLANT/GT WITH WHB

C3-3

C3-4

POWER SUMMARY - AIR SEPARATION PLANT

AIR SEPARATION PLANT SUMMARY OF CAPITAL COSTS:

DEC. 1978\$

$A-5$

A-11, 12

$A \div 18$

, :

$A-24,25$

A-31, 32

A-38

$A-44,45$

A-51, 52

B-3

B-51

B-54

B-57.

B-59

B- 62

B-66

B-68

B-69

B-79.

B-80

B-81

B-87

C-4

C-9 .

C-10

C 3-5

C3-6a

C3-6b

c3-6c

C3-7

RATE OF RETURN ON EQUITY SUMMARY FOR INDUSTRIAL

C-11:

COGENERATION

AIR SEPARATION PLANT FOR INDUSTRIAL OWNERSHIP

C-12, 13

AIR SEPARATION PLANT FOR UTILITY OWNERSHIP

C-1.4

AIR SEPARATION PLANT FOR THIRD PARTY OWNERSHIP

$\mathrm{C}-15$

C-16.

FUEL UTILIZATION, AIR SEPARATION PLANT

$\mathrm{C}-17$ 
TABLE NO

Page

C4-1

C4-2

C 4-3

C4-4

C4-5

C4-6

C4-7a

C4-7b

C4-7c

C4-8

C5-1

C5-2

C5-3

C5-4

C5-5

C5-6

C5-7a

C5-7b

C $5-7 \mathrm{c}$

C5-8

C6-1

STATEPOINTS FOR -ENERGY UTILIZATION SUBSYSTEM IN BREWERY

$\mathrm{C}-21$

STATEPOINTS FOR ENERGY CONVERSION SUBSYSTEM IN BREWERY

FUEL SPECIFICATIONS.

OHIO PITTSBURGH NO: 8 SEAM COAL

$\mathrm{C}-26$

POWER SUMMARY - BREWERY

$\mathrm{C}-27$

BREWERY SUMMARY OF CAPITAL COSTS: DEC. 1978\$

RATE OF RETURN ON EQUITY SUMMARY FOR INDUSTRIAL COGENERATION

BREWERY FOR INDUSTRIAL OWNERSHIP

$\mathrm{C}-28$

C-29

BREWERY FOR UTILITY OWNERSHIP

BREWERY FOR THIŔD PARTY OWNERSHIP

$\mathrm{C}-33$

C-34

C-35

FUEL UTILIZATION 'BREWERY

STATEPOINTS FOR ENERGY UTILIZATION SUBSYSTEM. IN

SOYBEAN OIL PLANT

$\mathrm{C}-36$

$c-39$

STATEPOINTS FOR CONVERSION SUBSYSTEM IN SOYBEAN

OIL PLANT

FUEL SPECIFICATIONS CHINOOK. MINE - INDIANA \#3

SEAM COAL

POWER SUMMARY - SOYBEAN OIL PLANT

$c-42$

SOYBEAN OIL MILL. SUMMARY OF CAPITAL COSTS: DEC. $1978 \$$

RATE OF RETURN ON EQUITY SUMMARY FOR INDUSTRIAL

COGENERATION

SOYBEAN OIL PLANT FOR INDUSTRIAL OWNERSHIP

SOYBEAN OIL PLANT FOR UTILITY OWNERSHIP

$\mathrm{C}-43$

C- -44

C- -46

$\mathrm{C}-47,48$

C- 49

C-50

SOYBEAN OIL PLANT FOR THIRD PARTY OWNERSHIP $\cdot{ }^{\cdot}$ C-51

FUEL UTILIZATION SOYBEAN OIL PLANT

C-52

STATEPOINTS FOR ENERGY UTILIZATION SUBSYSTEM IN

LARGE PETROLEUM REF INERY

C -55

FUEL SPECIFICATIONS LIGHT NAPTHA PROPERTIES

$c-60$

c6-3

LOW SULFUR RESIDUAL OIL

(Compliance LSFO)

C-61

C6-4

C6-5

C6- 6

STATTEPOINTS FOR CONVERSION SUBSYSTEM IN LARGE REFINERY

$c-62$

POWER SUMMARY - LARGE REFINERY

LARGE PETROLEUM REFINERY SUMMARY OF CAPITAL COSTS:

DEC • 1978\$

C6-7

RATE OF RETURN ON EQUITY SUMMARY-FOR INDUSTRIAL COGENERATION

C6-8a

$\mathrm{C} 6-8 \mathrm{~b}$

LARGE PETROLEUM: REFINERY FOR INDUSTRIAL OWNERSHIP

LARGE PETROLEUM REFINERY . FOR UTILITY OWNERSHIP

C-63

c-64

$\therefore:$

C- $-65,66$

C -67

C -68

LARGE PETROLEUM REFINERY FOR THIRD PARTY OWNERSHIP

C -69 .

FUEL UTILIZATION LARGE PETROLEUM REFINERY

C -70

C6-9

C7-1

STATEPOINTS FOR ENERGY UTILIZATION SUBSYSTEM IN

MEDIUM SIZE PETROLEUM REFINERY

$C-76$

C7-2

MEDIUM CAPACITY PETROLEUM REFINERY

SUMMARY OF CAPITAL COSTS; DEC. 1978\$

C $7-3$

RATE OF RETURN ON EQUITY SUMMARY FOR INDUSTRIAL

COGENERATION

$c-78$

C-79 
TABLE NO.

$\underline{\text { Page }}$

C7-3. MEDIUM CAPACITY PETROLEUM REFINERY ECONOMIC

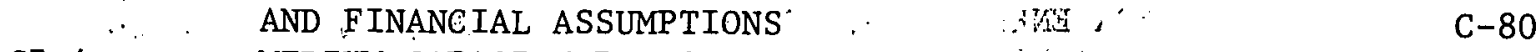

C7-4 MEDIUM CAPACITY PETROLEUM REFINERY FOR INDUSTRIAL

C7-5 $\because \quad$ FUEL UTILIZATION MEDIUM CAPACITY PETROLEUM REFINERY : C-82

C8-1. STATEPOINTS FOR ENERGY UTILIZATION SUBSYSTEM

IN WRITING PAPER. MILL: :

C8-2. . STATEPOINTS FOR CONVERSION SUBSYSTEM IN WRITING

PAPER MILL

C8-3: OHIO PITTSBURGH NO. 8 SEAM COAL

C8-4. POWER SUMMARY - WRITING PAPER MILL

C8-5 WRITING PAPER MILL SUMMARY OF CAPITAL COSTS:

DEC. 1978\$ C

C8-6 $\%:$ RATE OF RETURN ON EQUITY SUMMARY FOR IN̈DUSTRIAL COGENERATION $\cdot \cdot$

$\mathrm{C} 8-7 \mathrm{a}$

WRITING PAPER MILL FOR INDUSTRIAL OWNERSHIP

$\mathrm{C} 8-7 \mathrm{~b}$

WRITING PAPER MILL FOR UTILITY OWNERSHIP

$\mathrm{C}-85$

$\mathrm{C}-88$

$\mathrm{C}-89$

$\mathrm{C}-90$

$\mathrm{C} 8-7 \mathrm{c}$

WRITING PAPER MILL FOR THIRD PARTY OWNERSHIP

C-92, 93

$\mathrm{C}-94$

C-95

C-96

FUEL UTILIZATION WRITING PAPER MILL ".."

C-97

C9-1 $\because \quad$ STATEPOINTS FOR ENERGY UTILIZATION SUBSYSTEM.

IN KRAFT PAPER MILL (REGION I)

C9-2, STATEPOINTS FOR CONVERSION SUBSYSTEM

$C-100$

IN KRAFT PAPER MILL (SITE * \#1).

C-105

C $9-3$

POWER SUMMARY FOR KRAFT PAPER MILL (SITE \#1)

C-106

C $9-4$

KRAFT PAPER :MILL SUMMARY OF CAPITAL COSTS:

DEC. $1978 \$$

C-107

C9-5

RATE OF RETURN ON EQUITY SUMMARY FOR - INDUSTRIAL COGENERATION

c9-6a.

KRAFT PAPER MILL FOR INDUSTRIAL OWNERSHIP

C-109, 110

$\mathrm{c} 9-6 \mathrm{~b}$

KRAFT PAPER MILL FOR UTILITY OWNERSHIP

$\mathrm{C}-111$

C-112

KRAFT PAPER MILL FOR THIRD PARTY OWNERSHIP

$\mathrm{C}-113$

C9-7

C10-1

FUEL UTILIZATION, KRAFT PAPER MILL (SITE NO. I)

C-114

STATEPOINTS FOR ENERGY UTILIZATION SUBSYSTEM -

$\mathrm{C}-117$

C10-2 ... STATEPOINTS FOR CONVERSION SUBSYSTEM IN TEXTILE

FINISHING MILL.

C10-3 FUEL SPECIFICATIONS COAL FOR TEXTILE

FINISHING MILL

C10-4

POWER SUMMARY, TEXTILE FINISSHING MILL

C10-5 $\because$

TEXTILE FINISHING MILİ SUMMARY OF CAPITAL COSTS: DEC. $1978 \$$.

C10-6 RATE OF RETURN ON EQUITY SUMMARY FOR

INDUSTRIAL COGENERATION

C10-7a

TEXTILE FINISHING MILL FOR. INDUSTRIAL OWNERSHIP

C10-7b

TEXTILE FINISHING MILL FOR UTILITY OWNERSHIP.

C10-7c

TEXTILE FINISHING MILL FOR THIRD PARTY OWNERSHIP

FUEL UTILIZATION TEXTILE FINISHING MILL

C-121

$\mathrm{C}-122$

C-123

C-125

C-126, 127

$\mathrm{C}-128$

: $C-129$

C-130

: -131 
TABLE NO.

Page

C11-1 STATEPOINTS FOR ENERGY UTILIZATION SUBSYSTEM

IN INTEGRATED TEXTILE MILL

C-134

C11-2

FUEL SPECIFICATIONS INTEGRATED TEXTILE MILL

C-135

C11-3

STATEPOINTS FOR CONVERSION SUBSYSTEM IN

INTEGRATED TEXTILE MILL

C-138

POWER SUMMARY - INTEGRATED TEXTILE MILL

C-139

C11-5

INTEGRATED TEXTILE MILL SUMMARY OF CAPITAL COSTS : DEC. 1978\$

$\mathrm{C}-140$

C11-6

RATE OF RETURN ON EQUITY SUMMARY FOR INDUSTRIAL COGENERATION

C11-7a

INTEGRATED TEXTILE MILL FOR INDUSTRIAL OWNERSHIP

$\mathrm{C}-142,143$

C11-7b

C11-7c

INTEGRATED TEXTILE MILL FOR UTILITY OWNERSHIP

C-144

C-145

INTEGRATED TEXTILE MILL FOR THIRD PARTY OWNERSHIP

FUEL UTILIZATION - INTEGRATED TEXTILE MILL

C-146

C-147 
PROJECT MILESTONE SCHEDULE COGENERATION FACILITY AIR SEPARATION PLANT

BLOCK FLOW DIAGRAM AND HEAT BALANCE COGENERATION FACILITY LARGE REFINERY "B"

A-20

A-21

A-22

A5-E-1

LARGE REFINERY "B" ONE LINE ELECTRICAL DIAGRAM

A-23

PROJECT MILESTONE SCHEDULE COGENERATION FACILITY BLOCK FLOW DIAGRAM AND HEAT BALANCE COGENERATION

PROJECT MILESTONE SCHEDULE COGENERATION FACILITY

A7-M-1 WRITING PAPER PLANT

A-33

SITE PLAN INTEGRATED TEXTILE MILL

A7-M-2

PLOT PLAN

COGENERATION FACILITY INTEGRATED TEXTILE

MILL

A7-M-3 BLOCK FLOW DIAGRAM AND HEAT BALANCE COGENERATION FACILITY INTEGRATED TEXTILE MILL

PROJECT MILESTONE SCHEDULE COGENERATION FACILITY INTEGRATED TEXTILE MILL 
'LIST'OF: FIGURES (Continued)

FIGURE NO.

$\underline{\text { Page }}$

A8-E-1 $\because$ KRAFT PAPER MIUL ONE LINE ELECTRICAL DIAGRAM

$A 8-M-4$

PROJECT MILESTTONE SCHEDULE COGENERATION FACILITY

A-46

. KRAFT PAPER MILL

A9-M-1

SITE PLAN TEXTILE FINISHING MILL

A9-M-2

PLOT PLAN COGENERATION FACILITY TEXTILE FINISHING

MILL

A9-M-3 BLOCK FLOW DIAGRAM AND HEAT BALANCE COGENERATION

FACILITY TEXTILE FINISHING MILL

A-47

A -48

$\therefore$

TEXTILE FINISHING MILL ONE LINE ELECTRICAL DIAGRAM

A-49

A9-E-1

PROJECT MILESTONE SCHEDULE COGENERATION FACILITY

A9-M-4

TEXTILE FINISHING MILL

Bi-1

LIMITING TUBE-METAL TEMPERATURES TO AVOID EXTERNAL

CORROSION IN "ैं

FUELS CONTAINING SULPHUR

B2-1

GENERALIZED MODEL OF CONVENTIONAL STEAM COGENERATION SYSTEM

B2-2

BLOWDOWN REQU IREMENTS FOR STEAM BOILERS USED FOR

COGENERATION ÁṔPLICATIONS

$\mathrm{B} 2-3$

THERMODYNAMIC LOSS DUE TO BLOWDOWN FROM A POWER

BOILER AS A FUNCTION OF OPERATING PARAMETERS

B2-4

THEERMODYNAMIC LOSSES DUE TO BLOWDOWN FROM A PROCESS

STEAM BOILER AS A FUNCTION OF OPERATING PARAMETERS

B3-1

ENERGY UTILIZATION CHARACTERISTICS OF COGENERATION

TECHNOLOGY

A -50

A -53

$\cdot A-54$

B4-1

B $34-2$

CONVENTIONAL COAL-FIRED STEAM ENERGY CONVERSION

SÜBSYSTEM

CHARACTERIZATION OF CONVENTIONAL COAL-F̈IREDD ENERGY

CONVERSION SUBSYSTEM WITH FGD

OIL-FIRED GAS TURBINE ENERGY CONVERSION 'SU'BSYSTEM

$\mathrm{B} 5-1$

WITH WASTE HEAT BOILER

CHARACTERIZATION OF OIL-FIRED GAS TURBINE ENERGY

$\therefore \mathrm{B} 5-2$

$\therefore$.

CONVERSION :SUBSYSTEM WITH WASTE HEAT BOILER

CHARACTERIZATION OF OIL-FIRED GAS TURBINE 'ENERGY

B5-3

CONVERSION SUBSYSTEM WITH WASTE HEAT BOILER

B5 -4

CHÁRACTERIZATION OF OIL-FIRED GAS TTIRBINE ENERGY

CONVERSION SUBSYSTEM WITH WASTE HEAT - BOILER

B5-5

CHARACTERIZATION OF OIL-FIRED GAS TURBINE ENERGY

CONVERSION SUBSYSTEM WITH WASTE HEAT BOILER

$\bar{B}-6$

B-8

B-9

B-10

B-13

B-15

B-18

B-20

CHARACTERIZATION OF OIL-FIRED GAS TURBINE ENERGY

$\cdot B 5-6$

CON̈VERSION SÜBSYSTEM. WITH WASTE HEAT BOILER"

B6-1 OIL-FIRED COMBINED-CYCLE ÉNERGY CONVERṠION SUBSYSTEM

WITH MODIFIED HEAT RECOVERY STEAM GENERATÓR

$\therefore$ B6-2

CHARACTERIZATION OF OIL-FIRED COMBINED-CYCLE ENERGY

CONV̈ERSION SUBSYSTEM WITH MODIFIED/UNFIRED HRSG

B- 27

B6-3

CHARACTERIZATION OF OIL-FIRED COMBINED-CYCLE ENERGY

B-28

CONVERSION SUBSYSTEM WITH MODIFIED/UNFIRED HEAT

RECOUVERY STEAM GENERATOR

B-29 
FIGURE NO.

Page

B6-4 CHARACTERIZATION OF OIL-FIRED COMBINED-CYCLE ENERGY CONVERSION : SUBSYSTEM WITH MODIFIED/UNFIRED HRSG

B6-5

B6-6

B6-7

B7-1

B7-2

$\therefore$

CHARACTERIZATION OF OIL-FIRED COMBINED-CYCLE ENERGY

CONVERSION SUBSYSTEM WITH MODIFIED/UNFIRED HRSG .

CHARACTERIZATION OF. OIL-FIRED COMBINED-CYCLE ENERGY

CONVERSION SUBSYSTEM WITH MODIFIED/UNFIRED HRSG

CHARACTERIZATION OF - OIL-FIRED COMBINED-CYCLE ENERGY

CONVERSION SUBSYSTEM WITH MODIFIED/FIRED HRSG:

DIESEL ENGINE WITH WASTE - HEAT BOILER ENERGY CONVERSION

SUBSYSTEM

CHARACTERIZATION OF LOW SPEED TWO-CYCLE DIESEL PLUS

B $7-3$

WASTE HEAT BOILER ENERGY CONVERSION SUBSYSTEM

CHARACTERIZATION OF. FOUR-STROKE CYCLE DIESEL WITH A

' WASTE BOILER ENERGY CONVERSION SUBSYSTTEM

B-31

B-32

$B-33$

$B-36$

B $8 \div-1$

B8-2

CLOSED-CYCLE GAS TURBINE ENERGY .CONVERSION SUBSYSTEM

CHARACTERIZATION OF COAL-FIRED CLOSED CYCLE GAS

TURBINE ENERGY CONVERSTON SUBSYSTEM WITH FGD

.B9-1

COAL-FIRED, INDIRECTLY-HEATED OPEN-CYCLE GAS TURBINE

ENERGY CONVERSION SUBSYSTEM

B9-2

CHARACTERIZATION OF COAL-FIRED INDIRECTLY-HEATED

OPEN-CYCLE GAS TURBINE ENERGY CONVERSION SUBSYSTEM

B10-1

B10-2

PACKED BED INTEGRAL STORAGE AND EXCHANGER .

FLUID BED/PACKED BED EXCHANGER COMBINATION WITH

PACKED BED STORAGE

Bio-3

B10-4

B10-5

B10-6

B11-1

B11-2

B.11-3

B11-4

B11-5

B11-6

MOVING BED EXCHANGER/STORAGE

HOT LIQUID/PEBBLE BED STORAGE WITH THERMOCLINE

VARIABLE .PRESSURE SATURATED STEAM ACCUMULATOR

CONSTANT DELIVERY PRESSURE SATURATED STEAM ACCUMULATOR

T-S D.IAGRAM FOR FLUORINOL-85.

T-S DIAGRAM FOR AMMONIA

T-S DIAGRAM FOR METHANOL

SCHEMATIC DIAGRAM FOR SUPERHEATED CYCLES

SCHEMATIC DIAGRAM FOR SATURATED CYCLES

RATIO OF PLANT POWER TO THERMAL INPUT FOR' THE WORKING

FLUID AS A FUNCTION OF THROTTLE PRESSURE FOR THE.

WORKINNG FLUID FLUORINOL-85

B11-7 RATIO OF PLANT POWER TO THERMAL INPUT FOR THE WORKING

FLUID. AS A FUNCTION OF. THROTTLE PRESSURE FOR THE

WORKING FLUID METHANOL

B-85

B11-8 RATIO OF PLANT POWER TO THERMAL INPUT FOR THE WORKING

FLUID AS A FUNCTION OF THROTTLE PRESSURE FOR THE

WORKING FLUID AMMONIA .

B12-1

B12-2

C3-1

GAS TURBINE COSTS (GROUP 3) EXPANDER ASSEMBLY

GAS TURBINE COSTS. (GROUP 5) COMBUSTOR ASSEMBLY

B -37

B-40

B-43

B-44

B-46

B-47

B-49.

B-55

B -58

$B-61$

B-63

B-64

B-76

$\mathrm{B}-77$

B-7.8

B-82

$\mathrm{B}-83$

B-84

MODEL OF PROCESS HEAT UTILIZATION SUBSYSTEM FOR

AIR SEPARATION PLANT WITH GAS-FIRED GAS TURBINE WITH WASTE HEAT BOILER ENERGY CONVERSION SỤBSYSTEM.

$\mathrm{C}-3$ 
FIGURE NO.

$\underline{\text { Page }}$

C3-2

MODEL OF ENERGY :CONVERSION SUBSYSTEM FOR AIR SEPARATION PLANT

$\mathrm{C}-5$

$\mathrm{C} 3-3 \mathrm{a}$ ANNUAL ENERGY SAVINGS VS. RETURN ON FQUITY, INDUSTRIAL OWNERSHIP

C-6

c3-3b

ANNUAL ENERGY SAVINGS VS. RETURN ON EQUITY, THIRD PARTY OWNERSHIP

C4-1

FLOWSHEET OF PROCESS HEAT UTILIZATION SUBSYSTEM FOR

$\mathrm{C}-7$

BREWERY WITH CONVENTIONAL COAL-FIRED STEAM ENERGY

CONVERSION SUBSYSTEM

C4-2

MODEL OF ENERGY CONVERSION SUBSYSTEM CHOSEN FOR

OPTIMIZATION FOR BREWERY

C4-3

C4-4a

MODEL OF STEAM ACCUMULATOR SUBSYSTEM FOR BREWERY

ANNUAL ENERGY SAVINGS VS. RETURN ON EQUITY,

INDUSTRIAL OWNERSHIP

C4-4b

ANNUAL ENERGY SAVINGS VS. RETURN ON EQUITY, UTILITY OWNERSHIP

C5-1

FLOWSHEET OF PROCESS HEAT UTILIZATION SUBSYSTEM

FOR SOYBEAN OIL MILL WITH COAL-FIRED STEAM ENERGY

CONVERSION SUBSYSTEM

C5-2

MODEL OF CONVENTIONAL COAL-FIRED STEAM ENERGY

CONVERSION SUBSYSTEM

C5-3

ANNUAL ENERGY SAVINGS VS. RETURN ON EQUITY,

INDUSTRY AND UTILITY OWNERSHIP

C6-1

MODEL OF PROCESS HEAT UTILIZATION SUBSYSTEM FOR

LARGE PETROLEUM REFINERY WITH REFINERY FUEL-FIRED

COMBINED CYCLE ENERGY CONVERSION SUBSYSTEM

c6-2

C.6-3

POSSIBLE STEAM TURBINE CONFIGURATIONS

ANNUAL ENERGY SAVINGS VS. RETURN ON EQUITY,

INDUSTRIAL OWNERSHIP

C6-4

MODEL OF ENERGY CONVERSION SUBSYSTEM FOR LARGE

CAPACITY PETROLEUM REFINERY

C7-1

C7:-2

C7-3

C $7-4$

MEDIUM PETROLEUM REFINERY (CASE C1 REFERENCE CASE)

MEDIUM PETROLEUM REFINERY (CASE B2)

MEDIUM PETROLEUM REFINERY (CASE A1)

$-20$

$\mathrm{C}-22$

$\mathrm{C}-23$

$C-24$

$\mathrm{C}-25$

$\mathrm{C}-38$

$\mathrm{C}-40$

$\mathrm{C}-41$

MODEL OF PROCESS HEAT UTILIZATION SUBSYSTEM FOR

MEDIUM SIZE PETROLEUM REFINERY

c8-1

MODEL OF PROCESS HEAT UTILIZATION SUBSYSTEM FOR

WRITING PAPER MILL

MODEL OF PULVERIZED COAL-FIRED STEAM ENERGY CONVERSION

C8-2

SUBSYSTEM WITH FGD AND BACK-PRESSURE STEAM TURBINE FOR

WRITING PAPER MILL

c8-3

ANNUAL ENERGY SAVING VS. RETURN ON EQUITY, UTILITY

OWNERSHIP OPTION

$\mathrm{C}-86$

MODEL OF ENERGY UTILIZATION SUBSYSTEM FOR PLANT NO. 1

$C-87$

c9-1

OF KRAFT PAPER MILL (REGION 1)

C-99

c9-2a

ANNUAL ENERGY SAVINGS VS. RETURN ON EQUITY,

UTILITY OWNERSHIP

C-102

$$
x i
$$


FIGURE NO.

$\because$ Page

C9-2b ANNUAL ENERGY SAVINGS VS. RETURN ON EQUITY, THIRD-PARTY OWNERSHIP

C-103

C $9-3$

MODEL OF COAL-FIRED STE

FOR KRAFT PAPER MILL

$\therefore$

MODEL OF ENERGY UTILIZATION SUBSYSTEM FOR TEXTILE.

C-104

C10-1 FINISHING MILL

C10-2

MODEL OF COAL-FIRED SINGLE EXTRACTION STEAM TURBINE

C-116

ENERGY CONVERSION SUBSYSTEM FOR TEXTILE FINISHING

\section{MILL}

C10-3a

ANNUAT UTILITY OWNERSHIP

C10-3b

ANNUAL ENERGY SAVINGS VS. RETURN ON EQUITY, THIRD-PARTY OWNERSHIP

C11-1

FLOWSHEET OF PROCESS HEAT UTILIZATION SUBSYSTEM FOR

INTEGRATED TEXTILE MILL WITH WOOD-FIRED STEAM ENERGY CONVERSION SUBSYSTEM

$\therefore: \cdots$

$\mathrm{C}-118$

$\cdot$

C-119

MODEL OF CONVENTIONAL COAL-FIRED STEAM ENERGY CONVERSION SUBSYSTEM FOR INTEGRATED TEXTILE MILL

C-120

$\mathrm{C} 11-2$

ANNUAL ENERGY SAVINGS VS. RETURN ON EQUITY, UTILITY OWNERSHIP

Ci1-3 
In Volume I, Section 7.2.1, we presented, for the soybean oil plant, a. conceptual design of a cogeneration facility consisting of a site plan, plot plan, block flow diagram and heat balance, one-line electrical diagram, brief specifications of major components, capital cost estimates, and project milestone schedule. For the other. plants, only conceptual cost estimates were presented in section 7 as follows:

\begin{tabular}{|c|c|c|c|c|}
\hline Plant & SIC & DOE & & Report Sub- \\
\hline PLant & & Region & Location & Section \\
\hline
\end{tabular}

1. Soybean $0 i 1$

20

$\mathrm{V}$

Indiana

7.2 .1

2. Agri-Chem

28

III

Maryland. .

7.2 .2

3. Brewery

20

III

Pennsylvania.

7.2 .3

4. Air Separation

28

VI

Texas

7.2 .4

5. Refinery " $B$ "

29

IX .

California

7.2 .5

6. Writing Paper

III

Pennsylvania

7.2 .6

7. Integrated Textile

22

IV

Alabama

7.2 .7

8. Kraft Paper

New Hampshire

7.2 .8

9. Finishing Textile

22

IV

So. Carolina

7.2 .9

The remaining information for these plants is found in this appendix with table numbers and figure numbers corresponding to the report subsections listed above (e.g., Figures $A 2-M-1$; $A 3-M-1$ found in this appendix correspond to the agri-chem plant and the brewery plant found, respectively, in Sections 7.2.2 and 7.2.3 of Volume I). 


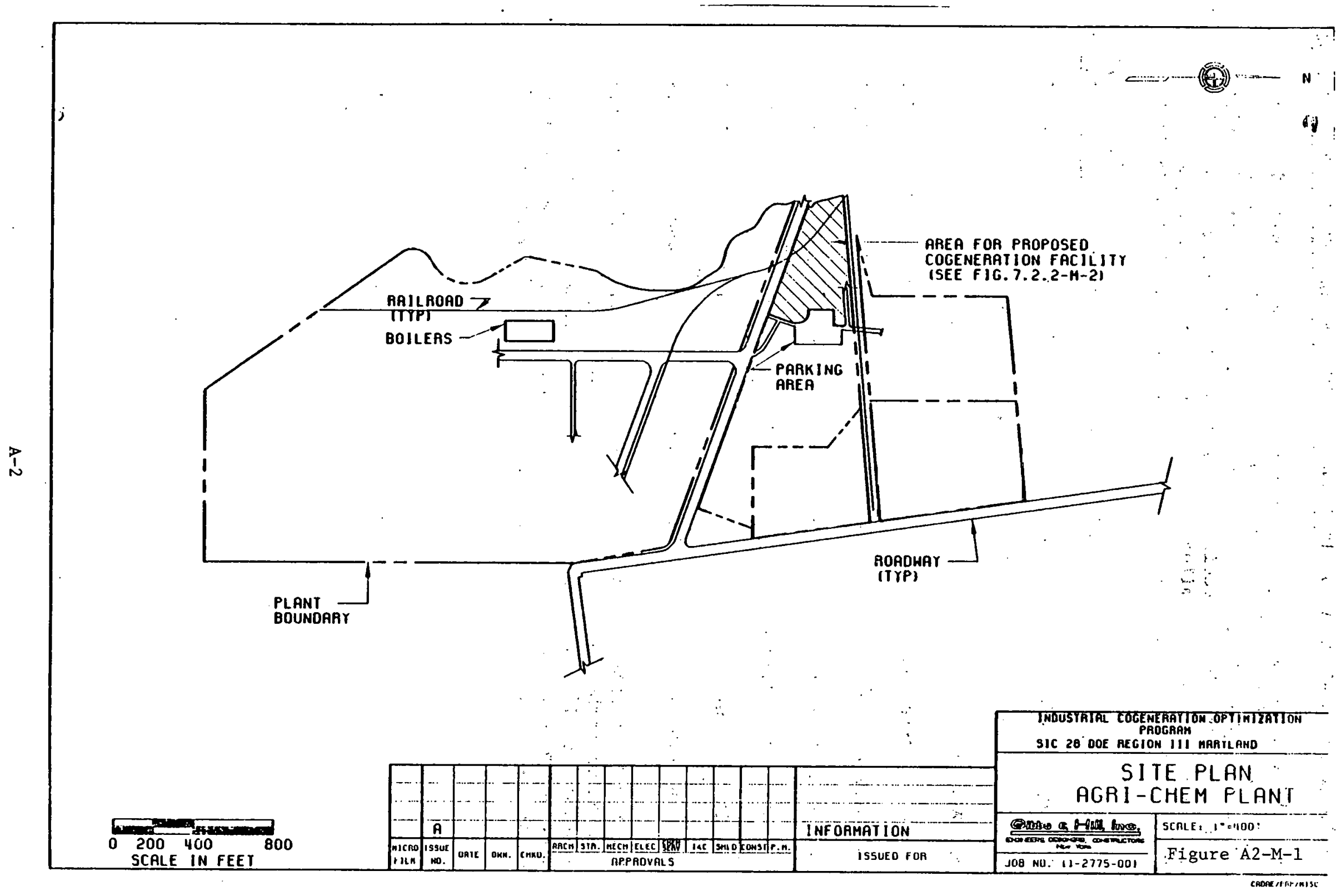




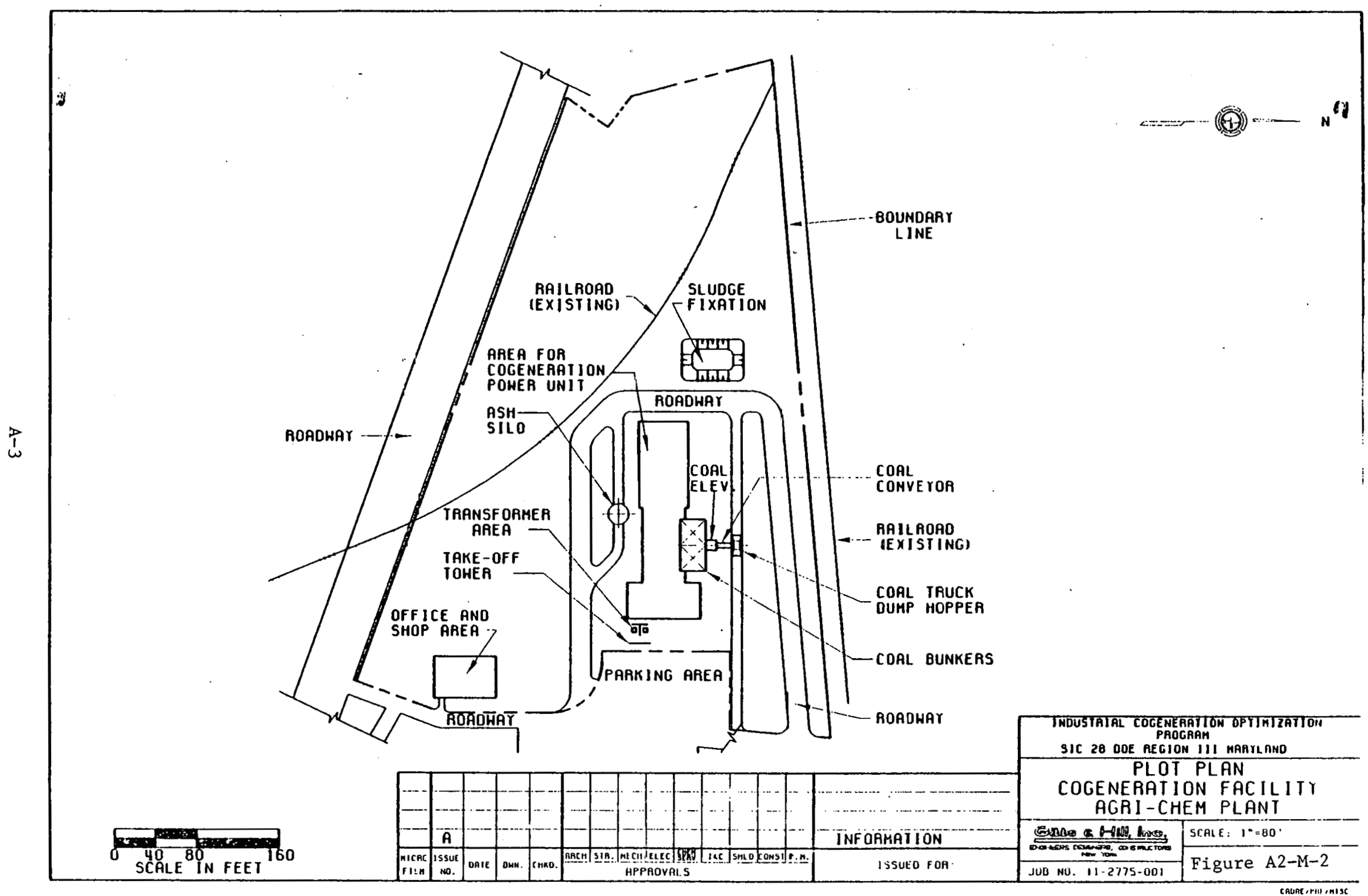




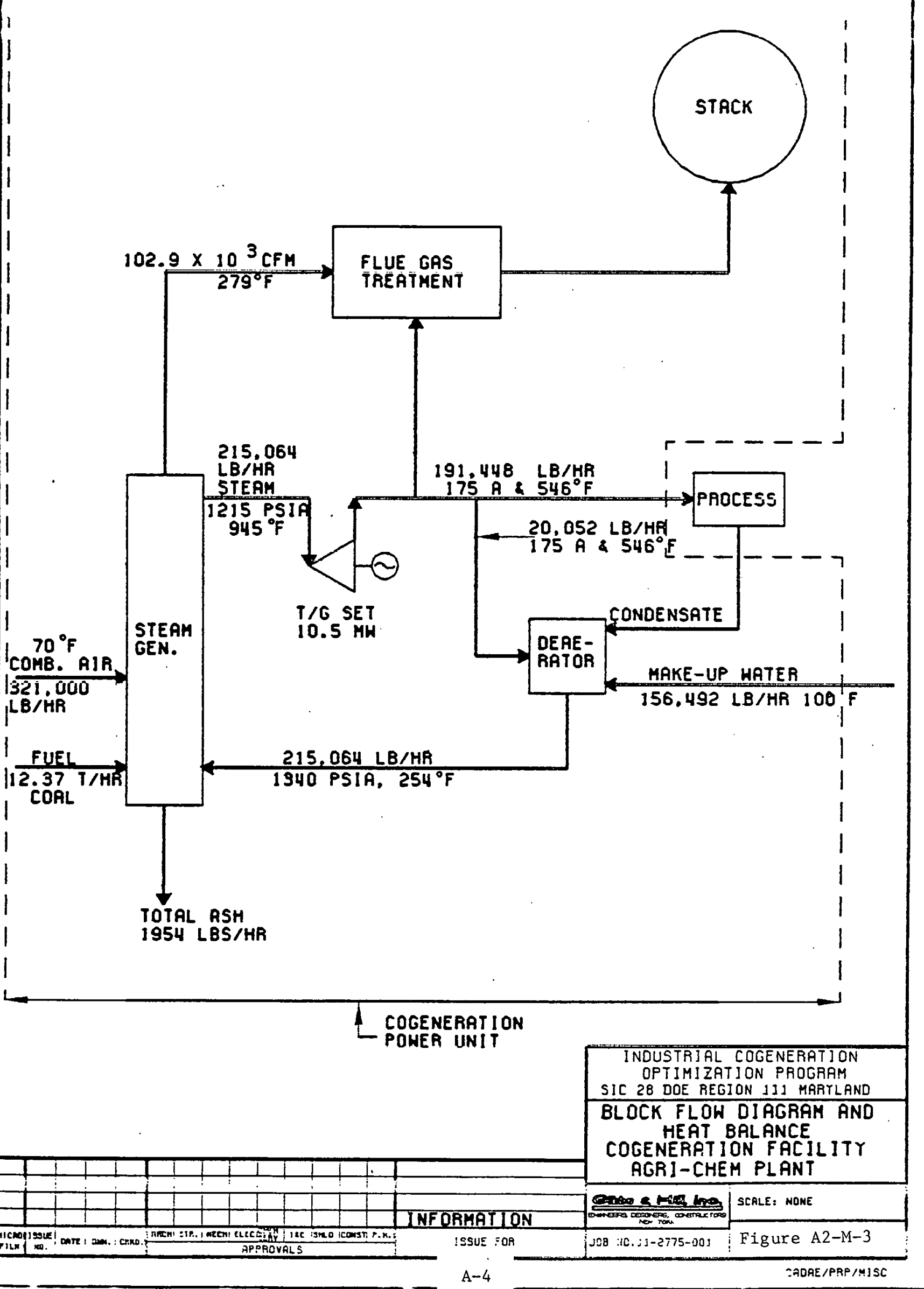


AGRI-CHEM PLANT COGENERATION FACILITY

PRELIMINARY SPECIFICATIONS OF MAJOR COMPONENTS

Steam Turbine

Type

Steam throttle conditions

steam exhaust conditions

speea

\section{Generator}

Rating

Voltage

power factor

Short circuit ratio

cooling

\section{Boiler}

Type.

Firing

Steam flow

Steam conditions

Flue Gas flow

Fly Ash Removal

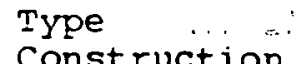

Construction

Net surface

Flue Gas Desulfurization

Type

Capacity

Deaerator

Type

Design pressure

Steam flow

Condensate flok:

Effluent oxygen content

storage capacity
Single shaft, noncondensing

1215 psia

$175 \mathrm{psia} / 370 \mathrm{~F}$

$3600 \mathrm{rpm}$

$10,500 \mathrm{~kW}$

$13.8 \mathrm{kV}$

0.9

0.64

Forced air

Non-reheat, balanced draft, water wall

Crushed coal, stoker fired

$215,064 \mathrm{lb} / \mathrm{hr}$

1215 psia at $945 \mathrm{~F}$

$102,900 \mathrm{cfm}$

Baghouse

Fiberglass cloth

$25,000 \mathrm{ft}^{2}$

Tray tower, caustic feed

$102,900 \mathrm{cfm}$ for coal, with

4.3 percent sulfur 


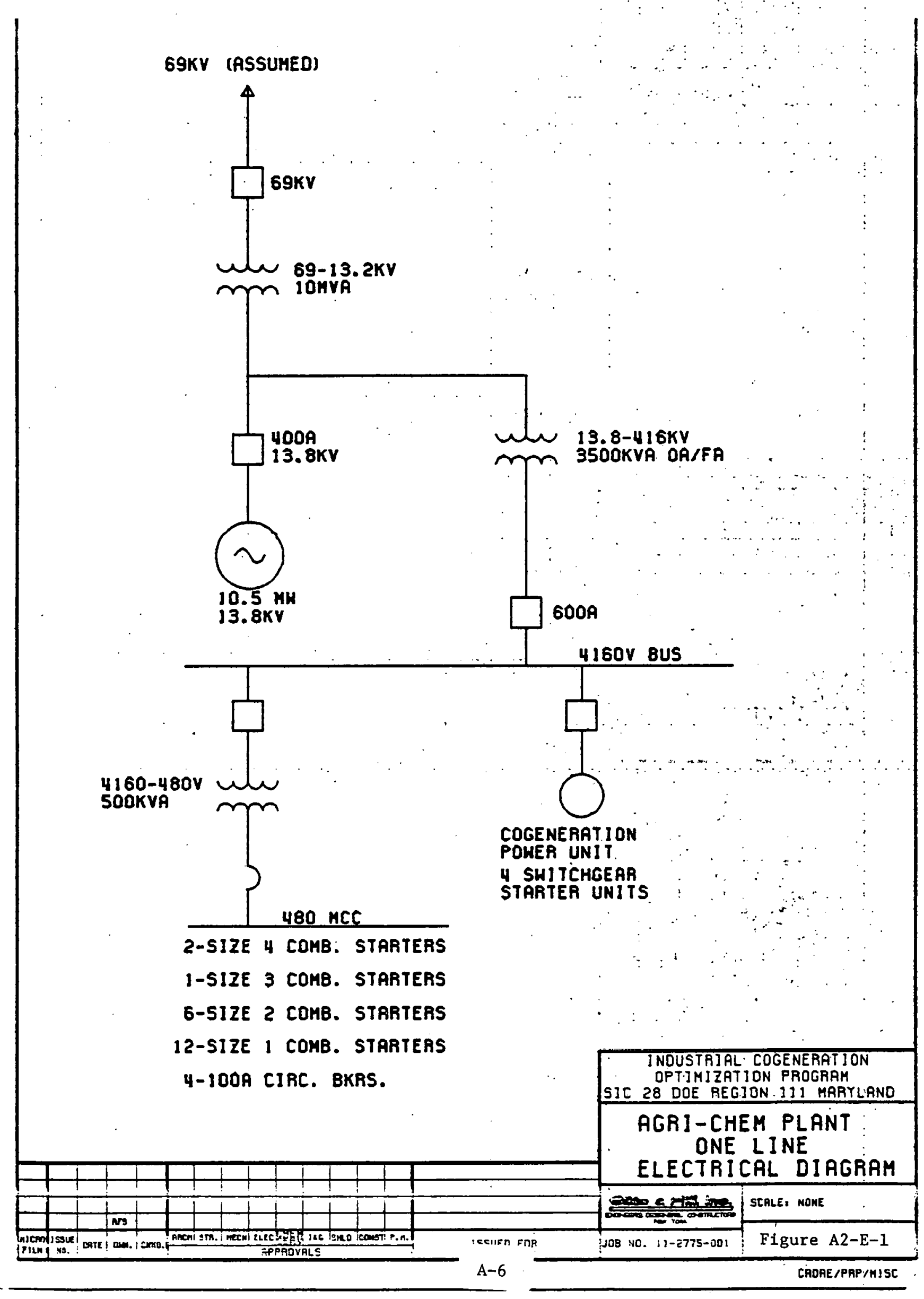




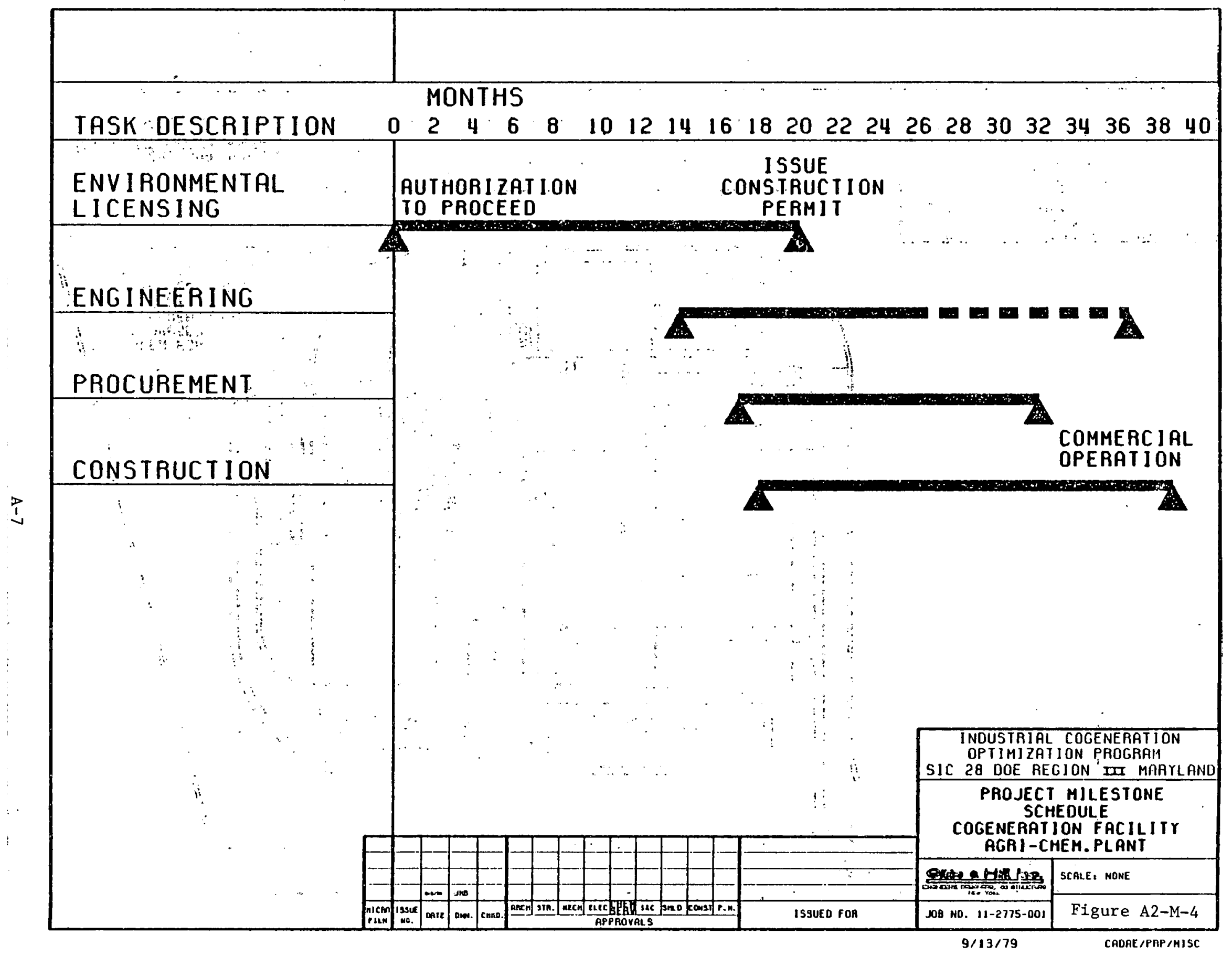




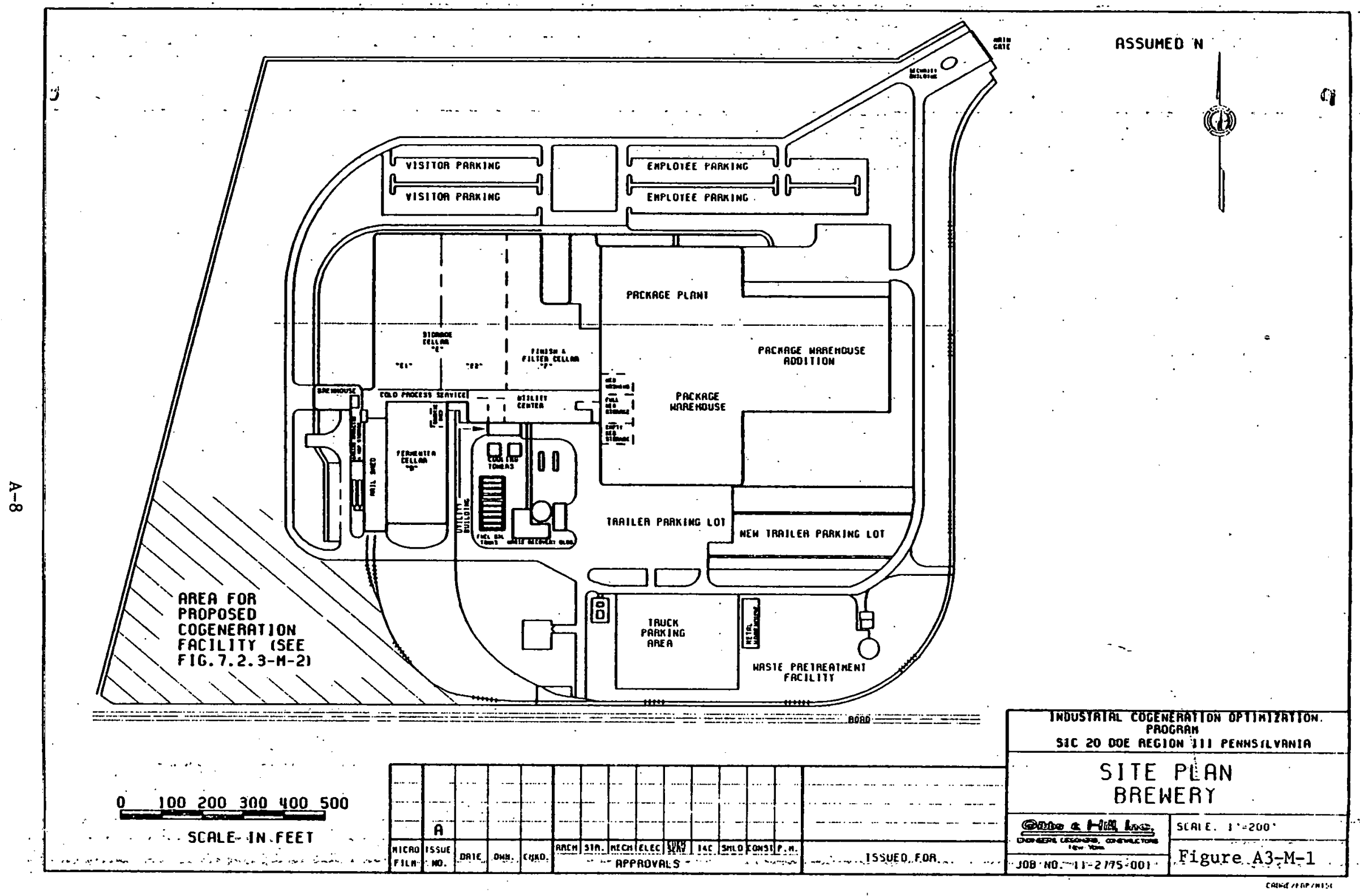




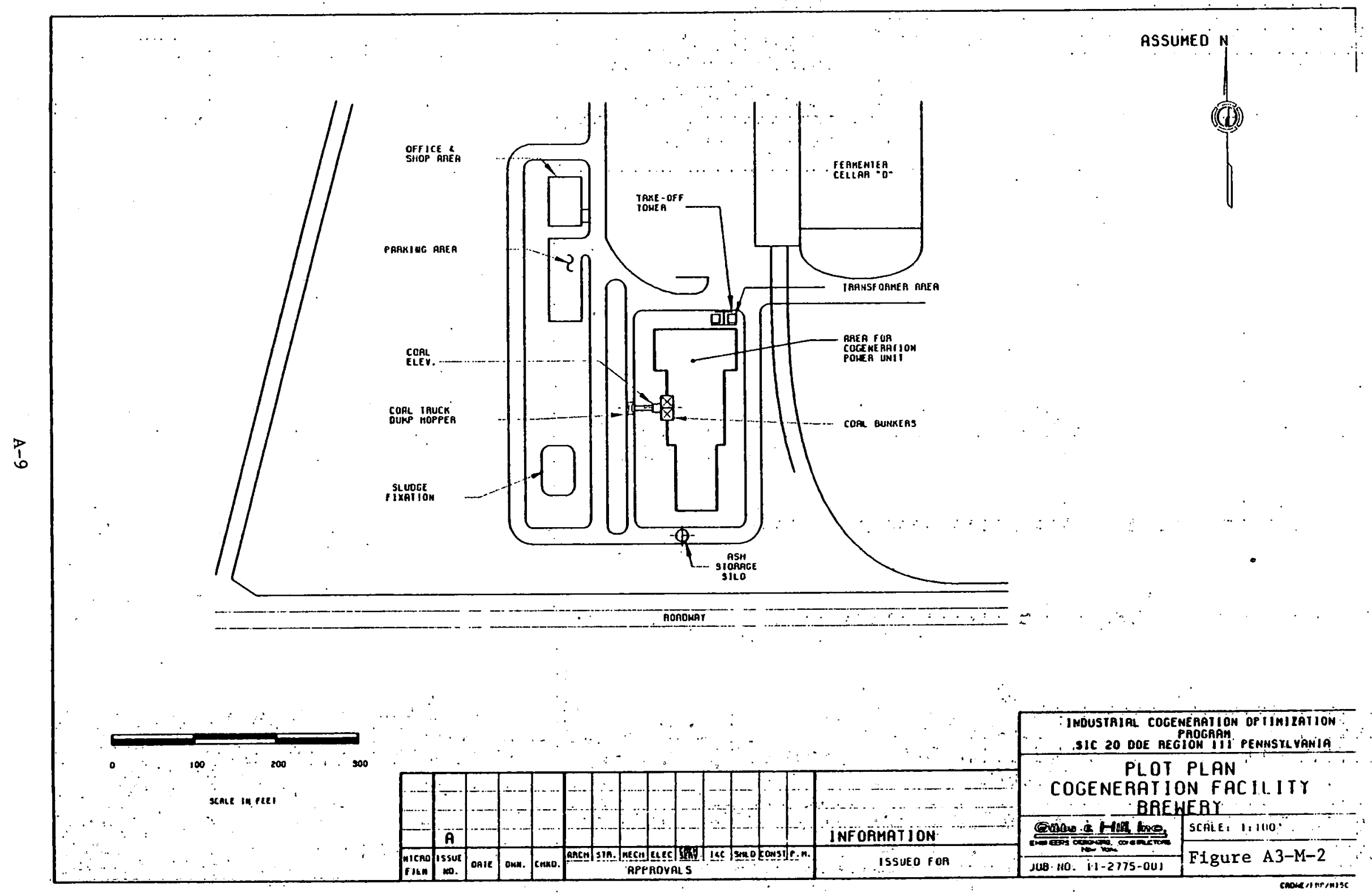




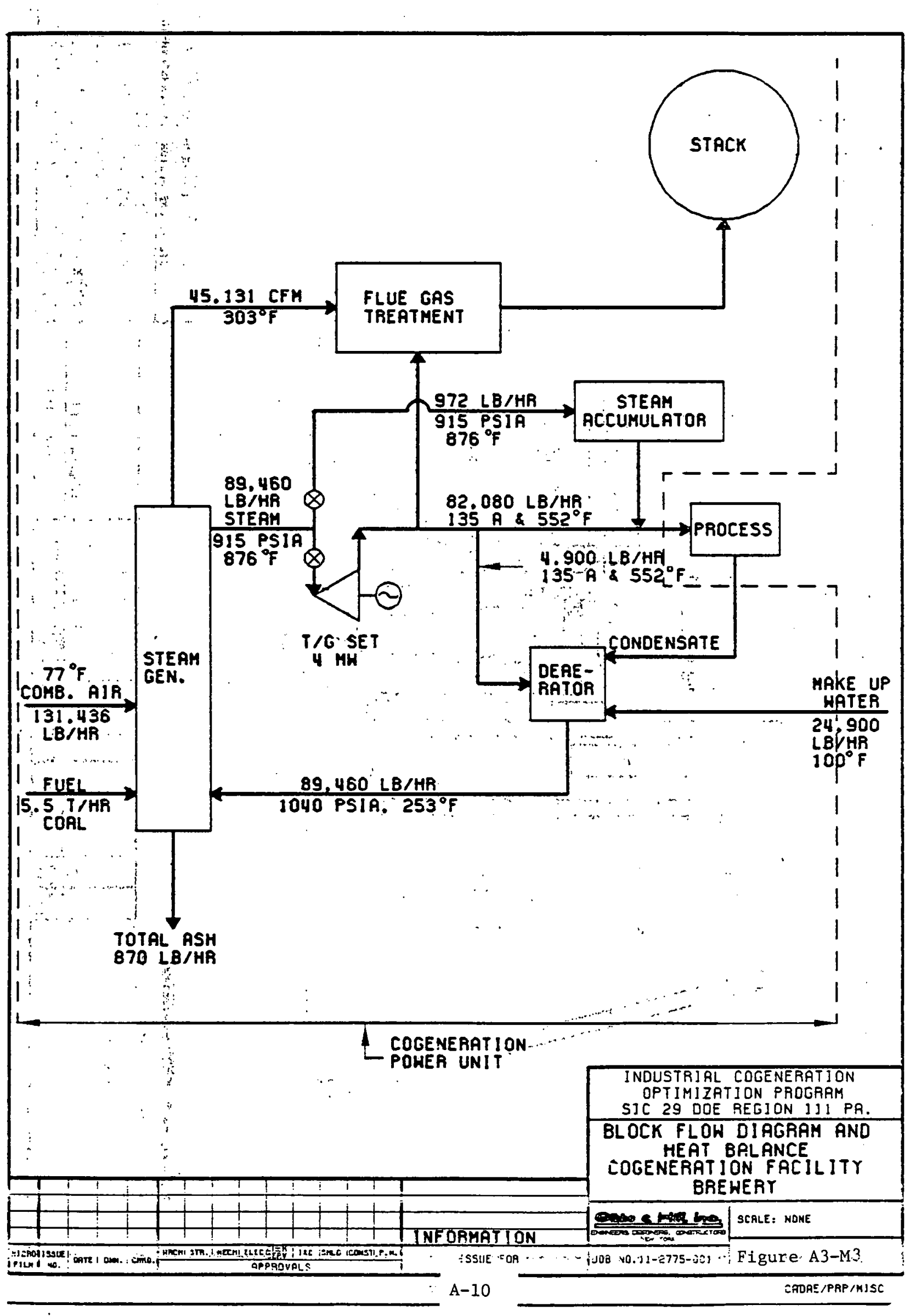


BREWERY PLANT COGENERATION FACILITY

PRELIMINARY SPECIFICATIONS OF MAJOR COMPONENTS

Steam Boiler

Type

Rating

Steam conditions

Flue gas flow

Steam Turbine

Type

steam throttle conditions

steam exhaust conditions

\section{Generator}

\section{Rating}

Voltage

Power factor

Short circuit ratio

cooling mechanism

\section{Electrostatic Precipitator}

Volumetric capacity

Dust loading, inlet

Dust loading. out

\section{Flue Gas Desulfurization}

Type

Efficiency

Removal

Filter discharge
Stoker fired

$90,000 \mathrm{lb} / \mathrm{hr}$

at 915 psig/875 F

45,130 cfm

Single shaft, noncondensing 900 psig/875 F

$120 \mathrm{psig} / 500 \mathrm{~F}$

$4000 \mathrm{~kW}$

$13.8 \mathrm{kV}, 60 \mathrm{~Hz}$

0.9

0.64

Forced air

45,131, acfm at $303 \mathrm{~F}$

5 grains acf

0.064 grains/acf 
Steam Accumulator

Type

Delivery rate

Duration of delivery

Deaerator Feedwater Heater

\section{Type}

Design pressure

Feedwater flow

Effluent oxygen content

storage capacity
Skid mounted, including pumps, piping, valves, and instrumentation

$115,000 \mathrm{lb} / \mathrm{hr}$

3.5 minutes

Spray tray deaerator

50 psig

$89,460 \mathrm{lb} / \mathrm{hr}$

Less than $0.5 \mathrm{ppm}$

10 minutes 


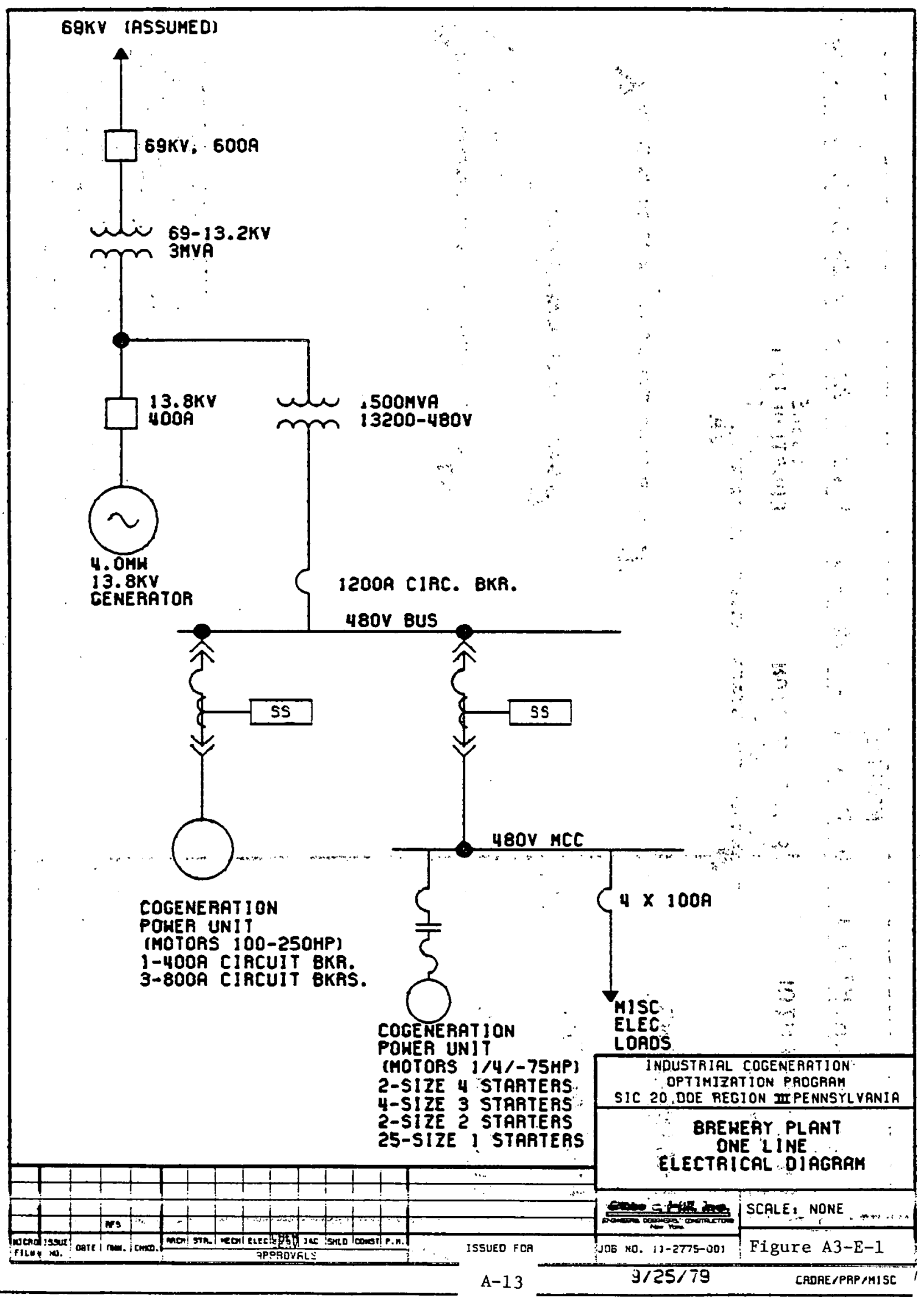




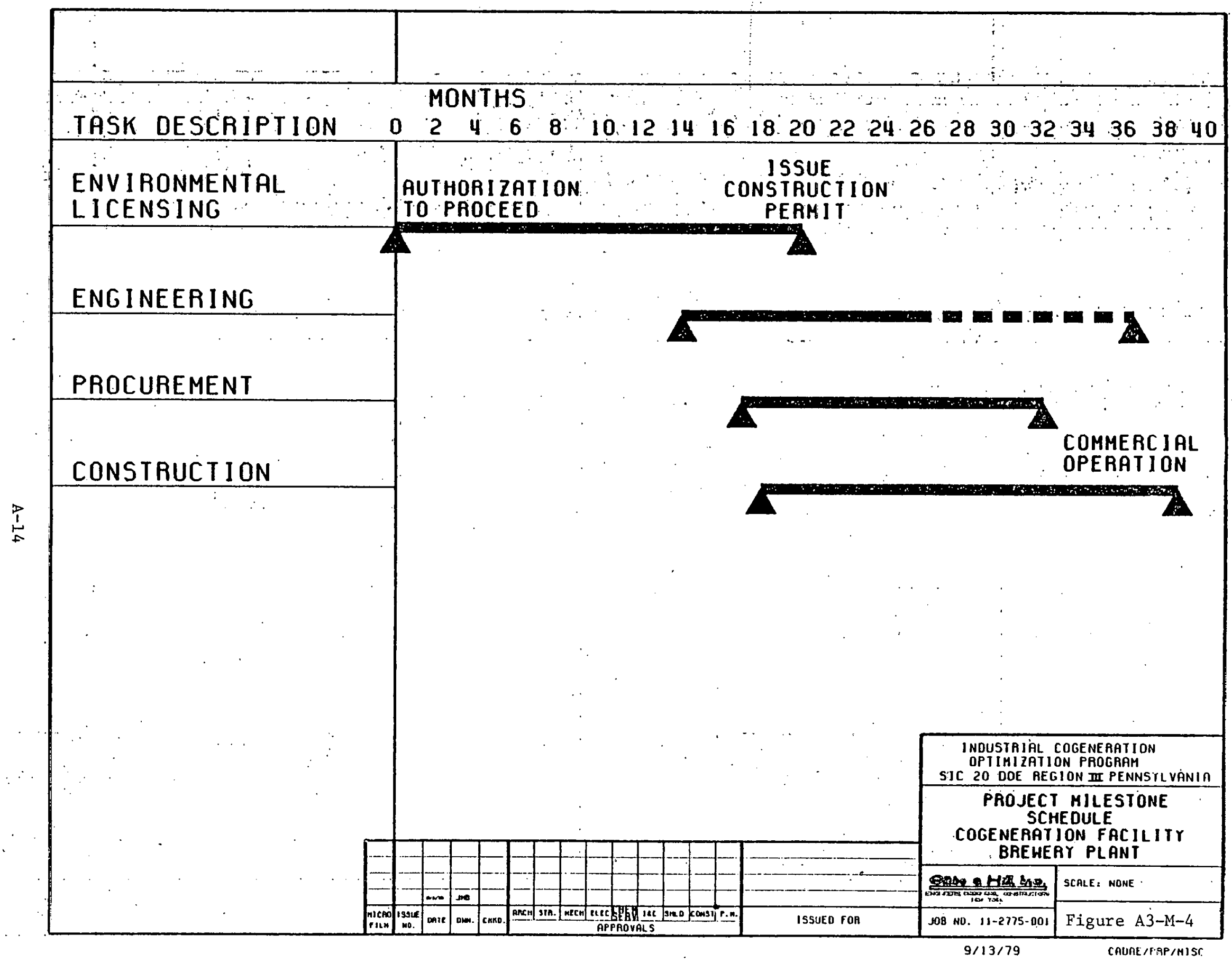




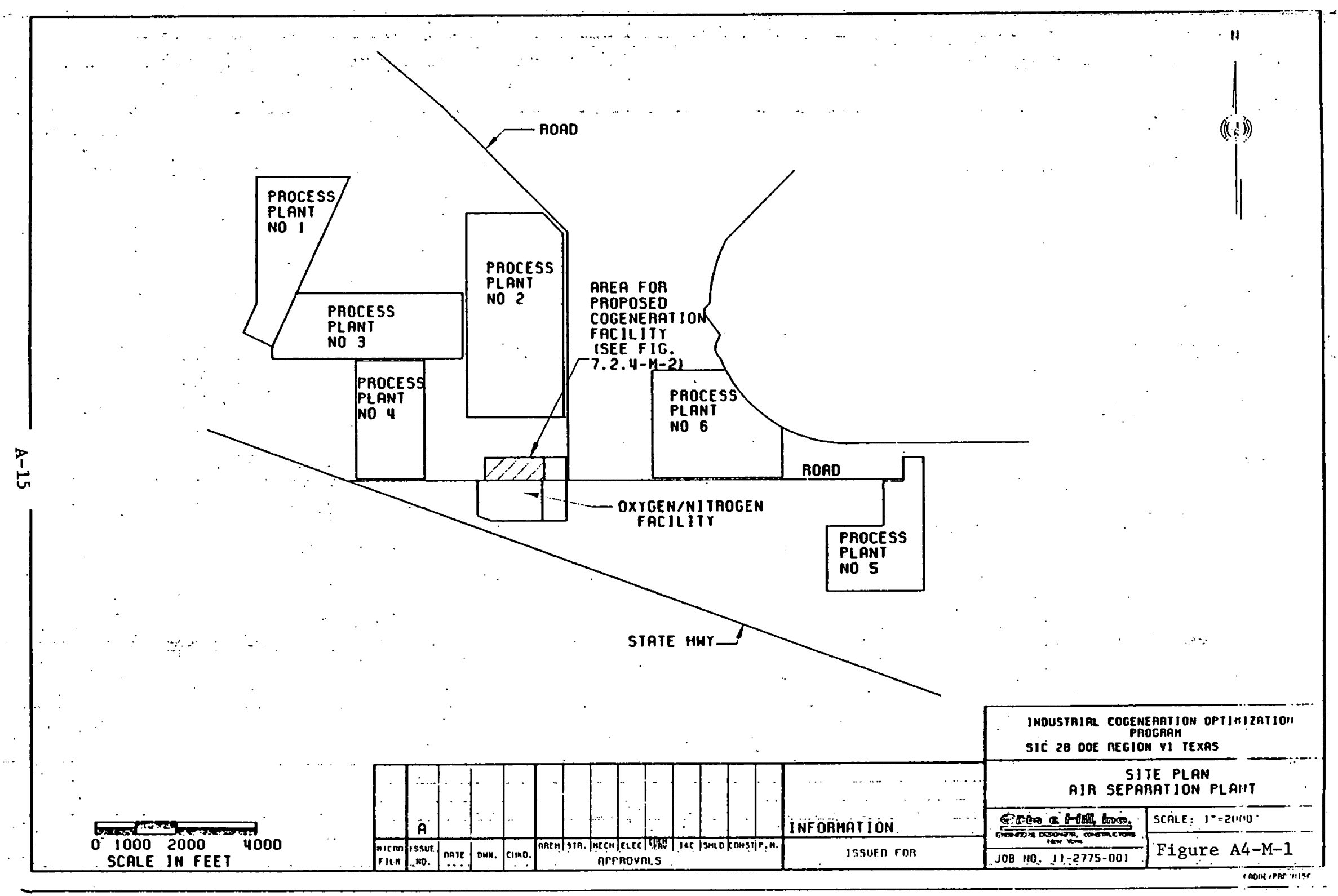




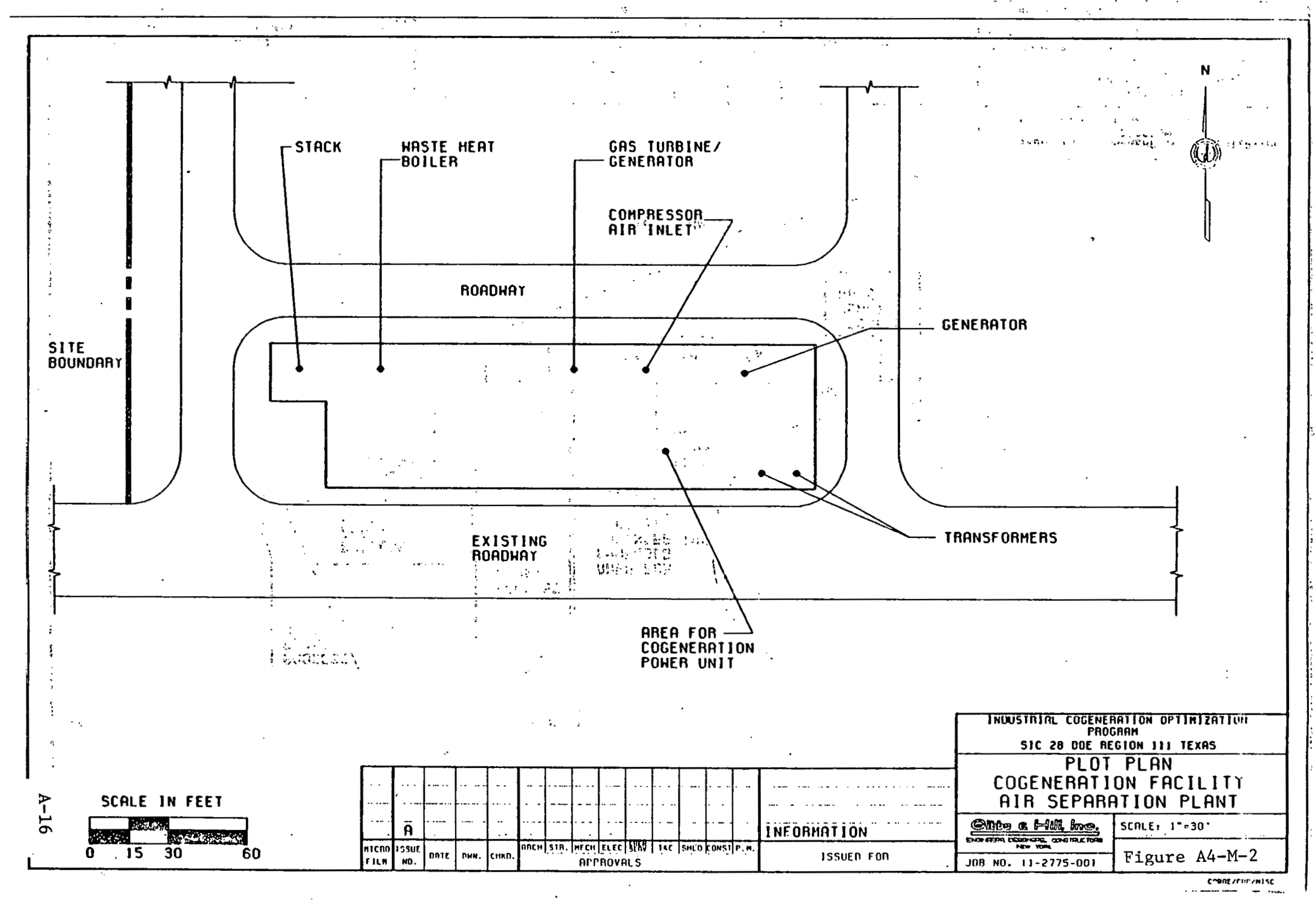




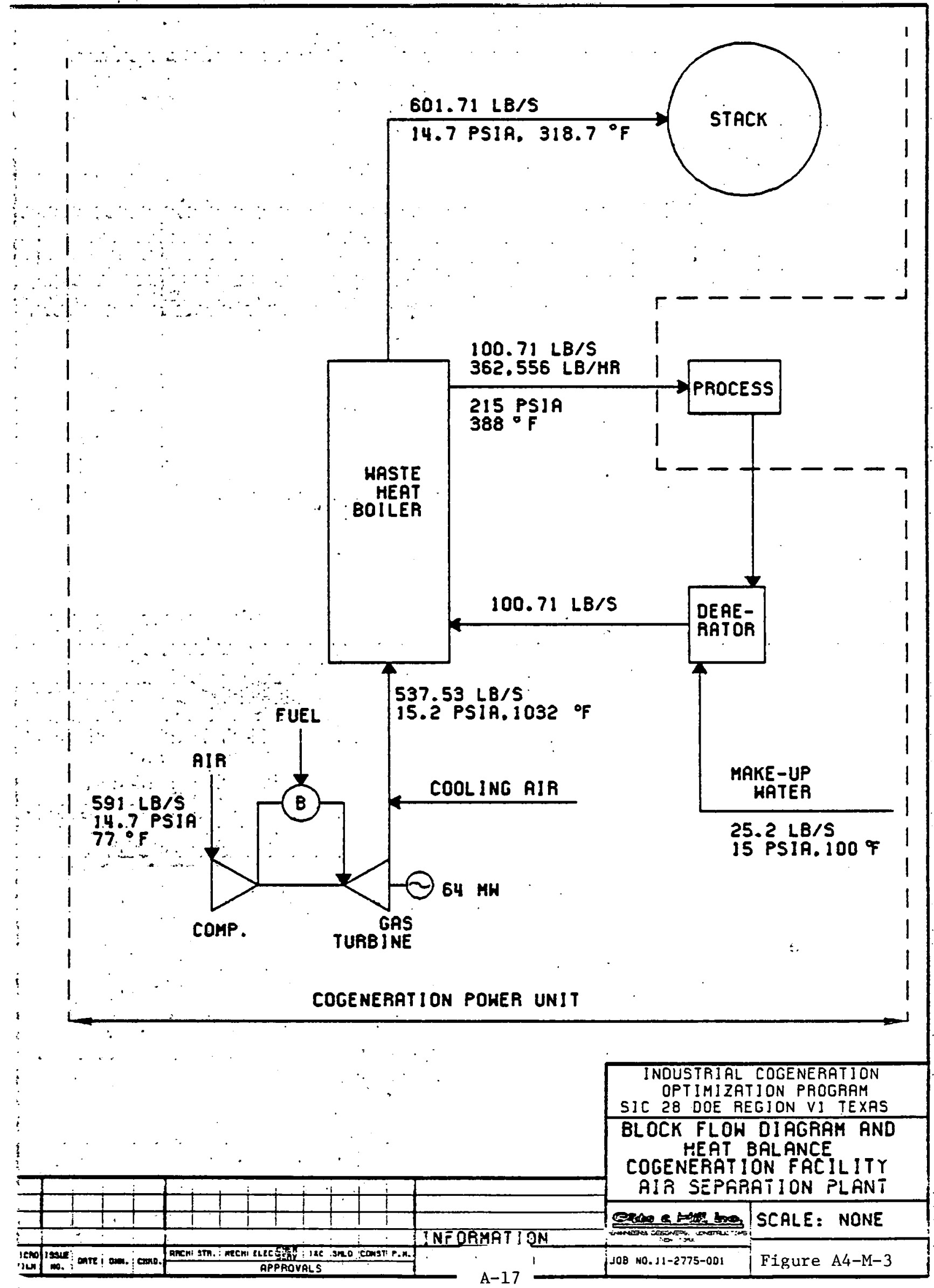




\section{GAS TURBINE/GENERATOR}

Type:

Rating:

Voltage:

Power Factor:

Short Circuit Ratio:

Cooling:

Fuel:

STEAM GENERATOR

Type:

Firing:

steam Flow:

Steam Conditions:

Flue Gas Flow:

DEAERATOR

Type:

Design :Pressure:

Steam Flow:

Feedwater Flow:

Effluent Oxygen:

storage Capacity:
Open Cycle

$64 \mathrm{MW}$

$13.8 \mathrm{kV}$

0.9

0.64

Hydrogen

2,167,000 1b/hr Nat. Gas

Waste Heat Boiler

Flue Gas. Only

$363,000^{\circ} \mathrm{lb} / \mathrm{hr}$

214 psia a $388^{\circ} \mathrm{F}$

$2,166,200 \mathrm{lb} / \mathrm{hr}$ @ $975^{\circ} \mathrm{F}$

\section{Tray}

50 psig

$35,500 \cdot 1 \mathrm{~b} / \mathrm{hr}$ $282,000 \mathrm{Ib} / \mathrm{hr}$ Less Than 0.5 ppm 5 min 


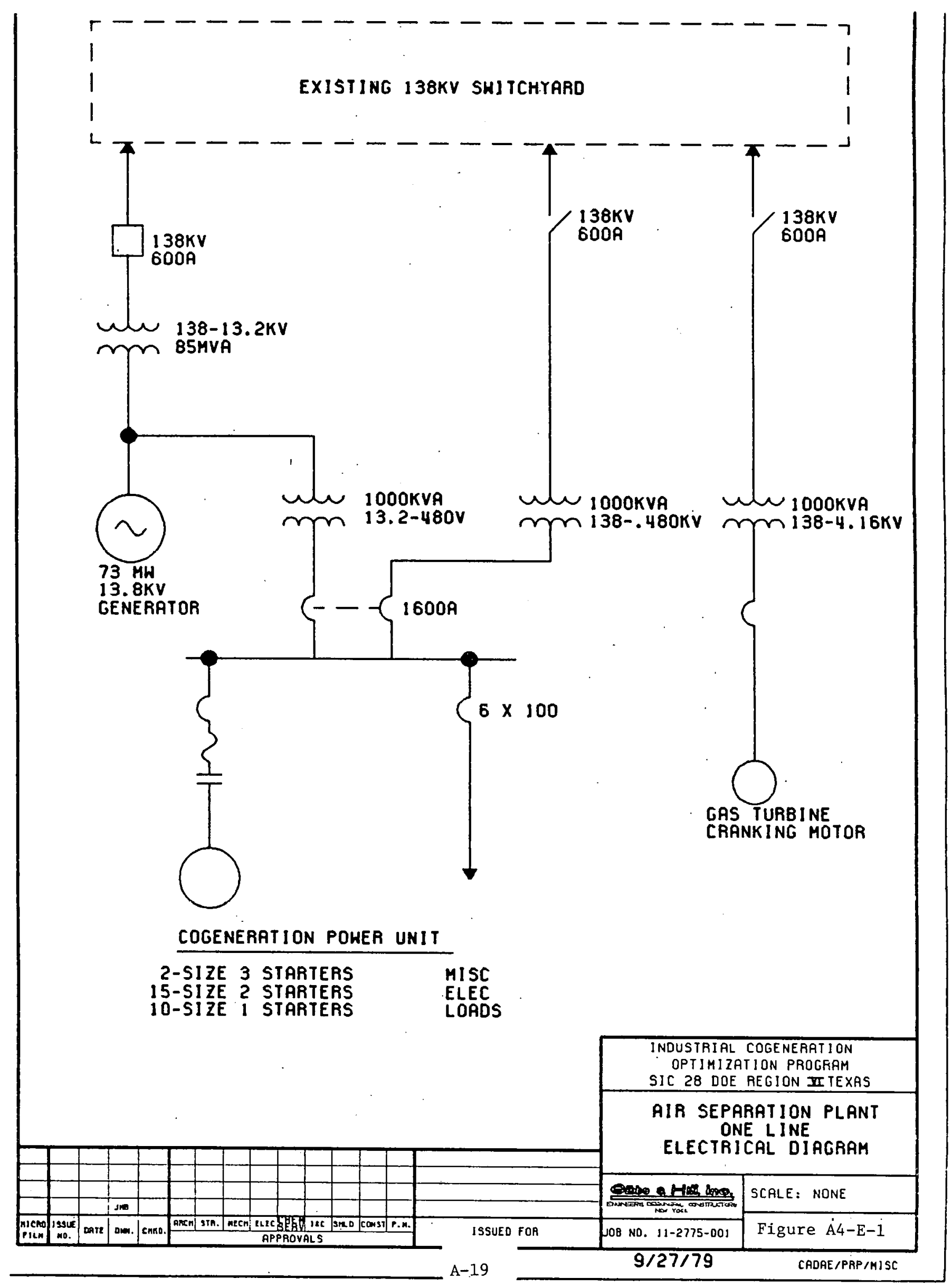




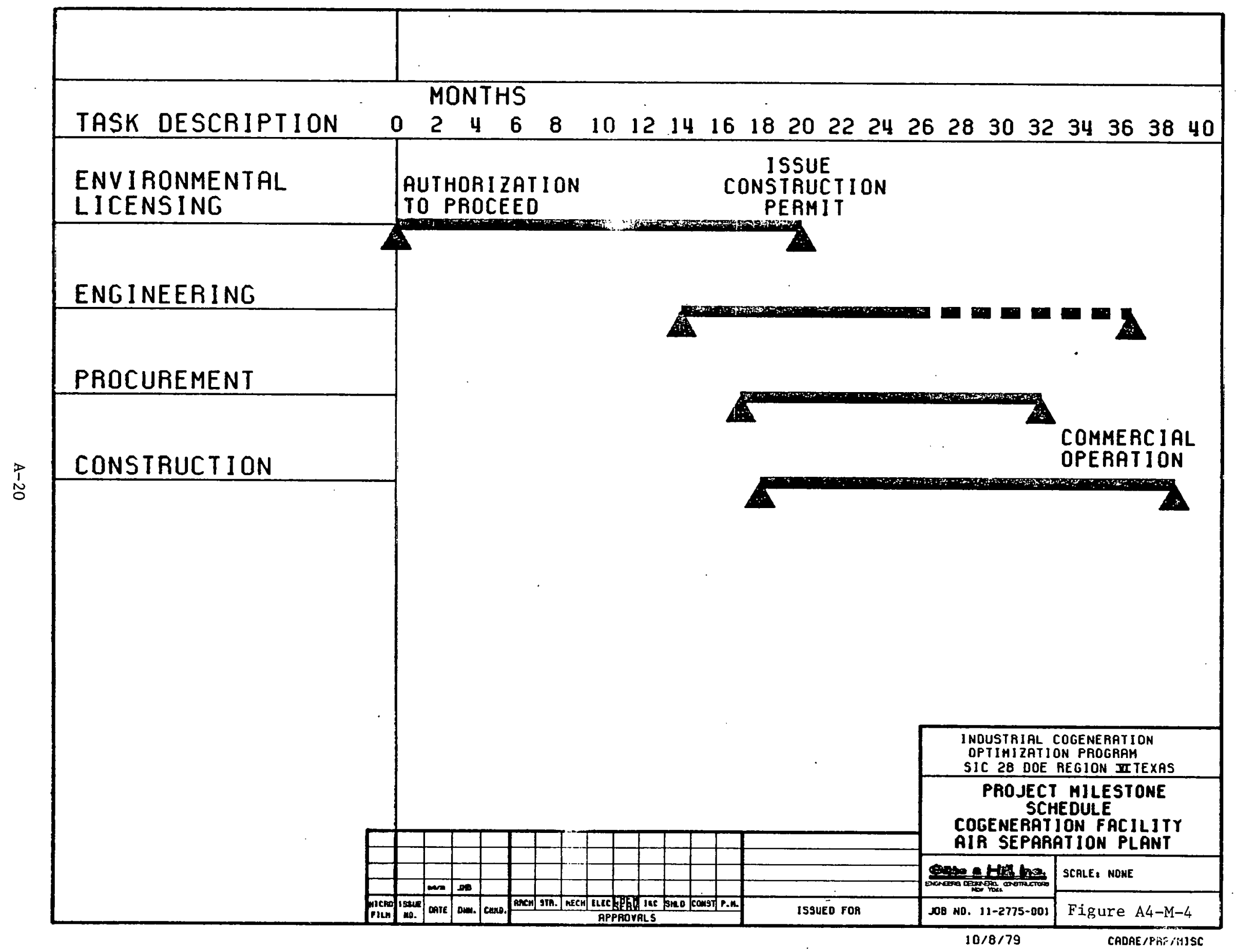




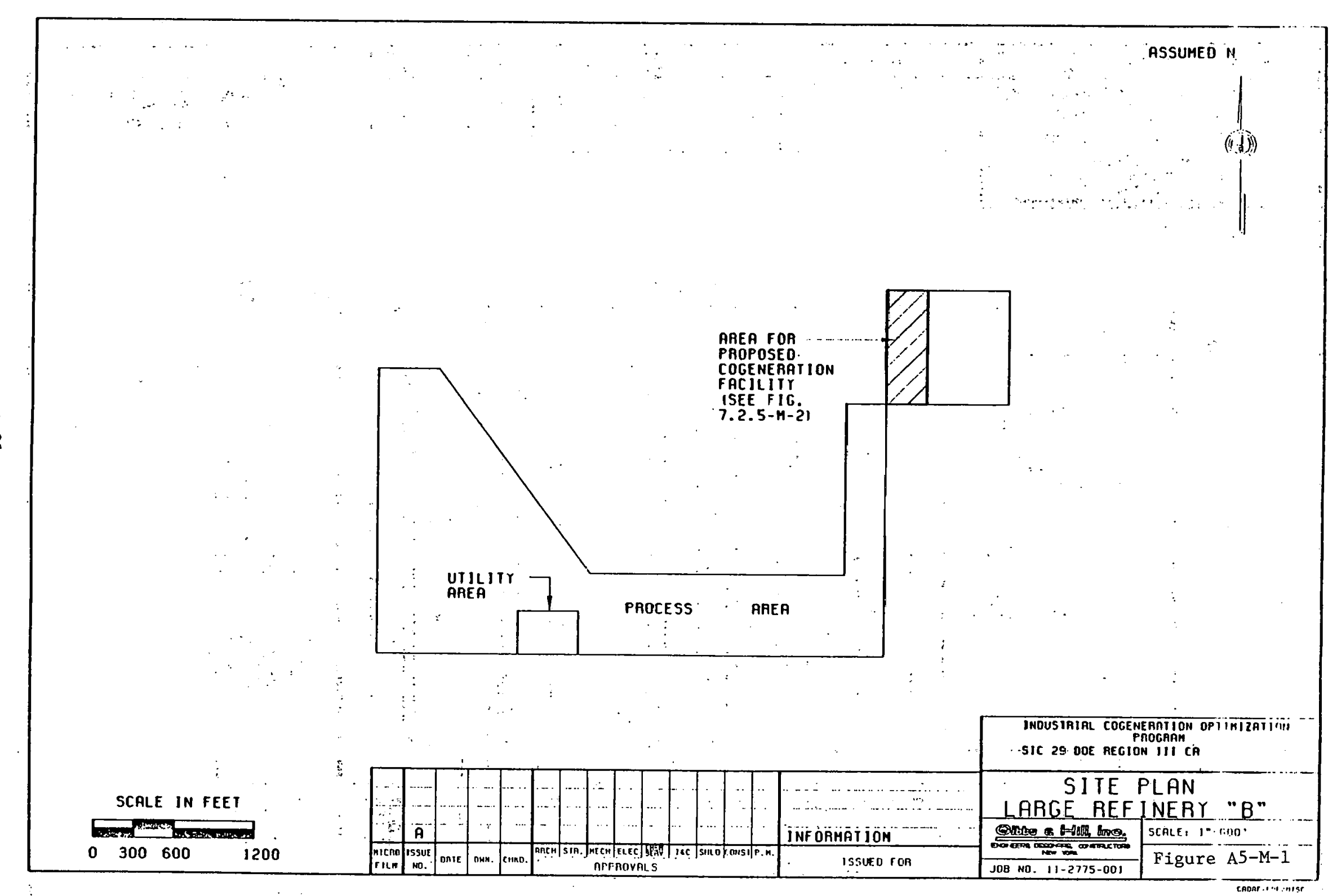




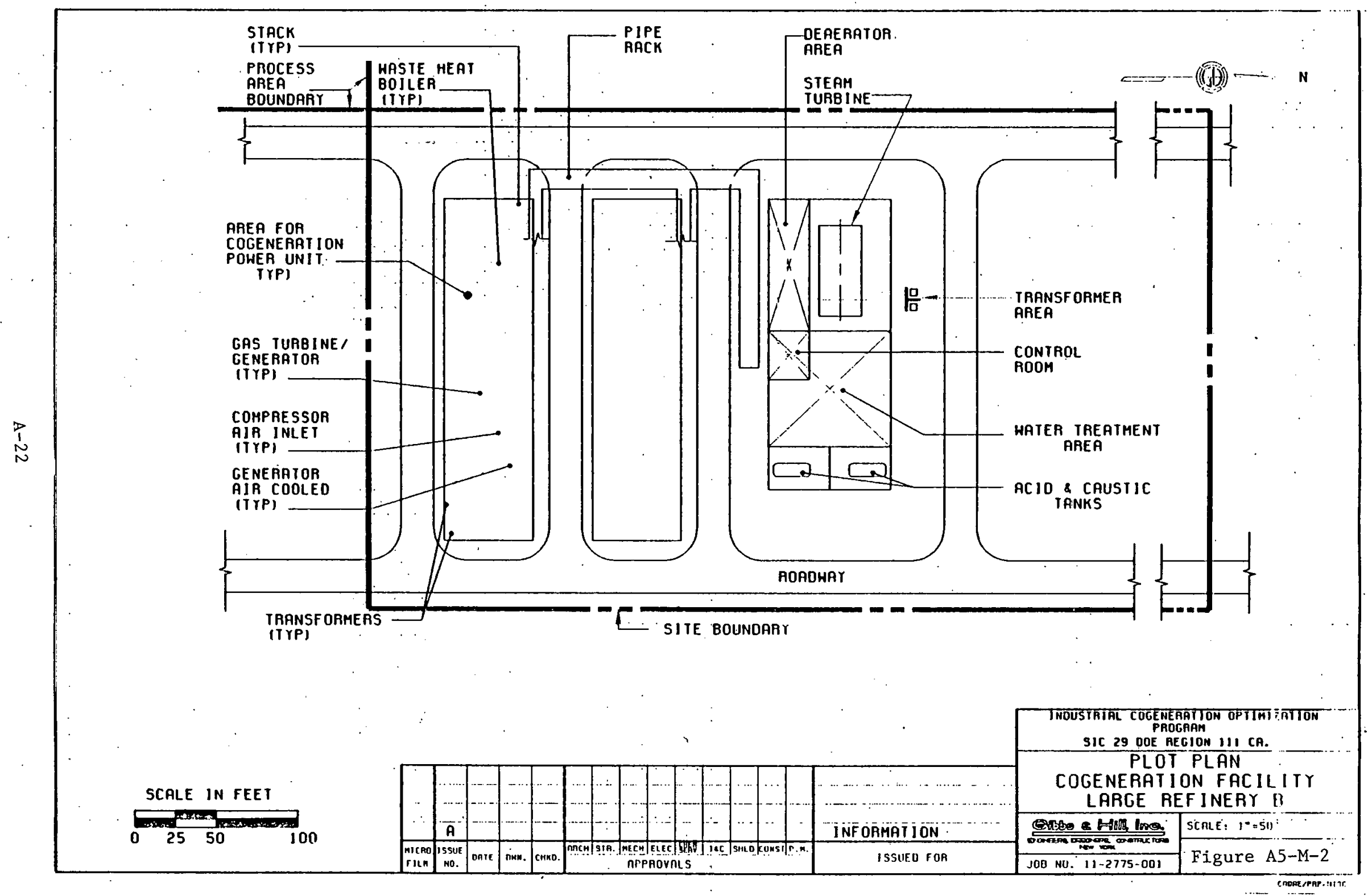




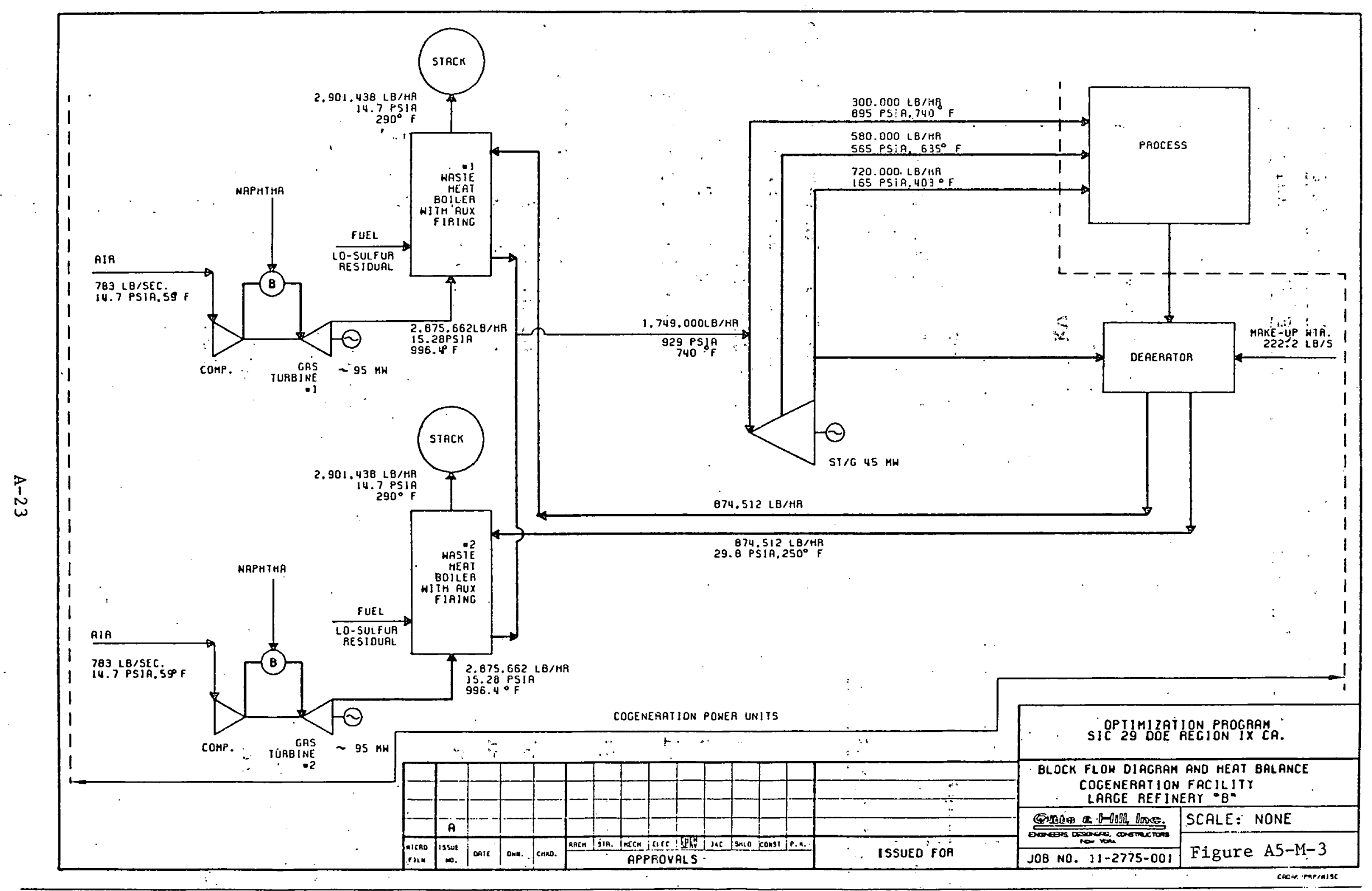


TABLE A5-1.

\section{LARGE - REFINERY "B" COGENERATION - FACILITY}

\section{PRELIMINARY SPECIFICATIONS O'F MAJOR COMPONENTS}

GAS TURBINE/GENERATOR

Type:

Rating:

Voltage:

Power Factor:

Short Circuit Ratio:

Cooling :

Fuel:

STEAM GENERATOR

Type:

Firing:

Steam Flow:

Steam. Conditions:

Flue Gas Flow:

\section{STEAM TURBINE}

Type:

Steam Throttle Conditions:

Steam Exhaust Conditions:

Extraction PT:

GENERATOR

Rating:

Voltage:

Power Factor:

Short Circuit Ratio:

Cooling :
Open Cycle

$95 \mathrm{MW}$

$13.2 \cdot \mathrm{kV}$

0.9

0.64

Hydrogen

113,750 1b/hr Naphtha

Waste Heat Boiler w/Supp. Firing Flue Gas \& Low S. Residual

$875,00.0 \mathrm{lb} / \mathrm{hr}$

929 psia e $739^{\circ} \mathrm{F}$

$2,901,400.1 \mathrm{~b} / \mathrm{hr}$ @ $996^{\circ} \mathrm{F}$

Extraction, non-condensing

929 psia, $740^{\circ} \mathrm{F}$

165 psia, $403^{\circ} \mathrm{F}$

565. psia, $635^{\circ} \mathrm{F}$

$45 \mathrm{MW}$

$13.2 \mathrm{kV}$

0.9

0.64

Hydrogen 
DEAERATOR

Type:

Design Pressure

Steam Flow

Feedwater Flow

Effluent Oxygen.

Storage Capacity
Tray.

50 psig

$149,100 \mathrm{lb} / \mathrm{hr}$

$1,600,000 \mathrm{lb} / \mathrm{hr}$

Less Than 0:5 ppm

$5 \mathrm{~min}$ 


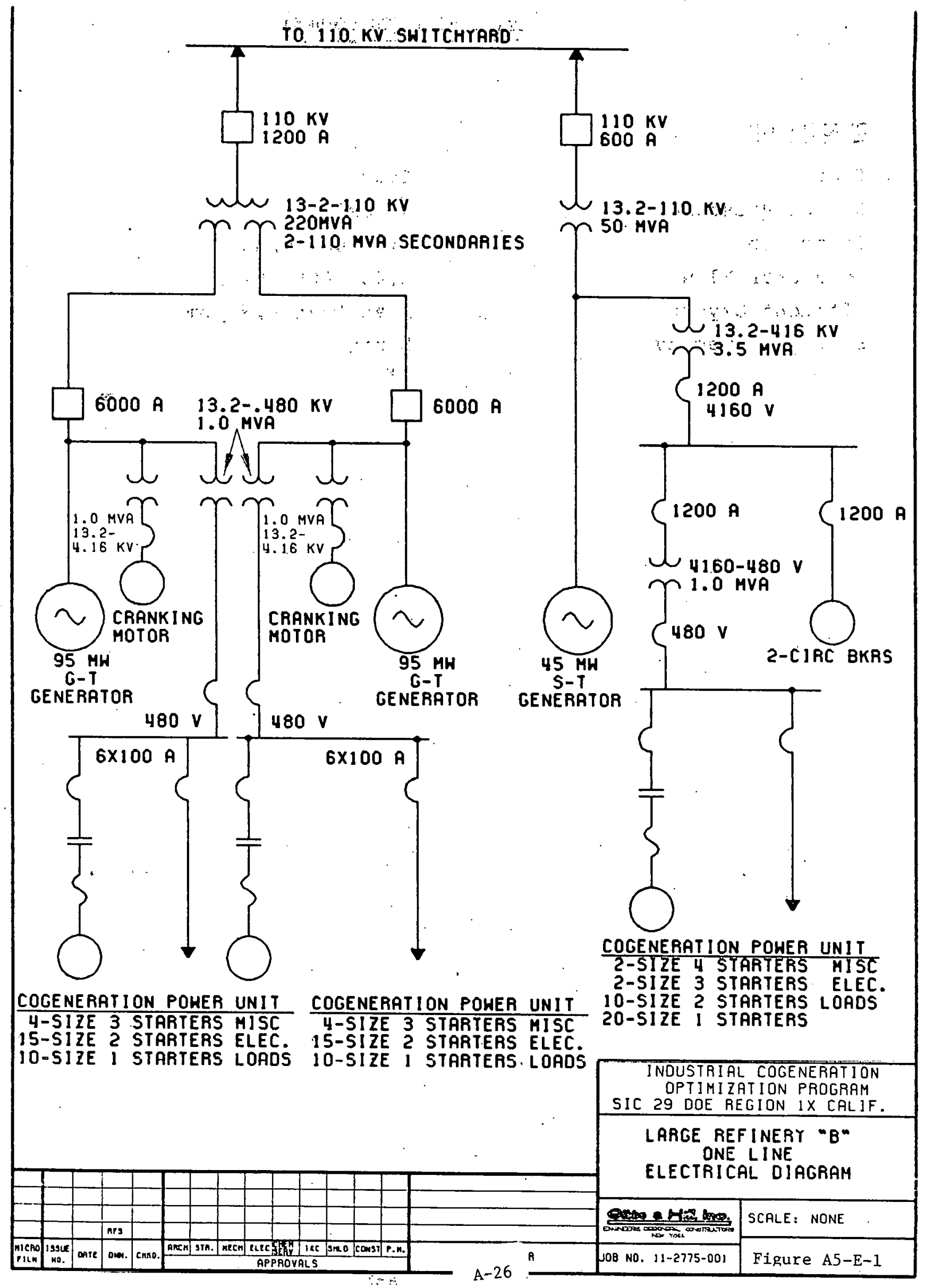




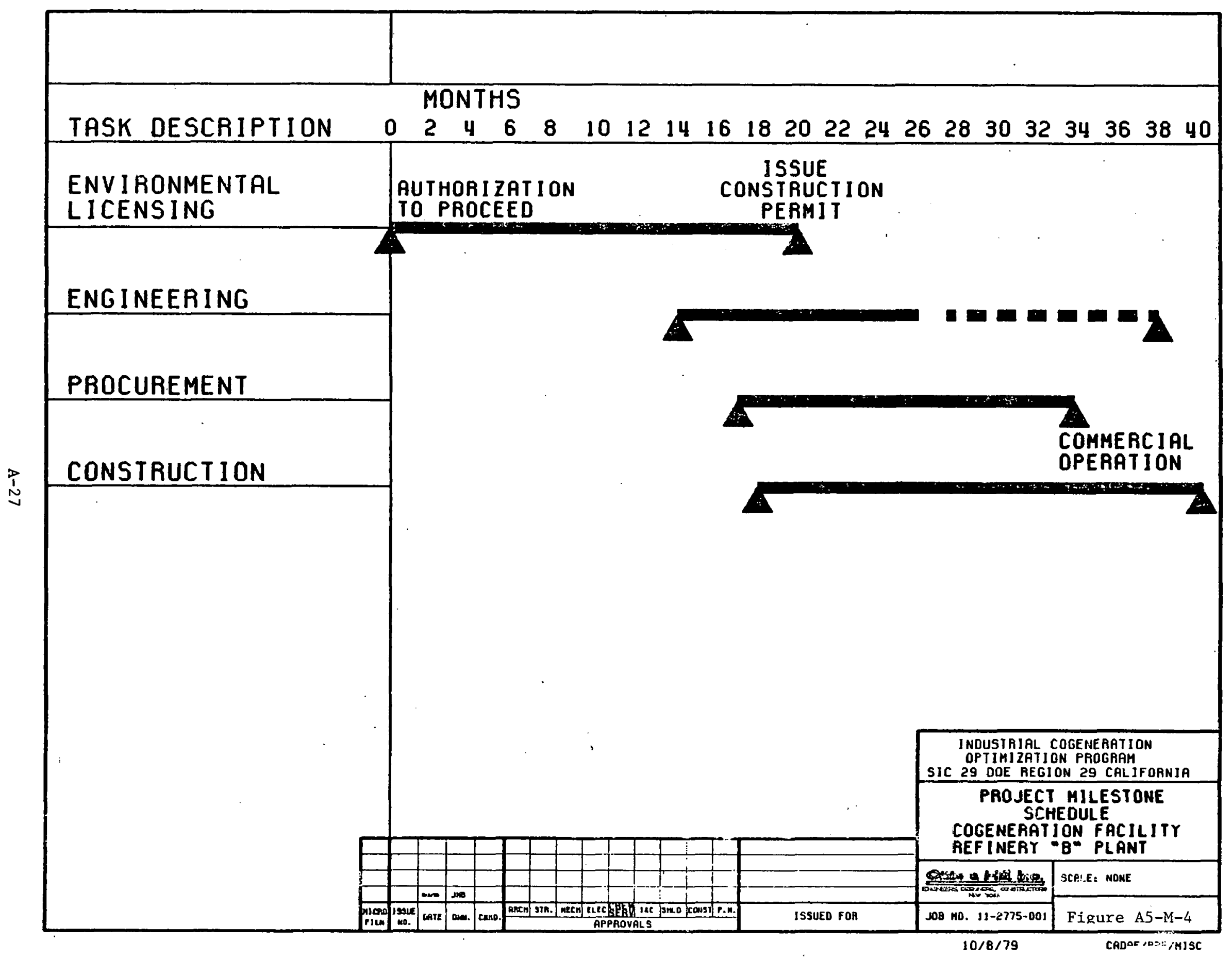




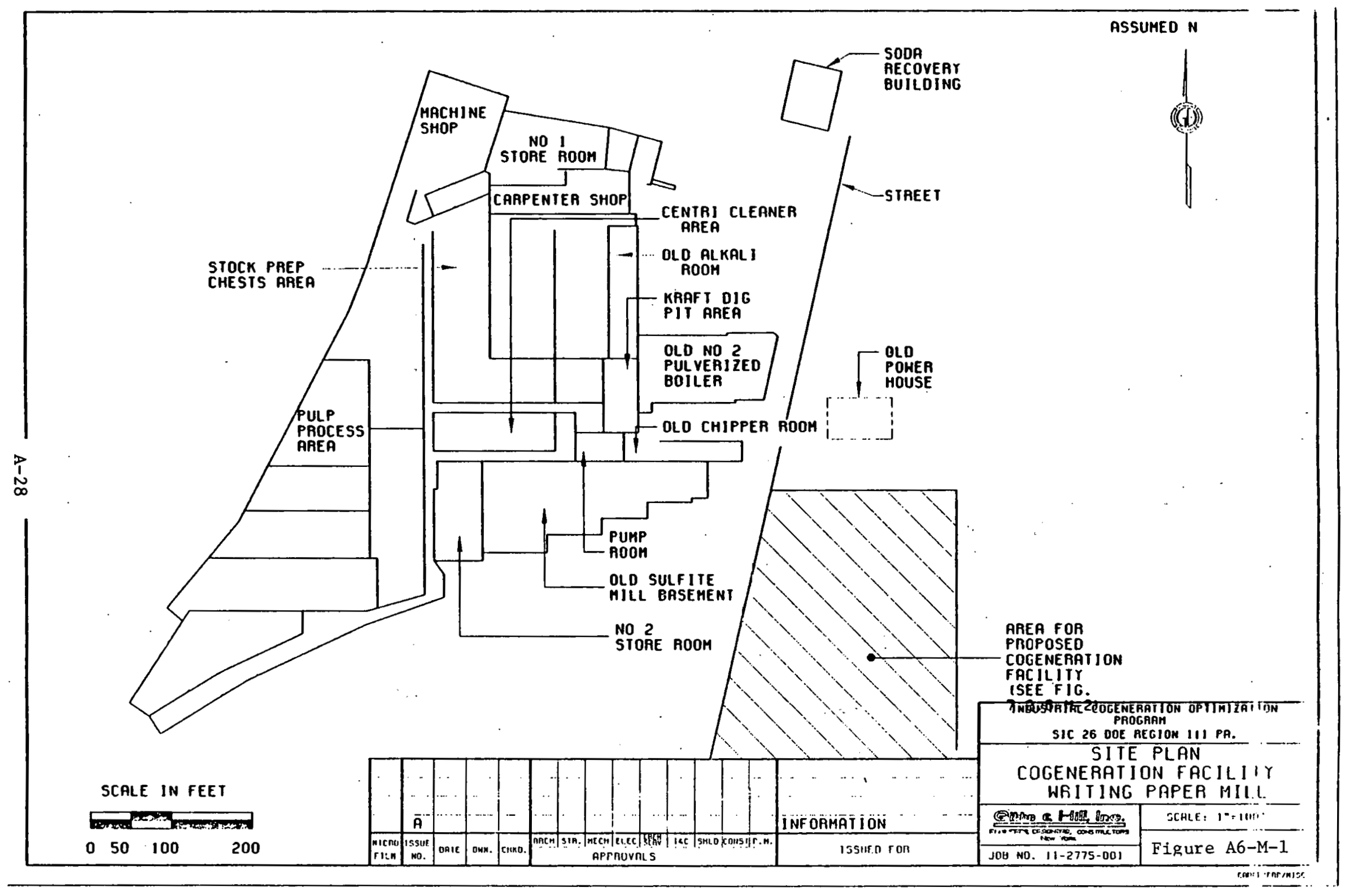




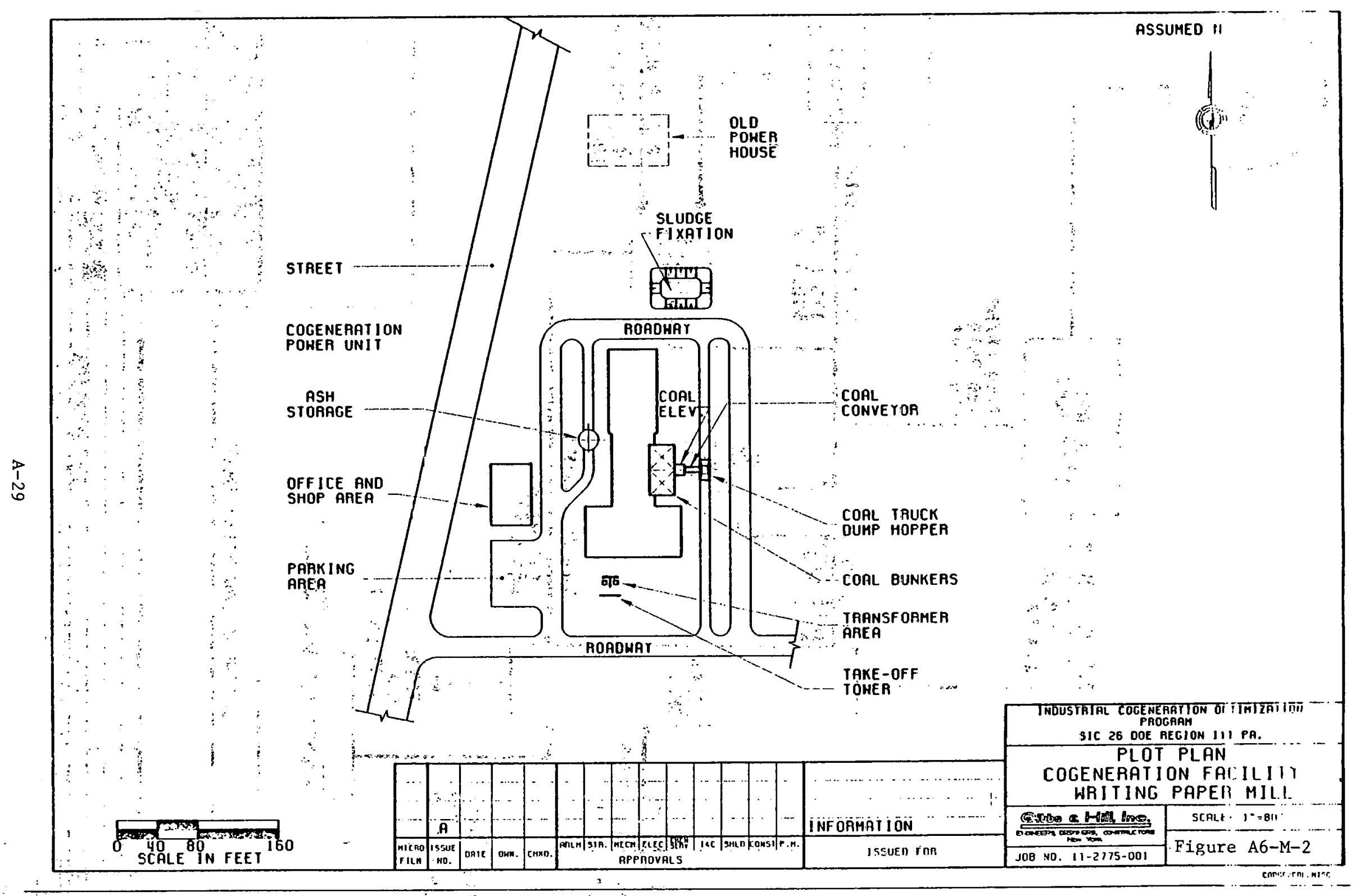




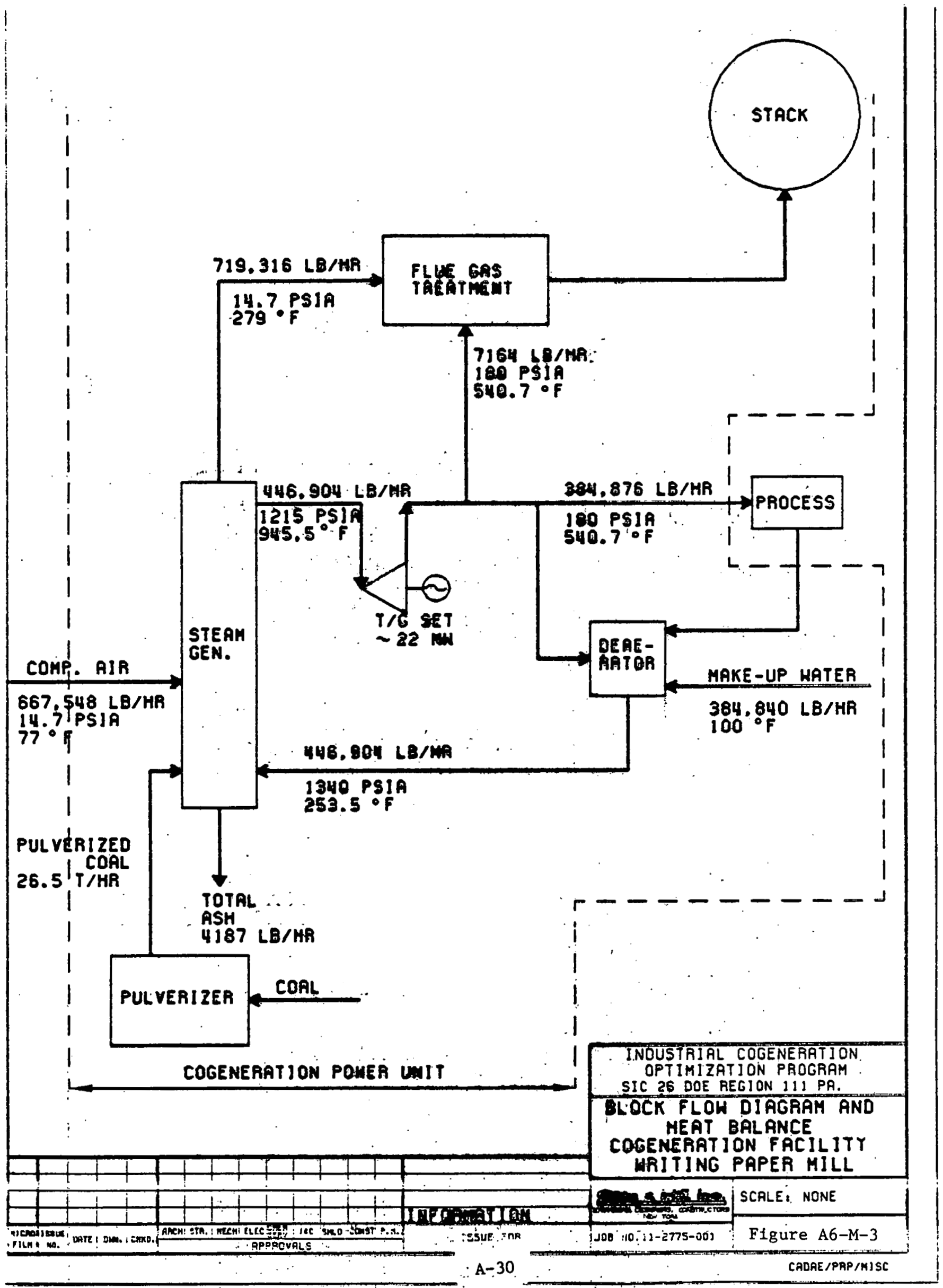


Type:

Firing:

Steam F.low:

Steam Conditions:

Flue Gas Flow:

STEAM TURBINE

Type:

Steam Throttle Conditions:

Steam Exhaust Conditions:

\section{GENERATOR}

Rating:

Voltage:

Power Factor:

Cooling :

ELECTROSTATIC PRECIPITATOR

Volumetric Capacity:

Dust Loading, Inlet:

Dust Loading; Out:

FLUE GAS DESULFURIZATION

Type:

Efficiency:

Removal:

Filter Discharge:
Non-Reheat, Balanced Draft

Pulverized coal

$446,904 \cdot 1 \mathrm{~b} / \mathrm{hr}$

1215 psia, $946^{\circ} \mathrm{F}$

$719,316 \mathrm{lb} / \mathrm{hr}$

Back. Pressure

1215 psia, $946^{\circ} \mathrm{F}$

180 psia; $541^{\circ} \mathrm{F}$

$22 \mathrm{MW}$

$13.2 \mathrm{kV}$

0.9

158,000 ACFM \& $350^{\circ} \mathrm{F}$

8 grains/ACF

0.075 grains/ACF

Venturi scrubber Using Soluble Caustic For $\mathrm{SO}_{2}$ Removal

908

$4240 \mathrm{lb} / \mathrm{hr}$ of $\mathrm{SO}_{2}$ Based on $26.5 \mathrm{~T} / \mathrm{hr}$ coal with 48 sulfur $13,500 \mathrm{lb} / \mathrm{hr}(608$ solid) 


\section{DEAERATOR}

Type:

Design Pressure:

Steam Flow:

Feedwater Flow;

Effluent oxygen;

Storage Capacity:
Tray

50 psig.

$54,900 \mathrm{lb} / \mathrm{hr}$ $385,000 \mathrm{lb} / \mathrm{hr}$

Less Than 0.5 pprm

5. $\min$ 


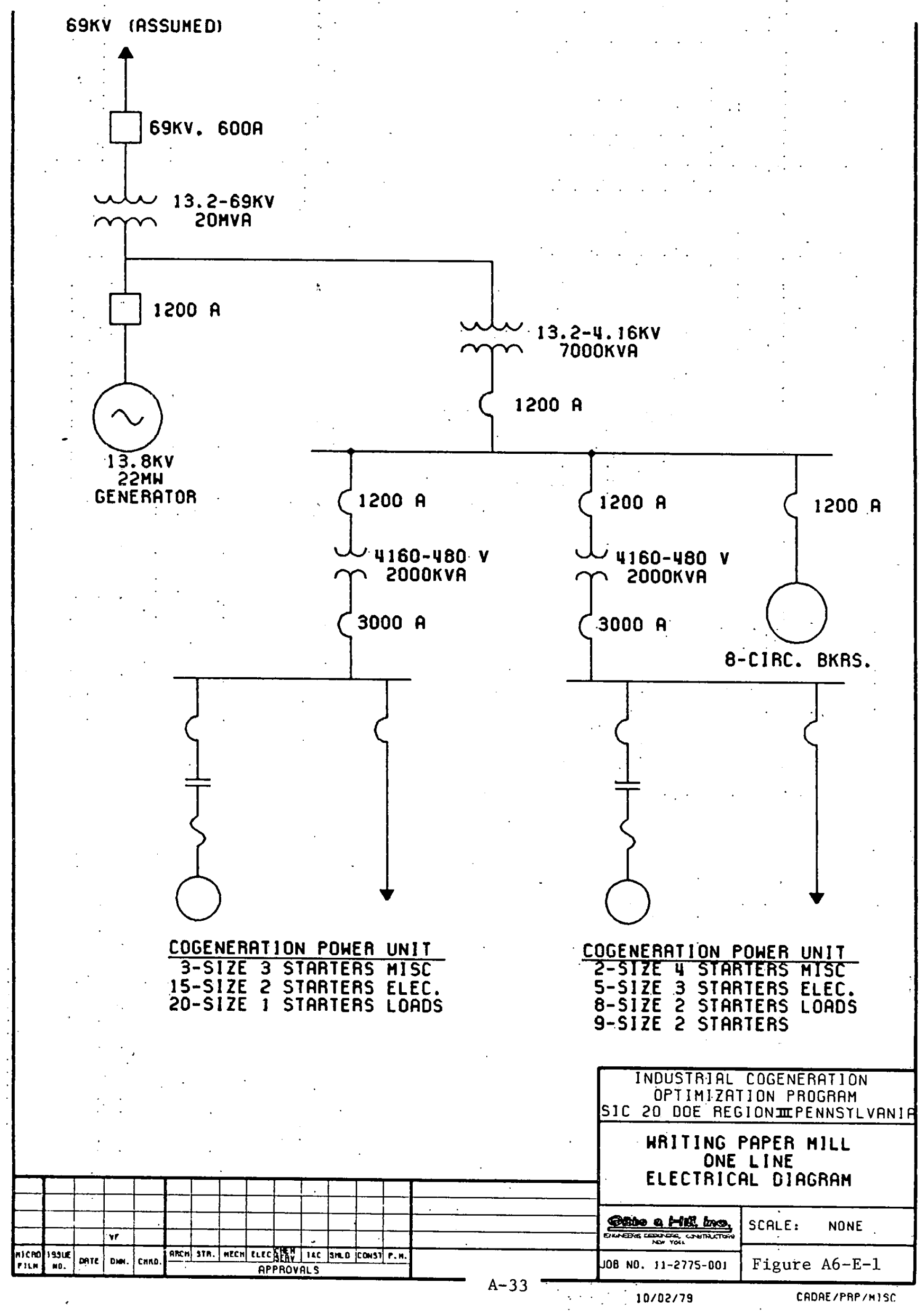




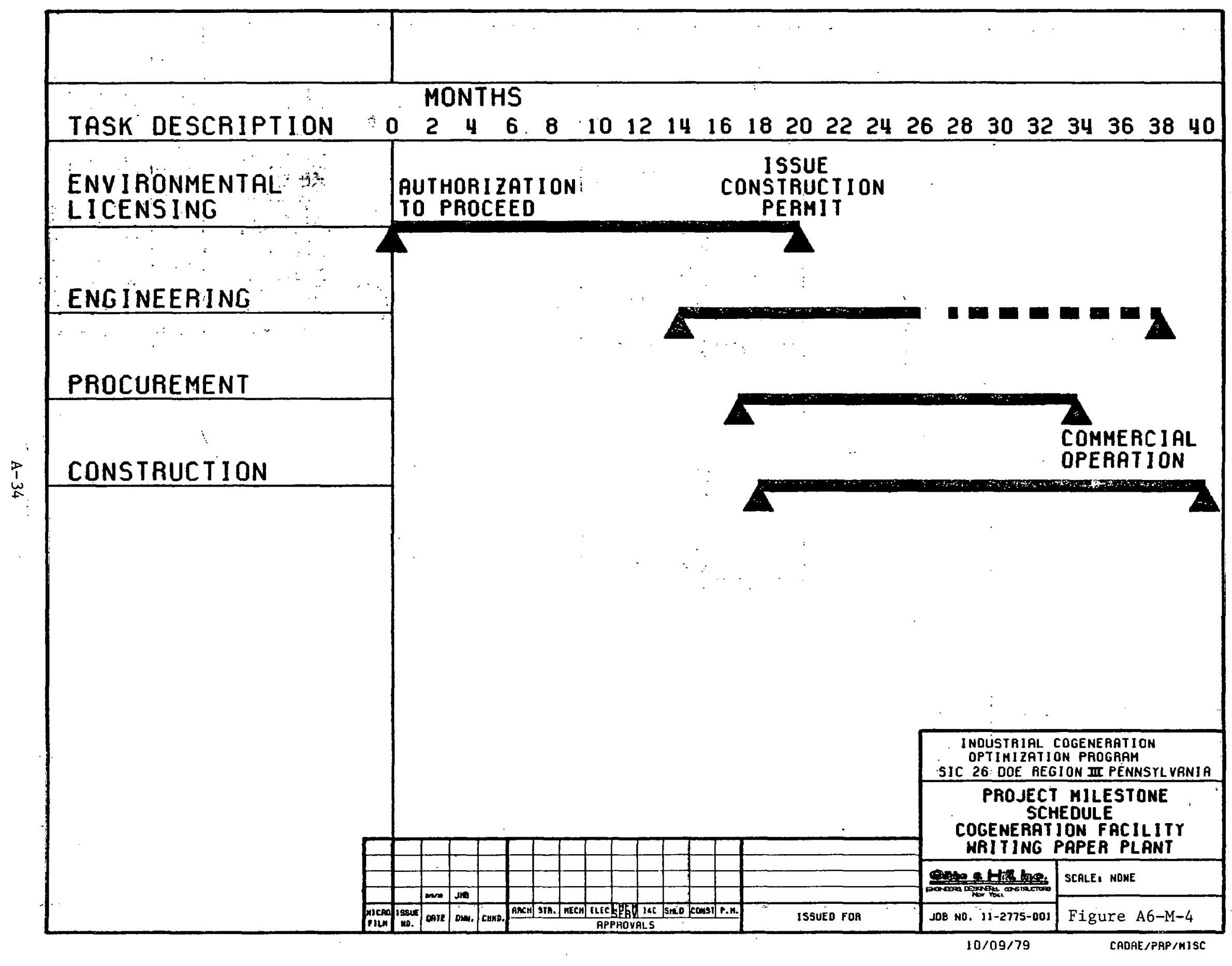




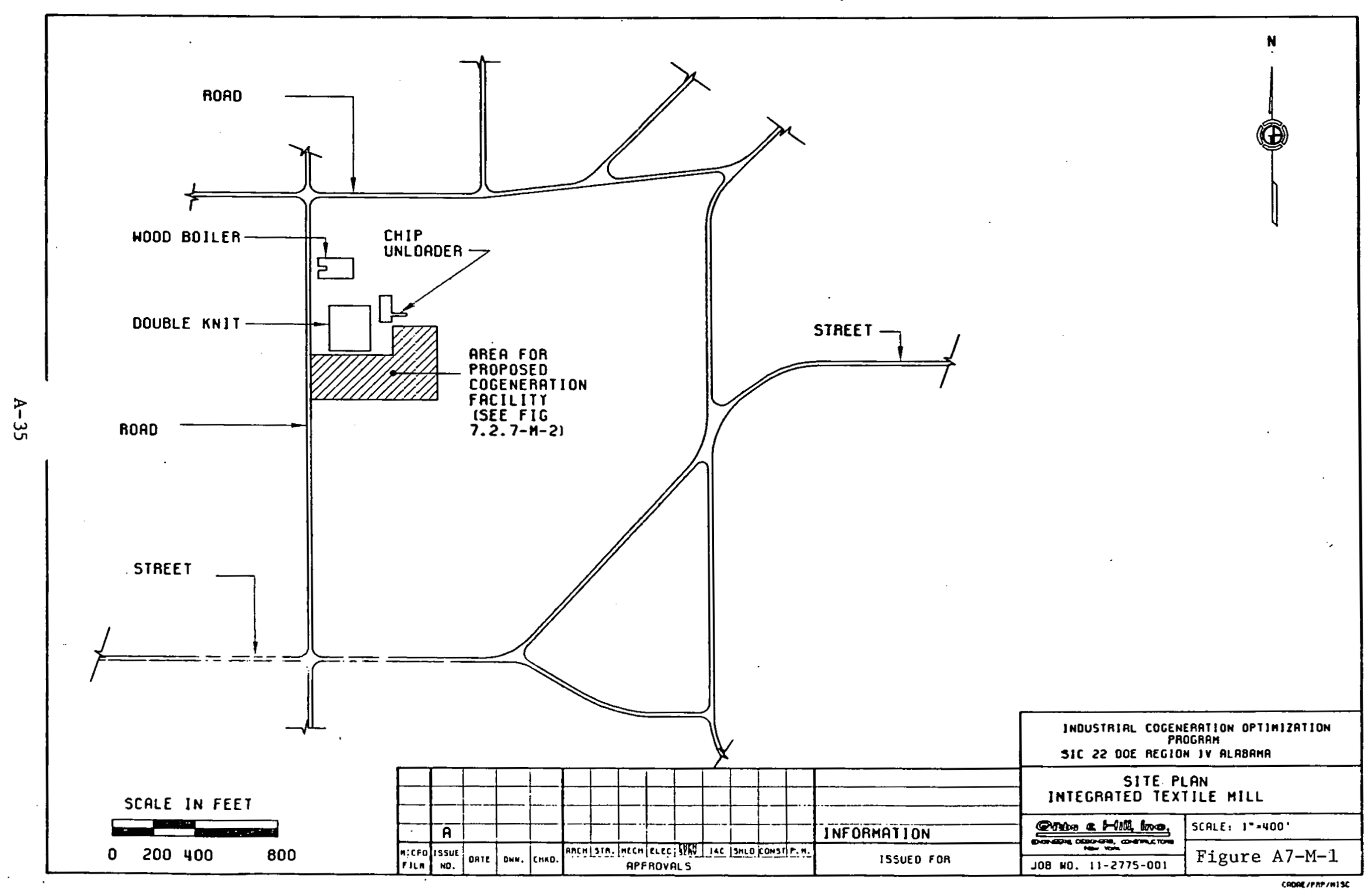




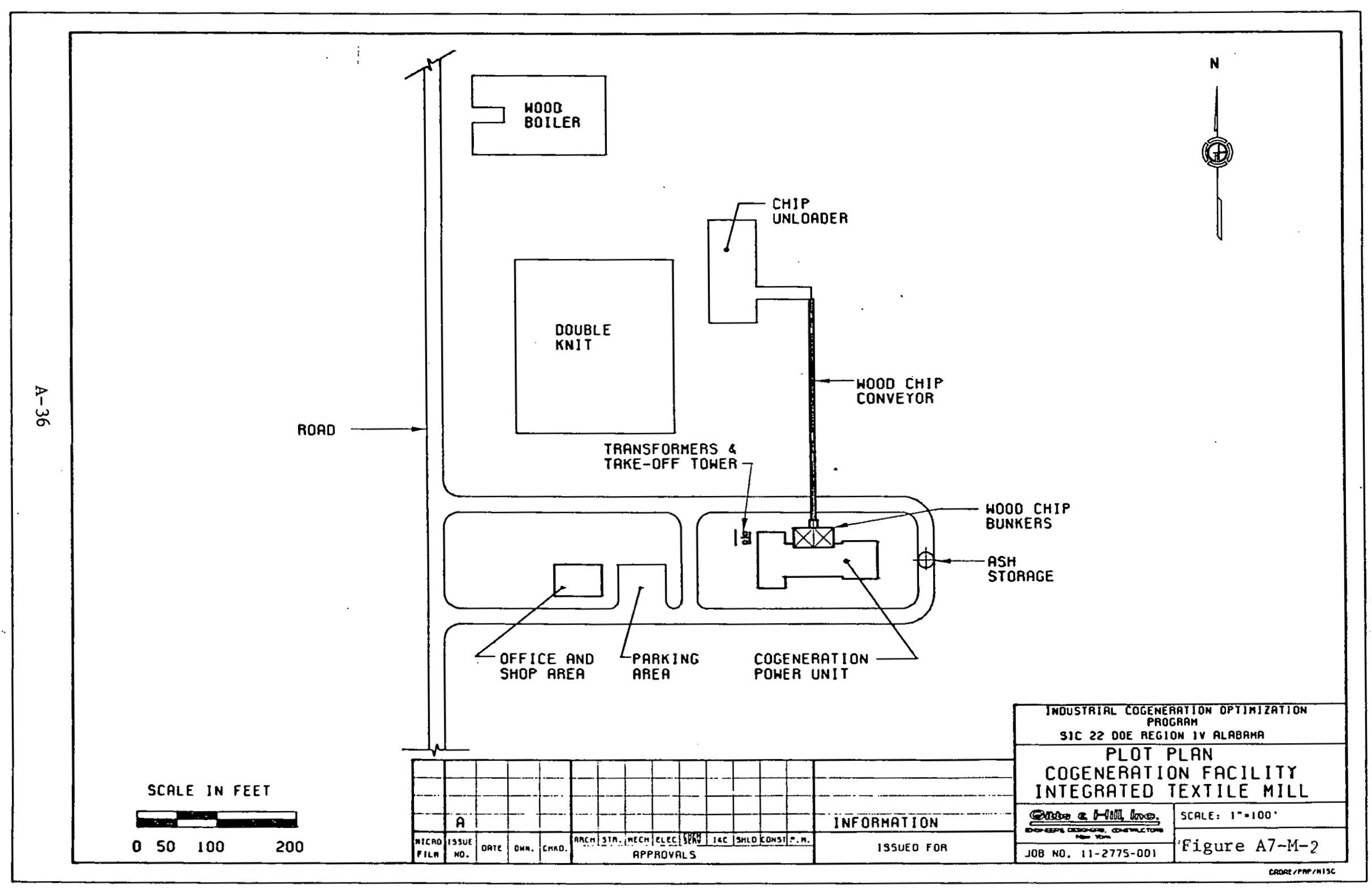




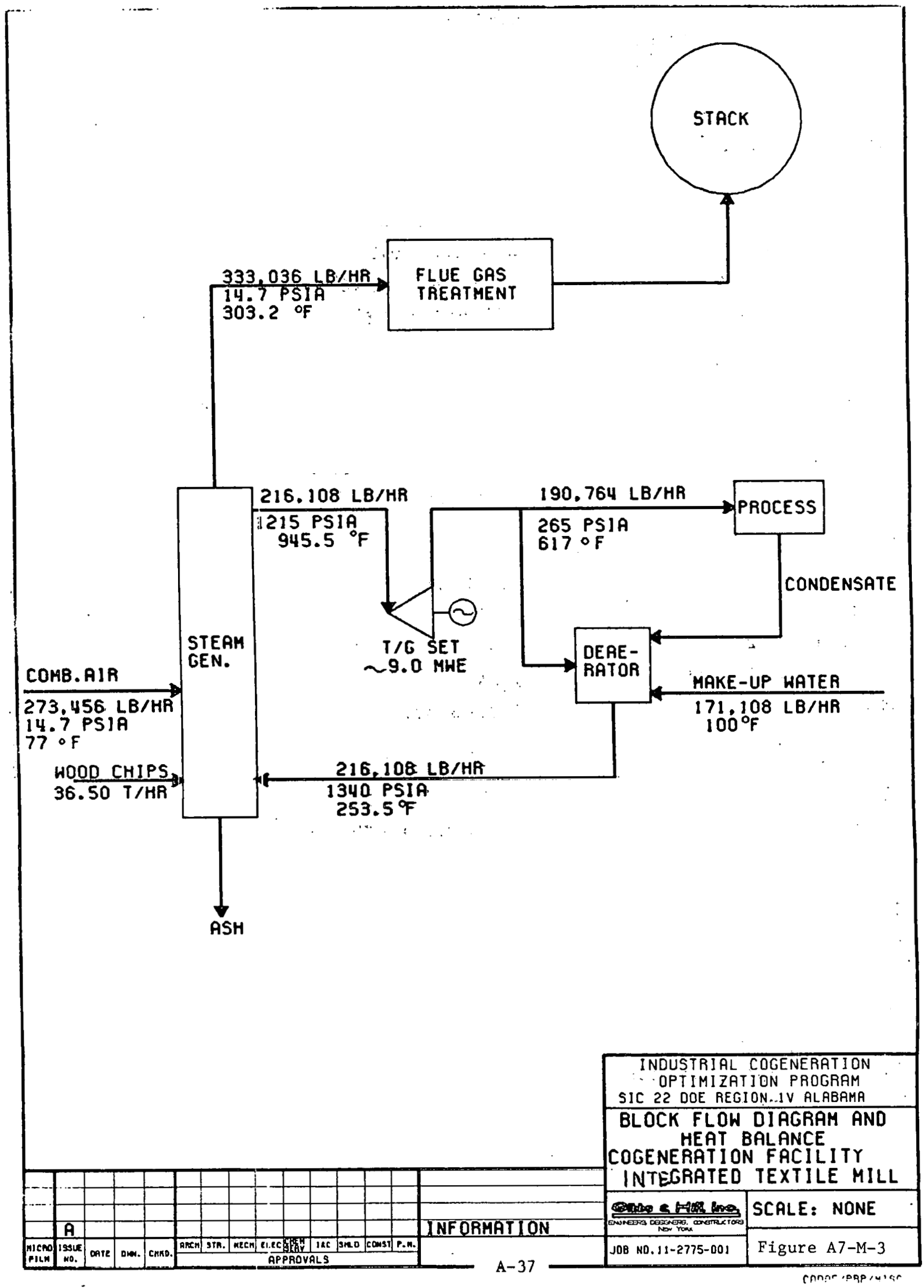




\section{Steam Generator}

Type

Firing

Steam Flow

Steam Conditions

Flue gas flow

Steam Turbine

Type

Steam throttle conditions

Steam exhaust conditions

speed

Generator

Rating

Voltage

Power Factor

Short circuit ratio

cooling

Scrubber

Type

Outlet Loading

Pressure Drop

Deaerator

Type

Design pressure

Steam flow

Feedwater flow

Effluent oxygen content

Storage capacity
Balanced draft, water wall, non-reheat wood chip stoker fired

$216,108 \cdot 1 \mathrm{~b} / \mathrm{hr}$

1215 psia, $946^{\circ} \mathrm{F}$

110,000 ACFM

Single shaft, non-condensing

1215. psia, $946^{\circ} \mathrm{F}$

265 psia, $617^{\circ} \mathrm{F}$

$3600 \mathrm{rpm}$

$9,000 \mathrm{~kW}$

$13.8 \mathrm{kV}$

0.9

0.64

Forced air

Venturi

.05 grains/ACF

$20 " \mathrm{H}_{2} \mathrm{O}$

Tray

50 psig

$25,350 \mathrm{ib} / \mathrm{hr}$

$190,800 \mathrm{lb} / \mathrm{hr}$

Less than $0.5 \mathrm{ppm}$

5 minutes 


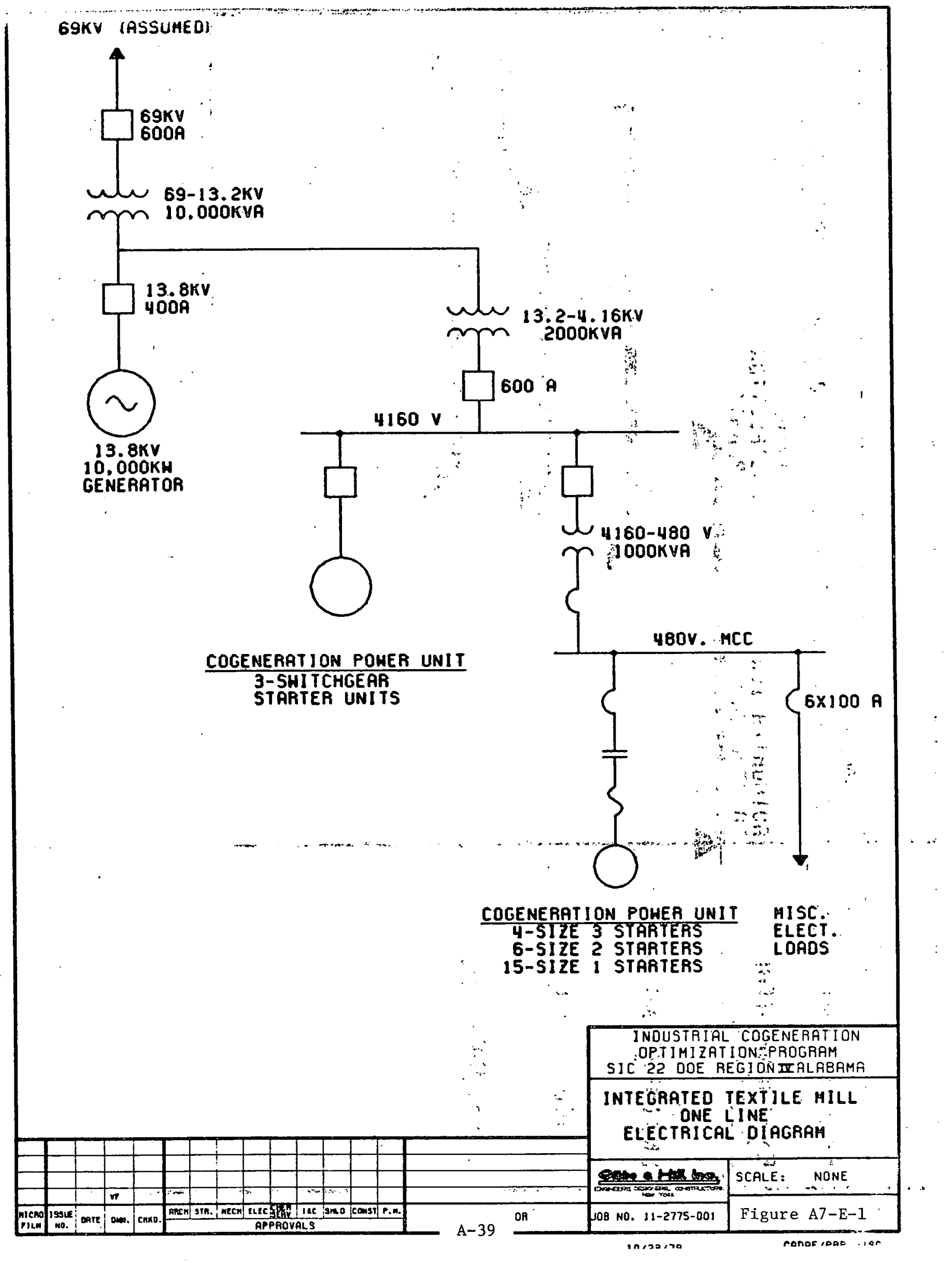




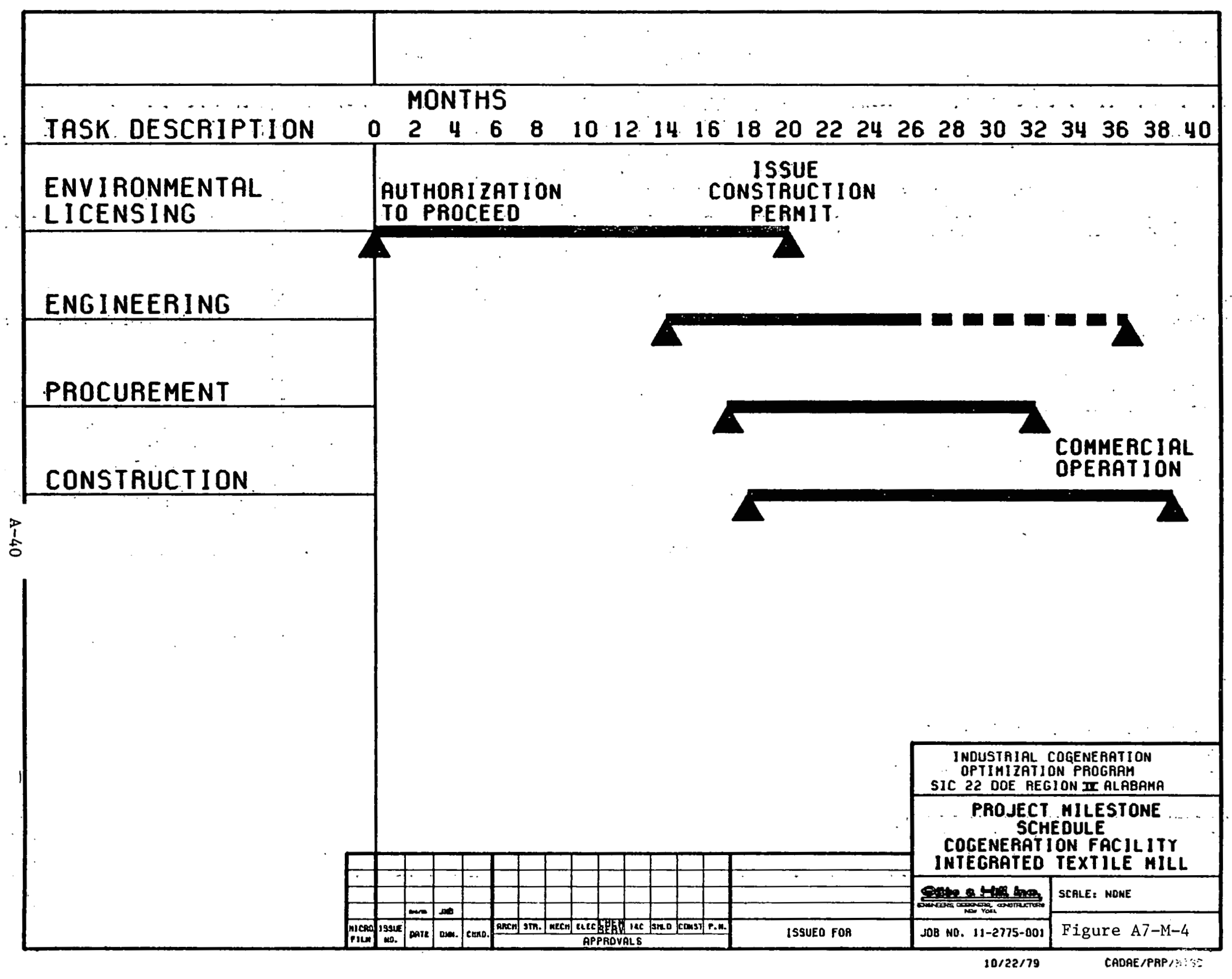




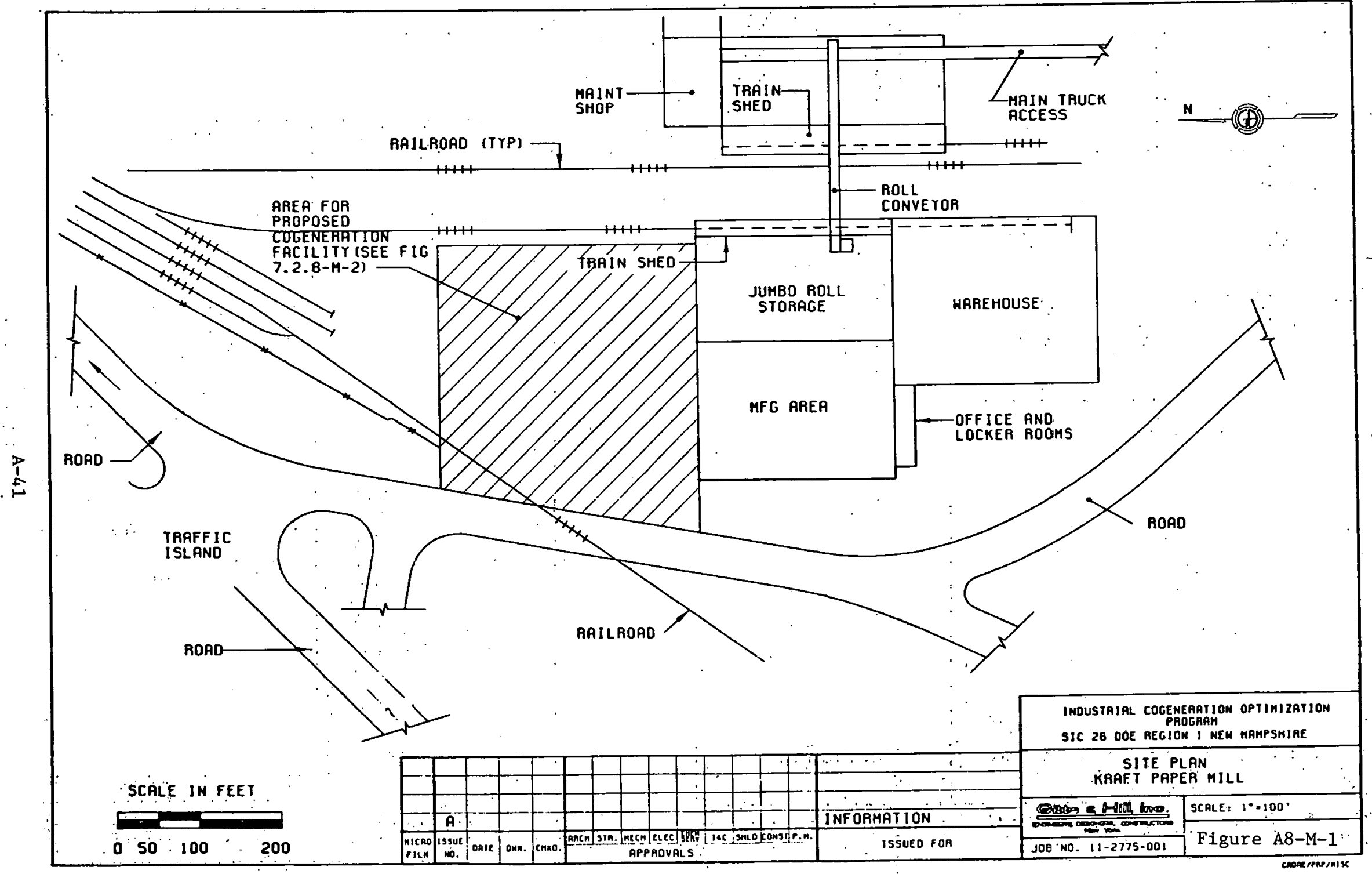




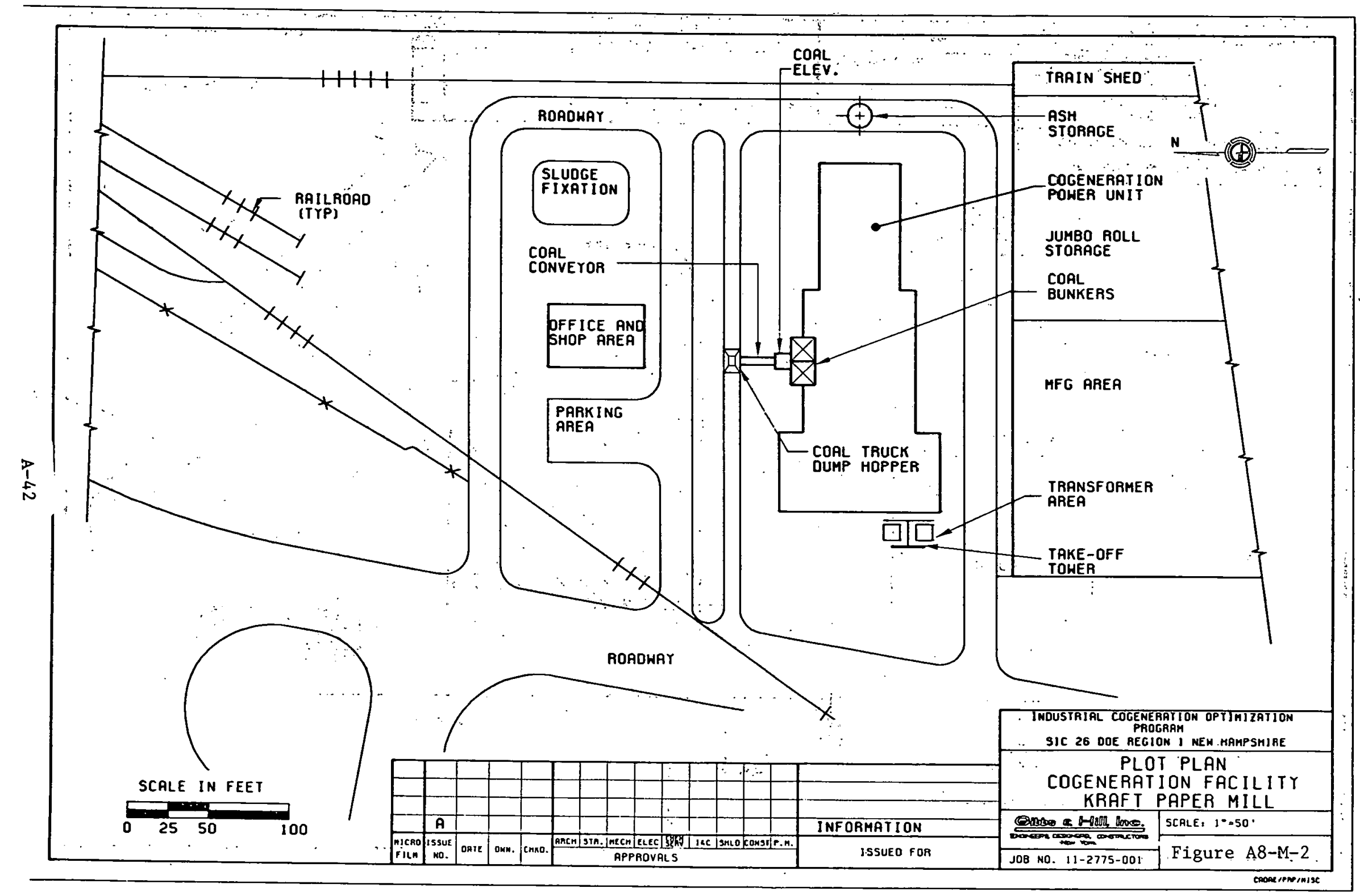




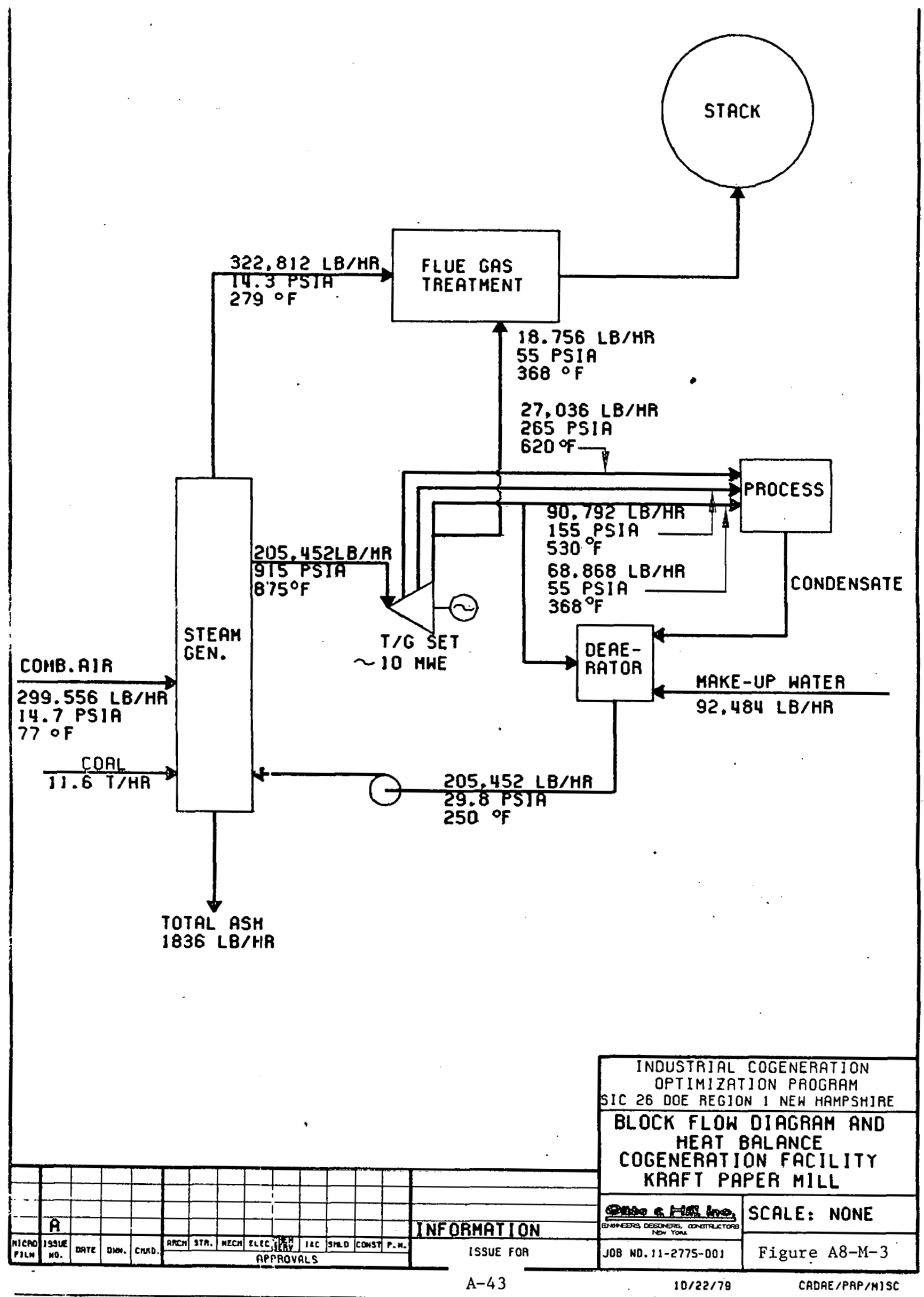




\section{- TABLE A8-1 \\ KRAFT PAPER MILI, COGENERATION FACILITY \\ PRELIMINARY SPECIFICATIONS OF MAJOR COMPONENTS}

Steam Generator

Type

Firing

Steam Flow

Steam Conditions

Flue gas flow

Steam Turbine

Type

Steam throttle conditions

Steam exhaust conditions

Speed

Generator

Rating

Voltage

Power Factor

short circuit ratio

cooling

Electrostatic Precipitator

Volumetric capacity

Dust loading inlet

Dust loading, outlet

Flue Gas Desulfurization

Type

Capacity
Balanced draft water wall, non-reheat

Crushed coal, stoker fired

$205,452 \mathrm{lb} / \mathrm{hr}$

915 psia, $875^{\circ} \mathrm{F}$

103,000 ACFM

Single shaft, non condensing

915 psia, $875^{\circ} \mathrm{F}$

55 psia, 155 psia

$3600 \mathrm{rpm}$
$10,000 \mathrm{~kW}$

$13.8 \mathrm{kV}$

0.9

0.64

Forced air
100,000 ACFM

$1 \mathrm{gr} / \mathrm{ACF}$

$90 \%$ removal efficiency

Spray tower, caustic feed

103,000 ACFM for coal with 4.3 percent sulfur 
TABLE A8-1 (Continued)

Deaerator

Type

Tray

Design pressure

50 psig

Feedwater flow

$185,000 \mathrm{lb} / \mathrm{hr}$

Effluent oxygen content

Less than $.5 \mathrm{ppm}$

Storage capacity

5 minutes 


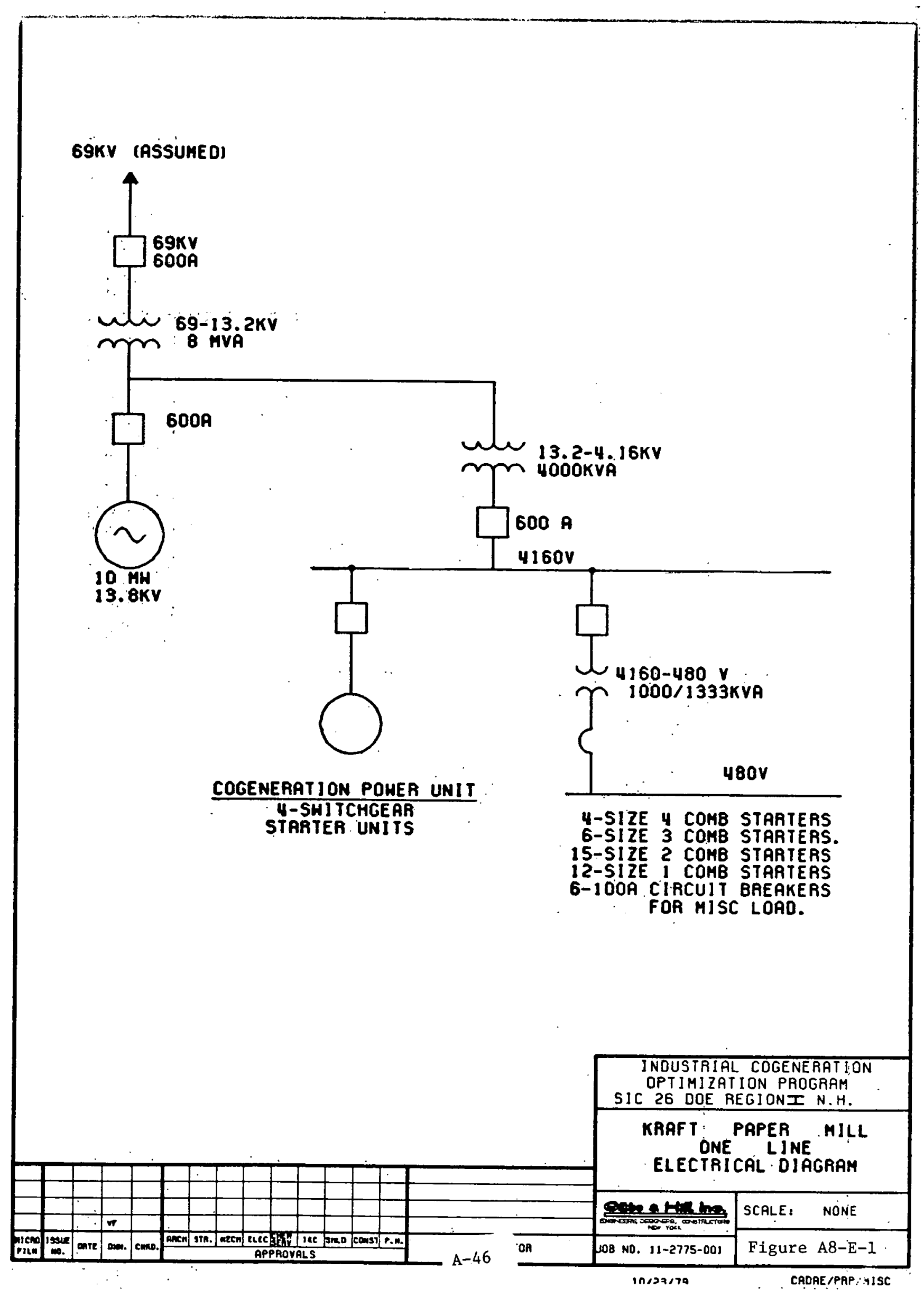




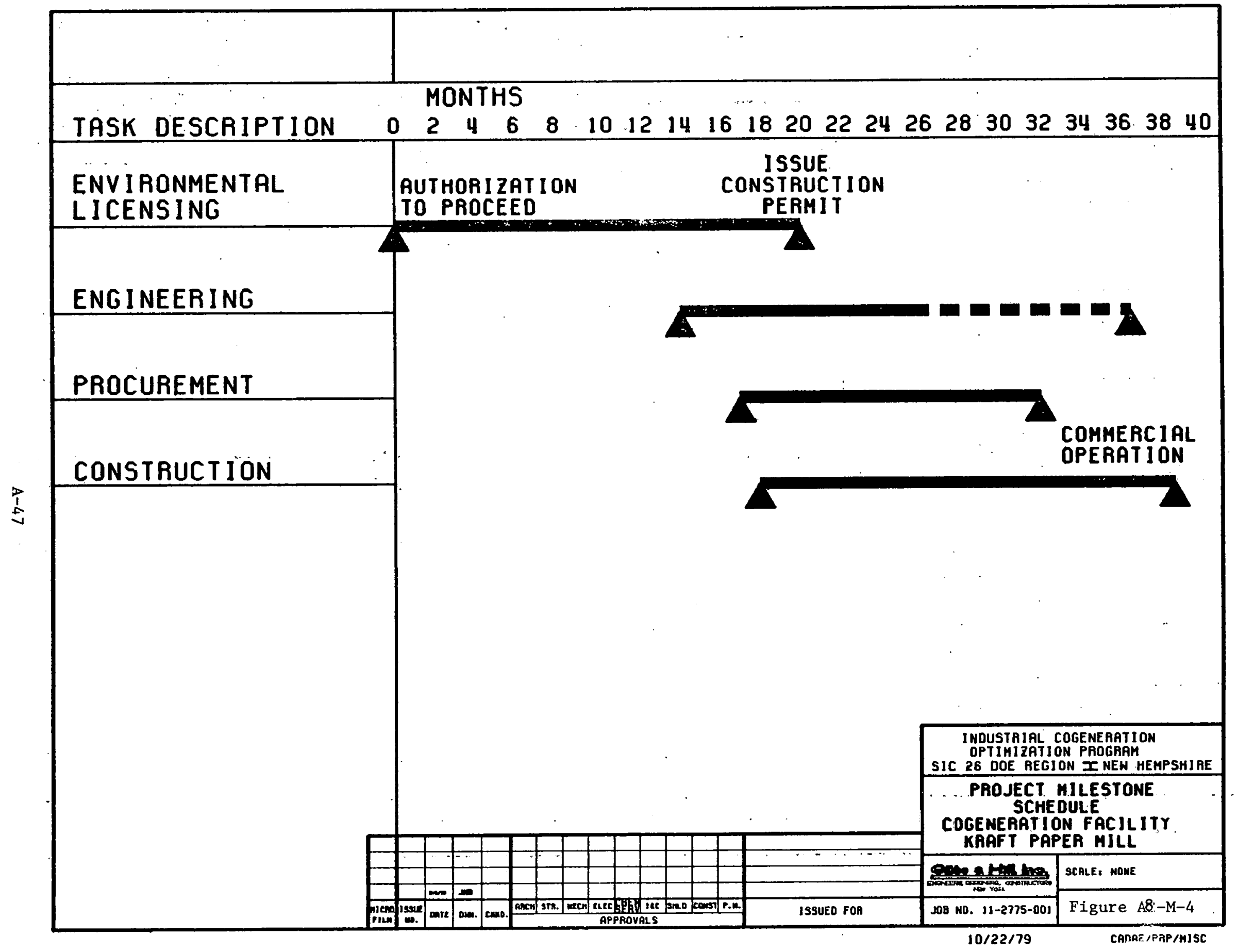




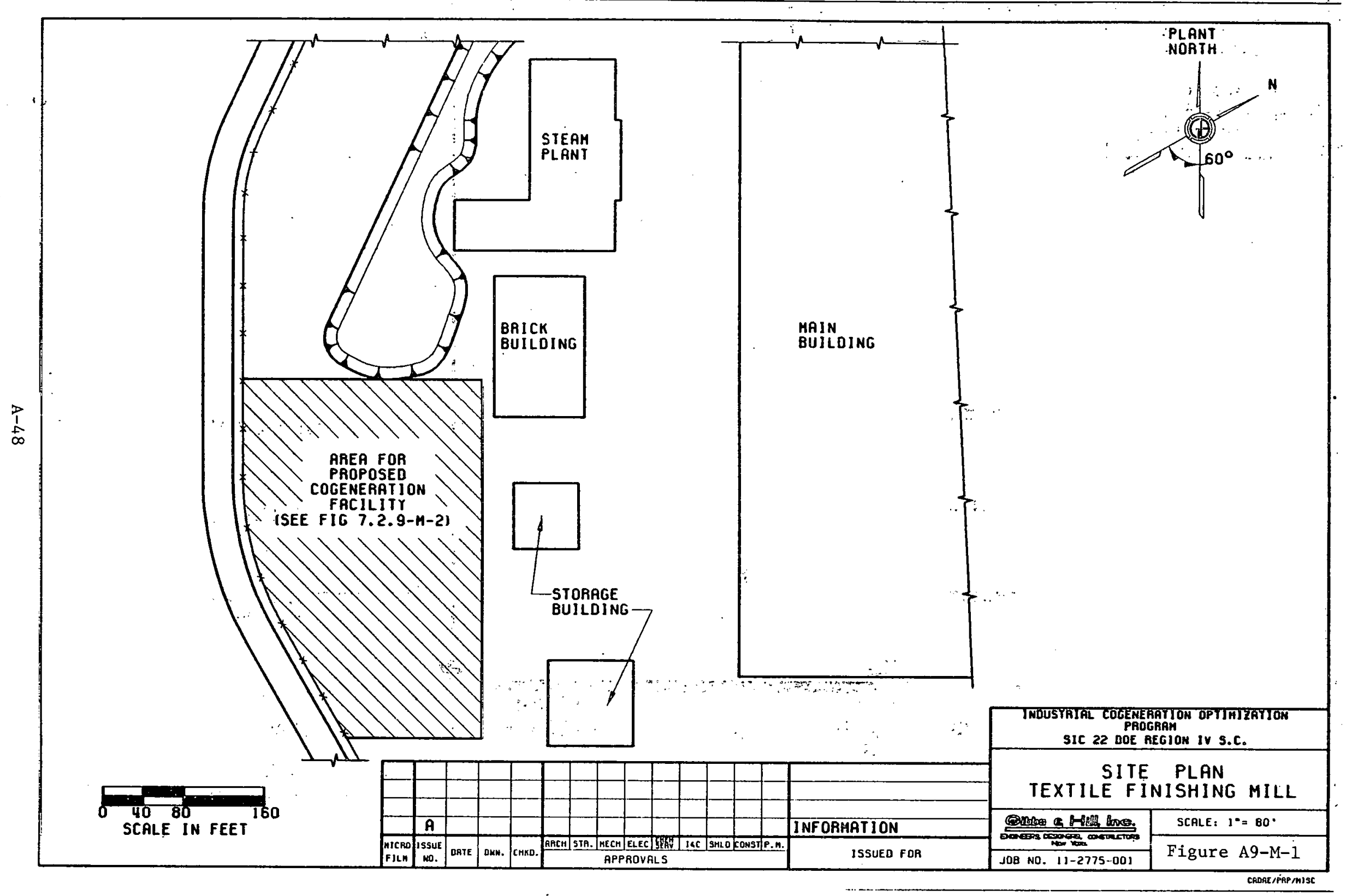




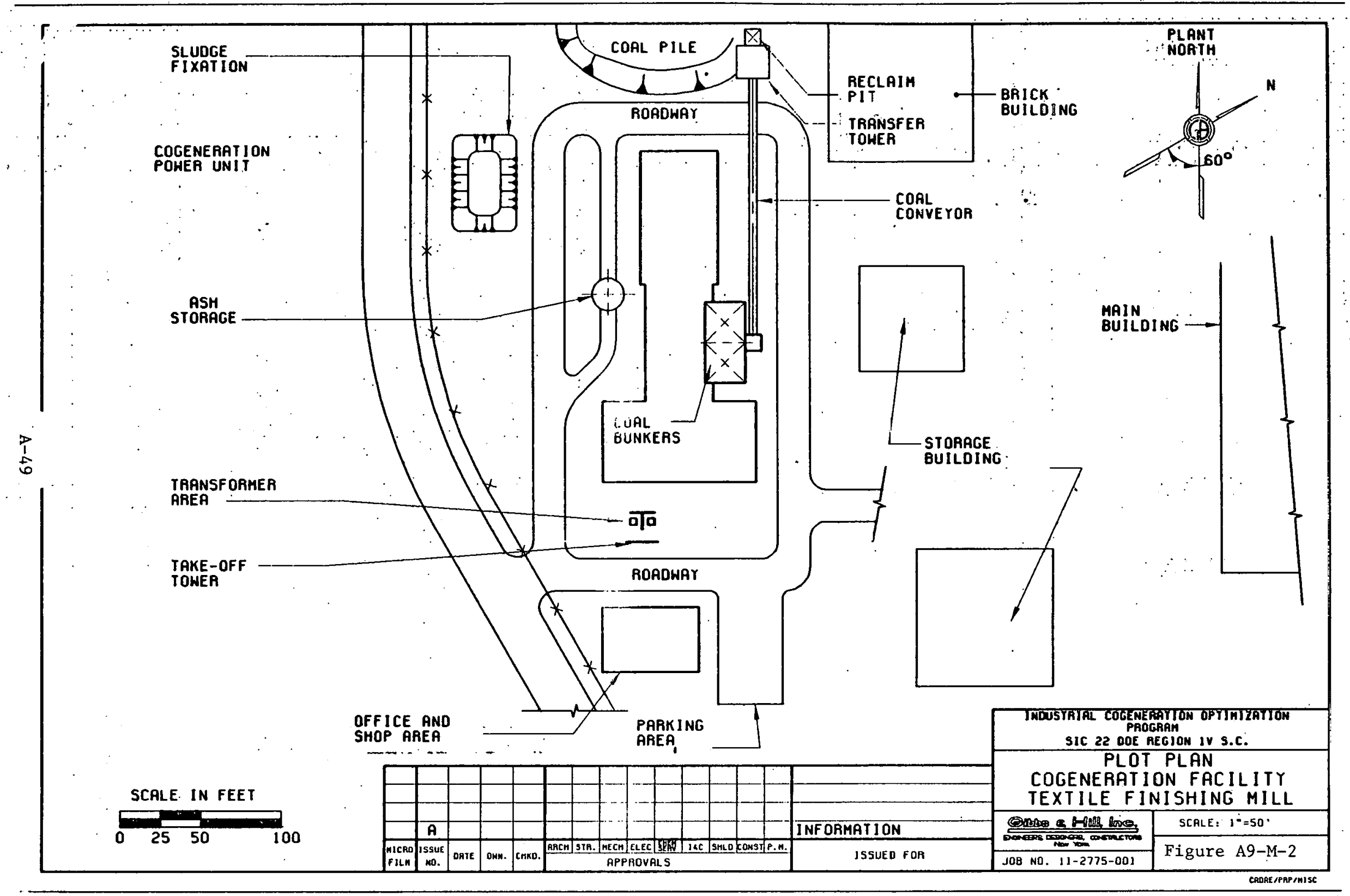




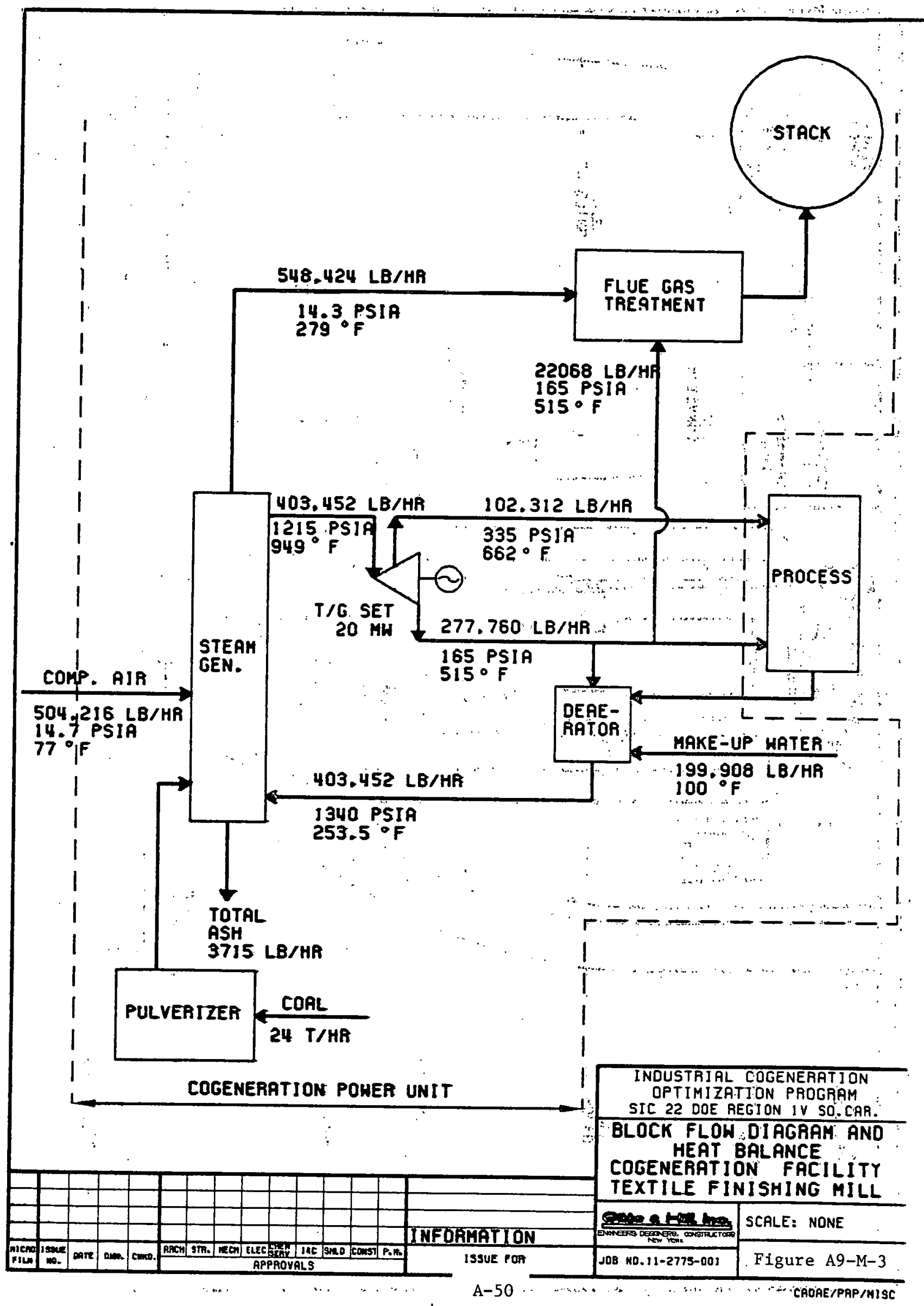


Steam Generator

Type

Firing

Steam Flow

Steam Conditions

Flue Gas Flow

Steam Turbine

Type

Steam throttle conditions

Steam Exhaust condition

Extraction Point

speed

Generator

Rating

Voltage

Power Factor

Short Circuit Ratio

cooling

Electrostatic Precipitator

Volumetric Capacity

Dust Loading, inlet

Dust Loading, outlet

Flue Gas Desulfurization

Type

Capacity
Balanced draft, waterwall, non-reheat Crushed coal, stoker fired

$403,452 \mathrm{lb} / \mathrm{hr}$

1215 psia, $949^{\circ} \mathrm{F}$

175,000 ACFM

Single shaft, non-condensing

1215 psia, $949^{\circ} \mathrm{F}$

165 psia, $515^{\circ} \mathrm{F}$

335 psia, $662^{\circ} \mathrm{F}$

$360 \mathrm{rpm}$

$20,000 \mathrm{~kW}$

$13.8 \mathrm{kV}$

0.9

0.64

Forced Air

175,000 ACFM

$1.5 \mathrm{gr} / \mathrm{ACF}$

$90 \%$ removal efficiency

Spray tower, caustic feed

175,000 ACFM for coal with $1.77 \%$ sulfur 
Deaerator

Type

Design Pressure

Feedwater Flow

Effluent Oxygen Content

Storage Capacity
Tray

50 psig

$301,1401 \mathrm{~b} / \mathrm{hr}$

Less than $0.5 \mathrm{ppm}$

5 min 


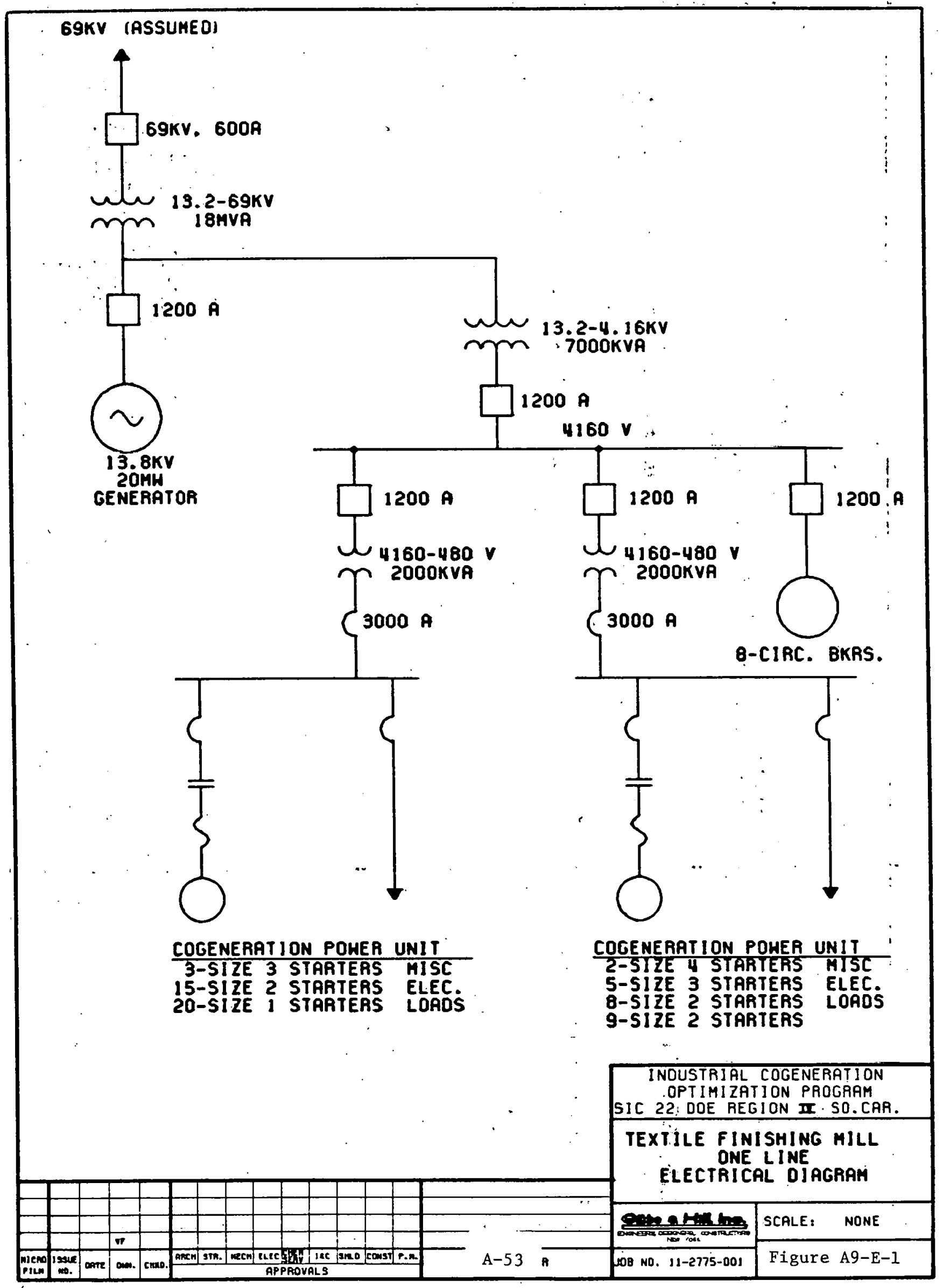




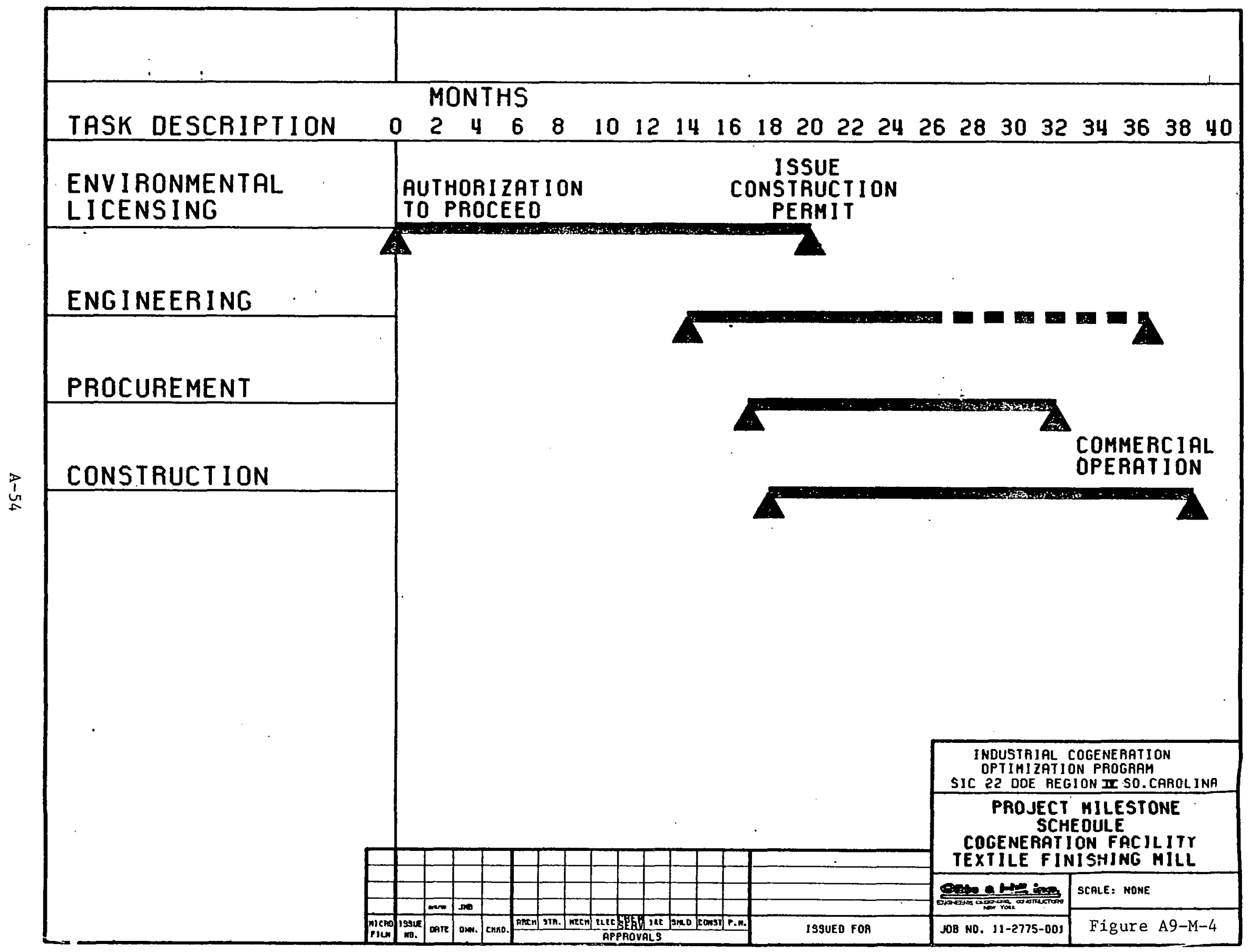




\section{APPENDIX B1: LIMITATIONS ON FUEL UTILIZATION IN ENERGY CONVERSION}

The primary factor limiting energy utilization by a fossil-fuel-fired cogeneration energy conversion system is the thermal losses through the stack gases and ash. These losses are in the following forms:

- Sensible heat of dry combustion products

- Sensibile heat of water vapor in products

- Sensible heat of ash in products

- Latent heat of water vapor in products.

Water vapor is derived from the moisture in the combustion air and the water and hydrogen in the fuel.

Since both the water content and the hydrogen content vary substantially with fuel type, these losses are a rather strong function of fuel type. If, however, the lower heating value of the fuel is used as the basis for loss analysis rather than the higher heating value, the latent heat factor is eliminated from consideration and a rational analysis of the sensible heat losses is possible.

The thermal losses in the combustion products in relation to the lower heating value of the fuel are given by the following expression:

$$
\begin{aligned}
& \frac{q_{\text {loss }}}{W_{f} \times L H V_{f}}=\left(\left(\left(\frac{W a}{W f}\right)_{S T}+1\right) \times \phi_{A I R} \times(C p)_{g a s} \times\left(t_{\text {stack }}-t_{a m b}\right)\right. \\
& \left.+A \times(C p) \text { solid } \times\left(t_{\text {solid }}-t_{a m b}\right)\right) / L H V_{f},
\end{aligned}
$$

where

$$
\begin{array}{ll}
\mathrm{q}_{\text {loss }} & =\text { thermal losses }-\mathrm{Btu} / \mathrm{hr} \\
\mathrm{W}_{\mathrm{f}} & =\text { fuel flow rate }-1 \mathrm{~b} / \mathrm{hr} \\
\mathrm{LHV}_{\mathrm{f}} & =\text { lower heating value of fuel }-\mathrm{Btu} / \mathrm{lb} \\
\mathrm{W}_{\mathrm{a}} & =\text { combustion airflow rate }-1 \mathrm{~b} / \mathrm{hr} \\
(\mathrm{Wa} / \mathrm{Wf})_{\mathrm{ST}} & =\text { stolchiometric air/fuel ratio } \\
\phi_{\mathrm{AIR}} & =\text { air equivalence ratio } \\
\left(\mathrm{Cp}_{\mathrm{g}}{ }_{\text {gas }}\right. & =\text { specific heat of gaseous products }-\mathrm{Btu} / 1 \mathrm{~b} /{ }^{\circ} \mathrm{F} \\
\mathrm{t}_{\mathrm{stack}} & =\text { temperature of gaseous products, }{ }^{\circ} \mathrm{F} \\
\mathrm{t}_{\mathrm{amb}} & =\text { ambient or reference temperature, }{ }^{\circ} \mathrm{F} \\
\mathrm{A} & =\text { fraction of ash in as-fired coal. }
\end{array}
$$


$t_{\text {solid }}=$ temperature of solid wastes.

The specific heat for gaseous products is approximately 0.25 and for ash about 0.20 .

The expressions for thermal losses for various conversion systems and fuel combinations are given in Table B.1-1.

The minimum allowable stack temperature is a function of the fuel type, the air equivalence ratio, the fuel sulfur content, and the heat exchange configuration. The fuel type and the air equivalence ratio determine the moisture content of the flue gases, and the fuel sulfur content and the air equivalence ratio determine the $\mathrm{SO}_{3}$ concentration. These two factors determine the acid dewpoint, which controls cold end corrosion. A major boiler manufacturer has published recommended minimum metal temperatures in the heat recovery train as a function of fuel type and sulfur content (see Figure B.1-1).

Table B.1-1 shows that, for a given stack-gas temperature, the sensible heat losses from an open-cycle gas turbine exhaust are, at a minimum, about $2-1 / 2$ times as much as those from boiler flue gases. This difference will be partially offset by the lower dewpoint of the gas turbine exhaust. 
IABLE B.1-1

THERMAL LOSSES FROM PRODUCTS OF COMBUSTION

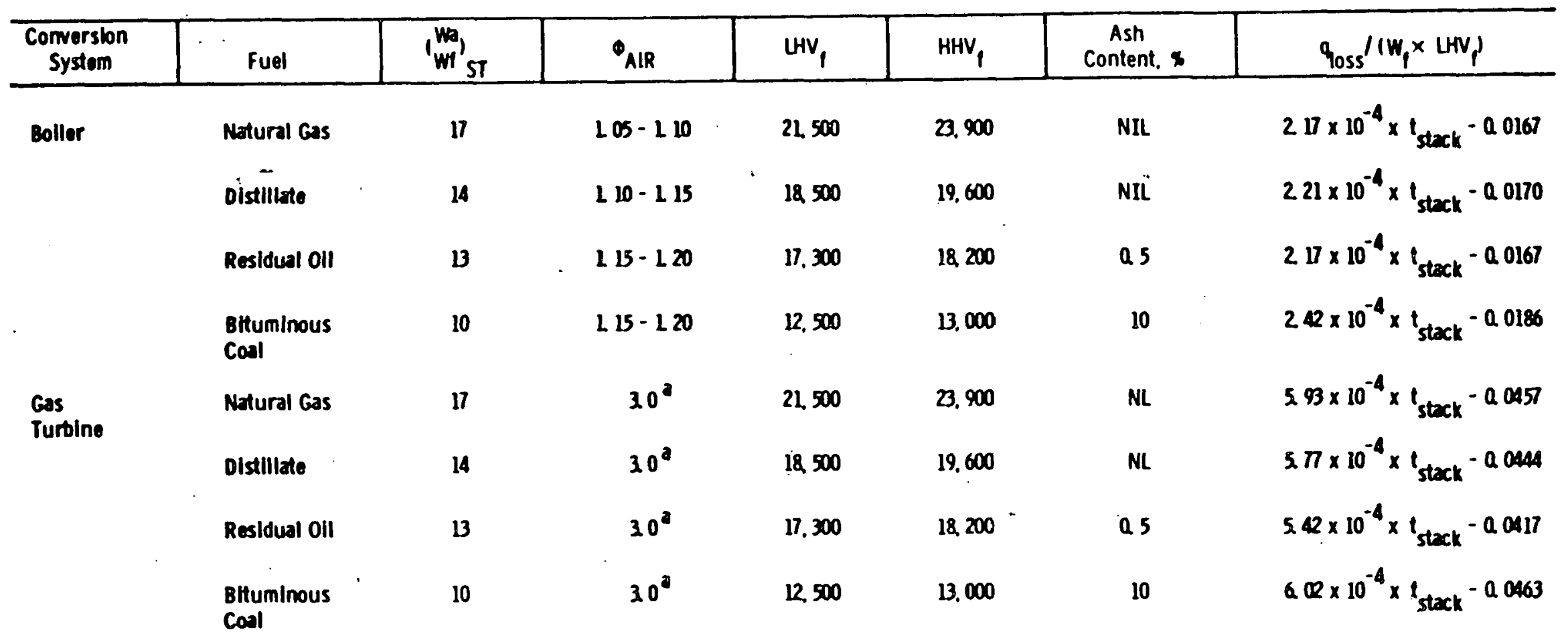

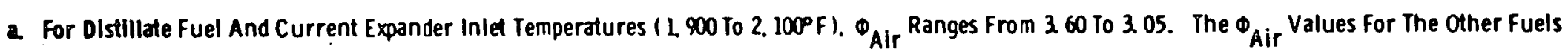
Over This Temperature Range Would Be Approximately The Same 


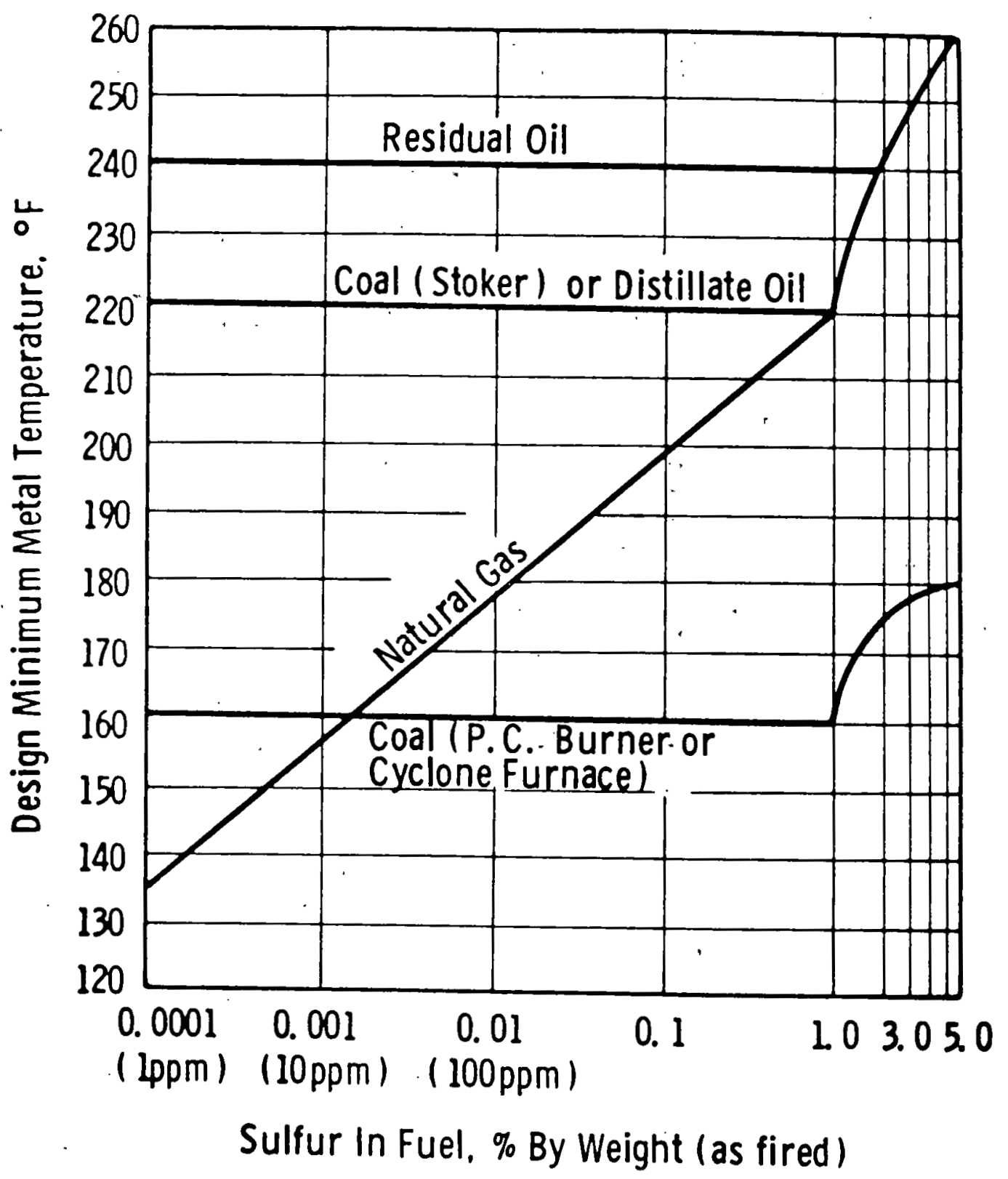

Fig. B.1-1 - Limiting tube-metal temperatures to avoid external corrosion in economizers or air heaters when burning fuels containing sulphur 
APPENDIX B2: ANALYSIS OF BOILER BLOWDOWN REQUIREMENTS AND THERMODYNAMIC LOSSES DIJE TO BLOWDOWN

Figure B.2-1 shows a generalized model of an industrial bolier for cogeneration application, with optlons for process steam and power steam production. The blowdown requirements ( $\mathrm{W}_{\mathrm{BD}} / \mathrm{WS}$ ) for this boiler model with either option are given in Figure B.2-2 as a function of the following:

$$
\begin{aligned}
& C_{M U} \text { - concentration of dissolved solids in makeup water } \\
& C_{B D} \text { - concentration of dissolved solids in blowdown from boiler drum } \\
& E \quad \text { - ratio of concentration of suspended solids in steam leaving } \\
& \quad \text { drum to concentration of dissolved solids in drum which is } \\
& \quad \text { equal to } C_{B D} \\
& R \quad \text { - ratio of condensate recycled from process to redundant steam } \\
& \text { supplied to process }
\end{aligned}
$$

Table B.2-1 gives the allowable concentrations of total dissolved solids for boiler water as specified by the American Bofler Manufacturers Association (Combustion Engineering, 1966). A realistic value for $\mathrm{E}$ is $1 \times 10^{-4}$ (Sokolowski and Schwartz, 1972)

TABLE B. $2-1$

ABMA ALLOWABLE BOILER WATER CONCENTRATIONS

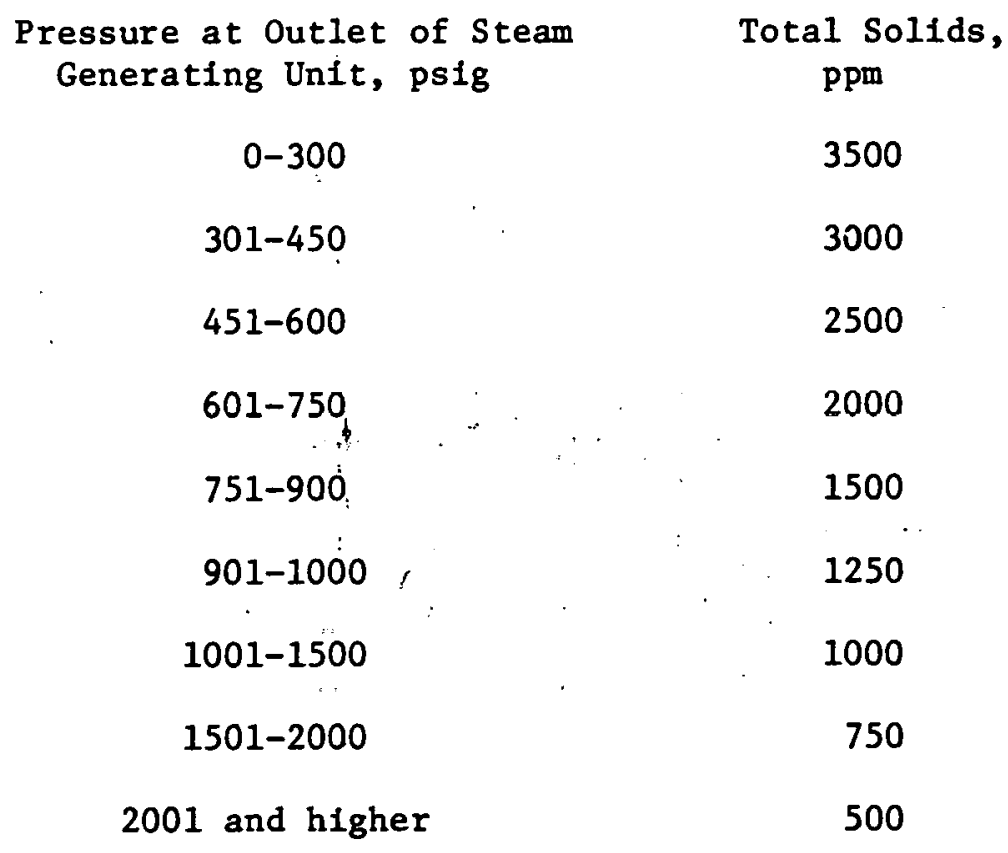




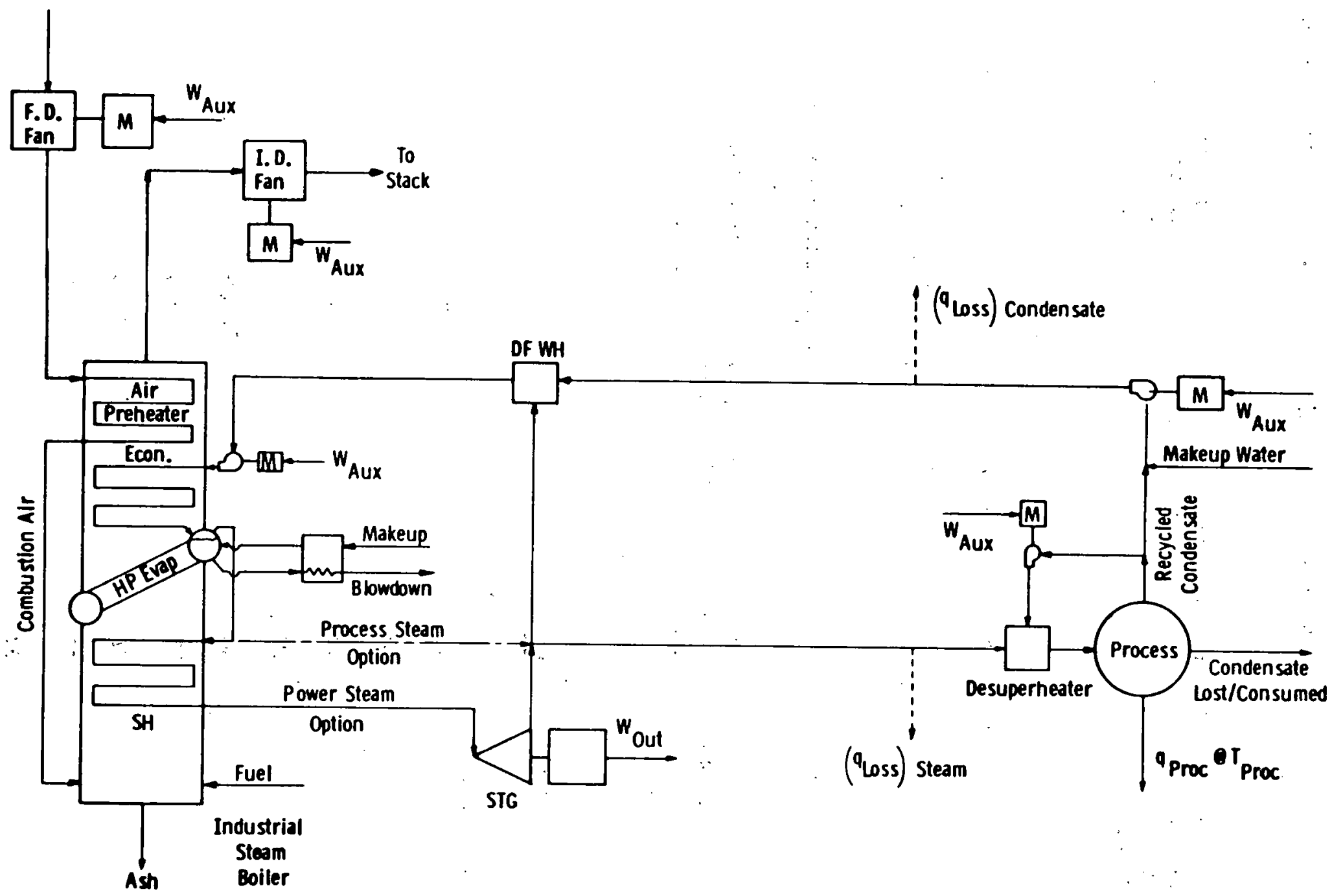

Fig. B.2-1 - Generalized model of conventional steam cogeneration system 
Distillation will yield makeup water with dissolved solids concentrations of 5 ppm or less (Handbook, 1973). Demineralization will give even lower concentrations.

The recycled condensate ratio is a function of the steam consumed and the steam and/or condensate lost in the process.

The blowdown requirements shown in Figure B.2-2 are minimum values. The condensate recycled from an industrial process may be contaminated by corrosion products or by in-leakage of raw water or materials used in the process. The use of chemicals for $\mathrm{pH}$ control and oxygen scavenging that contribute to the dissolved solids content of the boiler feedwater would increase the boiler blowdown requirements. This analysis indicates that blowdown rates often used in an industrial boiler ( $\sim 10 \%)$ are excessive.

Figure B.2-3 gives the thermodynamic loss due to blowdown from a powerboiler as a function of recuperator effectiveness, superheated steam temperature, condensate temperature, and superheated steam pressure.

Figure B.2-4 gives the thermodynamic loss due to blowdown from a process steam boiler as a function of recuperator effectiveness, condensate temperature, and process steam temperature (saturated temperature at process steam supply pressure).

Figures B.2-2, 3, and 4 are applicable to waste heat boilers for process steam and heat recovery steam generators for power steam, as well as to conventionally fired steam boilers for process or power steam, as shown. in Figure B.2-1.

Figures B.2-2 and 3 show that the use of recuperators on boiler blowdown will reduce the thermodynamic losses due to blowdown to nearly negligible levels:

\section{REFERENCES TO APPENDIX B 2}

Combustion Engineering, Revised Edition, 1966, p. 8-46.

Handbook of Environmental Control, Volume III, CRC Press, 1973, p. 508.

Sokolowski, P. F. and Schwartz, D. A., "Design and Development of High Pressure Modular Heat Recovery Steam Generators for Gas Turbine/Steam Turbine Combined Cycles," Presented at American Power Conference, Chicago, Ill., April 18-20, 1972. 


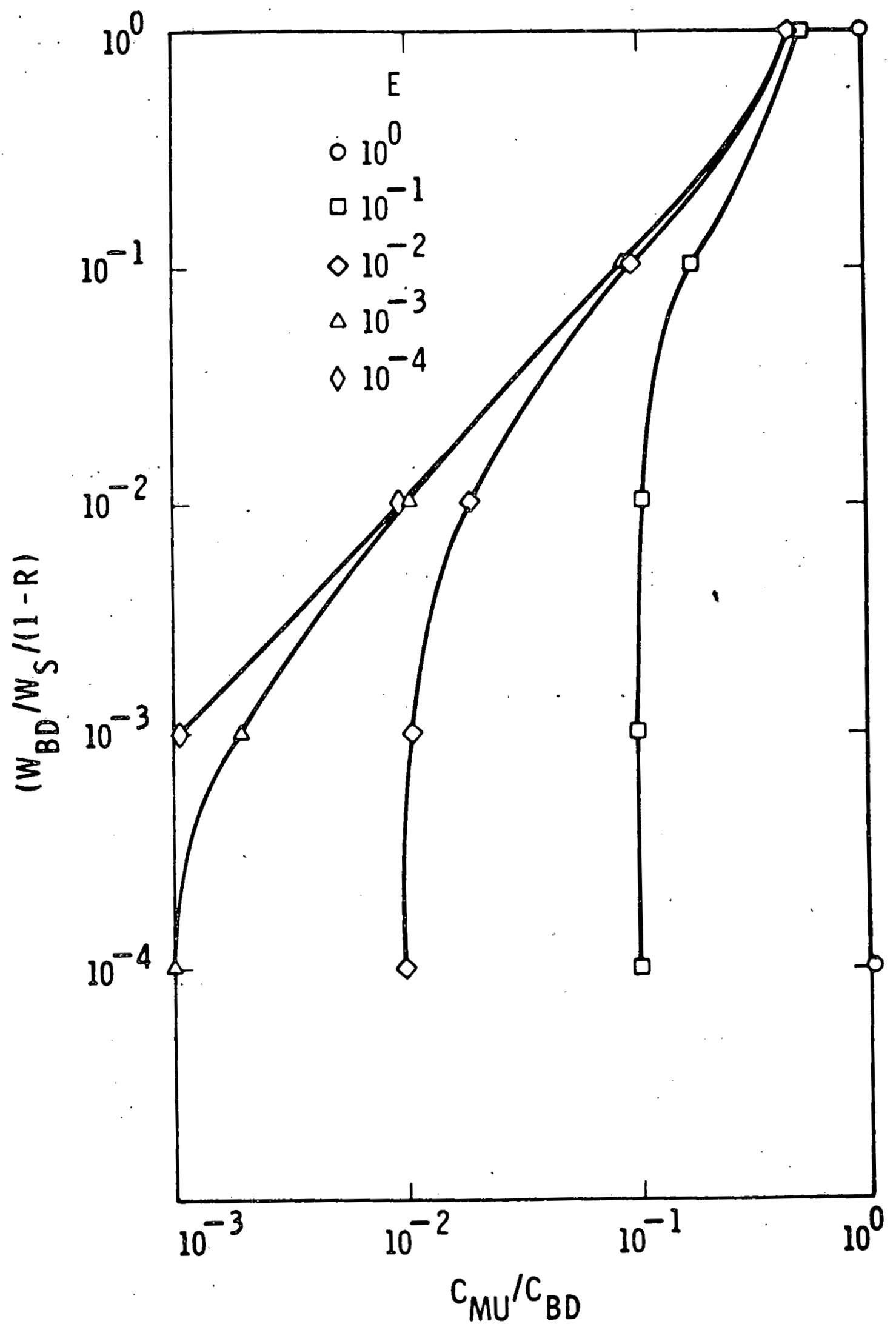

Fig. B. 2-2- Blowdown requirements for steam boilers used for cogeneration applications 

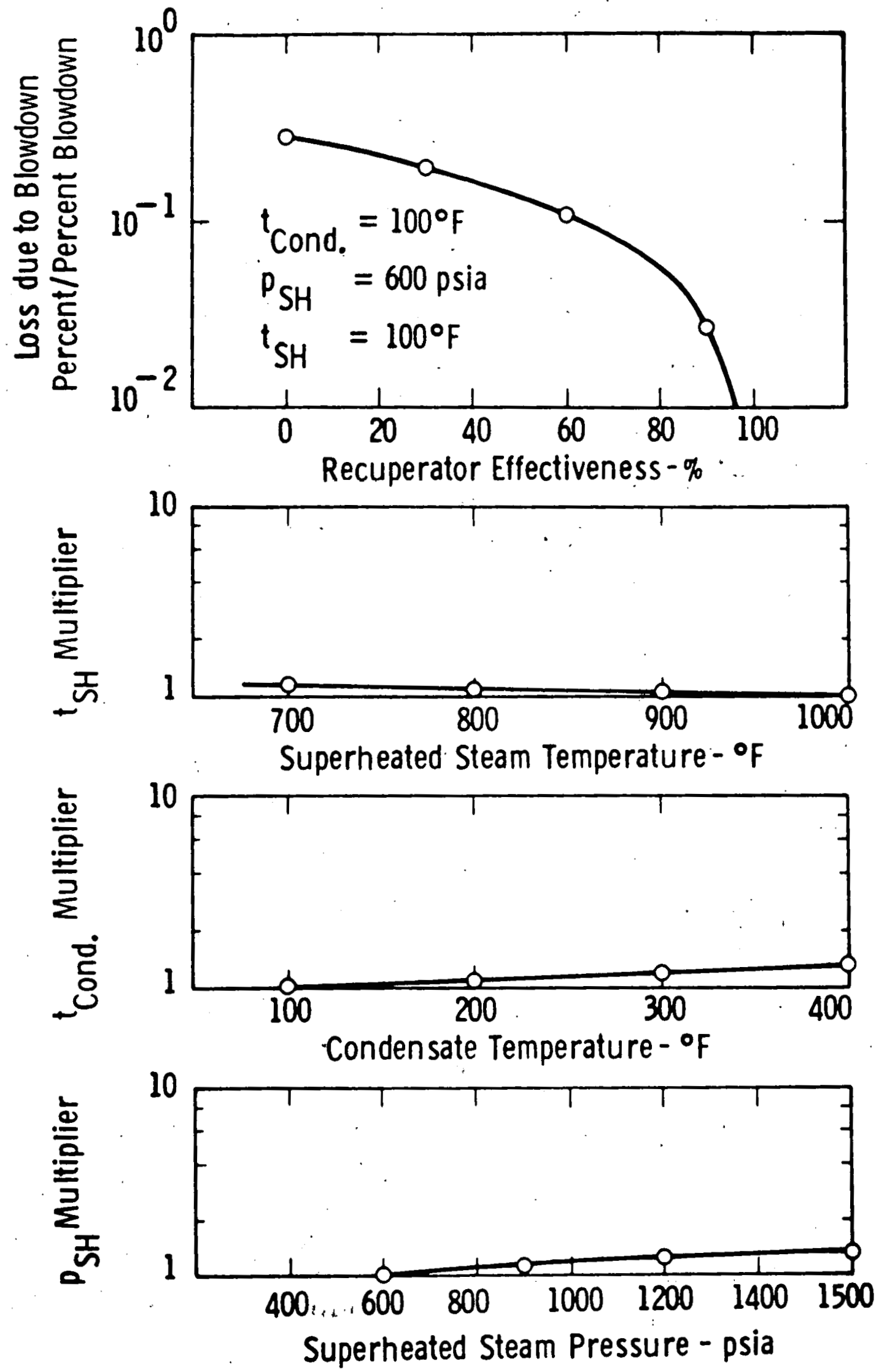

Fig. B.2-3 - Thermodynamic loss due to blowdown . from a power boiler as a function of operating parameters 

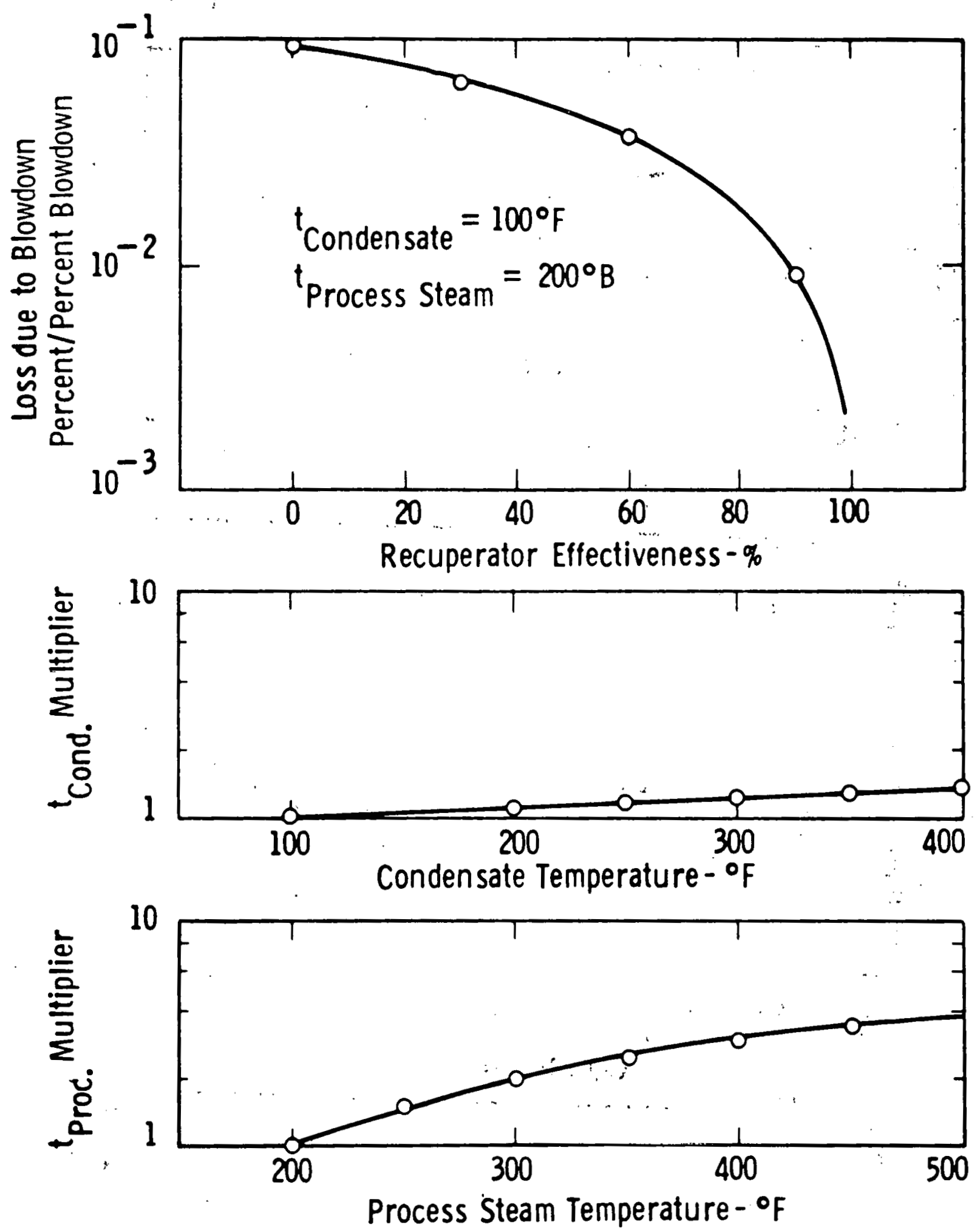

Fig. B. 2- 4 - Thermodynamic losses due to blowdown from a process steam boiler as a function of operating parameters 
The ideal energy utilization, factor and the ratio of gross process heat to electrical energy have been identified as variables for characterization of energy conversion systems for cogeneration applications. This appendix develops the relation of these two parameters to the electricity generating efficiency of the cogeneration system and the energy saved by cogeneration rather than separate generation.

The definition of electricity generation efficiency is well known. An expression for overall energy savings for cogeneration as compared to separate generation has been derived as follows:

Energy savings = energy consumed in separate generation - energy consumed in cogeneration

Energy consumed in cogeneration $=$ power generation + gross process heat generation + losses from. energy conversion subsystem

Energy consumed in separate generation = gross process heat generation/ process boiler efficiency + power generation $x$ utility plant heat rate ${ }^{(*)}$

Energy savings $=$ gross process heat generation/process boiler efficiency + power generation $x$ utility plant heat rate - power generation - gross process heat generation - losses from energy conversion subsystem

Losses from energy conversion subsystem $=$ (losses from energy conversion subsystem $\div$ energy consumed in cogeneration) $x$ energy consumed in cogeneration

Energy consumed in cogeneration = power generation + energy conversion subsystem power generation efficiency

Losses from energy conversion subsystem = (losses from energy conversion subsystem/energy consumed in cogeneration) $\mathbf{x}$ (power generation/energy conversion subsystem power generation efficiency)

* Power transmission losses were assumed to be zero 


\section{Energy savings $=$ gross process heat generation/process boiler efficiency + power generation $x$ utility plant heat rate - power generation - gross process heat generation - (losses from energy conversion subsystem/energy consumed' in cogeneration) $\mathrm{x}$ (power generation/energy, conversion subsystem power generation efficiency)}

Since cogeneration systems will normally be sized to match the process heat requirements, it is logical to reference the energy savings to the process heat generation.

Energy savings/gross process heat generation $=1 /$ process boiler efficiency + (power generation/gross process heat generation) $x$ utility plant heat rate - power generation/gross process heat generation - 1 (losses from energy conversion subsystem/energy consumed in cogeneration) $x$ (power generation/gross process heat generation) $\mathrm{x} 1$ /energy conversion subsystem power generation efficiency $=1 /$ process boiler efficiency + (power generation/gross process heat generation) $x$ (utility plant heat rate - 1 (losses from energy conversion subsystem/energy consumed in cogeneration) $x$ l/energy conversion subsystem power generation efficiency) -1

Energy savings/gross process heat generation $=1 / \mathrm{PBE}-1+$ $(E E / G P H) \times(1.0549 \times$ UHR - 1 - ECLF/ECPGE)

where

PBE - process boiler efficiency for separate generation

EE/GPH - ratio of electrical energy to gross process heat (kWs/Btu)

UHR - utility heat rate for separate generation (Btu/kWs)

ECLF - energy conversion subsystem loss fraction

ECPGE - energy conversion subsystem power generation efficiency

The Ideal energy utilization factor is:

IEUF $=1-E C L F$

Figure B.3-1 is a correlation of the IEUF for cogeneration systems with the ratio of gross process heat to electrical energy, the electricity generation efficiency of the energy conversion subsystem, and the ratio of energy savings to gross process heat for a utflity central station with FGD lower heating value efficiency of $36 \%$ (equivalent to a lower heating value heat rate of $9500 \mathrm{Btu} / \mathrm{kWh}$ ) and an industry process steam boller with FGD lower heating value efficiency of $85 \%$. The line for 0 energy savings is, of course, the line for separate generation. 


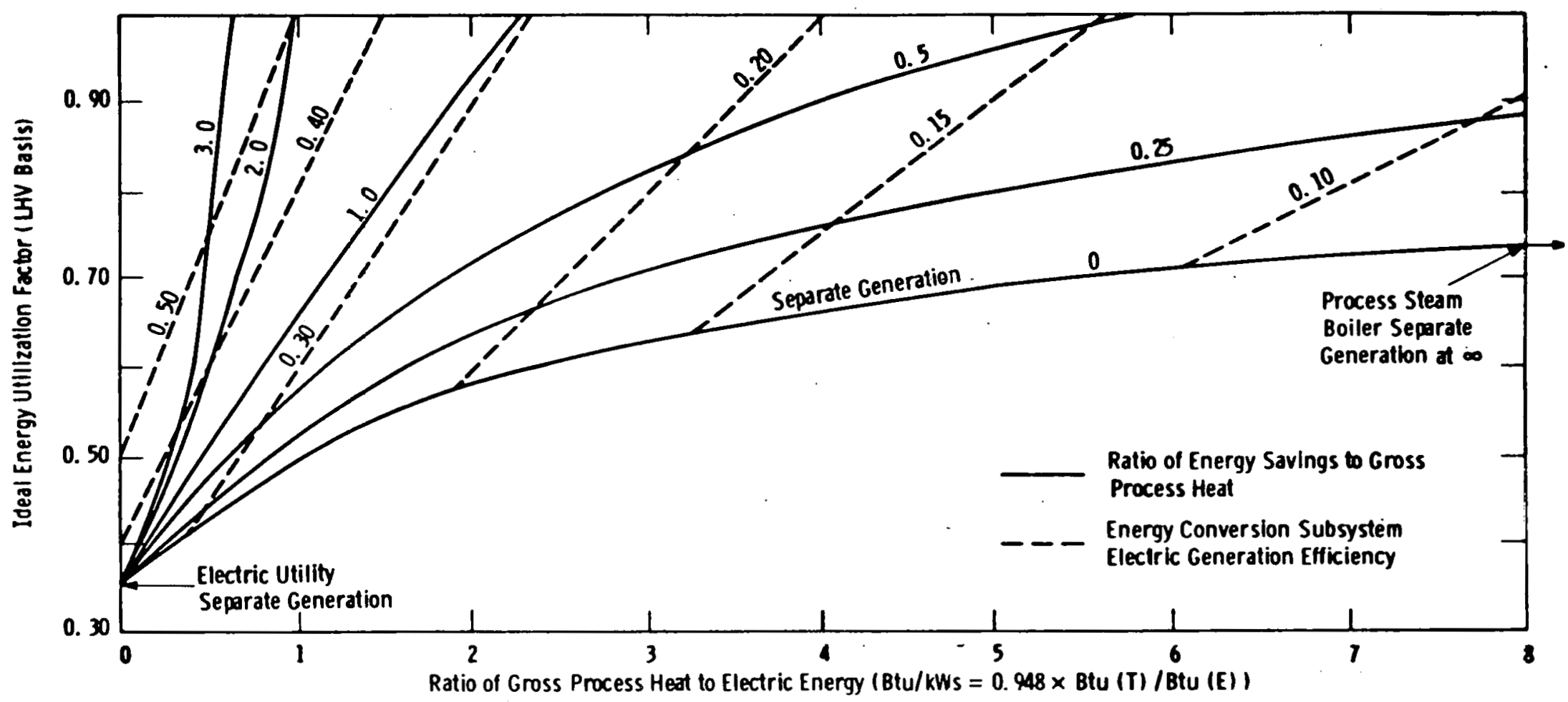

Fig. 8.3-1 - Energy utilization characteristics of cogeneration technology 
A generalized model of a conventional coal-fired steam energy conversion subsystem for cogeneration applications is shown in Figure B.4-1. The furnace, superheater, evaporator, economizer, and air preheater are treated as a package. Fuel, combustion air, recycled condensate, and makeup feedwater enter the package; and superheated steam, ash, products of combustion, and boiler blowdown leave. Energy losses from the package consist of incomplete combustion, heat losses. to the atmosphere, and sensible heat in the ash and boiler blowdown.

A forced draft fan supplies the combustion air to the air preheater. The products of combustion exhaust to an electrostatic precipitator, a flue gas desulfurization process, a stack-gas reheater, and an induced draft fan in series. A recuperator is used to minimize the thermodynamic losses in the boiler blowdown.

The superheated steam goes to an extraction/back-pressure steam turbine. The extraction steam is used for reheating the treated flue gas. A minor fraction of the exhaust steam is used for deaerating feedwater heating; the balance goes to the process. In some applications the steam conditions required for flue gas reheating and processing would be essentially the same, and extraction from the steam turbine would not be required.

The interface of the energy conversion subsystem and the process heat utilization subsystem is the process steam supply line and the condensate recycle line. In an ideal case the recycled condensate would be at the saturation temperature of the process steam supply pressure. In practice the recycled condensate will be at a temperature below the saturation value.

The losses associated with the combustion products are as follows:

- Loss in dry products of combustion (sensible)

- Loss due to moisture in air (sensible and latent)

- Loss due to moisture in fuel (sensible and latent)

- Loss due to hydrogen in fuel (sensible and latent).

Other losses that occur in the system are:

- Mechanical losses in the steam turbine

- Mechanical and electrical losses in the generator

- Mechanical and electrical losses in the boiler feed pump drive motor. 


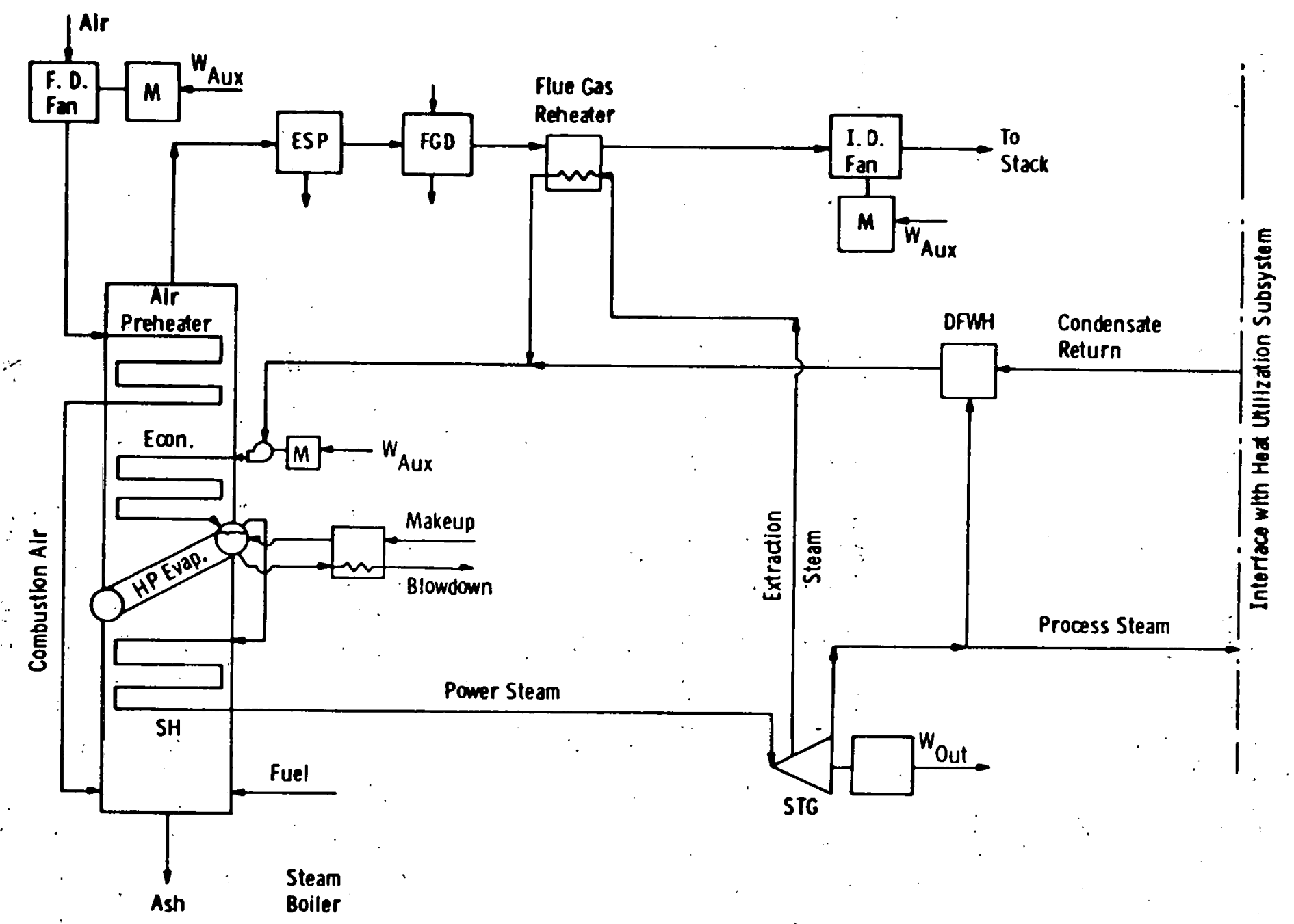

Fig. B.4-1-Conventional coal-fired steam energy conversion subsystem 
The net system electrical power output is equal to the generator output minus the power to the boiler feed pump drive motor and the other auxiliaries. These other auxiliaries include:

- Fuel handling and preparation

- Ash handling

- Combustion air handling

- Condensate pumps

- Water treatment.

A coal-burning steam-energy conversion subsystem with a back-pressure turbine has been characterized for cogeneration applications on the basis of the following assumptions:

Coal-Ohio P1ttsburgh No. 8 seam

Ambient air conditions $-70^{\circ} \mathrm{F} / 60$ percent $\mathrm{RH}$

Air preheat temperature $-600^{\circ} \mathrm{F}$

Fuel temperature $-70^{\circ} \mathrm{F}$

Carbon losses in furnace - 1.5 percent

Ash sensible heat loss - 0.11 percent

Radiation losses from boiler - $0.15 \%$

Steam turbine mechanical efficiency - 0.995

Generator efficiency (mechanical and electrical) - 0.975

Boiler feed pump drive motor efficiency - $95 \%$

Boiler feed pump efficiency - 75\%

Temperature of combustion products out of air preheater $-275^{\circ} \mathrm{F}$

Stack-gas temperature $-175^{\circ} \mathrm{F}$

Plant auxiliary power requirements - $2.5 \%$

(in addition to boiler feed pump)

FGD process - 11mestone slurry

FGD energy requirements - see Rubin and Nguyen, 1978

Boiler pressure drop - 100 psi

Excess atr - $20 \%$ 
Steam turbine characteristics - Westinghouse Type M

Boiler blowdown - thermodynamic effect negligible with recuperator.

The stack gas losses were calculated to be:
Dry gas loss
$3.88 \%$
Loss due to moisture in air.
0.08
Loss due to hydrogen and moisture in coal 4.14

TOTAT. $8 \cdot 10 \%$

The results of the characterization analysis for the coal-fired steam energy conversion subsystem model are given in Figure B.4-2. This characterization is independent of the process heat utilization subsystem model that connects with the energy conversion subsystem model. Since the air preheater determines the stack-gas temperature and, therefore, the thermal losses from the combustion products and the pinch temperature differences in the boiler are far from limiting values, then varying the recycled condensate temperature has no effect on the energy utilization characteristics of this energy conversion subsystem. It would, however, affect the boiler surface requirements and, thereby, the capital costs:

The ideal energy utilization factor is shown as a function of the ratio of gross process heat to electrical energy with variables of steam conditions $(600,900,1200$, and $1500 \mathrm{psig})$ and process steam supply pressure $(14.7,29.8,67.0,134.6,247.3$, and 422.6 psia).

The ideal energy utilization factor. for this energy conversion subsystem model is a weak function of the power steam conditions and a rather weak function of the process steam supply pressure. The spread in the energy utilization factor over the pertinent steam supply pressure range is less than 1 percent, which is hardly significant.

The ratio of gross process heat to electrical energy is also a weak function of steam conditions, but it is a strong function of process steam supply pressure.

Constraints on the operation of this system were assumed to be a back pressure of 0 psig and a turbine inlet to outlet pressure ratio of 3 .

The values assumed for certain losses from the steam boiler are typical of utlity-type boilers and the larger pulverized coal-fired industrial boilers. The smaller industrial boiler would have significantly greater losses than those used here.

\section{REFERENCES TO APPENDIX B-4}

Rubin, E. S. and D. G. Nguyen, "Energy Requirements of a Limestone FGD System", Journal of the Air Pollution Control Association, Vol. 28, No. 12, December 1978: 


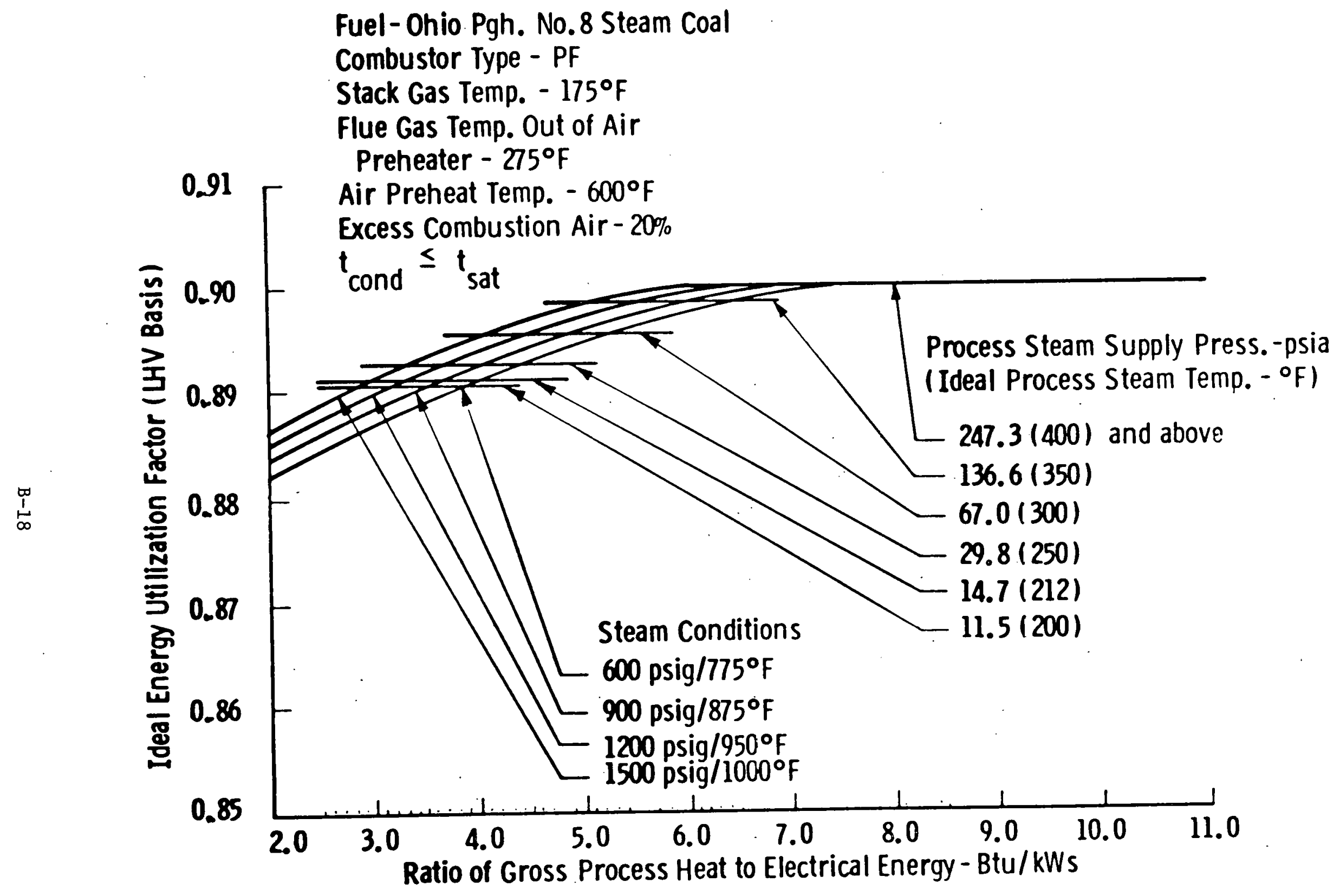

Fig. B.4.-2 - Characterization of conventional coal-fired energy conversion subsystem with FGD 
A model of an oil-fired gas turbine with waste heat boiler energy conversion subsystem for cogeneration application is shown in Figure B.5-1. The waste heat boiler (WHB), which is not fired, has a low pressure evaporator to avoid cold-end corrosion problems.

The characteristics of this energy conversion subsystem when fired on No. 2 distillate fuel are given in Figures B.5-2 through 6 . The ideal energy utilization factor and the ratio of gross process heat to electrical energy are shown as functions of gas turbine compressor pressure ratio, gas turbine expander inlet temperature, and process steam supply pressure (ideal process heat temperature). The temperature of the boiler feedwater is assumed to be $100^{\circ} \mathrm{F}$ less than the saturation temperature for the proces steam supply pressure.

In Figures B.5-2 through 5 the ideal energy utilization factor and the ratio of gross process heat to electrical energy are shown to be rather weak functions of gas turbine expander inlet temperature but moderately strong functions of process steam supply pressure (ideal process heat temperature). Figure B.5-6 shows that these quantities are rather strong functions of the gas turbine compressor pressure ratio.

The polytropic compressor and expander efflciencies used in this characterization $(0.89$ and 0.90$)$ are values which are thought to realistically represent the composite performance of commercially available gas turbines over a size range of 5 to $50 \mathrm{MW}$. 


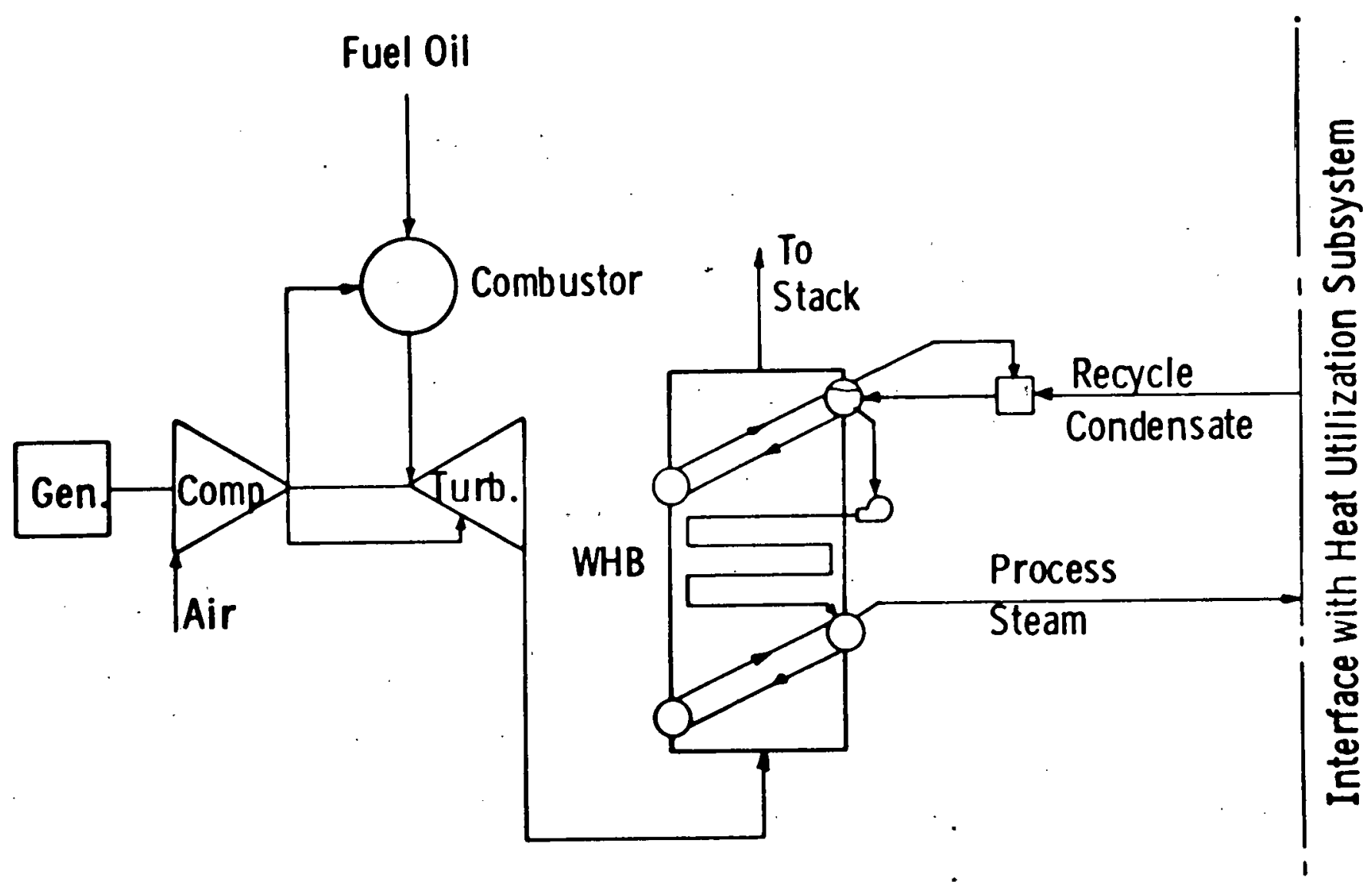

Fig. B.5-1 - Oil-fired gas turbine energy conversion subsystem with waste heat boiler 


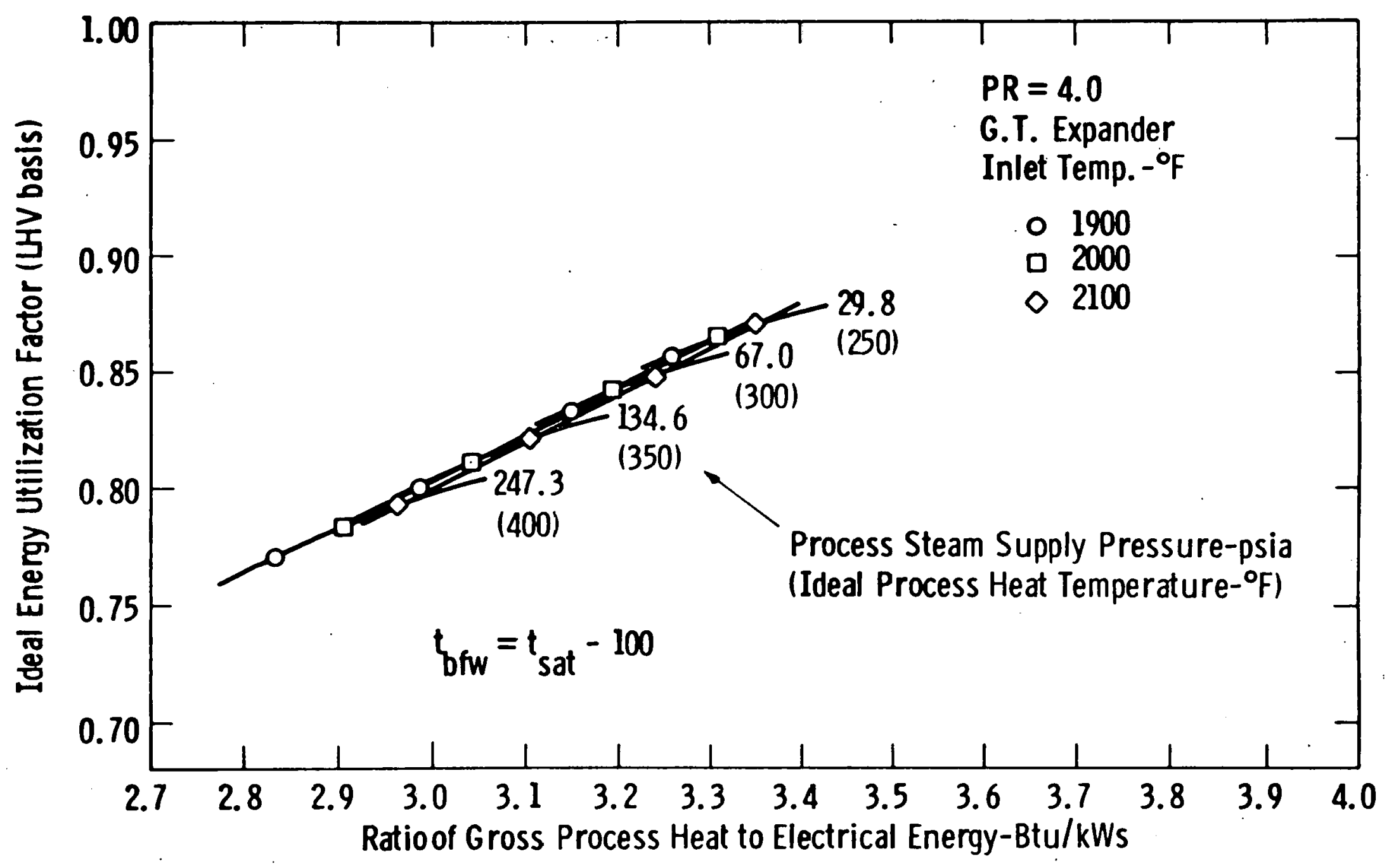

Fig. B.5-2-Characterization of oil-fired gas turbine energy conversion subsystem with waste heat boiler 


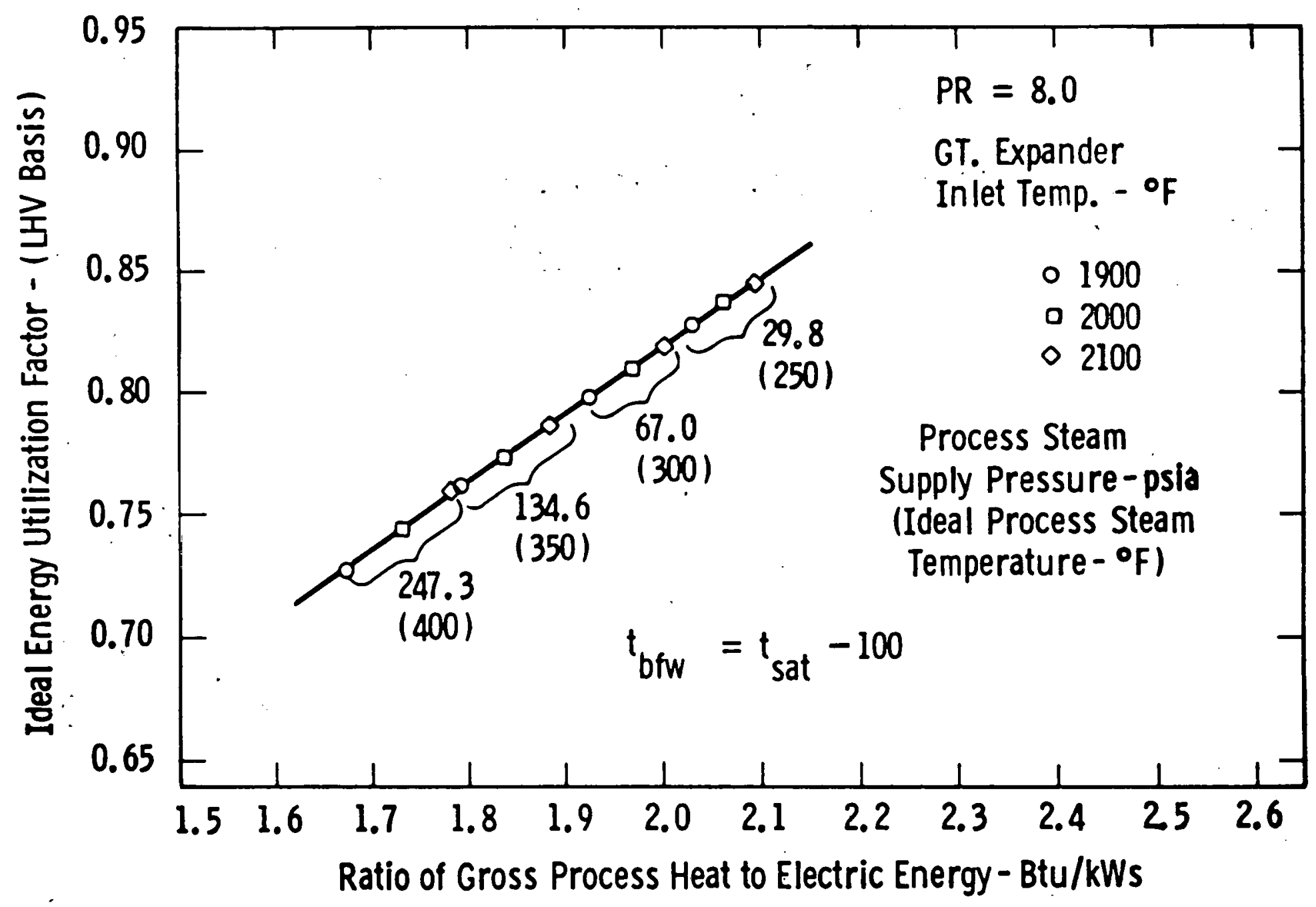

Fig. B.5:3 - Characterization of oil-fired gas turbine energy conversion subsystem with waste heat boiler 


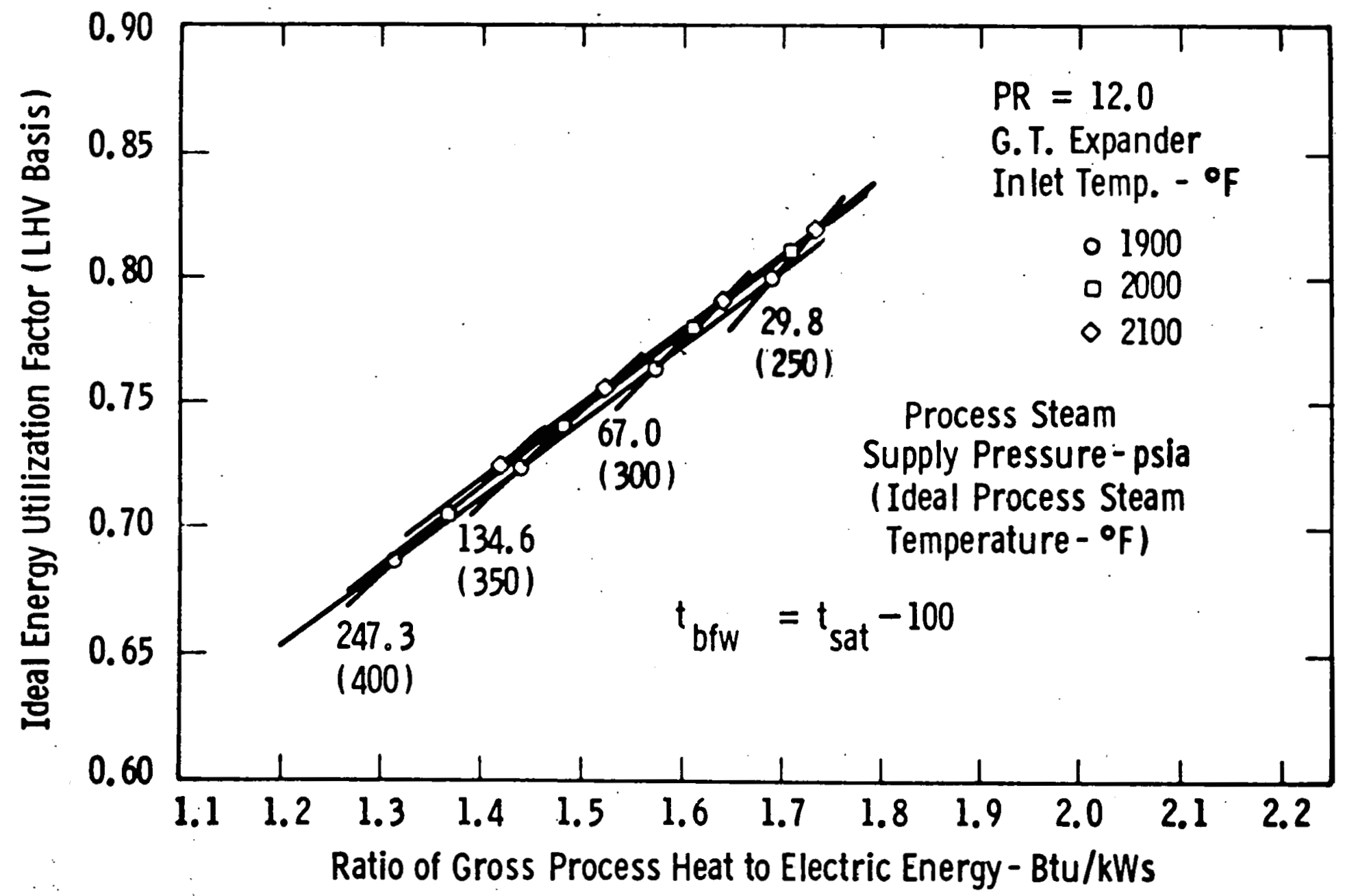

Fig. B.5-4 - Characterization of oil-fired gas turbine energy conversion subsystem with waste heat boiler 


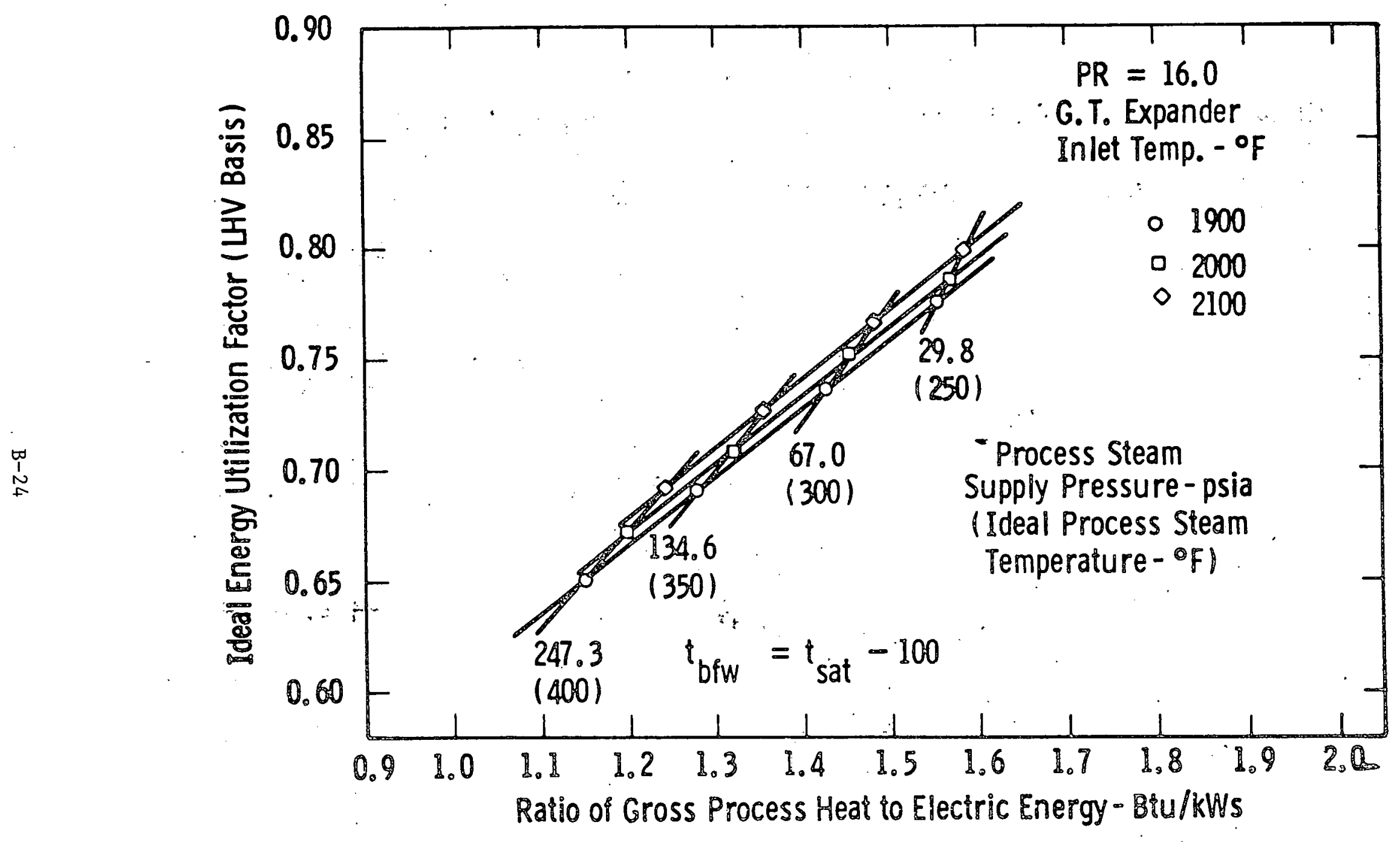

Fig. B.5-5 - Characterization of oil-fired gas furbine energy conversion subsystem wiln waste heat boiler 


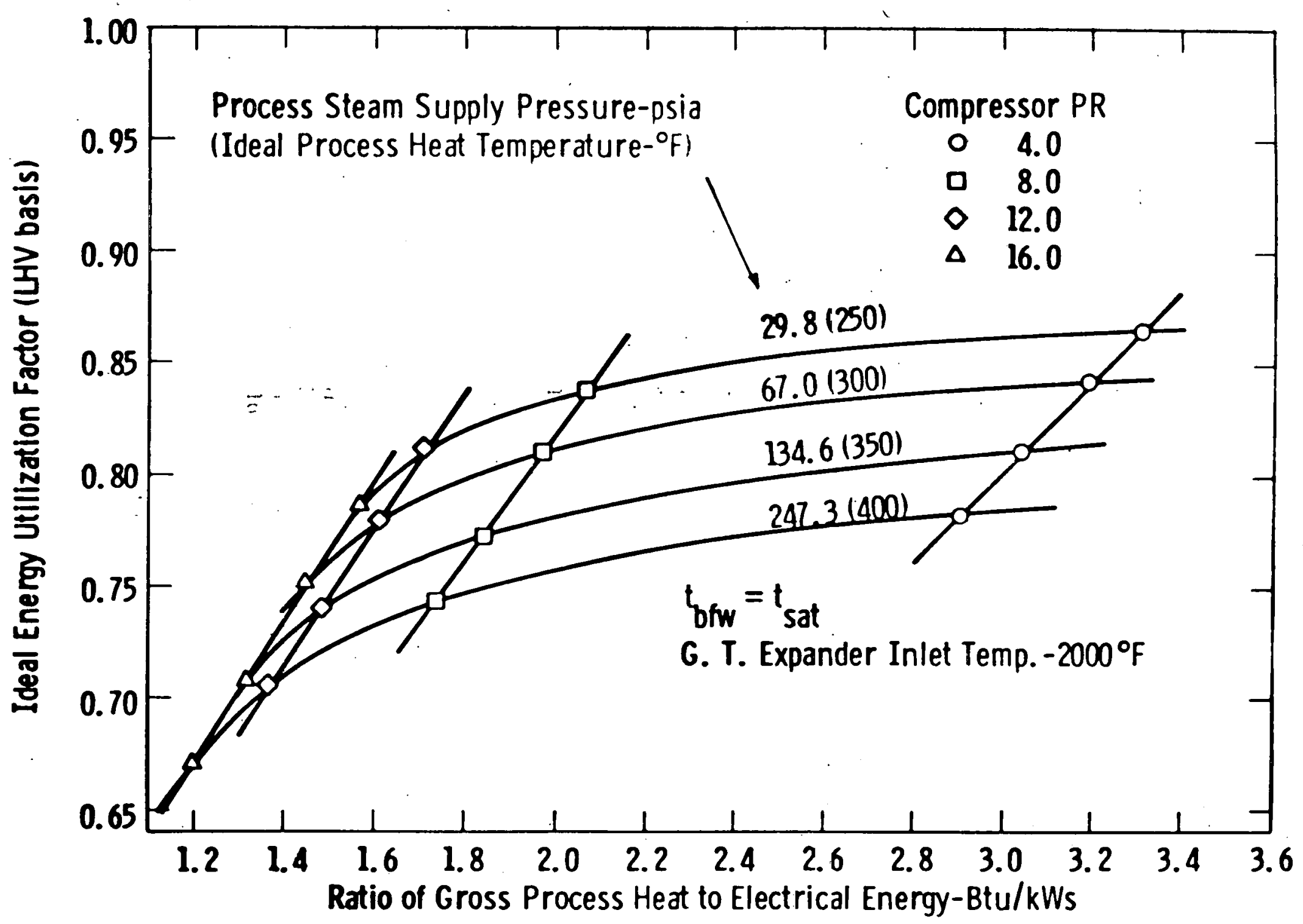

Fig. B.5-6-Characterization of oil-fired gas turbine energy conversion subsystem with waste heat boiler 


\section{APPENDIX B6: CHARACTERIZATION OF OIL-FIRED COMBINED -CYCLE ENERGY CONVERSION SUBSYSTEM}

Figure B.6-1 shows a generalized diagram of the ofl-fired combined-cycle energy conversion subsystem with provision for firing the heat recovery .steam generator (HRSG). The HRSG model shown in Figure B.6-1 is a modification of the configuration commonly used for utility applications, with three pressure levels rather than two. As in the utility configuration, a low-pressure evaporator is used to avoid cold-end corrosion problems. The intermediate pressure evaporator is added to provide an independent source of process steam at conditions either the same as or different from those for the process steam supply from the steam turbine. This significantly increases the quantity of process steam. which can be supplied by a combined-cycle system.

There are several possible steam turbine configurations for cogeneration applications: back pressure only, back pressure and extraction, and condensing and extraction. The choice of the steam turbine configuration will depend on the requirements of the process, heat utilization subsystem.

The characteristics of the oil-fired combined-cycle energy conversion subsystem with an unfired.HRSG and a back-pressure steam turbine are shown in Figures B.6-2 through 6 . The ideal energy utilization factor and the ratio of gross process heat to electrical energy are shown as functions of gas turbine compressor pressure ratio, gas turbine expander inlet temperature, and process steam supply pressure (ideal process heat temperature). The gas turbine combustor pressure loss is assumed to be 4-1/2 percent, and the temperature of the boiler feedwater is assumed to $100^{\circ} \mathrm{F}$ less than the saturation temperature for the process steam supply pressure.

Figure B.6-7 shows the effect of firing the heat recovery steam generator on the characteristics of the combined-cycle energy conversion system. Increasing the temperature at the inlet of the heat recovery steam generator increases both the ratio of process heat to electrical energy and the ideal energy utilization factor.

The polytropic compressor and expander efficiencies used in this characterization $(0.89$ and 0.90$)$ are values which are thought to realistically represent the composite performance of commercially available gas turbines over the size range of 5 to $50 \mathrm{MW}$. 


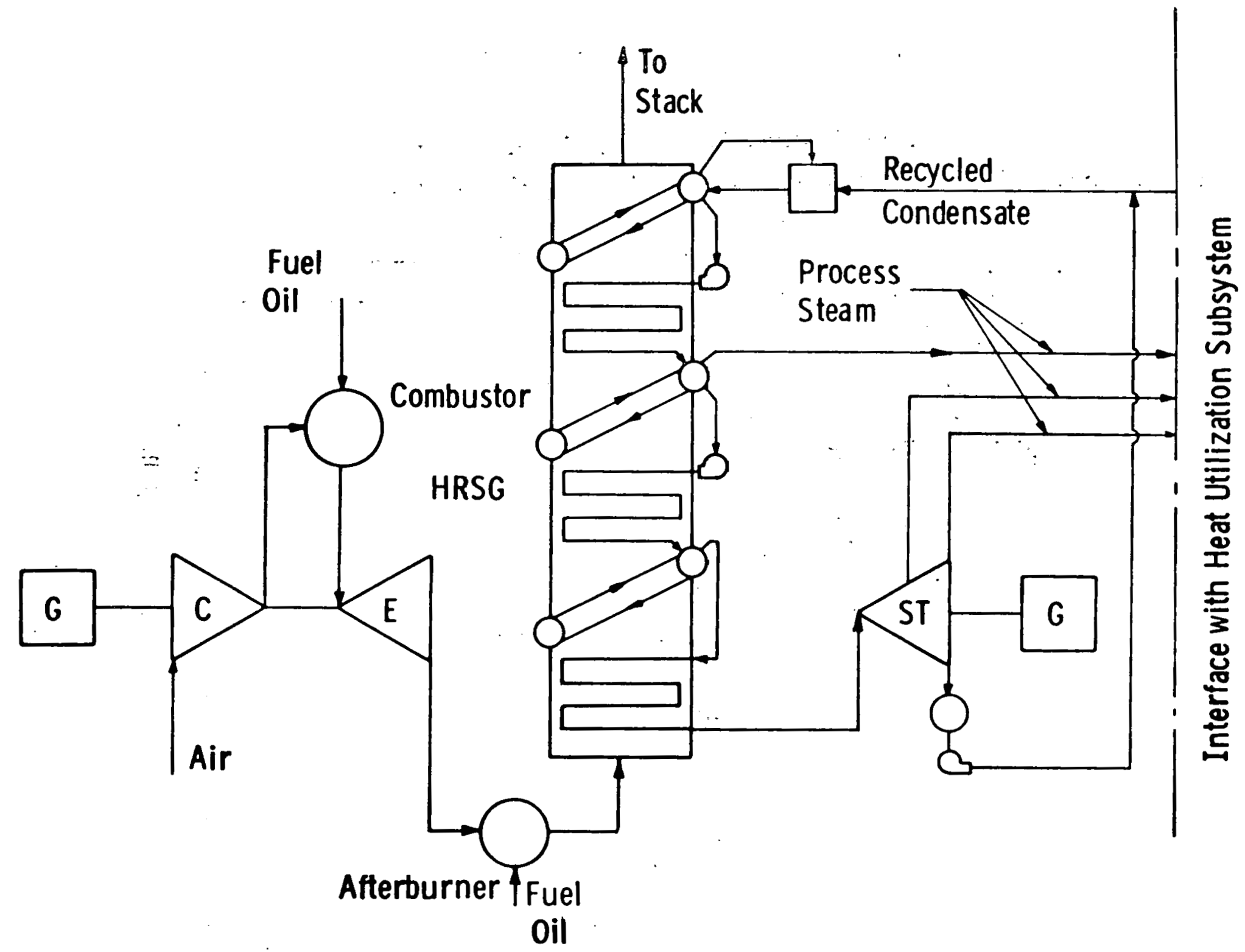

Fig. B.6-1-0il-fired combined-cycle energy conversion subsystem with modified heat recovery steam generator 


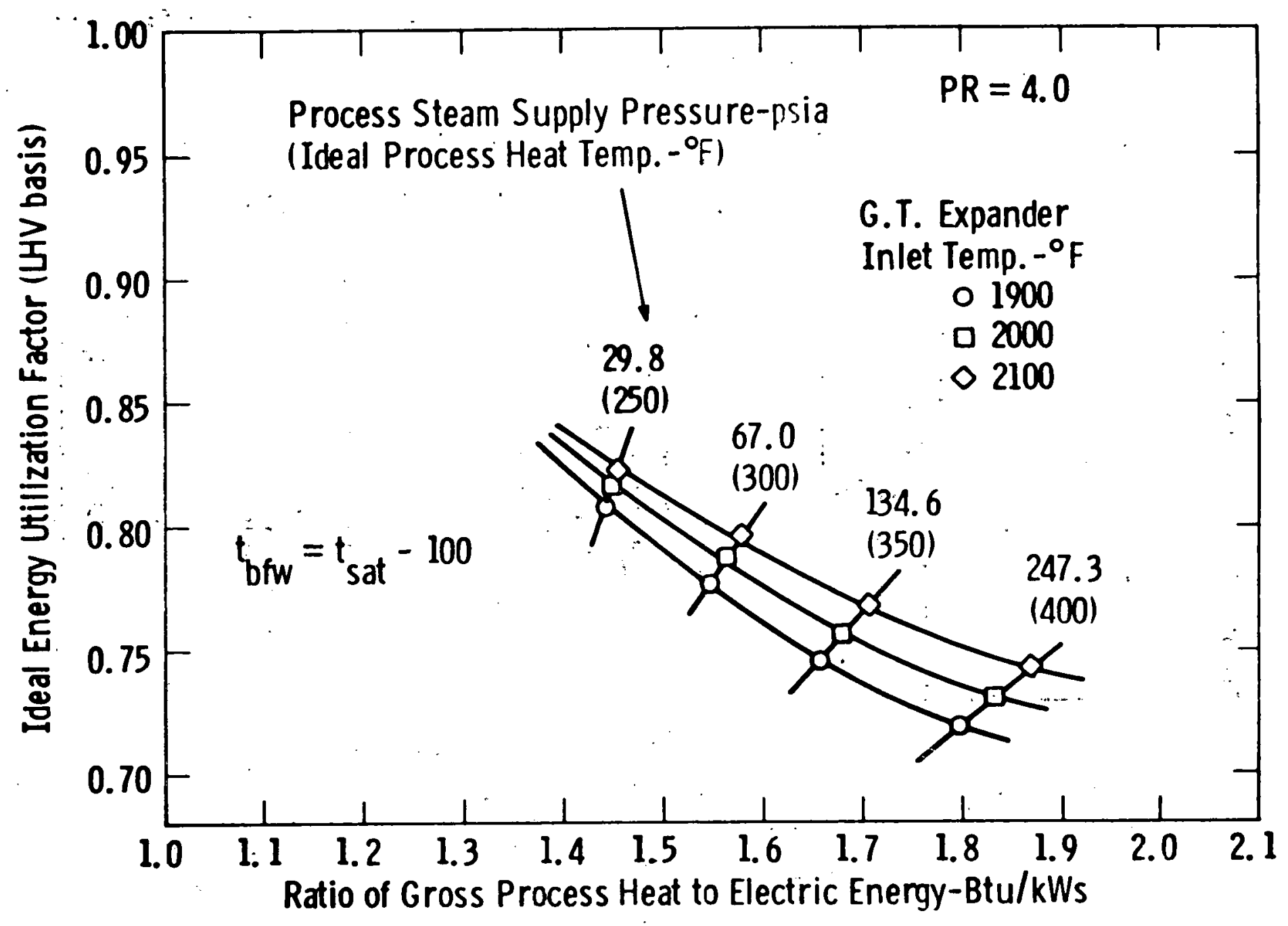

Fig. B.6-2-Characterization of oil-fired combined-cycle energy conversion , subsystem with modified/unfired HRSG 


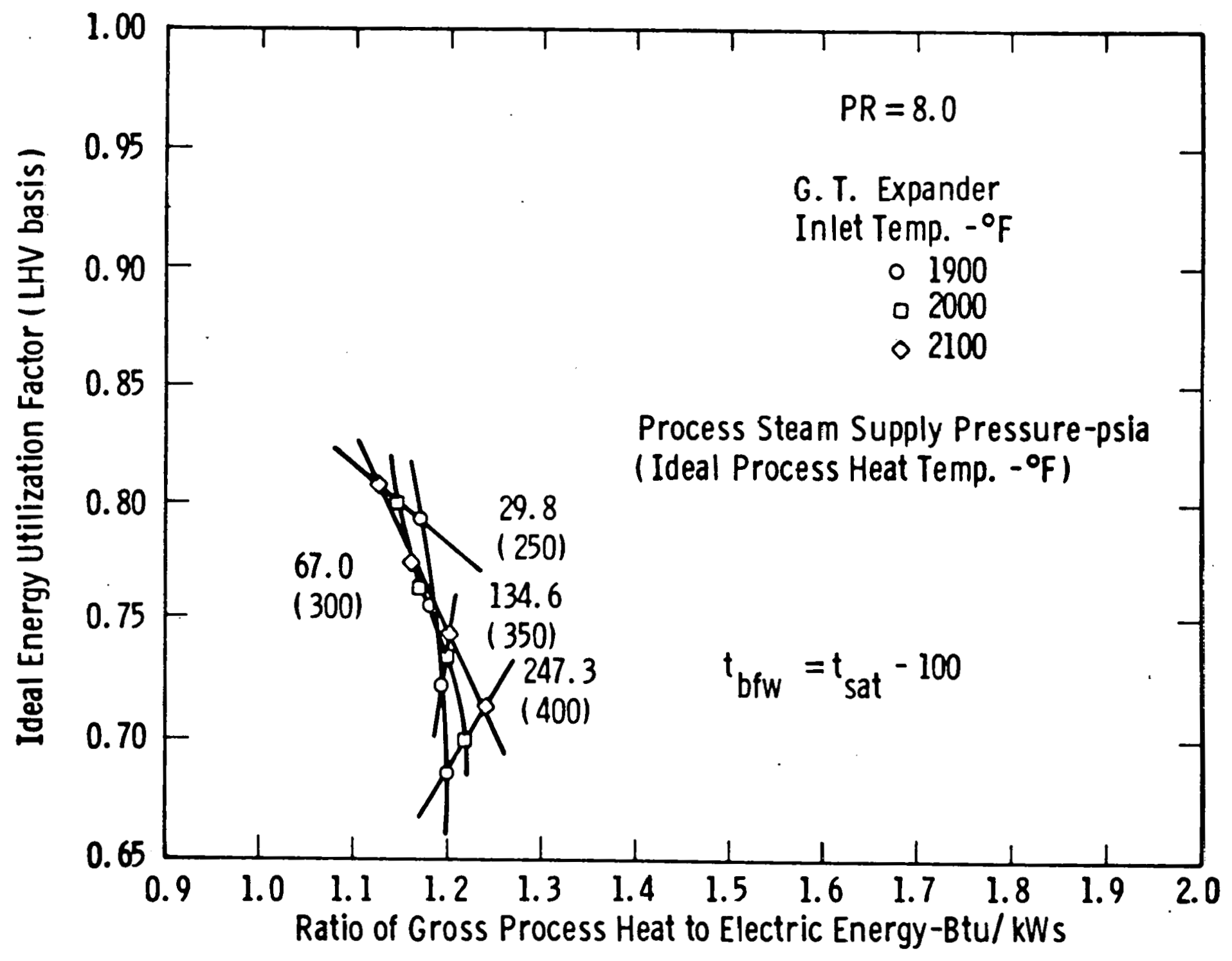

Fig. B.6-3-Characterization of oil-fired combined-cycle energy conversion subsystem with modified/ unfired heat recovery steam generator 


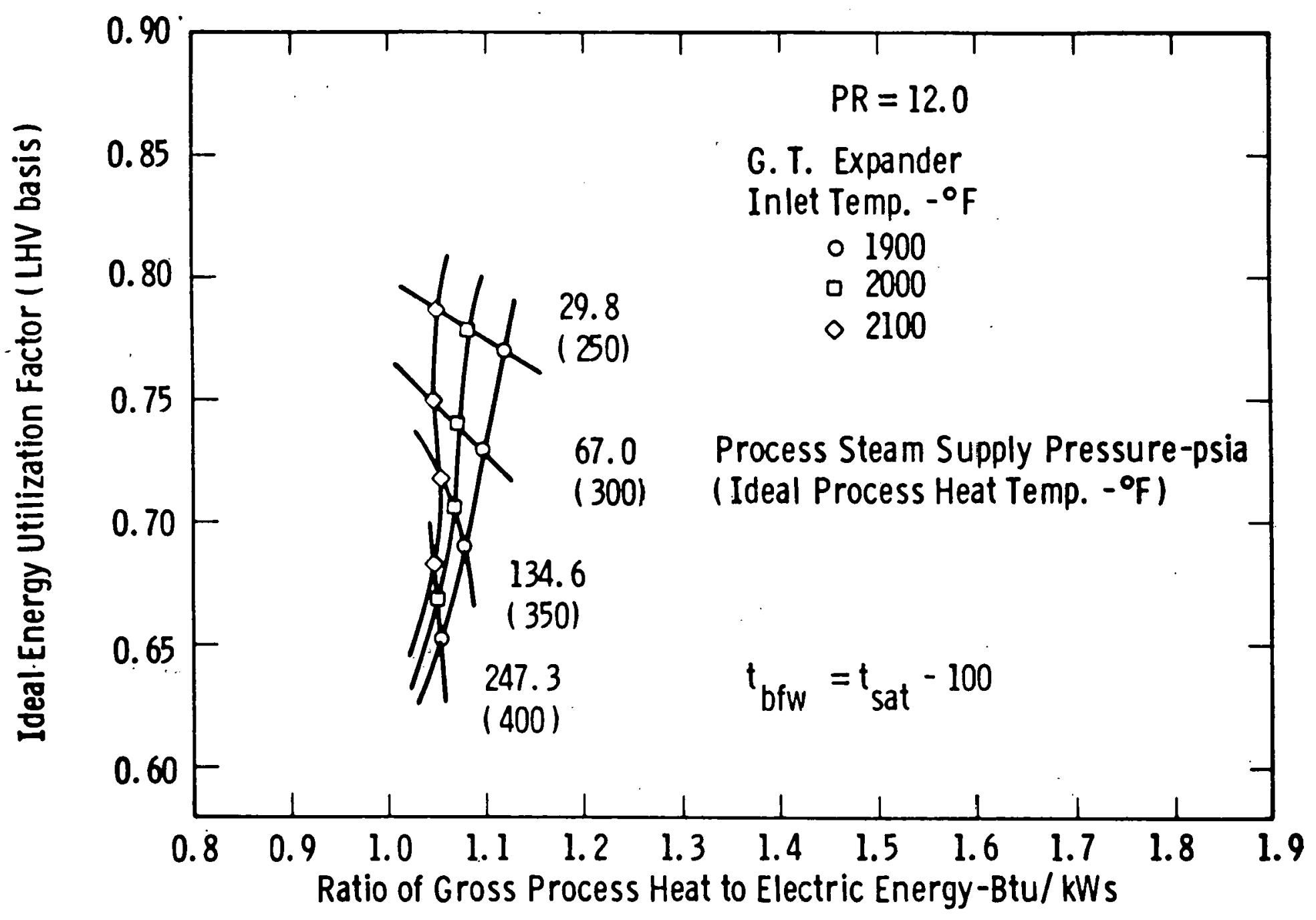

Fig. B.6-4-Characterization of oil-fired combined-cycle energy conversion subsystem with modified/ unfired HRSG 


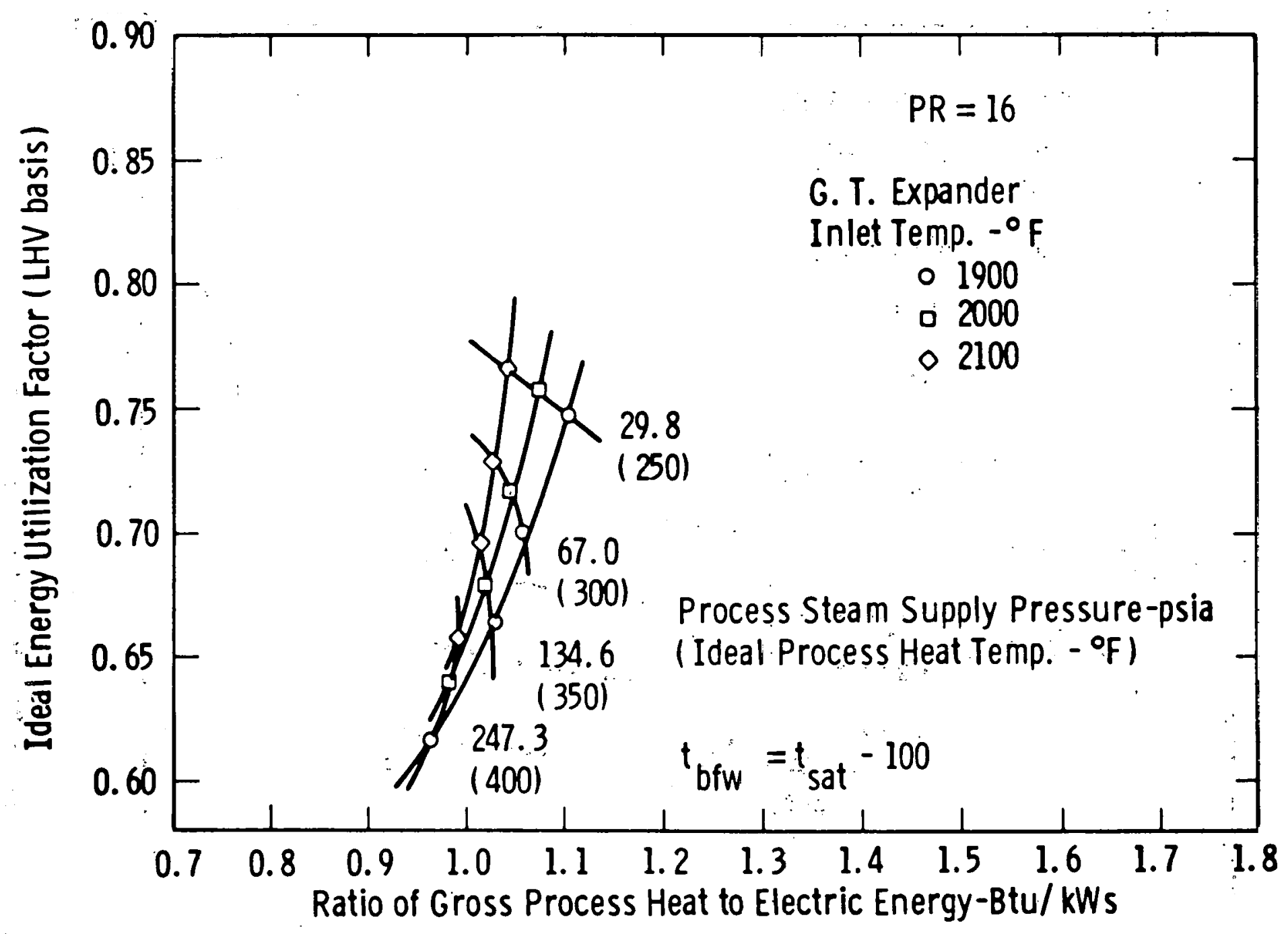

Fig. B.6-5-Characterization of oil-fired combined-cycle energy conversion subsystem with modified/ unfired HRSG 


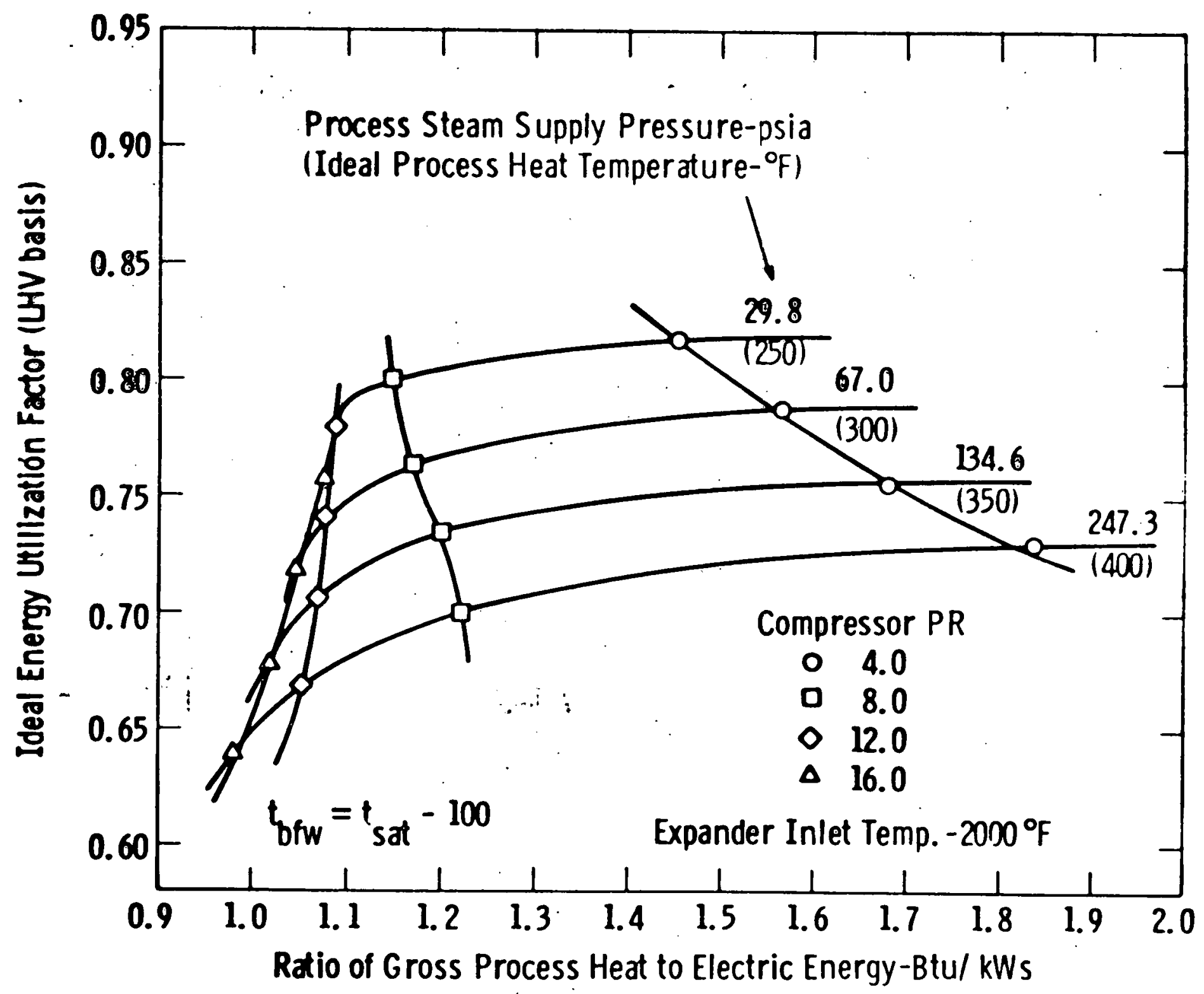

Fig. B.6-6-Characterization of oil-fired combined-cycle energy conversion subsystem with modified/ unfired HRSG 


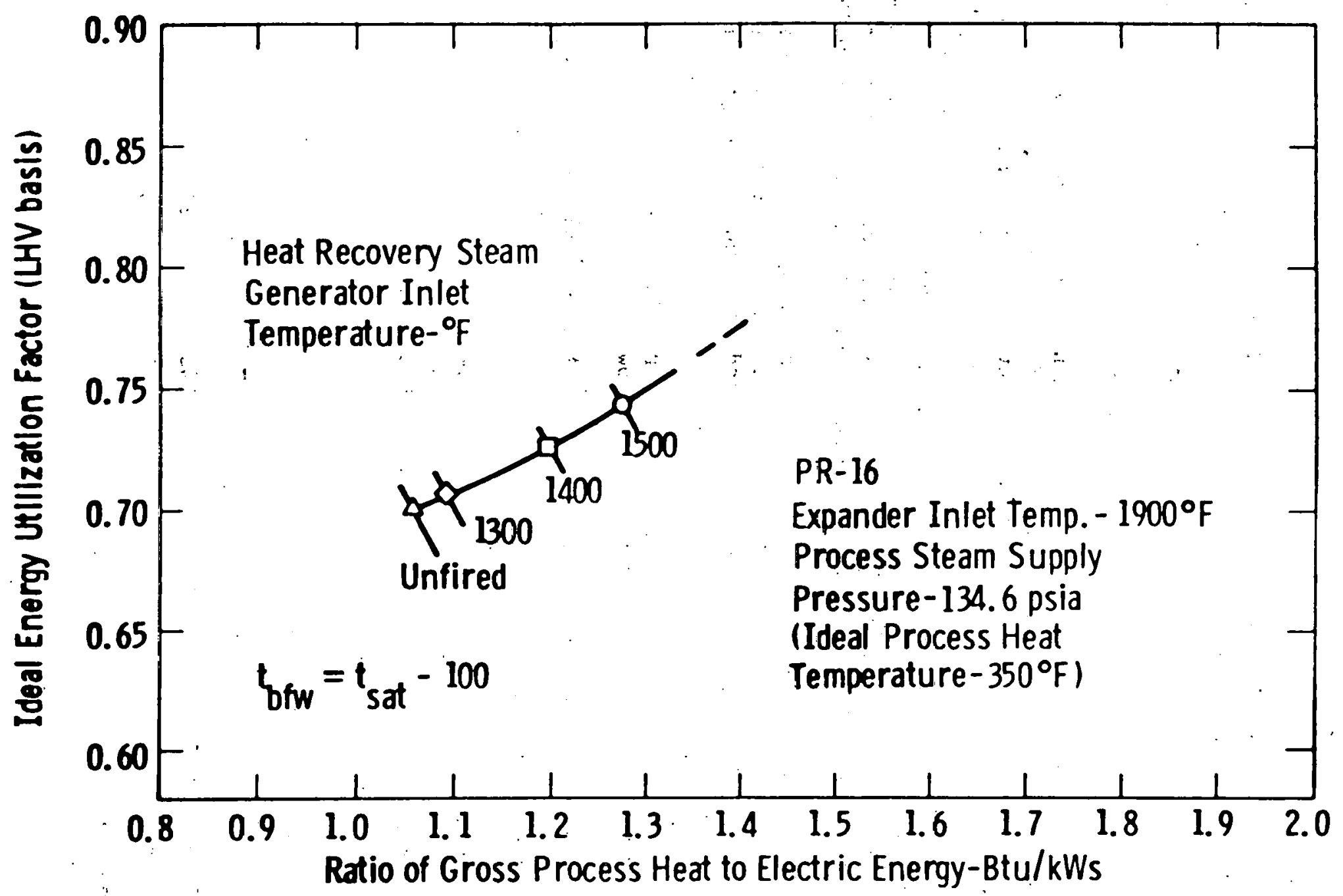

Fig. B.6-7-Characterization of oil-fired combined-cycle energy conversion subsystem with modified/ fired HRSG 
Two types of diesel engines with waste heat boilers have been characterized for cogeneration applications. These are:

- Slow-speed two-stroke-cycle marine diesels

- High-speed four-stroke-cycle industrial diesels.

Slow-speed two-stroke-cycle marine diesel engines have demonstrated performance superior to that of other types of diesel engines, and they are available in size ranges applicable to industrial cogeneration systems (Mac Morran and Comerford, 1977). The world leader in the manufacture of two-stroke-cycle marine diesels is Sulzer Brothers, Ltd. of Winterthur, Switzerland. The Westinghouse Marine Division in Sunnyvale, California has a license to manufacture the $76-$ and $90-\mathrm{cm}$ Sulzer diesels, which cover a power range from 12,000 to 40,000 metric brake horsepower (equivalent to 8605 to $28,685 \mathrm{~kW}$, if one assumes a generator combined efficiency of 0.975$)$.

The slow-speed two-stroke-cycle diesel engine has a shaft power efficiency of about 41 percent. Thirty-four percent of the energy input is rejected in the exhaust gases and 23 percent is rejected to engine cooling water. Mechanical losses amount to about 2 percent.

Typical performance data for the Sulzer Model RND 90 slow-speed, twostroke-cycle marine diesel engine are as follows:

- Specific fuel consumption (gravity $-25^{\circ}$ API) $-0.338 \mathrm{lb} / \mathrm{SHPh}$

- Speed - $115.5 \mathrm{rpm}$

- Load - 85 percent maximum continuous rating

- Turbosupercharger exit temperature - $300^{\circ} \mathrm{C}\left(572^{\circ} \mathrm{F}\right)$

- Exhaust flow rate - $16.1 \mathrm{lb} / \mathrm{SHPh}$

- Cooling-water conditions

$$
\text { Quantity - 1b/SHPh }
$$$$
t_{h}-{ }^{\circ} \mathrm{F} \quad \mathrm{t}_{\mathrm{c}}-{ }^{\circ} \mathrm{F}
$$

Piston

7.3

143

113

Jacke t

30.0

154

130

Fuel valves

nil 
Sulzer gives the following design data for waste heat boilers to be used for recovery of heat from their diesel engine exhaust:

- Temperature drop between turboexpander exit and boiler inlet $-18^{\circ} \mathrm{F}$

- Radiation losses from waste heat bol1er - 3 percent

- Minimum stack-gas temperature

- Diesel fuels - $338^{\circ} \mathrm{F}$

- Residual oils with high sulfur content $-356^{\circ} \mathrm{F}$.

Characterization calculations were made for a low-speed, two-strokecycle marine diesel with waste heat boiler energy conversion subsystem based on the following assumptions:

- Engine performance - Sulzer Model RND 90

- Fuel - diesel fuel with gravity $=25^{\circ} \mathrm{API}$

- $\mathrm{HHV}=19,150 \mathrm{Btu} / 1 \mathrm{~b}$

- $\mathrm{LHV}=18,000 \mathrm{Btu} / \mathrm{Ib}$

- specific gravity - 0.975

- Generator efficiency - 0.975

- Waste heat boiler inlet temperature $-554^{\circ} \mathrm{F}$

- Radiation losses from waste heat boiler - 2 percent

- Minimum metal temperature in waste heat boiler $-220^{\circ} \mathrm{F}$

- Pinch value for WHB $-40^{\circ} \mathrm{F}$

- Offset value for WHB $-5^{\circ} \mathrm{F}$

- Blowdown from waste heat boiler - 0 percent

- Recycled condensate temperature $\leq t_{\text {sat }}{ }^{\circ}$

A model of this energy conversion subsystem is shown in Figure B.7-1. The low-pressure evaporator shown in the waste heat boiler is used to heat the boiler feedwater to a temperature equal to the minimum recommended metal temperature when the recycled condensate temperature is below that temperature. In cases where sufficient heat is not recoverable from the engine exhaust, supplemental heat may be recovered from the engine cooling water.

The results of the characterization calculations for this energy conversion subsystem operating on diesel fuel are shown plotted in Figure B.7-2. The ideal energy utilization factor is given as a function of the ratio of gross process heat to electrical energy, with variables of process steam supply pressure (ideal process steam temperature) and degree of subcooling of recycled condensate. This shows the effect of process steam supply 


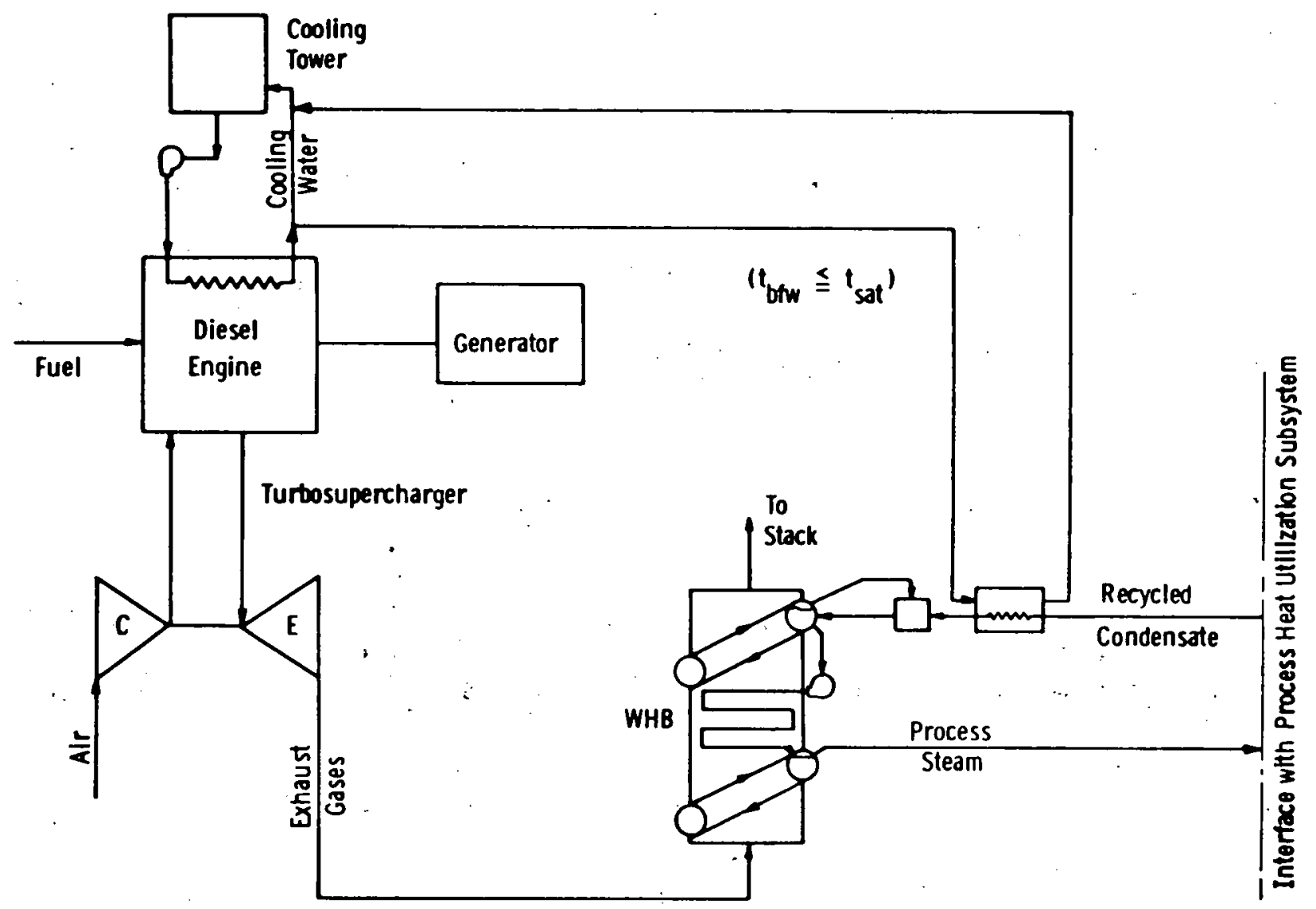

Fig. B.7 - 1 - Diesel engine with waste heat boiler energy conversion subsystem 


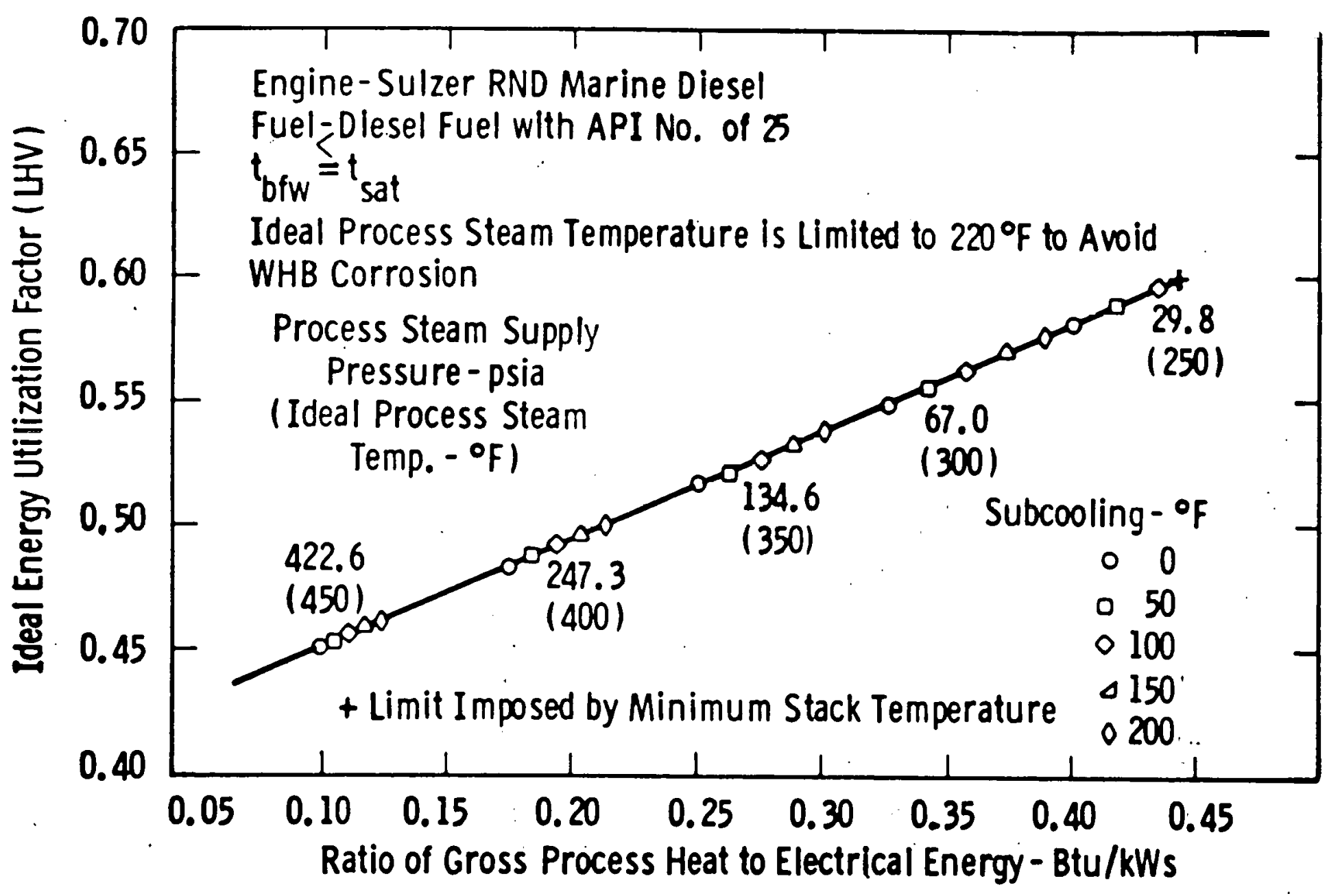

Fig. B.7-2 - Characterization of low speed two cycle diesel plus waste heat boiler energy conversion subsystem 
pressure on the ratio of gross process heat to electrical energy to be substantial and on ideal energy utilization factor to be significant. Both the ideal energy utilization factor and the ratio of gross process heat to electrical energy are weak functions of recycled condensate subcooling.

With distillate fuels the recommended minimum metal temperature in the botler is $220^{\circ} \mathrm{F}$. This value, coupled with the assumed minimum pinch temperature differential of $40^{\circ} \mathrm{F}$, gives a minimum stack temperature of $260^{\circ} \mathrm{F}$, the condition for the maximum heat recovery from the engine exhaust. This stack temperature requirement can be extended by the use of engine cooling water to preheat the recycled condensate.

The ideal process steam temperature cannot be less than the minimum metal temperature no matter what the degree of subcooling of the recycled condensate.

The Sulzer slow-speed diesels are capable of burning residual oils with sulfur contents up to 5 percent. The use of residual oils with sulfur contents greater than 1 percent is considered to be unlikely, since refining processes are available to desulfurize residual oil to values well below 1 percent, and flue gas desulfurization would be required if fuels containing more than 1 percent sulfur were used. The recomnended minimum metal temperatures for waste heat boilers operating on products of combustion of residual oil with a sulfur content of 1 percent or less is $240^{\circ} \mathrm{F}$ (Babcock \& Wilcox, 1972), increasing the constraints on heat recovery from the engine exhaust for the lower values of ideal process steam temperature and limiting the ideal process heat temperature to $240^{\circ} \mathrm{F}$. Here, again, the constraint on maximum heat recovery from the engine exhaust can be extended by the use of engine cooling water to preheat the recycled condensate.

Natural gas can also be used in the Sulzer slow-speed diesel engines with a minimum of about 5 percent liquid fuel (Sulzer Brothers $S t d$. , no date). With 5 percent pilot fuel the continuous rating is about 25 percent lower that with 100 percent liquid fuel because of knocking limitations. Full rating can be attained by the use of about 30 percent pilot fuel. The minimum recommended metal temperature for a waste heat boller operating on products of combustion from natural gas for sulfur contents less than 1 percent is $135+\% \mathrm{~S} 0.85$ (Babcock and Wilcox, 1972).

Four-stroke-cycle diesels with waste heat bollers are commerclally available from several U.S. manufacturers (Caterpillar Tractor Co., 1969; and Alexander, 1978). A number of four-stroke-cycle diesel generator sets that are currently being manufactured were examined for use with a waste heat boiler for cogeneration applications (Cummins Engine Co., 1976; and Caterpillar Tractor Co., 1974). The data evaluated are typical of a four-stroke-cycle diesel engine in the 500 to $1000 \mathrm{HP}$ range and not necessarily obtained from one manufacturer. A nominal four-cycle diesel generator set is about 30 percent efficient. Approximately 31 percent of the energy goes into water jacket heat, 5 percent is released as ambient loss, and 34 percent escapes up the stack. 
The following data were used in the characterization:

- Size - 12 cylinder, $825 \mathrm{HP}$, turbocharged

- Speed - $1800 \mathrm{rpm}$

- Fue1 consumption - $44 \mathrm{GPH}$, No. 2 diesel fuel

- Cooling water - $411 \mathrm{GPM}, 175-195^{\circ} \mathrm{F}$

- Exhaust gas - $5065 \mathrm{CFM}$ at $1000^{\circ} \mathrm{F}$

- Fuel - No. 2 diesel fuel, $\mathrm{HHV}=19,150 \mathrm{Btu} / 1 \mathrm{~b}$ $\mathrm{LHV}=18,000 \mathrm{Btu} / 1 \mathrm{~b}$

Specific gravity $=0.904$

- Generator efficiency - 93\%

- Waste heat boiler inlet temperature - $980^{\circ} \mathrm{F}$

- Radiation losses from waste heat boiler - $2 \%$

- Minimum metal temperature in WHB $-220^{\circ} \mathrm{F}(2)$

- Pinch value for WHB $-40^{\circ} \mathrm{F}$

- Offset value for WHB $-5^{\circ} \mathrm{F}$

For a four-stroke-cycle diesel engine only No. 2 diesel fuel and natural gas were considered to be satisfactory fuels. Four-strokecycle engines operate at higher $\mathrm{rpm}$ than do two-stroke-cycle engines, and, therefore, they have a higher piston speed. Heavier fuels tend to burn more slowly and would still be in the process of combustion as the downward stroke of the piston occurred. This delay would cause the lubricating oil film on the cylinder wall to be burned off, causing more cylinder wear. Heavy fuel oil contains higher amounts of vanadium and sodium than does No. 2 diesel fuel. The presence of these metals would cause a cracking-type corrosion on the valves of a fourstroke-cycle engine.

Figure B.7-1 can be applied to the supercharged four-stroke-cycle diesel as well as to the supercharged two-stroke-cycle diesel, except that a radiator rather than a cooling tower would probably be used for heat rejection.

Figure B.7-3 is a characterization of the four-stroke-cycle diesel with waste heat boiler energy conversion subsystem operating on No. 2 distillate fuel oil. The ideal energy utilization factor is plotted as a function of gross process heat to electrical energy with variables of process steam supply pressure (ideal process steam tempe ature) and recycle condensate subcooling. For the four-stroke-cycle diesel, the effects of process steam supply pressure on both the ratio of gross process heat to electrical energy and the ideal energy utilization factor are significant but not substantial. Both the ideal energy utilization factor and the ratio of gross process heat to electrical energy are weak functions of recycled condensate subcooling. 


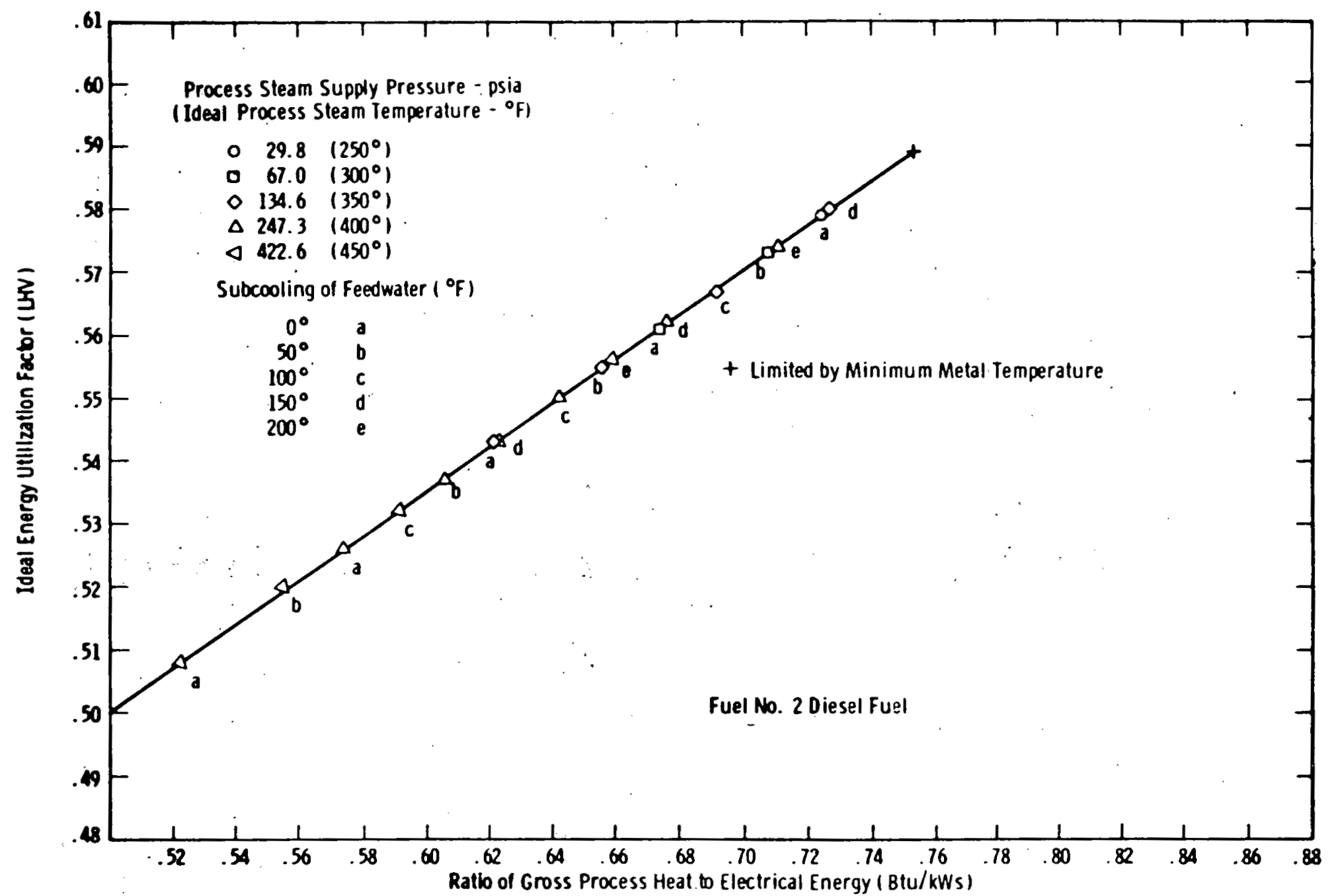

Fig. B.7-3-Characterization of four-stroke cycle diesel with a waste heat boiler energy conversion subsvstem 
The range of ratios of gross process heat to electrical energy is significantly higher for the four-stroke-cycle diesel than it is for the two-stroke-cycle diesel, as shown in Figure B.7-2.

Because of the higher exhaust temperature from the four-stroke-cycle engine, the constraints on heat recovery from the engine exhaust due to the minimum metal temperature are more severe than for the two-stroke cycle engine.

Substantial quantities of low-grade heat are rejected by both the twostroke-cycle diesel $\left(143-154^{\circ} \mathrm{F}\right)$ and the four-stroke-cycle diesel $\left(175-195^{\circ} \mathrm{F}\right)$. Some manufacturers utilize ebullient engine cooling, which will generate limited quantities of steam at $250^{\circ} \mathrm{F} .4$ Presentday technology heat pumps, which have maximum discharge temperatures of about $220^{\circ} \mathrm{F}$, could be used to recover heat from the engine cooling water when there is a need for $220^{\circ} \mathrm{F}$ process heat.

Currently, Federal emission control standards for diesel engines have not been established. Various state and local governments do limit exhaust gas releases to the atmosphere. They also may impose restrictions on the noise levels produced by such an engine. One obvious advantage to the waste heat boller system is that the engine is muffled by the heat exchanger.

\section{REFERENCES TO APPENDIX B 7}

Alexander, Tom, "The Little Engine That Scares Con. Ed", Fortune, December 31,1978 , p. 80-4.

Babcock \& Wilcox, "Steam", 38th Edition, 1972, p. 13-4.

Caterpillar Tractor Co., "Total Energy Handbook", 1969.

Caterpillar Tractor Co., Brochure on D-398 Generator Sets, June 1974.

Cummins Engine Co., Brochure on KT-2300-G Diesels, March 1976.

J. R. Mac Morran and Harry Comerford, "A Slow-speed Marine Diesel Engine in Review;" Presented at the Soclety of Naval Architects and Marine Engineers, Los Angeles Section Meeting, May 12, 1977.

Sulzer Brothers Std., Brochure on Dual-Fuel Engines, Winterthur, Switzerland, no date. 
A model of a coal-fired closed-cycle energy conversion subsystem with flue gas desulfurization (FGD) is shown in Figure :B.8-1. The closed-cycle working fluid is indirectly heated by a pulverized coal-fired heater. that has both radiant and convective heat transfer surfaces. A recuperative air heater is used to preheat the combustion air. The combustion products from the air preheater go to an electrostatic precipitator and a flue gas desulfurization process. The treated flue gas is then reheated with steam. Both forced and induced draft fans are used.

The exhaust from the gas turbine expander goes to a recuperator, a waste heat boiler (WHB), and a cooler in sequence before returning to the gas turbine compressor inlet. The WHB provides process steam in addition to the steam for reheating the treated flue gas. The condensate recycled from the process and the condensate from the flue gas reheater are heated in a deaerating feedwater heater before going to the WHB.

The characterization of this energy conversion subsystem is shown in Figure B.8-2. The design values of the gas turbine compressor pressure ratio and the expander inlet temperature are those that have been used in coal-fired closed-cycle gas turbine installations in Europe (Baummert and Groschup, 1976; and Harman, et.al., 1979). Both the ideal energy utilization. factor and the ratio of gross process heat to electrical energy are shown to be rather strong functions of recuperator effectiveness. These parameters are moderately strong functions of process steam supply. conditions.

The characterization shown in Figure B.8-2 includes only the process steam from the waste heat boiler. Additional low level waste heat could be recovered in the cooler following the waste heat boller.

\section{REFERENCES TO APPENDIX B 8}

Baummert, K. and Groschup, G., "Status Report on Closed-cycle Power Plants in the Federal Republic of Germany", ASME Paper No. 1976-GT-54.

Harman, Robert A., Kinney, Carey A., and Crifi, Winfred M.; Jr.; "Cogeneration in Europe and the Closed Cycle Gas Turbine", Turbomachinery International, March, 1979, pP". 29-34. 


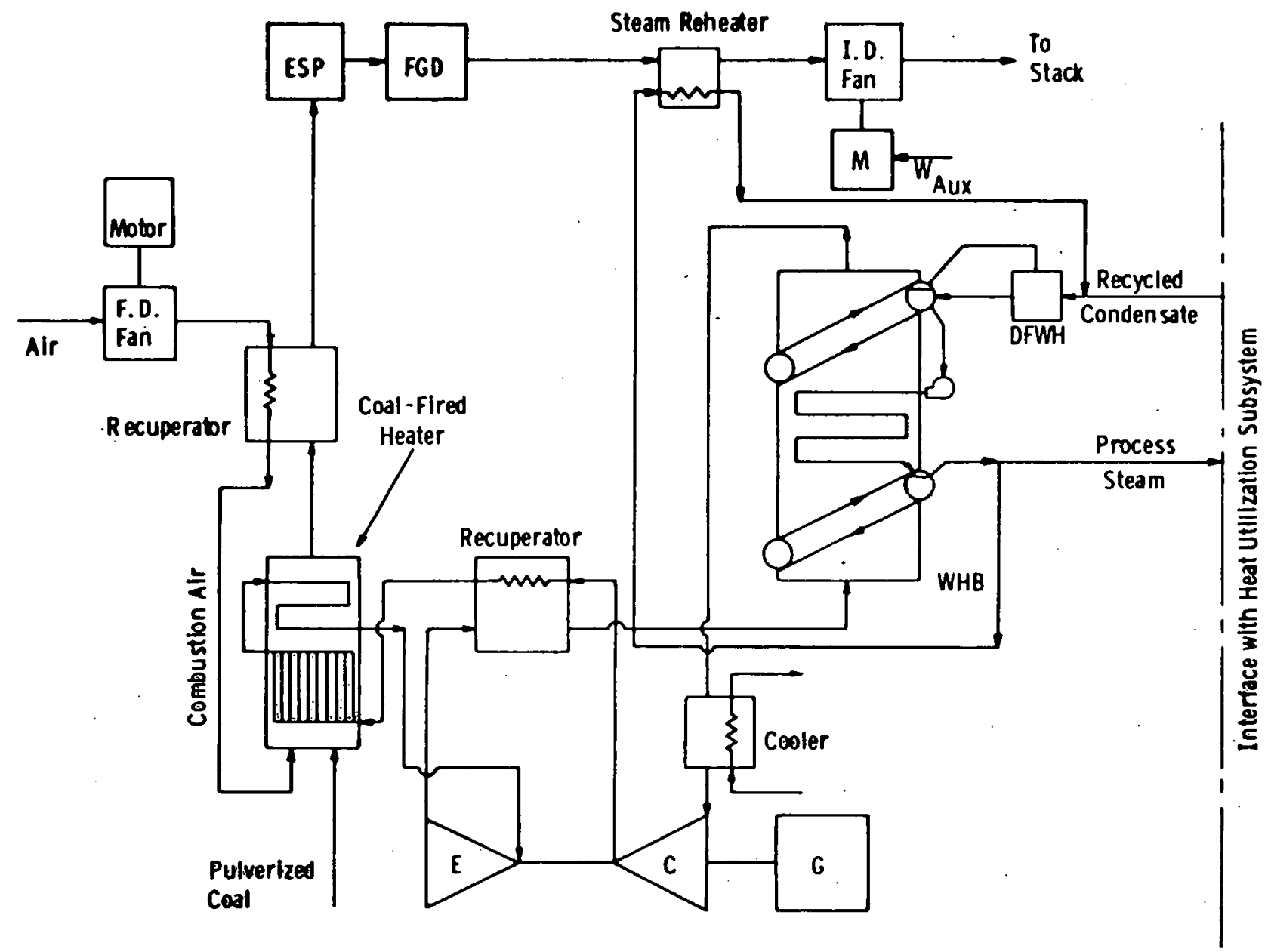

Fl. B.8-1-Closed-cycle gas turtine energy conversion subsystem 


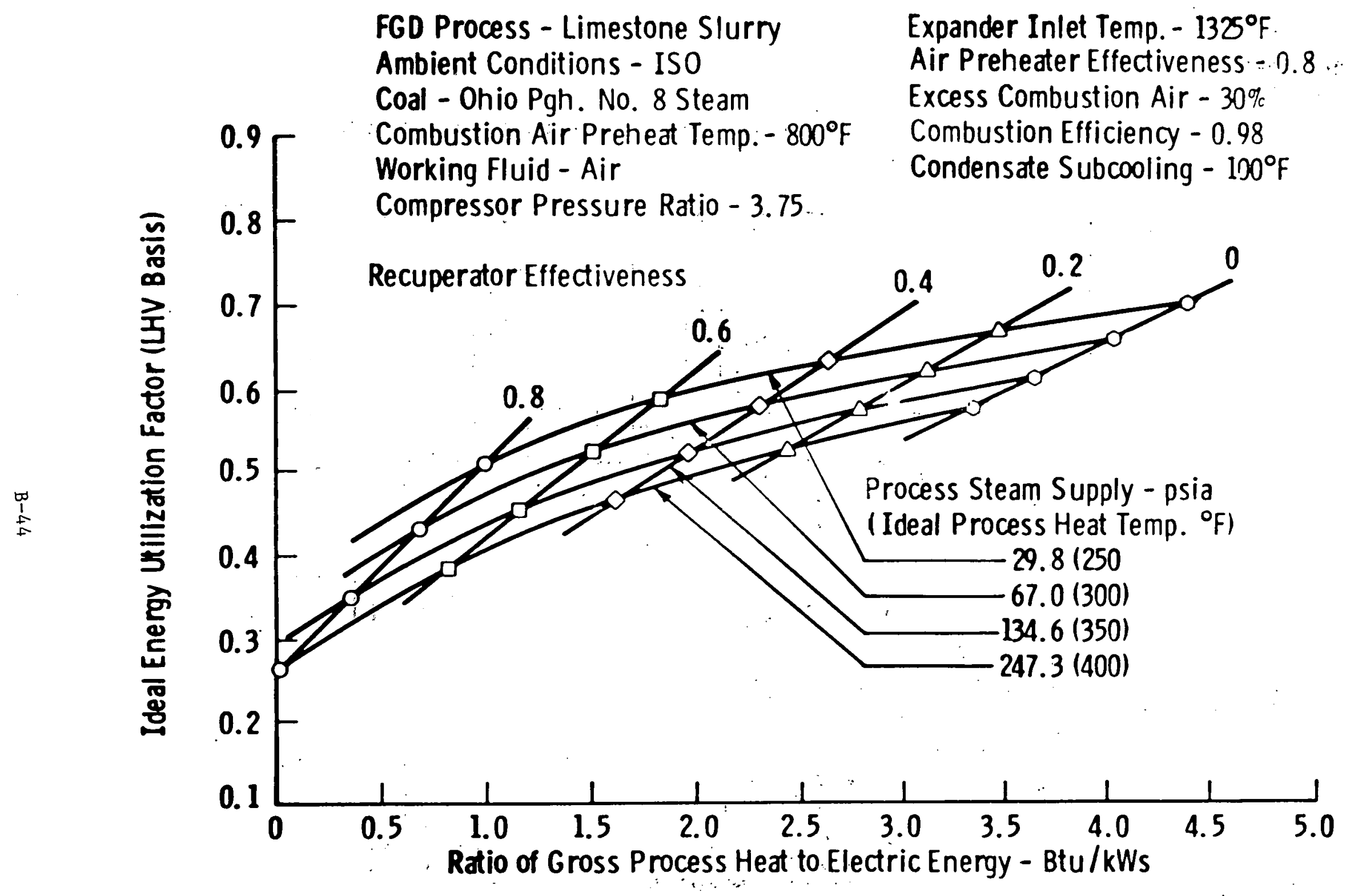

Fig. B.8-2 - Characterization of coal-fired closed cycle gas turbine energy conversion subsystem with FGD 
Figure B.9-1 is a flow diagram of the coal-fired indirectly heated open-cycle gas turbine energy conversion subsystem with flue gas desulfurization. The working fluid (air) is heated by a pulverized coal-fired heater. The exhaust from the gas turbine expander goes to a WHB and/or to a process. The unique feature of this energy conversion subsystem is that it can supply pure air to a process at a temperature in the range of 800 to $900^{\circ} \mathrm{F}$.

The waste heat boiler generates steam for process use and for flue gas reheating after desulfurization.

The combustion air circuit for the pulverized coal-fired heater is completely independent of the gas turbine working fluid. The air is preheated against the products of combustion. After being cooled in the air preheater, the combustion products are cleaned and desulfurized. The desulfurized combustion products are reheated by steam. Both forced and induced draft fans are used.

The characteristics of this energy conversion subsystem are shown plotted.in Figure B.9-2 for a compressor pressure ratio of 4 and an expander inlet temperature of $1325^{\circ} \mathrm{F}$. The state-of-the-art pulverized-coalfired-heater technology used in Europe for closed-cycle gas turbines is assumed to be applicable to the indirectly heated gas turbine, although this specific configuration has never been used commercially. The only design variable investigated was the process steam supply pressure which is shown to have a significant effect on both the ratio of gross heat to electrical energy and the ideal energy utilization factor. 
$\infty$
1
$a$

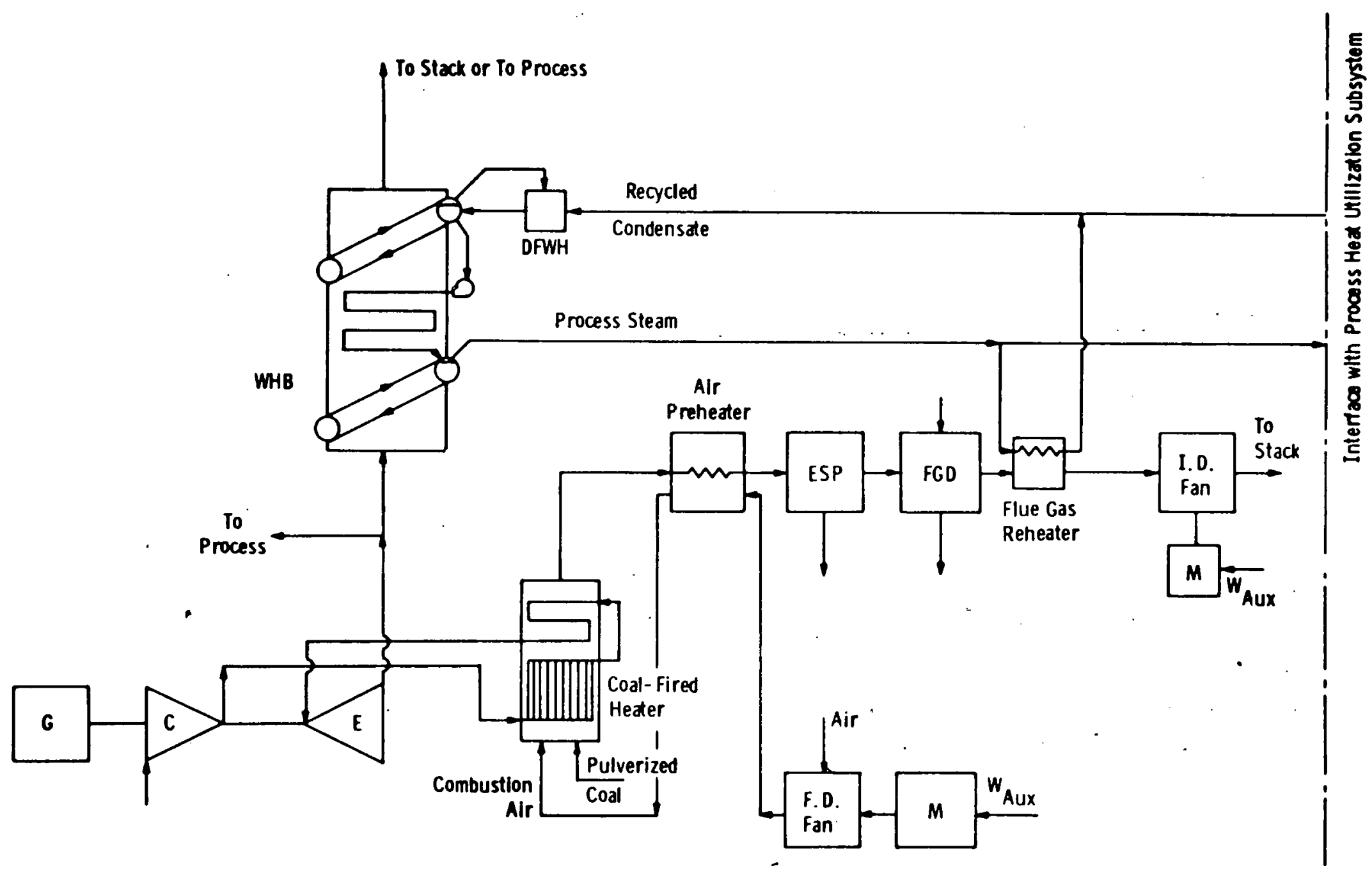

Flg. B.9-1 - Coal-fired indirectly-heated open-cycle gas turbine energy conversion subsystem 


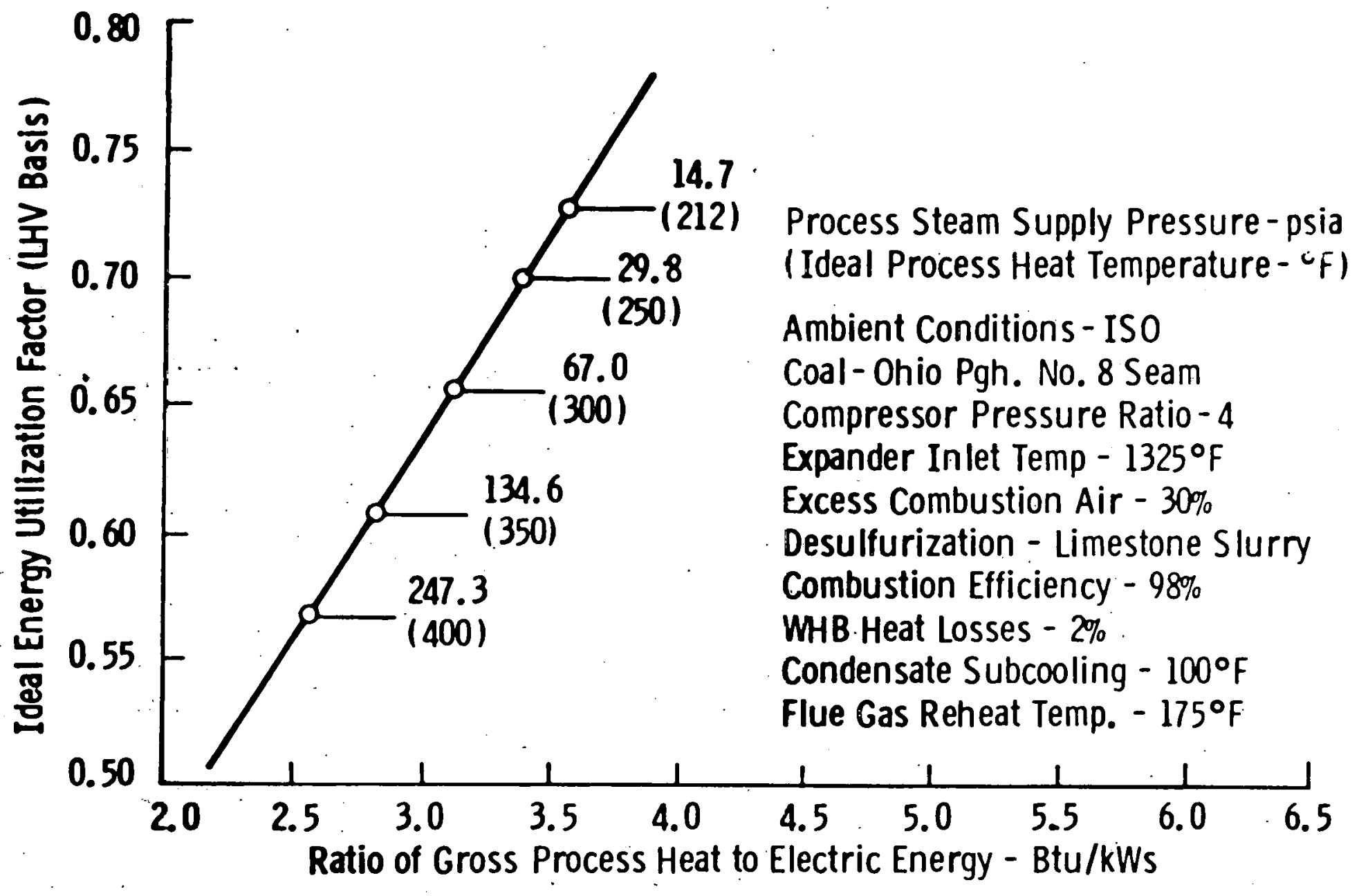

Fig. B.9-2 - Characterization of coal-fired indirectly-heated open-cycle gas turbine energy conversion subsystem. 


\section{INTRODUCTION}

We have investigated the possibility of using thermal energy storage to efficiently reconcile time-varying energy supplies and process heat requirements. An initial survey of proposed storage techniques, including storage modes and heat exchange options, was made. Then several representative near-term systems were characterized relative to one another with regard to storage material, mass, and volume, heat exchange requirements, and thermal effectiveness. Finally, a specific analysis of a process-steam load leveling scheme was performed. A bibliography was developed.

Thermal energy may be stored in packed beds of inexpensive solids such as rocks, sand, or firebrick. It may also be stored in pressurized water or in oils or other fluids at low pressures. Heat exchange between source, storage, and process load streams may be achieved by conventional techniques such as tube-side fluid to solid, liquid, or gas; or directly by fluids in contact with solids, be they packed, fluidized, or in dilute flow. These storage and exchange modes all utilize existing technology and are considered near term. Other much touted and promising techniques such as using phase change materials and reversible chemical reactions will require significant further development work and so are not considered here.

\section{PACKED BED STORAGE}

Thermal energy may be stored in stationary solid material. Typical proposed systems include geological rock or soil formations, brick checkerworks, or sand or pebble beds. All such systems have two major disadvantages: that they are poorly suited to heat transfer to tube-or channelenclosed fluids because the primary heat transfer mode is conductive and that oversize must be provided to permit the maintenance of a steady input or output of heat because of variation in heat transfer driving force with time. The mafor advantage is the system simplicity, primarily due to the avoidance of solids transport. The advantages of this system may be overwhelming if heat is transferred both. to and from the storage medium by direct contact with fluids, thus precluding the need for expensive heat exchange tubes. However, in such a case the simultaneous charging and discharging of heat in a single storage vessel is impossible.

Figure B.10-1 shows a system whereby waste heat in, say, a flue gas is transferred to a packed bed of granular material in the contactive mode. Steam is generated in tubes buried in the material. Thus the flexibility of simultaneous addition and removal of heat is permitted. By controlling 


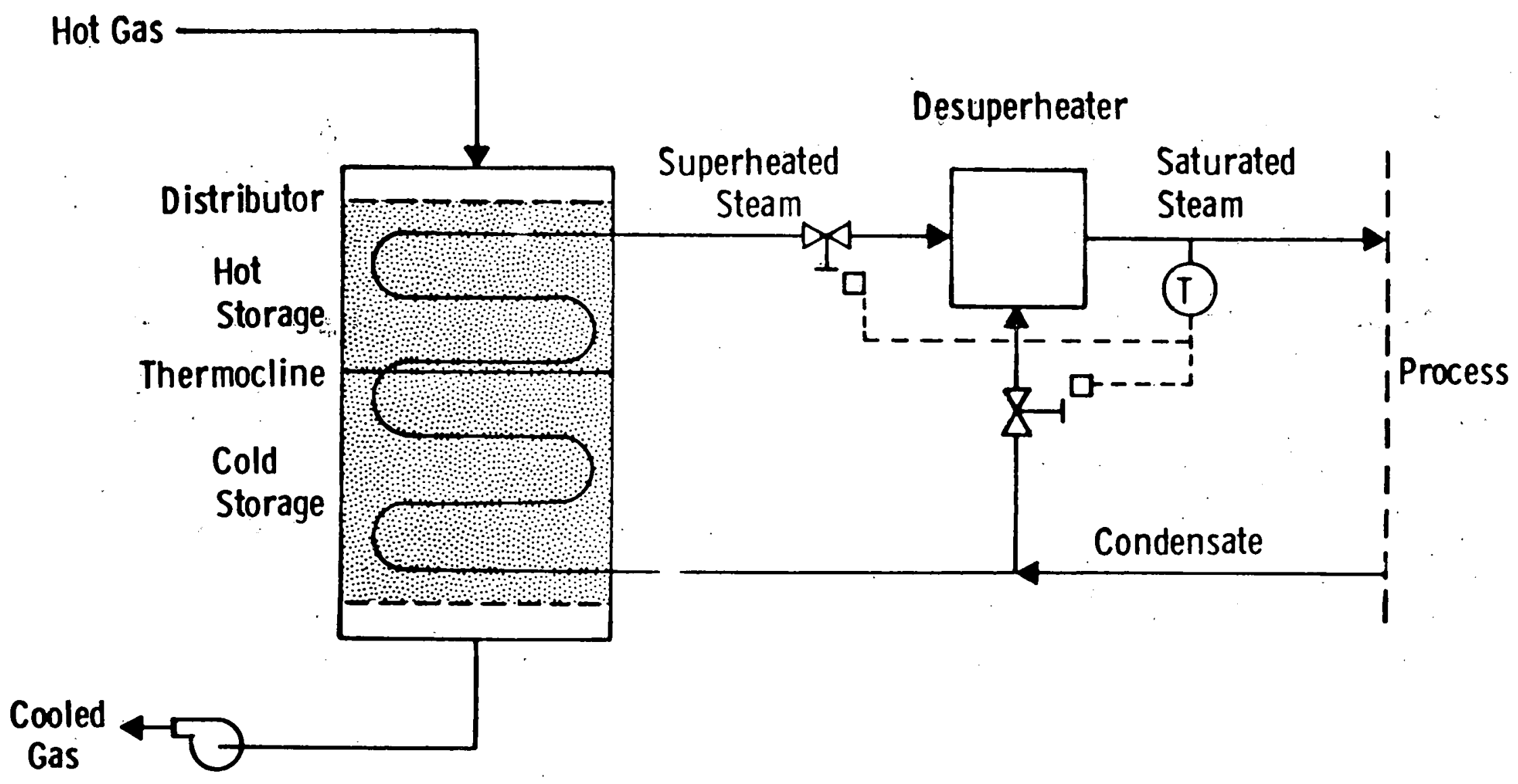

Fig. B. 10-1 - Packed bed integral storage and exchanger 
vessel dimensions and supplying hot gas to the top of the vessel, the bed may be made to have two thermal zones. The upper and lower zones are: essentially at the temperatures of the incoming gas and the outlet gas, respectively. The two zones are separated by a relatively sharp gradient, the thermocline, maintained by natural convection.

The system is characterized for constant saturated steam supply at 250 to $450^{\circ} \mathrm{F}$ with available supply of hot gas at 500 to $1500^{\circ} \mathrm{F}$. During discharge, the temperature of the superheated steam leaving storage wili gradually fall as the temperature driving force in the storage/exchanger is reduced. An energy balance on the desuperheater gives the ratio of superheated steam withdrawn from storage to saturated steam generated (Table B.10-1). The balance is recycled condensate $\left(\sim 100^{\circ} \mathrm{F}\right)$. Thus two flows must be feedbackcontrolled to maintain constant conditions as seen by the process. Note that withdrawal of superheated steam accelerates between charging cycles.

The heat transfer performance can be modeled by, assuming:

- No intra-particle gradients within bed

- The upper portion of the bed is at $T_{h}$

- The lower portion is at $\mathrm{T}_{\mathrm{c}}$

- Heat transfer area is proportional to the fraction of the bed still at $\mathrm{T}_{h}$ at any time.

In the above

$$
\begin{aligned}
& T_{h}=\text { hot gas temperature }\left({ }^{\circ} \mathrm{F}\right) \\
& T_{c}=\text { condensate recycle temperature }\left({ }^{\circ} \mathrm{F}\right) .
\end{aligned}
$$

The rate of energy withdrawal from storage at any time is constant at

$$
\Delta \mathrm{h}_{\mathrm{s}} \mathrm{m}_{\mathrm{s}}=\mathrm{UA} \frac{\mathrm{Qm}-\mathrm{Q}(\mathrm{t})}{\mathrm{Qm}} \overline{\Delta \mathrm{T}}
$$

where

$$
\begin{aligned}
\Delta_{\mathrm{S}}= & \text { difference between the enthalpies of } \\
& \text { saturated steam and condensate (Btu/lb) } \\
m_{s}= & \text { saturated steam rate (lb/hr) } \\
U^{=} & \text {overall heat transfer coefficient in } \\
& \text { storage/exchanger (Btu/hr } \left.-\mathrm{ft}^{2}-{ }^{\circ} \mathrm{F}\right) \\
\mathrm{A}= & \text { total heat transfer area in storage } \\
& \text { container ... }\left(\mathrm{ft}^{2}\right) \\
\mathrm{Q}_{\mathrm{m}}= & \text { energy storage capacity between } \mathrm{T}_{\mathrm{h}} \\
& \text { and } \mathrm{T}_{\mathrm{c}} \text { (Btu) } \\
\mathrm{Q}(\mathrm{t})= & \text { total heat withdrawn up to time } \mathrm{t} \text { (Btu) }
\end{aligned}
$$


TABLE B. $10-1$

STORAGE COASTDOWN

(Ib. superheated steam required per

1b. saturated steam)

$\begin{array}{cccc}\begin{array}{l}\text { Saturated Steam Temp, } \\ \text { Superheated Steam Temp } \\ \downarrow\end{array} & \rightarrow 250^{\circ} \mathrm{F} & 350 & 450 \\ 1500^{\circ} \mathrm{F} & . & & \\ 1200 & 0.63 & 0.65 & 0.65 \\ 900 & 0.69 & 0.71 & 0.72 \\ 600 & 0.78 & 0.80 & 0.81 \\ 300 & 0.87 & 0.89 & 0.92 \\ & 0.98 & -- & --\end{array}$




$$
\begin{aligned}
& =m_{s} \Delta h_{s} t \\
\overline{\Delta T} & =\left[\left(T_{h}-T_{s s}\right)-\left(T_{h}-T_{c}\right)\right] / \ell n\left[\left(T_{h}-T_{s s}\right) /\left(T_{h}-T_{c}\right)\right]
\end{aligned}
$$

The boundary conditions are

$$
\begin{array}{ll}
T_{s S}=T_{h}-T^{\prime} & \text { e } t=0 \\
T_{s S}=T_{s} & \text { e } t=t_{D}
\end{array}
$$

where:

$$
\begin{aligned}
& T_{\text {SS }}=\text { superheated steam temperature }\left({ }^{\circ} \mathrm{F}\right) \\
& T^{\prime}=\text { (parameter) temperature driving force }\left({ }^{\circ} \mathrm{F}\right) \\
& T_{S}=\text { saturated steam temperature }\left({ }^{\circ} \mathrm{F}\right) \\
& \mathrm{t}_{\mathrm{D}}=\text { discharge cycle length }(\mathrm{hr})
\end{aligned}
$$

Then

$$
\frac{m}{m_{s} t_{D}}=\frac{\Delta h_{s} R}{\int_{T}^{T_{h}} C_{p} d T}
$$

where

$$
\begin{aligned}
m & =\text { storage mass required }(1 \mathrm{~b}) \\
C_{p} & =\text { solid specific heat }(B t u / 1 b)
\end{aligned}
$$

and

$$
\frac{1}{R}=1-\left(\frac{T^{\prime}-\left(T_{h}-T_{c}\right.}{T_{c}-T_{s}}\right) \frac{\ln \left(\frac{T_{h}-T_{s^{\prime}}}{T_{h}-T_{c}}\right)}{\ln \left(T_{h}-T_{c}^{\prime}\right)}
$$

Note that the factor $R$ is the ratio of storage mass required to that which would be required if no dilution of the superheated steam were needed.

The heat transfer area required is that required to generate superheated steam at its initial temperature:

$$
\frac{U_{o}}{\Delta h_{s} m_{s}}=\frac{\ln \left(\frac{T^{\prime}}{T_{h}-T_{c}}\right)}{T^{\prime}-\left(T_{h}-T_{c}\right)}
$$


The results are summarized in Table B.10-2 for several combinations of parameters, assuming sand for a storage medium.

\section{FLUID BED HEAT EXCHANGER WITH PACKED BED STORAGE}

The poor heat transfer performance in the stationary packed bed storage mode can be overcome if the storage and heat exchange functions are separated, an example of which is shown in Figure B.10-2. Here, separate storage bins are provided for hot and cold storage. Cold material is lifted as needed to a raining bed heat exchanger in which the hot gas sensible heat is contactively transferred to the solids. This exchange can be virtually complete. From hot storage, material is delivered to a fluidized bed heat exchanger wherein the enthalpy is released to inbed heat exchange tubes containing the process steam. Fluid bed-toimmersed surface heat transfer rates are very much higher than surfaceto-settled bed rates. Therefore, much less heat transfer area is required.

The fluid bed exchanger shown in Figure B.10-2 is shown as-a countercurrent staged cascade device. This is because the solids in a single stage are essentially completely mixed and the solids' temperature leaving a stage cannot be reduced to a value below that of the leaving water/steam. Where the available waste heat temperature is much larger than the needed steam temperature, as in the current example, one or two stages may be economically feasible. When the temperatures are less divergent, however, more stages may be desirable for more complete use of the solids' thermal capacity. If multiple stages are used, the quantity of solids needed will be minimized (an R-factor of near unity as described in the previous section). However two bins, each capable of holding all the material must be provided. Also note that heat exchange temperature driving forces may be maintained constant simply by controlling solids flow rates.

A disadvantage of the depicted scheme is the power requirement for fluidizing and transporting solids. The fluid bed exchanger can be quite small, however, and power consumption can be further minimized by using small particles.

The fluid bed exchanger is characterized for one- and two-stage applications. Designating the temperature of the solids leaving the lower stage as $T_{0}$ then the effectiveness of heat exchanger in extracting heat from the waste heat stream is

$$
\varepsilon=\frac{T_{h}-T_{o}}{T_{h}-T_{c}}
$$

Defining the parameter $T$ ' as the temperature difference between the upper solids bed and steam, then for a single-stage bed

$$
T_{0}=T_{S}+T^{\prime}
$$


TABLE B. 10-2

PACKED BED STORAGE CHARACTERIZATION

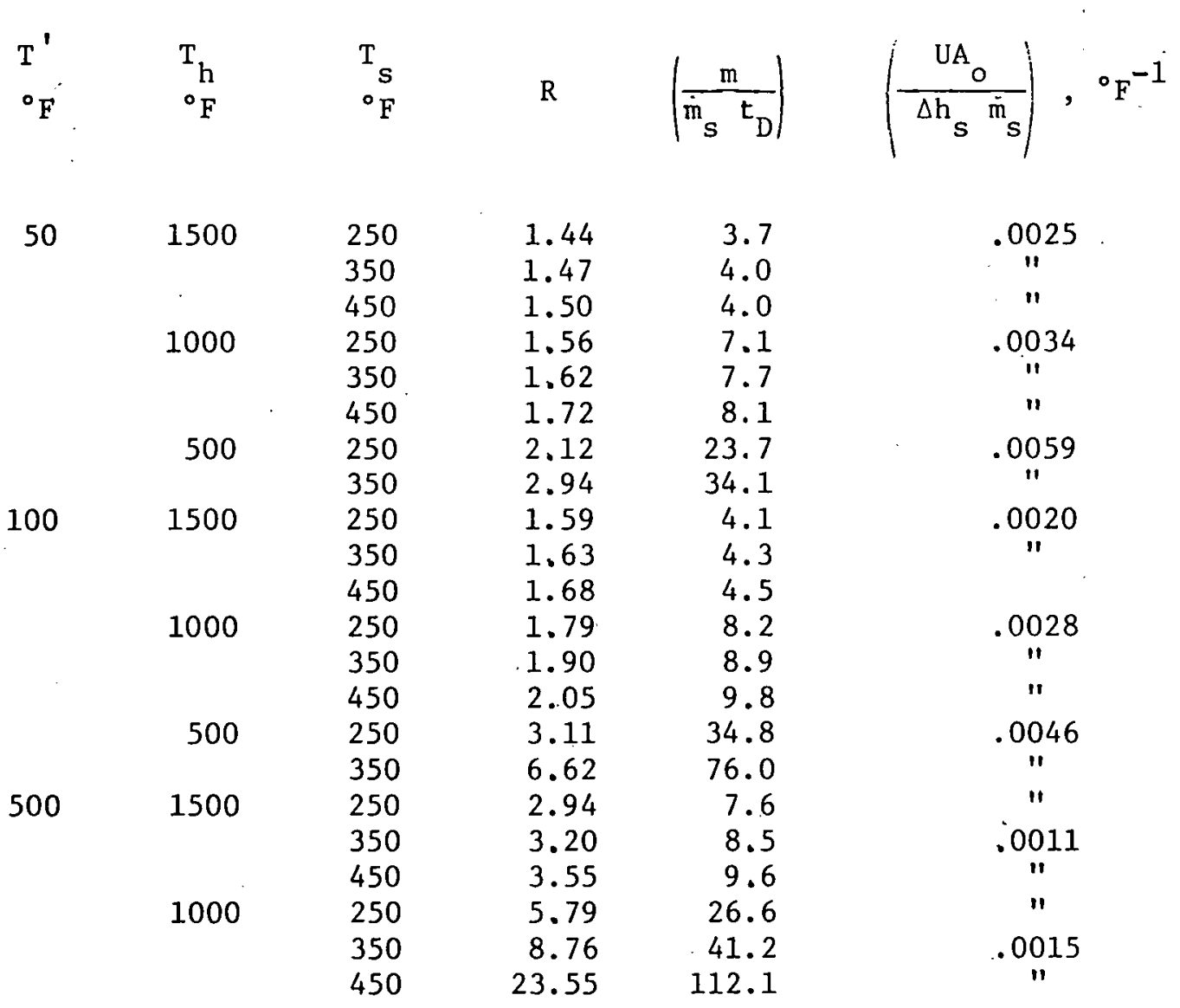




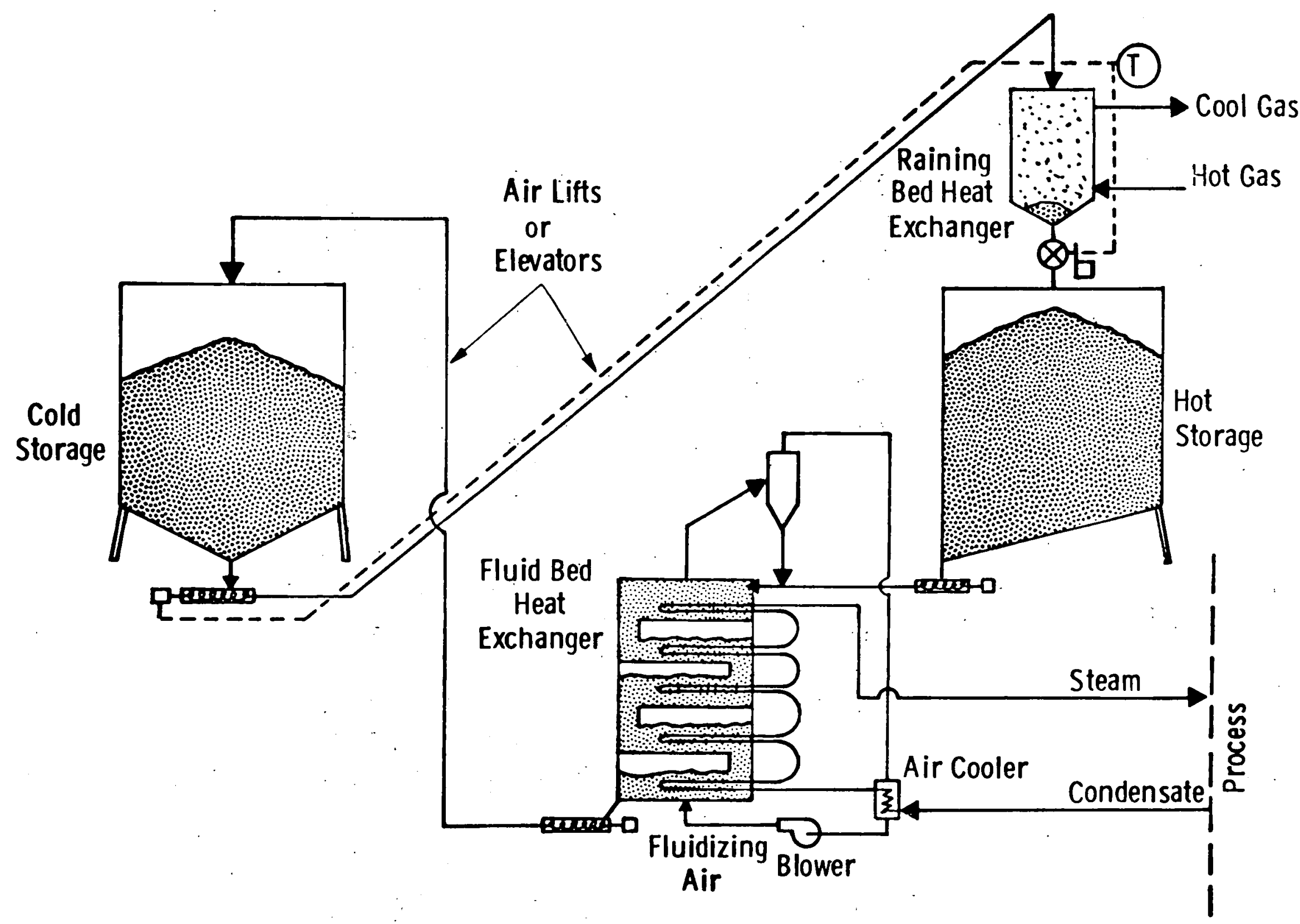

Fig. B.10-2 - Fluid bed/packed bed exchanger combination with packed bed storage 
and for a two-stage bed

$$
\begin{gathered}
T_{0}=2\left(T_{s}+T^{\prime}\right)-T_{h} \\
\text { or, if larger, } \\
T_{0}=T_{c}+T^{\prime}
\end{gathered}
$$

For either case, the mass of storage material required will be

$$
\frac{m}{m_{s} t_{D}}=\frac{\Delta h_{s}}{T \int_{0}^{T_{h}} c_{p} d T}
$$

and the heat exchange requirement will be approximated by the reciprocal of the log-mean temperature difference. The results are shown in Table B. 10-3.

\section{MOVING BED EXCHANGER/STORAGE}

Another way to circumvent the poor bed-to-tube heat transfer rates of the stationary packed bed system is to use an intermediate gas loop to extract heat from solids and deliver them to an evaporator. This arrangement is shown in Figure B.10-3. The Babcock and Wilcox Company has used a similar design (Glenn, 1976), with a moving bed exchanger substituted for the raining bed exchanger shown at the top of Figure B.10-3. We have made the change to prevent the passing of significant amounts of cold solids into hot storage when hot gas is not avaflable. The intermediate air loop shown results in some loss of energy avallability, but this is very low because of the very efficient nature of solids-to-gas heat transfer. Again, of course, there is the energy requirement for circulation of the gas stream and elevation of cold solids.

Again designating the cold sollds temperature as $\mathrm{T}_{O}$, the overall heat transfer effectiveness is given by equation 7 , the storage mass by equation 10, and the evaporator surface requirement, $U A / \Delta h_{s} m_{S}$, by the reciprocal of the log-mean temperature difference. Designating the temperature difference at the cold end of the evaporator as $T^{\prime}$ and the average temperature difference in the moving bed exchanger as $T_{E}$, then

$$
T_{0}=T_{c}+T_{E}+T^{\prime}
$$

The results are given in Table $B: 10-4$ for $T_{E}=10^{\circ} \mathrm{F}$. 
TABLE B. 10-3

FLUIDIZED HEAT EXCHANGER/PACKED BED STORAGE CHARACTERIZATION

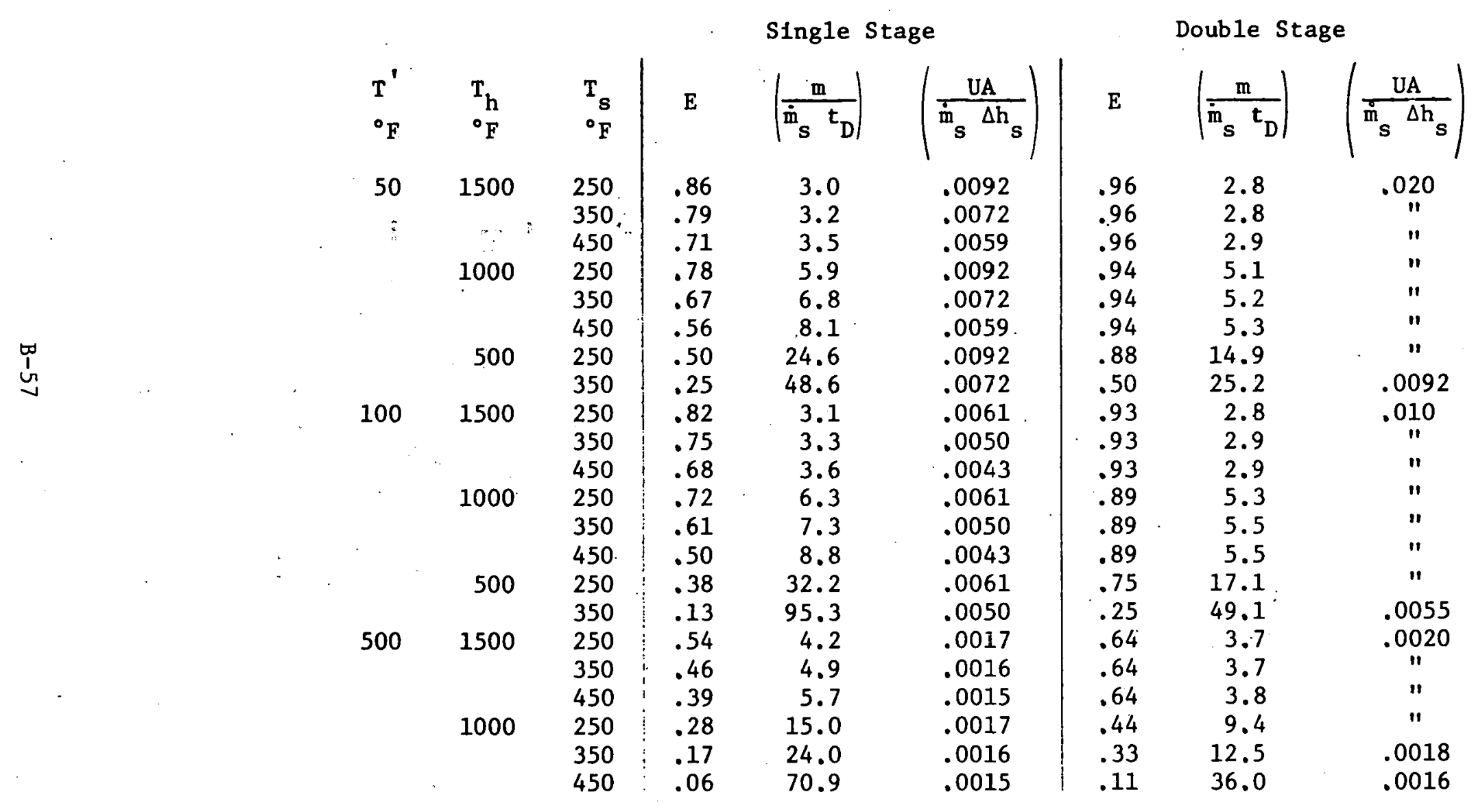




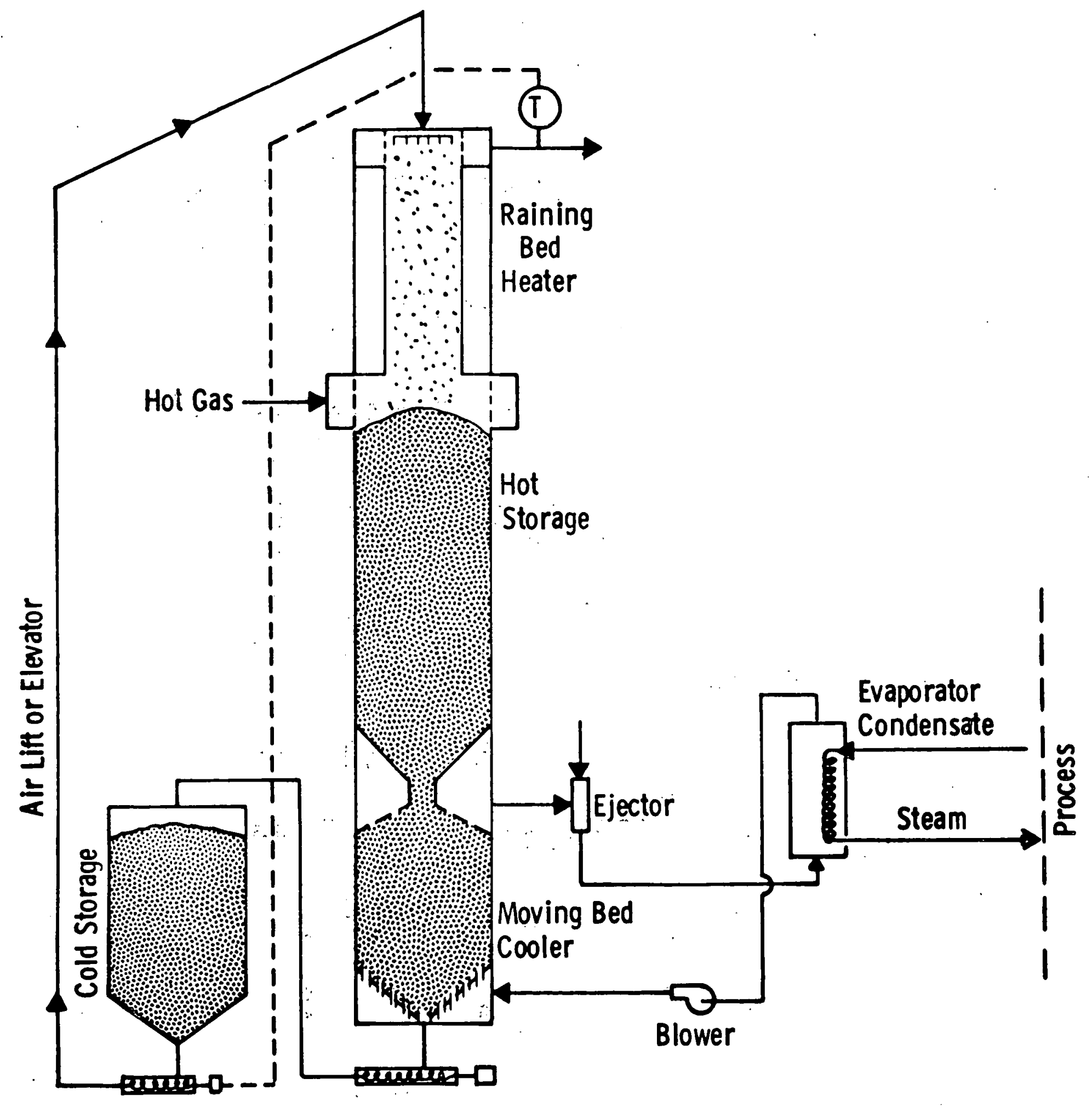

Fig. B.10-3 - Moving bed exchanger/storage 
TABLE $B \cdot 10-4$

MOVING BED EXCHANGER/PACKED BED STORAGE CHARACTERIZATION

ڤ్

\begin{tabular}{|c|c|c|c|c|c|}
\hline $\mathrm{T}^{\prime}$ & $T_{h}$ & $\mathrm{~T}_{\mathrm{s}}$ & $F$ & $\mathrm{~m}$ & UA \\
\hline${ }^{\circ} \mathrm{F}$ & ${ }^{\circ} \mathrm{F}$ & ${ }^{\circ} \mathrm{F}$ & 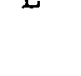 & $\mid \begin{array}{ll}\mathrm{m}_{s} & t_{p}\end{array}$ & $\Delta \mathrm{h}_{\mathrm{s}} \mathrm{m}_{\mathrm{S}}$ \\
\hline \multirow[t]{8}{*}{50} & 1500 & 250 & .96 & 2.8 & .0027 \\
\hline & & 350 & " & 2.8 & .0029 \\
\hline & & 450 & $"$ & 2.9 & .0031 \\
\hline & 1000 & 250 & .93 & 5.1 & .0039 \\
\hline & & 350. & $"$ & 5.3 & .0043 \\
\hline & & 450 & " & 5.3 & .0049 \\
\hline & 500 & 250 & .85 & 15.3 & .0083 \\
\hline & & 350 & " & 15.7 & .0114 \\
\hline \multirow[t]{8}{*}{100} & 1500 & 250 & .92 & 2.8 & .0022 \\
\hline & & 350 & " & 2.9 & .0023 \\
\hline & & 450 & " & 2.9 & .0025 \\
\hline & 1000 & 250 & .88 & 5.4 & .0031 \\
\hline & & 350 & $"$ & 5.5 & .0034 \\
\hline & & 450 & $"$ & 5.6 & .0038 \\
\hline & 500 & 250 & .72 & 17.5 & .0063 \\
\hline & & 350 & " & 18.0 & .0084 \\
\hline \multirow[t]{6}{*}{500} & 1500 & 250 & .64 & 3.7 & .0012 \\
\hline & & 350 & " & 3.8 & .0013 \\
\hline & & 450 & $"$ & 3.8 & .0014 \\
\hline & 1000 & 250 & .43 & 9.6 & .0016 \\
\hline & & 350 & $"$ & 9.9 & .0018 \\
\hline & & 450 & $"$ & 10.0 & .0019 \\
\hline
\end{tabular}


McDonnel1 Douglas Astronautics Company (MDAC) has developed a system whereby the packed bed thermocline concept is used without the need for either immersed heat exchange surfaces or the transport of solids

(Hallet and Gervais, 1977). This system is shown in Figure B.10-4. During charging, a commercial heat transfer fluid (Exxon's Calorla HT43), withdrawn from the bottom of a vessel containing a packed bed of one-inch rocks, is heated by the waste gas stream and restored to the top of the storage vessel. A separate steam generator is powered by hot fluid circulating from the top to the bottom of the vessel. Thus independent operation of the source and load are possible. The inventory of fluid in storage is constant and divided into hot and cold zones by natural convection. The rock bed ( $75 \%$ of storage volume) exchanges heat with the circulating oil and minimizes the amount of fluid needed. The disadvantage of this system is, of course, the cost of the heat transfer fluid.

Designating the, hot and cold fluid temperatures as $T_{1}$ and $T_{2}$ we will define the parameter $\mathrm{T}^{\prime}$, by

$$
\mathrm{T}_{2}+\mathrm{T}^{\prime}=\mathrm{T}_{0}
$$

and

$$
\mathrm{T}_{2}-\mathrm{T}^{\prime}=\mathrm{T}_{\mathrm{c}}
$$

where $T_{0}$ and $T_{C}$ are the cooled gas and condensate temperatures, respectively. We will also assume that $\mathrm{T}_{1}$ is the minimum of $\mathrm{T}_{\mathrm{h}}-\mathrm{T}^{\prime}$ and $600^{\circ} \mathrm{F}$, the maximum working temperature of the fluid. Then the specific storage volume $\left(\mathrm{V} / \mathrm{m}_{S} \mathrm{t}_{\mathrm{D}}\right)$ and masses of fluid and rock $\left(\mathrm{m}_{L} / \mathrm{m}_{S} \mathrm{t}_{D}\right.$ and $\left.\mathrm{m}_{R} / \mathrm{m}_{S} \mathrm{t}_{\mathrm{D}}\right)$ can be calculated from densities, heat capacities, $\Delta \mathrm{h}_{S}$, and $\mathrm{T}_{1}$ and $\mathrm{T}_{2}$. The results are in Table $B .10-5$.

\section{STEAM ACCUMULATORS}

The storage of steam as pressurized water is a well developed technology. It allows the storage of energy in a compact form due to the high heat of vaporization of water. The disadvantage is, of course, the requirement for large pressure vessels.

The two conventional accumulator types are illustrated in Figs. B.10-5 and 6 . These are the variable and constant pressure accumulators, respectively. Variable pressure storage (Fig. B.10-5) is suited to independent operation of the steam generation and steam use plants. As heat is available steam is generated at temperatures well above the eventual use temperatures and introduced into the saturated storage vesse1. When steam is needed saturated steam is withdrawn directly from storage. The saturated steam pressure and temperature constantly drop during discharge. The minimum storage pressure is, therefore, the steam delivery pressure. 


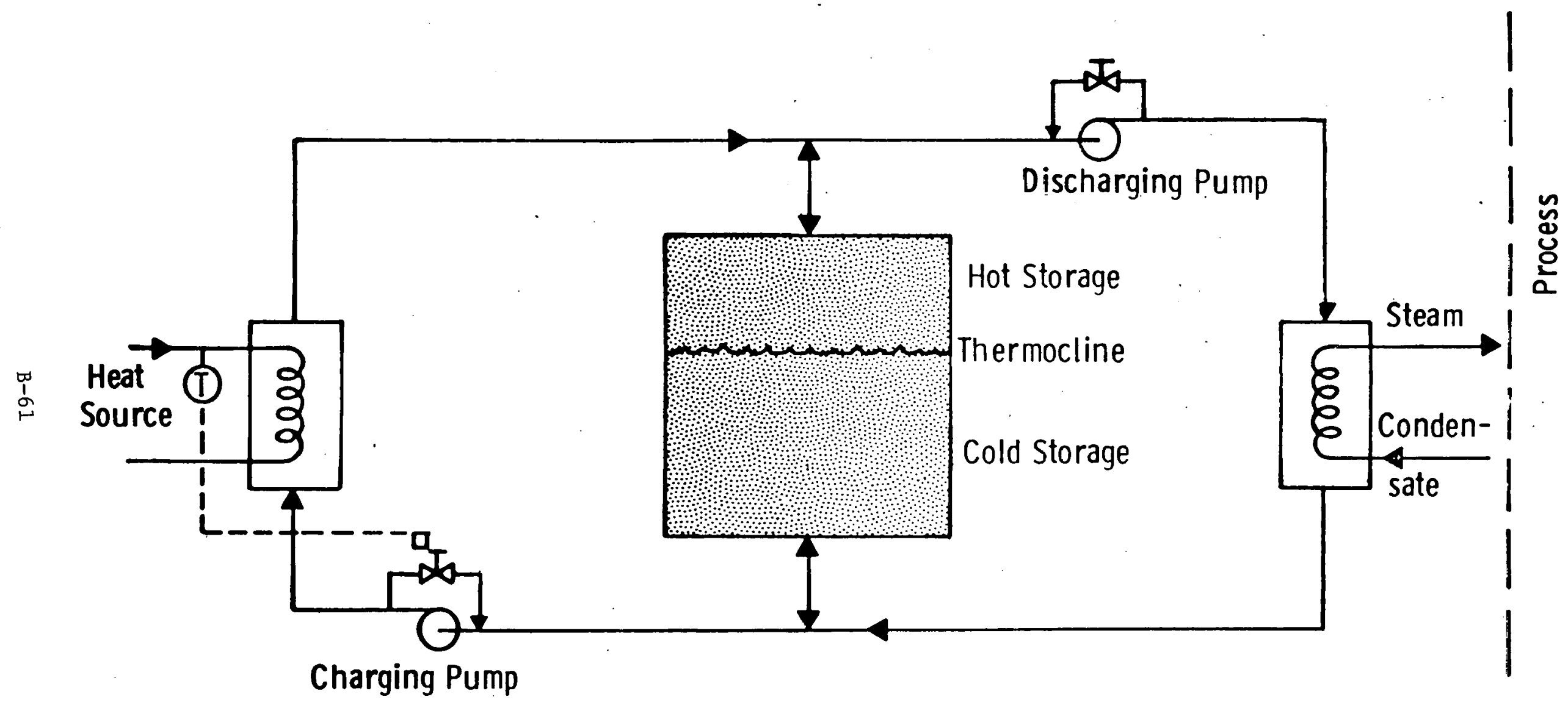

Fig. B. 10-4- Hot liquid/pebble bed storage with thermocline 
TABLE B. 10-5

MDAC COMBINED FLUID/ROCK STORAGE SYSTEM CHARACTERIŻATION

D
N
N

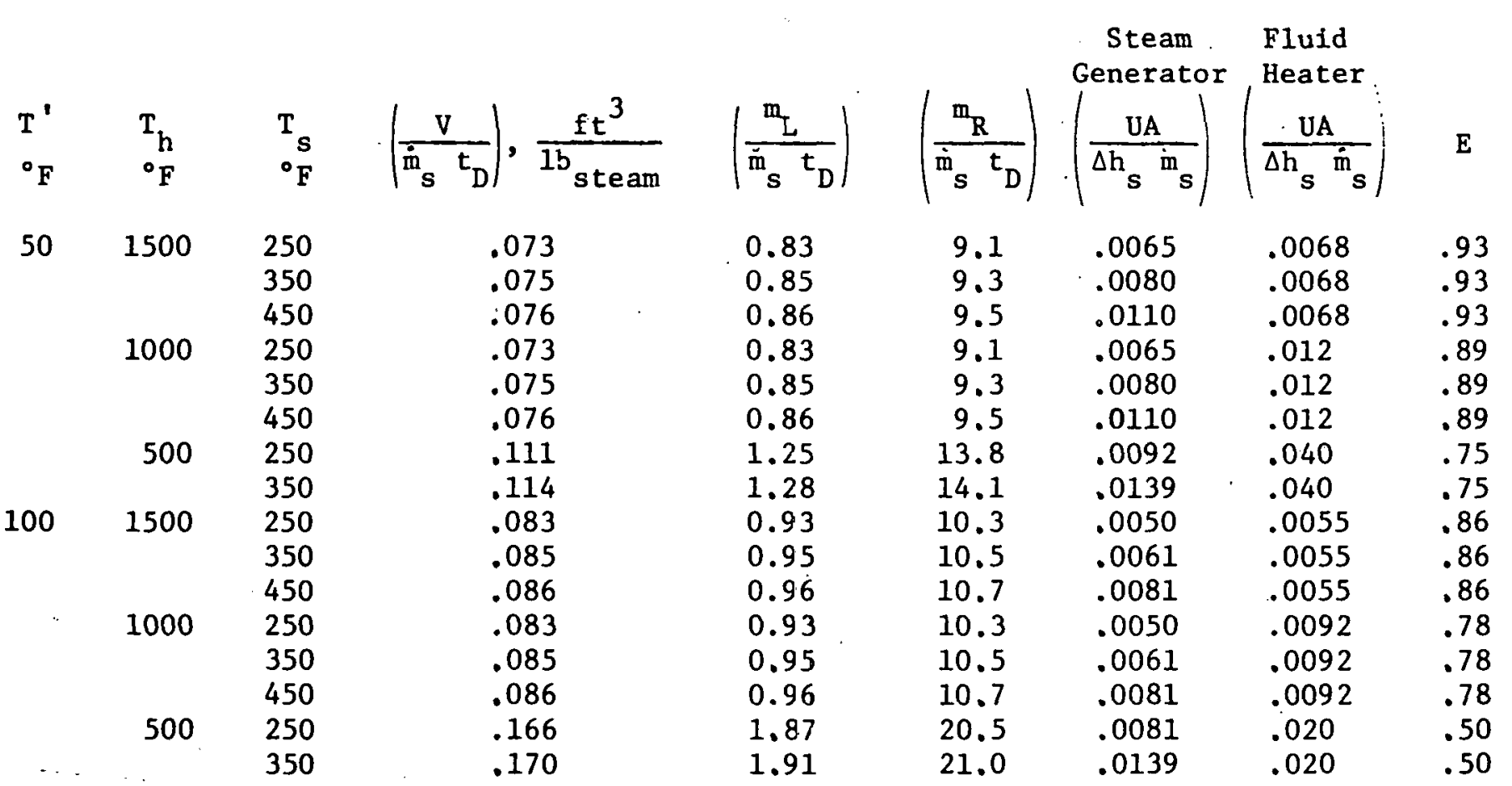




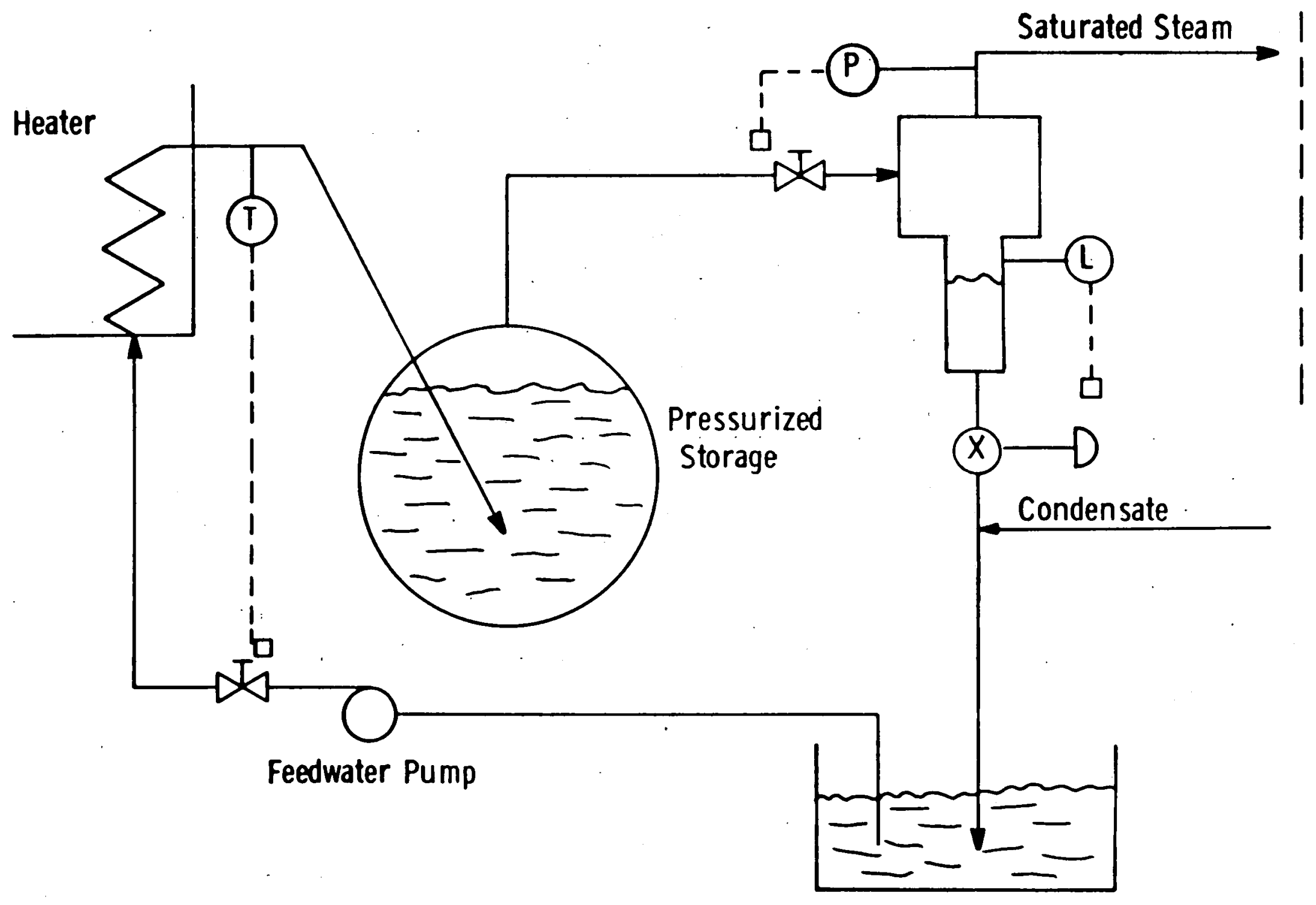

Fig. B.10-5 - Variable pressure saturated steam accumulator 


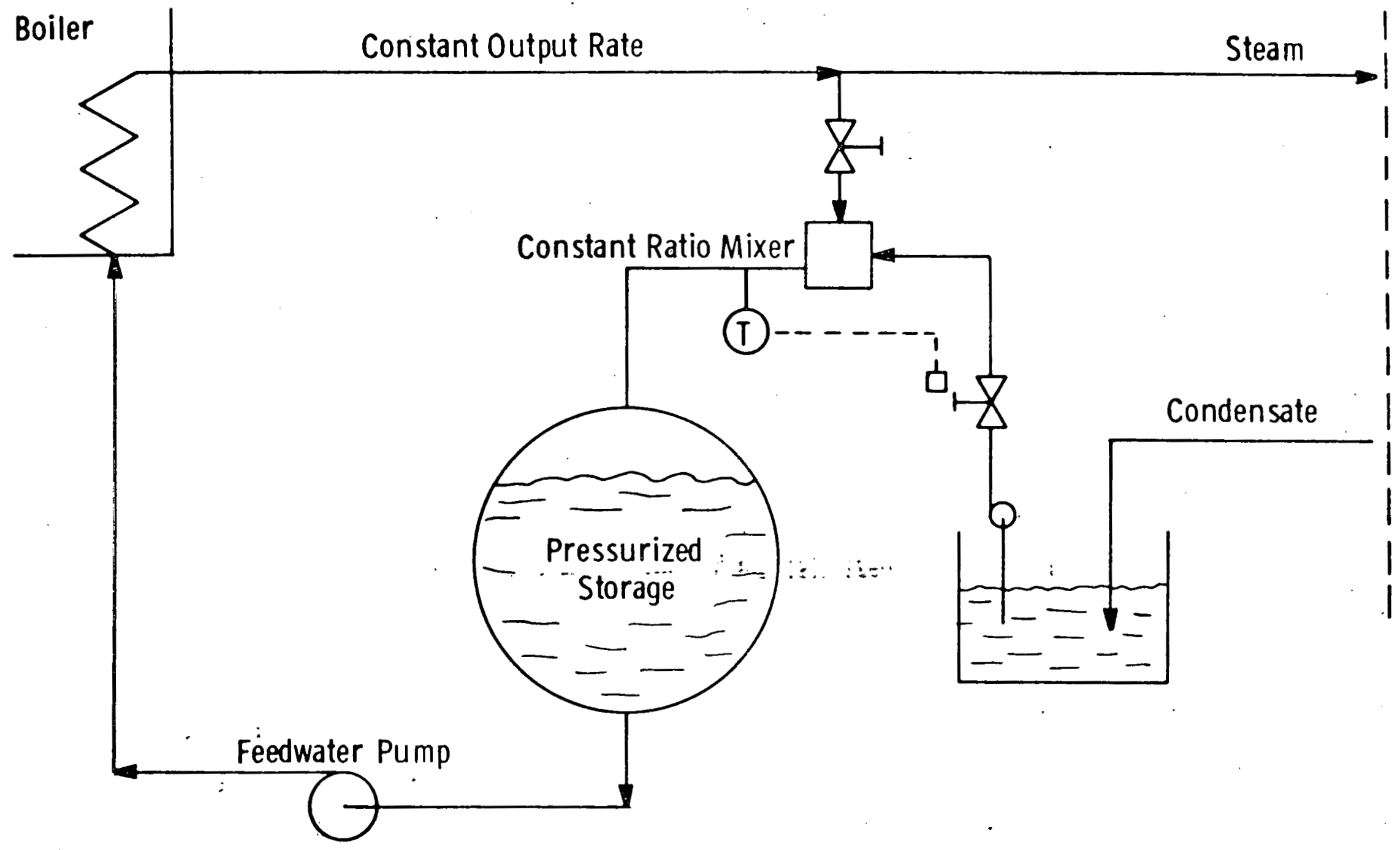

Fig. B.10-6-Constant delivery pressure saturated steam accumulator 
Carr,et.al. (1978) define the storage volume requirement ( $\mathrm{ft}^{3}$ of storage. per $1 \mathrm{~b}$ steam generated during discharge) as:

$$
\frac{V}{m_{s} t_{D}}=2 /\left[10 \log _{1 p} \frac{P_{1}}{P_{2}}+P_{1}-P_{2}\right]
$$

where $\mathrm{P}_{1}$ and $\mathrm{P}_{2}$ are the maximum and minimum storage pressures, respectively. Table B.10-6 gives the storage volume requirement at various pressure combinations. Note that if fine control of steam quality is required, a small amount of condensate will have to be added or subtracted from the expander. Table B.10-6 gives the ratio of steam being extracted from storage to steam generated $\left(\mathrm{m}_{1} / \mathrm{m}_{\mathrm{s}}\right)$ at any pressure.

The constant pressure accumulator is shown in Figure B.10-6. It is suitable to situations where steam generation is constant but demand varies. As such it is simply an added capacity in the boiler feedwater system. The boiler must always generate steam at the rate of maximum demand. $\Lambda$ t lower demands excess steam is mixed with cool feedwater in a constant ratio, yielding a constant enthalpy mixture which is stored. Preheated feedwater is removed from storage at a constant rate. The advantages of the constant pressure accumulator are that steam need not be generated at a pressure in excess of that needed by the process and the boiler can be designed for a lower maximum heat rate.

The ratio of steam to cold feedwater being delivered to storage is constant and has the value

$$
z=\frac{h_{h}-h_{c}}{h_{s}-h_{h}}
$$

The ratio of maximum (design) boiler heat rate in a no-storage system to the steady heat rate in the constant-pressure storage system is

$$
\frac{h_{s}-h_{c}}{h_{s}-h_{h}}=1+z
$$

equation 15 , the specific enthalpies are

$$
\begin{aligned}
& h_{h}=\text { saturated water at storage pressure } \\
& h_{c}=\text { cold feedwater } \\
& h_{s}=\text { delivered steam }
\end{aligned}
$$

The storage volume required is

$$
\frac{\mathrm{v}}{\mathrm{m}_{\mathrm{s}} \mathrm{t}_{\mathrm{D}}}=\frac{\mathrm{h}_{\mathrm{s}}-\mathrm{h}_{\mathrm{c}}}{\mathrm{h}_{\mathrm{h}}-\mathrm{h}_{\mathrm{c}}} \frac{1}{\mathrm{p}_{\mathrm{h}}}
$$


TABLE B. $10-6$

VARIABLE PRESSURE STEAM ACCUMULATOR REQUIREMENTS

\begin{tabular}{cccc}
\hline$T_{s}$ & $\begin{array}{c}\text { Storage } \\
\text { Pressure, } \\
\text { psia }\end{array}$ & $\left(\frac{\mathrm{m}_{1}}{\mathrm{~m}_{\mathrm{s}}}\right)$ & $\left(\frac{\mathrm{V}}{\mathrm{m}_{\mathrm{s}} \mathrm{t}_{\mathrm{D}}}\right)$, \\
$\mathrm{ft}^{3} / \mathrm{lb}$ \\
250 & 200 & .97 & .118 \\
& 500 & .96 & .069 \\
& 1000 & .97 & .048 \\
350 & 1600 & 1.00 & .039 \\
& 200 & .99 & .473 \\
& 500 & .99 & .123 \\
450 & 1000 & 1.00 & .070 \\
& 1600 & 1.03 & .051 \\
& 500 & 1.00 & .762 \\
& 1000 & 1.02 & .134 \\
& 1600 & 1.06 & .079
\end{tabular}


where $\rho_{h}$ is the stored water density. Typical requirements are listed in Table B.10-7.

7. COMPARISON OF THE THERMAL ENERGY STORAGE TECHNIQUES

Using the above relationships the storage requirements for the various systems were estimated for the specific case defined by:

$\begin{array}{ll}\text { Steam Rate } & 1000 \mathrm{lb} \\ \text { Discharge Time } & 10 \mathrm{hr} \\ \text { Steam Temperature } & 350^{\circ} \mathrm{F} \\ \text { Waste Heat Gas Temperature } & 1000^{\circ} \mathrm{F} \\ \text { Temperature Driving Force Parameter, T' } & 100^{\circ} \mathrm{F} .\end{array}$

Gas-particle heat transfer coefficients were evaluated according to the methods presented by Kunii and Levenspiel (1969). The packed bed to tube coefficlent is after Holt (1962). The fluid bed coefficient for immersed surfaces follows Zabrodsky et.al (1976). Other coefficients are engineering estimates.

The results of the comparison, including storage volume (total of hot and cold), storage material mass, exchanger sizes, and tube heat transfer areas are listed in Table B.10-8. Variable pressure steam accumulator volumes are given at two pressures. 
TABLE B.10-7

\section{CONSTANT PRESSURE ACCUMULATOR CHARACTERIZATION}

\begin{tabular}{rcc|c}
$\mathrm{T}_{\mathrm{s}}$ & $\begin{array}{c}\text { Storage } \\
\text { Pressure, } \\
\text { psia }\end{array}$ & $\mathrm{z}$ & $\left.\frac{\mathrm{V}}{\mathrm{m}_{\mathrm{s}} \mathrm{t}_{\mathrm{D}}}\right), \frac{\mathrm{ft}^{3}}{\mathrm{Ib}}$ \\
250 & 20 & .11 & .165 \\
350 & 20 & .11 & .169 \\
& 50 & .17 & .116 \\
450 & 100 & .24 & .092 \\
& 20 & .11 & .171 \\
& 50 & .17 & .118 \\
& 100 & .24 & .093 \\
& 200 & .32 & .076 \\
& 400 & .43 & .064
\end{tabular}




\section{TABLE B. 10-8}

COMPARISON OF DESIGN REQUIREMENTS FOR THERMAL ENERGY STORAGE SYSTEMS

$$
\text { ( } \sim 10^{7} \text { Btu Capacity) }
$$

\begin{tabular}{|c|c|c|c|c|c|c|c|}
\hline System & $\begin{array}{l}\text { Stationary } \\
\text { Bed }\end{array}$ & $\begin{array}{l}\text { Fluidi } \\
\text { one-stage }\end{array}$ & $\begin{array}{l}\text { Bed } \\
\text { two-stage }\end{array}$ & $\begin{array}{l}\text { Moving } \\
\text { Bed }\end{array}$ & $\begin{array}{l}\text { 011/Rock } \\
\text { Thermocline }\end{array}$ & $\begin{array}{l}\text { Variable } \\
\text { Steam. Ac }\end{array}$ & $\begin{array}{l}\text { Pressure } \\
\text { umulator }\end{array}$ \\
\hline Particle Size & any & $500 \mu \mathrm{m}$ & $500 \mu \mathrm{m}$ & $2000 \mu \mathrm{m}$ & 1 Inch & - & - \\
\hline Storage Pressure, psia & - & -- & - & -- & -- & 1000 & 1600 \\
\hline $\begin{array}{l}\text { Heat Transfer-Coefficients } \\
\text { - overall }\left(\mathrm{Btu} / \mathrm{hr}-\mathrm{ft}^{2} \mathrm{C}^{\circ} \mathrm{F}\right)\end{array}$ & & $\cdots$ & & & $\therefore$ & $\because$ & \\
\hline Sollds To Tube & 0.9 & 60 & 60 & - & - & - & -- \\
\hline Gas to Raining Solids & -- & 75 & 75 & 48 & - & -- & -- \\
\hline Gas to Packed Solids & - & - & - & 46 & - & - & -- \\
\hline $\begin{array}{l}\text { Gas to Tube } \\
\text { Liquid to Tube }\end{array}$ & - & - & - & 10 & $\begin{array}{r}15 \\
200\end{array}$ & - & $=$ \\
\hline Stored Sollds Mass, 1b & 89000 & 73000 & 55000 & 55000 & 105000 & - & -- \\
\hline Stored h,t. Fluid Mass, lb & - & - & - & - & 9500 & - & -- \\
\hline Storage volume, $\mathrm{ft}^{3}$ & 960 & 1460 & 1100 & 1100 & 850 & 700 & 510 \\
\hline Fluld Bed Vessel Volume, $\mathrm{ft}^{3}$ & -- & 90 & 110 & -- & -- & -- & -- \\
\hline Particle Heater Volume, $\mathrm{ft}^{3}$ & -- & 150 & 150 & 35 & -- & - & -- \\
\hline Moving Bed Exchanger Volume, $\mathrm{ft}^{3}$ & - & -- & - & 50 & -- & - & -- \\
\hline Steam Exchanger Tube Area, $\mathrm{ft}^{2}$ & 3400 & 90 & 190 & 380 & 35 & -- & -- \\
\hline Source Exchanger Tube Area, $\mathrm{ft}^{2}$ & - & -- & - & -- & 700 & -- & -- \\
\hline Fluldizing Alr Power, $\%$ of Load & -- & 1.4 & 2.0 & - & - & -- & -- \\
\hline
\end{tabular}


The following publications provide a cross-section of information on sensible and latent heat energy storage. In many cases the titles are sufficiently descriptive. In other cases we have added a few words to convey the salient points of the discussion. IECEC = Intersociety Energy Conversion Engineering Conference.

Atomics International, "Commercial Applications of Solar Total Energy Systems," Report to ERDA, April 1977, (AI-ERDA-13200). (overal1 system modeling)

Bachovchin, D.M., D. L. Keairns, R. A. Newby, D. H. Archer, "Thermal Energy Storage Systems Utilizing Fluidized Bed Combustion and Heat Exchange Modules," Paper presented at Third National Conference on Technology for Energy Conservation, Tucson, January, 1979.

Battelle Columbus Laboratories, "Final Report on Investigation of Storage Systems Designs and Techniques for Optimizing Energy Conservation in Integrated Utility Systems," Three volumes, March 1976, Report to NASA, (N76-22662 through 4 NASA CR-147591 through 3). (residential use temperature levels)

Bergougnou, M. A., "Storage and Recovery of Thermal Energy by Fluidizable Beds," Proc. 14th Southeastern Seminar on Thermal Sciences, North Carolina State University, Raleigh, April 1976.

Bergougnou, M.A. and C. J. Kim, "Versatile Solar Energy Storage by Means of Fluidizable Solids," Proc. Annual Meeting of Solar Energy Soc. of America, Denver, August 1978.

Bergougnou, M. A. and A. J. Roy, "Special Fluidized Techniques to Support Solar Energy Concentrators for Power Generation," Paper at Concentrating Solar Collector Conference, Georgia Institute of Technology, Atlanta, September 1977.

Berkowitz, J. B. and H. P. Silverman, editors, Proc. Symposium on Energy Storage, Electrochemical Society, Inc., rrinceton, 1976. (Emphasis on electrochemical storage techniques)

Beverly, W. D., W. W. Engle, and F. O. Mahony, "Integration of High Temperature Thermal Energy Storage Into a Solar Thermal Brayton Cycle Power Plant," 12th IECEC, 1977 p. 1195. (Sensible heat in cast iron magnesia brick; latent heat of fluoride mixture. Helium working fluid)

Birchena11, C. E., "Heat Storage Material", University of Delaware College of Engineering report to DOE, December 1977, (C00-4042-16) (emphasis on metal and metal eutectic phase change materials) 
Boeing Engineering \& Construction, "Technical and Economic Assessment of phase change and thermochemical advanced thermal energy storage (TES) systems," Report to EPRI, December 1976, (EPRI EM-256), (see \# 8 above)

Botterill, J. S. M. and D. E. Elliott, "Fluidized Beds: Answer to Peak Power?" Engineering, 198, July 1964, p. 146.

Bramlette, T. T., R. M. Green, J. J. Bartel, D. K. Ottesen, C. T. Schafer, T. D. Brumleve, "Survey of High Temperature Thermal Energy Storage," Sandia Laboratories report to ERDA, March 1976, (\# SAND 75-8063). (good general survey)

Calogeras, J. E. and L. H. Gordon, "Storage Systems for Solar Thermal. Power," 13th IECEC, 1978, p. 970. (overview of DOE programs)

Carr, J. H., et al., "Applications of Thermal Energy Storage to Process Heat Storage and Recovery in the Paper and Pulp Industry," Report by Boeing Engineering and Construction to DOE. September 1978, (CONS 1 5082-1, NASA CR 159398).(steam accumulators)

Cohen, B. M. and R. E. Rice, "NaOH-Based High Temperature Heat-ofFusion Thermal Energy Storage Device," 13th IECEC, 1978, p. 941.

Duffie, J. A. and W. A. Beckman, Solar Energy Thermal Processes, Chapter 9, "Energy Storage," Wiley, NY, 1974. (Mixed and stratified water, packed beds, phase-change, All at low temperatures.)

Eaton, W. W., Energy Storage: ERDA Office of Public Affairs, Washington, DC, 1975. (Pamphlet on thermal and other storage modes).

Edenburn, M. W. "Optimum Conditions for a Cylindrical Parabolic Collector/Rankine Power Generation Cycle System," 12th IECEC, 1977, p. 1700. (Therminol-66 fluid cycle with storage)

Eichelberger, J. L., "Investigation of Metal Fluoride Thermal Energy Storage Materials: Availability, Cost, and Chemistry," Report by Pennwalt Corp. to ERDA, December 1976, (NTIS C00-2990-6).

Eichelberger, J. L. and H. D. Gillman, "Investigation of Metal Fluoride Thermal Energy Storage Materials," 12th IECEC, 1977.

Energy Storage. User Needs and Technology Applications, Proc. Engineering Foundation Conference, Pacific Grove, CA: February 1976. (Overview with institutional, economic, environmental consideration)

Ferrara, A., R. Haslet and J. Joyce, "Molten Salt Thermal Energy Storage for Utility Peaking Loads," 12th IECEC, 1977, p. 547. (Costs, materials, thermodynamic cycles) 
Glenn, D. R., "Technical and Economic Feasibility of Thermal Energy Storage," General Electric report to ERDA.

a. February, 1976 (\# C00-2558-1) (Survey of energy use and storage potential by sector and by sector technology status)

b. October 1976 (\# COO-2558-2) (Application to brick industry)

Glenn, D. R., R. L. McCarthy, and J. D. Schelkopf, "Industrial Energy. Conservation Through Integration of Thermal Energy Storage into Process Energy Dynamics," 11th IECEC, 1976.

Goldstern, W., Śteam Storage Installations, Pergamon, NY, 1970.

Golibersuch,.D. C., F. P. Bundy, P. G. Kosky, and H. B. Vakil,

"Thermal Energy Storage for Utility Applications" in Berkowitz, op. cit. (Steam storage, turnaround efficiency, latent heat)

Green, R. M., D. K. Ottesen, J. J. Bartel, and T. T. Bramlette, "High Temperature Thermal Energy Storage," Boer, K. W. ed.; Sharing the Sun. Solar Technology in the Seventies. Vol. 8, American Section of the International Solar Energy Society, Cape Canaveral 1976. (See Bramlette et al., above)

Hallet, R. W. and R. L. Gervais, "Central.Receiver Solar Thermal Power System, Phase 1: Preliminary Design Report, Volume 5: Thermal Storage Subsystem," Report by McDonnell Douglas Astronautics Co. to DOE, November 1977, (\# SAN/1108-8/5).(Rock/oil thermocline storage)

Hardy, M. P., V. D. Albertson, T. P. Bligh, M. Riaz, and P. L. Blackshear, "Large-scale Thermal Storage in Rock: Construction, Utilization, and Economics", 12th IECEC, 1977, p. 583.

Harper, A. D. and W. W. Spragins, "Development of a Thermal Storage Heater for a Closed Brayton Cycle Engine," 12th IECEC, 1977, p. 208.

Hoffman, H. W., R. J. Ked1, and R. A. Duscha, Thermal Energy Storage for Industrial Waste Heat Recovery," 13th IECEC, 1978, p.910. (Example integrations with specific industries)

Holt, A. D., "Apply Theory to Solids Heat Transfer," Chemical Engineering,' January 8, 1962.

Hughes, P. J., S. A. Klein, and D. J. Close, "Packed Bed Thermal Storage Models for Solar Air Heating and Cooling Systems," Trans. ASME J Heat Transfer 98, May 1976, p. 336.

Johnson, T. L. and W. B. Thomson, "Design of a Sodium-cooled, Central Receiver Solar Power Plant," 12th IECEC, p. 1203. (Direct sodium storage) 
Jones, B. G., R. P. Roy, and R. W. Bohl, "Molten Salt Energy Storage System - A Feasibility Study," Winter meeting ASME, Atlanta, GA, Nov. 27 - Dec. 2, 1977.

Joy, P. and B. Shelpuk, "Solar Heating Thermal Storage Feasibility," ASME paper 76-WA/HT-36, 1976. (domestic use)

Katto, Y. and T. Masuoka, "Criterion for the Onset of Convective Flow in a Fluid in a Porous Medium," Int J. Heat \& Mass Transfer. 10, 1967, pp. 297-309. (Theory relating to thermocline stability)

Kunii, D. and $O$. Levenspiel, Fluidization Engineering, John Wiley \& Son, NY, 1969. (Heat transfer and fluid mechanics)

Lior, N., P. S. Ayyaswamy, J. O'Leary, K. W. Kauffman, and H. Yeh, "Solar Energy Storage Considerations for Solar Power Generation," 11th IECEC, 1976, p. 613. (Sensible and latent heat calculations)

Margolis, S. B., "Thermocline Degradation in a Packed Bed Thermal Storage Tank," ASME J Heat Transfer, 100, May 1978, p. 371.

Marianowski, L. G. and H. C. Maru, "Latent Heat Thermal Energy Storage Systems Above $450^{\circ} \mathrm{C}, " 12$ th IECEC, 1977 , p. 555. (Materials, salts, heat transfer analysis, cyclic tests)

Martin Marietta Corp., "Central Receiver Solar Thermal Power System, Phase 1: Preliminary Design Report," Report to DOE, April 1977, \# SAN/1110-77-2 (Vo1 2). (0il and molten salt storage)

Mitchell, R. C., G. R. Morgan, and G. Coleman, "Gravel and Liquid Storage System for Solar Thermal Power Plant," in Boer, K. W.,ed. (see \# 27 above)

NATO Science Committee Conference on Thermal Energy Storage, 1976, Fnergy (Oxford), 2, 1977, pp. 56-85. (concise summary)

Nemecek, J. J., D. E. Simmons, and T. A. Chubb, "Demand Sensitive Energy Storage in Molten Salts," Solar Energy, 20, 1978, p. 213.

Nicholson, E. W. and R. P. Cahn, "Storage in Oil of off-Peak Thermal Energy from Large Power Stations," 11th IECEC, 1976, p. 598.

(Cost estimates and cycle alternatives)

Pate, R. A. and W. E. Phillips, "Design Charts for Hot Liquid Energy Storage Systems Utilizing Forced Circulation," AIAA 10th Thermophysics Conference, Paper \# 75-742, Denver, May 1975.

Pierce, B. L., F. R. Spurrier, and M. K. Wright, "Thermal Energy Storage," 12th IECEC, 1977, P. 1190. (Phase change materials, Rankine cycle) 
Public Service Electric and Gas Co., "An Assessment of Energy Storage Systems Suitable for Use by Electric Utilities," Report to EPRI

(EM-264) and ERDA (E(11-1)-2501), July 1976. (steam, oil, molten salts)

Quade, R. N., D. L. Vrable, and D. D. Peterman, "Energy Distribution and Storage Alternates with a Centralized Heat Source," 13 th IECEC, 1978, p.1016. (chemical, molten salt, steam)

Reay, D. A., Industrial Energy Conservation, "Energy Storage" chapter, Pergamon, NY 1977. (steam accumulator, molten salts, sensible)

Reimels, R. and J. R. Howe1l, "Solar Energy for Process Heat," in Boer, K. W., ed, Vol. 5. (see \# 27 above). (system model with storage)

Riaz, M., "Analytical Solutions for Single and Two-Phase Models of Packed-Bed Thermal Storage Systems," ASME SEries C: J.of Heat Transfer, 99, August 1977, p. 489.

Ridgway, S, L. and J. L. Dooley, "Underground Storage of Off-Peak Power," 11th IECEC, 1976, p. 586.

Schmidt, F. W. and J. Szego, "Transient Response of Solid Sensible Heat Storage Units - Single Fluid;" ASME Series C: J. of Heat Transfer, 98, August 1976, p.471.

Turner, R. H. and H. I. Awaya, "High Temperature Thermal Energy Storage in Moving Sand," 1e5h IECEC, 1978, p. 923. (Rough cost estimates for systems with packed bed, fluid bed, and dilute phase exchangers)

Vrable, D. L. and R. N. Quade, "High Efficiency Thermal Energy Storage Systems for Utility Application," 13th IECEC, 1978, p. 917. (salts)

Yuan, S. W., A. M. Bloom, and M. Nazli, "Heat Transfer in Solar Energy Storage," ASME paper 77-HT-38, 1977. (Unprepared earch/waterpipe systems)

Zabrodsky, S. S., N. V. Antonishin, and A. L. Parnas, "On Fluidized Bed-to-Surface Heat Transfer," Canadian Journal of Chemical Engineering, 54, 1976, p.52. 
The application of Rankine bottoming cycles for cogeneration was investigated. The thermodynamic operating performance was determined for selected power generation subsystems in the temperature range 75 to $300^{\circ} \mathrm{C}$ and the capacity range from 3 to $30 \mathrm{MW}$.

The working fluids selected for top temperatures of $300^{\circ} \mathrm{C}, 200^{\circ} \mathrm{C}$, and $100^{\circ} \mathrm{C}$ were Fluorinol $-85^{*}$, methanol, and ammonia, respectively. These working cycle fluids were selected for application in bottoming cycles in an earlier study (Grimble and Somers, 1977). For the selected working fluids, the T-S diagrams are given in Figures B.11-1, 2, and 3 and the tables of thermodynamic properties are given in Tables B. 11-1, 2 , and 3. The cycles using Fluorinol - 85 were superheated and the cycles using methanol or ammonia were saturated. Schematic diagrams of the superheated and saturated cycles are shown in Figures B.11-4 and 5 .

The program TURB (Grimble and Somers, 1977), which calculates the turbine size, number of stages, and stage efficiency, was modified to incorporate a tabulation of the thermodynamic properties for each working fluid analyzed (Grimble and Somers, 1977; Din, 1956). The program treats the flow as one-dimensional with all parameters being referred to the mean blade radius. Two blading types are considered impulse for the high pressure stages, and $50 \%$ reaction for the low pressure stages. Turbine efficiency is estimated from Balje's correlation (Balje and Binsley, 1968), and is included as an iterated input to the turbine performance calculation.

The ratio of plant power to thermal input for the working fluid was correlated as a function of the inlet throttle conditions. This ratio increases with increasing throttle pressure (see Figures B.11-6, 7, and 8). For the superheated cycles, this ratio increases as the extent of superheating increases (see Figure B.11-6). The plant capacity does not influence the ratio of plant power to thermal input for the working fluids (see Table B.11-4).

\footnotetext{
* 85 mole percent trifluorethanol and 15 mole percent water
} 


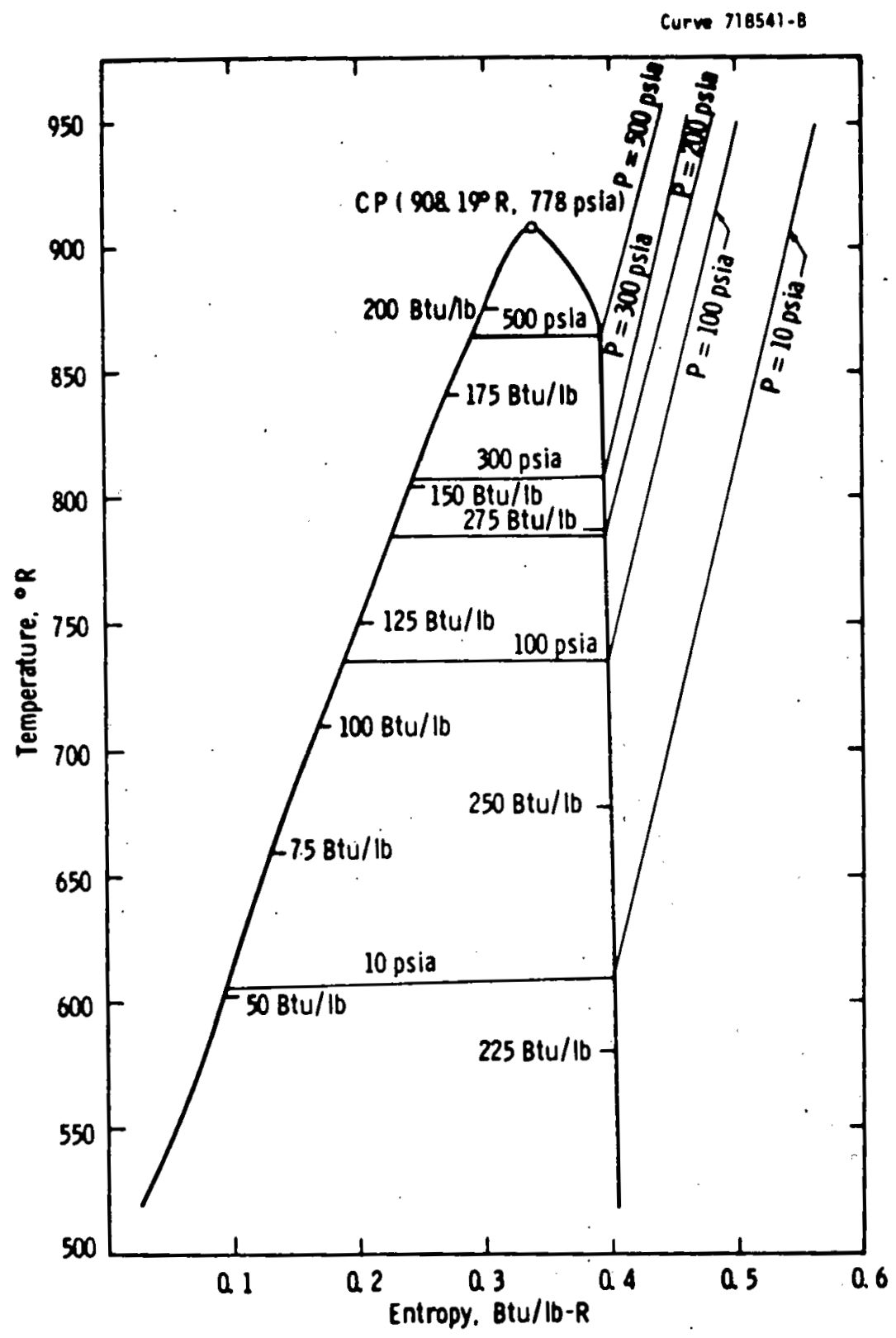

Flg. B.11-1 - T-S dlagram for fluorinol 85 


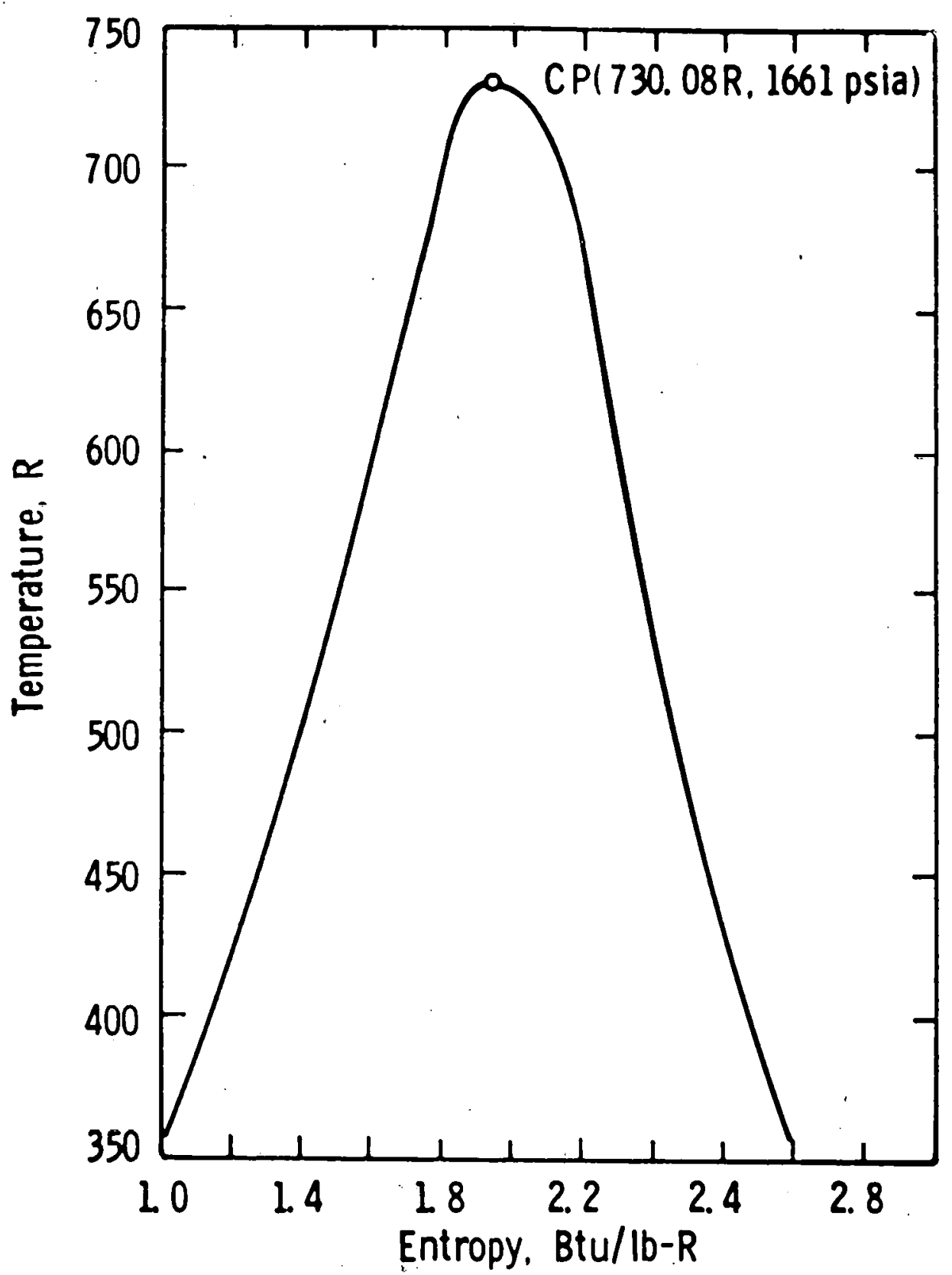

Fig. B.11-2-T-S diagram for ammonia 


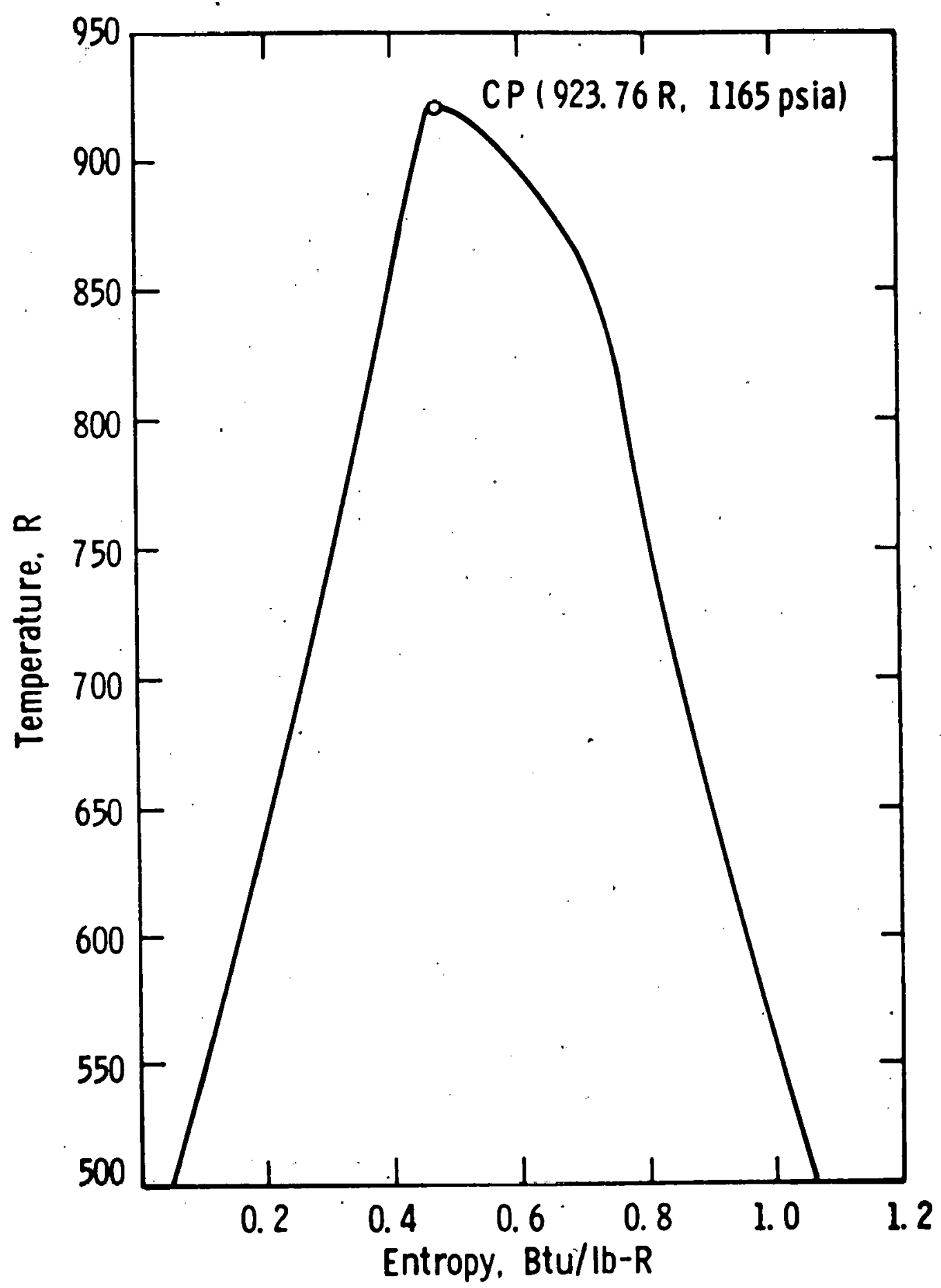

Fig. B.11-3-T-S diagram for methanol 
TABLE B. $11-1$

FLUORINOL-85 SATURATED LIQUID AND SATURATED VAPOR PROPERTIES

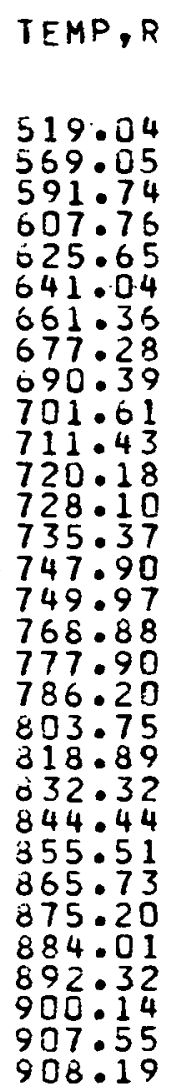

PRESS.
PSIA
1.00
4.00
7.00
10.00
1.4070
20.00
30.00
40.00
50.00
60.00
70.00
80.00
90.00
100.00
120.00
140.00
160.00
180.00
200.00
250.00
300.00
350.00
400.00
450.00
500.00
550.00
600.00
650.00
700.00
750.00
778.00

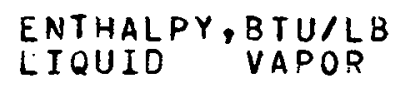

12.17

$12 \cdot 17$
$34 \cdot 55$
$44 \cdot 75$

51.96

67.09

67.09
76.43

83.43

90.02

95.46

104.50

108.46

$112 \cdot 15$

118.68

13.0 .01

139.84

150.40

$159: 93$

168.78

$177 \cdot 11$

195.45

200.38

207.98

215.72

223.61

234.72

239.35

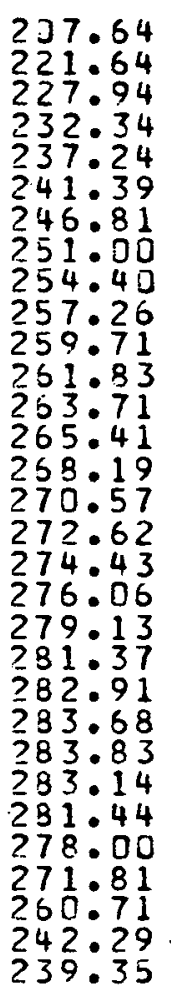

$\begin{array}{ll}\text { ENTROPY BTUILB-R } \\ \text { LIQUID } & \text { VAPOR } \\ .0241 & : 4005 \\ : 0652 & : 3938 \\ : 0828 & : 3922 \\ : 0948 & : 3914 \\ : 1079 & : 3910 \\ : 1190 & : 3903 \\ : 1333 & : 3904 \\ : 1444 & : 3911 \\ : 1535 & : 3915 \\ : 1612 & : 3918 \\ : 1779 & : 3921 \\ : 1794 & : 3923 \\ : 1845 & : 3926 \\ : 1933 & : 3928 \\ : 2011 & : 3931 \\ : 2082 & : 3934 \\ : 2147 & : 3938 \\ : 2208 & : 3940 \\ : 2341 & : 3942 \\ : 2459 & : 3941 \\ : 2565 & : 3937 \\ : 2665 & : 3927 \\ : 2759 & : 3913 \\ : 2848 & : 3892 \\ : 2936 & : 3861 \\ : 3022 & : 3814 \\ : 3109 & : 3737 \\ : 3197 & : 3609 \\ : 3367 & : 3450 \\ : 3413 & : 3418\end{array}$

VOLUME,FT* $\$ 3 / L B$
LIQUID VAPOR

:3418
.0115

- 0120

- 122

- 0126

-0127

.0130

.0132

. 0136

- 0138

.0139

- 0141

- 0142

-0145

.0149

- 0152

- 159

- 154

- 0170

.0175

. 0182

.0189

.0197

.0206

.0219

.0289
62.78

16.93

7.09

4.91

3.65

2.46

1.49

1.25

.93

.83

.61

.53

.45

.40

.36

$: 23$

.18

.16

$-14$

-12

-10

.07

$-05$

.05
.04

.04 
TABLE B.11-2

AMMONIA SATURATED LIQUID AND SATURATED VAPOR PROPERTIES

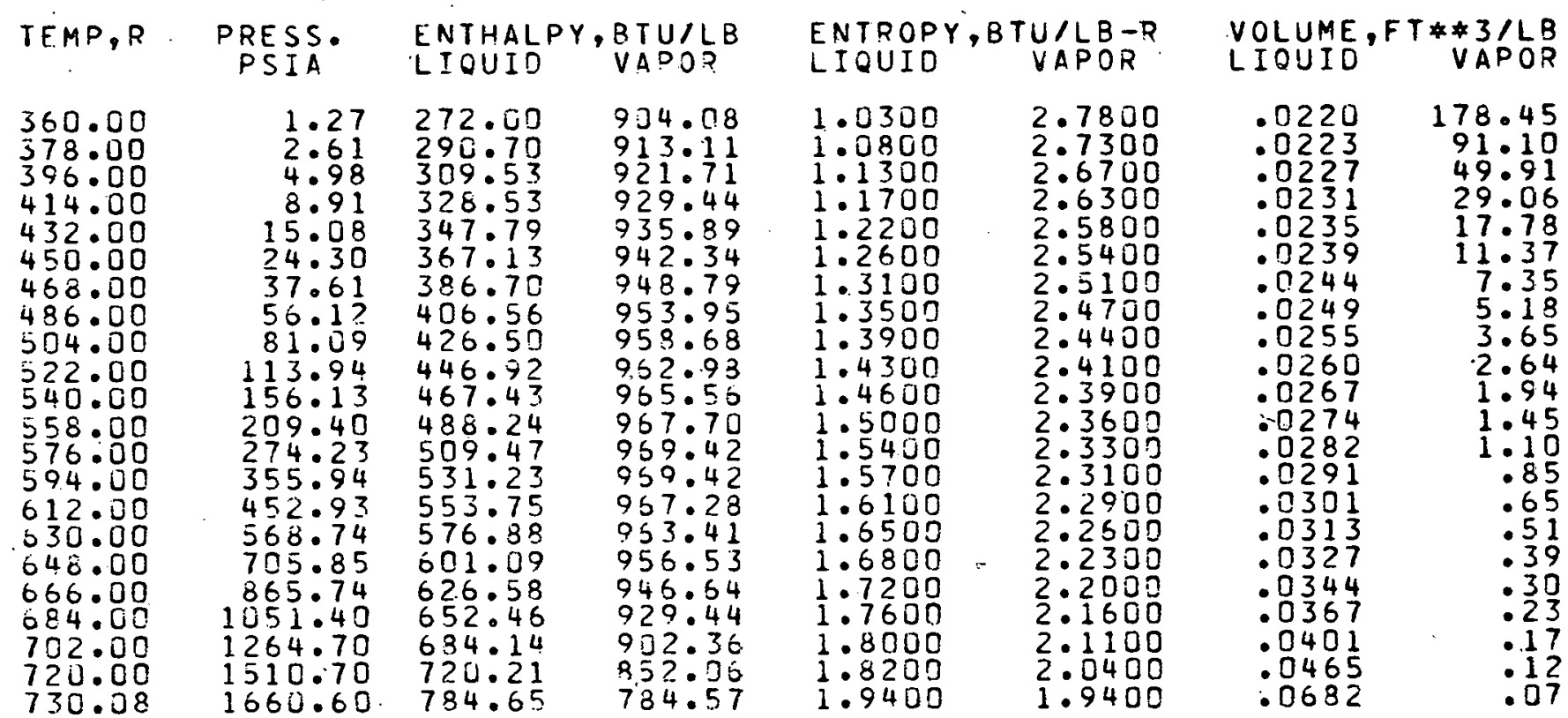


TABLE B:11-3

METHANOL SATURATED LIQUID AND SATURATED VAPOR PROPERTIES

$\varpi$
1
$\infty$
$\infty$

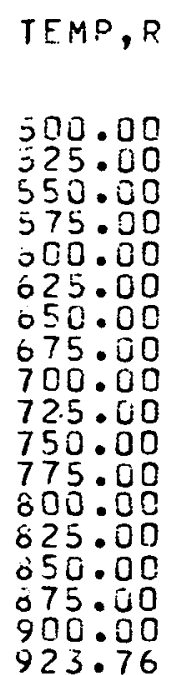

PRESS.
PSIA
.87
1.85
3.68
6.91
12.31
20.93
34.17
53.74
81.47
119.44
170.42
236.98
322.82
431.63
567.25
733.98
936.23
1165.55

ENTHALPY, RTU/LB
LIQUID VAPOR

23.29

$53: 2 \frac{1}{3}$

68.65

100.38

100.38

$116 \cdot 71$

133.35

167.65

185.32

203.36

221.80

240.66

259.97

279.76

936.23
1165.55
319.80

\subsection{4}

538.76

545.57

560.08

553.12

553.12

554.23

552.09

559.50

557.26

555.40

547.05

528.48

531.78

430.12
31.9 .40
ENTKOPY, ETU/LB-R

LIQUIO

VAPOR

.0485

.1055

:1330

.1597

.1858

.2113

.2363

.2608

$-2849$

$: 3547$

: 3772

- 3772

.3994

.4213

.4429

.4632

1.0565
1.0311
1.0007
.9748
.9526
.7262
.8998
.8758
.8491
.8254
.8045
.78690
.77372
.7153
.6750
.5874
.4626

VOLUME, FT \$3/LB

.0199

.0202

.0205

-0209

.0213

.0217

- 0221

- 0225

- 0230

- 0234

- 0240

-0245

-.0251

.0256

.0263

.0270

.0277

.0284 


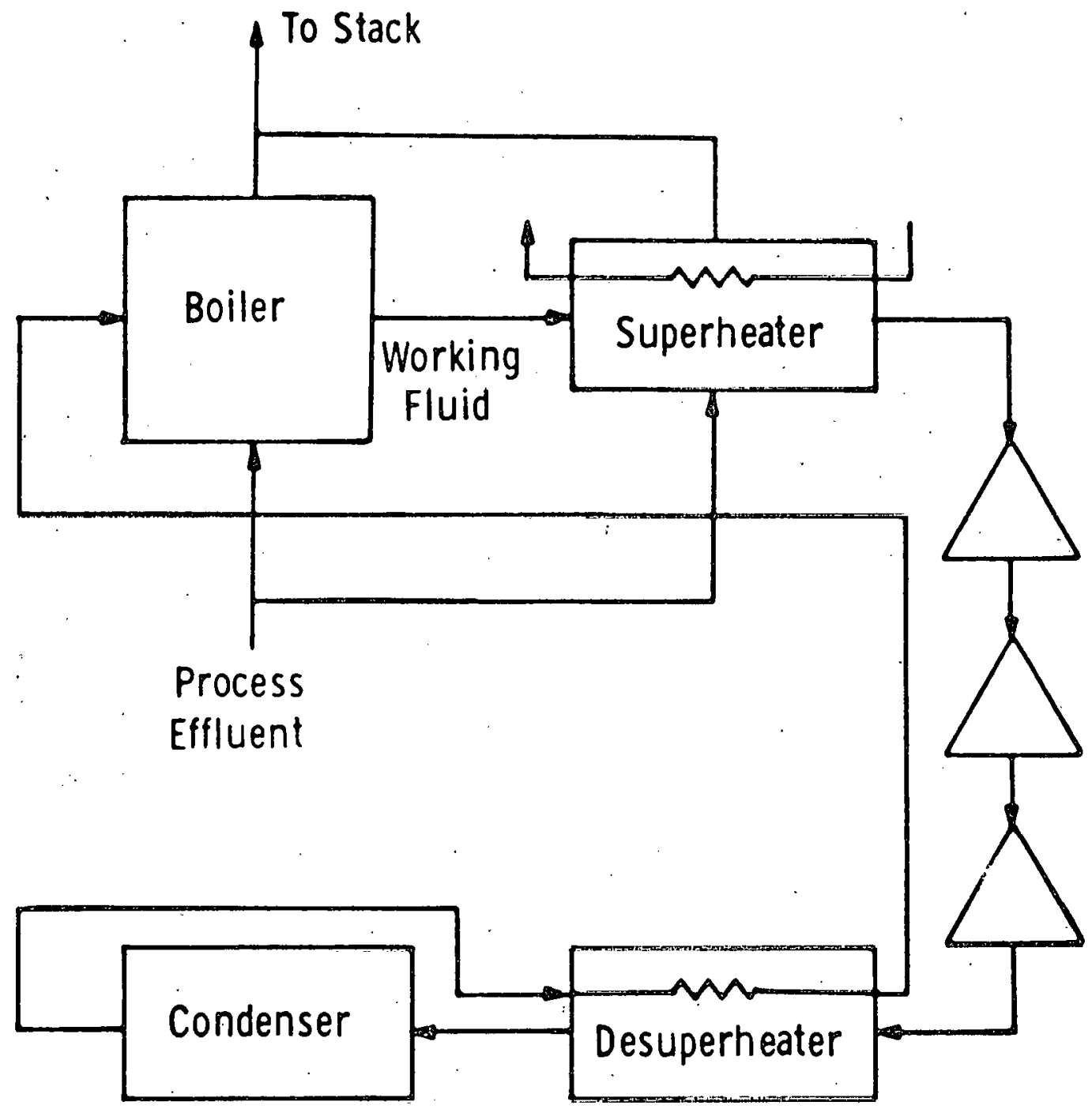

Fig. B.11-4 - Schematic diagram for superheated cycles 


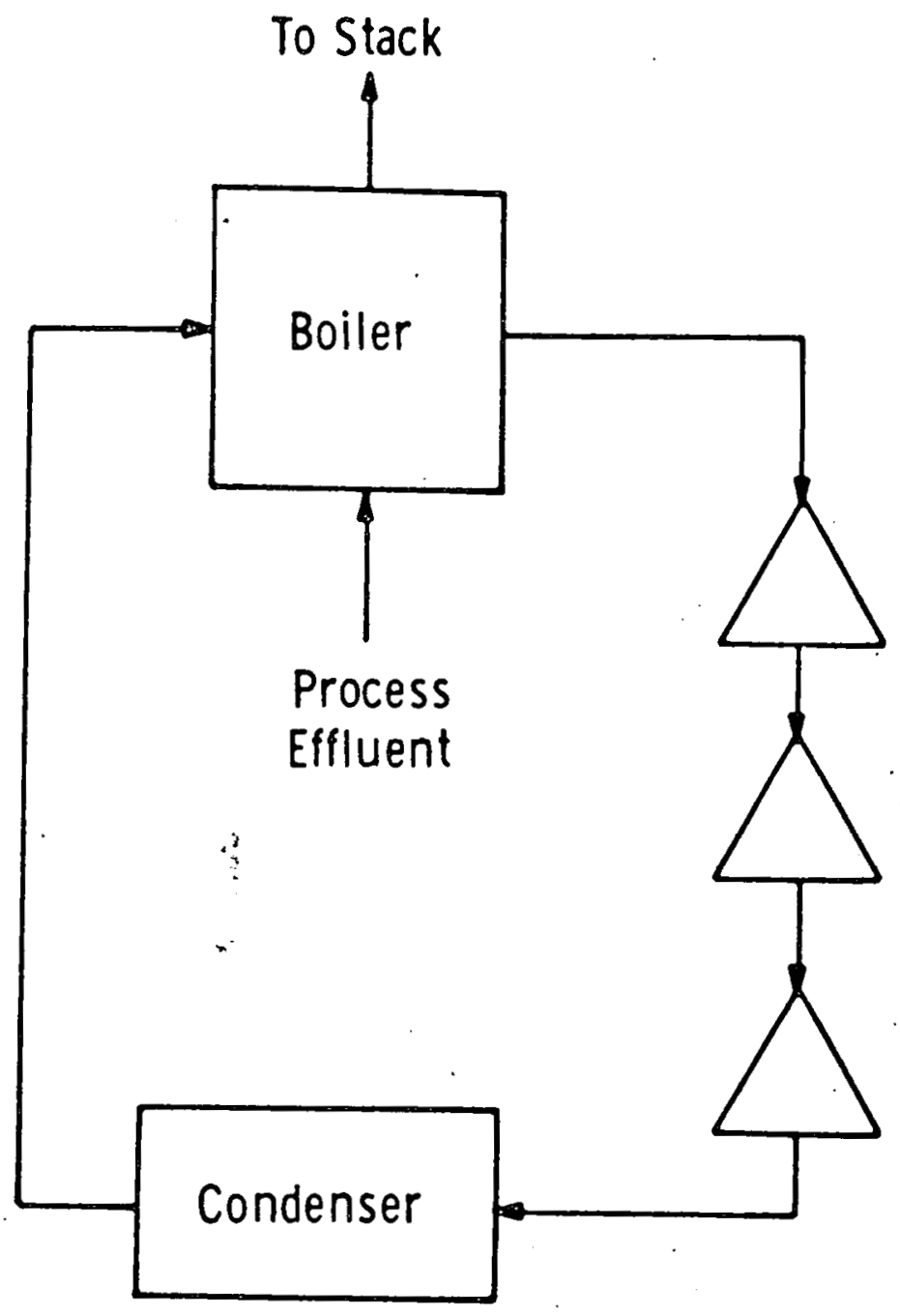

Fig. B.11-5 - Schematic diagram for saturated cycles 


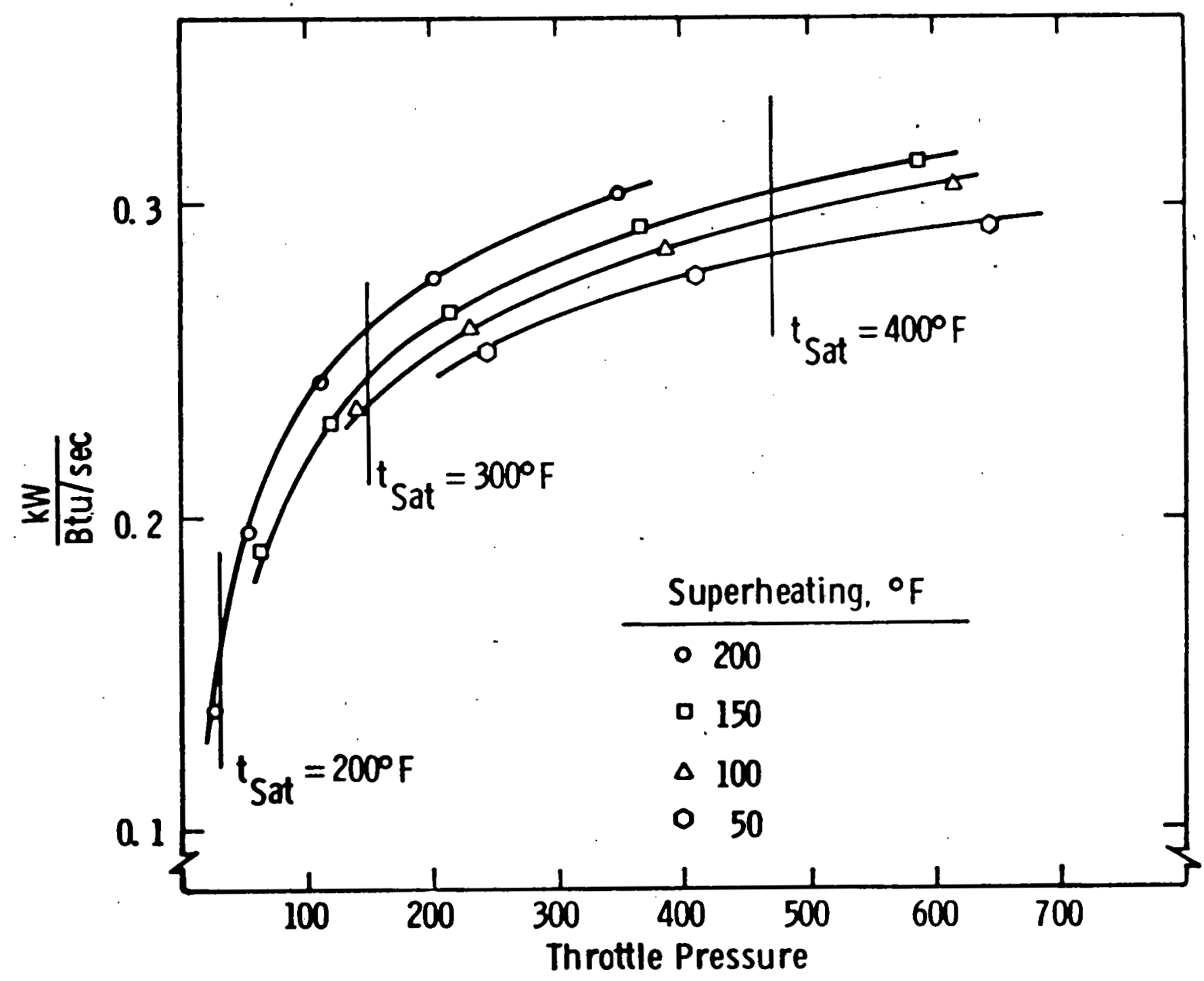

Fig. B.11-6-Ratio of plant power to thermal input for the working fluid as a function of throttle pressure for the working fluid fluorinol -85 


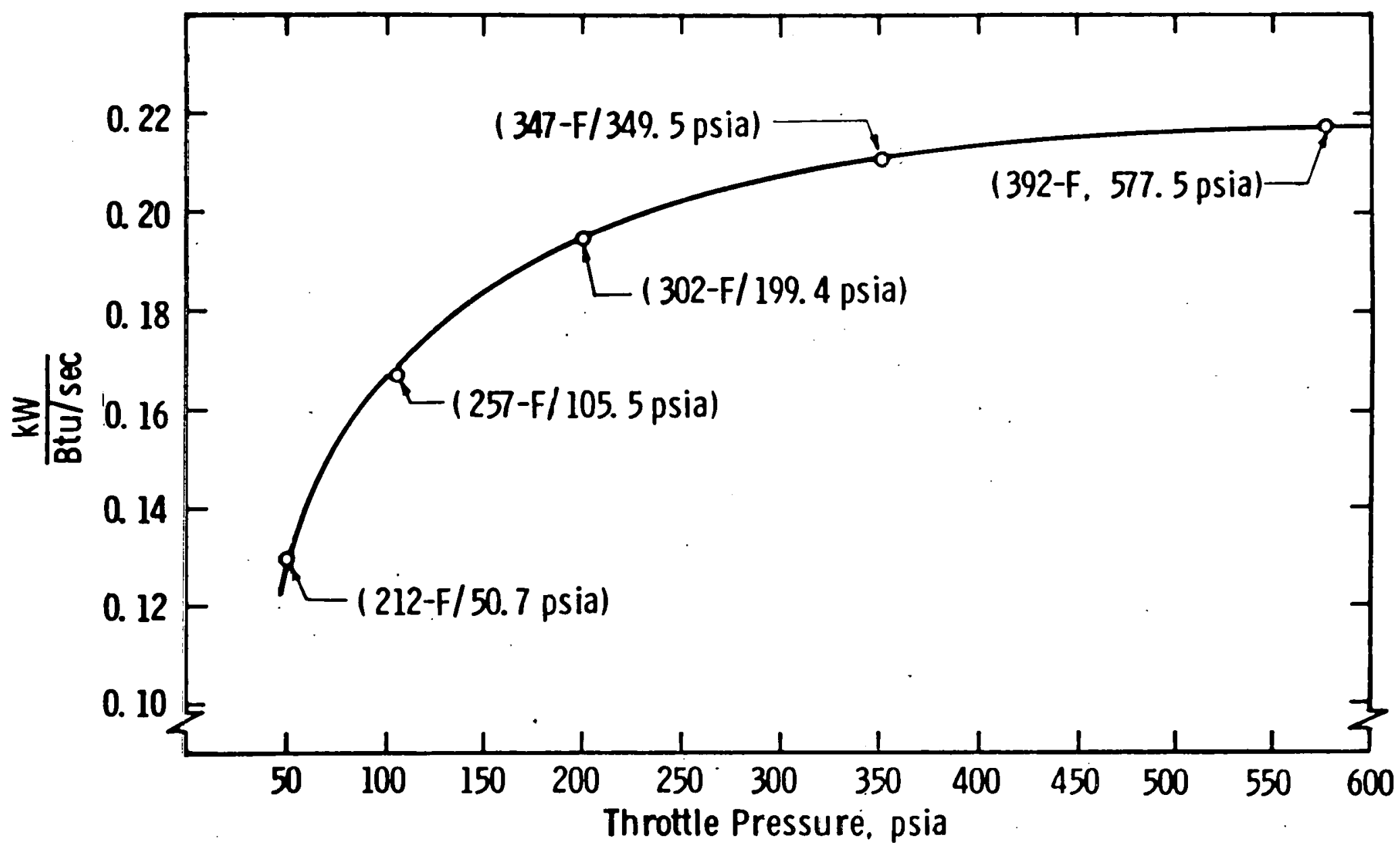

Fig. B.11-7 - Ratio of plant power to thermal input for the working fluid as a function of throttle pressure for the working fluid methanol 


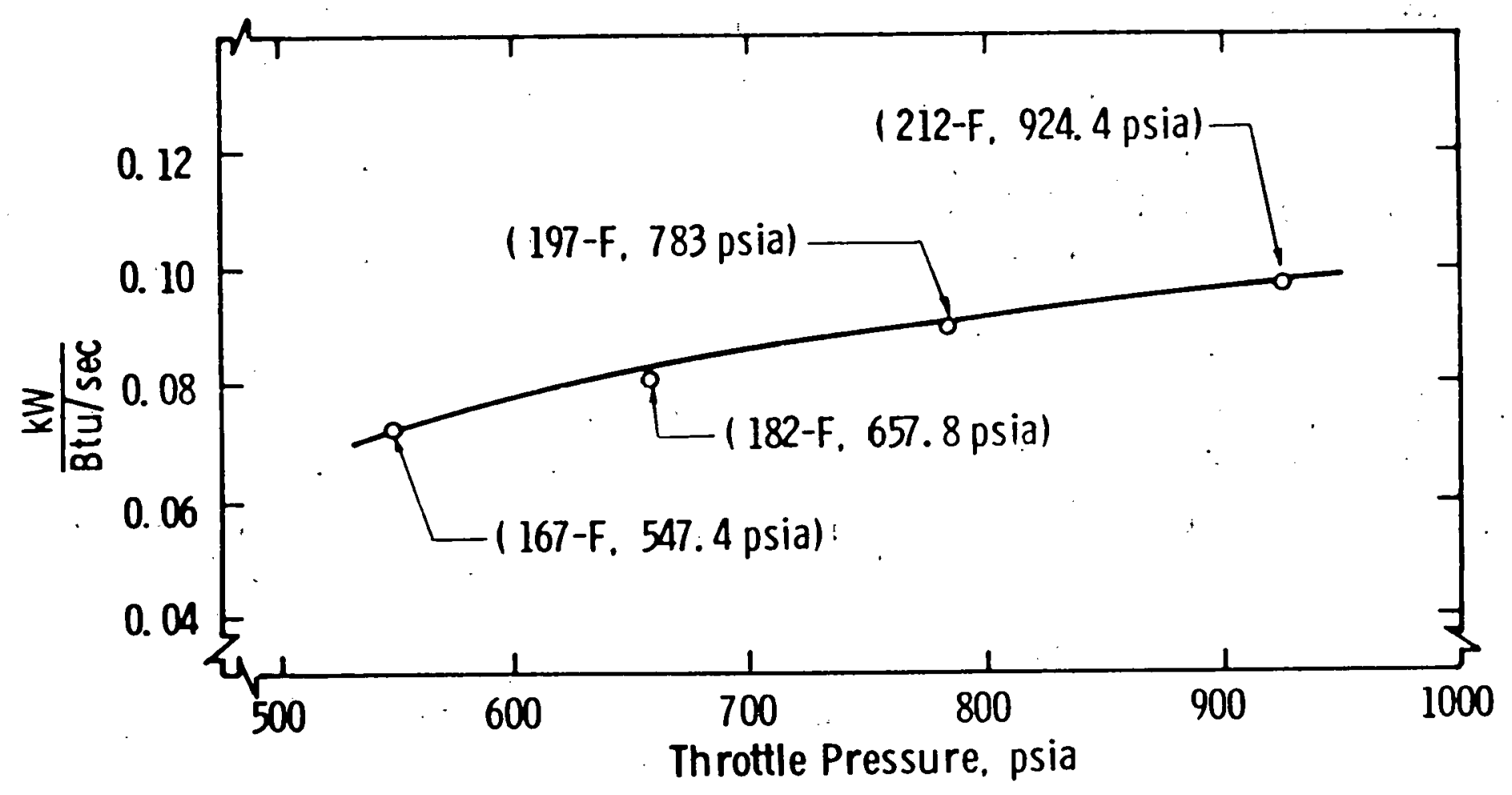

Fig. B. 11-8-Ratio of plant power to thermal input for the working fluid as a function of throttle pressure for the working fluid ammonia 
TABLE B. $11-4$

EFFECT OF PLANT CAPACITY ON THE RATIO OF PLANT POWER TO THERMAL INPUT FOR THE WORKING FLUIDS

\begin{tabular}{|c|c|c|c|c|}
\hline & & \multirow{2}{*}{$\begin{array}{c}\text { THROTTLE } \\
\text { WORKING }\end{array}$} & \multicolumn{2}{|c|}{ KW /BTU/SEC } \\
\cline { 4 - 5 } FLUID & $\begin{array}{c}\text { SUPERHEATING } \\
\text { OF }\end{array}$ & $\begin{array}{c}\text { PRESSURE } \\
\text { PSIA }\end{array}$ & $\begin{array}{c}\text { PLANT POWER } \\
3 \mathrm{MW}\end{array}$ & $\begin{array}{c}\text { PLANT POWER } \\
30 \mathrm{MW}\end{array}$ \\
\hline FLUORINOL - 85 & 200 & 347.6 & 0.3403 & 0.3413 \\
& 200 & 25.2 & 0.1573 & 0.1584 \\
& 50 & 646.2 & 0.2991 & 0.2997 \\
& 50 & 24.4 .1 & 0.2590 & 0.2600 \\
\hline METHANOL & 0 & 577.5 & 0.2171 & 0.2171 \\
& 0 & 50.7 & 0.1291 & 0.1296 \\
\hline AMMONIA & 0 & 924.4 & 0.0974 & 0.0974 \\
& 0 & 547.4 & 0.0721 & 0.0721 \\
\hline
\end{tabular}


Balje, 0. E. and R. L. Binsley, "Axial Turbine Performance Evaluation, Part A - Loss/Geometry Relationships," Trans. ASME, J. Engrs. Power, pp. 341-360, October 1968 .

Din, F., Thermodynamic Functions of Gases, Butterworths Scientific Publications, London, 1956.

Grimble, R. E. and E. V. Somers, "Solar Thermal-Electric Rankine Power Organic Working Fluids - Final Report," Westinghouse Research Report 77-1EO-SOLEP-R1, April 14, 1977.

Halocarbon, "Tables of Thermodynamic Properties - Fluorinol," Halocarbon Products Corporation, 1973. 
Costing algorithms were developed for the energy conversion equipment to be used in the various cogeneration configurations under consideration.* The algorithms covered the following types of equipment.

- Fired power steam generators (coal \& oil)

- Heat recovery steam generators (HRSG's)

- Waste heat boilers (generating saturated steam)

- Steam turbine/generators

- Gas turbine/generators

- Flue gas desulfurization systems

- Organic cycles

- Fired process steam boilers

\section{FIRED POWER STEAM GENERATORS}

The basic algorithms for coal-fired steam generators, based upon correlations provided by Gibbs \& Hill, computed cost as a function of steam capacity for two discrete pressure levels. The boller generating steam at $615 \mathrm{psia}$ and $750^{\circ} \mathrm{F}$ was limited to a capacity range 100,000 $400,000 \mathrm{Ib} / \mathrm{hr}$. The $915 \mathrm{psia} / 825^{\circ} \mathrm{F}$ boiler covered a range from $500,000-$ $1,800,000 \mathrm{lb} / \mathrm{hr}$ of superheated steam. To generalize the algortthms for in-place coal-fired bollers, a pressure correction factor was added. The resulting expressions are as follows:

$$
\begin{array}{ll}
\mathrm{W}_{\mathrm{S}}<300,000 \mathrm{lb} / \mathrm{hr} & \operatorname{cosT}(\mathrm{SG})=\left(1,072,600+16 \mathrm{w}_{\mathrm{S}}\right)\left(\frac{\mathrm{P}}{600}\right)^{0.3} \\
\text { - } 300,000<\mathrm{W}_{\mathrm{S}}<500,000 \mathrm{1b} / \mathrm{hr} & \operatorname{cosT}(\mathrm{SG})=\left(1,072,600+16 \mathrm{~W}_{\mathrm{S}}\right)\left(\frac{\mathrm{P}}{600}\right)^{0.2} \\
\text { - } 500,000<\mathrm{w}_{\mathrm{S}} & \operatorname{cosT}(\mathrm{SG})=\left(6,214,500+12 \mathrm{w}_{\mathrm{S}}\right)\left(\frac{\mathrm{P}}{900}\right)^{0.125}
\end{array}
$$

The following equipment is included

- Economfzer (stoker spreader units)

- Air heater (pulverized coal units)

- Mechanical collector

* The basic cost estimates were based upon prices at December, 1978 levels 
- F. D. fans, air and gas ducts

- Burner and combustion controls

- F. W. regulators and control valves

- Pulverizers (200,000 1bs and over)

- Soot blowers

- Stoker spreader (200,000 1bs and under)

- Ball mills (stoker spreader units)

- Overfire air nozzles

- Std boiler trim

- Foundations, supporting steel

The balance of plant costs was assumed to be $125 \%$ of the capital equipment cost.

The oil-fired steam generator correlations were based upon information supplied by Gibbs \& Hill. The algorithms are as follows:

- $\quad \mathrm{W}_{\mathrm{S}}<300,000 \mathrm{bb} / \mathrm{hr} \operatorname{cosT}(\mathrm{SG}) 718,000 \times\left(\frac{\mathrm{P}}{600}\right)^{0.3}\left(\frac{\mathrm{W}_{\mathrm{S}}}{100,000}\right)^{0.763}$

- $300,000<\mathrm{W}_{\mathrm{S}}<500,000 \mathrm{1b} / \mathrm{hr} \operatorname{cosT}(\mathrm{S} . \mathrm{G})=1,000,000 \times\left(\frac{\mathrm{P}}{600}\right)^{0.2}\left(\frac{\mathrm{W}_{\mathrm{s}}}{300,000}\right)^{0.8}$

- $500,000<\mathrm{w}_{\mathrm{S}} \quad \cdot \operatorname{cosT}(\mathrm{SG})=1,500,000 \times\left(\frac{\mathrm{P}}{900}\right)^{0.125}\left(\frac{\mathrm{W}_{\mathrm{S}}}{600,000}\right)^{1.0}$

The following equipment is included:

- Burner and combustion controls

- F. D. fans, air and gas ducts

- Air preheater (shop assembled units)

- Air heater

- F. W. regulator and control valves

- Soot blowers

- Std boiler trim

- Foundation, supporting steel

The balance of plant factor for the clean fuel-fired boilers was 3.0. 


\section{HRSG'S AND WASTE HEAT BOILERS}

A heat recovery steam generator is defined as a boiler which produces superheated steam for a mechanical drive or power generation turbine. A waste heat boiler, by contrast, generates saturated steam for use directly in a process. The HRSG costs for this study were derived from specific correlations for cost as a function of heat transfer units, i.e., the product of the overall heat transfer coefficient and the surface area required (in $\mathrm{Btu} / \mathrm{hr}{ }^{\circ} \mathrm{F}$ ). Included in the summation are the superheating, high pressure evaporating, economizing \& low pressure evaporating surfaces. The correlations are of the form:

$$
\operatorname{cosT}(\operatorname{HRSG})=a\left(\mathrm{UA} / 10^{6}\right)^{\mathrm{b}}
$$

where $\mathrm{a}$ and $\mathrm{b}$ are assigned according to the following tabulation:

Component

Superheater

High pressure evaporator."

Economizer

Low pressure evaporator a

$9.6 \times 10^{5}$

$2.7 \times 10^{5}$

$3.7 \times 10^{5}$

$2.87 \times 10^{5}$ $\mathrm{b}$

1.2146

The balance of the HRSG price is determined by using the following expression:

$$
\text { B O }(\mathrm{HRSG})=\left[500+12.214\left(\mathrm{~W}_{\mathrm{S}}\right)\right] \times 10^{3}
$$

The balance of plant cost for the HRSG was assumed to be $100 \%$ of the capital equipment cost.

The waste heat boiler cost was based upon an algorithm supplied by Gibbs \& Hill and was indicated to be valid for a wide range of steam generating capacity $(60,000-360,000 \mathrm{lb} / \mathrm{hr})$. The correlation is as follows:

$$
\cos T(\mathrm{WHB})=13 \mathrm{~W}_{\mathrm{S}}+1,450,500
$$

The balance of plant cost for a waste heat boiler was assumed to be $100 \%$ of the capital equipment cost.

\section{STEAM TURBINE/GENERATORS}

The costing procedure for the non-condensing steam turbine generator sets was based upon the "rule of thumb" costing correlation supplied by Gibbs \& Hill. The original data described two ranges of generating capacity for two different throttle pressures. Thus, a back pressure turbine generating from 5 to $15 \mathrm{MW}$ and having throttle condition of $650 \mathrm{psig} / 750^{\circ} \mathrm{F}$, with back pressures between 50 - 150 psig had the following algorithm: 
$\operatorname{cosT}(\mathrm{STG})=617,900+111,770(\mathrm{Pwr})$

where Pwr is in MWe. A second algorithm described a back pressure turbine producing from 5 to $75 \mathrm{MW}$, with throttle conditions of 850 psig and $825^{\circ} \mathrm{F}$, again with a back pressure between 50 and 150 psig. The second expression is as follows:

$$
\operatorname{cosT}(\mathrm{STG})=944,800+91,130(\mathrm{PWr})
$$

Since it is necessary, in the optimization procedure, to examine a range of throttle pressures and temperatures for a variety of capacitors and back pressures, cost was judged to be most sensitive to power and throttle pressure. Thus, a simple linear interpolation was used. First the cost at a given power level was computed for pressures of $600 \mathrm{psig}$ and $850 \mathrm{psig}$, using the above expressions. Subsequently, the cost at the specified throttle pressure was calculated according to:

$$
\operatorname{cosT}(S G)_{\rho}=\operatorname{cosT}(S G)_{600}+\left(\operatorname{cosT}(S G)_{850}-\operatorname{cosT}(S G)_{600}\right) \frac{p-600}{250}
$$

No attempt was made to account for the presumably small effect of back pressure on turbine costs. For steam turbines having double or single extraction points, information based on Westinghouse Canada small steam turbine costs showed that a multiplier of 1.17 for each extraction point were applied to the basic turbine cost. The balance of plant cost for a steam turbine/generator set was assumed to be $100 \%$ of the capital equipment cost.

\section{GAS TURBINE/GENERATORS}

The preliminary gas turbine/generator costs were based on Amos and Grube (1976) for existing, proven gas turbine systems. The components of the gas turbine/generator were grouped into five classifications to enable an estimate of cost which would be sensitive to a number of different operating parameters including air flow, pressure ratio and expander inlet temperature.

The Group 1 components are presented as a function of compressor air flow $(\mathrm{Wa})$. The group is comprised of the following components:

- Inlet manifold

- Inlet casing

- Expander diffuser

- Turbine exhaust manifold

- Turbine supports

- Longitudinal assembly 
The cost algorithms for Group 1 are as follows:

$$
\begin{aligned}
\mathrm{Wa}<200 \mathrm{lb} / \mathrm{s} & \operatorname{cosT}(1)=192,850 \times \frac{\mathrm{Wa}}{100}^{0.50} \\
200 \mathrm{lb} / \mathrm{s}<\mathrm{Wa}<500 \mathrm{lb} / \mathrm{s} & \operatorname{CosT}(1)=272,650 \times \frac{\mathrm{Wa}}{100}^{0.6878} \\
500 \mathrm{lb} / \mathrm{s}<\mathrm{Wa} & \operatorname{cosT}(1)=512,050 \times \frac{\mathrm{Wa}}{100}^{1.0908}
\end{aligned}
$$

The Group 2 components include the compressor/combustor she11, as well as the compressor spindle and diaphragm. The costs of these components are functions of pressure ratio and the compressor flow factor (CFF) which is defined as follows:

$$
C F F=W a \times P R * 3600^{2} / N^{2}
$$

where $\quad N=56022 \times(\text { Wa })^{-0.46}$

For pressure ratios of $4,8,12$ and 16 , the cost is related to CFF according to the following expression:

$$
\operatorname{cosT}(2)=a(C F F)^{b}
$$

and $a$ and $b$ are specific to pressure ratio as:

$\begin{array}{rcc}\text { PR } & a & b \\ 4 & 445,550 & 0.16765 \\ 8 & 704,900 & 0.24262 \\ 12 & 877,800 & 0.29562 \\ 16 & 1,064,000 & 0.32049\end{array}$

Costs for intermediate pressure levels are attained by using a threepoint interpolation method.

Group 3 is composed of the expander cylinder, vanes, and spindle, as well as the spindle assembly. The Group 3 cost is a function of the turbine power factor (TPF) which is equivalent to the product of the air flow (Wa) and the enthalpy change across the expander. The costing is performed by interpolating in a table which represents the data contained in Figure B.12-1.

Group 4 contains engine accessories, and a variety of auxiliary items including the generator/exciter. The cost is expressible in terms of the net power of the gas turbine (Pwr) as:

$$
\operatorname{cosT}(4)=e^{(0.0115 \times \text { Pwr }+14.35)}
$$




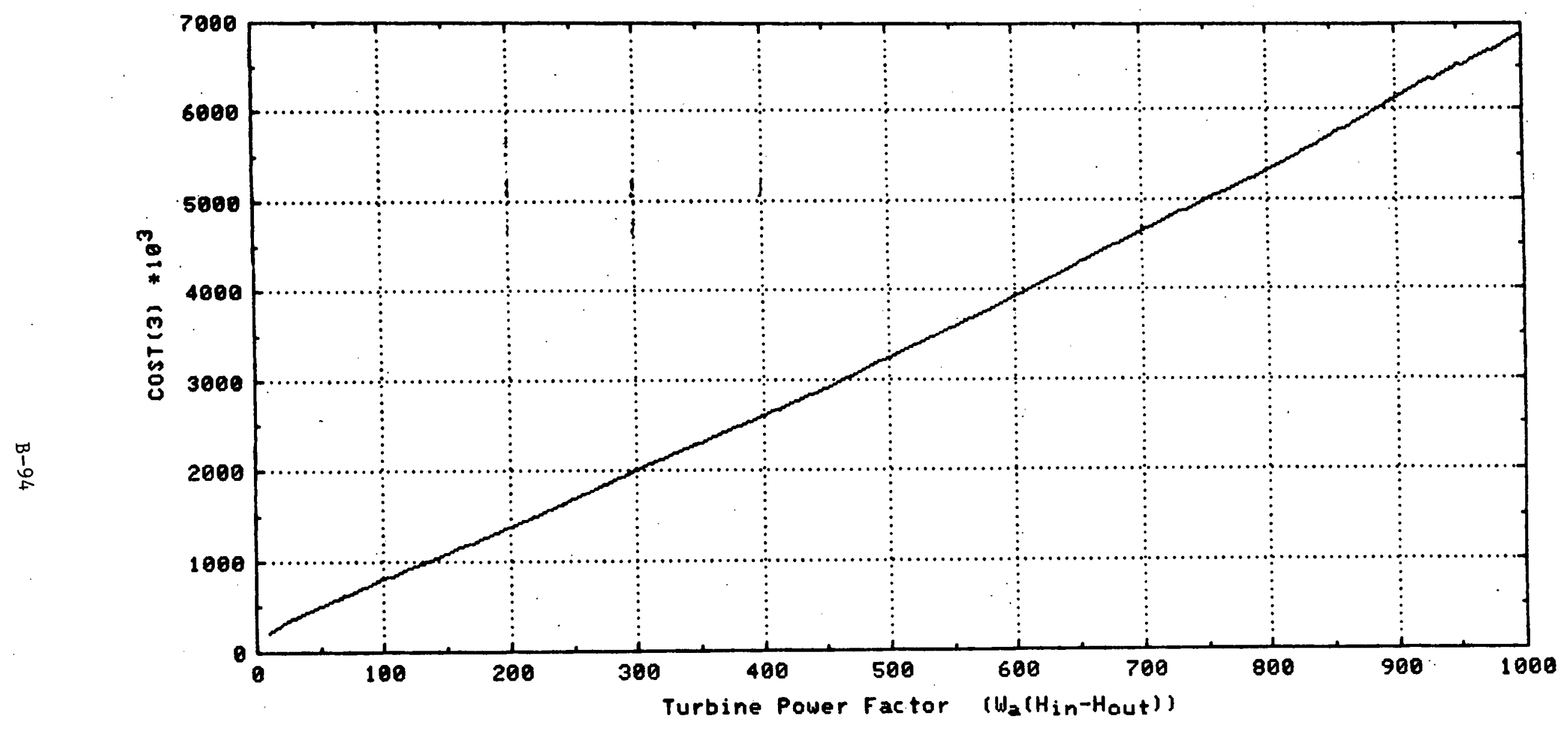

Fig. B.12-1 - Gas Turbine Costs (Group 3) Expander Assembly 
The combustor assembly is identified as.Group 5. The Group 5 is defined in terms of the pressure ratio, (PR) and the sum of the peak cycle temperature (EIT) and the air temperature at the compressor outlet (COT)

$$
\frac{\operatorname{COST}(5)}{W a(E I T+C O T)}=\varnothing(P R)
$$

where the value of $\phi(P R)$ is determined by interpolating on the data contained in Figure B.12-2.

The total gas turbine/generator cost. is simply the sum of the subassembly costs. The balance of plant cost was assumed to be $35 \%$ of the capital equipment cost.

\section{FLUE GAS DESULFURIZATION}

The flue gas desulfurization system costs were based upon an estimate of costs performed by Coffin (1979) for industrial applications. The relationship which was derived is expressed as a function of the quantity of fuel consumed. The correlation is as follows:

$$
\operatorname{cosT}(F G D)=e^{(0.6 \ln (0.85 Q \text { in } / 1000)+7.18)}
$$

This correlation included balance of plant.

\section{ORGÁNIC CYCLES}

Little information is available on the costs for organic bottoming cycle components. The turbine/generator cost for the methanol cycle was based on Grimble and Somers (1977) and was a function of the rated power and the exhaust end area. The following expression was used:

$$
\operatorname{cosT}(\mathrm{MTG})=\left(\mathrm{a}(\mathrm{Pwr})^{0.75}+\mathrm{bA}\right) \times 1.33 .
$$

where $a=170$ and $b=140,000$ for methanol and Fluorinol -85 .

The condenser/circulating water system was also based on correlations contained in Grimble and Somers (1977). For both: organic fluids the cost correlation is of the form:

$$
\operatorname{cosT}(\mathrm{CW}) 133,000+1.33 \zeta\left[\frac{\mathrm{QR}}{\delta \Delta \mathrm{T}} \ln \left\{\frac{\mathrm{TTD}+\Delta \mathrm{Tr}}{\mathrm{TTD}}\right\}\right]
$$

where $Q_{R}$ is the heat refected, TTD is the terminal temperature difference and $\Delta \mathrm{T}_{\mathrm{r}}$ is the temperature change in the cooling water. The constants $\delta$ and $\zeta$ are 1.64 and 137.7 respectively for methanol, and 0.87 and 101.6 for Flourinol - 85 .

The organic boller costs were not avallable and the correlation for a conventional unfired HRSG was used. 


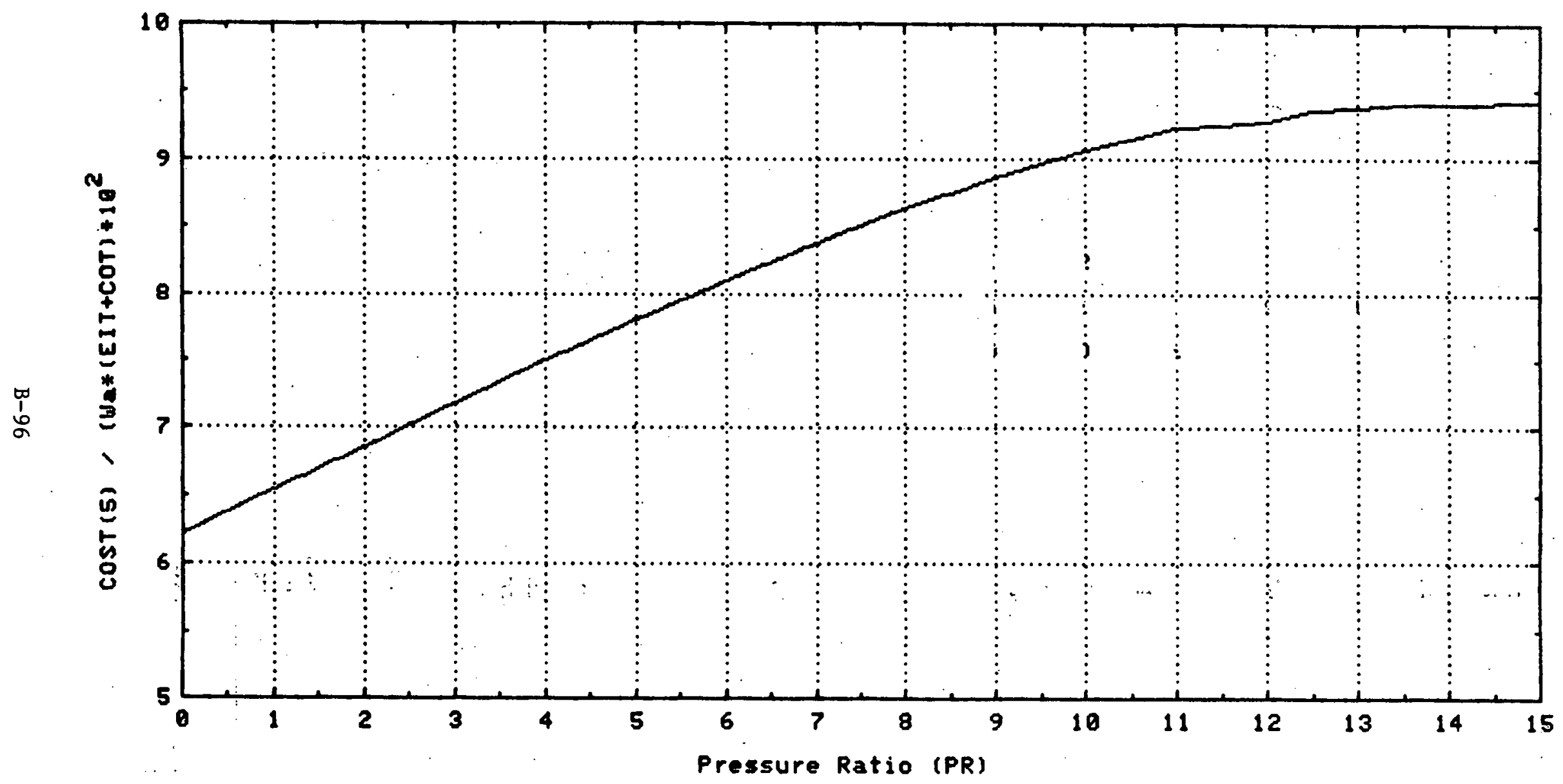

Fig. B.12-2 - Gas Turbine Costs (Group 5) Combustor Assembly 


\section{PROCESS STEAM BOILERS}

The reference case for most cogeneration studies is a single purpose process boiler generating steam at saturation conditions. In order to calculate the incremental cost of a cogeneration system, the cost of a process steam boiler generating an equivalent quantity of steam was required.

The following algorithms were used for oil or gas-fired boilers:

$\mathrm{W}_{\mathrm{s}}<100,0001 \mathrm{~b} / \mathrm{s}$

$\operatorname{cosT}(P B)=e^{\left(0.8 \ln W_{s}+4.907\right)}$

(Source: Coffin, 1979; Gibbs \& Hill)

$\mathrm{w}_{\mathrm{s}}>100,0001 \mathrm{~b} / \mathrm{s}$

$\operatorname{cosT}(P B)=e^{\left(0.8 \ln w_{s}+5.593\right)}$ (Source: Coffin, 1979; Gibbs \& Hill;
and Miller, 1968 )

For coal-fired process boilers, the following correlation was employed.

$\operatorname{cosT}(P B)=e^{\left(0.81 n W_{S}+6.258\right)}$

(Source: Coffin, 1979; Gibbs \& Hill)

Other Capital Cost Factors

Indirect Costs

For all equipment except gas turbines, the indirect costs were assumed to be $15 \%$ of the direct costs. For gas turbines, $7-1 / 2 \%$ was used.

Engineering Costs

Engineering costs were assumed to be $10 \%$ of direct capital costs.

Contingency

The allowance for contingency was $20 \%$ of the direct capital costs.

Interest During Construction

The interest rate on funds expended during the construction period was assumed to be $10 \%$.

\section{Escalation During Construction}

The general inflation rate of $7-1 / 2 \%$ per year was used in calculating the escalation during construction. 
Amos, D. J. and J. E. Grube, Energy Conversion Alternatives Study (ECAS), Westinghouse Phase. I Final Report Volume IV - Open Recuperated and Bottomed Gas Turbine Cycles, NASA Contract NAS 3-19407, February 12, 1976.

Coffin, B. Dwight, "Estimating Capital and Operating Costs For Industrial Steam Plants", Power, April 1979.

Gibbs \& Hill, letter from I. King to J. R. Hamm of Westinghouse Research Center, Ref. No. 11-2775-001; A-10717, dated March 2, 1979.

Grimble R.'E., and E. V. Somers, Solar Thermal-Electric Ranking Power Organic Working Flulds, Final Report, Westinghouse Research Report, 77-1E0-SOLEP-R1, April 1977.

Miller, Ryle, "Process Energy Systems", Chemical Engineering, May 20, 1968, pp. 130-148. 


\section{APPENDIX C: OPTIMIZED COGENERATION SYSTEMS}

\section{1 INTRODUCTION}

In this Appendix the procedures for determining the optimum cogeneration system for nine of the ten plants examined are described (the agricultural chemicals plant is covered in Volume I, Section 6.2). Discounted cash flow return on the equity portion of the incremental capital investments

$r$ is calculated for the optimum system for industry and utility ownership. Discounted cash flow return on the equity portion of the total capital investment is calculated for the optimum system with the third party ownership.

The energy requirements for separate generation and cogeneration are tabulated according to fuel source and both the total energy savings and the energy savings for each fuel are determined for the optimum cogeneration system.

\section{2 BACKGROUND}

Assumptions used in determining the rates of return can be found in Subsection 6.1.2. This includes:

- Financial data found in Subsection 6.1 .2 in hurdle rates, debt/equity ratios etc.

- Federal, state, and local tax rates, depreciation schedules and investment tax credits found in Subsection 6.1.2.3

- Energy cost data found in Subsection 6.1.2.4

- Inflation rates found in Subsection 6.1.3

- Maintenance requirements found in Subsection 6.1.4

- Standby power requirements found in Subsection 6.1.5

- Candidate energy conversion systems found in Subsection 6.1.6

- Assumption in the utility central station model found in Subsection 6.1 .7

- Process steam boiler costs for separation generation (as opposed to cogeneration) found in Subsection 6.1 .8

- Fuels for cogeneration found in Subsection 6.1.9 


\section{3 AIR SEPARATION PLANT / CLUSTER CHEMICAL COMPLEX}

The air separation plant is located in an industrial park in Texas (DOE Region VI). At this plant, as opposed to the others investigated, the owners intend to provide their own installation with sufficient power to supply in-house needs and to sell process steam to a number of petrochemical plants located within the industrial park.

The electric energy consumption of the plant is $530.4 \times 10^{6} \mathrm{kWh} / \mathrm{yr}$ which is equivalent to an average power demand of $60,500 \mathrm{~kW}$. The rated power demand is $67,275 \mathrm{~kW}$. The peak power demand, which results when the largest electric motor is started while all of other motors are running at rated load, is estimated to be $80,000 \mathrm{~kW}$.

The potential market for process steam to satisfy incremental steam requirements due to expansion of the petrochemical plants is estimated to be $500,000 \mathrm{lb} / \mathrm{hr}$ at $200 \mathrm{psig}$. There may also be a market for an additional 500,000 per hour of "backout" steam which would replace part of the $700,000 \mathrm{lb} / \mathrm{hr}$ of process steam being produced by existing boilers. Because the primary concern of this company is to satisfy its own electrical requirements, optimization was carried out on the basis of a power match rather than a process heat match.

Three optional configurations were explored for application in this environment: the conventional coal-fired steam with back-pressure steam turbine, a gas-fired gas turbine with waste heat boiler, and a gas-fired combined cycle. In DOE Region VI, natural gas prices were below those for coal, so a gas-fired system might be expected to be competitive with coal. Indeed, the conventional coal-fired steam with BPT failed to demonstrate acceptable economics and was discarded as a viable alternative. The combined cycle, while slightly more attractive than the coal-fired system, also resulted in extremely poor (negative) ROE's. On the other hand, the gas-fired GT with WHB did prove to be economically attractive, offering positive return on equity for all ownership options. Figure C.3-1 shows the model of the energy utilization subsystem for the process steam customers as a whole. The conditions at each of the indicated state points are given in. Table C. 3-1.

Figure C.3-2 displays the configuration of the energy conversion subsystem model. The optimization plots for the system use the gas turbine compressor pressure ratio and base load expander inlet temperature as parameters (see Figures C. 3-3a and C.3-3b for industrial and third party ownership). The optimum design parameters for this plant are compressor pressure ratios of 8 or less and expander inlet temperatures of $2100^{\circ} \mathrm{F}$ or greater, a combination which gives near maximum thermodynamic efficiency in recuperative open cycle gas turbines (Amos and Grube, 1976). A survey of commercially avatlable gas turbines shows, however, that the optimum design is not practically attainable. The typical commercially available industrial gas turbine with a power output of approximately $80,000 \mathrm{~kW}$ has a compressor pressure ratio of 10 to 12 and a base load expander inlet temperature of 1900 to $2100^{\circ} \mathrm{F}$. It should be noted that units in this capacity range which most recently have reached commercial status have compressor and expander polytropic efficiencies of approximately 91 


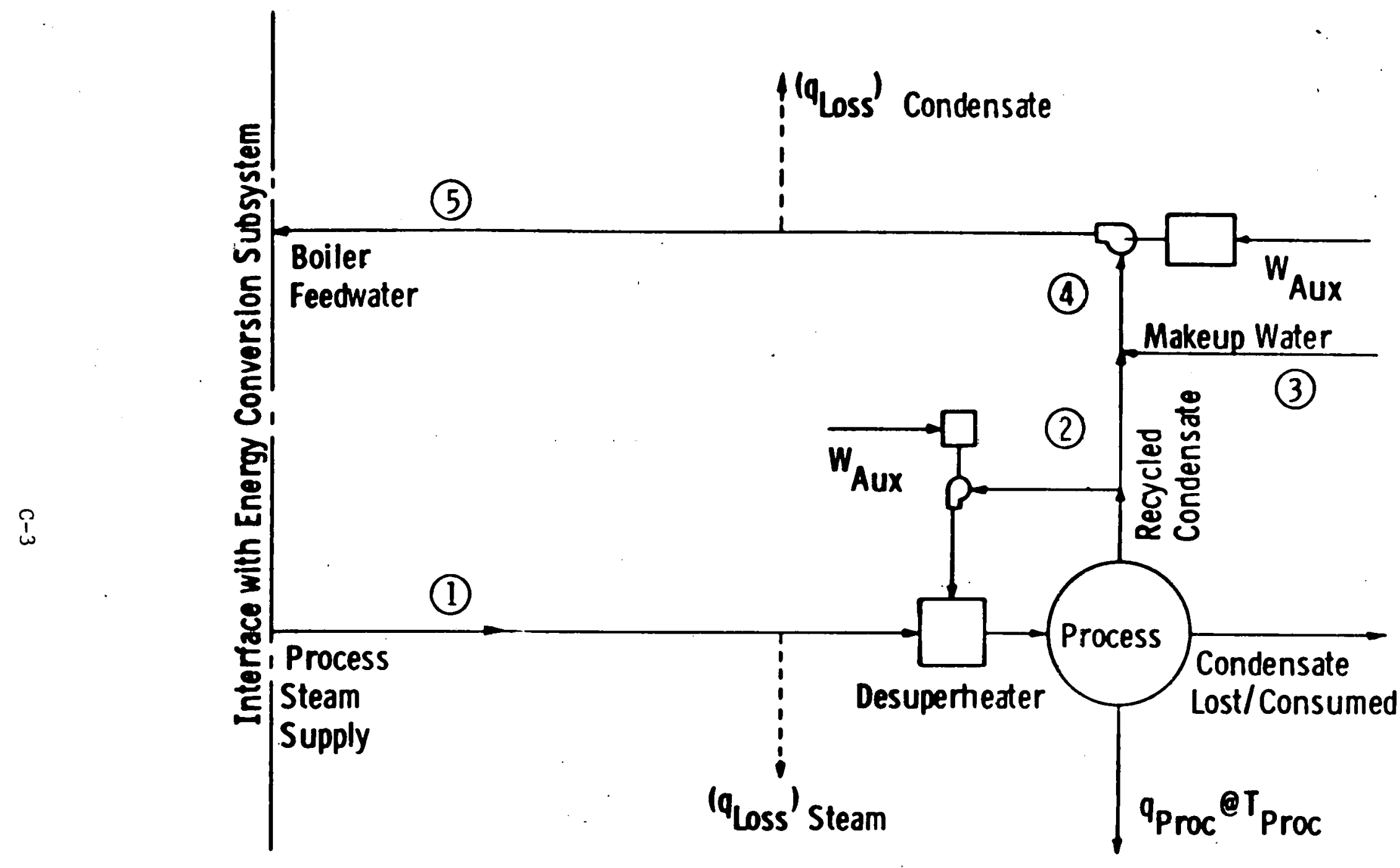

Fig. C. 3-1-Model of process heat utilization subsystem for air separation plant with gas-fired gas turbine with waste heat boiler energy conversion subsystem 
TABLE C. 3-1

STATEPOINTS FOR ENERGY UTILIZATION SUBSYSTEM IN AIR SEPARATION PLANT

$\begin{array}{ccccc}\text { STATION } & \begin{array}{c}\text { PRESSURE } \\ (\mathrm{psia})\end{array} & \begin{array}{c}\text { TEMPERATURE } \\ \left({ }^{\circ} \mathrm{F}\right)\end{array} & \begin{array}{c}\text { ENTHALPY } \\ (\mathrm{Btu} / \mathrm{lb})\end{array} & \begin{array}{c}\text { FLOW RATE } \\ (1 \mathrm{~b} / \mathrm{s})\end{array} \\ 1 & 215 & 387.9 & 1199.3 & 100.7 \\ 2 & >15 & 250 & 218 & 75.5 \\ 3 & 15 & 100 & 68 & 25.2 \\ 4 & >15 & 212.2 & 181.5 & 100.7 \\ 5 & 67.4 & 212.2 & 181.5 & 100.7\end{array}$




\section{AIR SEPARATION PLANT:}

\section{GAS-FIRED COMBUSTION TURBINE}

WITH WASTE HEAT BOILER

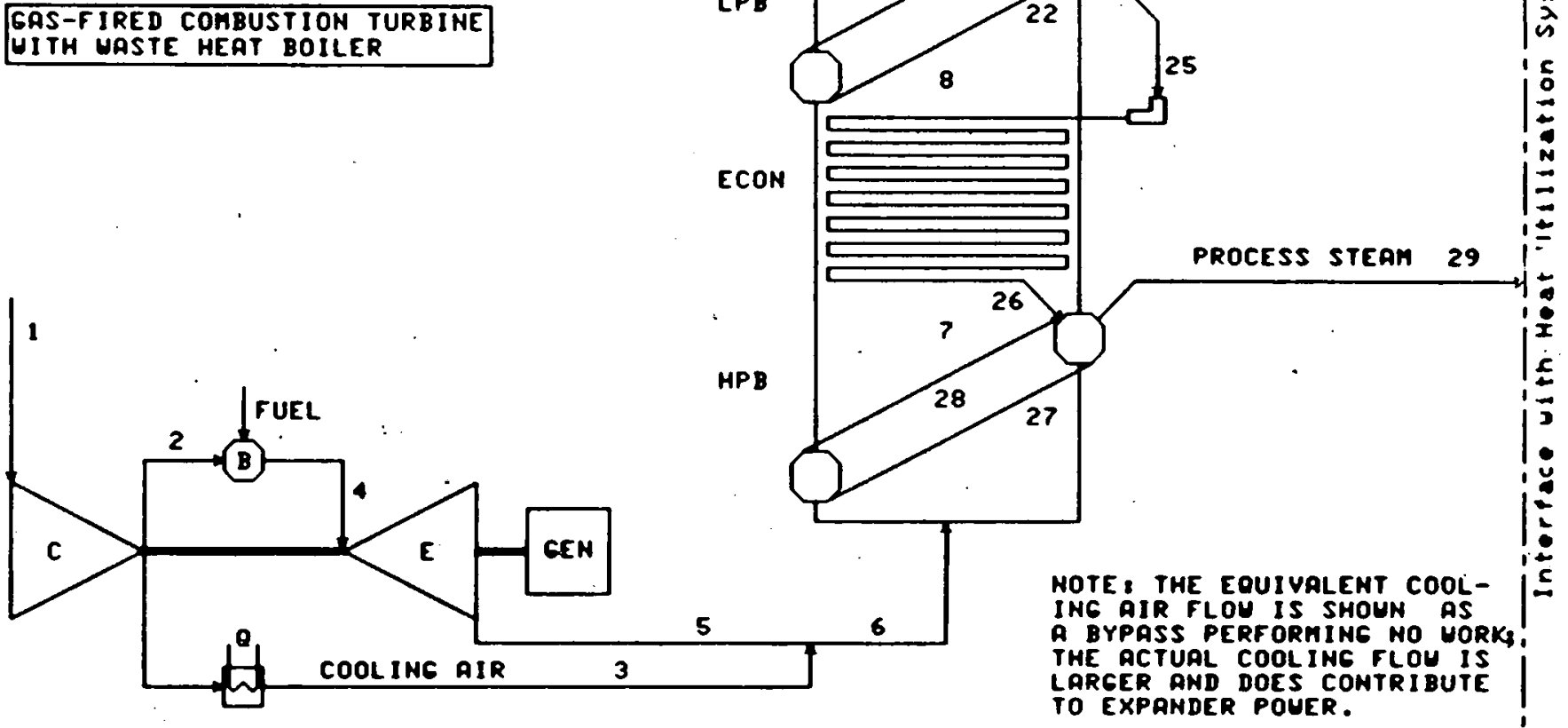

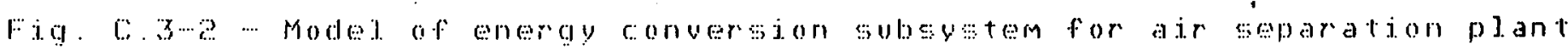




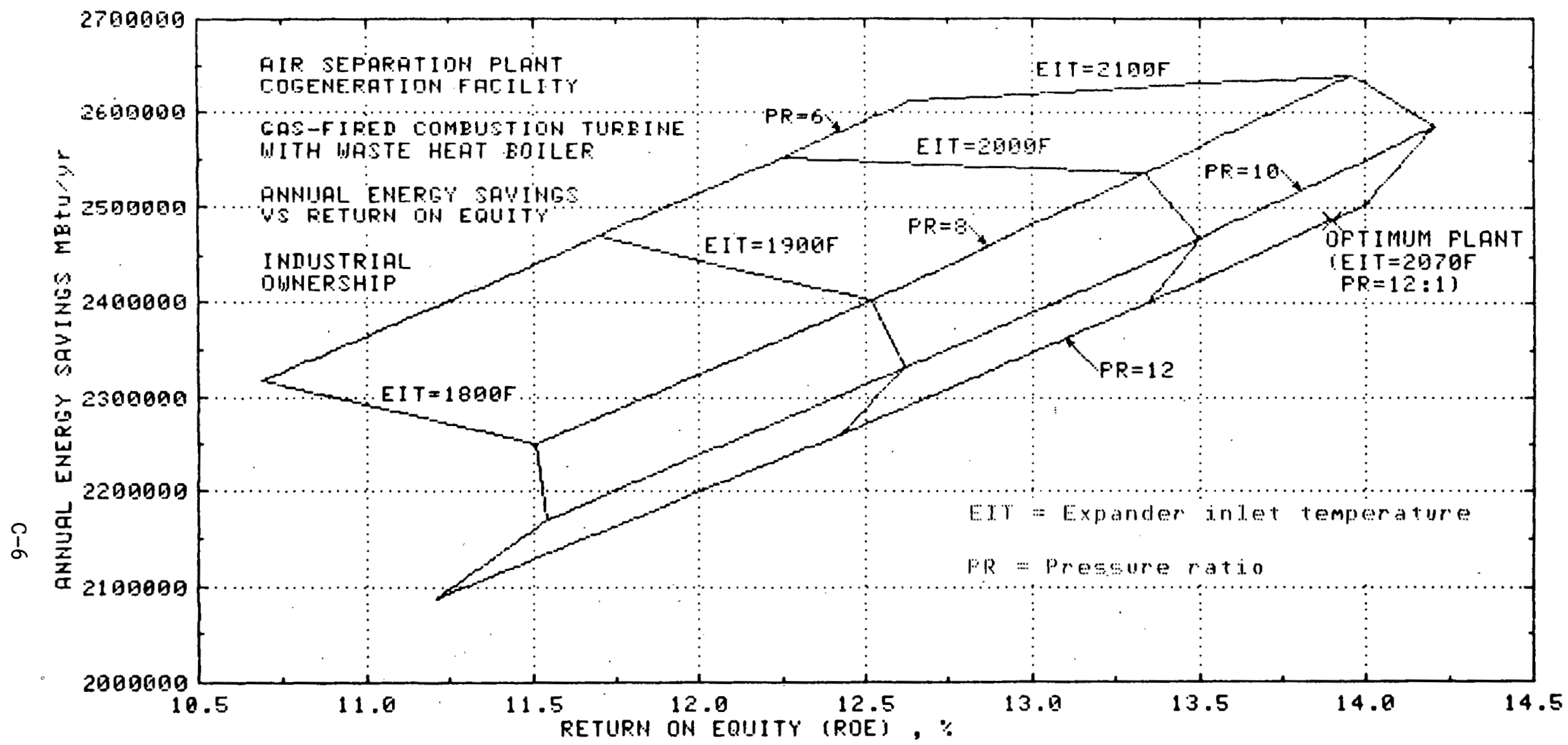

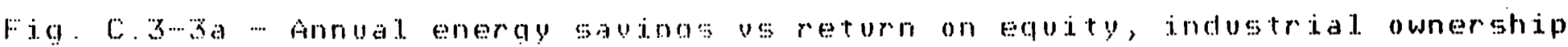




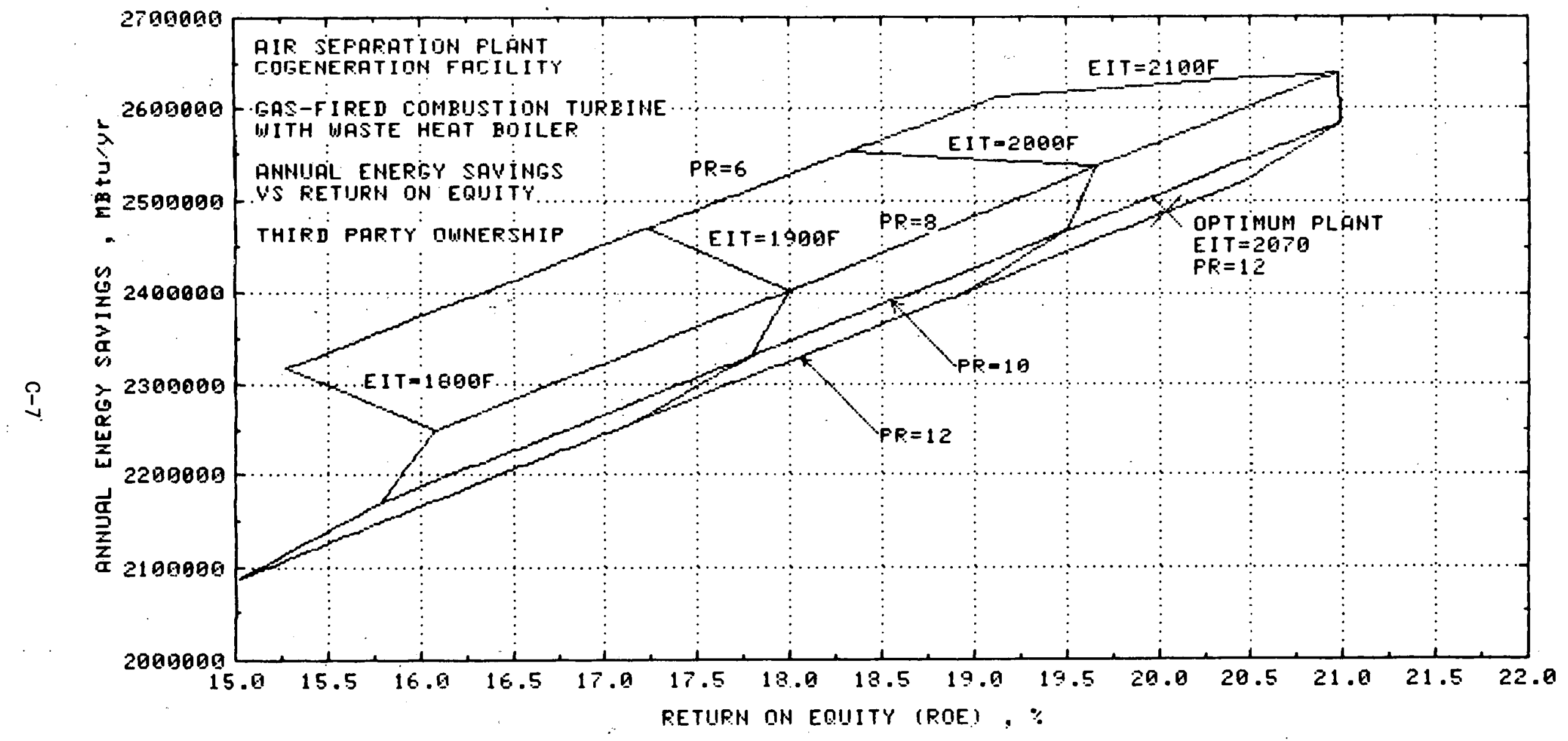

Fig. C.3-3b Annual energy savings us return on equity, third party ownership 
and $92 \%$, respectively (Stanford Research Institute, 1974). These are significantly higher than the composite values used in the characterization procedure (see Appendix B-5). The optimum practical gas turbine for this cogeneration application was assumed to have a compressor pressure ratio of 12 and an expander inlet temperature of $2070^{\circ} \mathrm{F}$ at the design point. Polytropic efficiencies of $91 \%$ for the compressor and $92 \%$ for the expander were assumed. The peak (maximum allowable for short periods) expander inlet temperature would be about $2180^{\circ} \mathrm{F}$. The compressor air flow rate required to provide the peak power output of $80,000 \mathrm{~kW}$ with an expander inlet temperature of $2180^{\circ} \mathrm{F}$ is approximately $538 \mathrm{lb} / \mathrm{s}$.

It should be noted that the ROE's in Figure C.3-3a are below the industrywide hurdle race of $21 \%$. We judged that for the likely third party ownership a hurdle rate of $12 \%$ was appropriate for this plant. Note that for utility ownership, essentially all operating points yield a negative incremental cost and very high ROE's.

For the air separation plant only, an analysis of the effect of component redundancy was made. A point was computed assuming three half-sized gas turbine sets and no stand-by power charges. The results showed that such redundancy is extremely costly and is fatal to the cycle's expected ROE.

Under normal electrical load which is about $84 \%$ of the design output, the gas turbine provides exhaust gas to the waste heat boiler at $880^{\circ} \mathrm{F}$, sufficient to generate $280,000 \mathrm{lb} / \mathrm{hr}$. of saturated steam at 215 psia for sale to the surrounding industries (see Table 6.1-6). Deaeration is accomplished through the use of steam generated in a low-pressure evaporator. In Table C.3-2, the state point conditions are given for the system design point. The energy distribution of the facility is summarized in Table C.3-3. The ideal energy utilization factor for this system is 0.735 and the ratio of process heat to electricity is 1.3635 .

The preliminary capital costs of the system, on the basis of which the economic analysis was performed, are given in Table C.3-4. Using these costs and the financial assumptions detailed in Table C.3-5, the cash. flow vectors were established and the discounted cash flow rate of return on equity was computed. Tables C.3-6a, C.3-6b, and C.3-6c give the results of the analysis. All three ownership options show positive. ROE's. However, only the utility ownership and the third party ownership options provide very attractive returns.

The potential energy savings to be realized as a result of this installation are shown in Table C.3-7. Based on the assumption that the central station capacity to be replaced by cogenerating capacity would ..be coalfired, we expect an increase in natural gas consumption, which is. balanced by a $30 \%$ decrease in the overall quantity of fuel consumed annually. 
STATEPOINTS FOR CONVERSION SUBSYSTEM IN

AIR SEPARATION PLANT/GT WITH WHB

\begin{tabular}{|c|c|c|c|c|}
\hline Station & $\begin{array}{l}\text { Pressure } \\
\text { (psia) }\end{array}$ & $\begin{array}{c}\text { Temperature } \\
\left({ }^{\circ} \mathrm{F}\right)\end{array}$ & $\begin{array}{l}\text { Enthalpy } \\
(\text { Btu/lb) }\end{array}$ & $\begin{array}{l}\text { Flow } \\
(1 \mathrm{~b} / \mathrm{s})\end{array}$ \\
\hline 1 & 14.7 & 77 & 0 & 537.6 \\
\hline 2 & 175.1 & 657.7 & 147.4 & 482.2 \\
\hline 3 & 167.2 & 450.0 & 95.2 & 55.4 \\
\hline 4 & 167.2 & 2070.0 & 559.4 & 492.9 \\
\hline 5 & 15.2 & 1027.6 & 254.5 & 492.9 \\
\hline 6 & 15.2 & 975.0 & 238.6 & 548.2 \\
\hline 7 & 15.0 & 427.9 & 93.4 & 548.2 \\
\hline 8 & 14.8 & 377.3 & 80.7 & 548.2 \\
\hline 9 & 14.7 & 318.7 & 65.9 & 548.2 \\
\hline 20 & 67.4 & 212.2 & 181.5 & 91.8 \\
\hline 21 & 57.4 & 300.4 & 270.1 & 100.8 \\
\hline 22 & 57.4 & 300.4 & 270.1 & 44.9 \\
\hline 23 & 57.4 & 300.4 & 452.1 & 44.9 \\
\hline 24 & 57.4 & 300.4 & 1179.9 & 8.98 \\
\hline 25 & 57.4 & 300.5 & 270.3 & 91.8 \\
\hline 26 & 215.0 & 372.9 & 346.0 & 91.8 \\
\hline 27 & 215.0 & 387.9 & 362.1 & 467.9 \\
\hline 28 & 215.0 & 387.9 & 529.5 & 467.9 \\
\hline 29 & 215.0 & 387.9 & 1199.3 & 91.8 \\
\hline
\end{tabular}


$\underline{\text { TABLE } \quad \text { C.3-3 }}$

POWER SUMMARY - AIR SEPARATION PLANT

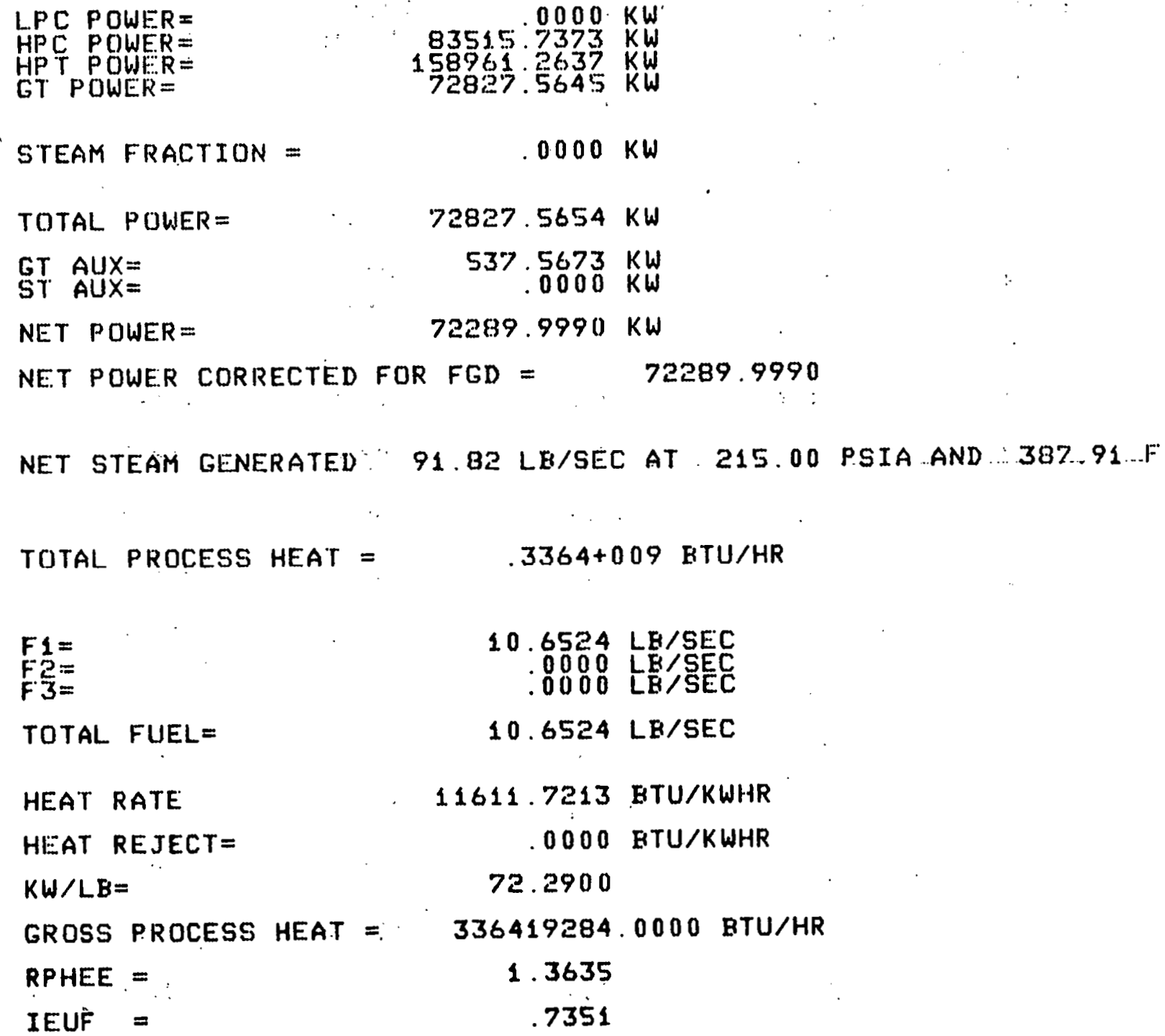


TABLE .C. 3-4

AIR SEPARATION PLANT

SUMMARY OF CAPITAL. COSTS: DEC. $1978 \%$

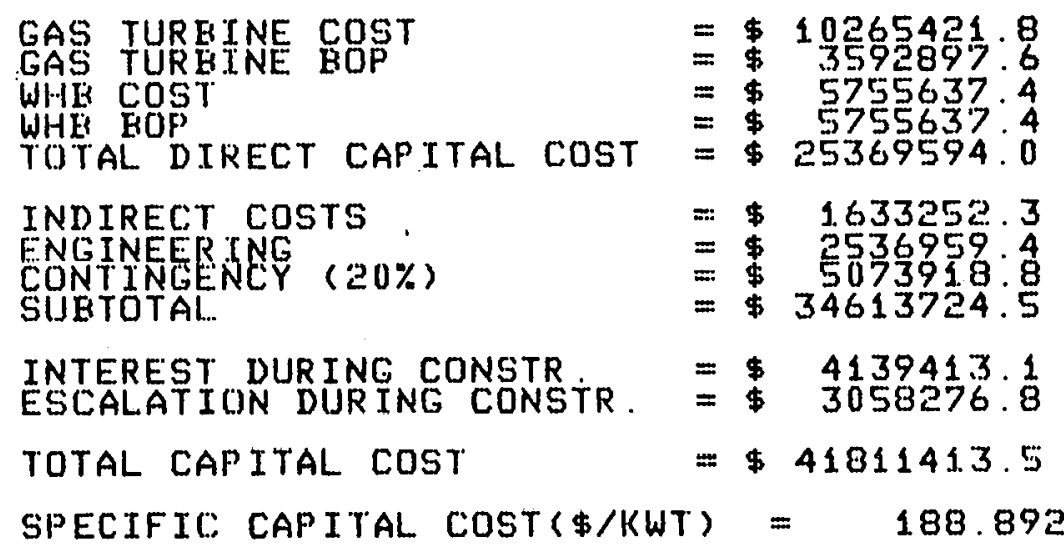


BATE: OF RETURN ON EQUTTY SUMMARY

EUR INDUG TRIAL. COGENERATION

********************************************************************************

ENERGY UTII. IZATION SYSTEM CHARACTERIZATION

ALR SEPARATION PLANT

***********************************************************************************

REQUTRED RATIO OF: PROCESS HEAT/ELECTRICITY =

$=\quad 2.4700$

REQUIRE: PROCESS HEAT

$=723590272.0$ (KWH/YR)

REQUTREI) ELECTRTC ENERGY

$=530672196.0$ (KWH/YR)

SUPPLEMENTAL. ELECTRIC ENERCY PURCHASED

$=.0$ (KWH/YR)

ASSUMED CAPACITY FAC:TOR

$=.8380$

ASSUMED) STANDEY POWER FRALTTION

$=1.0000$

**************************************************************************************

ENERGY CONUERSION SYSTEM CHARACTER IZATION

GAS-FIRED COMEUSTION TUREINE WITH WHB

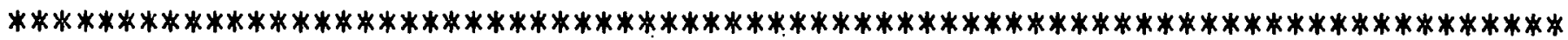

ACTUAL RATIO OF PROCESS HEAT/ELECTRICITY

$=\quad 1.3635$

IDEAL ENERGY UTILIZATION FACTOR

$=\quad .7351$

SPECIFIC; CAP ITAL.. COST OF CONUERSION SYSTEM

$=188.8921(\$ / K W T)$

INCR. LAEOR COST (INDUSTRY) (IST YEAR)

$=405376.2109(\$)$

INCR. LABOR COST (UTILITY) (1ST YEAR)

$=101.196 .9639(\$)$

INCR . LAEOR COST (3RD PARTY) (1ST YEAR)

$=405376.2109$ (\$)

$* * * * * * * * * * * * * * * * * * * * * * * * * * * * * * * * * * * * * * * * * * * * * * * * * * * * * * * * * * * * * * * * * * * * * * * * * * *$ 


\section{TABLE C. 3-5 (cont'd,)}

AIR SEPARATION PLANT

ECONOMIC AND FINANCIAL ASSUMPTIONS

$* * * * * * * * * * * * * * * * * * * * * * * * * * * * * * * * * * * * * * * * * * * * * * * * * * * * * * * * * * * * * * * * * * * * * * * * *$

\begin{tabular}{|c|c|c|c|}
\hline $\begin{array}{l}\text { DERT ， EQUTYY RATIR (INDUSTRY) } \\
\text { DEET ， EQUTY RATIO (UTIITY) } \\
\text { DEET ＥQUTY RATIO (JRD PARTY) }\end{array}$ & $\begin{array}{l}= \\
=\end{array}$ & $\begin{array}{l}1.6000 \\
5.0000\end{array}$ & \\
\hline LIFE OF PROJECT & $=$ & 28 & (YEARS) \\
\hline LIFE OF INUESTMENT FOR TAX PURPOSES & $=$ & 28 & (YEARS) \\
\hline INCOME: TAX RATES (FEDERAL + STATE) & $=$ & .4600 & $(\% / 100)$ \\
\hline INTEREST RATE: ON DEET & $=$ & 1000 & $(\% / Y R / 100)$ \\
\hline INUESTMENT TAX CREDIT RATE & $=$ & .0000 & $(\% / 100)$ \\
\hline ITCR UNDER SEPARATE GENERATION (INDUSTRY) & $=$ & .0000 & $(\% / 100)$ \\
\hline ITCR UNDER SEPARATE GENERATION (UTILITY) & $=$ & 1000 & $(\% / 100)$ \\
\hline PROPERTY TAX RATE (IST YEAR) & $=$ & .0150 & $(\% / 100)$ \\
\hline INSURANCE RATE (IST YEAR) & $=$ & .0150 & $(\% / 100)$ \\
\hline CHARGE FOR STANDEY POWER & $=$ & 67.1203 & $(\$ / K W)$ \\
\hline MAINTENANCE \& SUPPLIES COST FACTOR (1ST YR) & $=$ & .0375 & $(\% / 1.00)$ \\
\hline BOILER HEAT RATE (SEPARATE GENERATION) & $=$ & 3750.0000 & (ETU/KWH) \\
\hline CENTRAL STATION EUSS HAR HEAT RATE & $=$ & 9500.0000 & (ETU/KWH) \\
\hline TRANSMISSION LOSSES OF PURCHASED POWER & $=$ & .1000 & $(\% / 100)$ \\
\hline SPECIIFIC CAPITAL. COST OF NEW UTILITY STATION & $=$ & 1000.0000 & $(\$ / K W)$ \\
\hline PRICE OF: PRQCESS STEAM (IST YR) & $=$ & 3.1649 & $\left(\$ / 10^{\wedge} 6\right.$ ETU $)$ \\
\hline PRICE OF POWER AT CENTRAL STATION EUS BAR & $=$ & .0164 & $(\$ / K W H)$ \\
\hline PRICE OF POWER EOUGHT FROM UTILITY (1ST YR) & $=$ & .0273 & $(\$ / K W H)$ \\
\hline PRICE OF POWER SOLD TO UTILITY ( $1 S T$ YR) & $=$ & .0164 & $(\$ / K W H)$ \\
\hline PRICE OF FUEL (COGENERATION) & $=$ & 2.3226 & (\$/10^6 ETU) \\
\hline PRICE OF FUEL, (SEP.GEN.: INDUSTRY) & $=$ & 2.3226 & $\left(\$ / 10^{\wedge} G\right.$ ETU $)$ \\
\hline PRICE OF FUEL. SSEP.GEN. : UTILITY & $=$ & 2.3353 & $\left(\$ / 10^{\wedge} 6\right.$ BTU $)$ \\
\hline GENERAL INFLATION RATE & $=$ & .0750 & $(\% / 100 / Y R)$ \\
\hline FUEL PRICE RELATIVE ESC. (COGENERATION FUEL) & $=$ & .0444 & $(\% / 100 / Y R)$ \\
\hline FUEL PRICE REL. ESC. (SEP.GEN. : INDUSTRY) & $=$ & .0444 & $(\% / 100 / Y R)$ \\
\hline FUEL PRICE REL. ESC. (SEP.GEN.: UTILITY) & $=$ & -.0100 & $(\% / 100 / Y R)$ \\
\hline RELATIVE ESC. OF ELECTRICAL. ENERGY COSTS & $=$ & .0603 & $(\% / 100 / Y R)$ \\
\hline RELATIVE ESC. OF PROCESS STEAM COSTS & $=$ & .0222 & $(\% / 100 / Y R)$ \\
\hline
\end{tabular}




\section{AIR SEPARATION PLANT \\ FOR INDUSTRIAL OWNERSINIP}

C.APITAL INUESTMENT

NET EQUITY CAPITAL. INUESTMENT

$=\quad 41811412(\$)$
$=\quad 26132132(\$)$

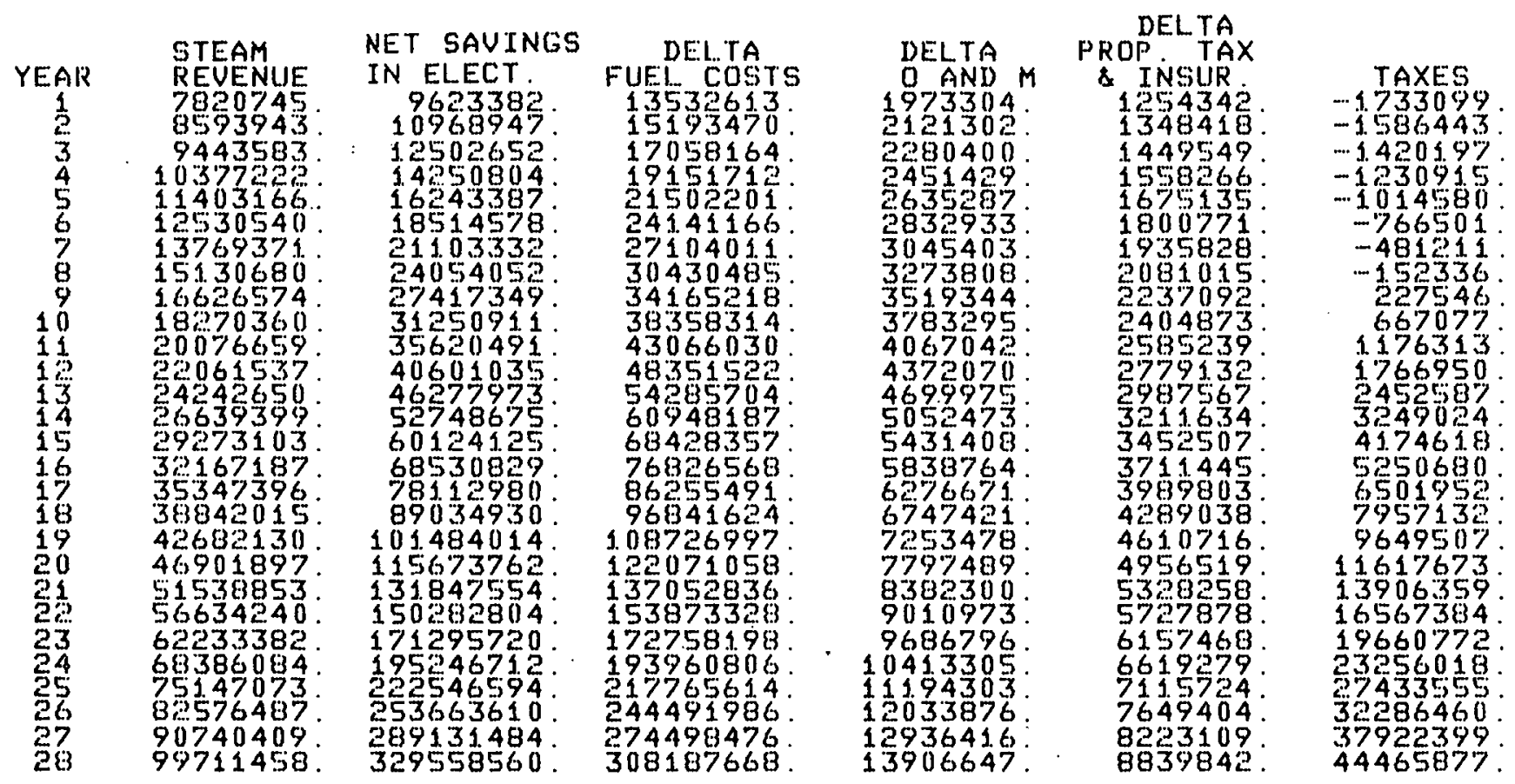

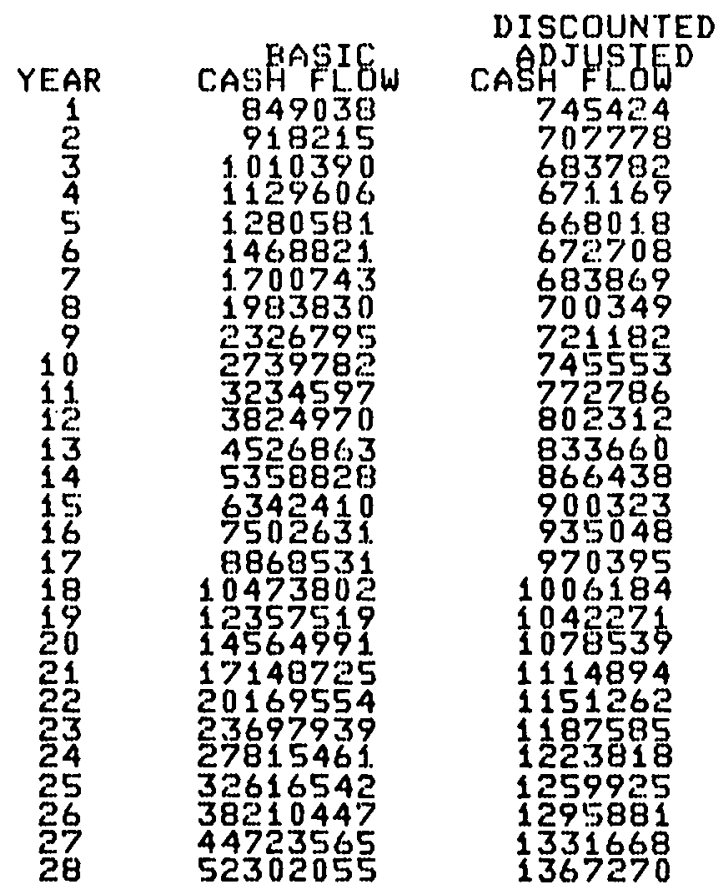

DISCOUNTED CASH FLOW RATE OF RETURN ON EQUITY(ROE) $=13.90 \%$ ANNUAL ENERGY SAUED UNDER COGENERATION = 
AIR SEPARATION PLANT

FOR UTILITY OWNERSHIP

INCREMENTAL CAPITAL INUESTMENT

NET INCREMENTAL EQUITY CAPITAL INUESTMENT

$$
\begin{aligned}
& =-38510806(\$) \\
& =-14513611(\$)
\end{aligned}
$$

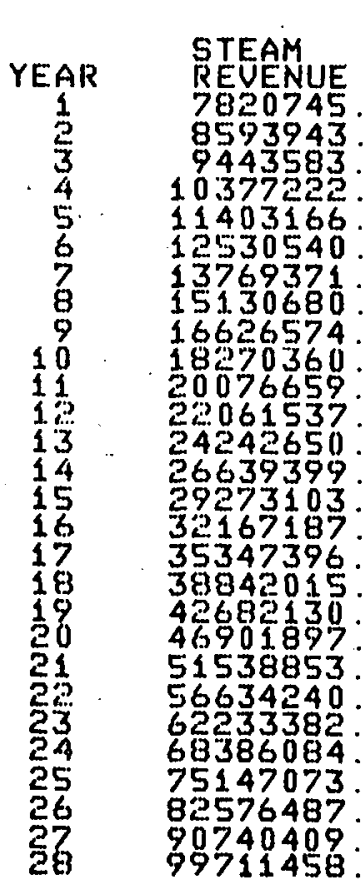

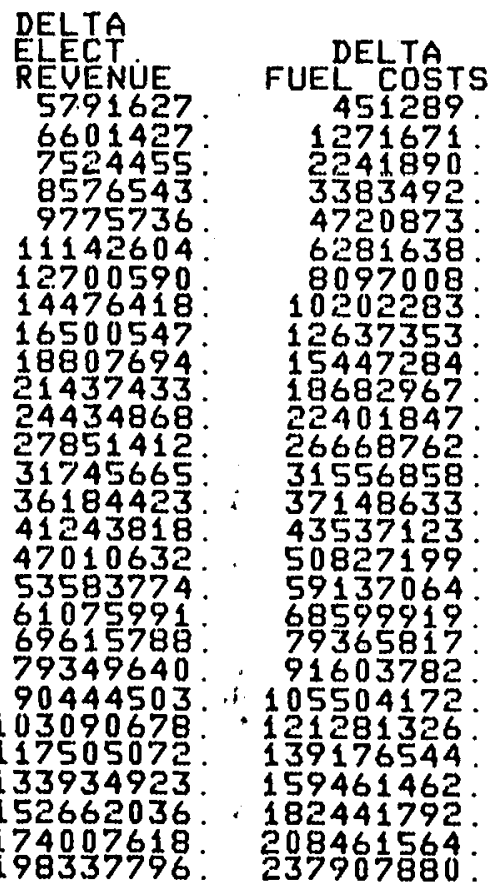

DELTA 57.91627 6601427 554455 8576543 .

11142604 . 14. 16500547 . 18807694

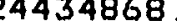
1745665 36184423 41243818 . . 6107591. . 90444503 . 105504172 . $117505070^{\circ} 139176544$. 133934923 . 159461462 . 194007618 . 20846956940

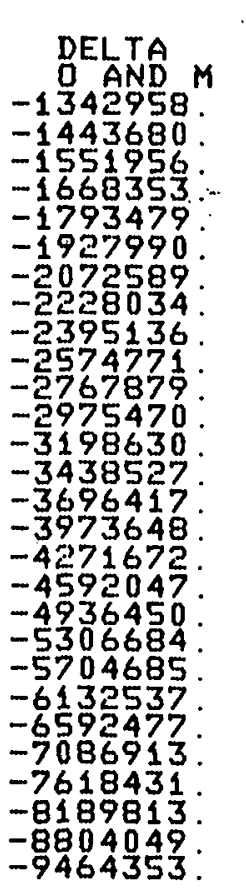

TAXES 9746318 . 10164466 10608735 11.080545 . 11581416 . 1 1.1929,87. $1327546 \%$. 13910416 . 14584195 . 15299382 . $16058856^{\circ}$. 16865847 . 17724014. 18637511. 1.9611101 . 20650256 . 更 1761598 . 24229629 25605456 . 27090763 28699298 30447225. 32353592 34440855

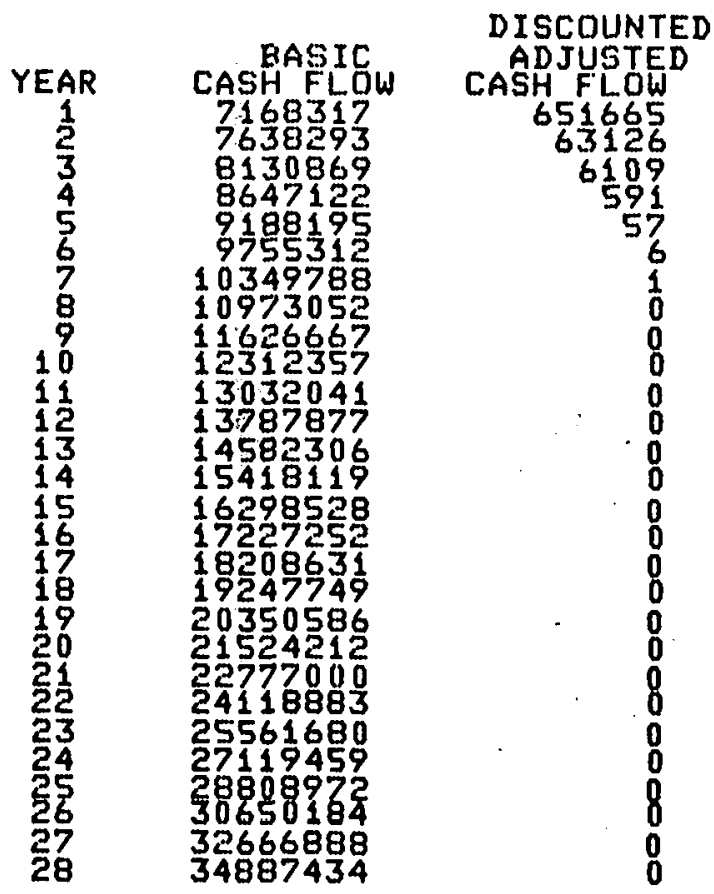

DISCOUNTED CASH FLOW RATE OF RETURN ON EQUITY $(R O E)=1000.0 .0 \%$ 
TABLE C. $3-6 c$

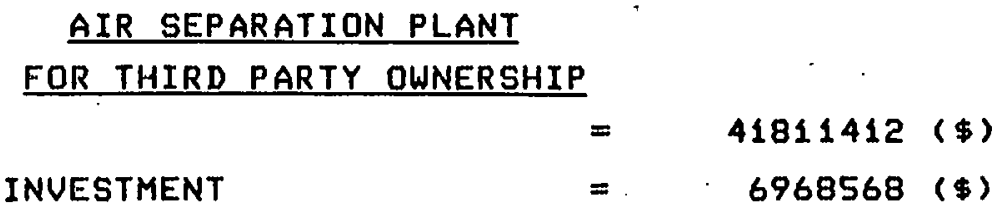

\begin{tabular}{|c|c|c|c|c|c|c|}
\hline $\begin{array}{l}\text { YEAR } \\
1 \\
2 \\
3 \\
4 \\
5 \\
6 \\
7 \\
8 \\
9 \\
10 \\
11 \\
12 \\
13 \\
14 \\
15 \\
16 \\
17 \\
18 \\
19 \\
20 \\
21 \\
23 \\
23 \\
24 \\
25 \\
26 \\
27 \\
28\end{array}$ & 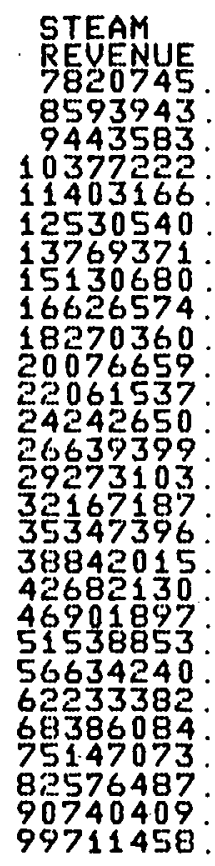 & 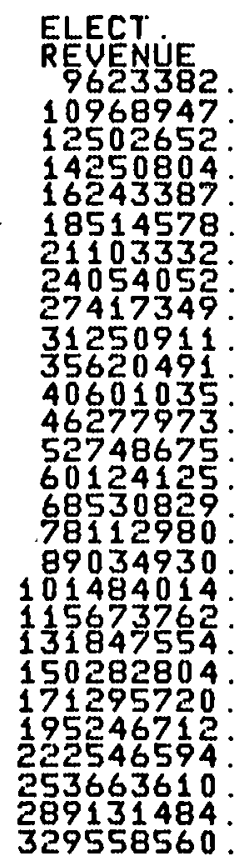 & 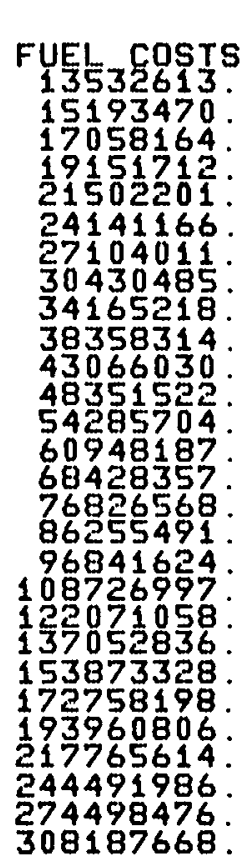 & 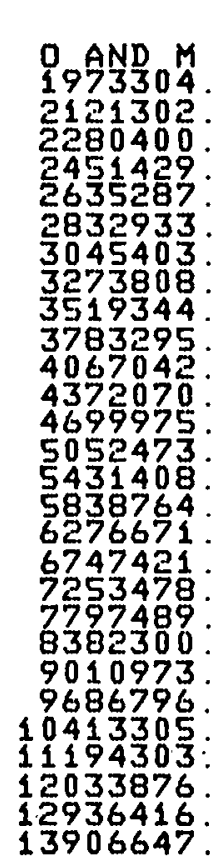 & 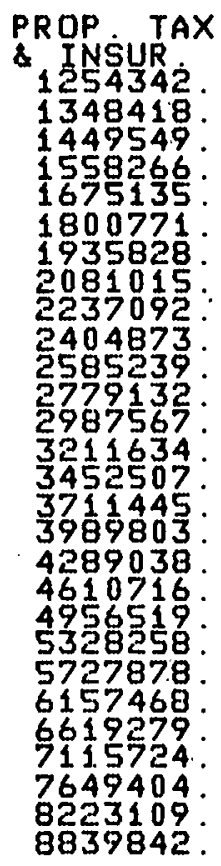 & $\begin{array}{r}\text { TAXES } \\
-2614622 \\
-2467967 \\
-2301721 \\
-2112439 \\
-1896104 \\
-1648025 \\
-16362734 \\
-1363734 \\
-1033860 \\
-653977 \\
-214447 \\
294790 \\
885426 \\
1571063 \\
2367500 \\
3393094 \\
4369156 \\
5620428 \\
7075608 \\
8767983 \\
10736449 \\
13024835 \\
15685860 \\
18779248 \\
22374494 \\
26552031 \\
31404935 \\
37040874 \\
4358435\end{array}$ \\
\hline
\end{tabular}

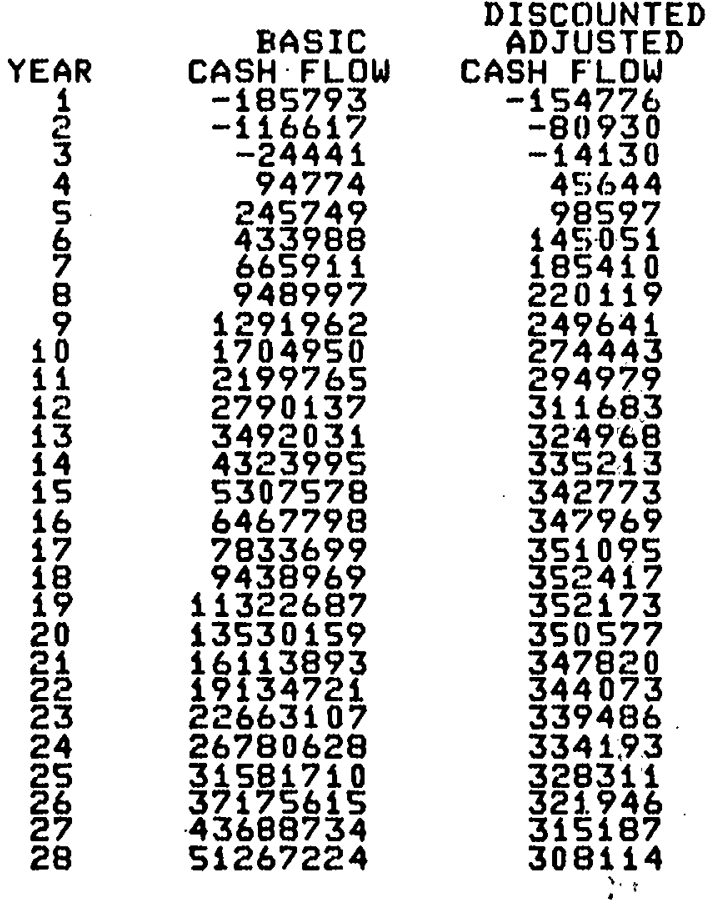

DISCOUNTED CASH FLOW RATE OF RETURN ON EQUITY(ROE) $=20.04 \%$ ANNUAL ENERGY SAUED UNDER COGENERATION $=2488484.3125 \mathrm{MBTU} / \mathrm{YR}$ 
TABLE C. $3-7$

FUEL UTILIZATION, AIR SEPARATION PLANT

$\begin{array}{lccr} & \begin{array}{c}\text { Separate Generation } \\ (\text { MBtu/yr) }\end{array} & \begin{array}{c}\text { Cogeneration } \\ (\text { MBtu/yr) }\end{array} & \begin{array}{c}\text { Savings } \\ (\text { MBtu/yr })\end{array} \\ \text { Gas } & 2713464 & 5826899 & -3113435 \\ \text { O11 } & - & - & - \\ \text { Coal } & 5601919 & - & 5601919 \\ \text { Overa11 } & 8315383 & 5826899 & 2488484\end{array}$

$\stackrel{?}{1}$

Percent Energy Savings $=29.9 \%$

Note: M designates one million 
When power requirements are matched for the gas turbine with waste heat boiler, the amount of process steam generated is significantly less than the $500,000 \mathrm{lb} / \mathrm{hr}$ potential market for process steam at premium prices. A gas turbine compressor air flow rate of $953 \mathrm{lb} / \mathrm{hr}$ would be required to match the $500,000 \mathrm{lb} / \mathrm{hr}$ process steam market under normal operating conditions. The amount of electric power generated would be proportionally larger and $47,500 \mathrm{~kW}$ of power would be available for sale to the local utility. A financial analysis of this option was not made. 


\section{4 BREWERY}

The brewery is located in Pennsylvania (DOE Region III) and requires a relatively small amount of energy compared with other industries. The energy requirements of the plant include the use of saturated steam and the use of electricity. The energy use pattern is complicated by short periods of large steam demands during three-hour brewing cycles. Any cogeneration facility chosen should be able to provide some form of energy storage in order to satisfy these peak demands. The overall required ratio of process heat to electricity is 4.42 . The annual energy requirements of the brewery are as follows:
- Process heat (sat'd steam)
172.1 million $\mathrm{kWh} / \mathrm{yr}$
- Electricity
38.93 million $\mathrm{kWhe} / \mathrm{yr}$

The candidate energy conversion subsystems considered for application to the brewery were a conventional coal-fired steam plant and an oilfired combined cycle. Both options contained steam accumulators to provide peaking capacity. The combined cycle option proved to be economically unfeasible and was dismissed from the optimization process. A detailed look at the conventional coal-fired boiler/BPT did, on the other hand, provide a near-acceptable return on equity for all ownership options.

Figure C.4-1 contains the energy utilization subsystem model for the brewery. The appropriate state points are given in Table C.4-1. In Figure C.4-2, the energy conversion subsystem configuration is shown for the coal/steam model chosen for optimization. The steam accumulator subsystem appears in a more detailed manner in Figure C.4-3. The boiler is designed to generate the 'base-load' steam demand as well as a small quantity of steam which is stored as hot water during the periods between peak steam demands.

The highest throttle pressure practical in the capacity range under consideration for the brewery is 915 psia. The optimization procedure revealed that, at that pressure, good return on equity may be expected for a utility owner, while a marginal ROE is predicted for the industrial and a negative ROE is predicted for the third-party owners. Figures C.4-4a and C.4-4b show the trend of energy saved vs. ROE for the industry and utility ownership options. The highest pressure was taken to be the limiting factor in the optimization, assuming that ownership would be arranged to guarantee the maximum possible energy savings. Table C.4-2 contains the state point data corresponding to the indicated points in Figure C.4-3.

The steam generator is a stoker-fired boiler using Ohio Pittsburgh No. 8 seam coal with the composition and physical properties shown in Table C.4-3. The steam generated is expanded to 135 psia through the back pressure turbine and, after extraction streams are taken off to supply energy for flue gas reheat and for deaeration of the recycled condensate, is piped to the process. A small fraction of the high pressure steam is used to store energy in the hot water contained in the high pressure accumulator. The gross power rating of the BPT is $3.4 \mathrm{MWe}$. In Table C.4-4, the energy distribution of the cogeneration facility is sumarized. The ideal energy utilization factor (IEUF) is 0.8723 and the generated ratio of process heat to electricity is 13.0 . The preliminary capital costs are listed in Table C.4-5. 


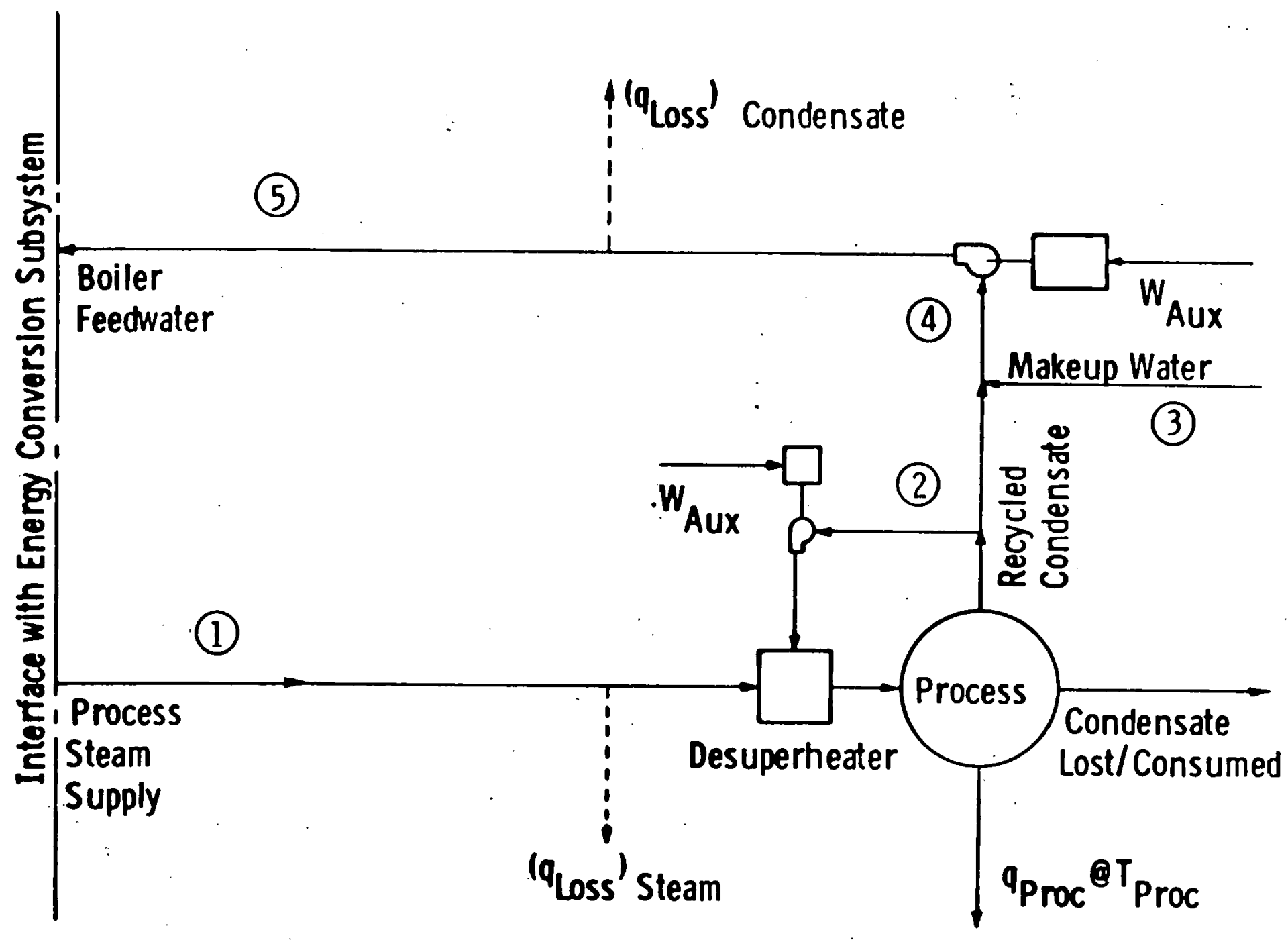

Fig. C. 4-1 - Flowsheet of process heat utilization subsystem for brewery with conventional coal-fired steam energy conversion subsystem 
$\underline{\text { TABLE } \quad \text { C.4-1 }}$

STATEPOINTS FOR ENERGY UTILIZATION SUBSYSTEM. IN BREWERY

$\begin{array}{ccccc}\text { Station } & \begin{array}{c}\text { Pressure } \\ (\mathrm{psia})\end{array} & \begin{array}{c}\text { Temperature } \\ \left({ }^{\circ} \mathrm{F}\right)\end{array} & \begin{array}{c}\text { Enthalpy } \\ (\mathrm{Btu} / \mathrm{b})\end{array} & \begin{array}{c}\text { Flow Rate } \\ (1 \mathrm{~b} / \mathrm{s})\end{array} \\ 1 & 135 & 551.5 & 1302.5 & 23.07 \\ 2 & >15 & 225 & 193 & 16.15 \\ 3 & 15 & 100 & 68 & 6.92 \\ 4 & >15 & 187.5 & 155.6 & 23.07 \\ 5 & 39.8 & 187.5 & 155.6 & 23.07\end{array}$

C-21 


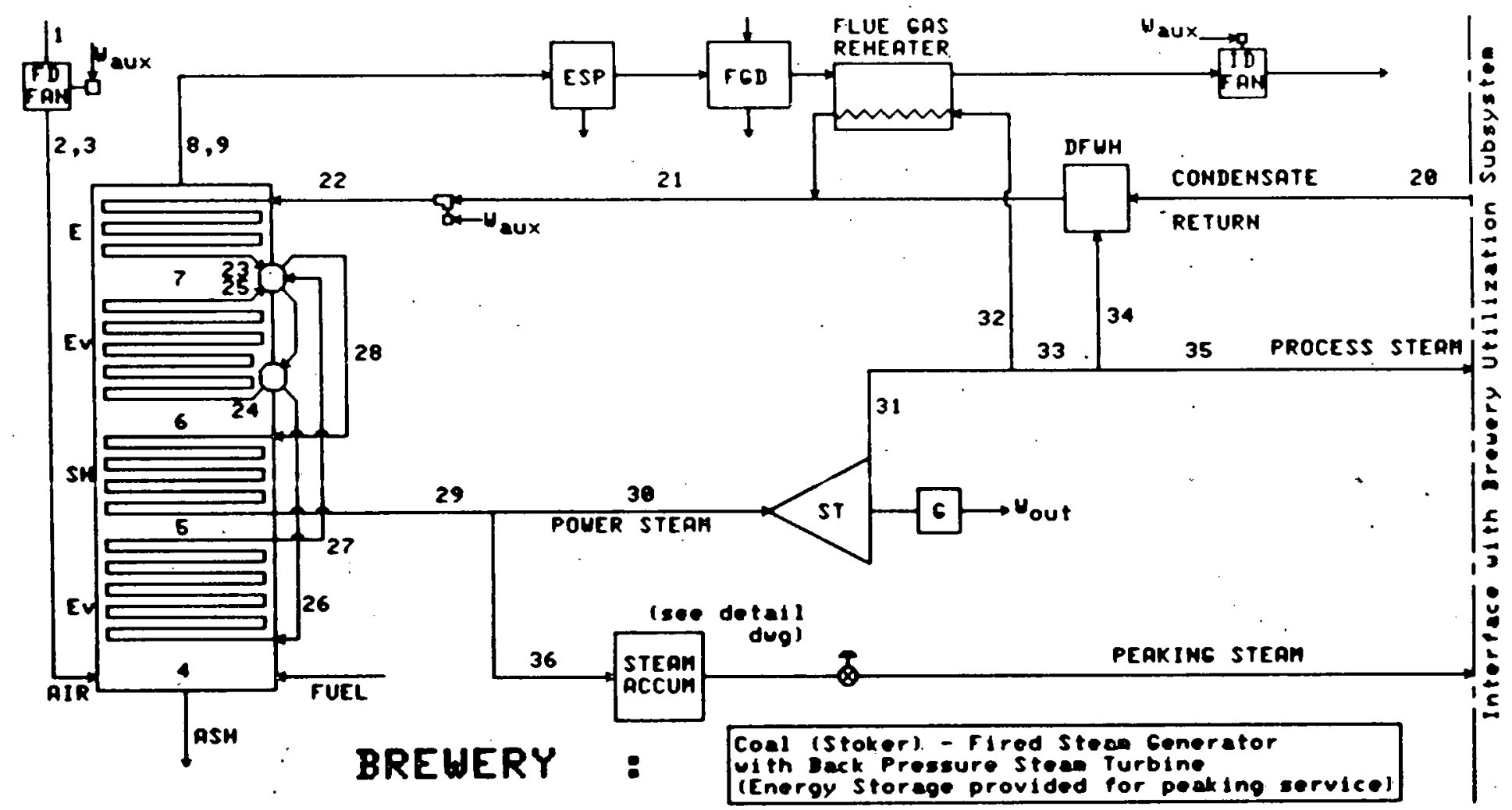

Fig. C. 4a.... Model of energy conversion gubsystem chosen for optimization for brem 


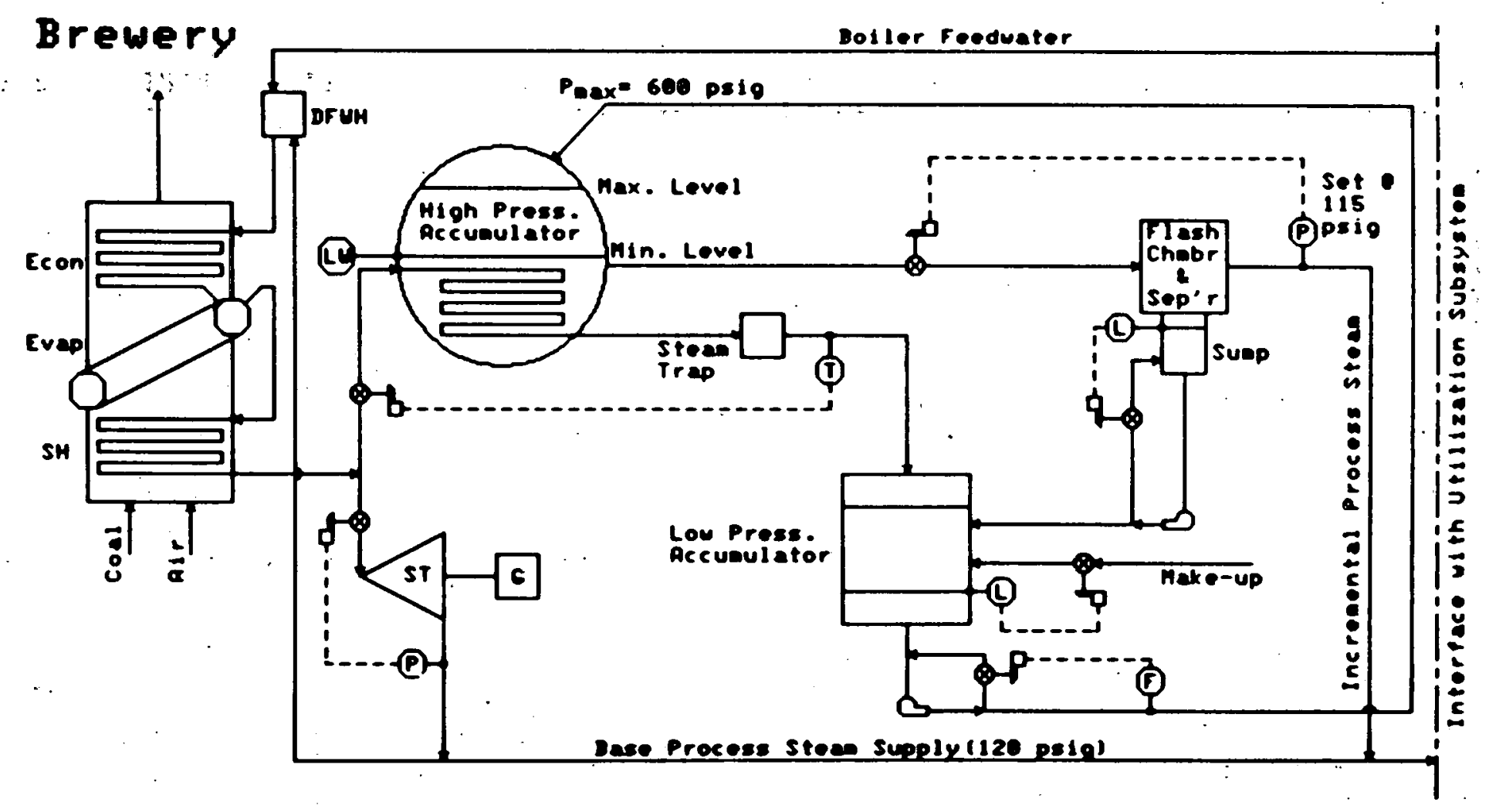

Fial. C. A 3 mode of steam arcumulator subsystem for brewery 


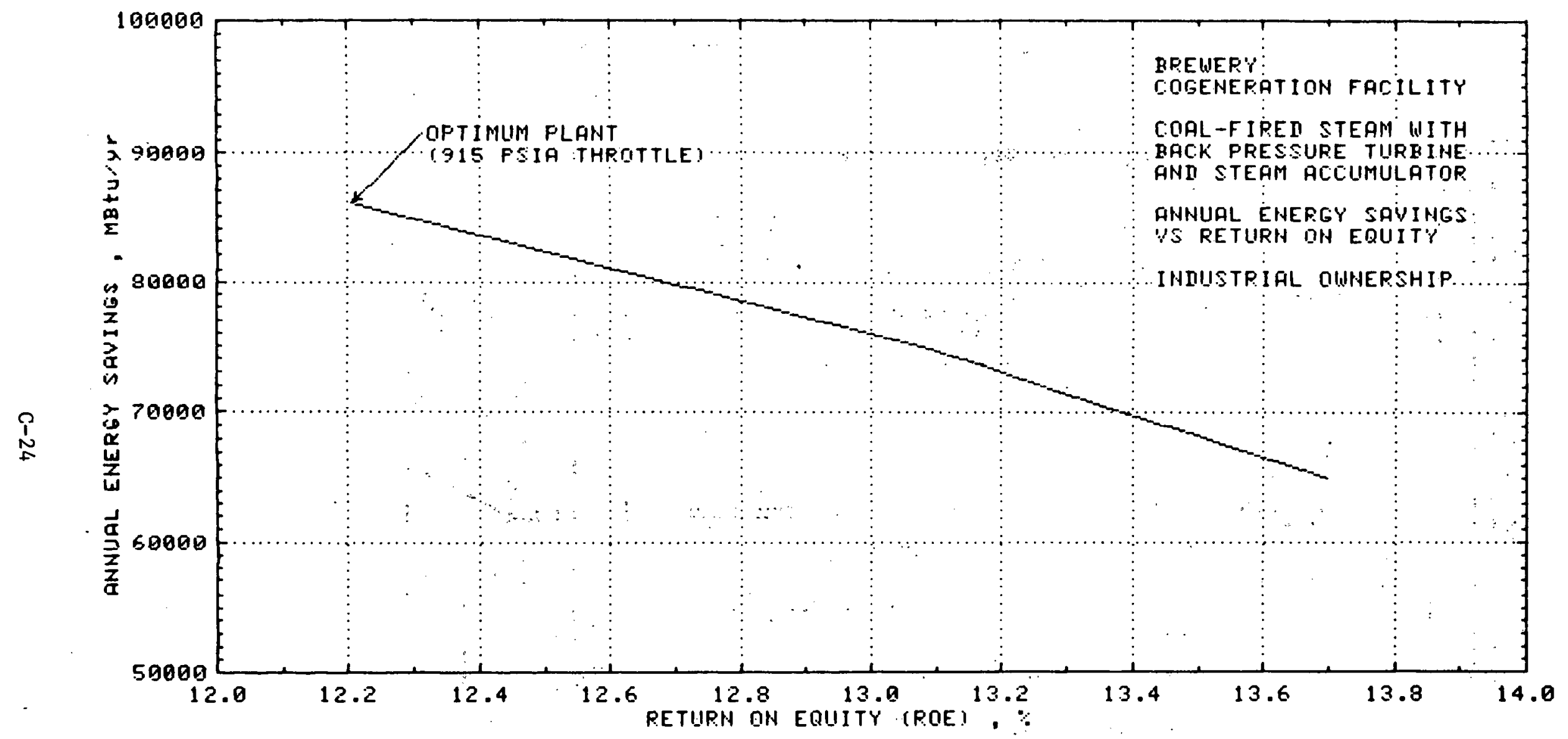

Fig. C. 4-4a - Annuaj. energy savings vs return on equity, industrial ownership 


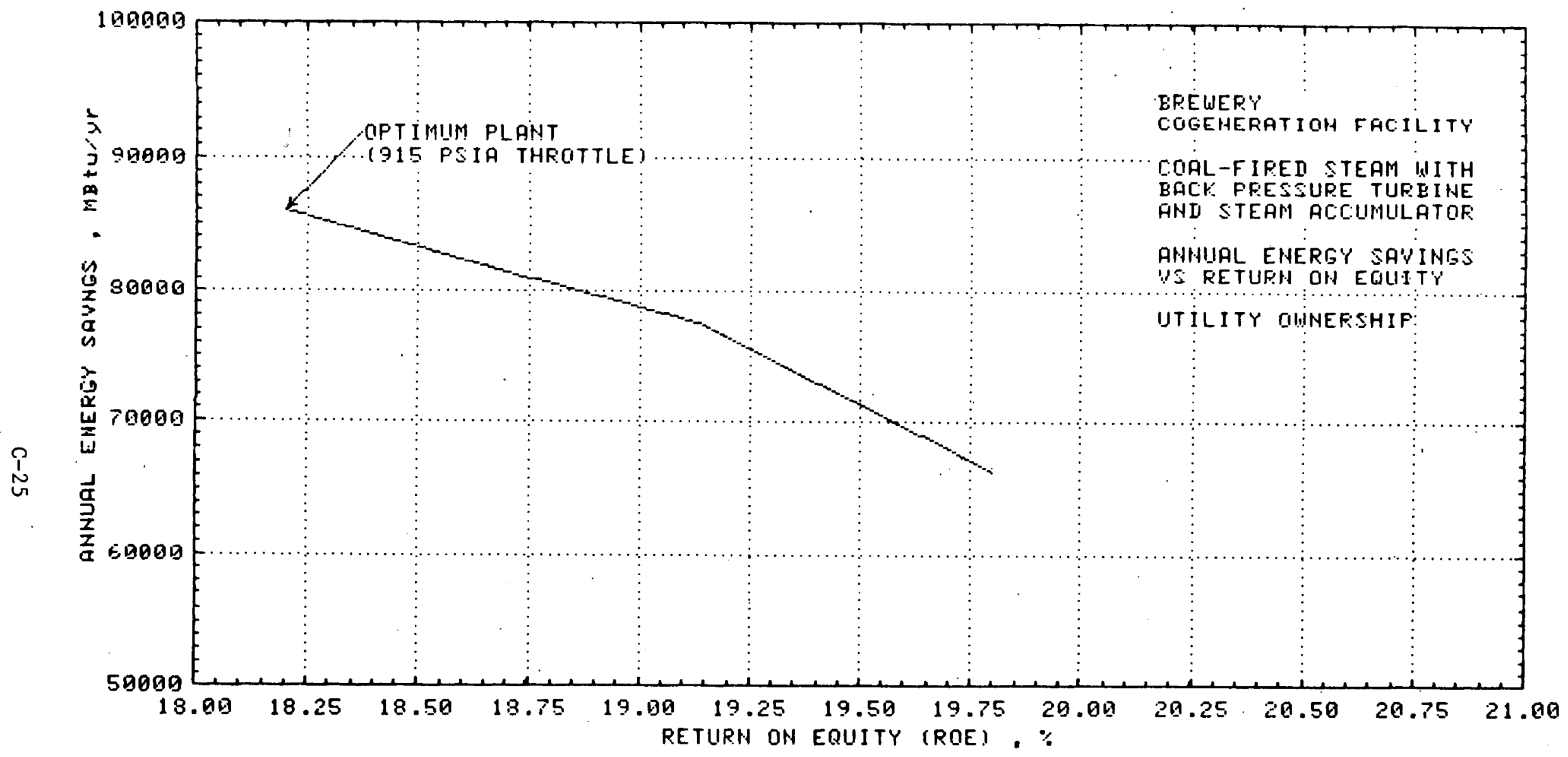

Fia. C. 4-4b Annual energy savinge us return on equity, utility ownership 
TABLE C. . 4-2

STATEPOINTS FOR ENERGY CONVERSION SUBSYSTEM IN BREWERY

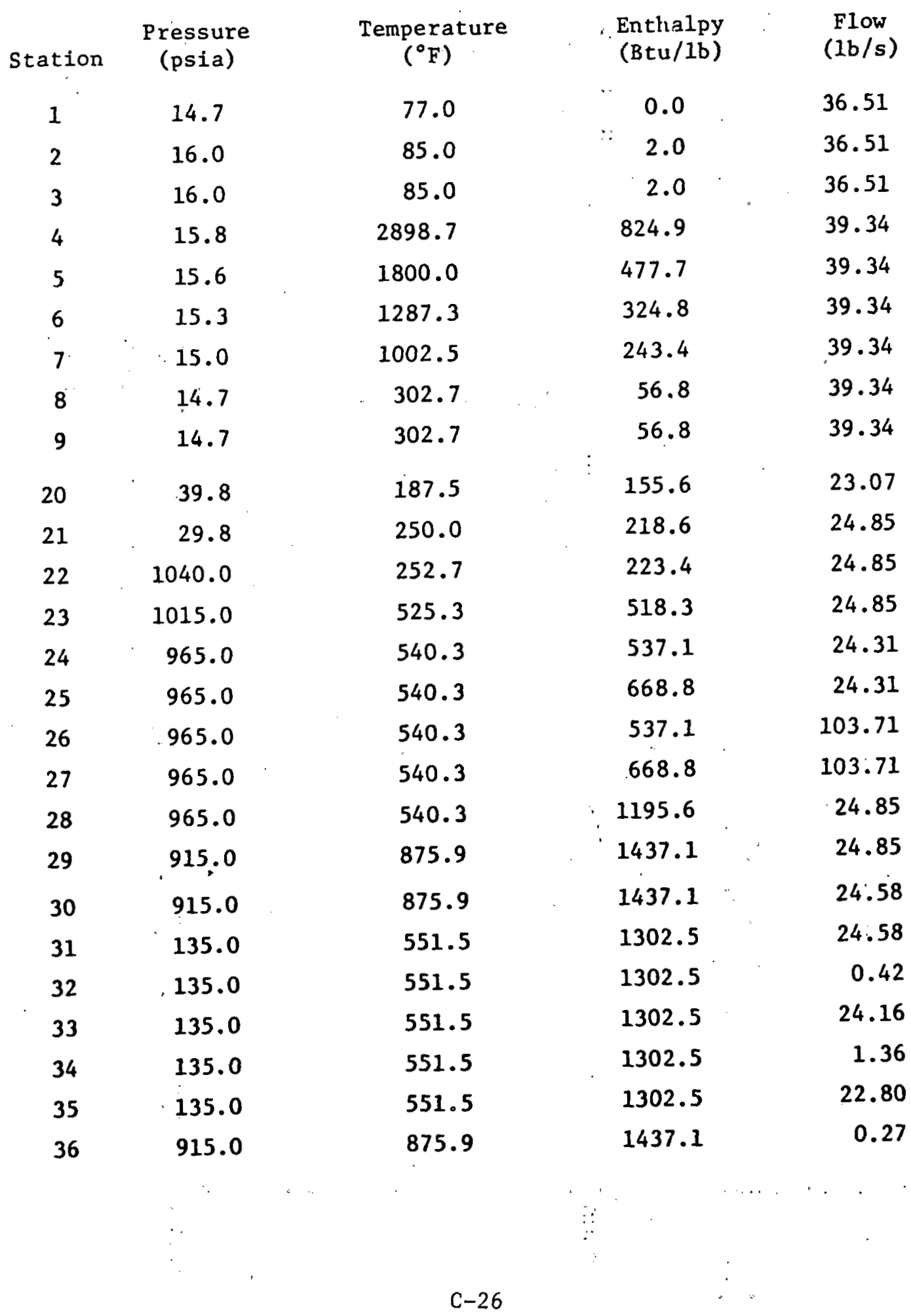


TABLE C. 4-3

FUEL SPECIFICATIONS

OHIO PITTSBURGH NO. 8 SEAM COAL

(Source of data: USBM, Pittsburgh, PA)

SAMPLE: Run of mine

$\begin{array}{cc}\text { As received } & \text { (1) } \\ & \text { As fired (2) } \\ 42.8 & 46.8 \\ 48.7 & 45.3 \\ \frac{8.5}{100.0} & \frac{7.9}{100.0}\end{array}$

ULTIMATE ANALYSIS (wt \%): c

(includes moisture) $\mathrm{H}$

$\mathrm{C}$
$\mathrm{H}$
$\mathrm{O}$

71.2

66.3

Volatile matter

Fixed carbon

Ash

5.4

5.8

9.3

1.3

14.6

$\mathrm{N}(3)$

4.3

1.2

Ash

$\frac{8.5}{100.0}$

4.0

$\frac{7.9}{100.0}$

GROSS HEATING VALUE:

NET HEATING VALUE:

$(B t u / 1 b)$

13000

12099

$(B t u / 1 b)$

12500

11634

ASH ANALYSIS (wt \%):

SiO

45.3

$\mathrm{Al}_{2} \mathrm{O}_{3}$

21.2

$\mathrm{Fe}_{2} \mathrm{O}_{3}$

27.3

$\mathrm{TiO}_{2}$

1.0

$\mathrm{P}_{2} \mathrm{O}_{5}$

0.11

$\mathrm{CaO}$

1.9

$\mathrm{MgO}$

0.6

$\mathrm{Na}_{2} \mathrm{O}$

0.2

$\mathrm{K}_{2} \mathrm{O}$

1.8

$\mathrm{SO}_{3}$

$\frac{0.7}{100.1}$

FUSIBILITY OF ASH:

Initial deformation temperature $--2080^{\circ} \mathrm{F}$

Softening temperature

$-2230^{\circ} \mathrm{F}$

Fluid temperature

$-2420^{\circ} \mathrm{F}$

PARTICLE DENSITY:

Coal -- $21.4 \mathrm{gm} / \mathrm{cc}$

Ash -- $22.8 \mathrm{gm} / \mathrm{cc}$

GRINDABILITY (Hardgrove): 50-60

FREE SWELLING INDEX: . 5-5.5

(1) $3.3 \%$ moisture

(2) $10 \%$ moisture assumed

(3) $~ 260 \%$ organic \& 40 pyritic 
TABLE C. 4-4

POWER SUMMARY - BREWERY

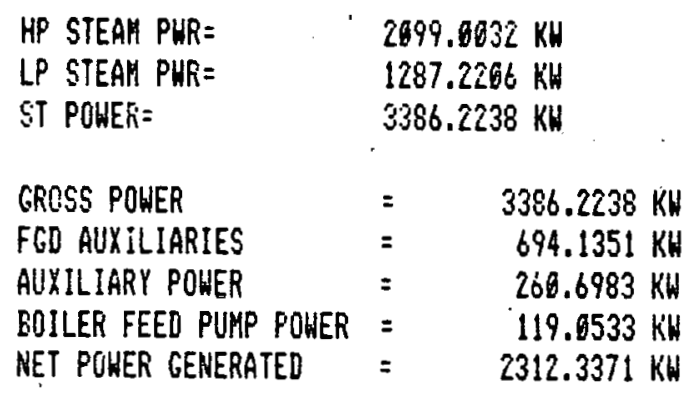

TOTAL FUEL =

$2.8326 \mathrm{LB} / \mathrm{SEC}$

THERHAL RATING $=118635967.9000 \mathrm{BTU} / \mathrm{HR}$

HEAT RATE

51365.2725 BTU/KHHR

TOTAL PROCESS HEAT $=\quad .9523+\square 68$ BTU/HR

PRUCESS HEAT AT $\quad 135.6$ PSIA $=.7523269+068 \mathrm{BTU} / \mathrm{HR}$

RPHEE $=\quad 13.0323 \mathrm{KHT} / \mathrm{KHE}$

IEUF $=\quad .8723$

$C-28$ 


\section{SUMMARY OF CAPITAL COSTS: DEC 1978\%}

\begin{tabular}{|c|c|}
\hline 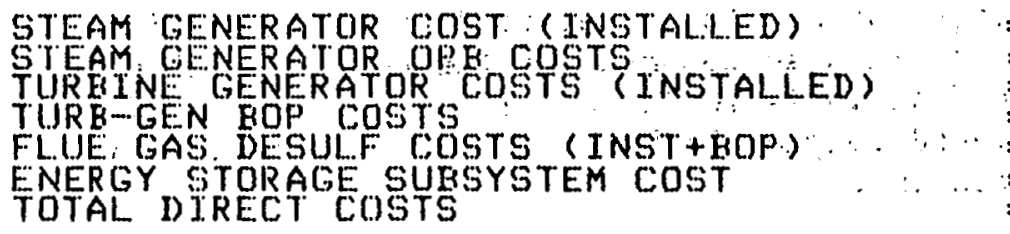 & $\begin{array}{l}=\$ 2950791 \cdot 4 \\
=\$ 368489.3 \\
=\$ 128454.6 \\
=\$ 1384554 \cdot 6 \\
=\$ 1328557.4 \\
=\$ 2000.0 \\
=\$ 10737547.1\end{array}$ \\
\hline $\begin{array}{l}\text { INDIRECY COSTS } \\
\text { ENGINEERING } \\
\text { CONTINGENCY (20\%) } \\
\text { SURTOTAL. }\end{array}$ & $\begin{array}{l}=\$ 1610643.1 \\
=\$ 307374.7 \\
=\$ 2147509 \cdot 4 \\
=\$ 15569443.3\end{array}$ \\
\hline $\begin{array}{l}\text { TNTEREST DURING CONSTRUCTION (36 mo.) } \\
\text { ESCALATION DURING CONSTR. }\end{array}$ & $\begin{array}{l}=\$ 2576742.9 \\
=\$ 1886163.7\end{array}$ \\
\hline TOTAL CAPITAL COST & $\$ 200$ \\
\hline OST $<\$$, & \\
\hline
\end{tabular}


The results of the cash flow analysis are based on financial and economic assumptions given in Table C.4-6. The cash flow vectors themselves are presented in Tables C.4-7a, C.4-7b, and C.4-7c for the three ownership options.

The potential energy savings to be realized as a result of this cogeneration installation as compared to the conventional energy system are broken down in Table C.4-8. The current fuel, No. 6 fuel oil, is replaced completely by coal and an overall savings in fuel is made possible. 
TABLE C. $4-6$

RATE OF RETURN ON EQUITY SUMMARY
FOR INDUSTRIAL COGENERATION

$* * * * * * * * * * * * * * * * * * * * * * * * * * * * * * * * * * * * * * * * * * * * * * * * * * * * * * * * * * * * * * * * * * * * * * * * * * *$

$$
\text { ENERGY UTILIZATION SYSTEM CHARACTERIZATION }
$$

$* * * * * * * * * * * * * * * * * * * * * * * * * * * \pi * * * * * * * * * * * * * * * * * * * * * * * * * * * * * * * * * * * * * * * * * * * * * * *$

REQUIRED RATIO OF PROCESS HEAT/ELECTRICITY

$$
\begin{aligned}
& =4.4700 \\
& =172077380.0(\mathrm{~K} W H / Y R)
\end{aligned}
$$$$
\text { REQUIRED PROCESS HEAT }
$$

REQUIRËD ELECTR IC ENE:RGY

SUPPLEMENTAL. ELEC.TRIC ENERGY PURCHASED = $=25292143.0(\mathrm{KWH} / Y \mathrm{H})$

ASSUMED CAPAC;ITY FACTOR $\quad \ldots . .7040$

ASSUMED STANDEY POWER FRACTION $=.1 .0000$

$* * * * * * * * * * * * * * * * * * * * * * * * * * * * * * * * * * * * * * * * * * * * * * * * * * * * * * * * * * * * * * * * * * * * * * * * * *$

ENERGY CONUERGION SYSTEM CHARACTER TZAT TON
COAL-FIRED STEAM WITH EPT ACCUMULATOR

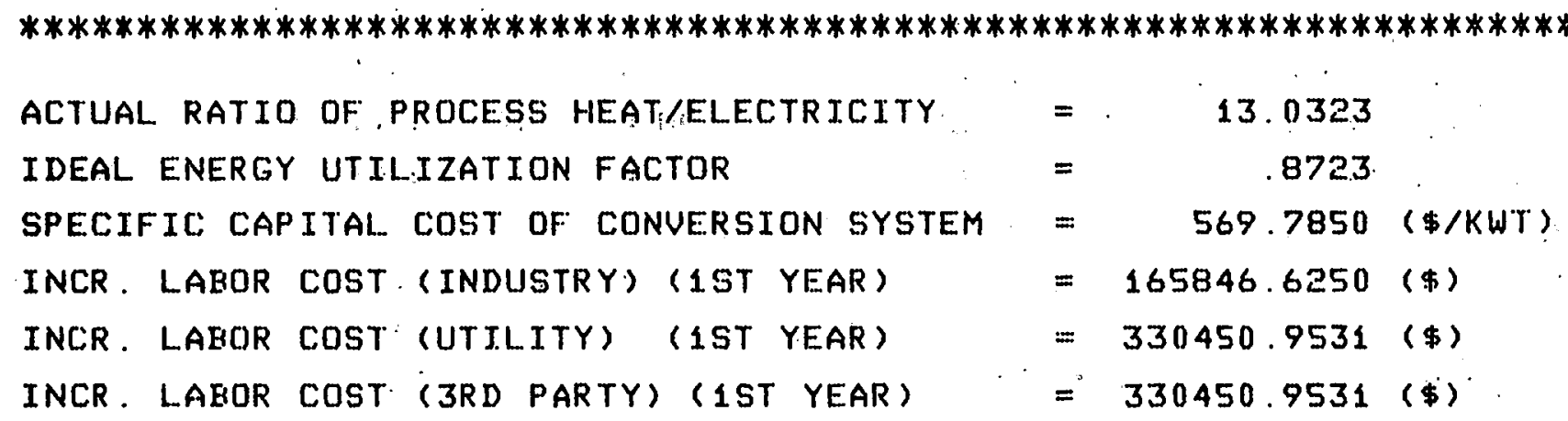

********************************************************************************** 
TABLE C. 4-6 (cont'd.)

BREWERY

ECONOMIC AND FINANCIAL ASSUMPTIONS

\begin{tabular}{|c|c|c|c|}
\hline 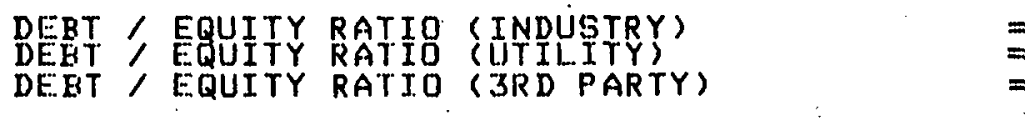 & $\begin{array}{l}= \\
= \\
=\end{array}$ & $\begin{array}{r}.3000 \\
5.9000 \\
5.0000\end{array}$ & \\
\hline LIFE OF PROJECT & $=$ & 28 & (YEARS) \\
\hline LIFE OF INUESTMENT FQR TAX PURPOSES & $=$ & 28 & (YEARS) \\
\hline INCOME TAX RATEG (FEDERAL + STATE) & $=$ & .5650 & $(\% / 100)$ \\
\hline INTEREST RATE: ON DEET & $=$ & .1000 & $(\% / Y R / 100)$ \\
\hline INUESTMENT TAX CIREDIT RATE & $=$ & .2000 & $(\% / 100)$ \\
\hline ITCR UNDER SEPARATE GENERATION (INDUSTRIAL) & $=$ & .0000 & $(\% / 100)$ \\
\hline ITCR UNDER SEPARATE GENERATION (UTILITY) & 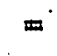 & .1000 & $(x / 100)$ \\
\hline PROPERTY TAX RATE (IST YEAR) & $=$ & .0150 & $(\% / 100)$ \\
\hline INSURANCE RATE (IST YEAR) & $=$ & .0150 & $(\% / 100)$ \\
\hline C.HARGE FOR STANDEY POWI:R & $=$ & 66.1108 & $(\$ / K W)$ \\
\hline MAINTENANCE \& SUPPLIES COST FACTOR (1ST YR) & $=$ & $.03 \% 5$ & $(\% / 100)$ \\
\hline BOILER HEAT RATE (SEPARATE GENERATION) & $=$ & 3750.0000 & (ETU/KWH) \\
\hline CENTRAL STATION BUS BAR HEAT RATE & $=$ & 9500.0000 & (BTU/KWH) \\
\hline TRANSMISSION LOSSES OF PURCHASED POWER & $=$ & .1000 & $(\% / 100)$ \\
\hline SPECIFIC CAPITAL COST OF NEW UTILITY STATION & $=$ & 1000.0000 & $(\$ / K W)$ \\
\hline PRICE OF PROCESS STEAM (IST YR) & $\therefore=$ & 4.0725 & $\left(\$ / 10^{\wedge} 6\right.$ ETU $)$ \\
\hline PRICE OF POWER AT CENTRAL STATION BUS BAR & $=$ & $: 0194$ & $(\$ / K W H)$ \\
\hline PRICE OF POWER EOUGHT FROM UTILITY (1ST YR) & $=$ & .0324 & $(\$ / K W H)$ \\
\hline PRICE OF POWER SOLD TO UTILITY (1ST YR) & $=$ & .0194 & $(\$ / K W H)$ \\
\hline PRICE OF FUEL. (COGENERATION) & $=$ & 1.5653 & $\left(\$ / 10^{\wedge} 6\right.$ ETU $)$ \\
\hline PRICE DF FUEL, (SEP.GEN.: INDUSTRY) & $=$ & 2.8090 & $\left(\$ / 10^{\wedge} 6\right.$ BTU $)$ \\
\hline PRICE OF FUEL (SEP.GEN.: UTILITY & $=$ & 1.5653 & $\left(\$ / 10^{\wedge} 6\right.$ ETU $)$ \\
\hline GENERAL INFLATION RATE & $=$ & .0750 & $(X / 100 / Y R)$ \\
\hline FUEL PRICE RELATIVE ESC. (COGENERATION FUEL) & $=$ & .0560 & $(\% / 100 / Y R)$ \\
\hline FUEL PRICE REL. ESC. (SEP.GEN. : INDUSTRY) & $=$ & .0770 & $(\% / 100 / Y R)$ \\
\hline FUEL PRICE REL. ESC. (SEP.GEN. : UTILITY). & $=$ & .0560 & $(\% / 100 / Y R)$ \\
\hline RELATIVE ESC. OF ELECTRICAL ENERGY COSTS & $=$ & .0210 & $(\% / 100 / Y R)$ \\
\hline RELATIVE ESC. OF PROCESS STEAM COSTS & $=$ & .0300 & $(\% / 100 / Y R)$ \\
\hline
\end{tabular}


BREWERY

FOR INDUSTR IAL DWNERSHJP

INCREMENTAL CAPITAL INUESTMENT

NET INCREMENTAL EQUTTY CAPITAL INUEGTMENT

$=19805594(\$)$
$=12188058(\$)$
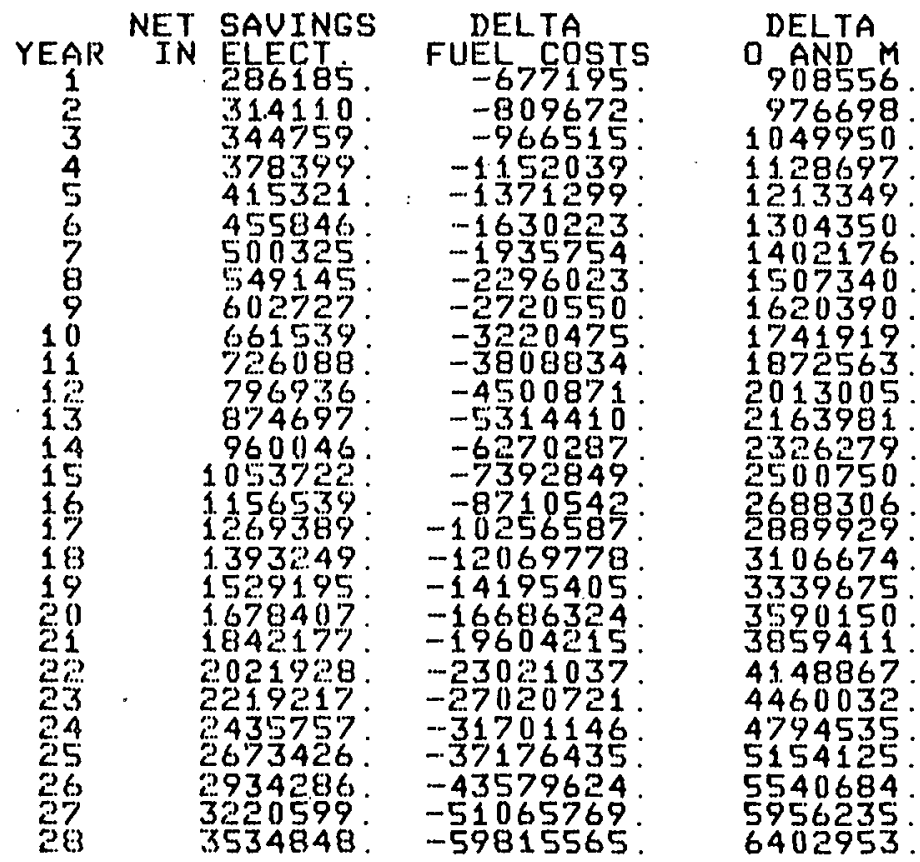

DELTA

PROP TAX INCOME TAXEG

\& INSUR ON SAUTNGS

$638730 .-1280188$

686635 . - - 2151.47

$738133 . \quad-1137345$

$853005 .-932436$

916980 .

$985754-638114$

1059685 . $\quad-446065$

$1139161 . \quad-216385$.

1316443.

1415179.

1635413 .

1758069

2031669

2184044.

2347847

2523936

2713231

2916723

3135477

3370638

3623436

3895194 385334 385334

1239583

1.791278

3.4365:58.

4142030 .

5229644

6514812

9821021.

11929095

14410849

1.73301 .98

20761711

24792382

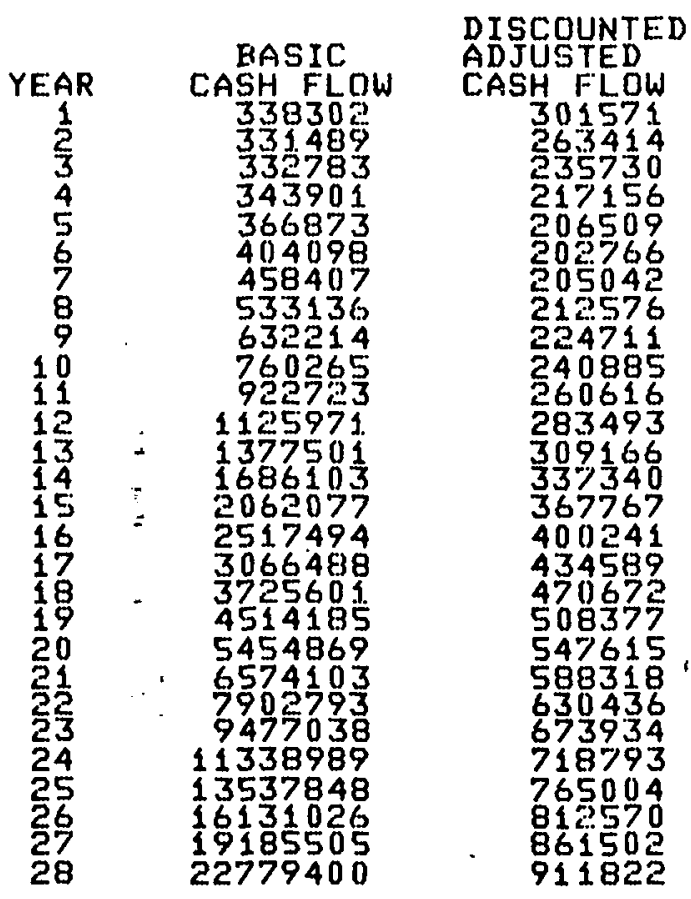

DISCOUNTED CASH FLOW RATE OF RETURN ON EQUITY(ROE)= $12.18 \%$ ANNUAL ENERGY SAVED UNDER COGENERATION =

85997.4141 METU/YR 
TABLE C. $4-7 \mathrm{~b}$

EREWERY

. FOR UTILITY OWNERSHIP

INCREMENTAL CAPITAL INUESTMENT

NEET INCREMENTAL EQUITY

CAPITAL INUESTMENT

$=16970968(\$)$
$=\quad 8038879(\$)$

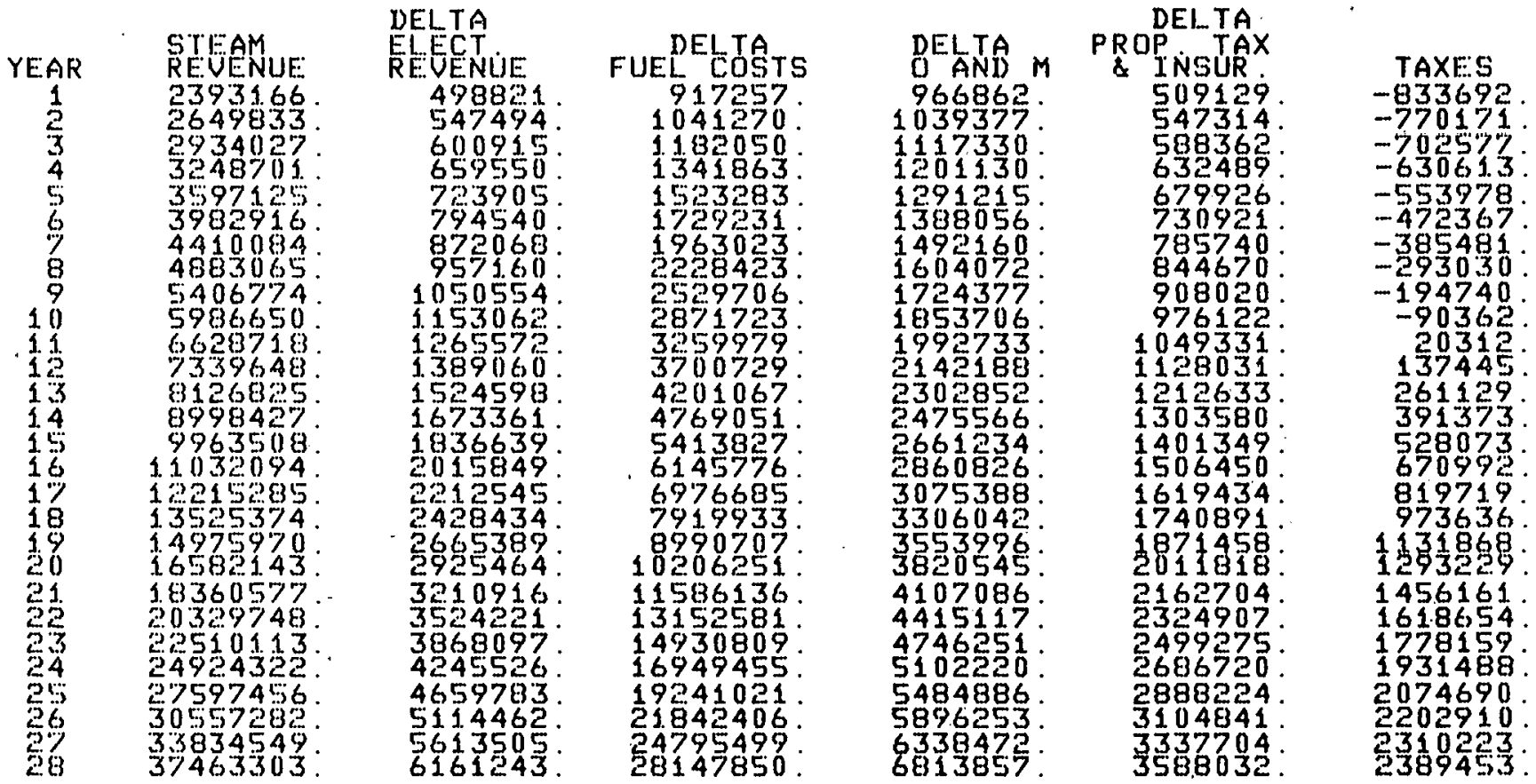

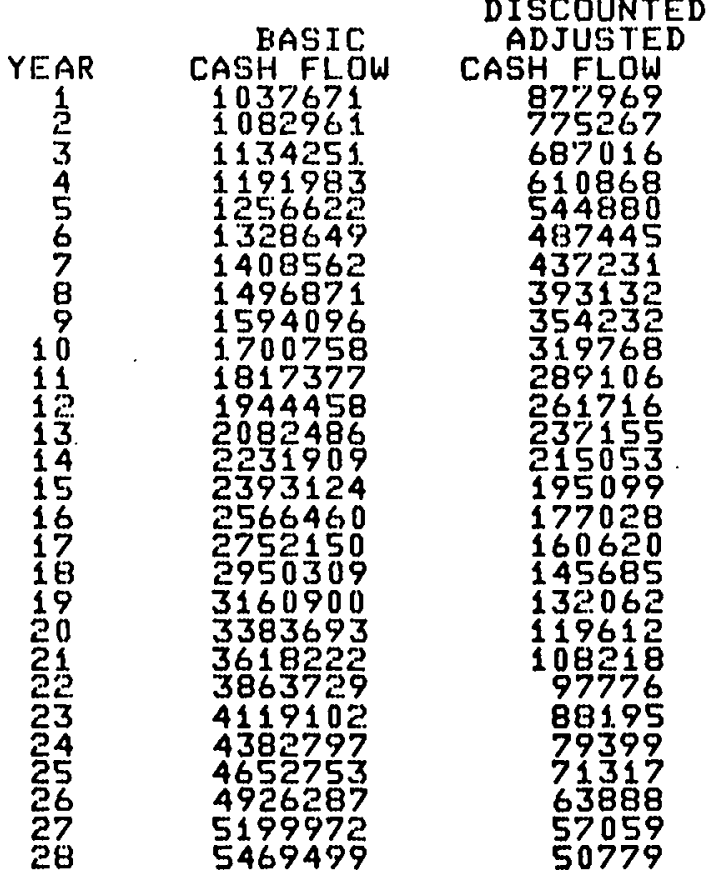

DISCOUNTED CASH FLOW RATE OF RETURN ON EQUITY(ROE) $=18.19 \%$ ANNUAL ENERGY SAUED UNDER COGENERATION $=\quad 85997.4141 \mathrm{MBTU} / Y R$ 
BREWERY

FOR THIRD PARTY OWNERSHIP

C.APITAL INUESTMENT

NET EQUITY CAPITAL INUESTMENT $=\quad 19805594(\$)$
$=\quad 2640745(\$)$

\begin{tabular}{|c|c|c|}
\hline $\begin{array}{l}\text { DELTA } \\
\text { O AND M } \\
073161 . \\
153648 . \\
240171 . \\
333184 . \\
433173 . \\
540661 . \\
656210 . \\
780426 . \\
913959 . \\
057505 . \\
311918 . \\
377704 . \\
556032 . \\
747734 . \\
953814 . \\
175350 . \\
413502 . \\
669514 . \\
944728 . \\
240592 . \\
558626 . \\
900523 . \\
268062 . \\
663167 . \\
087904 . \\
544497 . \\
035334 . \\
562984 .\end{array}$ & 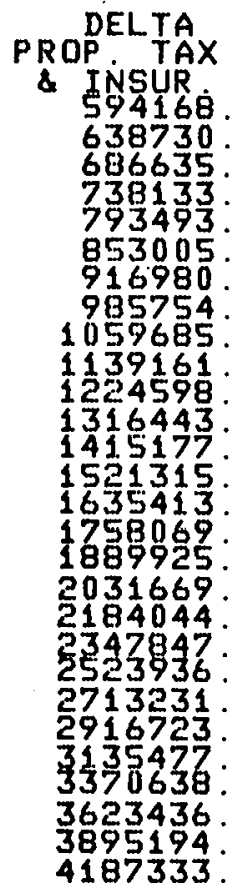 & 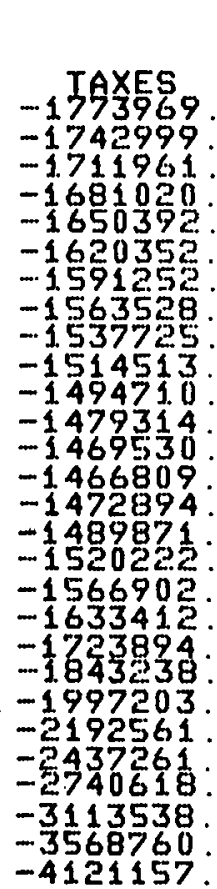 \\
\hline
\end{tabular}

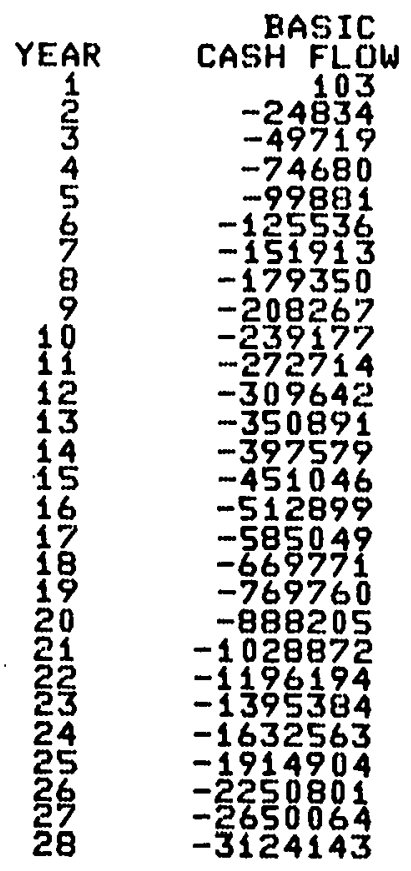

DISCOUNTED CASH FLOW RATE OF RETURN ON EQUITY(ROE) $=10 \quad x$ ANNUAL ENERGY SAUED UNDER COGENERATION $=. \quad 85997.4141 \mathrm{MBTU} /$ YR 
TABLE C. 4-8

FUEL UTILIZATION

BREWERY

\section{Separate Generation}

Natural Gas

No. 6011

Coa1

Overall

\section{Cogeneration}

645290

166072

811362
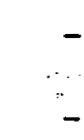

645290

725365

725365

$-559293$

85997

Percent Energy Savings $=10.6 \%$ 


\section{5 SOYBEAN OIL PLANT}

The soybean oil plant, located in Indiana (Region V), is the smallest of the industrial installations to be examined in thus study. The energy requirements of the plant are in the form of process heat (saturated steam at $150 \mathrm{psig}$ ), electricity, and direct heating supplied to dryers. The following table summarizes the annual energy requirements:

- Process heat (saturated steam) $128.2 \times 10^{6} \mathrm{kWht} / \mathrm{yr}$

- Direct process heat $18.5 \times 10^{6} \mathrm{kWht} / \mathrm{yr}$

- Electricity $14.22 \times 10^{6} \mathrm{kWht} / \mathrm{yr}$

The candidate energy conversion subsystems considered for the soybean oil plant were:

- Coal-fired steam with back pressure turbine (indirect heating of drying air) and flue gas desulfurization.

- Gas-fired gas turbine with WHB with exhaust products used for drying.

The gas turbine/WHB was quickly eliminated on the basis of very poor (negative) rates of return on equity for all ownership options in spite of large energy savings. The concept identified for detailed consideration is the coal-fired steam boiler driving a back pressure turbine. Figure C.5-1 shows the energy utilization system model reflecting the presence of the steam air heaters used for providing drying air. The conditions at each of the indicated state points are given in Table C.5-1.

The ratio of process heat to electricity required for this case is $10.32 \mathrm{~kW}_{t} / \mathrm{kW}_{e}$, a further indication that a system, such as the coalfired steam system selected, with an inherently high ratio of heat to electricity will provide a good match. Figure C.5-2 displays the system configuration for the soybean oil plant's cogeneration facility. Figure C. $5-3$ represents the optimization curves for indusirial and utility ownership. The operating parameter for the steam system is the turbine throttle pressure. High throttle pressures improve overall energy savings and for industry ownership, provide slightly lower ROE's. Utility ownership demonstrates little effect of pressure on ROE. The optimum plant was chosen to be the plant generating steam at 915 psia, the maximum practical pressure for boiler/turbines of this size. State point data are available in Table C.5-2... Third-party ownership is not a viable option.

The cogeneration facility is a stoker-fed boiler, firing Chinook Indiana \#3 seam coal (see Table C.5-3). Steam generated at 915 psia and $876^{\circ} \mathrm{F}$ is expanded through a back pressure steam turbine, producing a gross power output of $2102 \mathrm{~kW}$. The exhaust steam, at $165 \mathrm{psia}$, is used to deaerate the condensate return flow, to reheat the flue gas treated in the flue gas desulfurization system, and to supply the soybean plant with $57,100 \mathrm{lb} / \mathrm{hr}$ of usable steam. In Table C.5-4, the energy distribution 


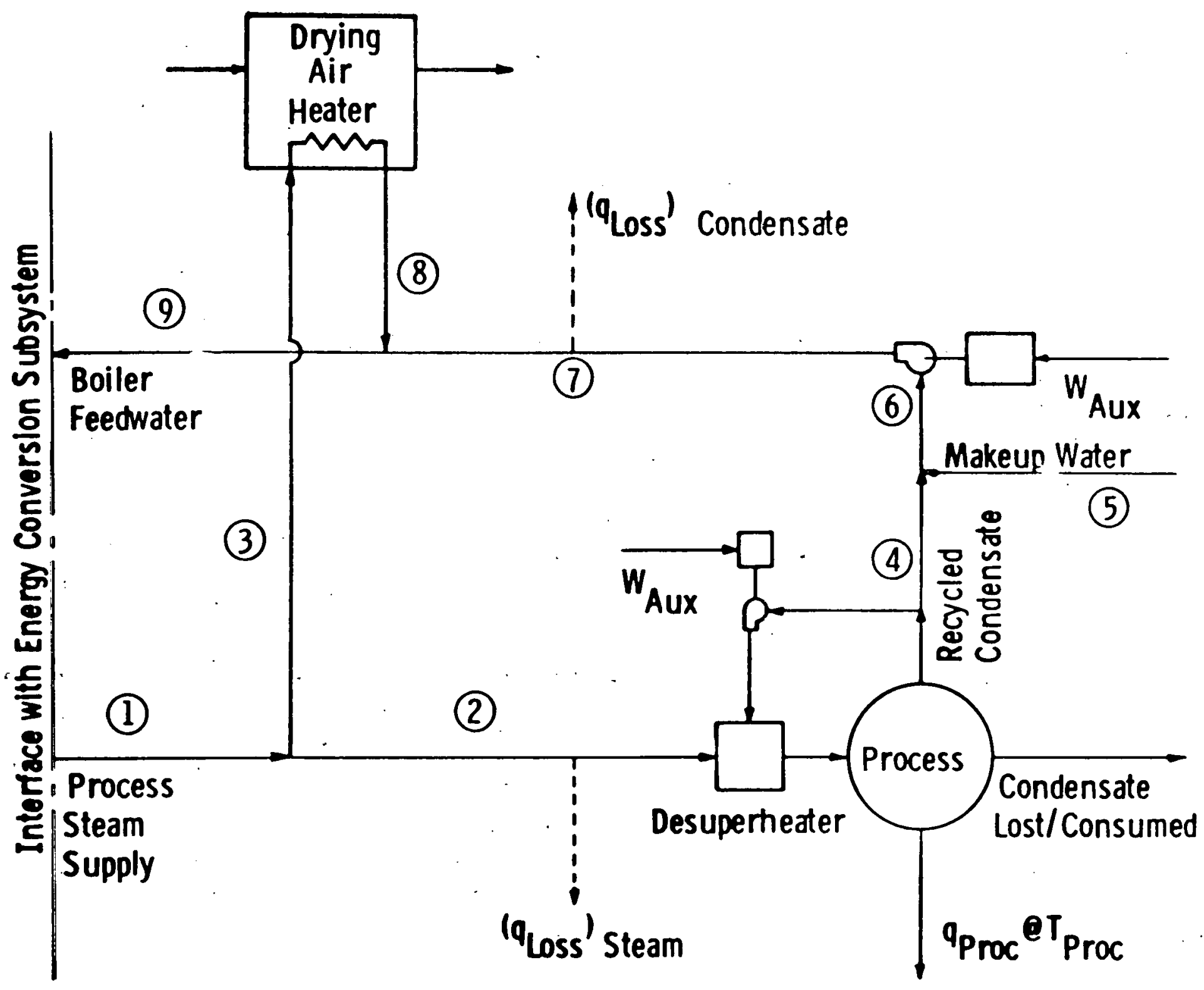

Fig. C.5-1 - Flowsheet of process heat utilization subsystem for soybean oil mill with coal-fired steam energy conversion subsystem 
TABLE C. 5-1

STATEPOINTS FOR ENERGY UTILIZATION SUBSYSTEM IN SOYBEAN OIL PLANT

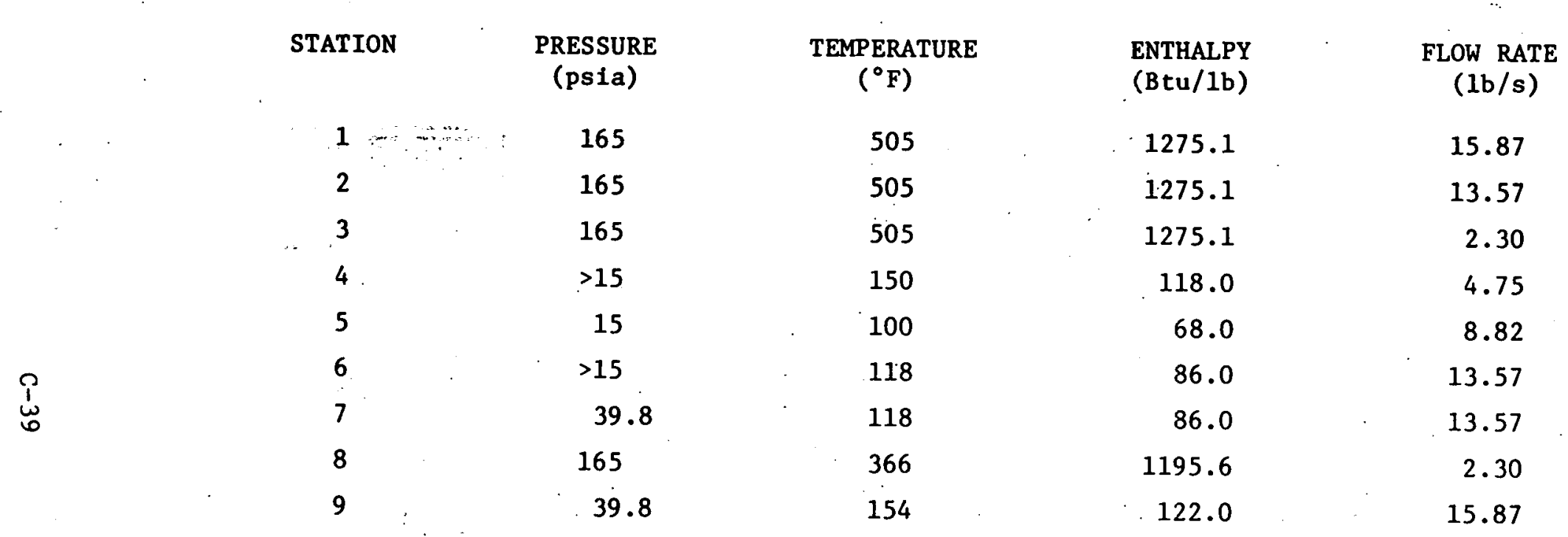




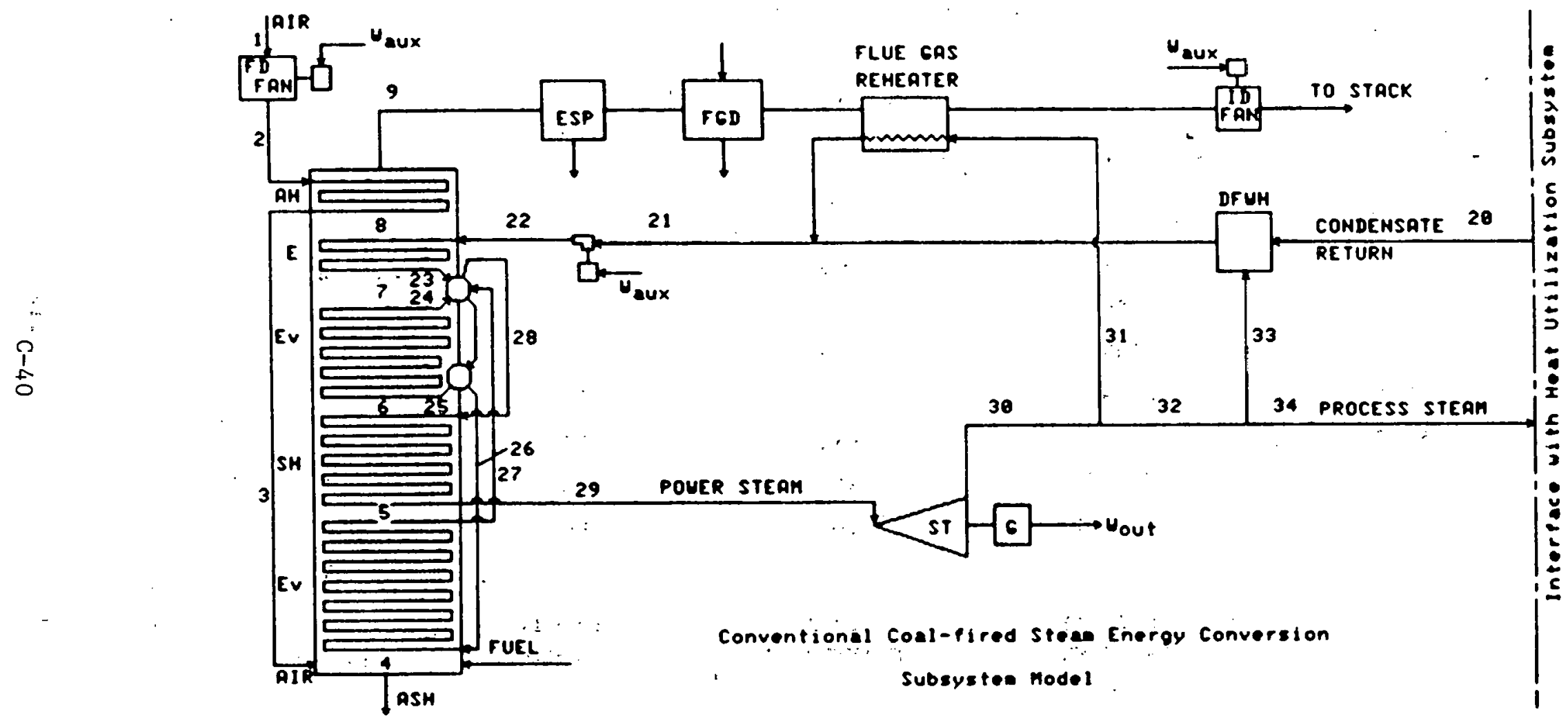

Fig. C. swa Moded of conventional coallwired steam energy conversion subsystem 


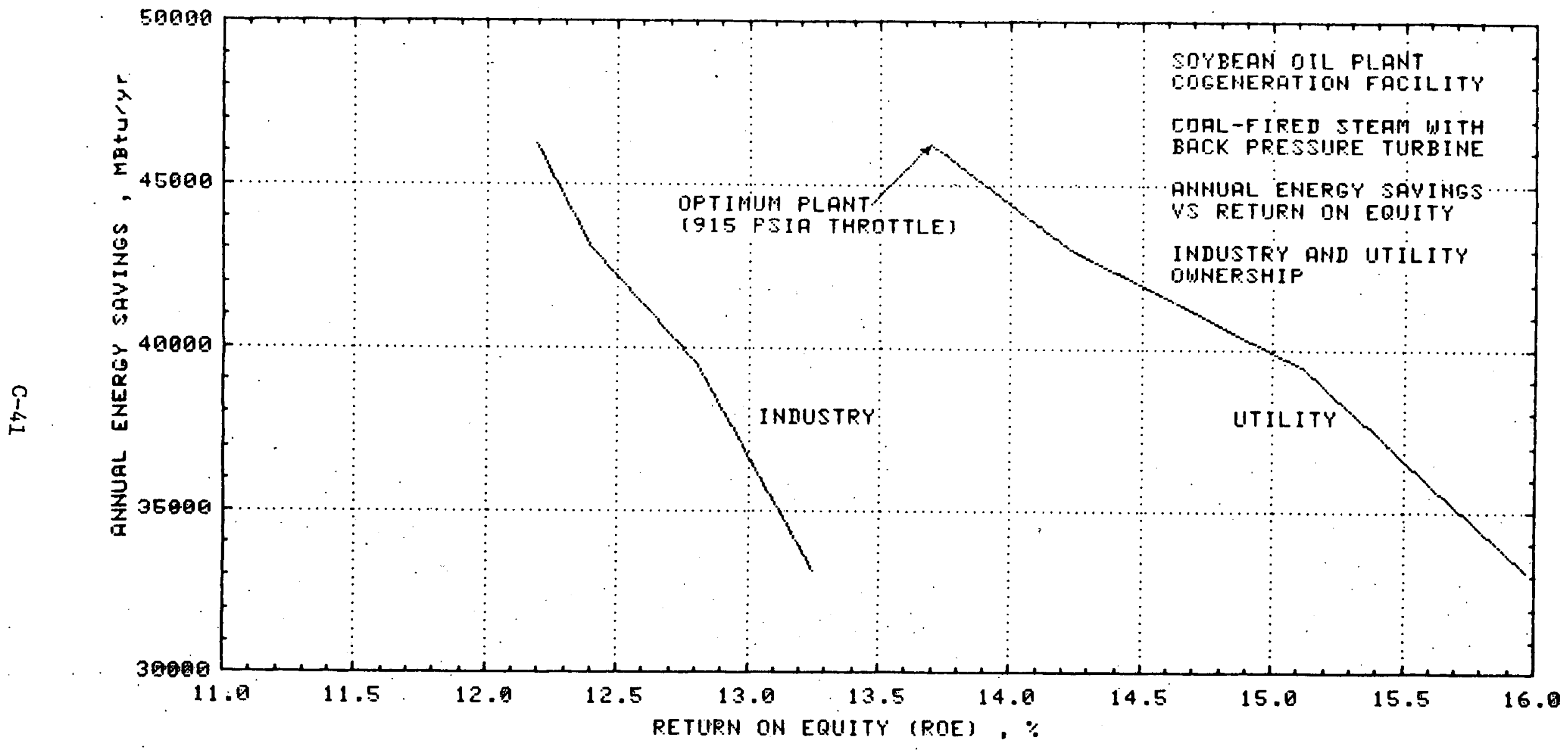

Fia. C.5-3 Annual energy savings ys return on equity, industry and utility ownership 
TABLE C. 5-2

STATEPOINTS FOR CONVERSION SUBSYSTEM IN

SOYBEAN OIL PLANT

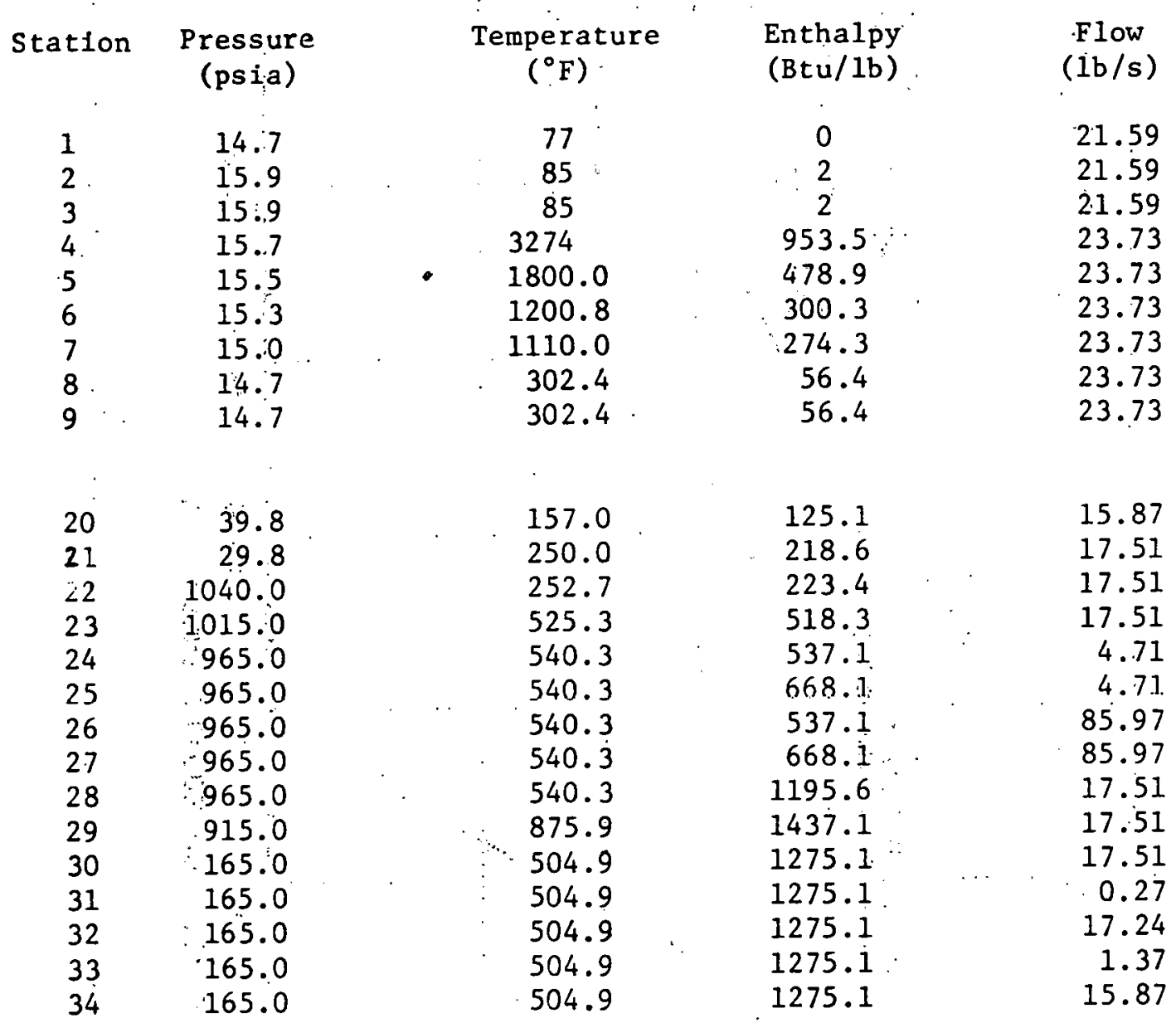


TABLE C. $.5-3$

FUEL SPECIFICATIONS

CHINOOK MINE - INDIANA \#3 SEAM COAL

(Source of data: Monthly Progress Report 10

May 1973; OCR Contract No. 14-32-0001-1514)

SAMPLE: Run of mine

PROXIMATE ANALYSIS (wt \%):

Volatile matter

Fixed carbon

Ash

ULTIMATE ANALYSIS (wt \%): C

(includes moisture)

GROSS HEATING VALUE:

NET HEATING VALUE:

ASH ANALYSIS (wt \%):
C

0

$\mathrm{N}$

$s(2)$

Ash

$(B t u / 1 b)$

$(B t u / 1 b)$

$\mathrm{SiO}_{2}$

$\mathrm{Al}_{2} \mathrm{O}_{3}$

$\mathrm{Fe}_{2} \mathrm{O}_{3}$

$\mathrm{TiO}_{2}$

$\mathrm{P}_{2} \mathrm{O}_{5}$

$\mathrm{CaO}$

$\mathrm{MgO}$

$\mathrm{Na}_{2} \mathrm{O}$

$\mathrm{K}_{2} \mathrm{O}$

$\mathrm{SO}_{3}$
Dry Basis

41.72

47.90

$\frac{10.38}{100.0}$

71.14

5.20

8.41

0.98

3.89

$\frac{10.38}{100.00}$

12524

-

45.9

23.8

23.5

1.4

-

1.5

0.7

0.5

1.9

FUSIBILITY OF ASH:

Initial deformation temperature -- $2560^{\circ} \mathrm{F}$ Softening temperature

Fluid temperature

$-2600^{\circ} \mathrm{F}$

$-2685^{\circ} \mathrm{F}$

GRINDABILITY (Hardgrove): -

FREE SWELLING INDEX: 2

(1) $10 \%$ moisture assumed i

(2) Sulfur forms (\%): Pyritic - 46

Sulfate - 53

Organic - 1 
TABLE C.5-4

POWER SUMMARY - SOYBEAN OIL PLANT

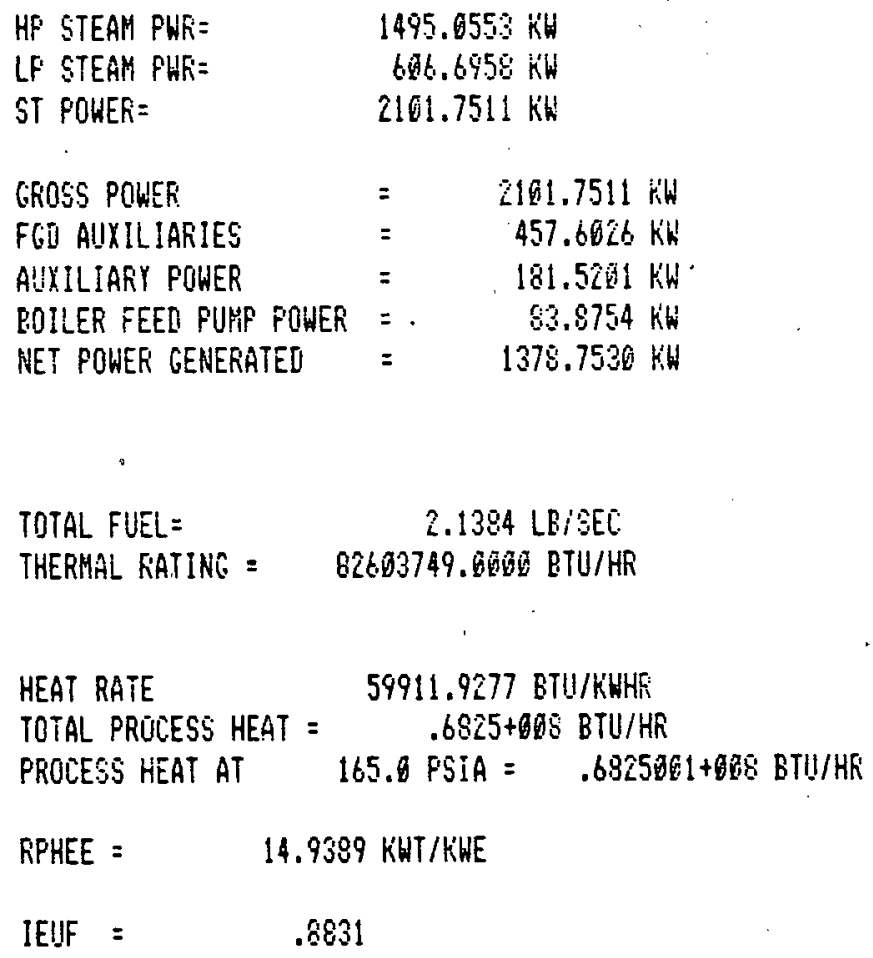


is sumarized. The ideal energy utilization factor (IEUF) for this case is 0.8831 and the ratio of process heat to electricity is 14.94 .

The preliminary capital costs of the cogeneration components are detailed in Table C.5-5. Using these costs and the economic and financial data appropriate to the company and the region involved, the cash flow analysis was performed and a discounted cash flow rate of return (DCFROE) on equity was computed for all ownership options. The assumptions used in this analysis are given in Table C.5-6. The results of the DCFROE computation, along with the specific contributors to the cash flow vector, are given in Tables $C .5-7 a, C .5-7 b$, and C.5-7c. The ROE for industry ownership has a marginal value of $12.2 \%$, while the ROE for utility ownership (13.7\%) is greater than the 1978 ROE for utilities in this DOE region. The third party option, for this case; was not acceptable.

The potential energy savings to be realized as a result of this installation are broken down in Table C.5-8. The net result is a shift from natural gas to coal, as well as a modest improvement in the overall quantity of fuel burned. 
TABLE C. 5-5

SOYBEAN OIL MILL

SUMMARY OF CAPITAL COSTS: DEC. 1978 \$

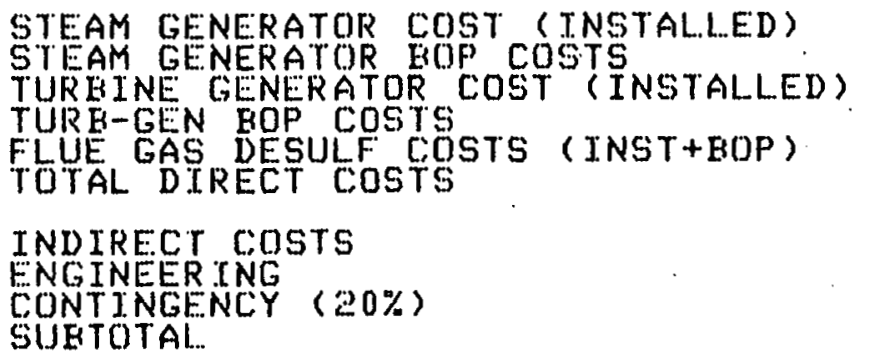

$$
\begin{aligned}
& =\$ 24718.4 \\
& =\$ 3058978.0 \\
& =\$ 1.54149 .2 \\
& =\$ 115414 \% .2 \\
& =\$ 1067688.4 \\
& =\$ 888214 \% .0 \\
& =\$ 133232 \% .0 \\
& =4888214.7 \\
& =\$ 17764.9 .4
\end{aligned}
$$
SUETOTAL.

$\begin{aligned} \text { INTEREST DURING CONSTRUCTION (36 MO .) } & =\$ 2131493.5 \\ \text { ESCALATTON DURING CONSTRUCTION } & =\$ 1560284.4\end{aligned}$

TOTAL CAPITAL COST

$=\$ 1.6570890 .7$

SPECIFIC: CAPITAL COST $(\$ / k W t)$

$=678.50 \%$ 


\section{TABLE C. $\quad$ - 6 \\ RATE OF RETURY ON EQUITY SUMMARY \\ EOR INDUSTRIAL COLENERALION}

$* * * * * * * * * * * * * * * * * * * * * * * * * * * * * * * * * * * * * * * * * * * * * * * * * * * * * * * * * * * * * * * * * * * * * * * * * * * *$

ENERGY UTILIZATION SYSTEM CHARACTERIZATION

SOYEEAN OIL PLANT

$* * * * * * * * * * * * * * * * * * * * * * * * * * * * * * * * * * * * * * * * * * * * * * * * * * * * * * * * * * * * * * * * * * * * * * * *$

REQUIRED RATIO OF PROCESS HEAT/ELECTRICITY

REQUIRED PRUCESS HEAT

$=10.8000$

REQUIRED ELECTRIC ENI::RGY

$=146796088.0$ (KWH/YR)

SUPPLEMENTAL ELECTRIC ENERGY PURCHASED

$=3.3592230 .4(K W H / Y R)$

ASSUMED CAPACITY FACTOR

$=3765798.2$ (KWH/YR)

ASSUMED STANDEY POWER FRACTION

$=.8380$

$=1.0000$

$* * * * * * * * * * * * * * * * * * * * * * * * * * * * * * * * * * * * * * * * * * * * * * * * * * * * * * * * * * * * * * * * * * * * * * * * * * *$

ENERGY CONUERSION SYSTEM CHARACTERIZATION

COAL-FIRED STEAM WITH EPT

$* * * * * * * * * * * * * * * * * * * * * * * * * * * * * * * * * * * * * * * * * * * * * * * * * * * * * * * * * * * * * * * * * * * * * * * * * *$

ACTUAL RATIO OF PROCESS HEAT/ELECTRICITY _ = 14.9389

IDEAL ENERGY UTILIZATION FACTOR

SPECIFIC CAPITAL. COST OF CONUERSION SYSTEM $=.678 .5020(\$ / K W T)$.

INCR. LABOR COST (INDUSTRY) (1ST YEAR) $=228582.6152$ ( $\$$ )

INCR. LABOR COST (UTILITY) (1ST YEAR) $=454680.6367$ (\$)

INCR. LAEOR COST (3RD PARTY) (1ST YEAR) $=454680.6367$ (\$)

$* * * * * * * * * * * * * * * * * * * * * * * * * * * * * * * * * * * * * * * * * * * * * * * * * * * * * * * * * * * * * * * * * * * * * * * * ;$ 
TABLE. C.5-6 (cont'd)

SOYEEAN OIL PLANT

ECONOMIC AND FINANCIAL ASSUMPTIONS

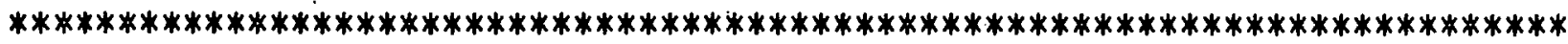

DEBT / EQUITY RATIO (INDUSTRY)

DEET \% EQUTTY RATIO (UTTLTTY)

LIFE OF PROJECT

LIFE OF INUESTMENT FOR TAX PURPOSES

INCOME TAX RATES (FEDERAL + STATE)

INTEREST RATE ON DEIST

INUESTMENT TAX CREDIT RATE

ITCR UNDER SEPARATE GENERATION (INDUSTRY)

ITCR UNDER SEPARATE GENERATION (UTILITY)

PROPERTY TAX RATE (1ST YEAR)

INSURANCE RATE (1ST YEAR)

CHARGE FOR STANDEY POWER

MAINTENANCE \& SUPPLIES COST FACTOR (1ST YR) =

HOILER HEAT RATE (SEPARATE GENERATION)

CENTRAL STATION EUS GAR HEAT RATE

TRANSMISSION LOSSES OF PURCHASED POWER

SPECIFIC CAPITAL COST OF NEW UTILITY STATION =

PRICE OF PROCESS STEAM (1ST YR)

PRICE OF POWER AT CENTRAL STATION EUS BAR=

PRICE DF POWER EOUGHT FROM UTILITY (1ST YR) =

PRICE OF POWER SOLD. TO UTILITY (1ST YR) =

PRICE OF FUEL (COGENERATION)

PRICE OF FUEL, (SEP.GEN.: INDUSTRY)

PRICE OF FUEL (SEP.GEN.: UTILITY )

GENERAL INFLATION RATE

FUEL PRICE RELATIUE ESC. (COGENERATION FUEL)

FUEL PRICE REL. ESC. (SEP.GEN.: INDUSTRY) =

FUEL PRICE REL. ESC. (SEP.GEN.: UTILITY) =

RELATIUE ESC. OF ELECTRICAL ENERGY COSTS =

RELATIUE ESC. OF PRDCESS STEAM COSTS $=\quad .5000$
$=\quad 1.0000$
$=\quad 5.0000$

$=$

$=$

$=$

$=$

$=$

$=$

$=$

$=$

$=$

$=$

$=$

$=$

$=$

$=$$$
=
$$$$
=
$$

$=$

$=$

$=$

$=$

$=$

$=$

$=$

$=$

$=$

$=$

$=$

$=$

$=$
28 (YEARS)

28 (YEARS)

$.5000(\% / 100)$

$.1000(\% / Y R / 100)$

$.2000(\% / .00)$

$.0000(\% / 100)$

$.1000(\% / 100)$

$0150(\% / 100)$

$.0150(\% / 100)$

$67.8746(\$ / K W)$

$.0375(\% / 100)$

3750.0000 (ETU/KWH)

9500.0000 (BTU/KWH).

$.1000(\% / 100)$

$1000.0000(\$ / K W)$

$3.8960(\$ / 10 \wedge 6$ BTU $)$

$.0212(\$ / K W H)$

$.0353(\$ / K$ WH $)$

.0212 ( $\$ / K W H)$

1. 5532 (\$/10^G ETU)

$2.2215\left(\$ / 10^{\wedge} 6\right.$ ETU )

1. $5532\left(\$ / 10^{\wedge} 6\right.$ ETU)

$.0750(\% / 100 / Y R)$

$.0500(\% / 100 / Y R)$

$.0850(\% / 100 / Y R)$

$.0500(\% / 100 / Y R)$

$.0300(\% / 100 / Y R)$

$.0300(\% / 100 / Y R)$ 
SOYEEEN OIL PLANT

FOR TNDUSTRTAL OWNERSHTTP

INCREMENTAL CAPITAL INUESTMENT

NET INCREMENTAL EQUITY CAPITAL INUESTMENT
$=$

$=$
15424445 (\$)

8093421 (\$)

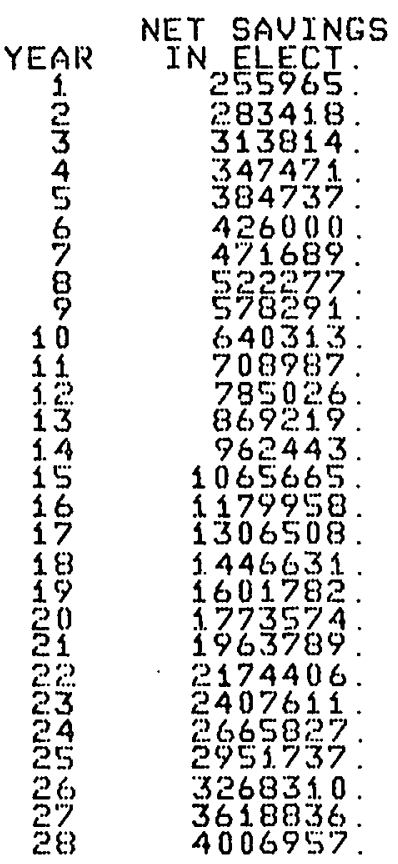

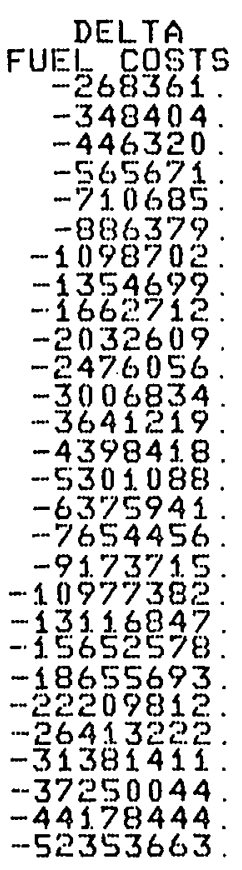

DIELTA

PROP. TAX TNCOME TAXES

$\$$ INSUR. 462733 . 497438 . 534746 . 574852 . 617966 . 664314 . 714137 . 767697 . 825275 887170 . 953708 . 1025036. 1184788 . 1273647. 1369171 . 1471.859 . 1582248 1.700917 . 1828486. 2113044 . 2271522 2441886 3821904 3033904 3261343

$$
\begin{aligned}
& \text { ON SAUINGS } \\
& \text {-1180.351. } \\
& \text {-1156625. } \\
& \text {-1126166. } \\
& \text {-1087312. } \\
& -976057 \text {. } \\
& -80178 \text {. } \\
& \text { - } 68209 . \\
& -534565 \text {. } \\
& -353487 \text {. } \\
& -132108 . \\
& 465033 \text {. } \\
& 8614 \% \text {. } \\
& 1340122 . \\
& \text { ง. } 91661.4 \text {. } \\
& 2609388 . \\
& 3440185 \text {. } \\
& 4434631 \text {. } \\
& 7040554 \text {. } \\
& 8729377 . \\
& 10738565 \text {. } \\
& 15959473 . \\
& 1.9319008
\end{aligned}
$$

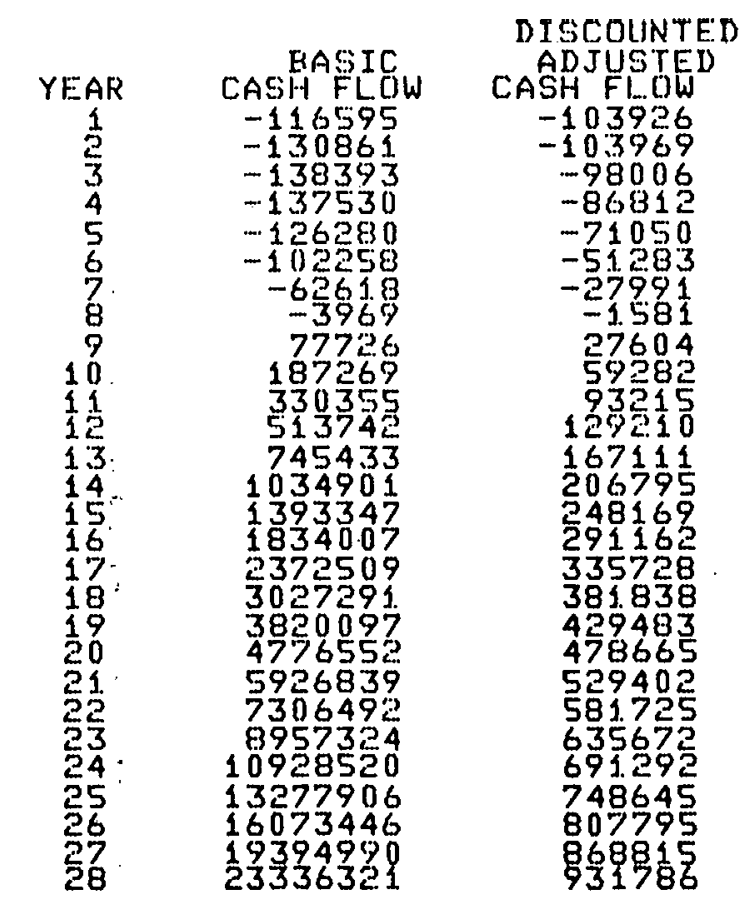

DISCOUNTED CASH FLOW RATE OF RETURN ON EQUITY(ROE)

$12.19 \%$ ANNUAL ENERGY SAVED UNDER COGENERATION = 


\section{SOYEEAN OIL PLANT}

FOR UTIL.T.TY OWNERSHIP

INCREMENTAL CAP ITAL INUESTMENT $=14877245(\$)$
NET INCREMENTAL EQUITY CAPITAL INUESTMENT $=16694760(\$)$

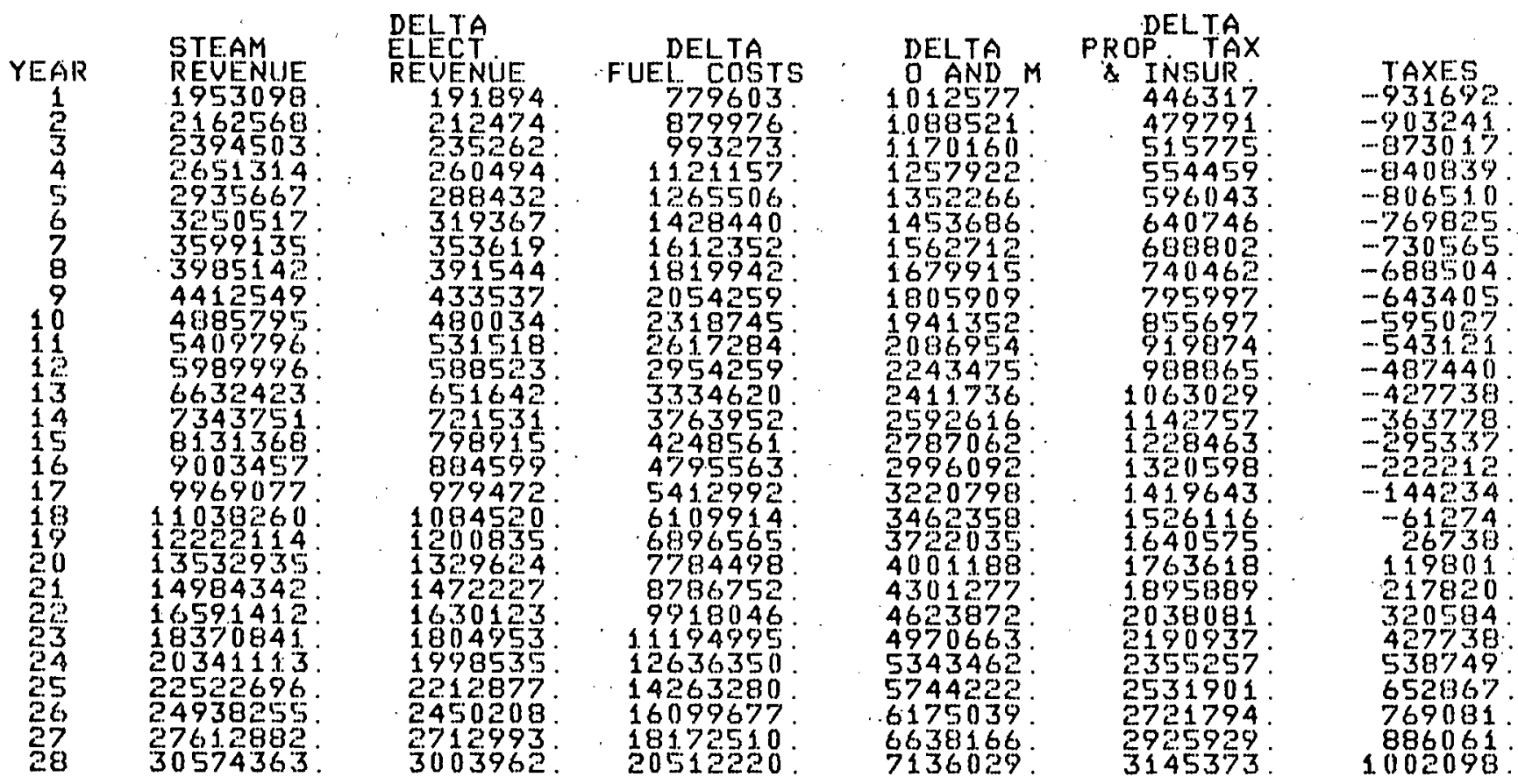

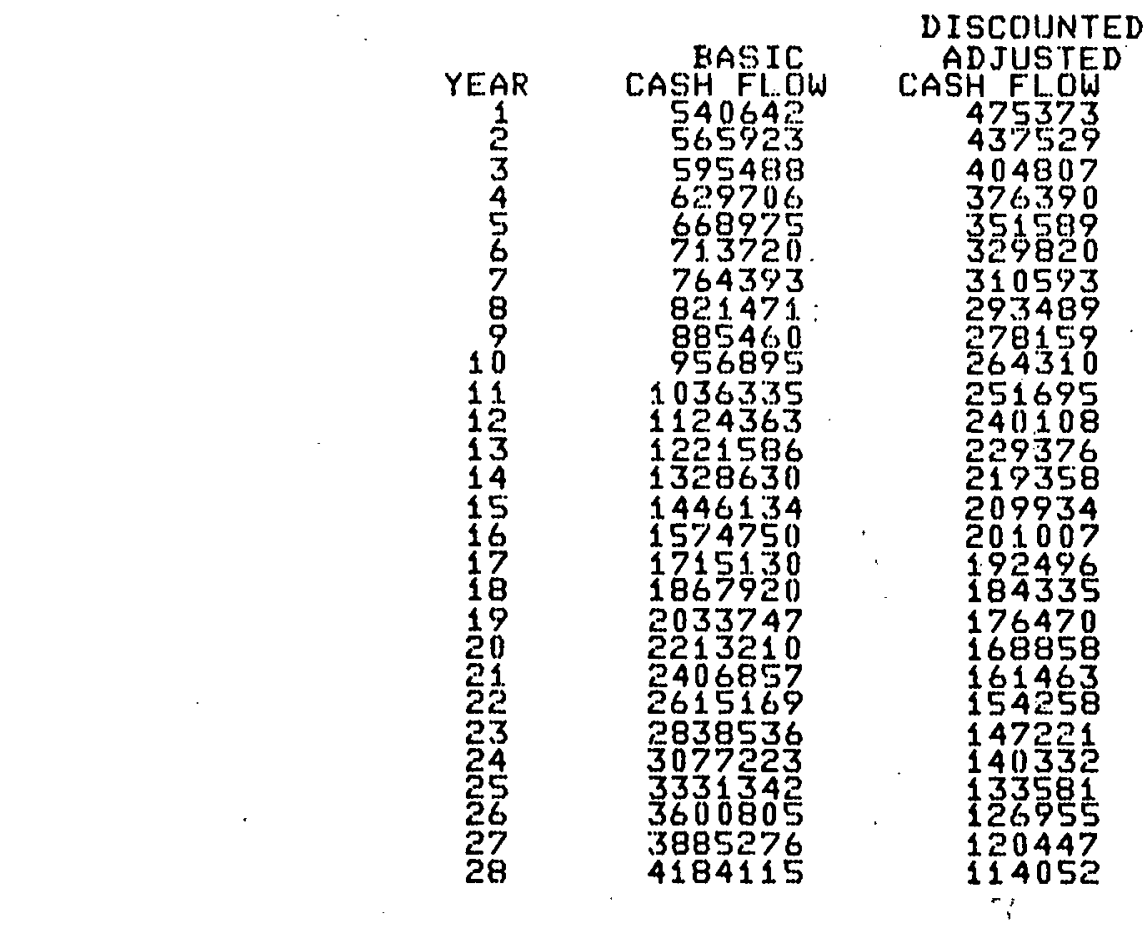

DISCOUNTED CASH FLOW RATE OF RETURN ON EQUITY(ROE) $=13.73 \%$ ANNUAL ENERGY SAUED UNDER COGENERATION $=\quad 46289.8359 \mathrm{METU} / \mathrm{YR}$ 
TABLE C. $5-7 c$

SOYEEAN OIL PLANT

FOR THIRD PARTY DWNERSHIP

CAPITAL INUESTMENT

NET EQUITY CAPITAL JNUESTMENT

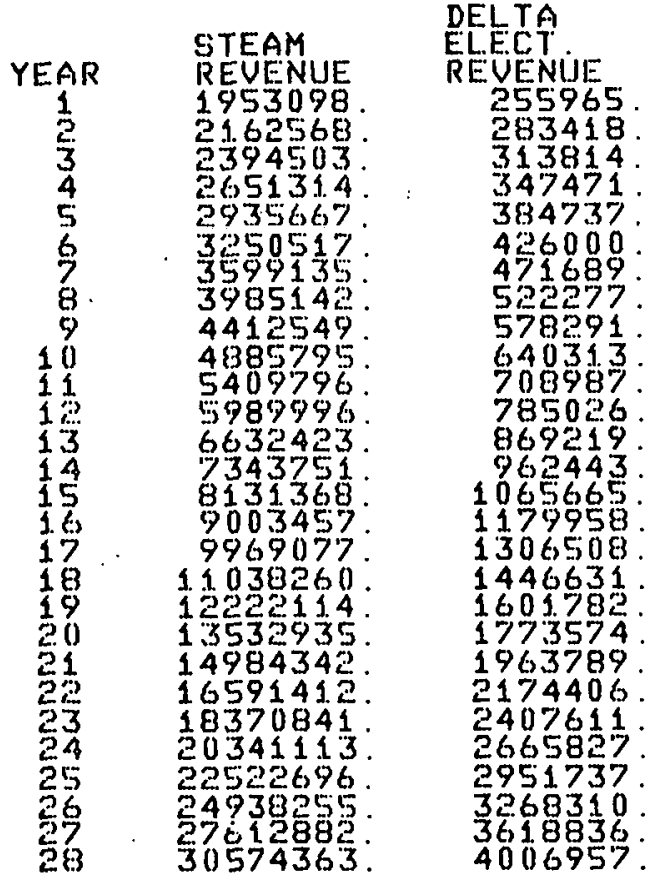

$$
\begin{aligned}
& =\quad 16421567(\$) \\
& =\quad 2189542 \text { (\$) }
\end{aligned}
$$
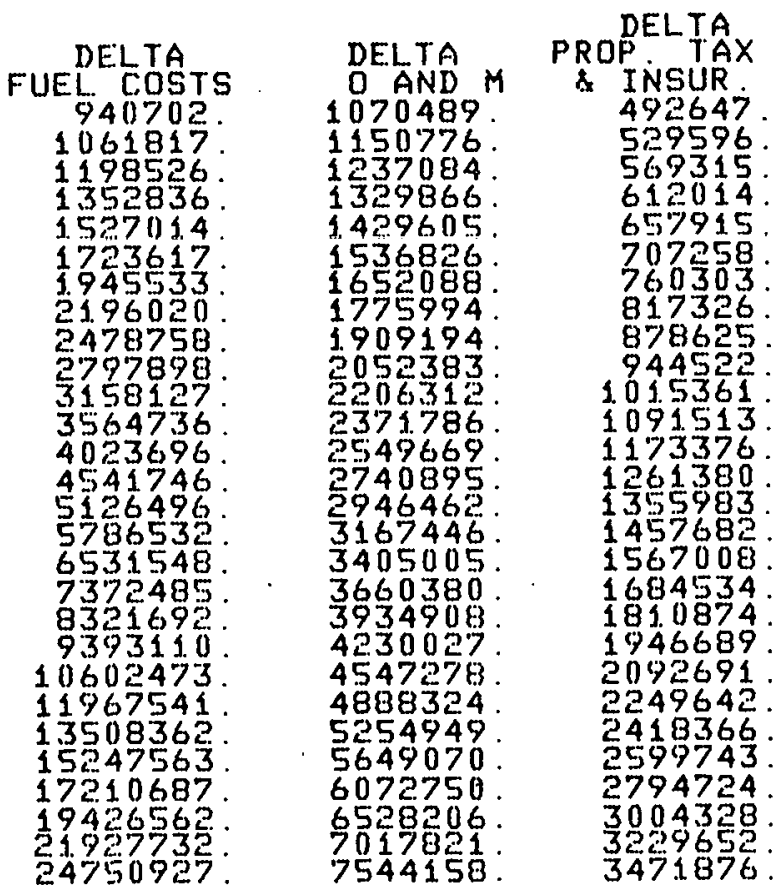

TAXES $-1397880$ $-1378371$ -1358350 . $-1337788$ ....1316664 -1294967 . -..1272701. -1249888. $-1226572$. $-1302828$ -..1.178766 $-1154539$ $-113035 \%$ $-1106499$ - 1.083316 - 1061262 ...1 $1040 \% 03$. -1022945 .

$-100825 \%$ $-997903$. $-993176$ $-995642$. -...1.0071.836. -1030068 . -1.068990 . $-1121168$. -1297276 .

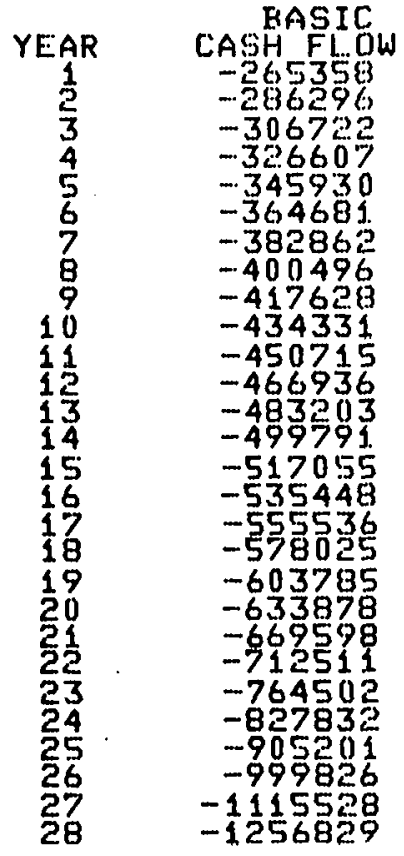

DISCOUNTED CASH FLOW RATE OF RETURN ON EQUITY $(R O E)=<0 \%$ ANNUAL ENERGY SAUED UNDER COGENERATION $=\quad 46289.8359 \mathrm{MBTU} / \mathrm{YR}$ 
TABLE C. 5-8

FUEL UTILIZATION

SOYBEAN OIL PLANT

\section{Separate Generation \\ $(\mathrm{MBtu} / \mathrm{yr})$}

Gas

544,270

Oil

Coal

Wood

Total

\section{Cogeneration}

(MBtu/yr)
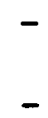

641,444

143,474

687,744

641,444
Overall Savings (MBtu/yr)

544,270

$-497,970$

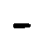

46,300

Percent Energy Savings $=6.7 \%$ 


\section{6 LARGE CAPACITY PETROLEUM REFINERY}

The large petroleum refinery is located in California (DOE Region IX). The energy use pattern is the most complex to be considered in this study. Steam is required at three separate pressure levels for mechanical drives as well as for process heat. The steam requirements are as follows:
- Mechanical drive steam (895 psia) $300,000 \mathrm{lb} / \mathrm{hr}$
- Mechanical drive steam (565 psia) $580,000 \mathrm{lb} / \mathrm{hr}$
- Process steam (165 psia) $720,000 \mathrm{lb} / \mathrm{hr}$

In addition, a peak electrical demand of $120 \mathrm{MW}$ is expected.

Figure C.6-1 shows the energy utilization subsystem for the large refinery. The corresponding statepoints are given in Table C.6-1. A number of steam turbine configurations were considered (shown in Figure C.6-2), all of which were required to provide the specified quantities of steam at the needed pressure levels. In the first configuration, the steam turbine throttle pressure would be in excess of $895^{\circ}$ psia, up to $1500 \mathrm{psia}$, and a double-extraction/back pressure turbine would be used. However, inquiries to steam turbine manufacturers revealed that the maximum extraction pressure allowable under those conditions was 700 psig. A second configuration used a high-pressure element exhausting to a single-extraction/back pressure turbine at $895 \mathrm{psia}$, with a sidestream providing the $300,000 \mathrm{lb} / \mathrm{hr}$ of mechanical drive steam. This system was also rejected as impractical on the same basis as the first; that is, that a high pressure steam turbine must have a pressure ratio well in excess of $2: 1$. The only configuration which is technically feasible is a single extraction steam turbine, with a throttle pressure of 895 psia, exhausting to the process at 165 psia. The high pressure mechanical drive steam is generated in parallel with the steam sent to the power turbine.

Two steam generating options were considered for the large refinery. The first is a conventional power steam boiler fired by petroleum coke. The economic analysis of this system showed that all ownership options may expect a positive return on equity. However, the energy savings realizable under this system are quite modest. The other cycle examined was a combined cycle fired by refinery fuels such as light naphtha and a low-sulfur residual. This configuration will provide a positive ROE for all owners, but the results of the utility ownership ROE calculation were particularly favorable. In addition, the energy savings were substantially higher than the conventional coke-fired system. The optimization curve for the industrial ownership case is given in Figure C. 6-3.

The configuration of the energy conversian subsystem is presented in Figure C.6-4. Since the temperature out of the gas turbine expander is less than $1000^{\circ} \mathrm{F}$, it is necessary to provide an afterburner to boost the enthalpy of the combustion products. The afterburner temperature 


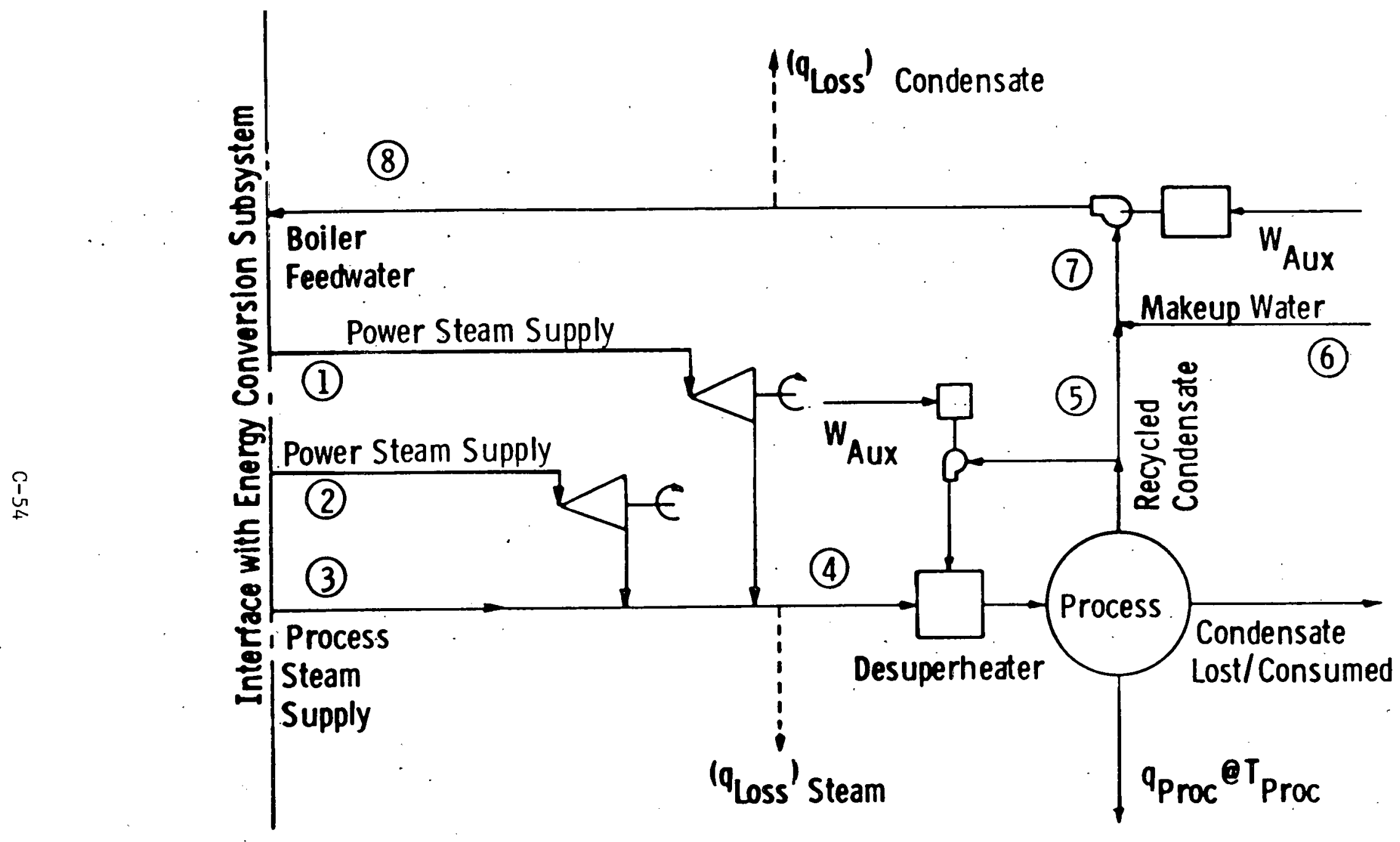

Fig. C.6-1 - Model of process heat utilization subsystem for large petroleum refinery with refinery fuel-fired combined cycle energy conversion subsystem 
TABLE C. $5-1$

STATEPOINTS FOR ENERGY UTILIZATION SUBSYSTEM IN

LARGE PETROLEUM REFINERY

$\begin{array}{ccccc}\text { Station } & \begin{array}{c}\text { Pressure } \\ (\mathrm{psia})\end{array} & \begin{array}{c}\text { Temperature } \\ \left({ }^{\circ} \mathrm{F}\right)\end{array} & \begin{array}{c}\text { Enthalpy } \\ (\mathrm{Btu} / \mathrm{lb})\end{array} & \begin{array}{c}\text { Flow Rate } \\ (1 \mathrm{~b} / \mathrm{s})\end{array} \\ 1 & 895 & 739.2 & 1357.9 & 83.3 \\ 2 & 565 & 635.0 & 1315.0 & 161.1 \\ 3 & 165 & 403.0 & 1219.8 & 200.0 \\ 4 & - & - & - & 444.4 \\ 5 & >15 & 225 & 193.0 & 222.2 \\ 6 & 15 & 100 & 68 & 222.2 \\ 7 & >15 & 163.0 & 131.4 & 444.4 \\ 8 & 39.8 & 163.0 & 131.4 & 444.4\end{array}$


Double Qutomatic Extraction Back Pressure Steam Turbine

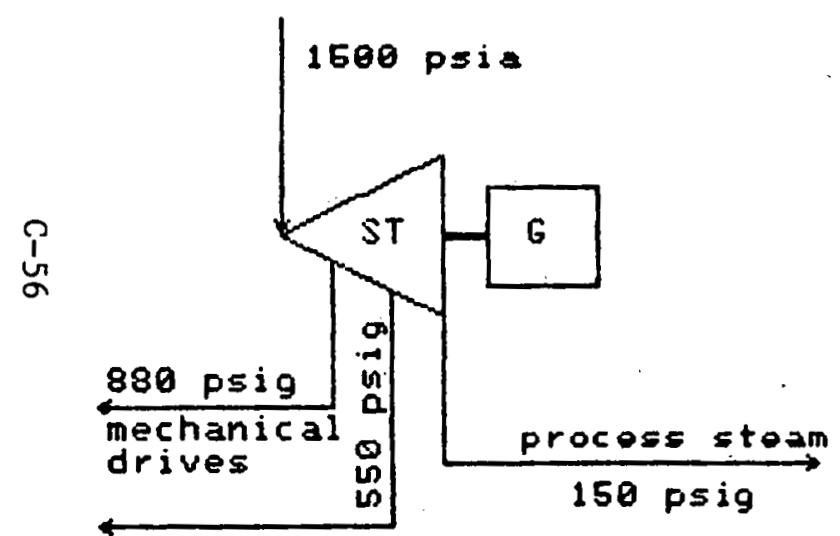

mechanical

drives
HPT Back Prossure

LPT Single Extraction/Back

Pressure steam Turbine

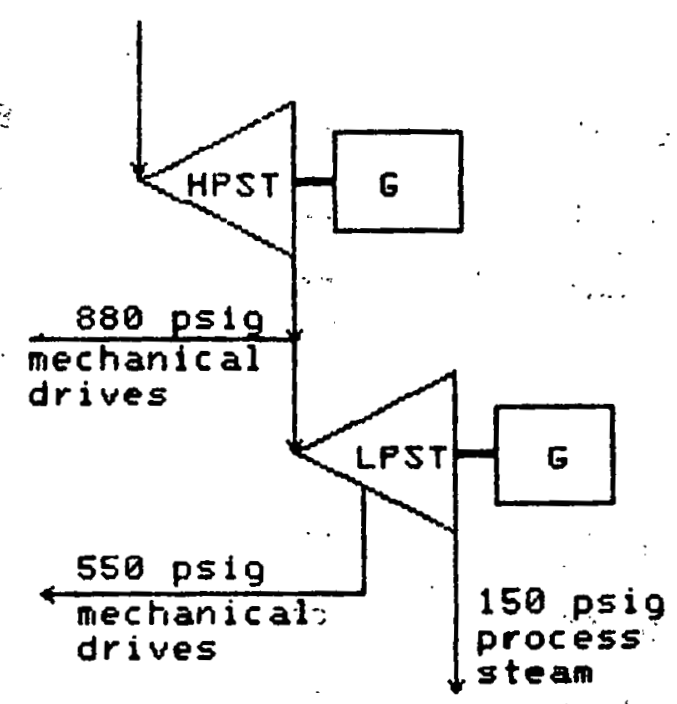

Single Extraction/Back Prossure steam Turbine

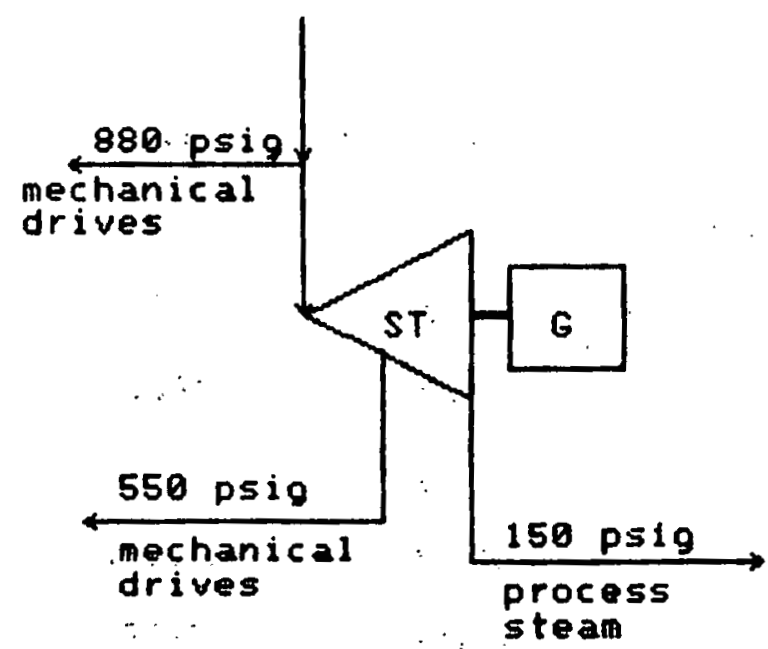

wig. C.6-2 - Possible steam turbine configurations 


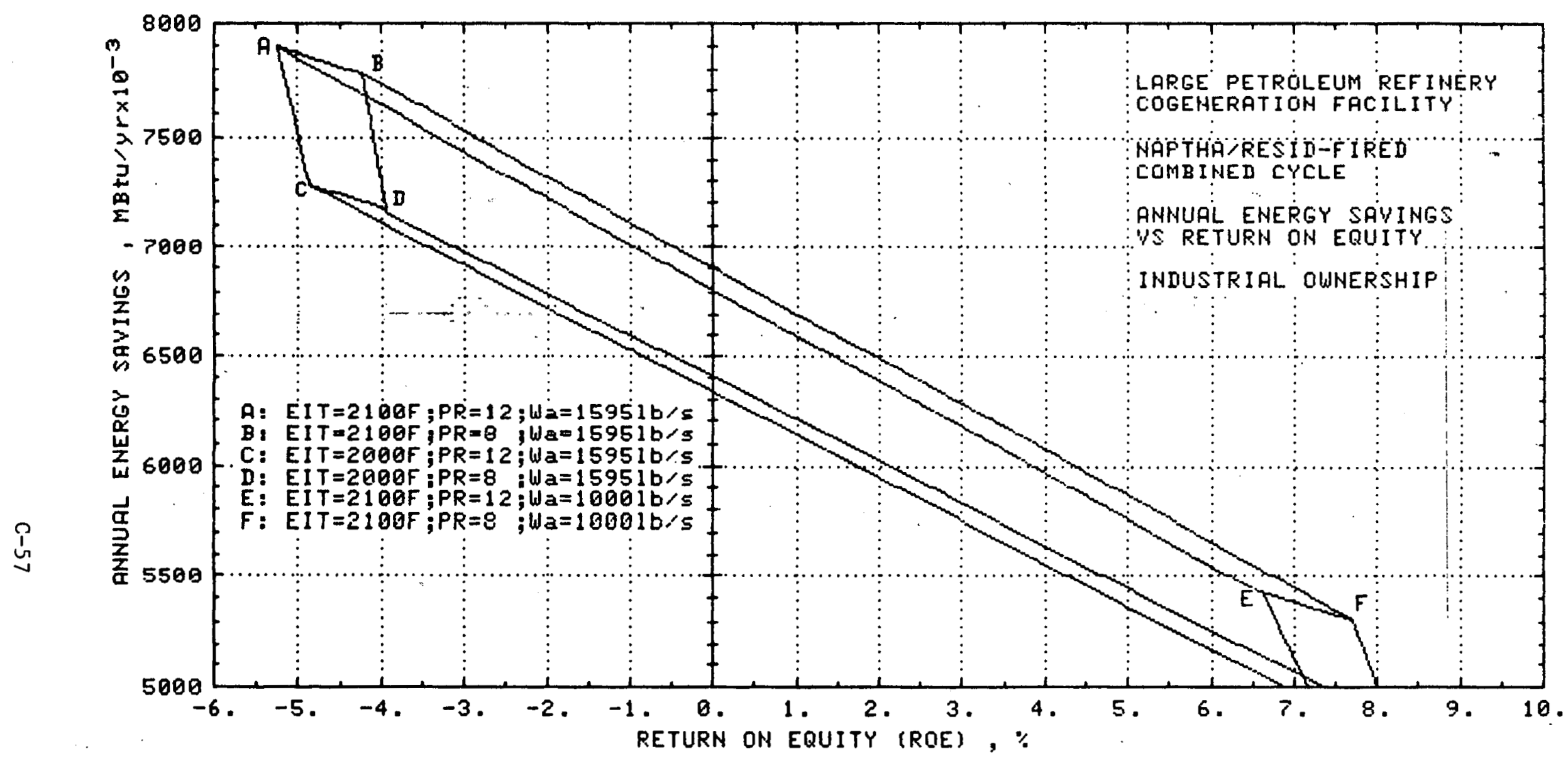

Fig. C.6-3 - Annual energy savings us return on equity, inclustrial ownership 


\section{Large Refinery:}

\section{MaPHTHa RESID - FIRED CONBINED CYCLE UITH SIMCLE EXTROCTIOH}

DACK PRESSURE STEAM TURDIME

MOTE: EOUIYALEMT COOLIME AIR FLOU Is SNOUn AS A DY-PASS, PRODUCIMC CO POUER IN TWE EXPANLER THE ACTUAL COOLING AIR FLOW IS LARCER AND DO

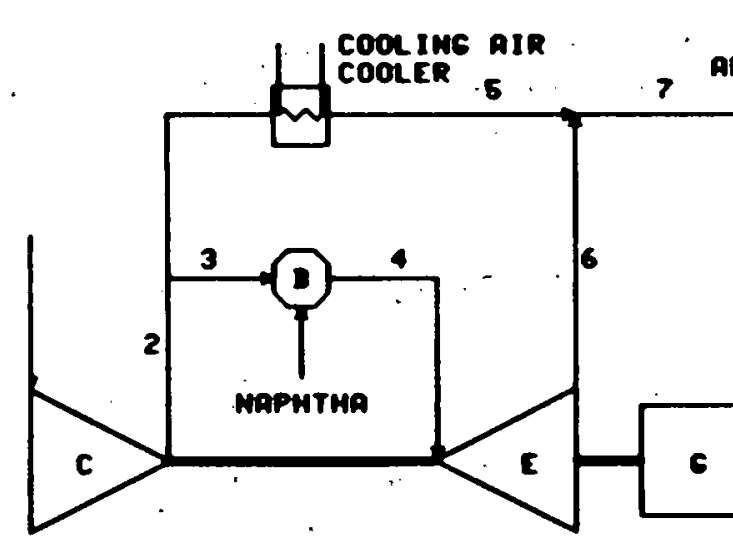

SH

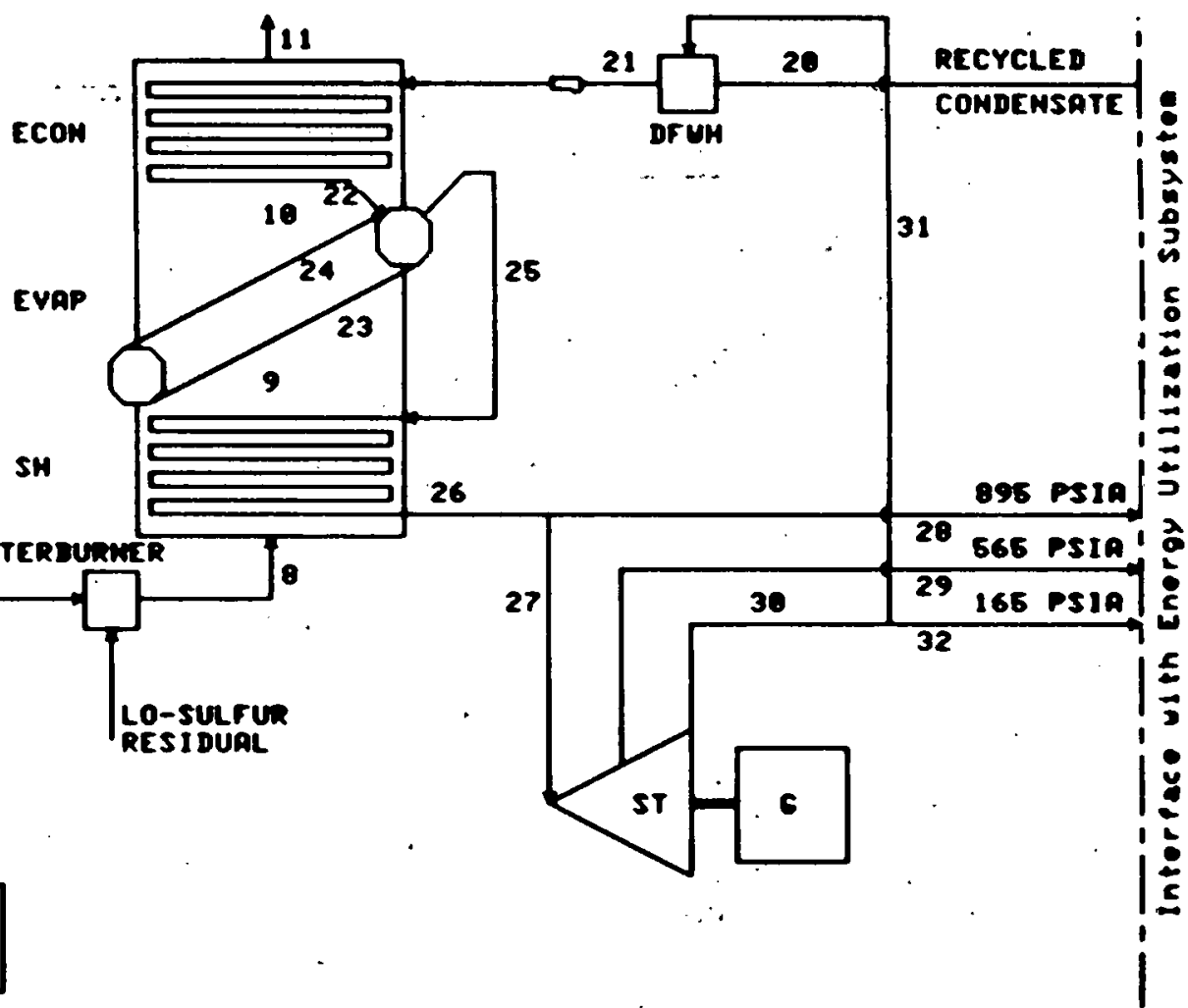

Fia. C.6-4 - Model of energy conversion subsystem for large capacity petroleum refinery 
was used to provide a match between the steam flows required for onsite use and the capacity of the gas turbines, making it possible to design the system to use available gas turbine technology. Two alternatives were examined: firing the afterburner with naphtha as in the turbine proper, and firing the afterburner with a low-sulfur residual. The latter option gave superior results, and is shown schematically in Figure C.6-2. The properties of the two fuels are given in Tables C. 6-2 and C.6-3.

The analysis of the combined cycle cogeneration system indicated that optimum gas turbine configuration for this application was approximately as follows:

- Pressure ratio - 12:1

- Expander inlet temperature - maximum state-of-the-art ( $2100^{\circ} \mathrm{F}$ )

- Compressor air flow rate (total) - $1595 \mathrm{lb} / \mathrm{s}$

The most advanced commercially available gas turbines with the above pressure ratio and expander inlet temperature and air flow rates which are integrally proportional to the above air flow rate have polytropic compressor and turbine efficiencies of approximately 91 and $92 \%$, respectively. These values are significantly higher than the composite values which were used in the characterization calculations (see Appendix B-5).

Performance calculations were made for the optimum gas turbine configuration as described above. A model of this energy conversion subsystem is shown in Figure C.6-3. The conditions at the statepoints shown in Figure C.6-3 are listed in Table C.6-4. Two gas turbine modules, each with an inlet air flow of $745.6 \mathrm{lb} / \mathrm{s}$, were assumed, with a pressure ratio of $12: 1$ and an expander inlet temperature of $2100^{\circ} \mathrm{F}$. In Table C.6-5, the energy distribution for the cogeneration facility is given in detail. The net power generated in the gas turbine and the steam expander is $247.8 \mathrm{MW}$, making it possible for the facility owner not only to provide full electrical service to the refinery, but also to export over $125 \mathrm{MW}$ for sale to other customers. The ideal energy utilization factor (IEUF) for the combined cycle is 0.8453 and the ratio of process heat to electricity is 2.2507 .

The preliminary capital cost of the cogeneration facility is given in Table C.6-6. Using these costs as well as the economic and financial assumptions listed in Table C.6-7, the cash flow analysis was performed and a discounted cash flow rate of return on equity was derived for the ownership options. The ownership cash flows are broken down in Tables .C.6-8a, C.6-8b, and C. 6-8c.

The fuel utilization shift to be expected as a result of this installation is given in Table C.6-9. The use of oil is decreased by $76 \%$ and is replaced by light naphtha. The overall fuel savings is nearly $23 \%$. If it is assumed that the new central station generating capacity for the utility serving the large petroleum refinery will be coal-fired rather than oilfired, the discounted cash flow return on equity for utility ownership becomes negative also because of the relatively low cost of coal compared to that of oll. 
TABLE C. 6-2

FUEL SPECIFICATIONS

LIGHT NAPHTHA PROPERTIES

Gravity $\left({ }^{\circ} \mathrm{API}\right)-70$
$\mathrm{H} / \mathrm{C}$ ratio -2.25 (assumed)
Gross Heating Value $(\mathrm{Btu} / \mathrm{lb})-20,350$
Net Heating Value $(\mathrm{Btu} / \mathrm{lb})-19,045$
Ratio of net/gross Heating Values -0.936

C-60 
LOW SULFUR RESIDUAL OIL

(Compliance LSFO)

Sulfur - \% by wt.

$\mathrm{Ni}+\mathrm{V}$, ppm by wt.

Gravity - ${ }^{\circ} \mathrm{API}$

Specific Gravity

Gross Heating Value (Btu/lb) -

Net Heating Value (Btu/1b) -

Ratio of net/gross Heating Values -
$0.25-0.50$

$<0.5$

26.8

0.893

19,230

18,090

0.941 
TABLE C. 6-4

STATEPOINTS FOR CONVERSION SUBSYSTEM IN

LARGE REFINERY

Pressire

(psia)

$\begin{array}{rr}1 & 14.70 \\ 2 & 183.30 \\ 3 & 183.80 \\ 4 & 175.60 \\ 5 & 15.36 \\ 6 & 15.36 \\ 7 & 15.28 \\ 8 & 15.21 \\ 9 & 15.00 \\ 10 & 14.85 \\ 11 & 14.70\end{array}$

$20 \quad 39.8$

$21 \cdot 29.8$

$22 \quad 963.6$

23945.0

24945.0 .

$25 \quad 945.0$

$26 \quad 929.0$

$27 \quad 895.0$

$28 \quad 895: 0$.

$29 \quad 565.0$

$30 \quad 165.0$

$31 \quad 165.0$

$32 \quad 165.0$

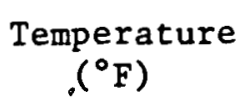

59

695.3

695.3

2100

450

1051.0

993.2

1551.9

1381.8

642.2

290.0

163.0

250.0

525.1

540.1

540.1

540.1

739.2

739.2

739.2

635.0

403.0

403.0

403.0

$\begin{array}{rc}\begin{array}{r}\text { Enthalpy } \\ (\mathrm{Btu} / 1 \mathrm{~b})\end{array} & \begin{array}{c}\text { Flow } \\ (\mathrm{lb} / \mathrm{s})\end{array} \\ 0.0 & 1595.2 \\ 156.8 & 1595.2 \\ 156.8 & 1472.01 \\ 571.0 & 1460.67 \\ 95.3 & 168.70 \\ 265.1 & 1460.67 \\ 245.1 & 1628.79 \\ 408.6 & 1643.62 \\ 358.5 & 1643.62 \\ 151.6 & 1643.62 \\ 60.0 & 1643.62\end{array}$

131.4

218.6

518.1

536.9

668.4

1194.2

1357.9

1357.9

1357.9

1315.0

1219.8

1219.8

1219.8
444.44

485.84

485.84

2115.45

2115.45

485.84

485.84

402.51

83.33

161.11

241.40

41.40

200.00 
TABLE C. $6-5$

POWER SUMMARY - LARGE REFINERY

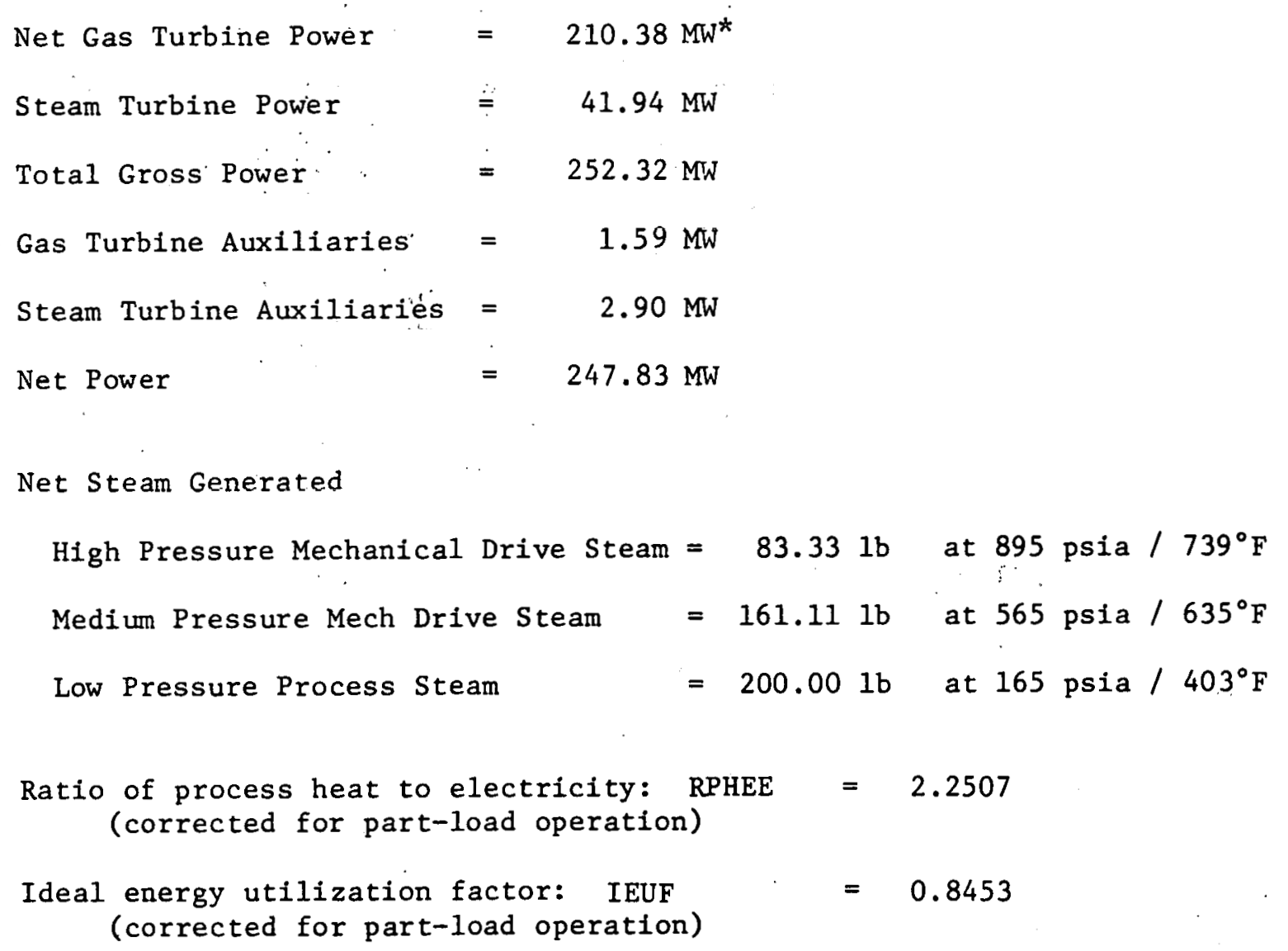

*Two (2) gas turbine modules 
TABLE C. 6-6

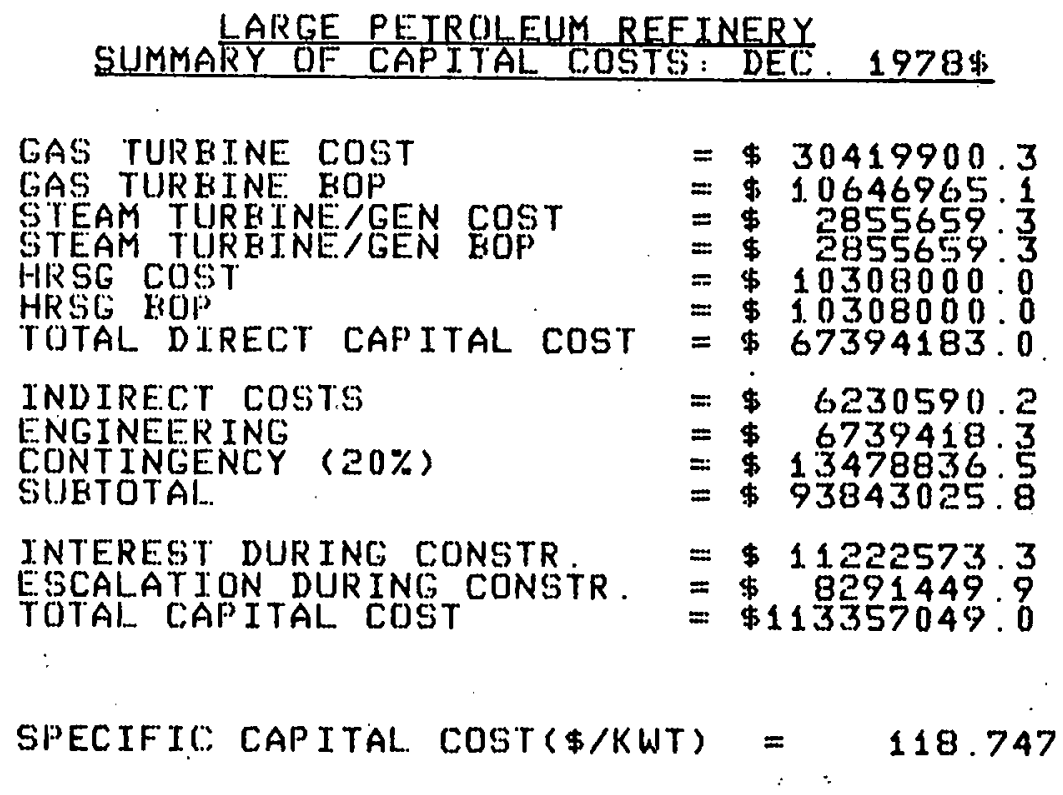




\section{BATE OF RETURN ON EQUITY SUMMARY \\ FOR INDUSTRTAL COGENERATION}

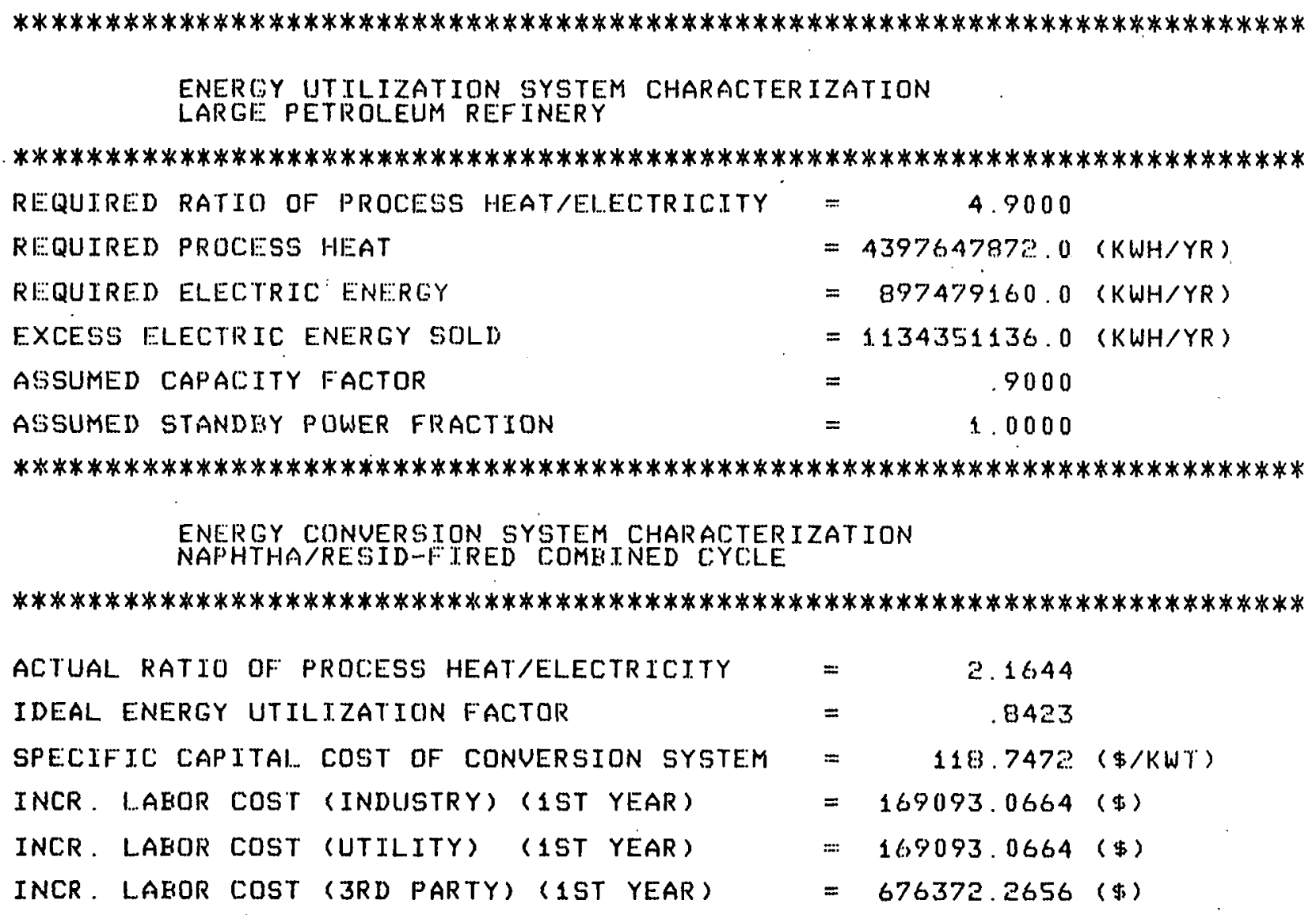


TABLE C.6-7 (cont'd)

LARGE PETROLEUM REF INERY

ECONOMIC AND FINANCIAL ASSUMPTIONS

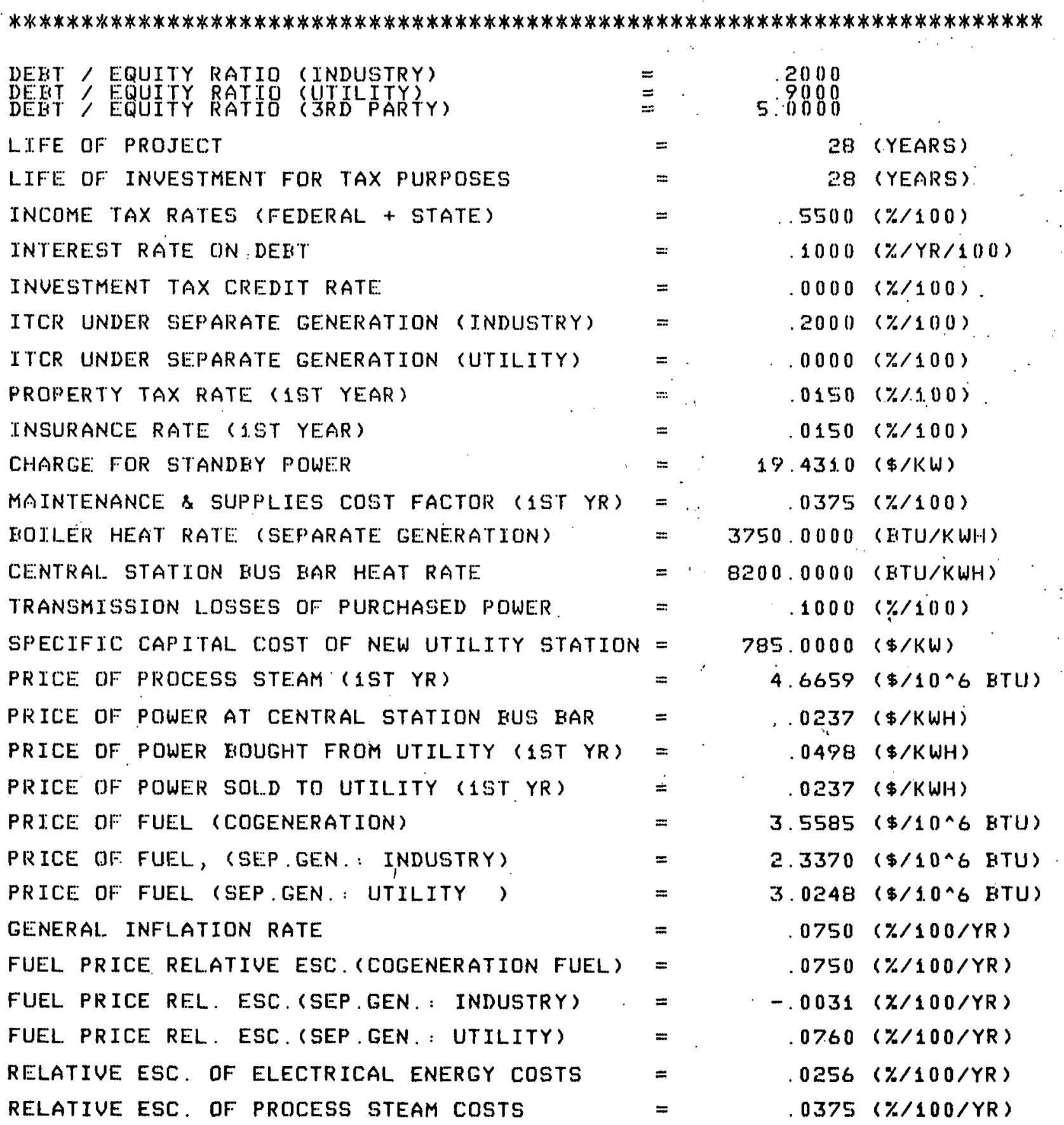


TABLE C. 6-8a

\section{LARGE PETROLEUM REFINERY}

FOR INDUSTRIAL OWNERSHIP

INCREMENTAL CAPITAL INUESTMENT

NET INCREMENTAL EQUITY CAPITAL INUESTMENT $=\quad-36358642(\leqslant)$

$=\quad-5346254(\$)$

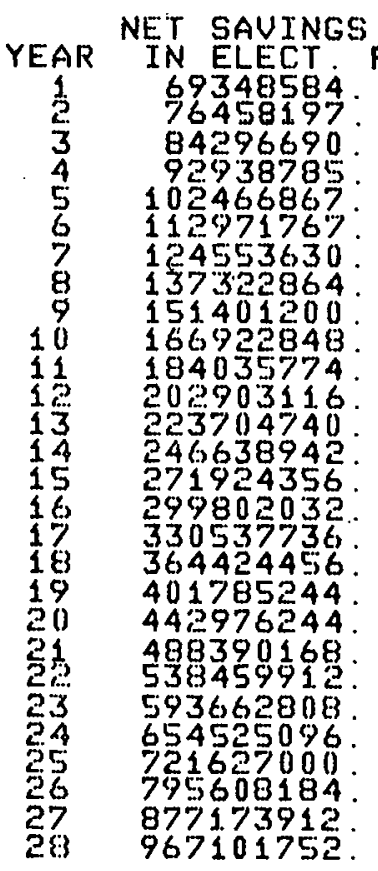

DELTA

TUEL COSTS 54218700 . 79614379 . 95720540 $11459955 \%$ 136702028 . 162550068 . 192748504 . 227997856 . 2691.09348 . 317022256. 372923956. 437773136. 513326584 . 601170352 703254648 . 821837184 95950906

1119351104 . 1304797616 . 1589363752 2058564192 . 2393763584 2782191520. 3232507968. 3753479264 . 4357182016 .
DELTA 4419982 . 4751481. 5107842 . 5490930. 5902750 . 6345456. 6821365 . 7332967 7882940 . 8474160 . 9109722. 9792951. 4052742 . 11316979 13078183 . 14059047 15113475 16246986 . 17465509 1877542 ? 21697347 23324648 . 55073996. 26954546 . 28976136 . 31149346

DEL.TA PROP. TAX INCOME TAXE:S \& INSUR ON SAUINGS

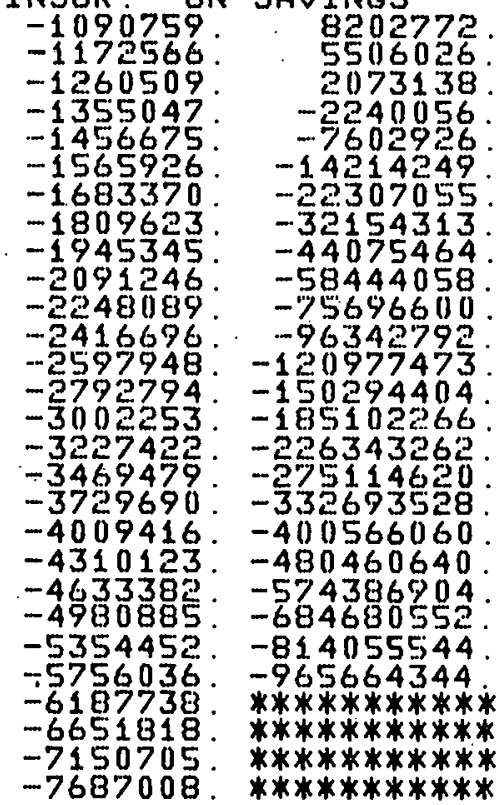

DISCOUNTED CASH FLOW RATE OF RETURN ON EQUITY(ROE) $=<0 \%$ ANNUAL ENERGY SAUED UNDER COGENERATION $=7903218.0000 \mathrm{MBTU} / Y$ R 
TABLE C. $6-8 \mathrm{~b}$

LARGE PETROLEUM REFINERY

FOR UTILITY OWNERSHIP

INCREMENTAL CAPITAL INUESTMENT

NET INCREMENTAL EQUITY CAPITAL INUESTMENT

$$
\begin{aligned}
& =-98878734(\$) \\
& =-52041439(\$)
\end{aligned}
$$

\begin{tabular}{|c|c|c|c|}
\hline $\begin{array}{c}\text { EAR } \\
1 \\
2 \\
23 \\
4 \\
5 \\
6 \\
7 \\
8 \\
9 \\
10 \\
11 \\
12 \\
13 \\
14 \\
5.5 \\
16 \\
3.7 \\
183 \\
19 \\
20 \\
21 \\
25 \\
25 \\
23 \\
24 \\
25 \\
28 \\
57\end{array}$ & 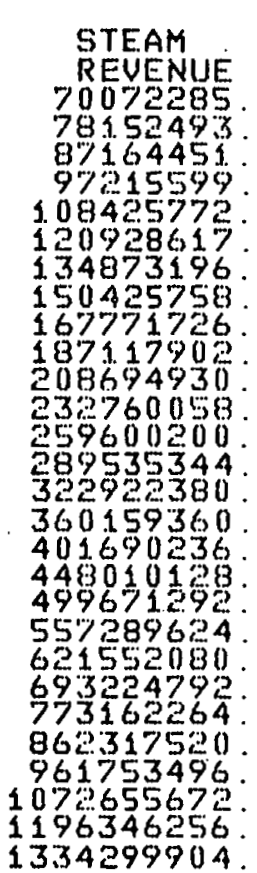 & 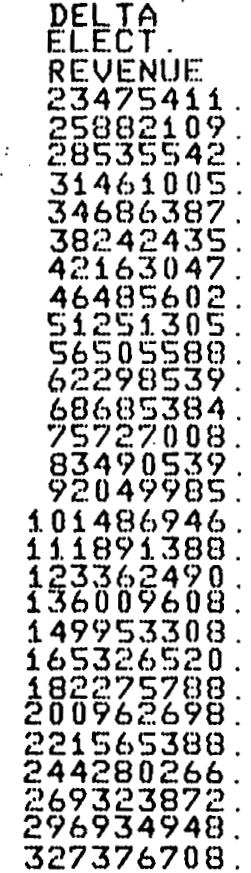 & 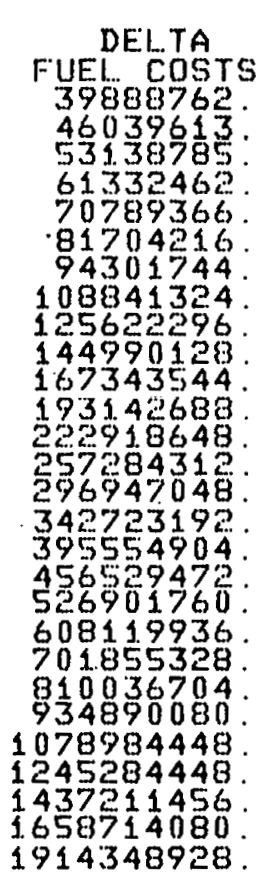 \\
\hline
\end{tabular}
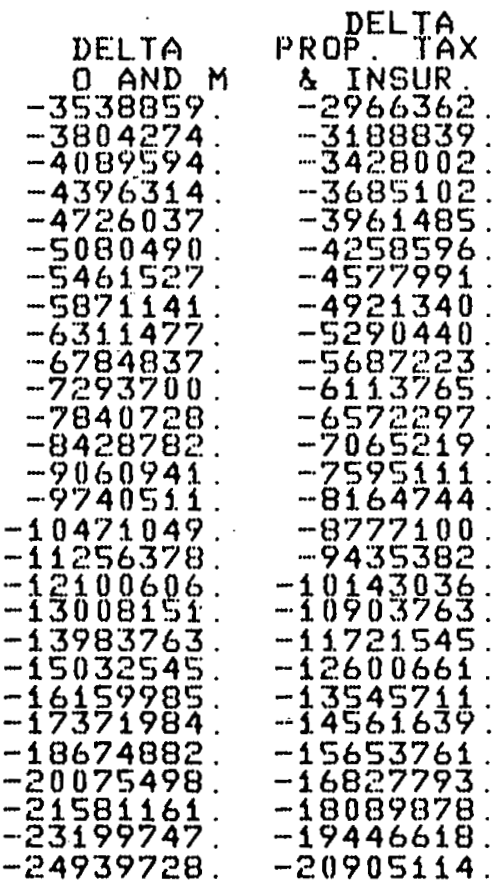

TAXES

394169083 41936129 44602066 $4 \% 40883 \%$ $5034649 \%$

53400134

56548636 59763363 830064883 66029063 69368696 73346860 $706564 \%$ 77403975 792131507 $803135 \% 9$ $8047860 \%$ 79447250 72437156 65608704

$5595695 \%$ 24820696 . 1. $8207 \%$

$-27580587$ $-646886,35$ $-1110451.13$.
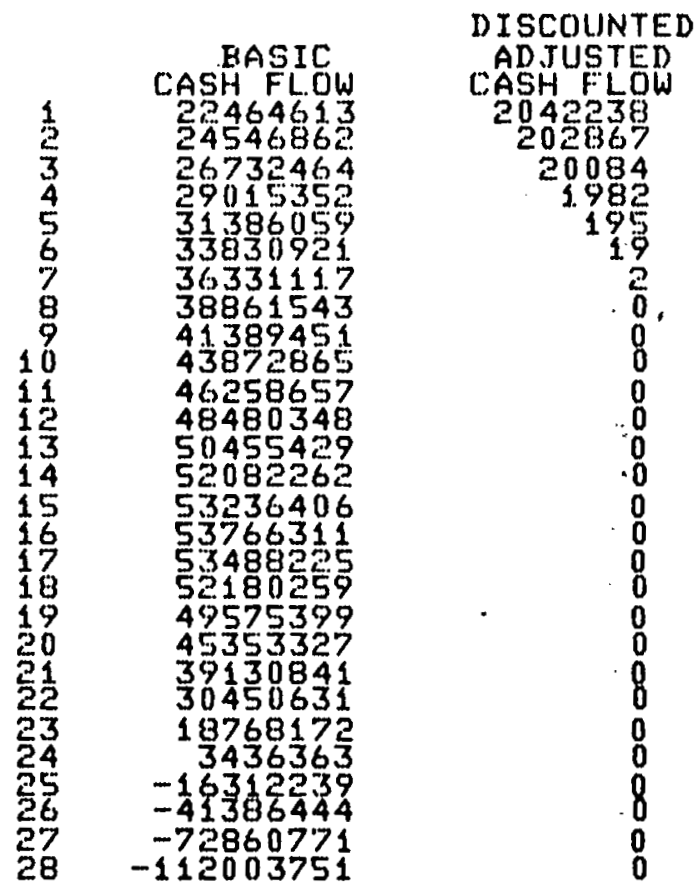

DISCOUNTED CASH FLOW RATE OF RETURN ON EQUITY(ROE) $=1000.00 \%$ ANNUAL ENERGY SAVED UNDER COGENERATION = $7903218.0000 \mathrm{MBTU} / \mathrm{YR}$ 
TABLE . C. $6-8 \mathrm{c}$

\section{LARGE PETROLEUM REFINERY}

FOR THIRD PARTY OWNERSHIP

CAPITAL INUESTMENT

NEIT EQUITY CAPITAL INUESTMENT

$=113357047(\$)$
$=18892841$ (\$)

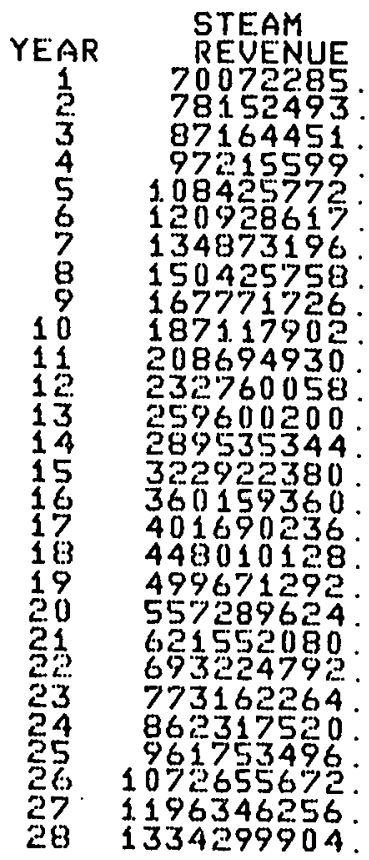

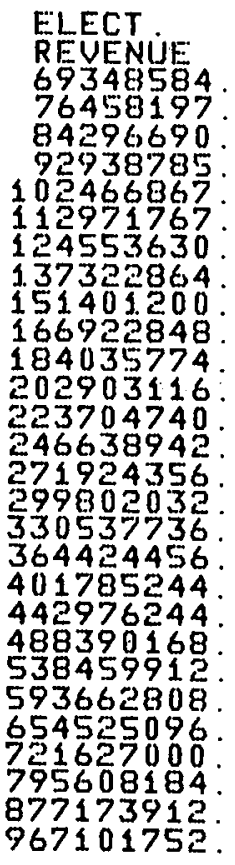

FUEL COSTS 107259155 123876981. 143155334 165433880 . 220931830 255314338 295047628 . 340964412 394026988 455347428 . 526210860 608102416 . 702738328

812101960 938485320 1084537072 1253318128 1448365712 1673767616 1934247632 2235264864 2583127904 2985127136 3449687488 . 3986544960 . 4606950976 .

\begin{tabular}{|c|}
\hline $\begin{array}{l}0 \\
49 D \\
4927261 \\
5296806 \\
5694066 \\
6121121 \\
6580205 \\
7073721 \\
7604250 \\
8174568 \\
8787661 \\
9446735 \\
0155240 \\
0916883 \\
1735649 \\
2615823 \\
3562009 \\
4579160 \\
5672597 \\
6848041 \\
8111644 \\
9470017 \\
0930268 \\
2500038 \\
4187541 \\
6001606 \\
7951726 \\
0048106\end{array}$ \\
\hline
\end{tabular}

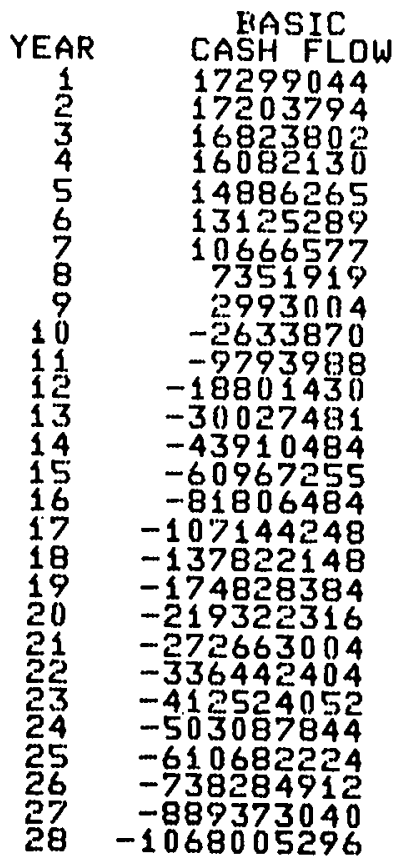


TABLE C.6-9

FUEL UTILIZATION

\section{LARGE PETROLEUM REFINERY}

$\begin{array}{lccc} & \begin{array}{c}\text { Separate Generation } \\ \text { (MBtu/yr) }\end{array} & \begin{array}{c}\text { Cogeneration } \\ (\text { MBtu/yr) }\end{array} & \begin{array}{c}\text { Savings } \\ \text { (MBtu/yr) }\end{array} \\ \text { Gas } & - & - & -- \\ \text { Oil } & 33970648 & 7986691 & 25983957 \\ \text { Coal } & -- & - & -- \\ \text { Naphtha } & - & 18080739 & -18080739 \\ \text { Overall } & 33970648 & 26067430 & 7903218 \\ & \text { Percent Energy } & \text { Savings }=23.3 \%\end{array}$

C-70 


\section{7 MEDIUM CAPACITY PETKOLEUM REFINERY}

The medium capacity petroleum refinery is located in Oklahoma (DOE Region VI). The application under consideration is an energy recovery system for a catalyst regenerator servicing a proposed heavy oil catalytic cracker. The analysis was undertaken not to compare the economic feasibility of a cogeneration system with respect to a conventional separately generated system, but to determine which of several cogeneration systems compared most favorably with a minimally cogenerated facility. The reference case was determined to be that in which sufficient electrical energy would be generated to supply on-site power requirements while satisfying process steam needs as well.

The flow diagram for the reference case is shown in Figure C.7-1. Steam generation is effected in two places: the catalyst regenerator at 600 psig, and elsewhere in the catalytic cracker at 250 psig. Two additional heat exchangers supply superheated process steam and power steam to drive a wet gas compressor and a pump, as well as to generate $10,005 \mathrm{~kW}$ in electric power for use on-site. Note that the process effluent itself is pressurized to 55 psia and is subsequently throttled to 17 psia. Note also that the exhaust temperature from the final superheater is $949^{\circ} \mathrm{F}$.

The first cogeneration configuration examined is shown in Figure C.7-2. Thermal recovery is achieved by installing larger heat exchangers for superheating power steam for the wet gas compressor and pump and for a double extraction condensing steam turbine producing a peak of $28.4 \mathrm{MW}$. Further recovery is accomplished by subposing a Fluorinol Rankine cycle in the exhaust gas path which produces an additional $7 \mathrm{MW}$. No pressure recovery from the exhaust gas is included. The economic analysis shows that the industrial owner (the only ownership option considered in this case) could expect a return on equity of $53 \%$ at a projected energy savings of $2,119,000 \mathrm{MBtu} / \mathrm{yr}$.

The second cogeneration configuration examined is shown in Figure c.7-3. This configuration added pressure recovery equipment which resulted in additional 22.6 MW of power for export. The exhaust gases from the process are cleaned and expanded through a turboexpander before being directed to the heat recovery superheaters. The thermal recovery equipment is similar to the previous case. Two larger superheaters replace the minimal surface in the reference case and a double extraction steam turbine/generator provides a peak of $23.2 \mathrm{MW}$. The bottoming cycle for this option was a methanol Rankine cycle generating $2.2 \mathrm{~kW}$. The return on equity computed for this configuration was $88 \%$ with an energy savings of 3,150,760 MBtu/yr. Having performed better both financially and as an energy conservation measure, the second case was chosen as the preferred cogeneration concept.

Figure C.7-4 presents the energy utilization system corresponding to the preferred concept. The conditions and flows at the indicated state points are given in Table C..7-1. 


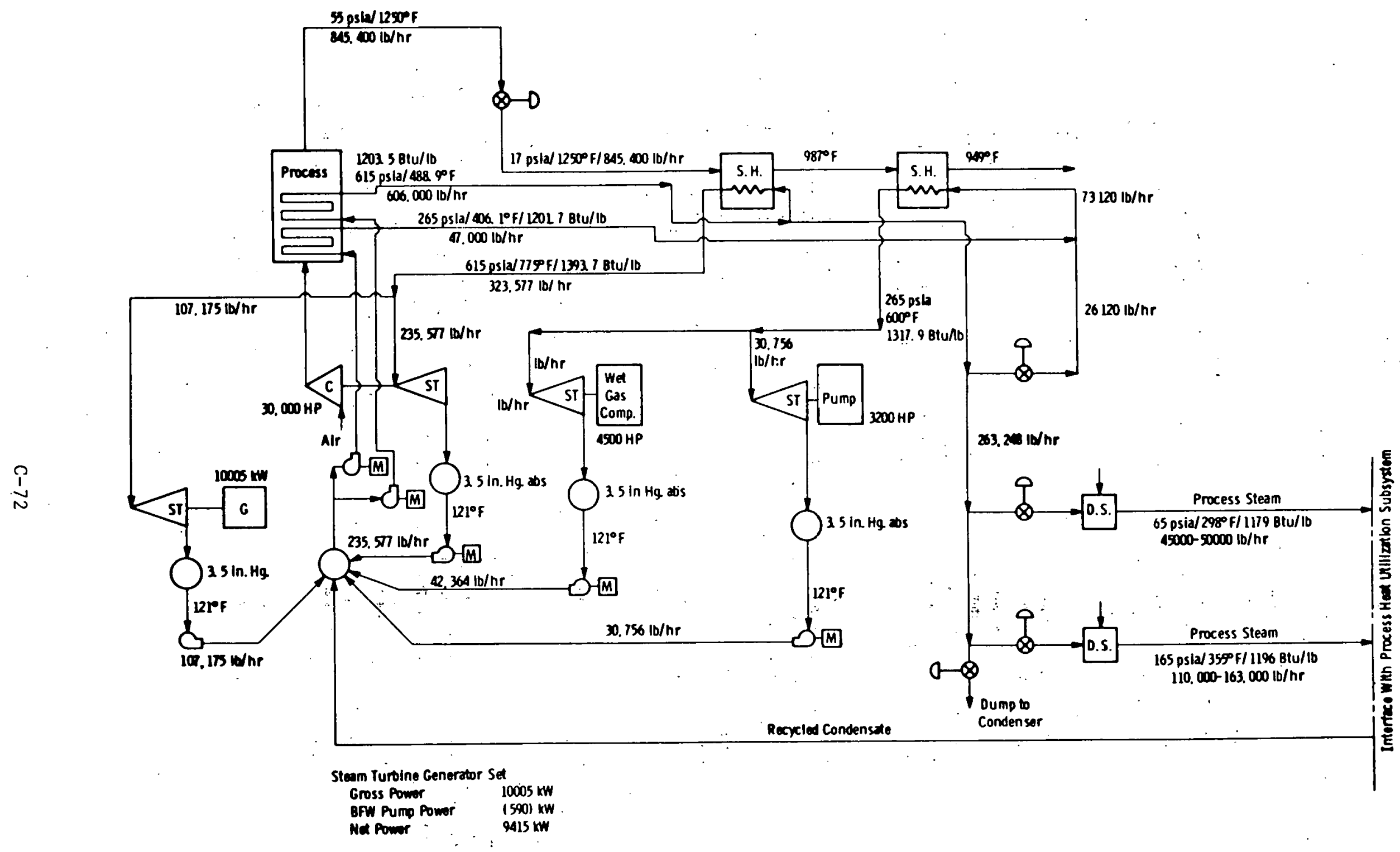

Ha C. 1 - I-Medum petroleum refinery (Case Cl roterence case) 


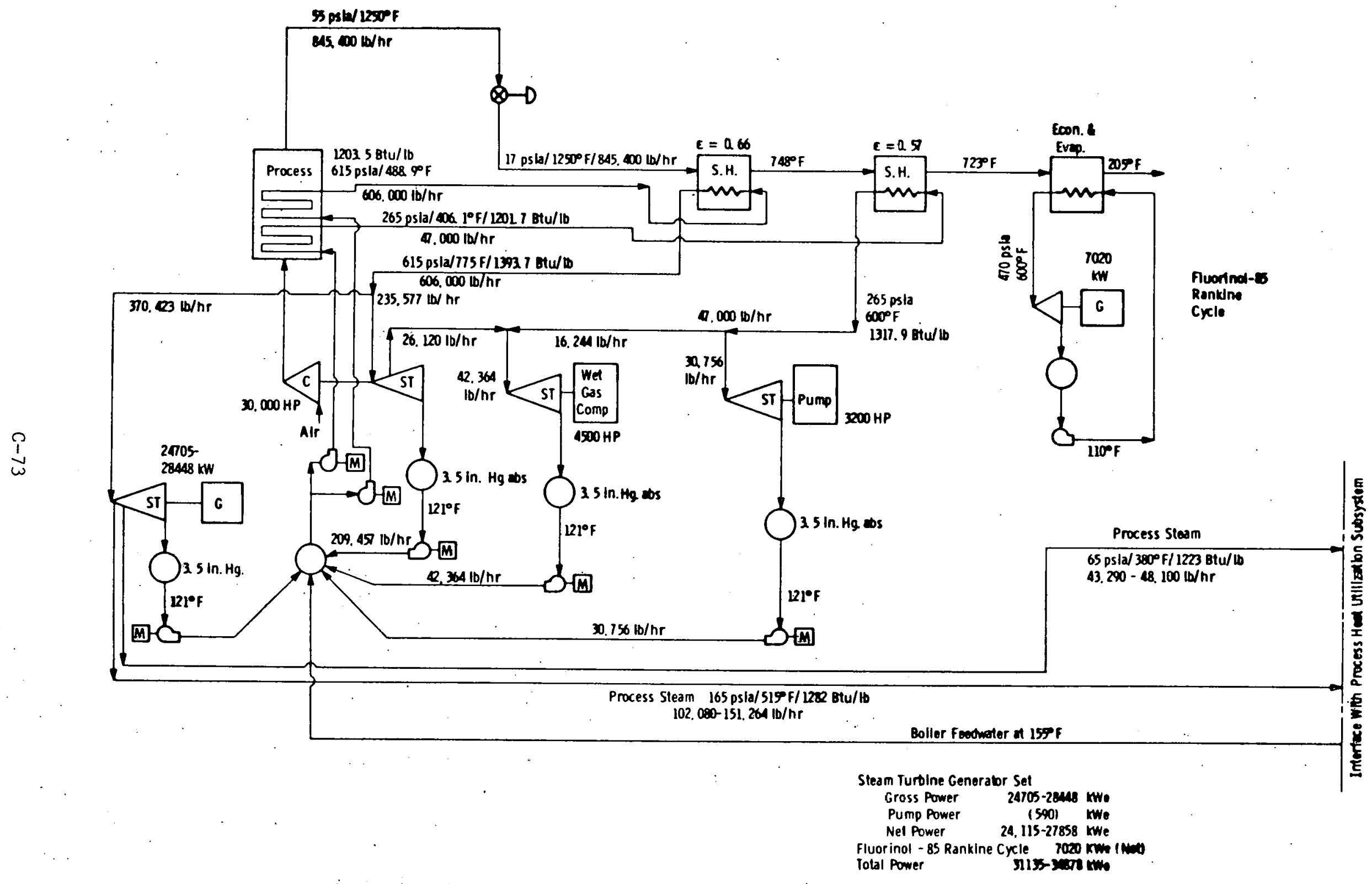

Fle C. 1-2-Medium potroleum milinery (Cose 82) 


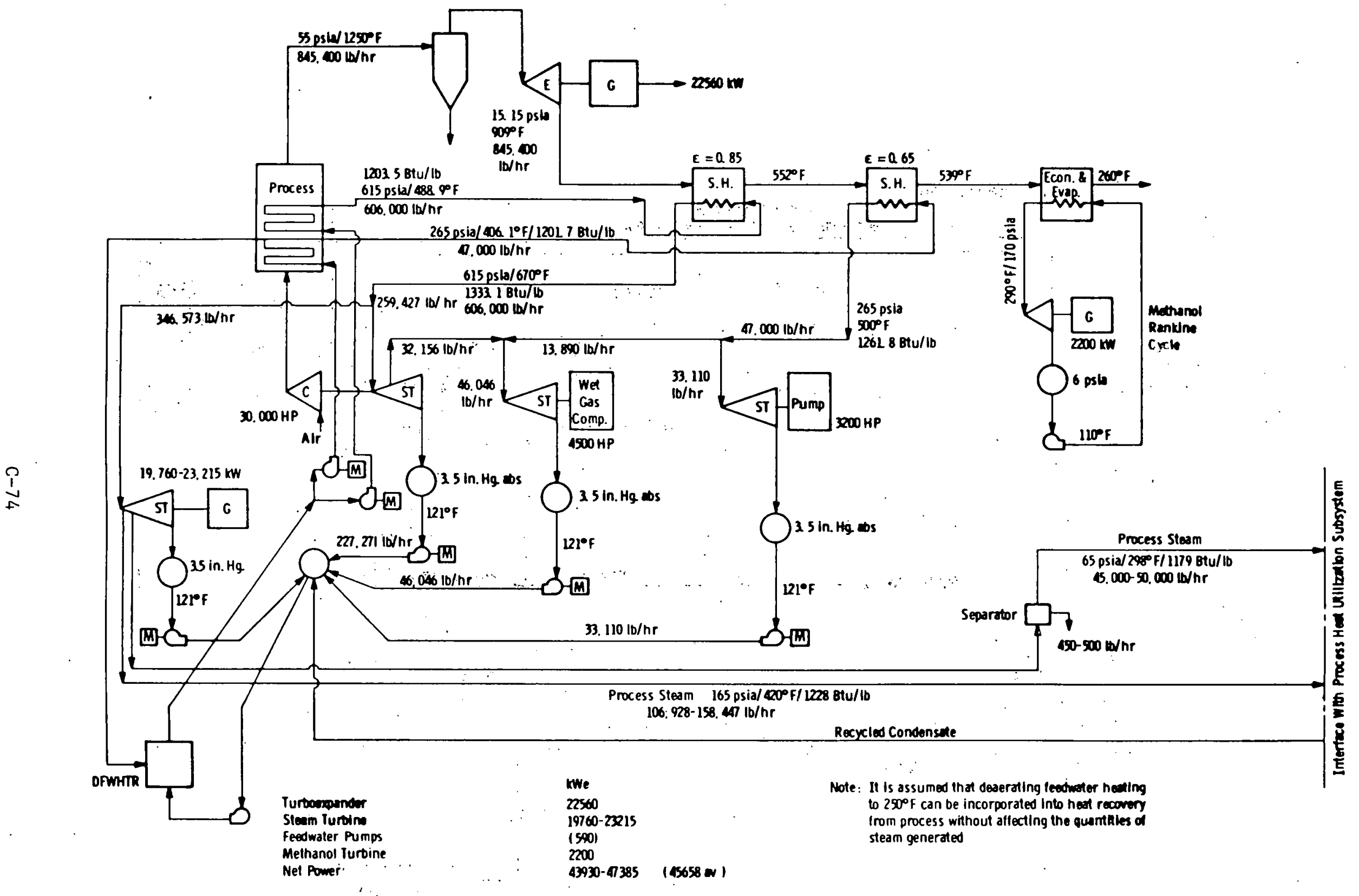

Fg. C. 7-3-Modium potroloum refinery (Case Al) 


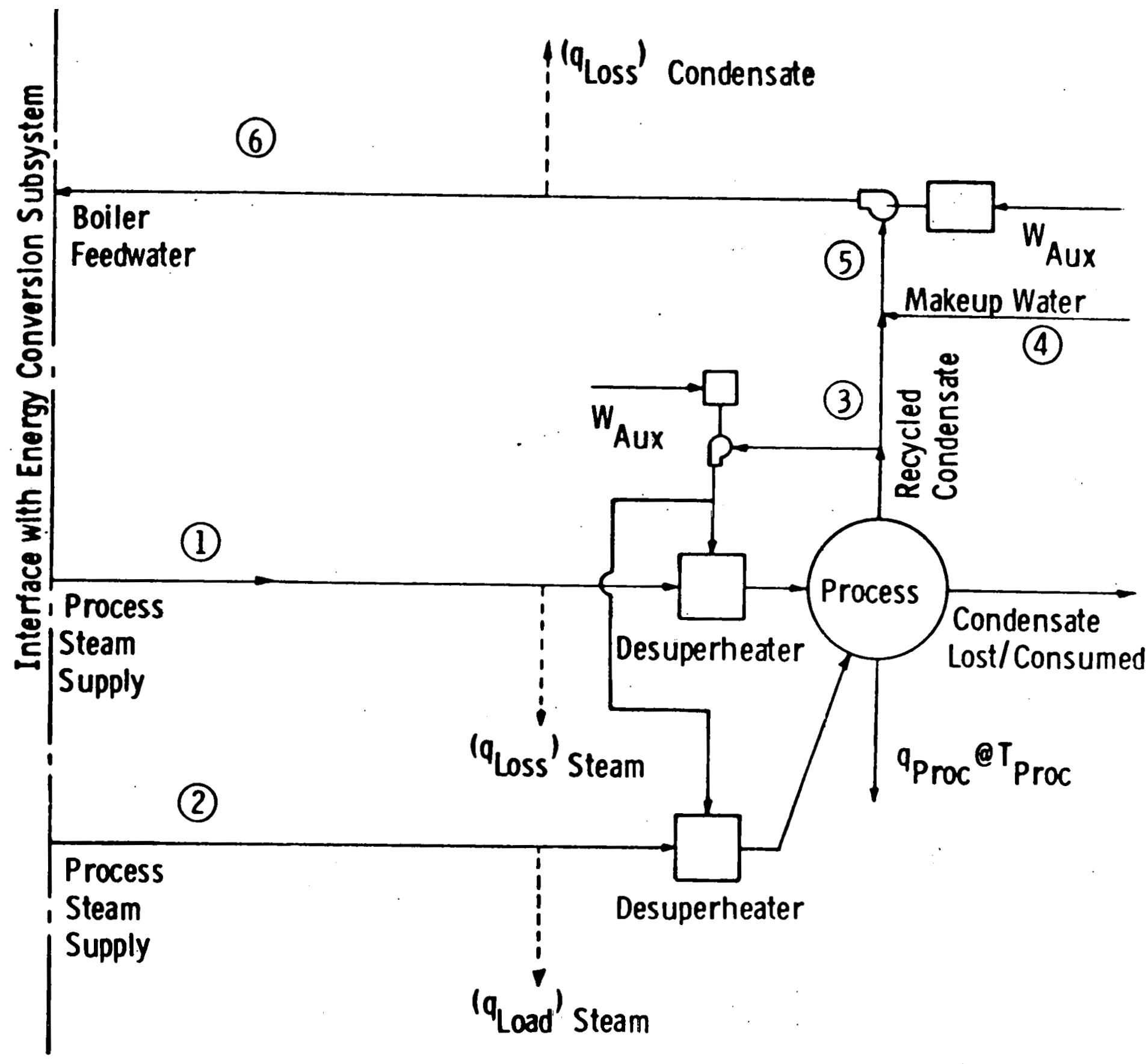

Fig. C.7-4-Model of process heat utilization subsystem for medium size petroleum refinery 
TABLE C. 7-1

STATEPOINTS FOR ENERGY UTILIZATION SUBSYSTEM IN

MEDIUM SIZE PETROLEUM REFINERY

$\begin{array}{ccccc}\text { Station } & \begin{array}{c}\text { Pressure } \\ \text { (psia) }\end{array} & \begin{array}{c}\text { Temperature } \\ \left({ }^{\circ} \mathrm{F}\right)\end{array} & \begin{array}{c}\text { Enthalpy } \\ (\mathrm{Btu} / \mathrm{lb})\end{array} & \begin{array}{c}\text { Flow Rate } \\ (\mathrm{lb} / \mathrm{s})\end{array} \\ 1 & 165 & 420 & 1228 & 44.01 \\ 2 & 65 & 298 & 1179 & 13.89 \\ 3 & >15 & 210 & 178 & 28.95 \\ 4 & 15 & 100 & 68 & 28.95 \\ 5 & >15 & 155 & 123 & 57.90 \\ 6 & 39.8 & 155 & 123 & 57.90\end{array}$


The preliminary costs for the cogeneration components are given in Table C.7-2. Since all other components are common to both the preferred concept and the reference case, only those items which differ or appear in the preferred configuration need be used in the analysis.

The economic and financial assumptions used in the ROE. analysis are given in Table C.7-3. The detailed results of that analysis are shown in Table C. 7-4 for the industrial ownership case.

The difference in fuel utilization to be expected as a result of the installation of this preferred concept is shown in Table C.7-5. The energy saved is accomplished simply by displacing the utility - produced power $(332.6 \times 106 \mathrm{kWh} / \mathrm{yr})$. No other fuel is involved. 
TABLE C. 7-2

MEDIUM CAPACITY PETROLEUM REFINERY

SUMMARY OF CAPITAL COSTS : DEC. 1978\$

COMPONENT/SYSTEM

EXPANDER/GENERATOR COST

EXPANDER GENERATOR BOP COSTS

PARTICULATE REMOUAL (InCI

SUPERHEATER \#: (InCI. BOP)

ORGANIC RANK INE CYCLE (METHANOL) TURBINE/GENERATOR CONDENSER/CIRC, H2O BOILER

BOP COSTS

STEAM TUREINE/GENERATOR COST

TUR H/GEN EOP' COSTS

TOTAL DIRECT COSTS

INCREMENTAL CAPITAL COSTS

INDIRECT COSTS

ENGINEERING

CONTINGENCY (20\%)

SUBTOTAL.

INTEREST DURTNG CONSTR (27 MO) = ESCALATION DURING CONSTRUCTION

TOTAL. INCREMENTAL CAPITAL COST =

COGENERATION FACILITY

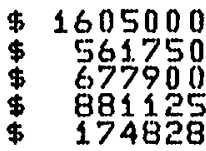

\$ 327845

$\$ 207320$

\$ 129868

\$ 665052

$\$ 6021228$

\$ 6021228

$=\$ 17273144$

$=\$ 11581833$

$=\quad \$ 496530$

$=12316370$

$=\$ 16552918$

事 19792543

$\$ 19994985$
REFERENCE'FACILIT

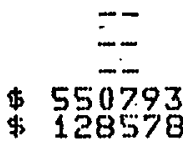

$\cdots-$

$-$

$\$ 2505970$

$\$ 2505970$

$\$ 5691311$ 


\section{RATE OF RETURN ON EQUTTY SUMMARY}

EUR INDUSTRTIAL CUGENERATION

$* * * * * * * * * * * * * * * * * * * * * * * * * * * * * * * * * * * * * * * * * * * * * * * * * * * * * * * * * * * * * * * * * * * * * * * * *$

ENERGY UTILIZATION SYYSTEM CHARACTERIZATION

MEDIUM CAPACIYY PETROLEUM REFINERY

*********************************************************************************

REQUIRED RATIO OF PROCESS HEAT/ELECTRICITY

REQUTRED PROCESS HEAT

$=\quad 5.9000$

REQUIRED ELECTRIC ENEERGY

$=486639320.0$ (KWH/YR)

EXCESS ELECTRIC ENERGY SOI...

$=82481241.0$ (KWH/YR)

ASSUMED CAPACITY FACTOR

$=332598356.0$ (KWH/YR)

ASSUMED STANDEY POWER FRACTION

$=\quad 1.0000$

$=\quad 1.0000$

$* * * * * * * * * * * * * * * * * * * * * * * * * * * * * * * * * * * * * * * * * * * * * * * * * * * * * * * * * * * * * * * * * * * * * * * * * * * * * *$

ENERGY COONUERSION SYSTEM CHARACTERIZATION

TURBOEXPANDER/STEAM/ORTANIC EUTTOMER

**********************************************************************************

ACTUAL RATIO OF PROCESS HEAT/ELECTRICITY

$=$.

$=$

$=1.9994985 .0000(\$)$

ACTUAL INCREMENTAL COST

INCR. LAEOR COST. (INDUSTRY) (1ST YEAR)

INCR. LAEOR COST (UTILITY) (1ST YEAR)

$=.0000(\$)$

INCR. LABOR COST (3RD PARTY) (1ST YEAR)
$=314798.0156(\$)$

$=314798.0156$ (\$)

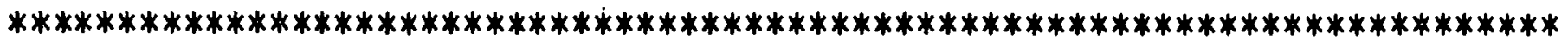


TABLE C. $7-3$ (cont'd.)

MEDIUM CAPACITY PETROLEUM REFINERY

ECONDMIC AND FINANCIAL ASSLIMPTIONS

******************************************************************************

DEHT / EQUITY RATIO (INDUSTRY)

LIFE OF PROJECT :

LIFE OF INUESTMENT FOR TAX PIJRPOSES

INCOME TAX RATES (FEDERAL + STATE)

INTEREST RATE ON DEBT

INUESTMENT TAX CREDIT RATE (COGENERATION)

ITCR UNDER ALTERNATE SYSTEM (INDUSTRIAL)

PROPERTY TAX RATE (IST YEAR)

INSURANCE RATE (IST YEAR)

CHARGE FOR STANDEY POWER

MAINTENANCE \& SUPPLLIES COST FACTOR (IST YR)

PRICE OF POWER AT CENTRAL STATION EUS BAR

GENERAL INFLATION RATE

RELATIVE ESC. OF ELECTRICAL ENERGY COSTS

$\begin{array}{lc}= & 3.0000 \\ = & 28(\text { YEARS }) \\ = & 28(\text { YEARS }) \\ = & .5000(\% / 100) \\ = & .1000(\% / \text { YR/100) } \\ = & .1000(\% / 100) \\ = & .1000(\% / 100) \\ = & .0150(\% / 100) \\ = & .0150(\% / 1 / 00) \\ = & 74.0426(\$ / K W) \\ = & .0375(\% / 100) \\ = & .0187(\$ / K W H) \\ = & .0750(\% / 100 / Y R) \\ = & .0603(\% / 100 / Y R)\end{array}$




\section{MEDIUM CAPACITY PETROLEUM REFINERY}

FOR INDUSTRIAL OWNERSHIP

INCREMENTAL CAPITAL INUESTMENT

NET INCREMENTAL EQUITY CAPITAL INUESTMENT

$=\quad 19994985(\$)$
$=\quad 4498871(\$)$

DELTA

PROPLTA TAX INCOME TAXES

\& INSUR ON SAUINGS

$\begin{array}{ll}599850 . & 1922723 \\ 644838 & 2461178\end{array}$

$693201 \quad 3074758$

745191 . 3774244

801081 . 4571818 .

861162.5481578

$92574 \%$ 6519481.

995180.27703773

1069818 . 9055276

1.150055 .10597750

$1236309 . \quad 12358305$

1329032 14367874

$1428709-16661739$

1535862 19280167.

1651052 . 32569082

1774881. 25680871

$1907997 \%$.

1053097 34005506

$2304930^{\circ} 3909425$

$2370299^{\circ} \quad 44885199$

5548071 . 53494465

5739176.59037376

$2944614 \quad 67645451$.

3165460 . 77468667 .

3409870 88678049

$3658085^{\circ} 101468626$.

3932442.116062782

4227375 . 132714094.

283242571672

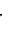

4915552

5284218 .

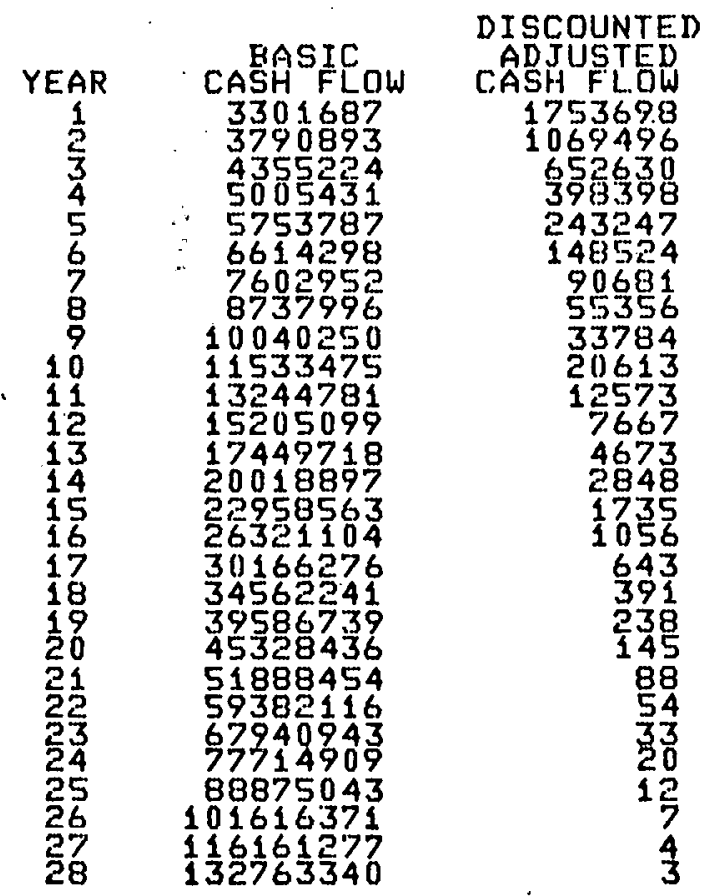

DISCOUNTED CASH FLOW RATE OF RETURN ON EQUITY(RQE)= $88.27 \%$ 
TABLE C . 7-5

FUEL UTILIZATION

MEDIUM CAPACITY PETROLEUM REFINERY

Minimal Cogeneration

(MBtu/yr)

011

Gas

Coal

Overall

$$
3,150,760
$$$$
3,150,760
$$

Preferred Concept

(MBtu/yr)

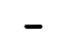

$-$

Percent Energy Savings $=100 \%$, relative to reference system
Savings

(MBtu/yr)
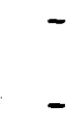

$3,150,760$

$3,150,760$ 


\section{8 WRITING PAPER MILL}

The writing paper mill is a medium-sized facility located in Pennsylvania (DOE Region III). The required ratio of process heat to electricity is fairly typical at 5.23 . The gross annual energy requirements are as follows:

- Process heat (sat'd steam (a 180 psia)

- Electricity
$635.1 \times 10^{6} \mathrm{kWht} / \mathrm{yr}$

$120.9 \times 10^{6} \mathrm{kWhe} / \mathrm{yr}$

The choice of an energy conversion subsystem in this case was simplified for this application by price considerations. A large percentage of the existing coal-fired process steam boiler capacity is more than 60 years old and must be replaced. Current fuel contracts for the site indicate that oil prices have recently doubled, making the cost of coal approximately one-fifth that of oil. Natural gas prices are also considerably higher than the price of coal. A coal-fired steam system with BPT and FGD is therefore the only reasonable choice of configuration.

The energy utilization system model is shown in Figure C.8-1. In Table C.8-1, the conditions in the process energy utilization subsystem are given. The coal-fired boiler configuration is shown in Figure C.8-2. The significant operating parameter, the turbine throttle pressure, was varied to provide a correlation between the energy savings attainable for each point and the characteristic return on equity. The ROE's for industrial and third-party were very poor. The ROE for the utility ownership case was, however, acceptable but demonstrated little sensitivity to the system pressure level (see Figure C.8-3). The optimum case was, therefore, determined to correspond to the highest allowable steam conditions feasible in this size-range (1215 psia). Table C.8-2 contains the conditions and flows associated with the state points indicated in the cycle schematic.

The cogeneration system burns pulverized Ohio Pittsburgh \#8 seam coal having the composition and properties indicated in Table C.8-3. Steam is generated at 1215 psia and is expanded to 180 psia in a back pressure turbine generator (22.2 MW/gross). The exhaust steam is used to deaerate the makeup water and to heat it to the saturation condition at 29.8 psia, to reheat the flue gas from the desulfurization system, and to provide process heat at a peak rate of $471.4 \times 106 \mathrm{Btu} / \mathrm{hr}$. In Table C.8-4, the energy distribution for the facility is shown. The ideal energy utflization factor (IEUF) for this case is 0.874 and the gross ratio of process heat to electricity is $8.2974 \mathrm{kWt} / \mathrm{kWe}$.

The preliminary capital costs of the components are listed in Table C.8-5. Table C.8-6 contains the financial and economic assumptions used in analyzing the cash flow to be attained. The results of that analysis for the three ownership cases are given in Tables $C .8-7 a, b$, and $c$.

The fuel utilization comparison between separate generation and a cogeneration installation is performed in Table C.8-8. As can be seen, the net result is a transfer from oil and natural gas to a reliance on coal with overall energy savings of $14 \%$. A small amount of energy is still derivable from a black liquor boller. which operates in the same fashion in both cases and, thus, is not shown in the comparison. 


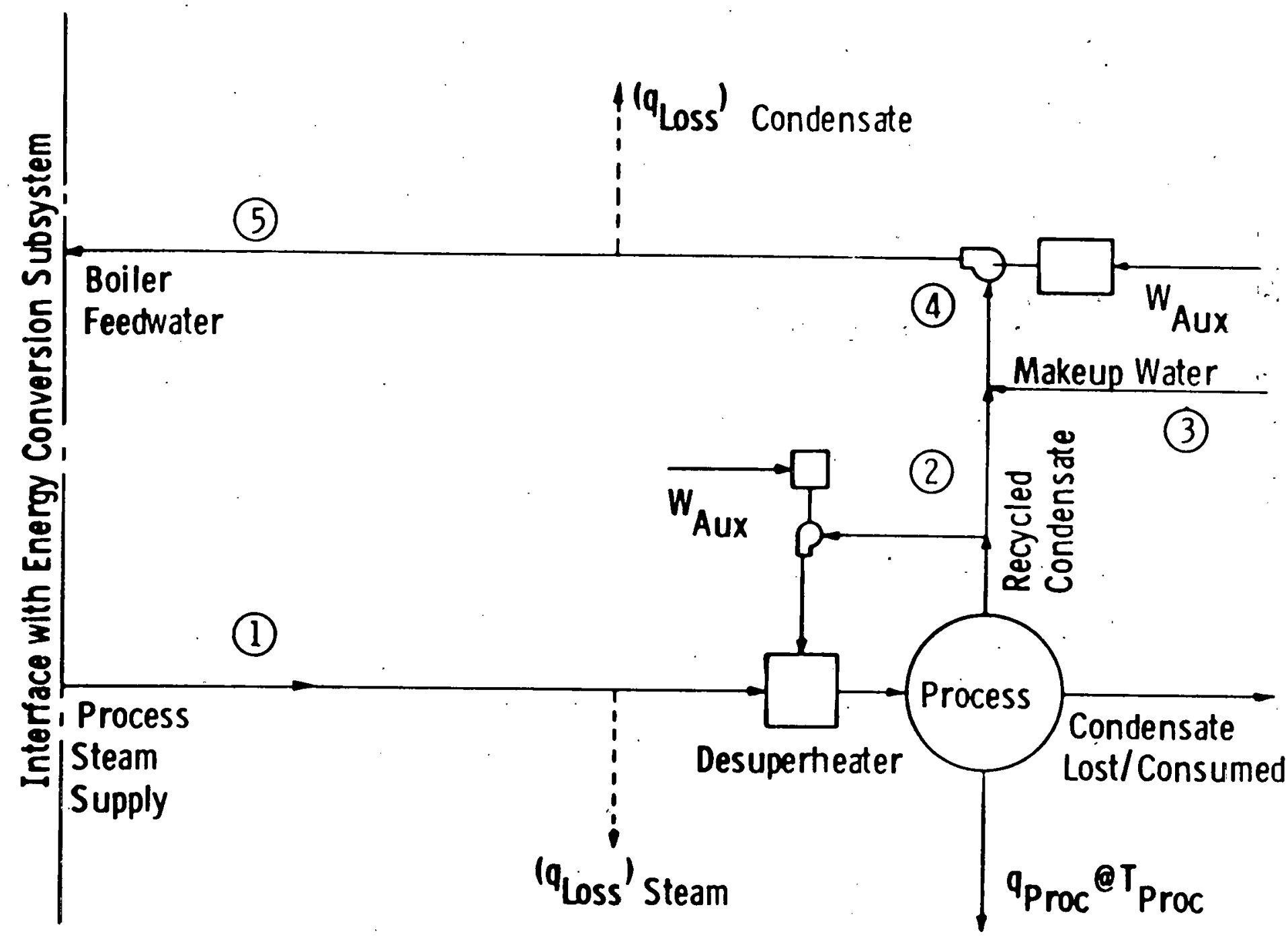

Fig. C. 8-1 - Model of process heat utilization subsystem for writing paper mill 
TABLE C. $8-1$

STATEPOINTS FOR ENERGY UTILIZATION SUBSYSTEM

IN WRITING PAPER MILL

$\begin{array}{ccccc}\text { Station } & \begin{array}{c}\text { Pressure } \\ (\text { psia) }\end{array} & \begin{array}{c}\text { Temperature } \\ \left({ }^{\circ} \mathrm{F}\right)\end{array} & \begin{array}{c}\text { Enthalpy } \\ (\mathrm{Btu} / \mathrm{lb})\end{array} & \begin{array}{c}\text { Flow Rate } \\ (\mathrm{lb} / \mathrm{s})\end{array} \\ 1 & 180.0 & 540.7 & 1293.0 & 106.9 \\ 2 & - & - & - & - \\ 3 & 15 & 100 & 68 & 106.9 \\ 4 & >15 & 100 & 68 & 106.9 \\ 5 & 39.8 & 100 & 68 & 106.9\end{array}$




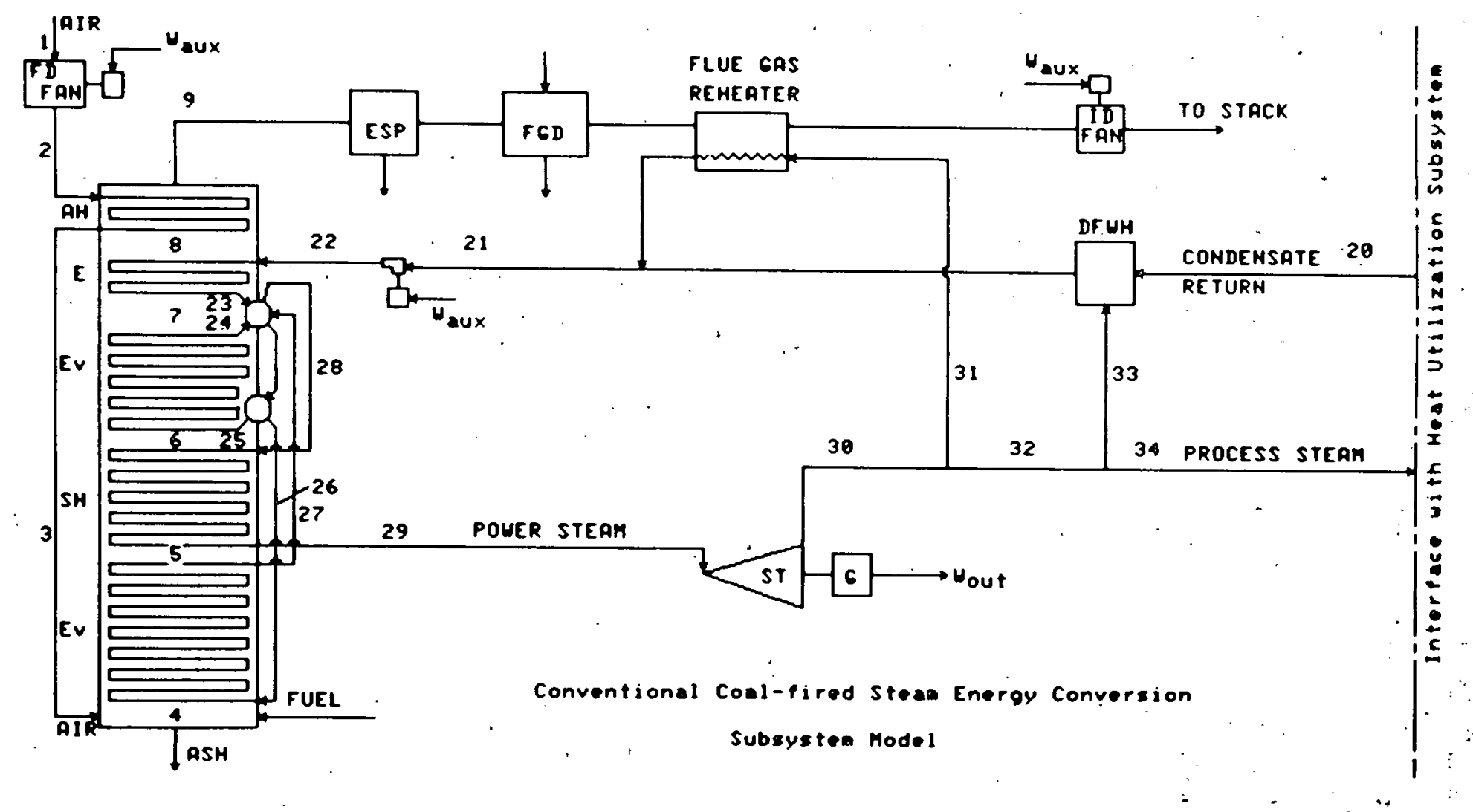

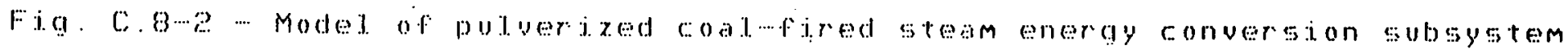
with Fod and bakk aressure steam turbine for writing paper mill 


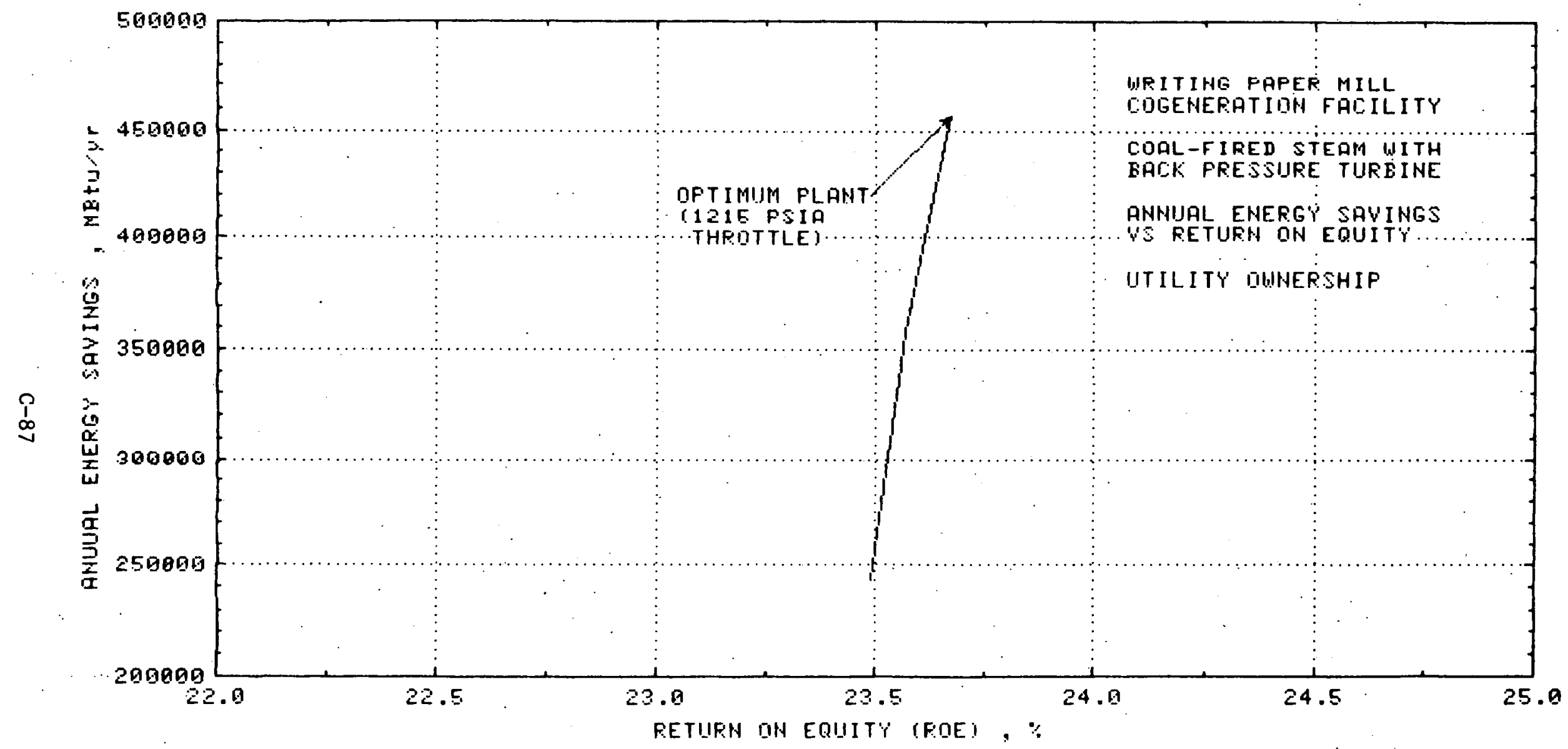

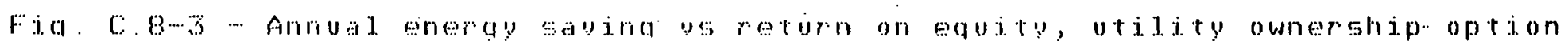


TABLE C. 8-2.

STATEPOINTS FOR CONVERSION SUBSYSTEM

IN WRITING PAPER MILL

\begin{tabular}{|c|c|c|c|c|}
\hline Station & $\begin{array}{l}\text { Pressure } \\
\text { (psia) }\end{array}$ & $\begin{array}{c}\text { Temperature } \\
\left({ }^{\circ} \mathrm{F}\right)\end{array}$ & $\begin{array}{l}\text { Enthalpy } \\
(\text { Btu/1b) }\end{array}$ & $\begin{array}{l}\text { Flow } \\
(\mathrm{lb} / \mathrm{s})\end{array}$ \\
\hline 1 & 14.7 & 77.0 & 0 & 185.43 \\
\hline 2 & 16.0 & 85.0 & 2.0 & 185.43 \\
\hline 3 & 15.8 & 540.0 & 112.7 & 185.43 \\
\hline 4 & 15.5 & 3212.9 & 929.4 & 199.81 \\
\hline 5 & 15.3 & 2006.5 & 541.4 & 199.81 \\
\hline 6 & 15.1 & 1423.0 & 364.5 & 199.81 \\
\hline 7 & 15.1 & 1423.0 & 364.5 & 199.81 \\
\hline 8 & 14.9 & 682.1 & 155.6 & 199.81 \\
\hline 9 & 14.7 & 279.0 & 50.8 & 199.81 \\
\hline 20 & 39.8 & 100.1 & 68.2 & 106.91 \\
\hline 21 & 29.8 & 250.0 & 218.6 & 124.14 \\
\hline 22 & 1340.0 & 253.5 & 224.8 & 124.14 \\
\hline 23 & 1315.0 & 558.9 & 560.5 & 124.14 \\
\hline 24 & - & - & $\therefore=$ & - \\
\hline 25 & - & - & $\therefore-$ & - \\
\hline 26 & 1265.0 & 573.9 & 580.8 & 641.64 \\
\hline 27 & 1265.0 & 573.9 & 701.4 & 641.64 \\
\hline 28 & 1265.0 & 573.9 & 1183.7 & 124.14 \\
\hline 29. & 1215.0 & 945.5 & 1467.9 & 124.14 \\
\hline 30 & 180.0 & 540.7 & 1293.0 & 124.14 \\
\hline 31 & 180.0 & 540.7 & 1293.0 & 1.99 \\
\hline 32 & 180.0 & 540.7 & 1293.0 & 122.15 \\
\hline 33 & 180.0 & 540.7 & 1293.0 & 15.24 \\
\hline 34 & 180.0 & 540.7 & 1293.0 & 106.91 \\
\hline
\end{tabular}


OHIO PITTSBURGH NO. 8 SEAM COAL

(Source of data: Monthly Progress Report 10

May 1973; OCR Contract No. 14-32-0001-1514)

SAIPLE: Run of mine

$\begin{aligned} \text { PROXIMATE ANALYSIS (wt \%): } & \text { Volatile matter } \\ & \text { Fixed carbon }\end{aligned}$ Ash ULTIMATE ANALYSIS (wt \%): $\quad$ (includes moisture)
$\quad$ i

\section{$\mathrm{H}$}

0

$\mathrm{N}$

s(2)

Ash

GROSS HEATING VALUE:

NET HEATING VALUE:

ASH ANALYSIS (wt \%):
Dry Basis

$$
\begin{aligned}
& 41.72 \\
& 47.90 \\
& 10.38 \\
& \hline 100.0
\end{aligned}
$$

71.14

5.20

8.41

0.98

3.89

$\frac{10.38}{100.00}$

12524

$-$

45.9

23.8

23.5

$\mathrm{Fe}_{2} \mathrm{O}_{3}$

$\mathrm{TiO}_{2}$

$\mathrm{P}_{2} \mathrm{O}_{5}$

$\mathrm{CaO}$

MgO

$\mathrm{Na}_{2} \mathrm{O}$

$\mathrm{K}_{2} \mathrm{O}$

$\mathrm{SO}_{3}$

1.4

-

1.5

0.7

0.5

1.9
As fired (1)

47.55

43.11

$\frac{9.34}{100.0}$

64.03

5.79

16.45

0.89

3.50

$\frac{9.34}{100.00}$

11272

10730

FUSIBILITY OF ASH:

Initial deformation temperature $-2560^{\circ} \mathrm{F}$

Softening temperature

Fluid temperature

$-$

2

FREE SWELLING INDEX:

2

(1) $10 \%$ moisture assumed

(2) Sulfur forms (\%): Pyritic - 46

- Sulfate - 53

Organic - 1 
POWER SUMMARY - WRITING PAPER MILL

\begin{tabular}{|c|c|c|}
\hline $\begin{array}{l}\text { HF STEAM PWR }= \\
\text { LP STEAM PWF }=\ldots \\
\text { ST FOWER }=\end{array}$ & & $\begin{array}{r}14511.3910 \mathrm{KW} \\
7701.7369 \mathrm{KW} \\
22213.1279 \mathrm{KW}\end{array}$ \\
\hline $\begin{array}{l}\text { GFOSS FOWER } \\
\text { FGLI AUXILI ARIES } \\
\text { AUXILIARY POWEF } \\
\text { EOILER FEED PUMF } \\
\text { NET POWER GENEFA }\end{array}$ & $\begin{array}{l}\vdots \\
\text { FOWWF } \\
\text { FE[ }\end{array}$ & $\begin{array}{r}22213.1279 \\
3471.5942 \\
1323.7694 \\
771.4177 \\
16646.1558\end{array}$ \\
\hline
\end{tabular}

TOTAL FUEL =

$14.3853 \mathrm{LB} / \mathrm{SEC}$

THEFIMAL FIATING $=\quad 602490264.0000 \mathrm{BTU} / \mathrm{HR}$

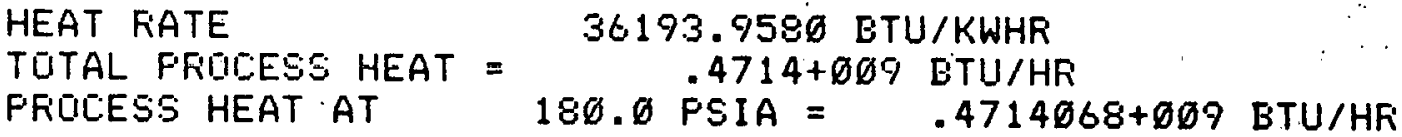

FPHEE $=\quad 8.2974 \mathrm{KWT} / \mathrm{KWE}$

IEUF $=.8740$ 
TABLE C.8-5

SUMMARY OF CAPITAL COSTS: DEC. 19784

STEAM CEENERATOR COSTS (INSTALLED)

STEAM CENERATOR RUP COSTS

TUR BI INE GENESATOR COST (INSTALLED)

TIURB - GEN EOP COSTS

FLUE GAS DESULF CDSTS (TNST+EDP)

TOTAL DIRECT COSTS

$=\$ 1.762855 .7$

$=\$ 14703569.6$

$=2998320.2$

$=\$ 3502599.1$

INDIRECIT COSTS

ENGINEER ING

CONYTEENCY (20\%)

SIISTOTAL.

INTEREST DUR ING CONGTRUCTION (36 MO.) EGCALATION DURING CONSTRUCTION

$=\$ 35965664.8$.

TOTAL CAP ITAL COST

$=\$ 5394849.7$

$=3596566.5$

$=\$ 7193133.0$

$=\$ 52150214.0$

$=\$ 8630860.4$

$=\$ 6317916.9$

$=\$ 6,7098991.3$

SPECIFIC CAPITAL COST ( $\$ / k W T)$

$=379.32$ 


\section{TABLE C. $8-6$}

\section{RAT:: OF RETURN ON EQUITY SUMMARY \\ EOR TNDUSTRIAL COGENERATION}

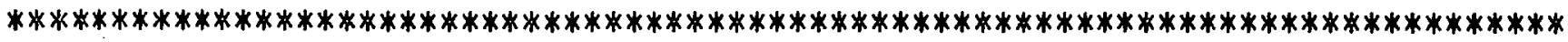

ENERGY UTILIZATION SYSTEM CHARACTERTZATTON

WR ITING PAPER MILL

\begin{tabular}{|c|c|c|c|}
\hline REQUIREID RATIO OF PROCESS HEAT/ELECTRICITY & $=$ & 5.2340 & \\
\hline REQQUIRED PRQC,ESS, HEAT & $=$ & 635218240.0 & ( $K W H / Y R)$ \\
\hline REQUIRED ELECTRIC ENERGY & $=$ & 121363820.0 & $(K W H / Y R)$ \\
\hline SUPPLEMENTAL ELECTRIC ENERGY PURCHASED & $=$ & 44807521.0 & $(K W H / Y R)$ \\
\hline ASSUMED CAPACITY FAC:TOR & $=$ & .52 .50 & \\
\hline ASSUMED STANDEY POWER FRACTION & $=$ & 1.0000 & \\
\hline
\end{tabular}

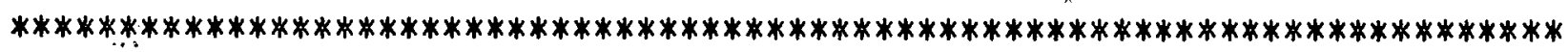

ENERGY CONUERSION SYSTEM CHARACTERIZATION

COAL -FIRED STEAM WITH BPT

$* * * * * * * * * * * * * * * * * * * * * * * * * * * * * * * * * * * * * * * * * * * * * * * * * * * * * * * * * * * * * * * * * * * * * * * * * *$

ACTUAL RATIO OF PROCESS HEAT/ELECTRICITY

IDEAL ENERGY UTILIZATION FACTOR =

$=8.2974$

SPECIFIC, CAPT.TAL COST DF CONUERSION SYSTEM

INCR . LAEOR COST (INDUSTRY) (IST YEAR)

INCR. LAEOR COST (UTILITY) ( $1 S T$ YEAR)

INCR . LABOR COST (3RD PARTY) (1ST YEAR) =314798.0156 (\$)

*********************************************************************************** . 
TABLE C.8-6 (cont'd.)

WRITING PAPER MILL.

ECONOMIC AND FINANCIAL ASSUMPTIONS

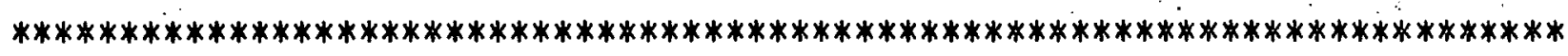

DEET / EQUTTY RATIO (INDUSTRY)

DEET \% EQUITY RATIO (UTILITY)
DEETT

LIFE: OF PROJECT

LIFE OF INUESTMENT FOR TAX PURPOSE:S

INCOME TAX RATES (FEDERAL. + STATE)

INTEREST RATE ON DEET

INUESTMENT TAX CREDIT RATE:

ITCR UNDER SGEPARATE GENERATION (INDUSTRTAL) ITCR UNDER SEPARATE GENERATJON (UTILTTY) PROPERTY TAX RATE (IST YEAR)

INSURANCE RATE: (1ST YEAR)

CHARGE FOR STANDHY POWER

MAINTENANCE \& SUPPLIES COST FAC:TOR (1ST YR) : =

BOILER HEAT RATE (SEPARATE GENERATION)

CIENTRAL:. STATION EUS BAR HEAT RATE

TRANSMISSION LOSSES OF PURCHASED POWER

SPECIFIC: CAPITAL. COST DF NEW UTTLITY STATION =

PRICE OF PROCESS STEAM (1ST YR)

PRICE OF POWER AT CENTRAL STATION BUS BAR = PRICE QF POWER BOUGHT FROM UTILITY (1ST YR) = PRICE OF FOWER SOLD TO UTILITY ( $1 S T$ YR) = PRICE OF FUEL (COGENERATION)

PRICE OF FUEL, (SEP.GEN.: INDUSTRY)

PRICE OF FUEL (SEP.GEN.: UTILITY )

GENERAL INFLATION RATE:

FUEL PRICE RELATIVE ESC. (COGENERATION FUEL)

FUEL PRICE REL. ESC. (SEP. GEN. : INDUSTRY).

FUEL PRICE REL. ESC. (SEP.GEN.: UTILITY)

RELATIVE ESC. OF ELECTRICAL ENERGY COSTS

RELATIUE ESC. OF PROCESS STEAM COSTS $=\quad .5000$

$\begin{array}{llll}1.0 & 0 & 0 & 0 \\ 5.0 & 0 & 0 & 0\end{array}$

$=$

$=$

$=$

$=$

$=$

$=$

$=$

$=$

$=$

$=$

$=$

$=$

$=$

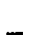

$=$

$=$

$=$

$=$

$=$

$=$

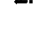

$=$

$=$

$=$

$=$

$=$

$=$

$=$
26 (YEARS).

2E: (YEARS)

$.5650(\% / 1.00)$

$.1000(\% / Y R / 100)$

$.2000(\% / 100)$

$.2000(\% / 100)$

$.1000 .(\% / 100)$.

$.0150(\% / 100)$

$.0150(\% / 1.00)$

$66.1108(\$ / K W)$

$.0375(\% / 100)$

3750.0000 (BTU/KWH)

9500.0000 (BTU/KWH)

$.1000(\% / 100)$

$1000.0000(\$ / \mathrm{KW})$

$3.8464\left(\$ / 10^{\wedge} 6\right.$ ETU $)$

.0190 (\$/KWH)

.0317 (\$/KWH)

.0190 (\$/KWH)

$1.4775\left(\$ / 10^{\wedge} 6\right.$ ETU )

1. $4775 ;\left(\$ / 1.0^{\wedge} 6\right.$ ETU $)$

1.4775 ( $\$ / 10^{\wedge} 6$ BTU)

$.0750(\% / 100 / Y R)$.

$.0560(\% / 100 / Y R)$

$.0560(\% / 100 / Y R)$

$.0560(\% / 100 / Y R)$

$.0210(\% / 100 / Y R)$

$.0280(\% / 100 / Y R)$ 
WR ITING PAPER MILL

FOR INDUSTR IAL QWNERSHIP

\section{- INCREMENTAL CAPITAL INUESTMENT}

NET INCREMENTAL EQUITY CAPITAL INUESTMENT

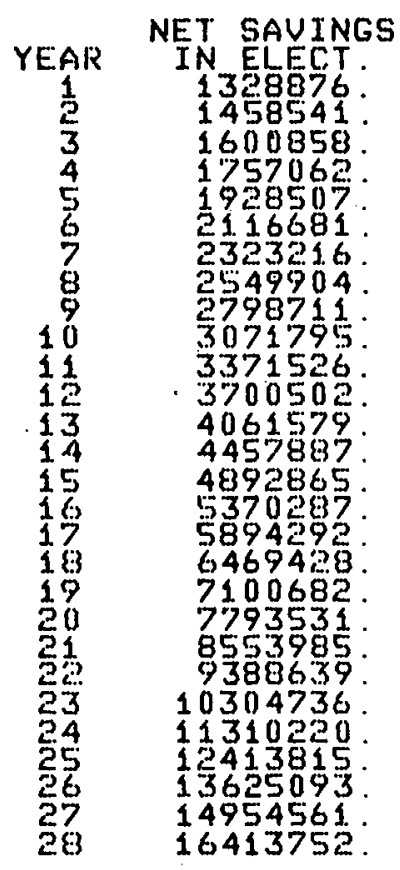

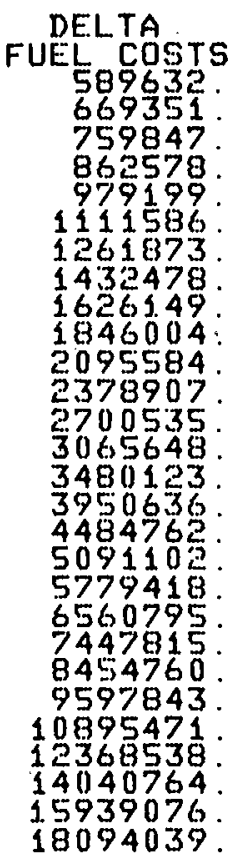

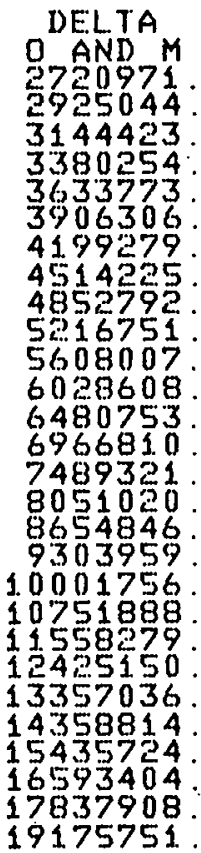

$=37541.664(\$)$
$=\quad 20022221(\$)$

DEE.TA

PROP.TAX TNCOME TAXE:S

\& INSUR ON SAUTNGS

$-3925872$

$\begin{aligned} 1210719 & -4008435 \\ 1301522 & -4302165\end{aligned}$

$1399137^{\circ}-4208106$

$1504072 . \quad-432741$.

$1616877^{\circ}-4461365$.

$1738143 . \quad-4611386$

$1868504 \quad-4779053$

$2008642 . \quad-4966126$.

$2159390 . \quad-5174561$

$2321236 . \quad-5406541$

$2495329 . \quad-5664505$.

$2682479 . \quad-5951174$

2883665 - -6269597

$3099939^{\circ} \quad-66231.82$.

$3332435 . \quad-7015755$

$3582367 . \quad-7451603$

$3851045 . \quad-7935541$

$4139873 . \quad-8472981$.

$4450364 . \quad-9070006$

$4784141 . \quad \ldots 9733468$.

$5142951 . \quad-10471077$

$5528673 .-11291529$

$5943323 . \quad-12204628$

$6389072 . \quad-13221439$

$6868252 . \quad-14354456$

$7383371--15617706$

$7937124 . \quad-17027415$.

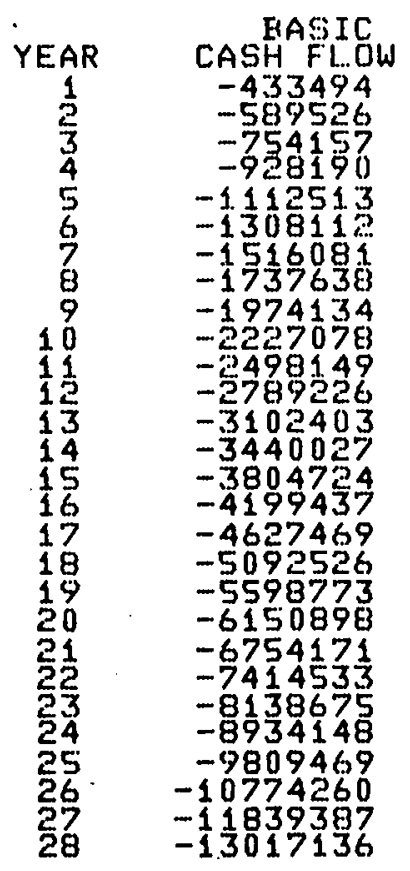

DISCOUNTED CASH FLOW RATE OF RETURN ON EQUITY(ROE) $=<0 \%$ ANNUAL ENERGY SAUED UNDER COGENERATION = 
WR ITING PAPER MILL

FOR UTILITY OWNERSHIP

INCREMENTAL CAPITAL INUESTMENT

NEET INCREMENTAL EQUITY CAPITAL. INUESTMENT

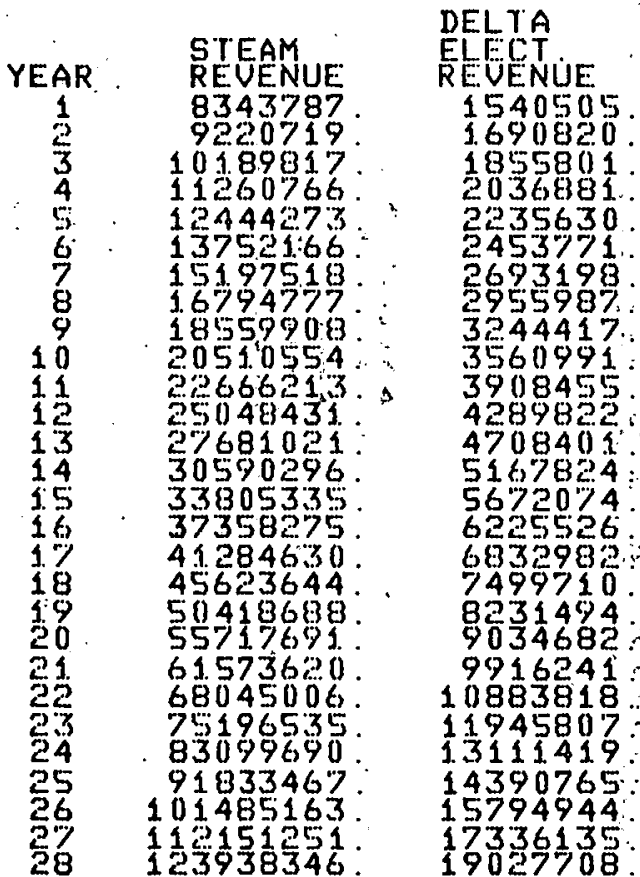

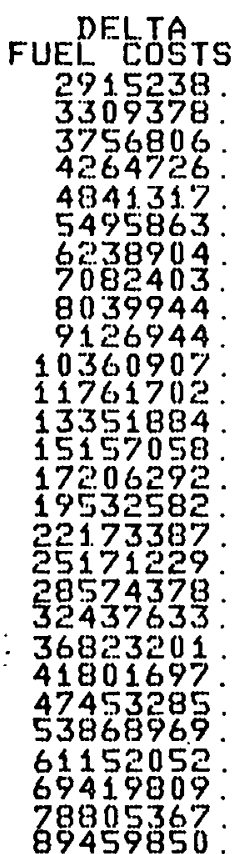

YEAR
1
2
3
3
4
5
6
7
8
9
10
11
12
13
14
15
16
17
18
19
20
21
222
23
24
25
26
27
28

$$
\begin{aligned}
& \text { CASH FLDW } \\
& 3740516 \\
& 3941974 \\
& 4166124 \\
& 4414623 \\
& 4689004 \\
& 4991673 \\
& 5323899 \\
& 5687905 \\
& 6085356 \\
& 6518536 \\
& 6989336 \\
& 7499713 \\
& 8051569 \\
& 8646697 \\
& 9286736 \\
& 9973111 \\
& 10706945 \\
& 11488981 \\
& 12319472 \\
& 13198047 \\
& 14123563 \\
& 15093925 \\
& 16105872 \\
& 17154730 \\
& 18234117 \\
& 19335600 \\
& 20448294 \\
& 21558399
\end{aligned}
$$

$=47382200(\$)$
$=\quad 21321990(\$)$

DELTA 2091631 2417140 2598426 2793308 3002806 3228016 3470118 3730376 4010154 . 4310916 . 4634235 4981802 . 5355437 5757095 6188877. 6653043 . 7152021. 7688422. 8265054 8884933 9551303 1. 0267650 . 11865553 12755470
13712130
14740539
TAXES

$-1232203$.

$-663563$.

-349238 . $-13037$. 34.6484 730786. 1141327. 157.9538 . 2046799 2544398 . 3073493 . 3635057. 4229816 . 4858174 . 5520121. 6345127. 6942012. 8699799. 9089054 10112789 . 10946423. 12603399 . 3400118 . 4452485.

\section{ADJUSTED}

CASH FLOW

3024594

2577419

1887279

1620979

1395275

1039513

899304

778944

675348

585966

5083679

341723

333120

$28 \% 182$

250913

188461

163077

140924

104723

947207

77176

65996

DISCOUNTED CASH FLOW RATE OF RETURN ON EQUITY(ROE) $=23.67 \%$ ANNUAL ENERGY SAUED UNDER COGENERATION =

456326.7500 METU/YR 
TABLE C. 8-7c

WRITING PAPER MILL

FOR THIRD PARTY QWNERSHIP

CAPITAL INUESTMENT

NET EQUITY CAPITAL INUESTMENT

$$
\begin{aligned}
& =\quad 66960623(\$) \\
& =\quad 8928083(\$)
\end{aligned}
$$

I)ELTA

REUENUंE 1328876 . j. 458541 . 1600858 . 1.757062 . 1928507 2116681 2323216 . 2549904 2798711 3071795 . 3371526 3700502 4061579 4457887 4892865 5370287 6469428 7100682. 7793531 9383639 . 10304736 . 11310220. 12413815 . 13625093 . 14954561 .

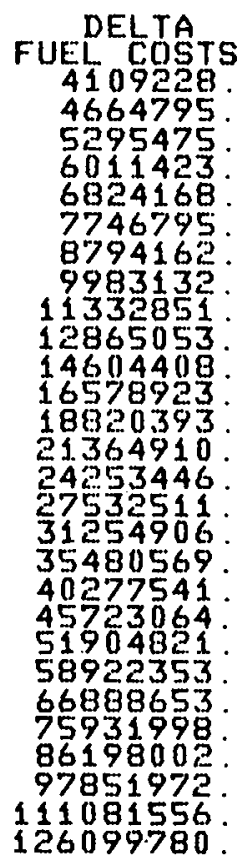

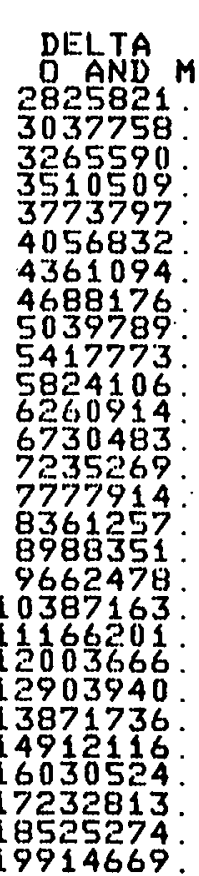
TAXES $-5350115$ - 5206967. $-5062401$. $-4917136$. $-4772112$. $-462852 \%$ -4487905 .

$-4352132$. -4223550 . $-4105029$ -4000066.
-3912897. $-3848628$ $-3813392$ $-3914517$ -3860738 . $-3962433$. -4131896 . $-4383657$ -4734851. -52056.36 . $-5819693$. $-6604776$. $-7593381$. $-8823480$ -10339398 . $-12192793$.

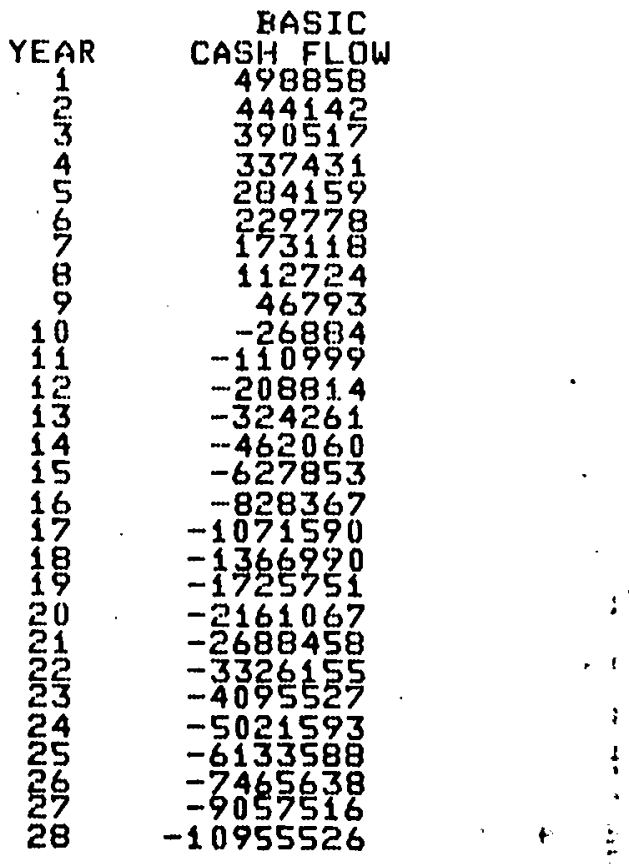

\footnotetext{
DISCOUNTED CASH FLOW RATE OF RETURN ON EQUITY(ROE) $=\langle 0 \quad x$ ANNUAL ENERGY SAUED UNDER COGENERATION = 
TABLE $\quad$ C. $8-8$

FUEL UTILIZATION

WRITING PAPER MILL

Separate Generation

Savings

011

(MBtu/yr)

(MBtu/yr)

(MBtu/yr)

Gas

501485

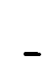

501485

Coal

2735955

2781118

$-45163$

Overall $\quad 3237440$

2781118

456322

Percent Energy Savings $=14.1 \%$ 


\section{9 KRAFT PAPER MILL}

The Kraft paper mill located in DOE Region I is really two plants interconnected electrically but not thermally. Plant No. 1 is a paper mill which currently has a limited amount of cogeneration, both mechanical drive and electrical generation $(\sim 2,100 \mathrm{~kW})$. A model of the energy utilization subsystem for Plant No. 1 is shown in Figure C.9-1. The corresponding state . point data is shown in Table C.9-1. Process steam is required at three pressure levels; 265, 155, and 55 psia. Power steam is required at 155 psia. The overall* steam generation profile for Plant No. 1 is as follows:

$$
\begin{aligned}
& \text { Maximum monthly average - 208,000 Ib/hr } \\
& \text { Minimum monthly average - 147,000 1b/hr } \\
& \text { Annual average rate } \quad-179,000 \mathrm{lb} / \mathrm{hr} \\
& \text { Capacity factor } \quad-0.86
\end{aligned}
$$

Plant No. 2 is a pulp and paper mill which currently has a substantial amount of cogeneration, both mechanical drive and electric generation $(\sim 12,600 \mathrm{~kW})$. Process and power steam are required at 415 psia and process steam at 155 psia. The overall* steam generation profile for Plant No. 2 is as follows:

$$
\begin{aligned}
& \text { Maximum monthly average - 647,000 1b/hr } \\
& \text { Minimum monthly average - 501,000 } \mathrm{lb} / \mathrm{hr} \\
& \text { Annual average rate - 570,000 } 1 \mathrm{~b} / \mathrm{hr} \\
& \text { Capacity factor } \quad-0.88
\end{aligned}
$$

This company has plans to install a bark-burning boiler in Plant No. 2, capable of generating $200,000 \mathrm{lbs}$. per hour of steam at $850 \mathrm{psig}, 735^{\circ} \mathrm{F}$. Initially, this boiler will be operated at 400 psig to supply an existing 400 psig header. The installation of a steam turbine generator with 850 psig, $735^{\circ} \mathrm{F}$ throttle conditions would be made at a future date.

Since the proposed installation of a bark-fired boller in Plant No. 2 would substantially reduce the consumption of fuel oil there, it was decided that Plant No. I had the greatest potential for improvement and should be the subject of optimization in this study. The reference configuration for Plant No. 2 was assumed to be with the bark-flred boller producing 400 psig steam.

Consumption of electrical power by the Kraft paper mill complex is very nearly constant around the year. In addition to the 2,100 kW generated in Plant No. 1 and the $12,000 \mathrm{~kW}$ generated in Plant No. 2, there are 5 hydroelectric facilities owned by the company which generate about $6,000 \mathrm{~kW}$. About $8,000 \mathrm{~kW}$ are purchased from the local power company.

\footnotetext{
* Includes steam used for feedwater heating and boiler feed pump drive.
} 


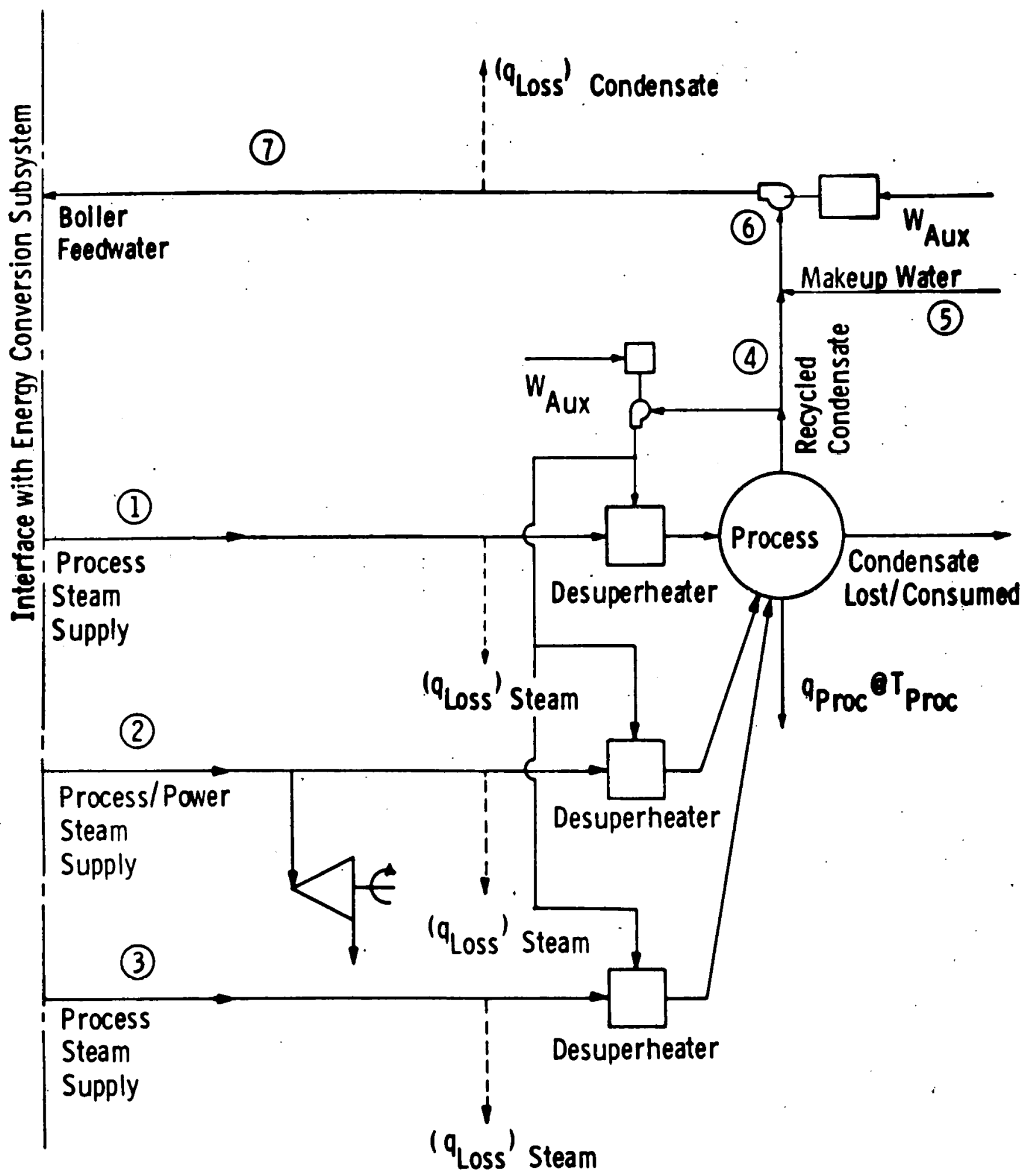

Fig. C.9-1-Model of energy utilization subsystem for Plant No.1 of Kraft Paper Mill (Region I) 
TABLE C.9-1

STATEPOINTS FOR ENERGY UTILIZATION SUBSYSTEM

IN KRAFT PAPER MILL (REGION I)

$\begin{array}{ccccc}\text { Station } & \begin{array}{c}\text { Pressure } \\ (\mathrm{psia})\end{array} & \begin{array}{c}\text { Temperature } \\ \left({ }^{\circ} \mathrm{F}\right)\end{array} & \begin{array}{c}\text { Enthalpy } \\ (\mathrm{Btu} / \mathrm{lb})\end{array} & \begin{array}{c}\text { F1ow Rate } \\ (1 \mathrm{~b} / \mathrm{s})\end{array} \\ 1 & 265 & 620 & 1324 & 7.51 \\ 2 & 155 & 530 & 1288 & 25.22 \\ 3 & 55 & 368 & 1218 & 18.64 \\ 4 & >15 & 200 & 168 & 25.69 \\ 5 & 15 & 100 & 68 & 25.69 \\ 6 & >15 & 150 & 118 & 51.37 \\ 7 & 39.8 & 150 & 118 & 51.37\end{array}$


It was stipulated that the low-pressure steam turbine generator set in Plant No. 1 would be eliminated in the optimized cogeneration system. The net power demand for the two plants would then be the sum of the power currently being purchased and the power now being generated in Plant No. 1 $(8,000+2,100=10,100 \mathrm{~kW})$.

The energy conversion subsystem design factors for the Plant No. 1 cogeneration system are:

$$
\begin{aligned}
& \text { Process steam } \\
& 265 \mathrm{psig} * 27,050 \mathrm{lb} / \mathrm{hr} \\
& 140 \mathrm{psig}-90,780 \mathrm{lb} / \mathrm{hr} \\
& 40 \mathrm{psig}-67,090 \mathrm{~b} / \mathrm{hr} \\
& \mathrm{QS}=461 \times 10^{6} \mathrm{kWht} / \text { year } \\
& \mathrm{EP}=87.95 \times 10^{6} \mathrm{kWh} / \text { year } \\
& \text { RPHEP }=5.24 \\
& \text { Condensate recycle fraction - } 50 \% \\
& \text { Recy.cle condensate temperature }-200^{\circ} \mathrm{F}
\end{aligned}
$$

The candidate energy conversion subsystems considered for this application were

- Coal-fired steam with extraction/back pressure turbine

- Low sulfur residual-fired steam with extraction/back pressure turbine

The optimization analysis showed that both the utility and third-party ownership options are viable and that the ROE is relatively insensitive to the turbine throttle pressure. Figures $\mathrm{C.9}-2 \mathrm{a}$ and $\mathrm{C.9}-2 \mathrm{~b}$ are the optimization curves. The coal-fired steam energy conversion subsystem for this application is shown in Figure C.9-3. State point conditions are given in Table C.9-2. A pulverized coal-fired boiler** with economizer and air preheater generates steam at $915 \mathrm{psia} / 875^{\circ} \mathrm{F}$. The steam turbine has double automatic extraction to supply process steam at 265 and 140 psig and exhausts at a pressure of 40 psig.

The energy distribution for Plant No. 1 is given in Table C.9-3. The ideal energy utilization factor is 0.8647 and the RPHEE is 7.87 . The preliminary capital costs are given in Table C.9-4.

\footnotetext{
*Pressure of 265 psia was inadvertently used in performance calculations **Ohio P1ttsburgh No.- 8 seam coal
} 


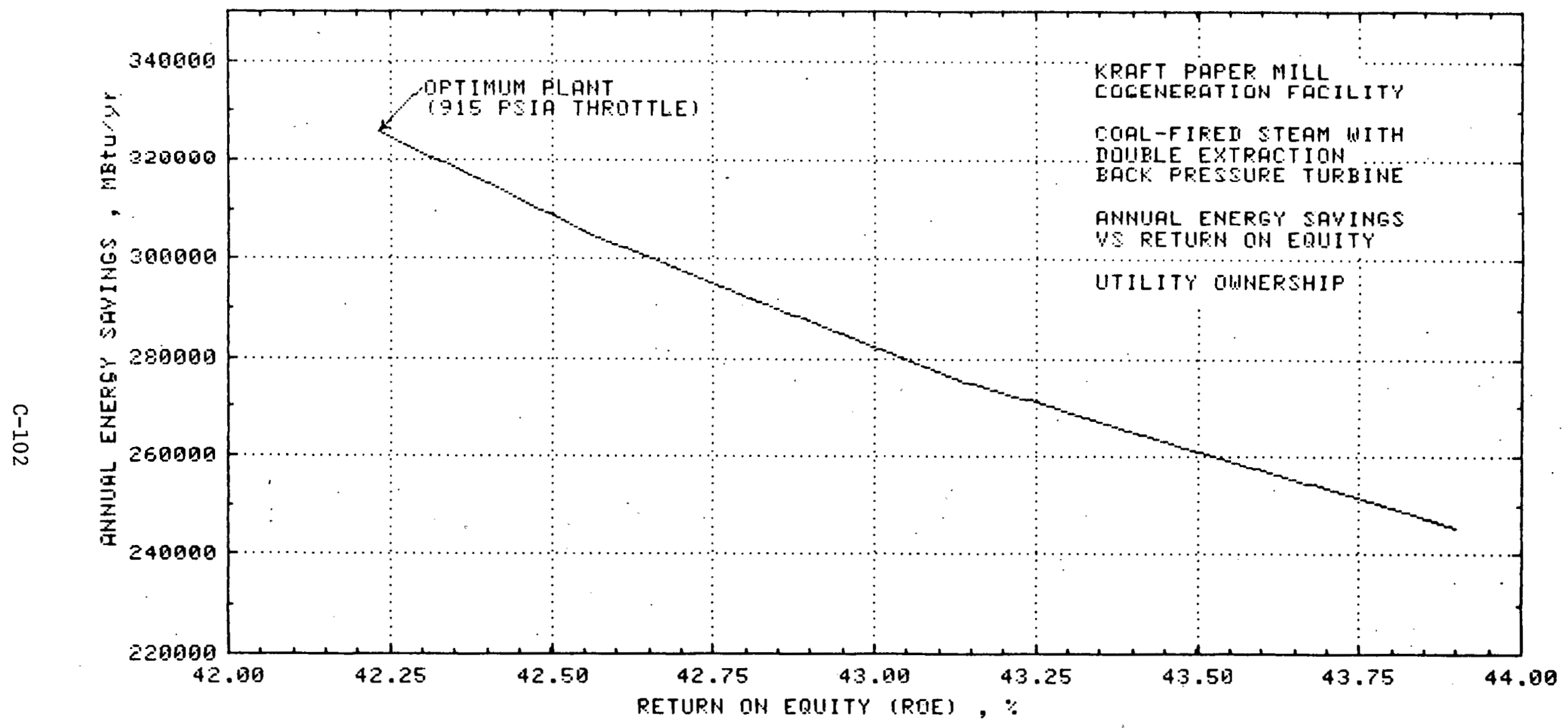

Fig. C.9-za Annul energy savings vs return on equity, utility ownership 


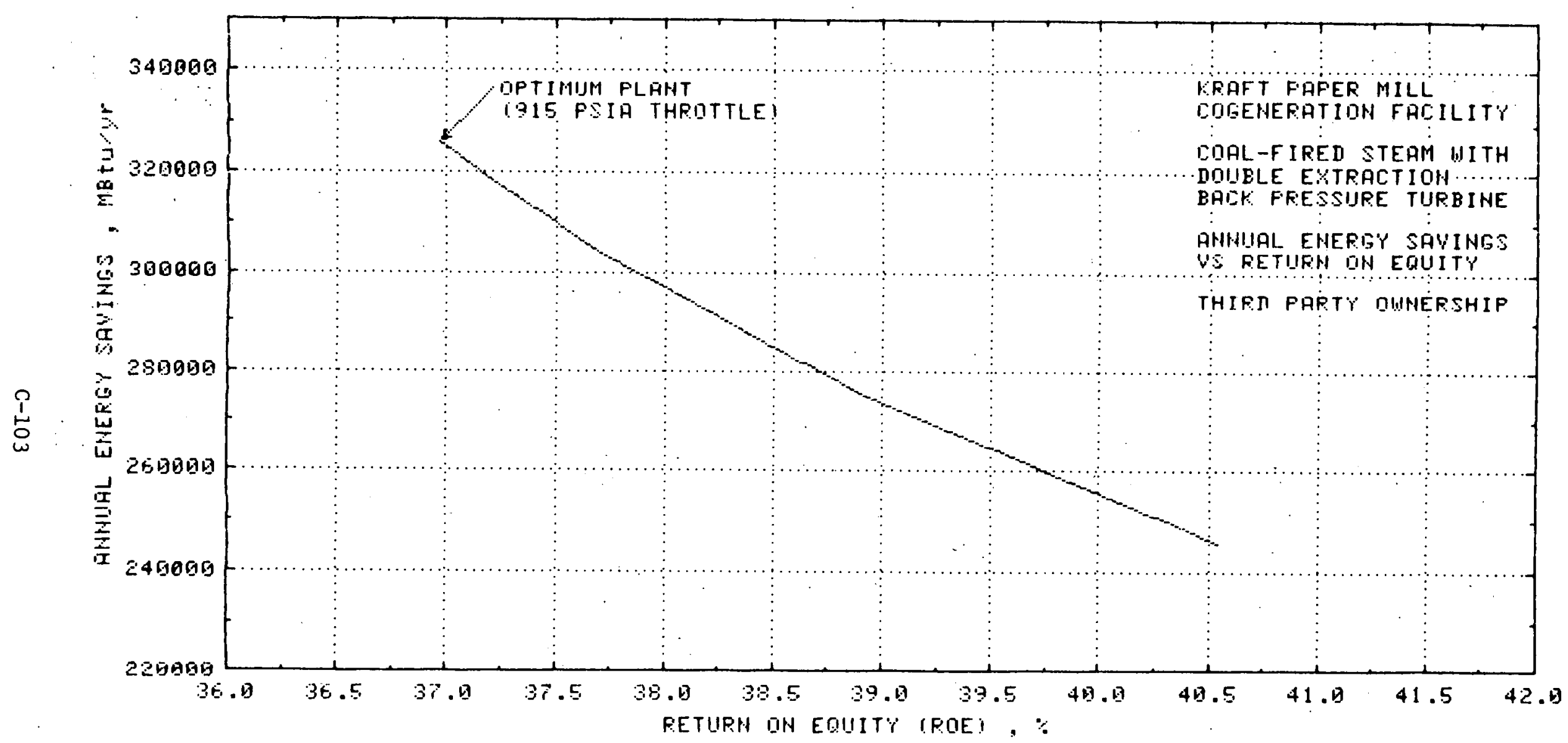

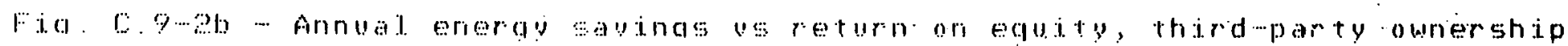




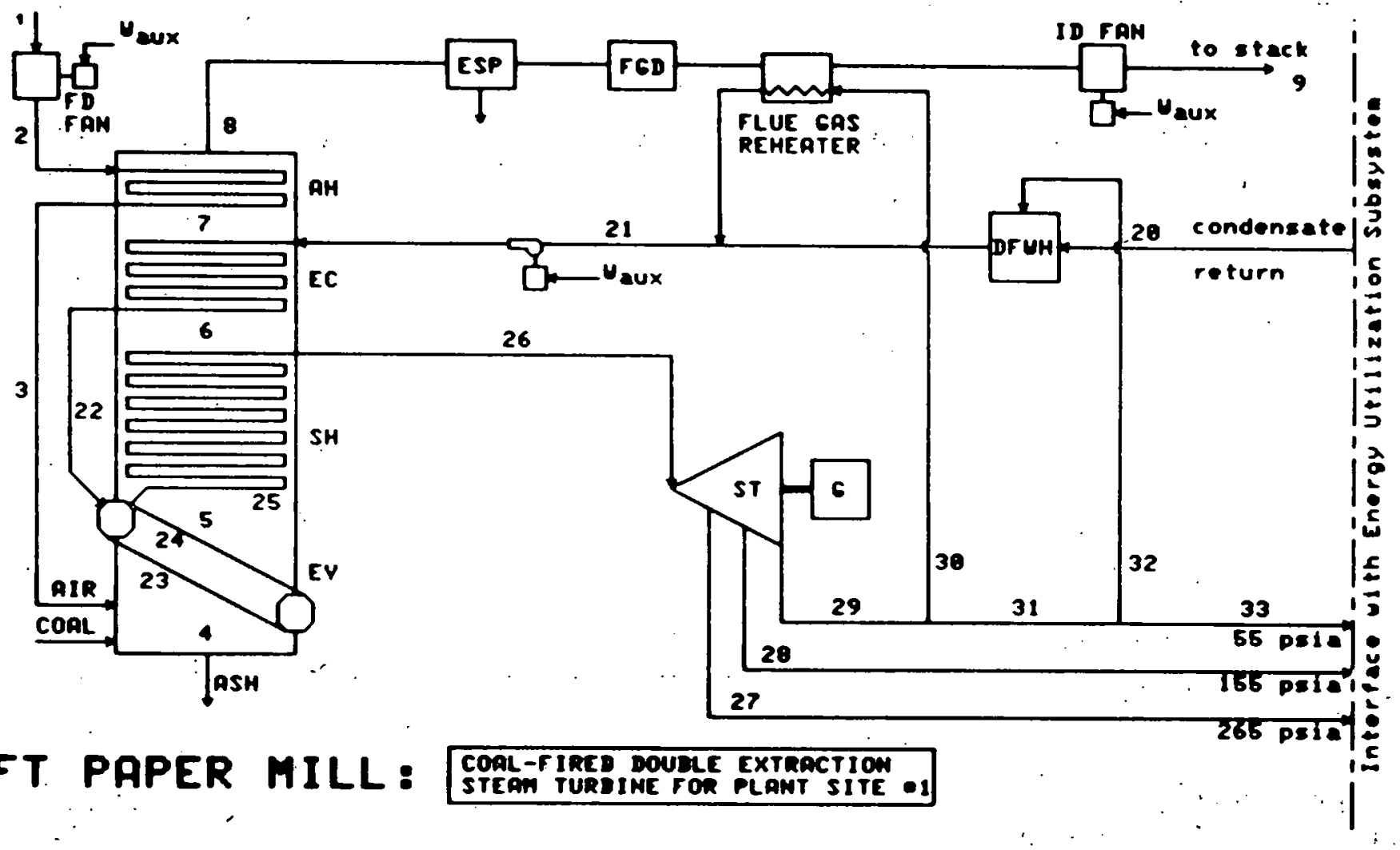

Fig. C.9-3 moded of coad fired steam energy conversion subsystem for kraft paper milis 
TABLE C. 9-2

STATEPOINTS FOR CONVERSION SUBSYSTEM

IN KRAFT PAPER MILL (SITE \#1)

\begin{tabular}{|c|c|c|c|c|}
\hline Station & $\begin{array}{c}\text { Pressure } \\
\text { (psia) }\end{array}$ & $\begin{array}{c}\text { Temperature } \\
\left({ }^{\circ} \mathrm{F}\right)\end{array}$ & $\begin{array}{l}\text { Enthalpy } \\
(B t u / 1 b)\end{array}$ & $\begin{array}{l}\text { Flow } \\
(1 \mathrm{~b} / \mathrm{s})\end{array}$ \\
\hline 1 & 14.7 & 77.0 & 0.0 & 83.21 \\
\hline 2 & 15.9 & 85.0 & 2.0 & 83.21 \\
\hline 3 & 15.7 & 540.0 & 112.7 & 83.21 \\
\hline 4 & $15.5 \%$ & 3212.9 & 929.4 & 89.67 \\
\hline 5 & 15.2 & 1864.5 & 497.6 & 89.67 \\
\hline 6 & 14.9 & 1351.7 & 343.6 & 89.67 \\
\hline 7 & 14.5 & 682.1 & 155.6 & 89.67 \\
\hline 8 & 14.3 & 279.0 & 50.8 & 89.67 \\
\hline 9 & 14.7 & 175.0 & 23.8 & 89.67 \\
\hline 20 & 39.8 & 150.0 & 118.1 & 51.37 \\
\hline 21 & 29.8 & 250.0 & 218.6 & 57.07 \\
\hline 22 & 1040.0 & 252.7 & 223.4 & 57.07 \\
\hline 23 & 965.0 & 540.3 & 537.1 & 104.33 \\
\hline 24 & 965.0 & 540.3 & 668.8 & 104.33 \\
\hline 25 & 965.0 & 540.3 & 1195.6 & 57.07 \\
\hline 26 & 915.0 & 875.0 & 1437.1 & 57.07 \\
\hline 27 & 265.0 & 620.0 & 1324.0 & 7.51 \\
\hline 28 & 155.0 & 530.0 & 1280.0 & 25.22 \\
\hline 29 & 55.0 & 367.9 & 1218.0 & 24.34 \\
\hline 30 & 55.0 & 367.9 & 1218.0 & 5.21 \\
\hline 31 & 55.0 & 367.9 & 1218.0 & 19.13 \\
\hline 32 & 55.0 & 367.9 & 1218.0 & 0.49 \\
\hline 33 & 55.0 & 367.9 & 1212.0 & 18.64 \\
\hline
\end{tabular}


TABLE C.9-3

POWER SUMMARY FOR KRAFT PAPER MILL (SITE \#1)

Steam Turbine Power.

$10283 \cdot \mathrm{kW}$

Flue Gas Desulfurization Auxiliaries

$1657 \mathrm{~kW}$

Auxiliary Power

$594 \mathrm{~kW}$

Boller Feed Pump Power

$273 \mathrm{~kW}$

Net Power Generated

$7757 \mathrm{~kW}$

Fuel Flow (Pittsburgh Seam)

$6.456 \mathrm{1b} / \mathrm{s}$

Fuel Energy Input

$270.37 \times 10^{6}$. Btu/hr.

RPHEE

$7.872 \mathrm{kWt} / \mathrm{kWe}$

IEUF

0.8647 


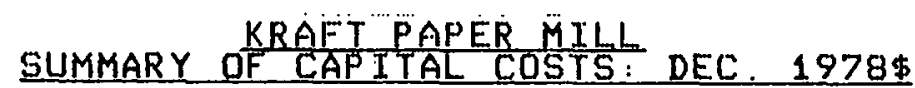

STEAM GENERATOR COST (INSTALLED)

STEAM GENERATOR EOOP COSTS

TURBINE GENERATOR COST (INSTALLED)

TURB-GEN HOP COSTS

FLUE GAS DESULF COSTS (INST+BOP)

TOTAL DIRECT COSTS

$=\$ 510559 \% .4$

$=\$ 6381996.7$

$=\$ 2243600.5$

$=\$ 2243600.5$

$=2163630$.

$=\$ 18138425.0$

IND IRECT COSTS

ENGINEERTNG

SUETOTAL

$=\$ 2.720763 .7$

$=\$ \frac{1813842 \cdot 5}{3627685}$

- $\$ 26300716.2$

INTEREST DURING CONSTRUCTION (36 Mo.) $=\$ 4352768.5$

ESCALATION DURING CONSTRUCTION $=\$ 3186290.6$

TOTAL CAPITAL COST

$=\$ 33839775.3$

SPECIFIC CAPITAL COST $(\$ / k W t)$

$=426.974$ 
This information, with the data given in Table C.9-5 was used to develop the financial analysis shown in Tables C.9-6a, $-6 b$, and $-6 c$ for the ownership options. As was indicated the industrial option was not successful.

The fuel utilization under both separate generation and cogeneration is given in Table C.9-7. While effecting an overall energy savings of $13.7 \%$, the use of oil is entirely eliminated, being replaced by coal. 


\section{TABLE C.9-5}

\section{BATE OF RETURN ON EQUTTY SUMMARY
EOR TNOUTHRIAL. COOENERATION}

$* * * * * * * * * * * * * * * * * * * * * * * * * * * * * * * * * * * * * * * * * * * * * * * * * * * * * * * * * * * * * * * * * * * * * * * * *$

$$
\text { ENERGY UTILIZATION SYSTEM CHARACTERIZATION }
$$

KRAFT PAPER MILL

********************************************************************************

REQUIIRED RATIO OF PROCESG HEAT/ELECTRJCSTY =

$=5.2400$

RE:QUIRED PROCESS HEAT

REQUTRED ELECTRIC: ENE:RGY

SIJPPLEMENTAL ELECTRIC ENEERCY PURCHASED

ASSUMMED CAPACITY FACTTOR

$=460818140.0$ (KWH/YR)

$=87942392.0$ (KWH/YR)

$=2943333.0(K W H / Y R)$

$=.8600$

ASSUMED STANIEYY POWER FRAC:TION

**********************************************************************************

ENERGY CONUERSION SYSTEM CHARACTER IZATION

$* * * * * * * * * * * * * * * * * * * * * * * * * * * * * * * * * * * * * * * * * * * * * * * * * * * * * * * * * * * * * * * * * * * * * * * * * *$

ACTUAL RATID OF PROCESS HEAT/ELECTRICITY =

$=\quad 7.8 \% 60$

IDEAL. ENERGY UTIL...IZATION FACTOR

$=.8647$

SPECIFIC CAPITAL. COST OF CONUERSION SYSTEM

$=426.9740(\$ / \mathrm{KWT})$

INCR. LAEOR COST (INDUSTRY) (IST YEAR)

$=163237.8027(\$)$

INCR. LAEOR COST (UTILITY) (1ST YEAR)

$=122366.2373$ (\$)

INCR . LAEOR COST (3RD PARTY) (1ST YEAR)

$=244856.7051$ ( $\$)$

$* * * * * * * * * * * * * * * * * * * * * * * * * * * * * * * * * * * * * * * * * * * * * * * * * * * * * * * * * * * * * * * * * * * * * * * * * * * * *$ 
TABLE $\quad$ C.9-5 (cont'd)

KRAFT PAPER MILL

ECONOMIC AND FINANCIAL. ASSUMPTIONS

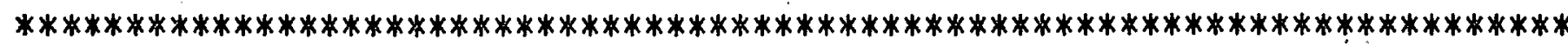

DEET / EQUITY RATIO (INDUSTRY)

DEET ， EQUTTY RATTO (UTILITY)
DEET / EQUITY RATIO (JRD PARTY)

LIFE OF PROJECT

LIFE. OF INUESTMENT FOR TAX PURPOSES

INCOME TAX RATES (FEDERAL + STATE)

INTEREST RATE ON DEET

INUESTMENT TAX CREDIT RATE

ITCR UNDER SEPARATE GENERATION (INDUGTRIAL)

ITCR UNDER SEPARATE GENERATION (UTILITY)

PROPERTY TAX RATE ( 1 ST YEAR)

INSURANCE RATE (1ST YEAR)

CHARGE FOR STANDEY POWER

MAINTENANCE \& SUPPLIES COST FACTOR (IST YR) = BOILER HEAT RATE (SEPARATE GENERATION)

CENTRAL STATION HUS BAR HEAT RATE

TRANSMISSION LOSSES OF PURCHASED POWER SPECIFIC CAPITAL COST OF NEW UTILITY STATION =

PRICE DF PROCESS STEAM ( 1 ST YR)

PRICE OF POWER AT CENTRAL STATION EUS BAR = PRICE OF POWER ROUGHT FROM UTILITY ( $1 S T$ YR) = PRICE OF POWER SOLD TO UTILITY (IST YR) = PRICE OF FUEL (COGENERATION)

PRICE OF FUEL, (SEP.GEN.: INDUSTRY)

PRICE OF FUEL (SEP.CEN.: UTILITY)

GENERAL INFLATION RATE

FUEL PRICE RELATIUE ESC. (COGENERATION FUEL)

FUEL PRICE REL. ESC. (SEP.GEN.: INDUSTRY)

FUEL PRICE REL. ESC. (SEP. GEN.: UTILITY)

RELATIUE ESC. OF ELECTRICAL ENERGY COSTS

RELATIVE ESC. OF PROCESS STEAM COSTS

\begin{tabular}{|c|c|c|c|}
\hline $\begin{array}{l}= \\
= \\
=\end{array}$ & & $\begin{array}{r}5000 \\
.0000 \\
.0000\end{array}$ & \\
\hline$=$ & & 28 & (YEARS) \\
\hline$=$ & & 28 & (YEAR S) \\
\hline$=$ & & 5100 & $(\% / 100)$ \\
\hline$=$ & & .1000 & $(\% / Y R / 100)$ \\
\hline$=$ & . . & .2000 & $(\% / 100)$ \\
\hline$=$ & & .2000 & $(\% / 100)$ \\
\hline$=$ & & .1000 & $(\% / 100)$ \\
\hline$=:$ & & .0150 & $(\% / 100)$ \\
\hline$=$ & & .0150 & $(\% / 100)$ \\
\hline$=$ & 63 & .5608 & $(\$ / K W)$ \\
\hline$=$ & & .0375 & $(\% / 100)$ \\
\hline$=$ & 3750 & .0000 & ( $\mathrm{BTU} / \mathrm{KWH}$ ) \\
\hline$=$ & 9500 & .0000 & ( $\mathrm{BTU} / \mathrm{KWH}$ ) \\
\hline$=$ & & .1000 & $(\% / 100)$ \\
\hline$=$ & 1000 & .0000 & $(\$ / K W)$ \\
\hline$=$ & & .0907 & $\left(\$ / 10^{\wedge} 6\right.$ BTU $)$ \\
\hline$=$ & & .0267 & $(\$ / K W H)$ \\
\hline$=$ & & .0445 & $(\$ / K W H)$ \\
\hline$=$ & & .0267 & $(\$ / K W H)$ \\
\hline$=$ & & .1375 & $\left(\$ / 10^{\wedge} 6\right.$ BTU $)$ \\
\hline$=$ & & .1375 & $\left(\$ / 10^{\wedge} 6\right.$ ETU $)$ \\
\hline$=$ & & .1375 & $\left(\$ / 10^{\wedge} 6\right.$ ETU) \\
\hline$=$ & & .0750 & $(\% / 100 / Y R)$ \\
\hline$=$ & & .0332 & $(\% / 100 / Y R)$ \\
\hline$=$ & & .0332 & $(\% / 100 / Y R)$ \\
\hline$=$ & & .0332 & $(\% / 100 / Y R)$ \\
\hline$=$ & & .0077 & $(\% / 100 / Y R)$ \\
\hline$=$ & & .0175 & $(\% / 100 / Y R)$ \\
\hline
\end{tabular}


TABLE C. $9-6 a$

KRAFT PAPER MILL

FOR INDUSTR IAL OWNERSHIP

$\begin{array}{lll}\text { INCREMENTAL CAPITAL INUESTMENT } & = & 20475313(\$) \\ \text { NET INCREMENTAL EQUITY CAPITAL INUESTMENT } & =10920167(\$) .\end{array}$

\begin{tabular}{|c|c|c|c|c|c|}
\hline & & & & & \\
\hline & NET SAUINGS & DELTA & DELTA & PROP TAX & INCOME TAXES \\
\hline $\begin{array}{c}\text { YEAR } \\
1\end{array}$ & IN ELECT & FUEL COSTS & AND M & $\&$ INSUR & DN SAUINGS \\
\hline$\frac{5}{2}$ & 20 & 766672 & 1539006. & 660329 & -1389709. \\
\hline 4 & 2681732 & 945796. & 1978514 & 763092 & -1401978 \\
\hline 6 & 3146986 & 1166764 & 2055295 & 881849 & $\begin{array}{l}412769 \\
427676\end{array}$ \\
\hline & $\begin{array}{l}3409059 \\
3692957 .\end{array}$ & $\begin{array}{l}1295914 \\
1439358\end{array}$ & 2209443. & $\begin{array}{r}947987 . \\
1019086 .\end{array}$ & $\begin{array}{l}446510 \\
69931\end{array}$ \\
\hline & 4000497. & 1598681 & $5=-5=0=$ & 1095518 & 8449 \\
\hline & 4694543. & 973184 & 3050642 & 177682 & 332637 \\
\hline & 85493 & 90485 & 171 & 360958 & 200648 \\
\hline & 367776. & 432950 & 407 & $\begin{array}{l}3030 \\
3758\end{array}$ & $\overline{-}$ \\
\hline 5 & 64757 & 001365 & 940492 & 690714 & 813749 \\
\hline 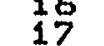 & 86320 & 586 & 028 & 817518 & 287 \\
\hline 18 & 518099. & 15400 & 1895260 & 2100369 & 3104877. \\
\hline 29 & 702481. & 367623 & 262 & 2257897 & 29859 \\
\hline 21 & 446974 . & 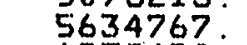 & $\therefore$ & 609282 & 2531847 \\
\hline 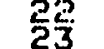 & 721 & & $748+2$ & 304978 & 712939 \\
\hline 4 & 13280354 & & 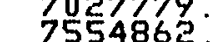 & $55 \frac{1}{3}$ & \\
\hline 5 & 14386 & 85 & (1) & 4615 & 6434 \\
\hline & 64. & 0 & 3 & $\begin{array}{l}5961 \\
6908\end{array}$ & $\begin{array}{l}7729 \\
5048\end{array}$ \\
\hline & & & & 9700 & \\
\hline
\end{tabular}

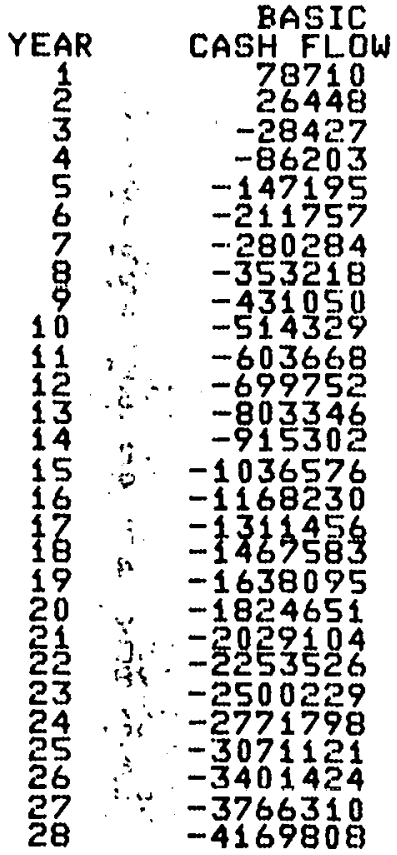

SISCOUNTED CASH FLOW RATE OF RETURN ON EQUITY(ROE) $=\cdots<0 ; x$ ANNUAL ENERGY SAUED UNDER COGENERATION $=325729.5937 \mathrm{MBTU} / \mathrm{H}$ 
TABLE C.9-6b

KRAFT PAPER MILL

FOR UTJLITY OWNERSHIP

INCREMENTAL CAPITAL INUESTMENT

$=24760430(\$)$

NET INCREMENTAL EQUITY CAPITAL INUESTMENT

$=9450998 \cdot(\$)$

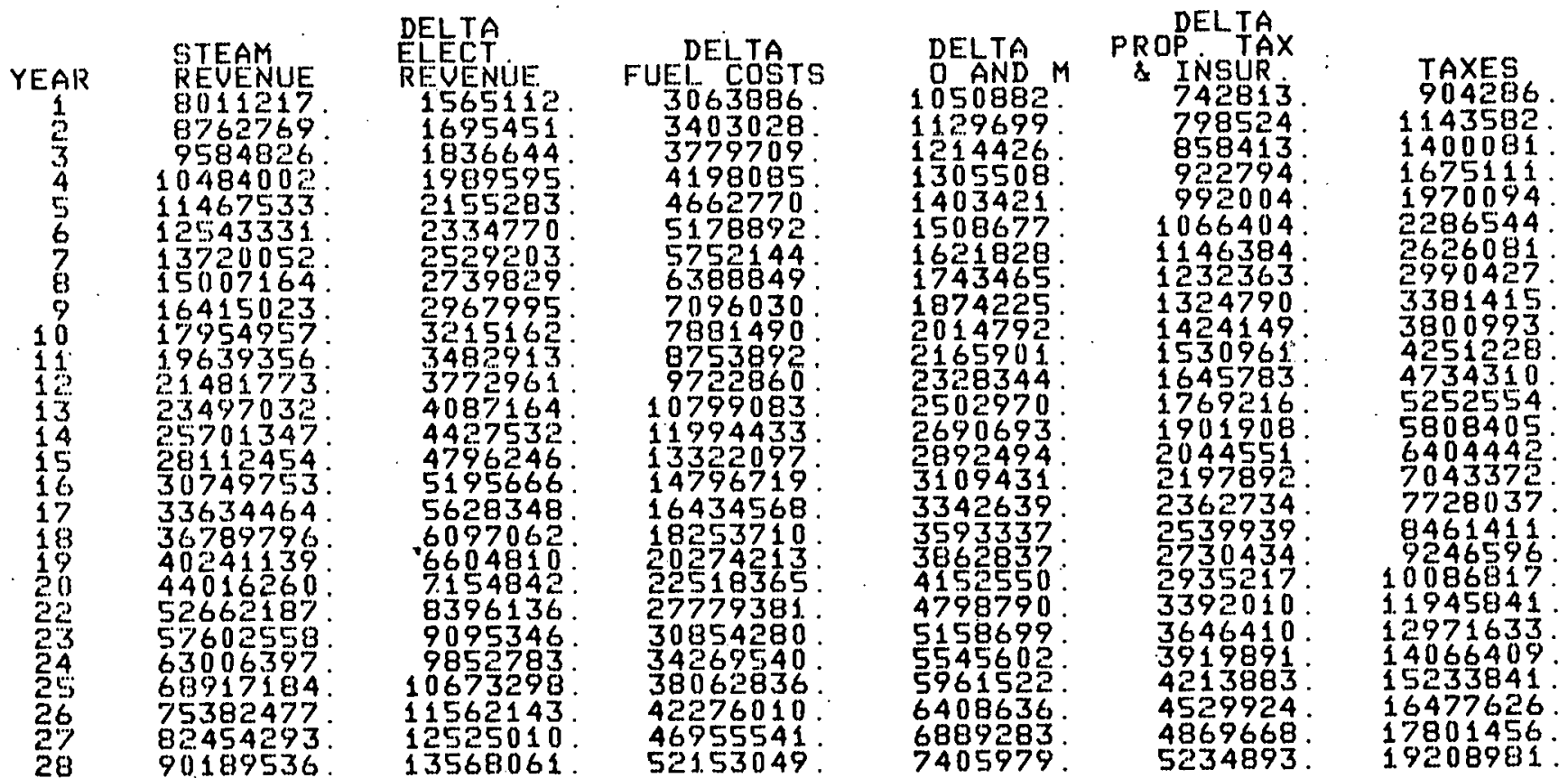

\begin{tabular}{|c|c|c|}
\hline $\begin{array}{c}Y E A R \\
1 \\
2 \\
3 \\
4 \\
4 \\
5 \\
6 \\
7 \\
8 \\
9 \\
10 \\
11 \\
12 \\
13 \\
14 \\
15 \\
16 \\
17 \\
18 \\
19 \\
20 \\
21 \\
22 \\
23 \\
23 \\
24 \\
25 \\
26 \\
27 \\
28\end{array}$ & $\begin{array}{c}\text { HASIC } \\
\text { CASH FLOW } \\
3319252 \\
354388 \\
3789232 \\
4056871 \\
4349509 \\
4665964 \\
5011180 \\
5386230 \\
5793326 \\
6234923 \\
6713226 \\
7231199 \\
7791568 \\
8397326 \\
9051645 \\
9757874 \\
10519546 \\
1134379 \\
12224281 \\
13175348 \\
14197863 \\
15296299 \\
16475269 \\
17739608 \\
19094262 \\
20544323 \\
22095006 \\
23751566\end{array}$ & 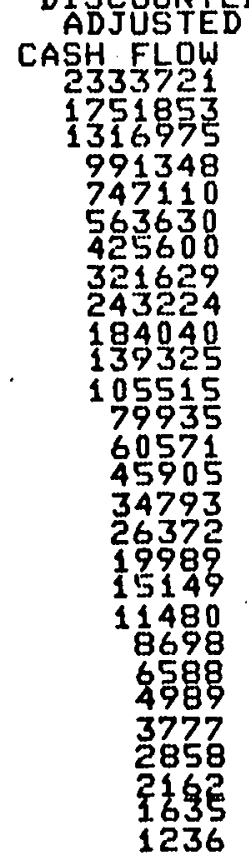 \\
\hline
\end{tabular}

DISCOUNTED CASH FLOW RATE OF RETURN ON EQUITY(ROE) = $42.23 \%$ ANNUAL ENERGY SAUED UNDER COGENERATION $=325729.5937 \mathrm{MBTU} / \mathrm{Y}$ 
KRAFT PAPER MILL

FOR THTRD PARTY OWNERSHTP

CAP I TAL INUESTMENT

NET EQUITY CAPITAL INUESTMENT

$=\quad 33823896(\$)$
$=\quad 4509852(\$)$

PROP. TAX

\& INSUR

1014717 .

$11963 . \quad-819479$.

$1260580^{\circ}-\quad-450347$.

$1355123 . \quad-251584$.

$1456757 .-42823$.

1566044 176308.

1683465 . 406155 .

1809725 . 647018 .

$1945454 \quad 899146$.

$2091363 \ldots 1162723$.

2248215.1437844 .

2416835.1724503

2598094

5790951 .

300542.

3227604 .

3469674 .

3729900

4009642 .

4310365 .

4633643.

4981166.

5354753 .

5756360

6188086

6852193 .

2022569 .

2331957.

2981415.

3320262 .

3666898.

4049725.

4376729.

4735414 .

$5092 \% 1.7$.

5444926 .

5787572

8584490.

9228337

9920451.
10664485

6115316 .

64218112 .

54463563.

15584364

67186773

\begin{tabular}{|c|c|c|}
\hline & & \\
\hline & BASIC & $\begin{array}{l}\text { DISCOUNTED } \\
\text { AD JUSTED }\end{array}$ \\
\hline & CASH FLOWW & CASH FIOWW \\
\hline & 1462030 & 779301 \\
\hline & $\begin{array}{l}1650066 \\
1757724\end{array}$ & $\begin{array}{l}4683813 \\
364606\end{array}$ \\
\hline 6 & $\begin{array}{l}1874986 \\
2002216 \\
2139738\end{array}$ & $\begin{array}{l}28.3953 \\
221377 \\
175726\end{array}$ \\
\hline & $\begin{array}{l}2287846 \\
244677 \%\end{array}$ & $\begin{array}{l}134833 \\
105279\end{array}$ \\
\hline & $\begin{array}{l}2616707 \\
2797729\end{array}$ & $\begin{array}{l}82201 \\
641.65\end{array}$ \\
\hline & $\begin{array}{l}2989836 \\
3192903\end{array}$ & $\begin{array}{l}50063 \\
39033\end{array}$ \\
\hline 15 & $\begin{array}{l}3406656 \\
3630646\end{array}$ & $\begin{array}{r}30405 \\
23658\end{array}$ \\
\hline & $\begin{array}{l}3864217 \\
4106466\end{array}$ & $\begin{array}{l}18384 \\
14263\end{array}$ \\
\hline 20 & $\begin{array}{l}4356198 \\
4611879\end{array}$ & $\begin{array}{l}11046 \\
8538\end{array}$ \\
\hline 50 & $\begin{array}{l}487553 \\
5132882\end{array}$ & 6585 \\
\hline & 392862 & 3885 \\
\hline לִ & $\begin{array}{l}5647950 \\
5893849\end{array}$ & $\begin{array}{l}2971 \\
2263\end{array}$ \\
\hline 7 & $\begin{array}{l}6125430 \\
6336596\end{array}$ & $\begin{array}{l}1717 \\
1297\end{array}$ \\
\hline & 65201 & \\
\hline
\end{tabular}

DISCOUNTED CASH FLOW RATE OF RETURN ON EQUITY(ROE) $=36.97 \%$ ANNUAL ENERGY SAUED UNDER COGENERATION $=325729.5937 \mathrm{METU} /$ YR 
TABLE C.9-7

FUEL UTILIZATION, KRAFT PAPER MILL (SITE NO. 1)

$\begin{array}{ccc}\begin{array}{c}\text { Separate Generation } \\ (\text { MBtu/yr) }\end{array} & \begin{array}{c}\text { Cogeneration } \\ (\text { MBtu/yr) }\end{array} & \begin{array}{c}\text { Savings } \\ (\text { MBtu/yr) }\end{array} \\ - & - & - \\ 1728068 & - & 1728068 \\ 648941 & 2051118 & -1402177 \\ 2377009 & 2051118 & : 325891\end{array}$

Percent Energy Savings $=13.7 \%$ 
The textile finishing mill is located in South Carolina (DOE Region IV). The energy demands for the plant are as follows:

- Process steam (325 psia)
- Process steam (165 psia)
- Electricity
- RPHEP

$$
\begin{aligned}
& 410.49 \times 10^{6} \mathrm{kWht} / \mathrm{yr} \\
& 165.84 \times 10^{6} \mathrm{kWht} / \mathrm{yr} \\
& 65.02 \times 10^{6} \mathrm{kWhe} / \mathrm{yr} \\
& 8.86 \mathrm{kWt} / \mathrm{kWe}
\end{aligned}
$$

A small amount of hot gas heating for drying and curing, which is lumped in the above tabulation with the process steam, is also required.

Three alternatives for fulfilling these needs suggest themselves. The first two represent partial cogeneration cases. Currently, natural gas is burned to provide the hot gas heat while dual fuel (oil/gas) boilers are used to generate process steam. The first alternative would replace the natural gas burners with a combustion turbine using exhaust gases for the direct heating. The existing boilers would continue to provide process steam. The second alternative would convert the existing boilers to an unfired mode, using the existing heat transfer surface to generate process steam with the exhaust from a new combustion turbine. Natural gas would continue to be used for drying and curing.

Neither of these options would provide significant energy savings and both would require the continued use of economically sensitive fuels. The third option, the one eventually chosen, is a conventional coal-fired power boiler with a single extraction back pressure turbine providing the main process steam (at 165 psia) as well as sufficient steam (at 325 psia) for use in steam/air heaters to satisfy the direct heating requirements.

The energy utilization system model is given in Figure C.10-1. The conditions at the indicated statepoints are given in Table C.10-1: The system to be optimized for energy savings is shown in Figure C.10-2. A range of throttle pressures was analyzed in order to assess the effect on cycle performance and cost. Figures $c .10-3 a$ and $c .10-3 b$ represent the optimization plots for the utility and third-party ownership. Both show a reasonable return on equity: The maximum energy savings occur at the highest allowable steam turbine throttle pressure (1215 psia). The optimum case was, therefore, determined to correspond to the highest allowable steam conditions feasible in this size-range (1215 psia). Table C.10-2 contains the pertinent data on steam and gas conditions and flow rates corresponding to the points in Figure C.10-2.

Steam is generated in conventional boller, fed with pulverized Alabama coal having the composition noted in Table C.10-3. The turbine expands the steam from its throttle pressure if 1215 psia to 165 psia, extracting a fraction of the flow at 325 psia. The gross power generated by the turbine is $19.7 \mathrm{MW}$ at design load. A quantity of steam is recycled to the deaerating feedwater heater to bring the recycled and make-up condensate to saturation at the return pressure of 29.8 psia. Another sidestream is used to reheat the flue gas from the desulfurization system to a temperature adequate to provide a draft at the stack. Table C.10-4 


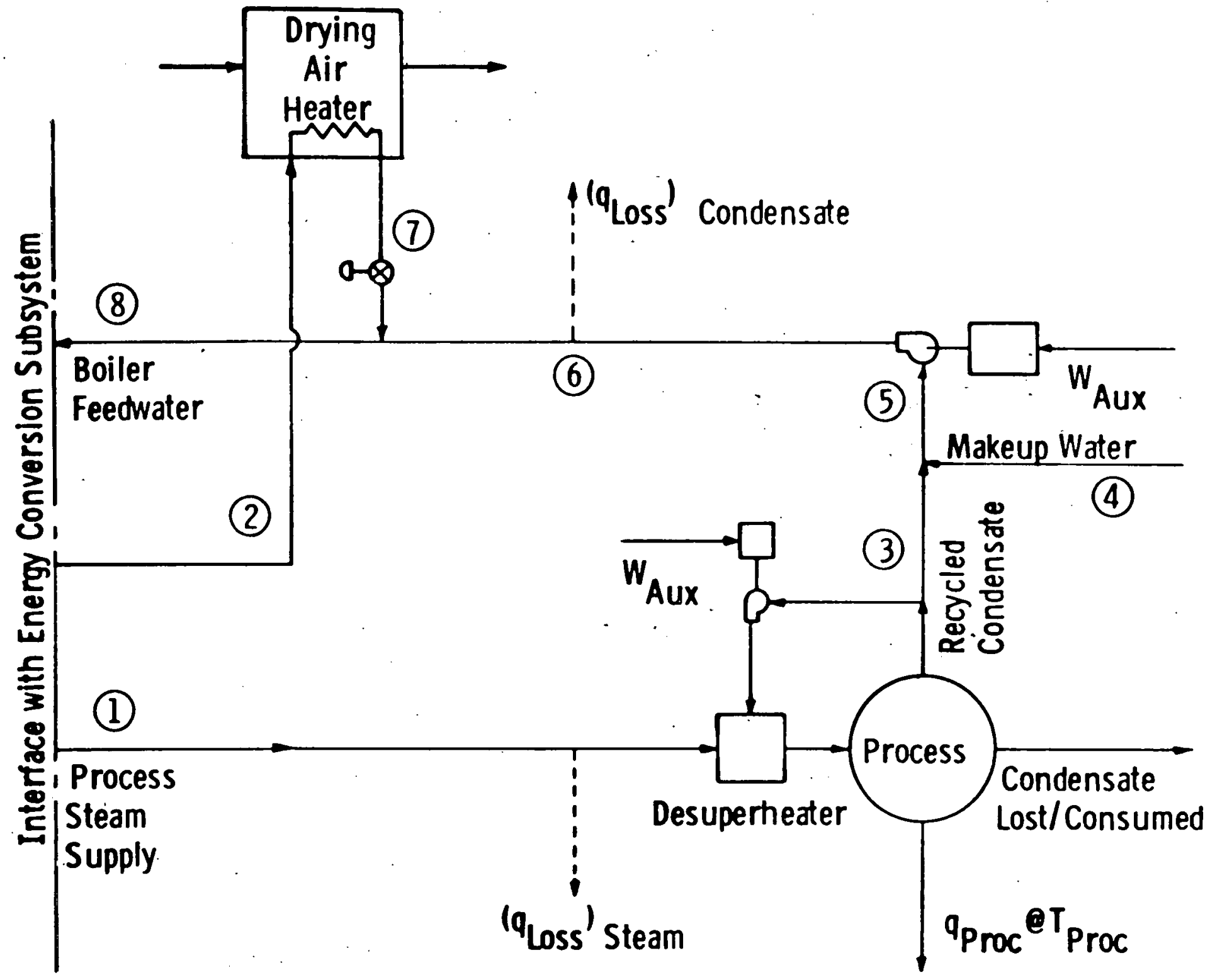

Fig. C. 10-1 - Model of energy utilization subsystem for textile finishing mili 
TABLE C. 10-1

STATEPOINTS FOR ENERGY UTILIZATION

SUBSYSTEM IN TEXTILE FINISHING MILL

$\begin{array}{ccc}\text { Station } & \begin{array}{c}\text { Pressure } \\ \text { psia }\end{array} & \begin{array}{c}\text { Temperature } \\ { }^{\circ} \mathrm{F}\end{array} \\ 1 & 165 & 514.7 \\ 2 & 335 & 661.8 \\ 3 & >15 & 200 \\ 4 & 15 & 100 \\ 5 & >15 & 100 \\ 6 & 39.8 & 100 \\ 7 & 335 & 350 \\ 8 & 39.8 & 189\end{array}$

\section{Enthalpy}

(Btu/1b)

1280.6

1345.0

132

68

68

68

321.8

157.1
Flow Rate

$(1 b / s)$

77.13

28.42

21.60

55.53

77.13

77.13

28.42

105.55 


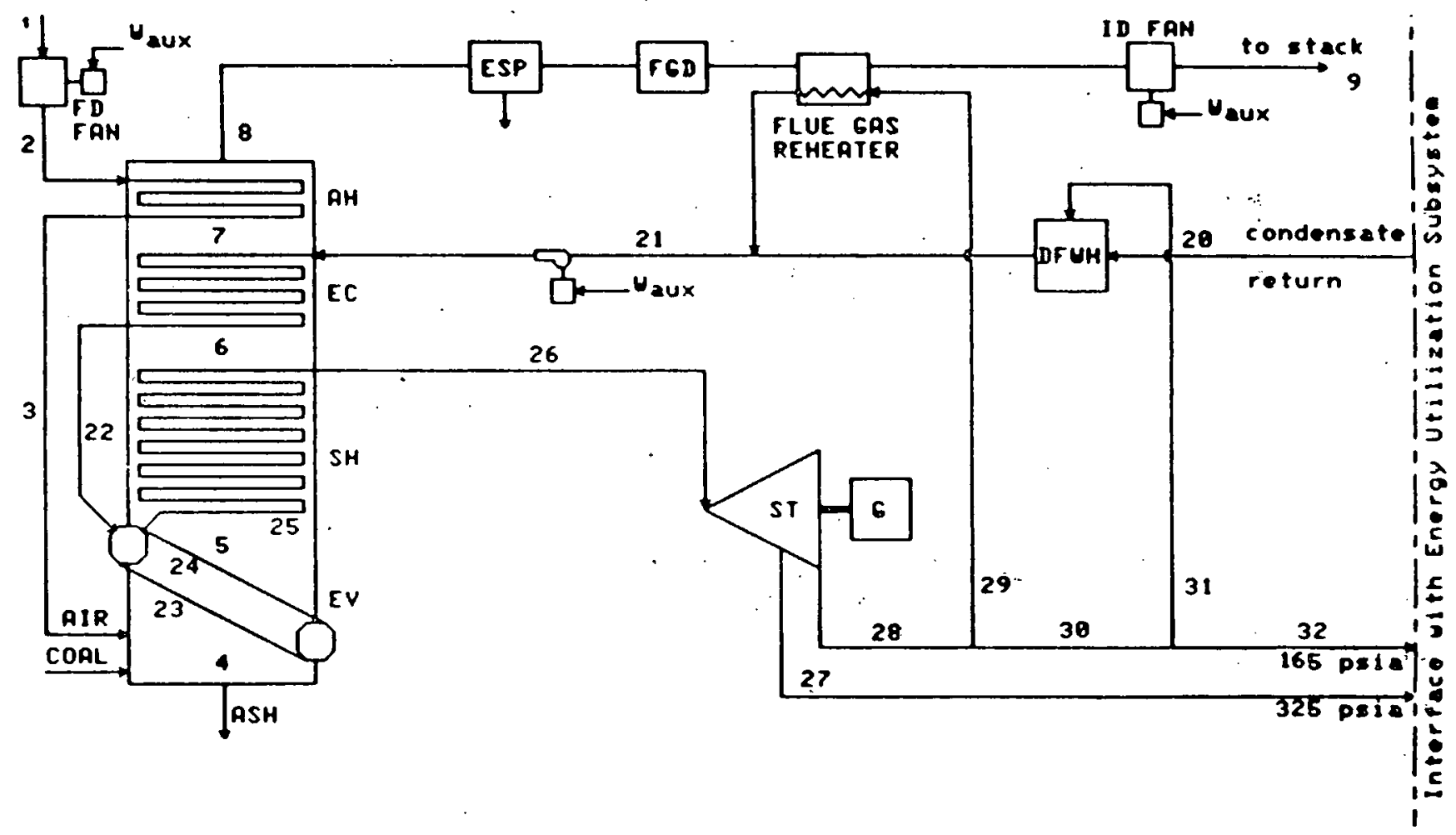

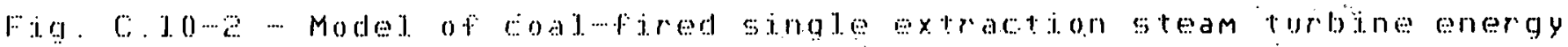
conversion subsustem for text le finishing mill 


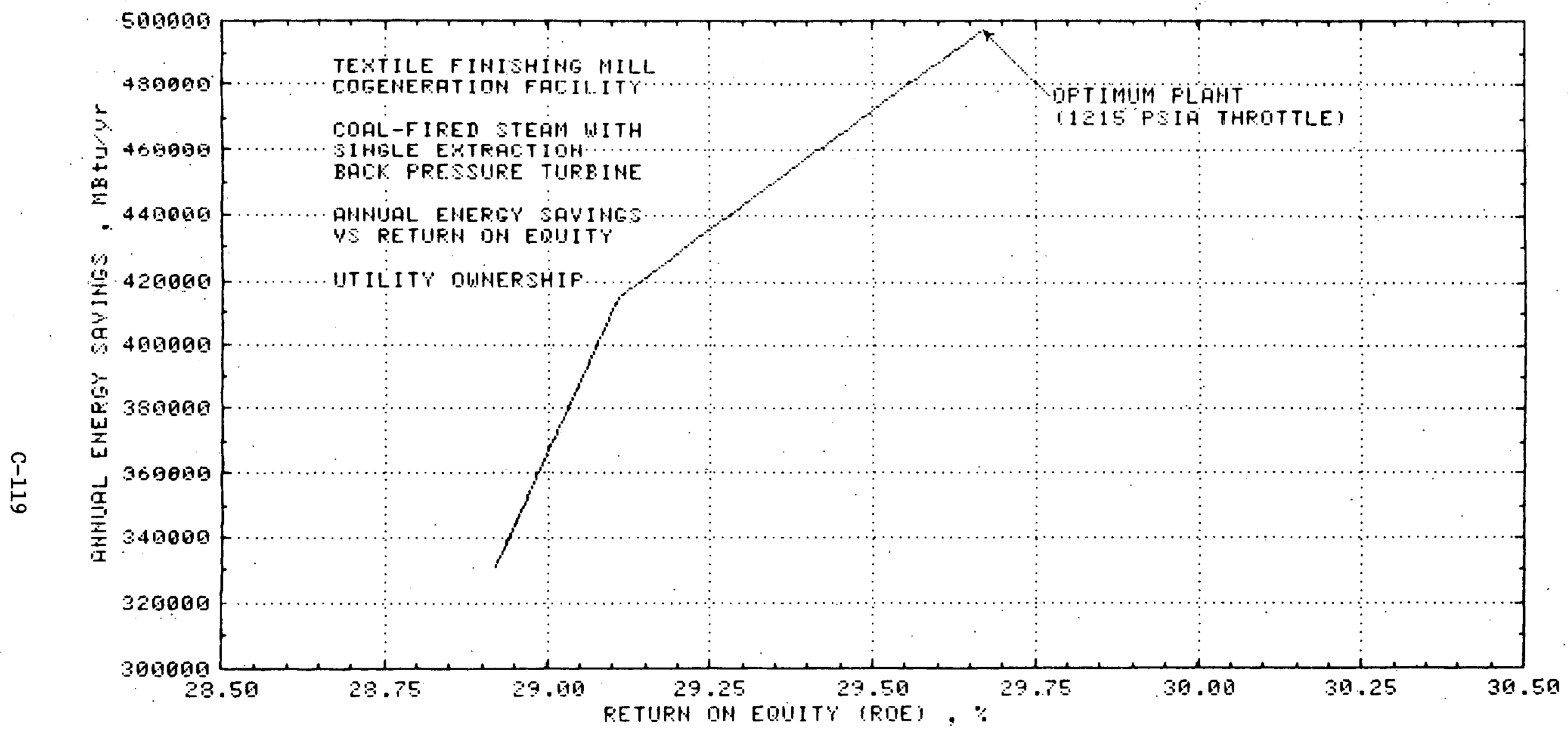

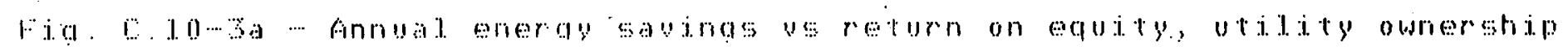




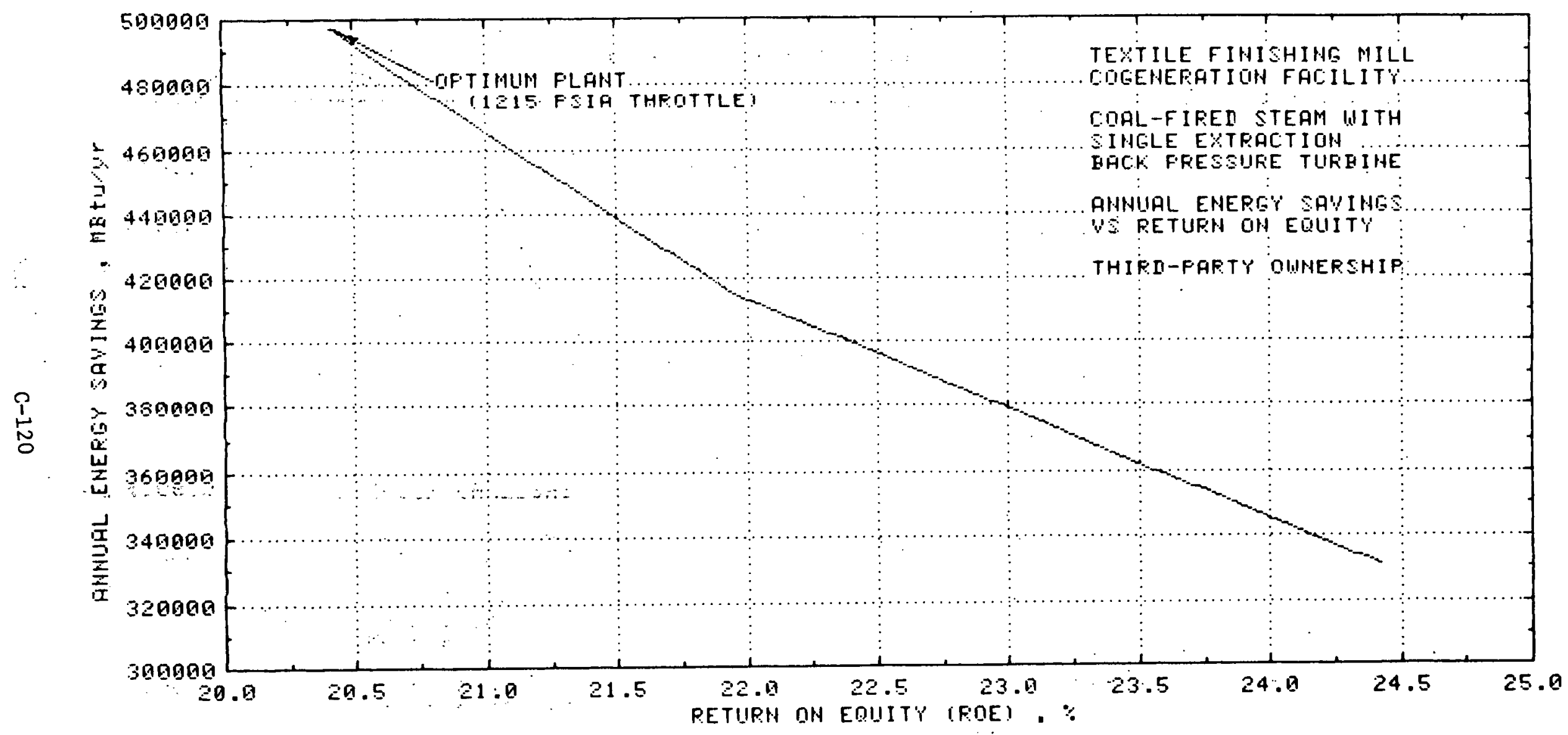

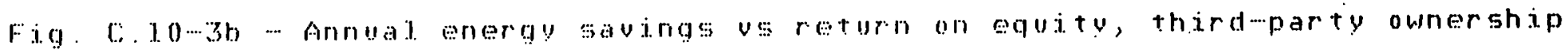


TABLE C. 10-2

STATEPOINTS FOR CONVERSION SUBSYSTEM

IN TEXTILE FINISHING MILL

Steam Turbine Throttle Pressure: 1215 psia

Pressure

(psia)

$\begin{array}{ll}1 & 14.7 \\ 2 & 15.9 \\ 3 & 15.7 \\ 4 & 15.5 \\ 5 & 15.2 \\ 6 & 14.9 \\ 7 & 14.5 \\ 8 & 14.3 \\ 9 & 14.7\end{array}$

$\begin{array}{lll}20 & \cdots & 39.8\end{array}$

$21 \quad 29.8$

$22 \quad 1340.0$

$23 \quad 1265.0$

$24 \quad 1265.0$

$25 \quad 1265.0$

$26 \quad 1215.0$

$27 \quad 335.0$

$28 \quad 165.0$

$29 \quad 165.0$

$30 \quad 165.0$

$31 \quad 165.0$

32.165 .0

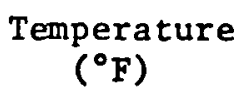

77.0

85.0

540.0

3613.8

2235.1

1550.8

678.9

279.0

175.0

189.0

250.0 .

253.5

573.9

573.9

573.9

948.6

$661: 8$

514.7

514.7

514.7

514.7

514.7
Enthalpy

(Btu/Ib)

0.0

2.0

112.7

1071.5

612.1

401.8

154.4

50.6

23.8

157.1

218.6

224.8

580.8

701.4

1183.7

1469.0

1345.0

1280.6

1280.6

1280.6

1280.6

1280.6
Flow

$(1 b / s)$

340.06

140.06

140.06

152.34

152.34

152.34

152.34

152.34

152.34

105.55

112.07

112.07

580.31

580.31

112.07

112.07

28.42

83.65

6.13

77.52

0.39

77.13 
TABLE C. 10-3

FUEL SPECIFICATIONS

COAL FOR TEXTILE FINISHING MILL

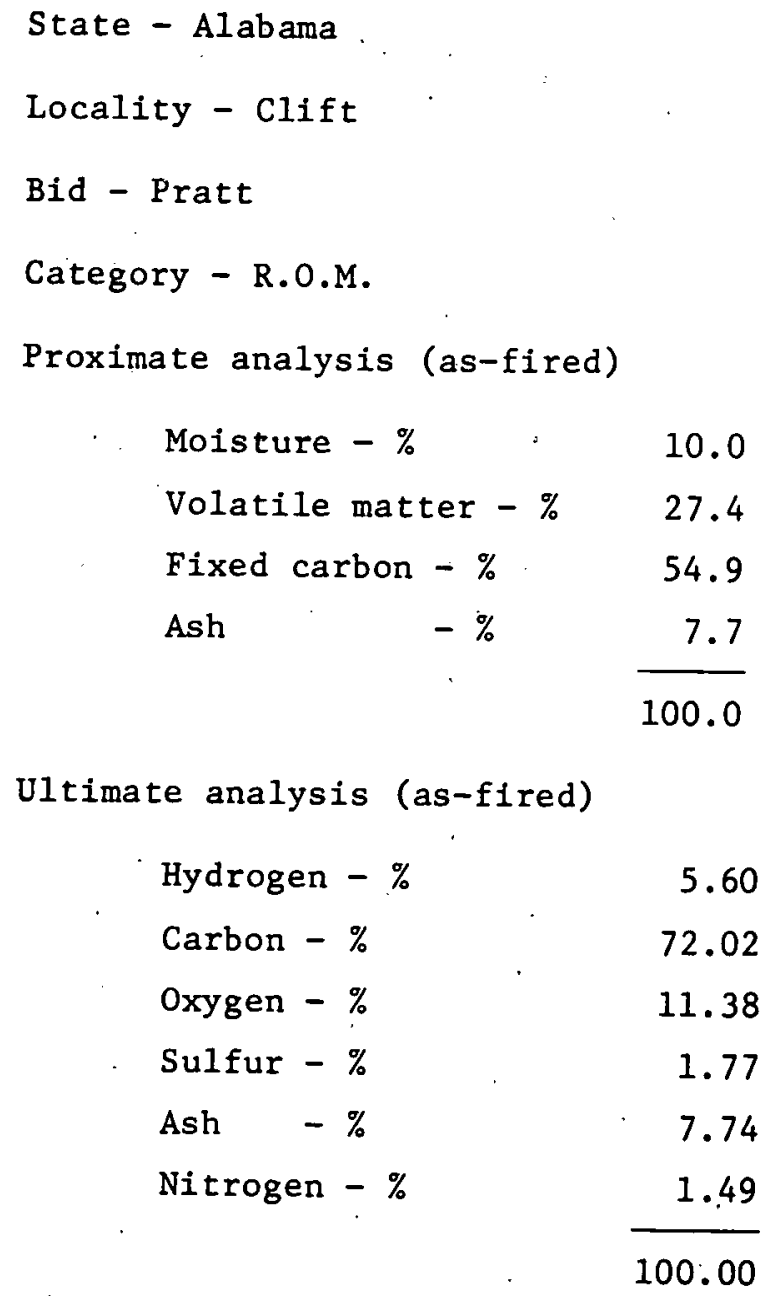


TABLE C. 10-4

POWER SUMMARY

TEXTILE FINISHING MILL

\begin{tabular}{|c|c|c|}
\hline $\begin{array}{l}\text { HP STEAM PUR= } \\
\text { IP STEAH PUR= } \\
\text { LP STEAM PHR: } \\
\text { ST POHER = }\end{array}$ & \multicolumn{2}{|c|}{$\begin{array}{r}12498.1164 \mathrm{KH} \\
1673.2067 \mathrm{KH} \\
5546.1967 \mathrm{KW} \\
19717.5976 \mathrm{KH}\end{array}$} \\
\hline GROSS POHER & $=$ & $19717.5976 \mathrm{KN}$ \\
\hline FGD AUXILIARIES & $=$ & $859.4674 \mathrm{KH}$ \\
\hline AUXILIARY POHER & $=$ & $1184.8886 \mathrm{KW}$ \\
\hline BOILER FEED PUMP POHER & $=$ & $696.3968 \mathrm{KW}$ \\
\hline NET POUER GENERATED & & $16976.7551 \mathrm{KW}$ \\
\hline
\end{tabular}

TOTAL FUEL =

$12.2790 \mathrm{LB} / \mathrm{SEC}$

THERMAL RATING $=539203320.0690 \mathrm{BTU} / \mathrm{HR}$

HEAT RATE $\quad 31761.2708 \mathrm{BTU} / \mathrm{KHHR}$

TOTAL PROCESS HEAT $=\quad .4314+609$ BTU/HR

PROCESS HEAT AT 165.0 PSIA $=.4313972+609$ BTU/HR

RPHEE $=\quad 8.2643 \mathrm{KWT} / \mathrm{KHE}$

IEUF $=\quad .9158$ 
presents the energy distribution for the finishing mill cogeneration plant. The ideal energy utilization factor (IEUF) for the plant was 0.9158 and the actual ratio of process heat to electricity was 8.2643 $\mathrm{kWt} / \mathrm{kWe}$, quite close to the desired ratio of $8.86 \mathrm{kWt} / \mathrm{kWe}$.

The preliminary capital cost of the system is given in Table C.10-5. The economic and financial assumptions detailed in Table .C.10-6 are used to perform an analysis of the cash flow for the facility. Tables C. 10-7a, C. 10-7b, and C.10-7c contain the results of that analysis, including the breakdown of the specific cash flow components and the return on equity to be expected.

The fuel utilization for this installation in both the separate generation and cogeneration modes is given in Table C.10-8. As can be seen, the use of natural gas and ofl is curtailed, at the expense of higher coal consumption. An overall energy savings of $17 \%$ is expected. 
TABLE C. 10-5

\section{SUMMARY OF CAPITAL COSTS: DEC $1978 \$$}

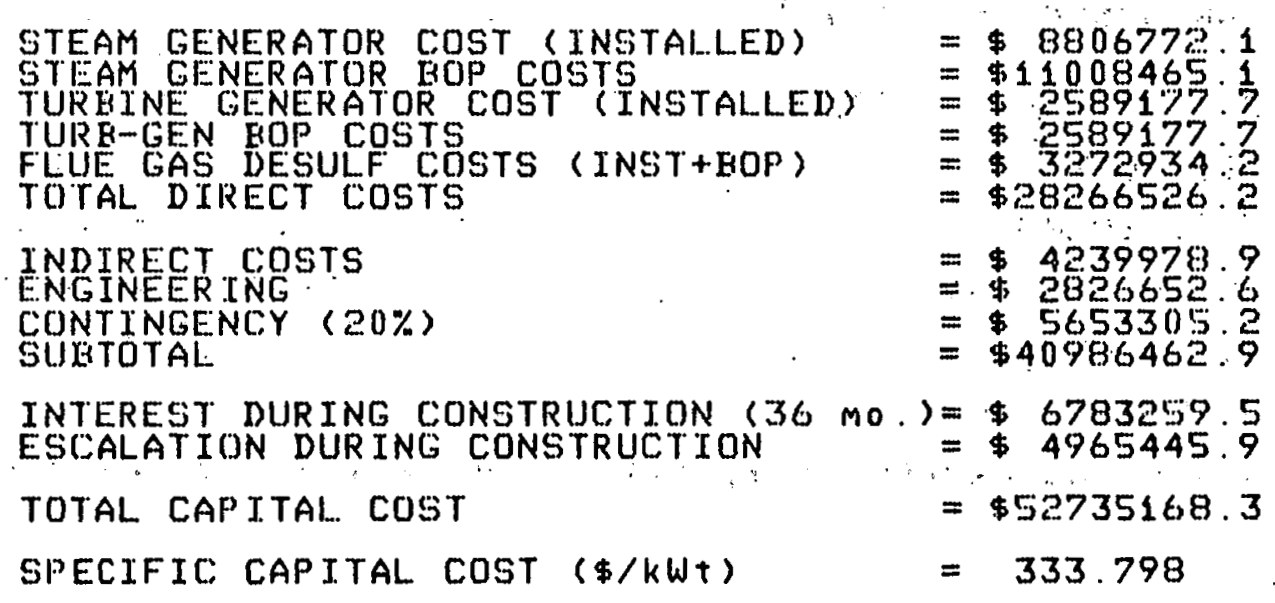




\section{RATE OF RETURN ON ERUTTY SUMMARY}

FOR INDUSTR IAL COIENERATION

***************************************************************************

\section{ENERGY UTILIZATION SYSTEM CHARACTERIZATION}

TEXTILE: FINISHING MILL

**********************************************************************************

REQUTRED RATIO OF PROCESS HEAT/ELECTRTCITY . =

$=\quad 8.8700$

REQUTRED PROCESS HEAT

$\therefore \quad 593485240.0$ (KWH/YR)

REQUTRED ELECTRIC ENERGY

$=669092 \% 1.5$ (KWH/YR)

EXCESS ELECTRIC ENE::RGY SOI..D

$=4903857.0$ (KWH/YR)

ASSUMMED CAP'ACITYY FACTOR

$=.5360$

ASSUMED STANDEY POWER FRACTION

$=1.0000$

************************************************************************************

ENERGY CONUERSION SYSTEM CHARACTERTZATION

COAL-FTRED STEAM WITH I-EEXTR IBPT

*********************************************************************************

ACTUAL RATIO OF PROCESS HEAT/ELECTRICITY $=$
IDEAL ENERGY UTILIZATION FACTOR .
SPECIFIC CAPITAL COST OF CONUERSION SYSTEM

********************************************************************************** 
TEXTTLE- FINISHING MILL

ECONOMIC AND FINANCIAL. ASSUMPTIONS

\begin{tabular}{|c|c|c|c|}
\hline 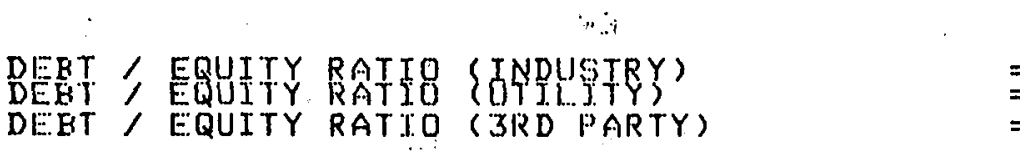 & $\begin{array}{l}= \\
= \\
=\end{array}$ & $\begin{array}{r}.7800 \\
5.0000\end{array}$ & \\
\hline LIFE OF PROJECY & $=$ & 283 & (YEARS) \\
\hline LIFE OF INUESTMENT FOR TAX PURPOSES & $=$ & 28 & (YEARS) \\
\hline INCDME TAX RATES (FEDERAL. + STATE) & $=$ & .5200 & $(\% / 1.00)$ \\
\hline INTEREST RATE ON DEET & $=$ & .1 .000 & $(\% / Y R / 100)$ \\
\hline INUESTMENT TAX CREDIT RATE: & $=$ & .2000 & $(\% / 100)$ \\
\hline ITCR UNDER SEPARATE GENERATTION (INDUSTRIAL) & $=$ & .2000 & $(\% / 100)$ \\
\hline ITCR UNDER SEPARATE GENERATION (UTILITY) & $=$ & .1000 & $(\% / 100)$ \\
\hline PROPERTY TAX RATE. ( $1 S T$ YEAR) & $=$ & .0150 & $(\% / 100)$ \\
\hline INSURANCE RATE (1ST YEAR) & $=$ & .0150 & $(\% / 1.00)$ \\
\hline CHARGE FOR STANDHY POWER & $=$ & 69.0676 & $(\$ / K W)$ \\
\hline MAINTENANCE \& SUPPLIES COST FACTOR (IST YR) & $=$ & .0375 & $(\% / 100)$ \\
\hline BOILER HEAT RATE (SEPARATE: GENERATION) & $=$ & 3750.0000 & (BTU/KWH) \\
\hline CENTRAL STATION EUS EAR HEAT RATE: & $:::$ & 9500.0000 & ( $E T U / K W H)$ \\
\hline TRANSMISSION LOSSES OF PURCHASED POWER & $=$ & $\because 1000$ & $(\% / 100)$ \\
\hline SPECIFIC CAPITAL.. COST OF NEW UTILYTY STATION & $=$ & 1000.0000 & $(\$ / K W)$ \\
\hline PRICE OF PROCESS STEAM (IST YR) & $=$ & 4.671 .4 & $\left(\$ / 10^{\wedge} 6\right.$ Bru $)$ \\
\hline PRICE OF POWER AT CENTRAL.. STATION BUS BAR & $=$ & .0196 & $(\$ / K W H)$ \\
\hline PRICE OF POWER EOUJGHT FROM UTILITY (1ST YR) & $=$ & .0326 & $(\$ / K W H)$ \\
\hline PRICE: OF POWER SOLD TO UTILITY (1ST YR) & $=$ & .0196 & $(\$ / K W H)$ \\
\hline PRICE OF FUEL. (COCENERATION) & $=$ & 1.7894 & $\left\langle \$ / 10^{\wedge} 6\right.$ BTH $\rangle$ \\
\hline PRICE OF FUEL, (SEP.GEN.: INDUSTRY) & $=$ & 1.7894 & $\left(\$ / 10^{\wedge} 6\right.$ FTU $)$ \\
\hline PRICE OF FUEL (SEP.GEN.: UTILITY ) & $=$ & 1.7894 & (\$/10^6 ETU) \\
\hline GENERAL INFLATION RATE & $=$ & .0750 & $(\% / 100 / Y R)$ \\
\hline FUEL PRICE RELATIUE ESC. (COGENERATION FUEL). & $=$ & .0484 & $(\% / 100 / Y R)$. \\
\hline FUEL PRICE REL. ESC..(SEP.GEN.: INDUSTRY) & $=$ & .0484 & $(\% / 100 / Y R)$ \\
\hline FUEL .PRICE REL. ESC .(SEP.GEN : UTILITY) & $=$ & .0484 & $(\% / 100 / Y R)$ \\
\hline RELATIVE ESC. OF ELECTRICAL ENERGY COSTS & $=$ & .0360 & $(\% / 100 / Y R)$ \\
\hline RELATIUE ESC. OF PROCESS STEEAM COSTS & $=$ & .0242 & $(\% / 100 / Y R)$ \\
\hline
\end{tabular}


IEXIILE FINISHING MILL

FOR INDUSTRIAL OWNERSHIP

INCREMENTAL CAPITAL INUESTMENT -

NET INCREMENTAL EQUITY CAPITAL INUESTMENT

$$
\begin{aligned}
& =-28878642(\$) \\
& =13589949(\$)
\end{aligned}
$$

DE:LTA

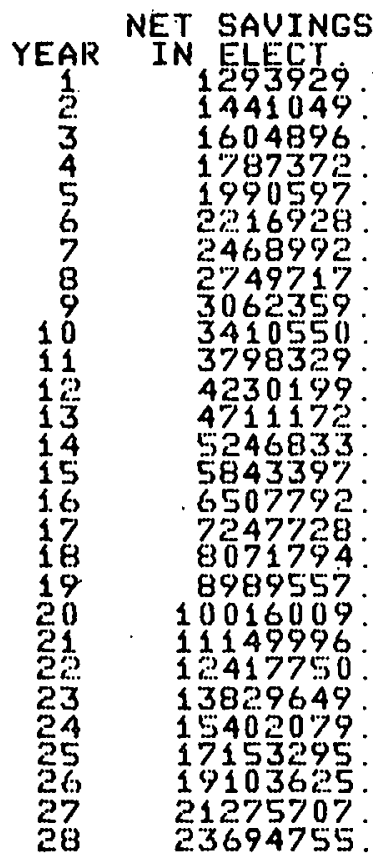

\begin{tabular}{|c|}
\hline 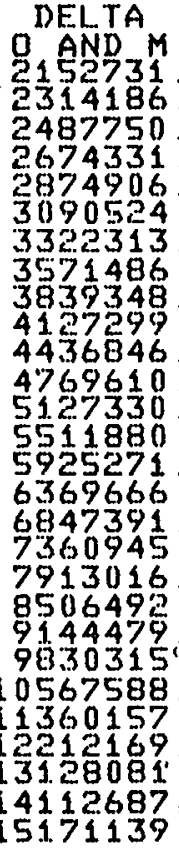 \\
\hline
\end{tabular}

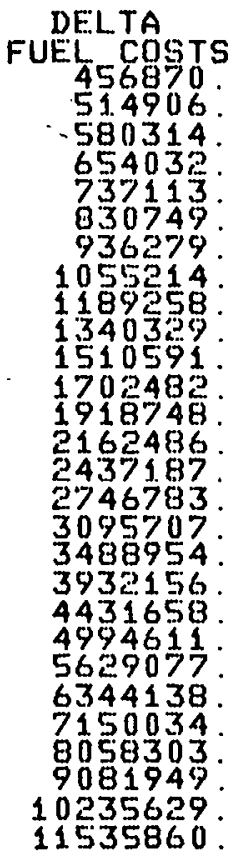

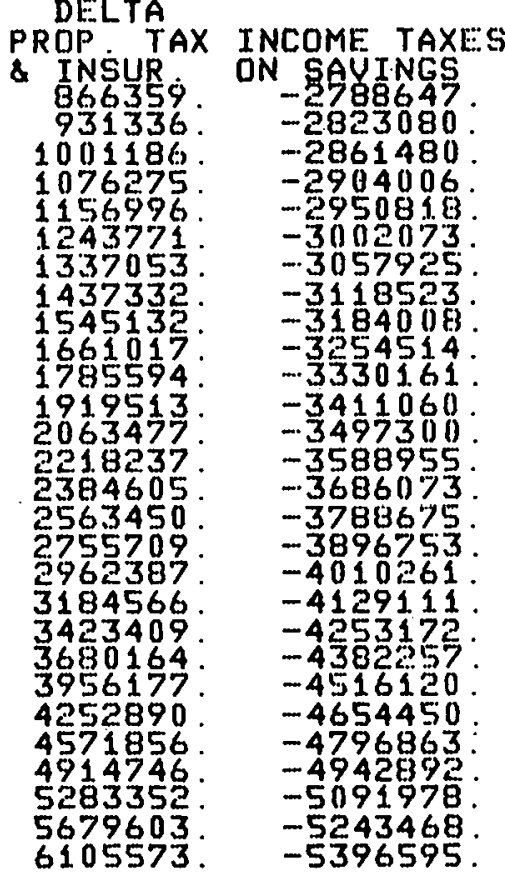

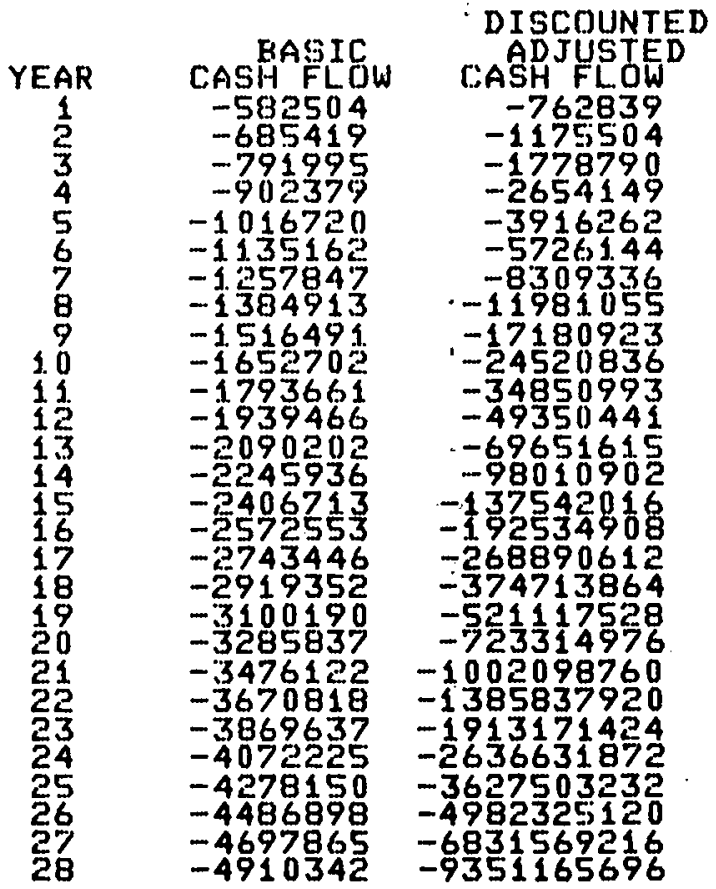

DISCOUNTED CASH FLOW RATE OF RETURN ON EQUITY(ROE) $=-23.64 \%$ ANNUAL ENERGY SAVED UNDER COGENERATION = 497536.4375 METU/YR 
TEXTILE FINISHING MILL

EQR UTILITY OWNERSHIP

INCREMENTAL CAPITAL INUESTMENT

NET INCREMENTAL EQUITY CAPITAL INUESTMENT

$=\quad 35857296(\$)$
$=\quad 16965035(\$)$

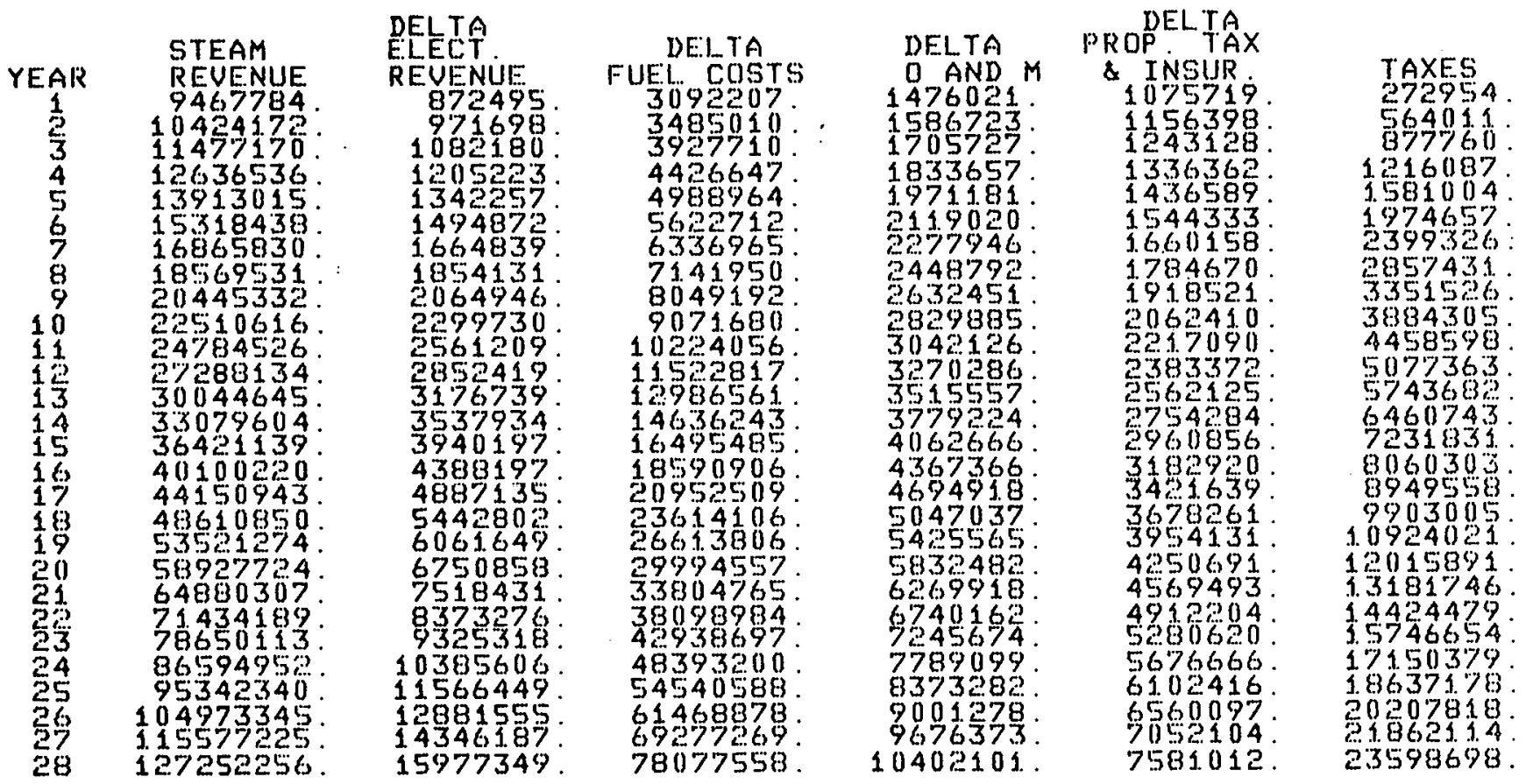

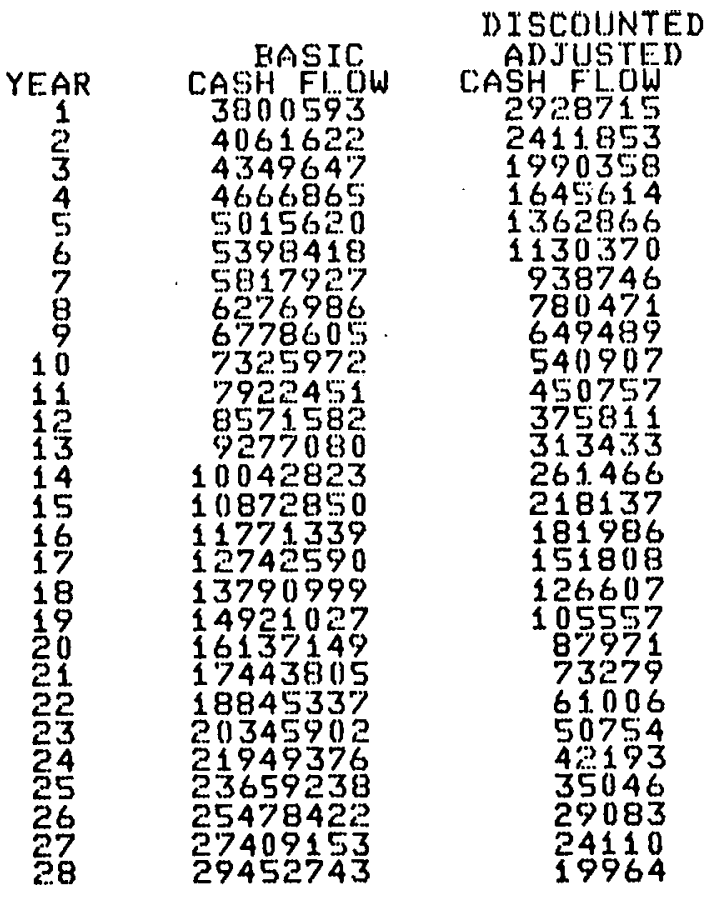

DISCOUNTED CASH FLOW RATE OF RETURN ON EQUITY(ROE) $=29.77 \%$
ANNUAL ENERGY SAUED UNDER COGENERATION $=4$ M 
TEXTILE FINISHING MILL

FOR THIRD PARTY OWNFRSHIP

CAF ITAL INNESTMENT

NET EQUTTY CAPITAL INUE:STMENT

$=\quad 52735126(\$)$
$=\quad 7031350(\$)$

DELTA

REVENIIE

1293929

1441049 .

1604896

1787372

$199059 \%$

2468992

274971.7 .

3062359

3410550

3798329.

4230199

5246,8333 .

$584339 \%$

6507792

7247728.

8071.794 .

8989557

10011669 .

$111499 \% 6$.

12417750 .

13829649 .

15402078

19103625 .

21.275707.

78650113

86594952.

104973345

11.5572255

23694755 .
DEI...TA

DELTA PROP TAX

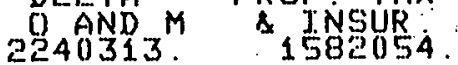
$2408336 . \quad 1700708$. $2588962 . \quad 1828261$. 2783134 . 2991869 3216259 3457478 . 3955548 4295214 4617355 4963657 5335931 5736126 6166335 6628810 7125971. 7660419 . 8234950 . 8852571 9516514 10230252 1.0997521. 11832335. 13662186 14686849 15788363 .

$1965380^{\circ}$

2112784 .

257. 243

2441586

2624705 .

30331.74

3260662.

3505212

3768103 .

$405071\}$.

435454.

4681102

5032185.

5409599

5815319

6251467.

6720327.

7204352 .

7766178 .

8348641 .

8974789.

9647898 . 3716789
28: 1558 .

88048987

99459253

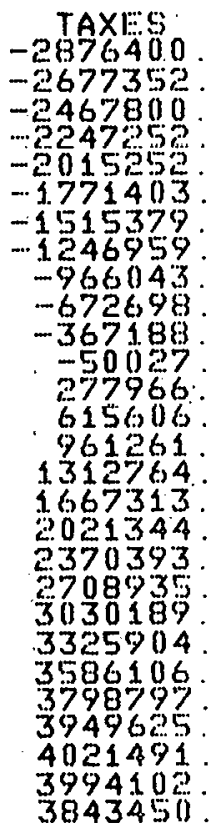

\begin{tabular}{|c|c|c|}
\hline \multirow{3}{*}{\multicolumn{3}{|c|}{$\begin{array}{l}D I S C O U N T E D \\
\text { ADJUSTED }\end{array}$}} \\
\hline & & \\
\hline & & \\
\hline$\frac{2}{2}$ & & \\
\hline & & \\
\hline & & \\
\hline & & \\
\hline & & \\
\hline & & \\
\hline & & \\
\hline & & \\
\hline & & \\
\hline & & $\begin{array}{l}148345 \\
131.759\end{array}$ \\
\hline & & \\
\hline & & \\
\hline 21 & & \\
\hline & & \\
\hline & & \\
\hline & & \\
\hline & & \\
\hline & & \\
\hline YEAR & CASH FLOW & CASH FLOW \\
\hline$\frac{1}{2}$ & 981.766 & $\begin{array}{l}815353 \\
714286\end{array}$ \\
\hline 3 & 1099156 & 625610 \\
\hline $\begin{array}{l}4 \\
5 \\
5\end{array}$ & 1.172850 & 496663 \\
\hline 9 & 1352317 & $\begin{array}{l}443714 \\
397507\end{array}$ \\
\hline $\mathrm{R}$ & 1576640 & 356806 \\
\hline 106 & 1846947 & 288290 \\
\hline & 2161941 & 232752 \\
\hline & 2334815 & 208756 \\
\hline & 2705770 & $\begin{array}{l}166860 \\
148542\end{array}$ \\
\hline & 3097731 & 131759 \\
\hline 38 & $\begin{array}{l}32948.39 \\
3486949\end{array}$ & 735358 \\
\hline 20 & 3669560 & 89405 \\
\hline$\frac{5}{5} \bar{z}$ & 3979291 & $\begin{array}{l}66870 \\
57074\end{array}$ \\
\hline 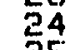 & 4156059 & $\begin{array}{l}48170 \\
40095\end{array}$ \\
\hline 5 & 4101814 & 32791 \\
\hline & 19 & 307 \\
\hline
\end{tabular}

DISCOUNTED CASH FLOW RATE OF RETURN ON EQUITY $(R D E)=$

$20.41 \%$ ANNUAL ENERGY SAVED UNDER COGENERATION =

$497536.4375 \mathrm{MHTU} / Y R$ 
TABLE C. 10-8

FUEL UTILIZATION

\section{TEXTILE FINISHING MILL}

$\begin{array}{ccc}\begin{array}{c}\text { Separate Generation } \\ (\mathrm{MBtu} / \mathrm{yr})\end{array} & \begin{array}{c}\text { Cogeneration } \\ (\mathrm{MBtu} / \mathrm{yr})\end{array} & \begin{array}{c}\text { Savings } \\ (\mathrm{MBtu} / \mathrm{yr})\end{array} \\ 1889766 & - & 1889766 \\ 763475 & - & 763475 \\ 895478 & 2957617 & -2062139 \\ 3548719 & 2957617 & 591102\end{array}$

Percent Energy Savings $=16.7 \%$ 


\section{11 INTEGRATED TEXTILE MILL}

The integrated textile mill is a medium-sized facility located in Alabama (DOE Region IV). The energy requirements for the plant are in the form of process steam (saturated at 265 psia), direct process heat, electrical energy, and direct power steam for mechanical drives. The physical configuration of the plant precludes the use of exhaust gas from a gas turbine as a source of direct process heat, making it possible to combine the requirement for direct process heat with that for steam. The need for power steam for mechanical drives has been accounted for by combining the drive steam demand with the conventional electrical demand. The overall ratio of process heat to electricity is 2.34 . The annual energy needs of the plant may be given as follows:

- Process heat (sat'd steam)

- Electricity
302.5 million. kWht/yr

129.6 million $\mathrm{kWhe} / \mathrm{yr}$

The preferred fuel, identified by the company, was wood which is available in plentiful supply locally. Thus, the only energy conversion subsystems considered were a gas-fired combustion turbine with WHB and a wood-fired boiler generating steam for a back pressure steam turbine. The gas turbine case, upon investigation, proved to result in unacceptable ROE's and was therefore eliminated. The wood-fired steam plant, on the other hand, provided an acceptable ROE only for the utility and the thirdparty ownership cases.

Figure C.11-1 shows the energy utilization system model for the integrated textile plant. The conditions at each of the indicated state points are given in Table C.11-1. In Figure C.11-2, the system configuration of the wood-fired boller/BPT system is shown schematically. The analysis was based upon the wood composition shown in Table C.11-2, a southern yellow pine having $40 \%$ moisture content. The throttle pressure of the steam turbine was varied, producing the optimization plot for utility ownership shown in Figure C.11-3. The industrial and third-party ownership plots are not given due to their poor (negative) ROE. In this case, the optimum plant was not dictated by the ROE hurdle rate, but by the maximum practical throttle pressure in the steam turbine. Table C.11-3 gives the state point data for the optimum case at 1215 psia throttle pressure.

The boiler is a wood-fired unit with no combustion air preheater. Rather than an ESP, particulate control is achieved with either a bag filter or cyclone separators. Since wood contains little sulfur, no flue gas desulfurization system is required. After partial expansion through the steam turbine, steam exhausts to the process at 265 psia. A fraction of that steam is used to deaerate the recycled condensate.

The energy distribution for the cogeneration facility is shown in Table C.11-4. The ideal energy utilization factor (IEUF) is 0.908 and the ratio of process heat to electricity (RPHEE) 1s 10.58. Since the latter value exceeds the required ratio, supplemental power must still be imported. The preliminary capital costs of the facility are shown in Table C.11-5. 


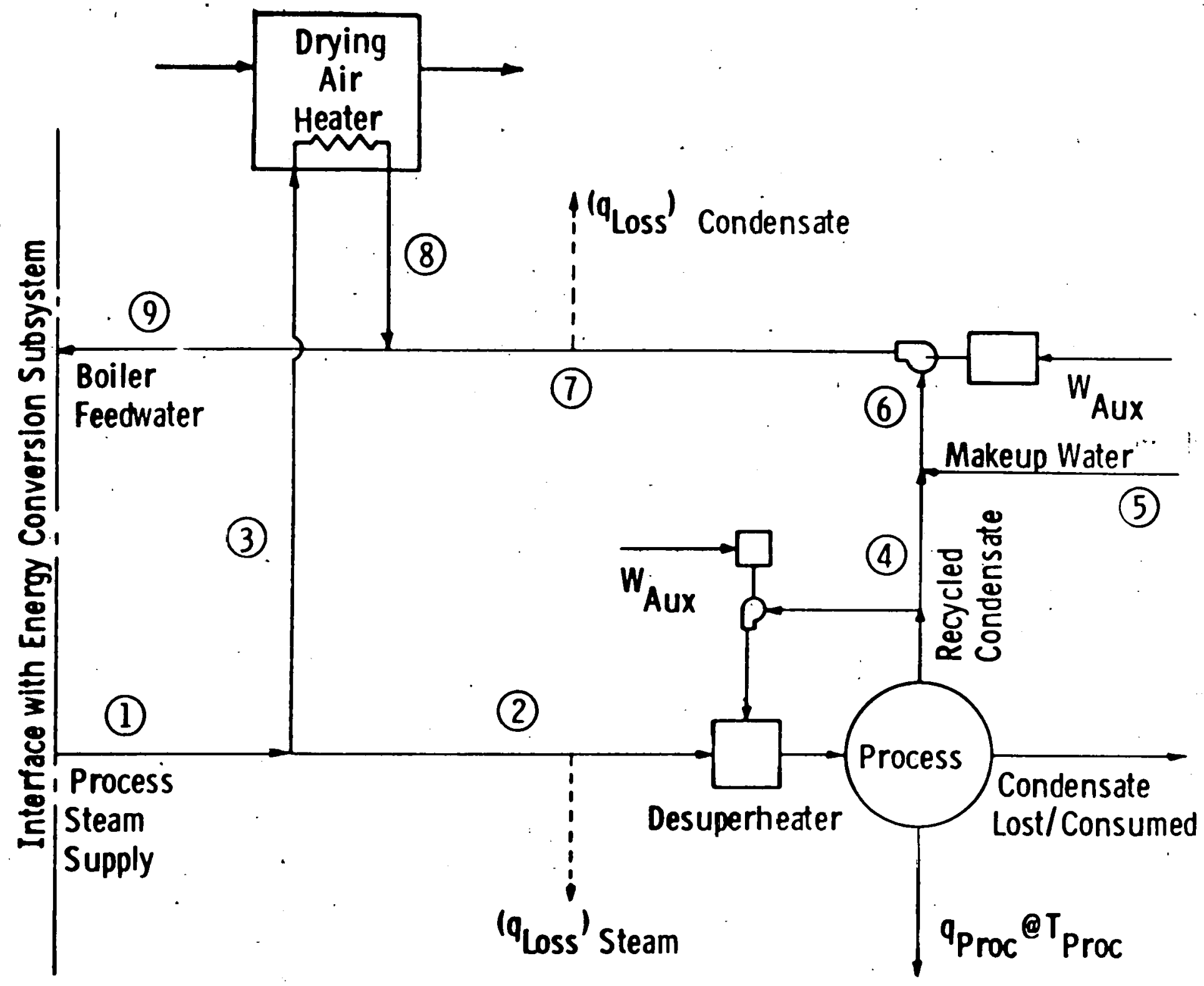

Fig. C.11-1 - Flowsheet of process heat utilization subsystem for integrated textile mill with wood-fired steam energy conversion subsystem 
TABLE C. $11-1$

STATEPOINTS FOR ENERGY UTILIZATION SUBSYSTEM

IN INTEGRATED TEXTILE MILL

$\begin{array}{ccccc}\text { Station } & \begin{array}{c}\text { Pressure } \\ (\text { psia) }\end{array} & \begin{array}{c}\text { Temperature } \\ \left({ }^{\circ} \mathrm{F}\right)\end{array} & \begin{array}{c}\text { Enthalpy } \\ (\mathrm{Btu} / \mathrm{lb})\end{array} & \begin{array}{c}\text { Flow Rate } \\ (1 \mathrm{~b} / \mathrm{s})\end{array} \\ 1 & 265 & 617.1 & 1327.1 & 52.99 \\ 2 & 265 & 617.1 & 1327.1 & 47.53 \\ 3 & 265 & 617.1 & 1327.1 & 5.46 \\ 4 & - & - & - & 0 \\ 5 & 15 & 100 & 68 & 47.53 \\ 6 & >15 & 100 & 68 & 47.53 \\ 7 & 39.8 & 100 & 68 & 47.53 \\ 8 & 265 & 406 & 1201.7 & 5.46 \\ 9 & 39.8 & 103.1 & 71.2 & 52.99\end{array}$


TABLE C. $11-2$

FUEL SPECIFICATIONS

INTEGRATED TEXTILE MILL

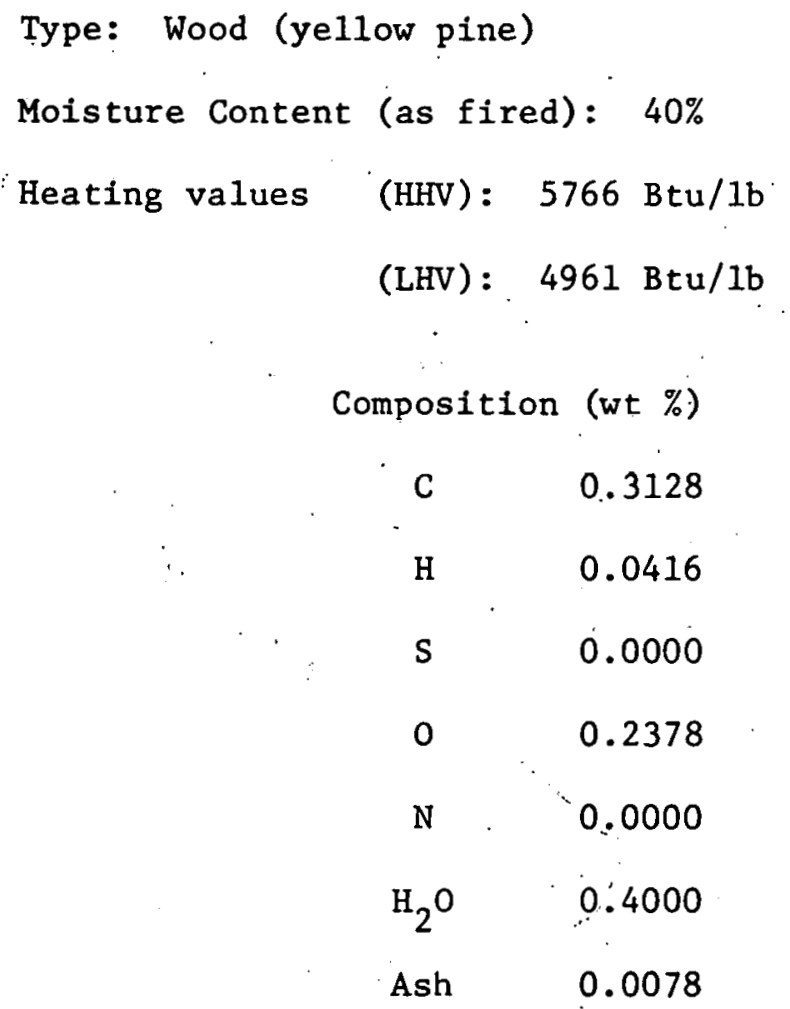


Integrated Text 1 le Mi11:

No FGD

Replace ESP with bag f11ter or cyclones

No air preheater

Replace coal with wood

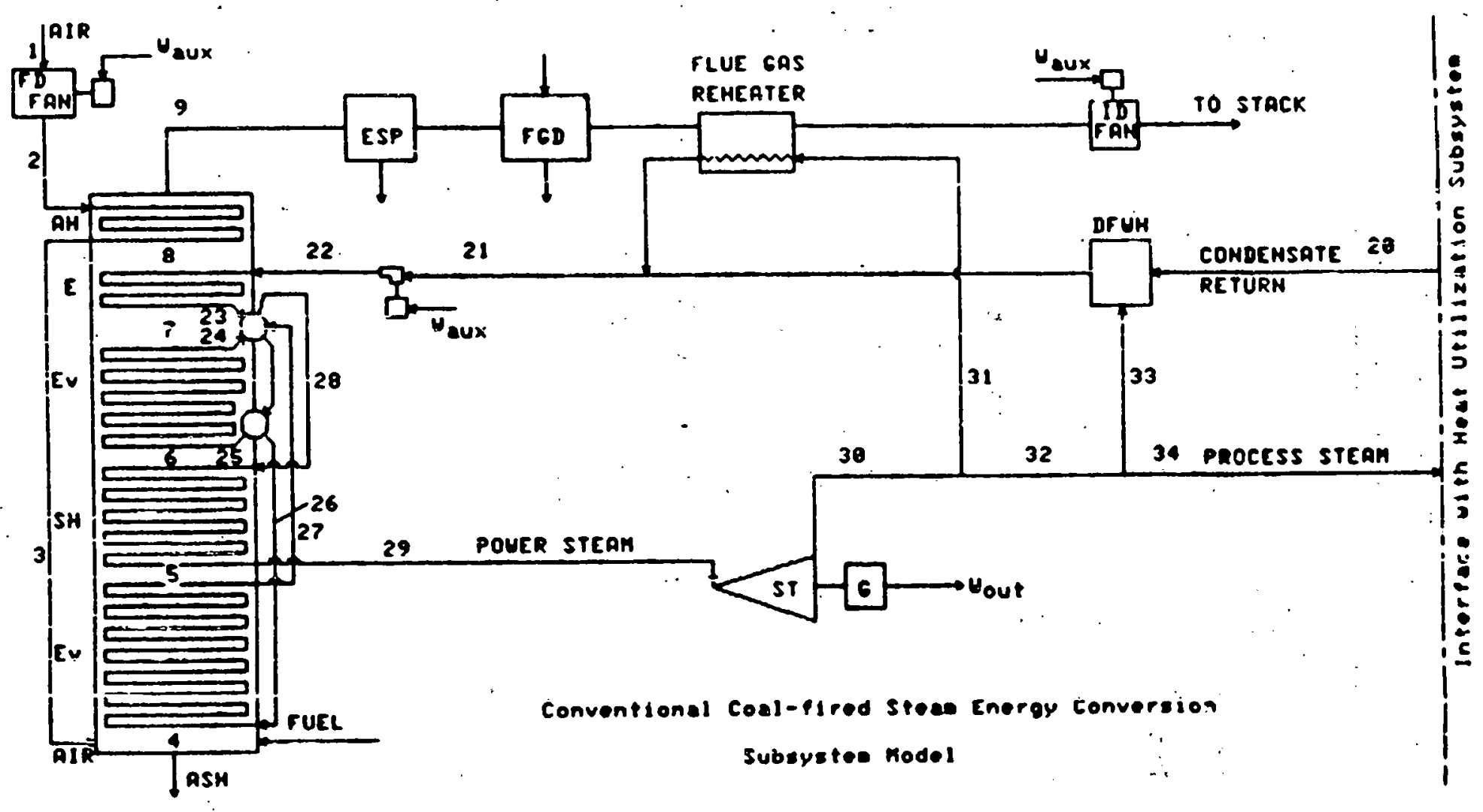

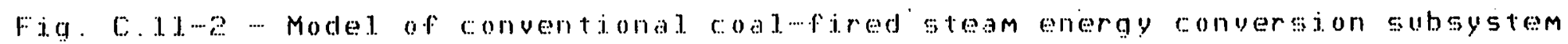
for integrated textile mill th 


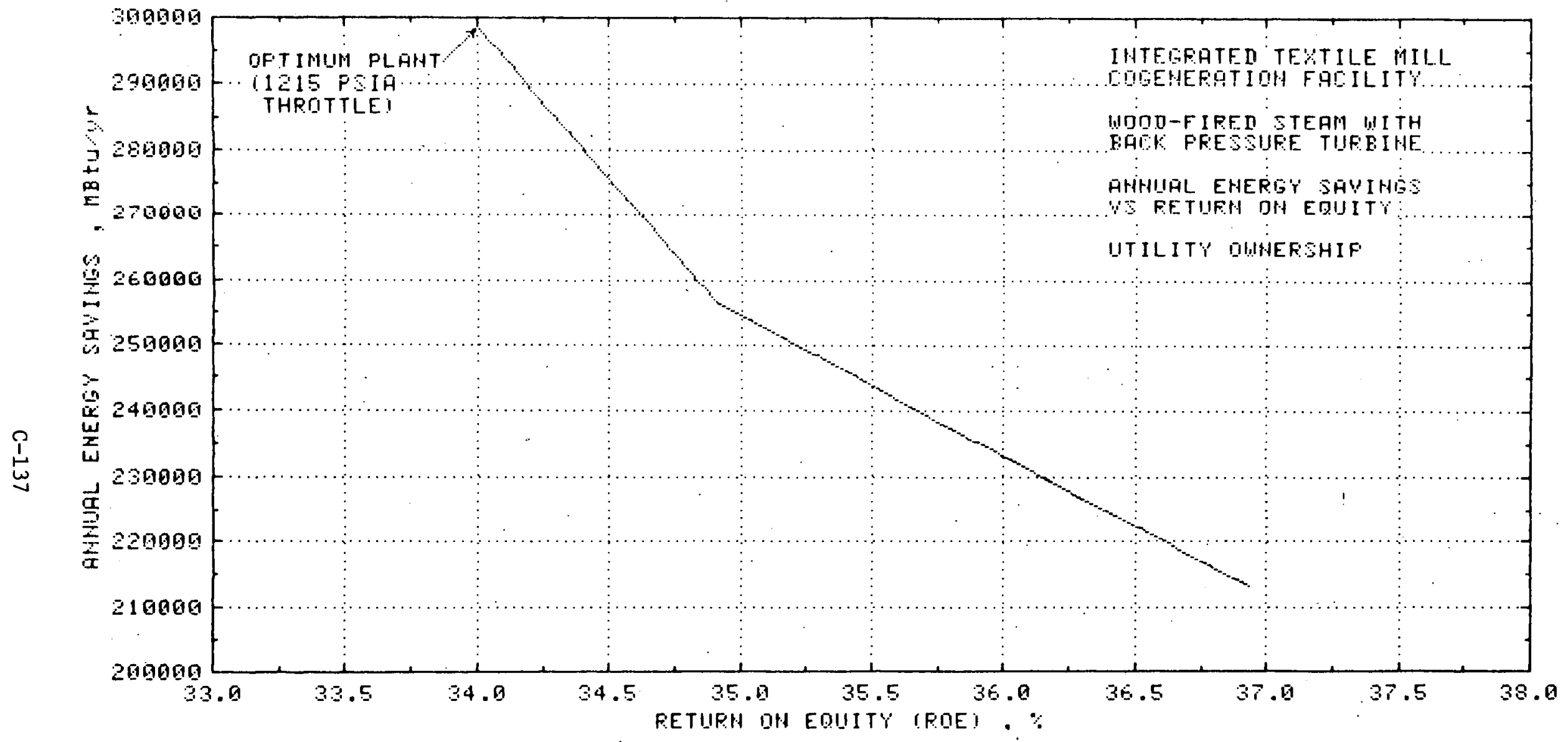

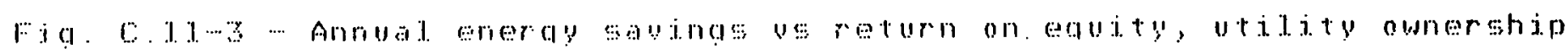




\section{TABLE C. 11-3}

STATEPOINTS FOR CONVERSION SUBSYSTEM

IN INTEGRATED TEXTILE MILL

\begin{tabular}{|c|c|c|}
\hline Stati & & $\begin{array}{r}\text { Pressur } \\
\text { (psia) }\end{array}$ \\
\hline 1 & & 14.7 \\
\hline 2 & & 16.0 \\
\hline 3 & & 16.0 \\
\hline 4 & & 15.8 \\
\hline 5 & & 15.6 \\
\hline 6 & & 15.3 \\
\hline 7 & & 15.0 \\
\hline 8 & & 14.7. \\
\hline 9 & & 14.7 \\
\hline 20 & . & 39.8 \\
\hline 21 & & 29.8 \\
\hline 22 & & 1340.0 \\
\hline 23 & & 1315.0 \\
\hline 24 & & 1265.0 \\
\hline 25 & & 1265.0 \\
\hline 26 & & 1265.0 \\
\hline 27 & & 1265.0 \\
\hline 28 & & 1265.0 \\
\hline 29 & & 1215.0 \\
\hline 30 & & 265.0 \\
\hline 31 & & - \\
\hline 32 & & 265.0 \\
\hline 33 & & 265.0 \\
\hline 34 & & 265.0 \\
\hline
\end{tabular}

Temperature

$\left({ }^{\circ} \mathrm{F}\right)$

77

85

85

2811.6

1800.0

1230.3

1056.5

303.2

303.2

103.1

250.0

253.5

558.9

573.9

573.9

573.9

573.9

573.9

945.5

617.1

617.1

617.1

617.1
Enthalpy

(Bțu/lb)

Flow

$(1 b / s)$

75.96

75.96

75.96

92.51

92.51

92.51

92.51

92.51

92.51

64.0

71.2

52.99

218.6

224.8

560.5

580.8

701.4

580.8

701.4

1183.7

1467.9

1327.1

60.03

60.03

60.03

41.58

41.58

287.50

287.50

60.03

60.03

60.03

327.1

60.03

1327.1

7.04

1327.1

52.99 
TABLE C. 11-4

POWER SUMMARY - INTEGRATED TEXTILE MILL

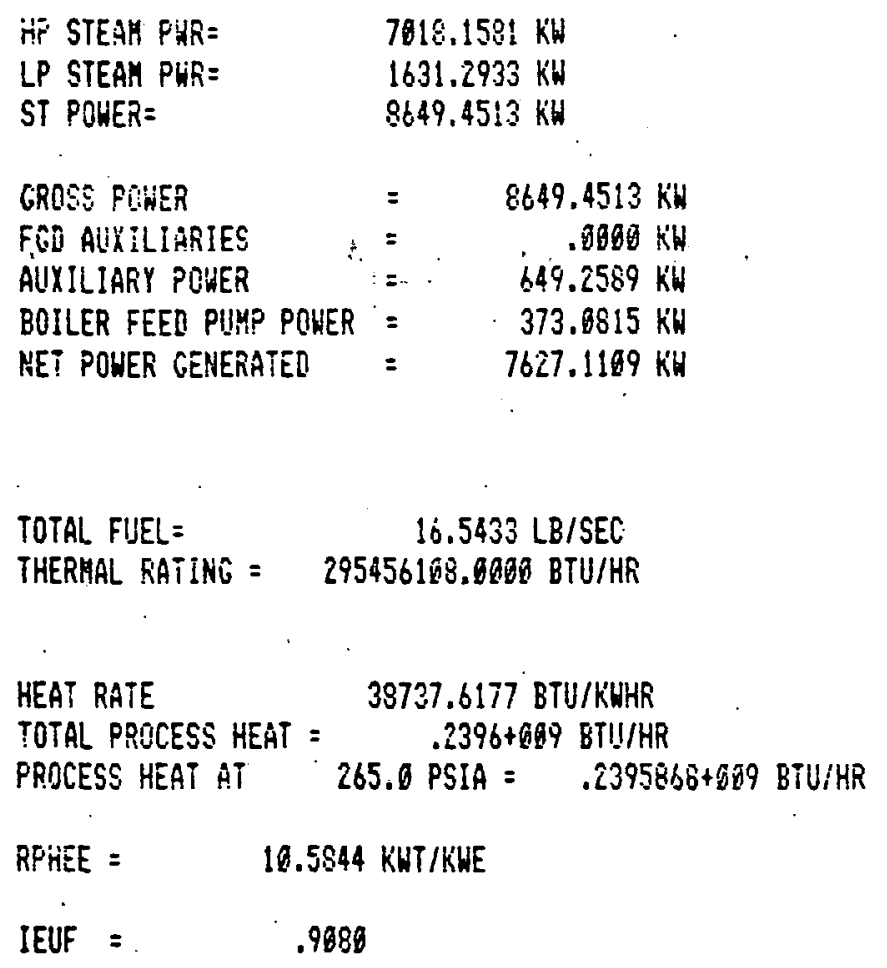


TABLE C. $11-5$

INTEGRATED TEXTILE MILL SUMMARY DI CAPT TAL COST:: DEC. 1978\$

STE:AM GENERATOR COST (JNSTALLED)

STEAM GENERATOR HOP COSTS.

INSTALLED) $=\$ 1741710.8$

TURTINE GENERATOR BOP COSTS

TOTAL DTRECT COSTS $=\$ 16395635.4$

IND TRECT COOSTS $=\$ 2.459345 .3$

ENGINEERTNG $=\$ 1639563.5$

CONTTNCENCY (20\%)

SUETÖTAL...

INTEREST DÜRING CONSTRUCTION $(36 \mathrm{MO})=.\$ 393454 \% .6$

ESCALATION DURING CONSTRUCTION

TOTAL CAP T.TAL. COOST

$=\$ 30588256.8$

SPECIFIC CAPITAL COST ( $\$ / k \omega t)$

$=352.907$ 
These costs, as well as the financial and economic data specified for the company and the region involved, are used to analyze the cash flow over the desired project 1ife. The DCFROE for the optimum case was based on the assumptions detailed in Table C.11-6. The results of the DCFROE calculations, as weil as the specific contributors to the cash flow vector, are reported in Tables C.11-7a, C. 11-7b, and C.11-7c.

The fuel utilization shift to be expected as a result of the installation of the specified cogeneration facility is shown in Table C.11-8. A small amount of overall conservation is accomplished. The most significant factor, though, is the replacement of over a million MBtu/yr of natural gas with wood. 


\section{BATE OF RETURN ON EQUTTY SUMMARY IOR INUUSTRTAL COGENERATION}

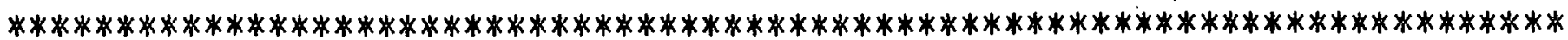

ENERGY UTILTZATION SYSTEM CHARACTERIZATION

INTEGRATED TEXTTLE MILL.

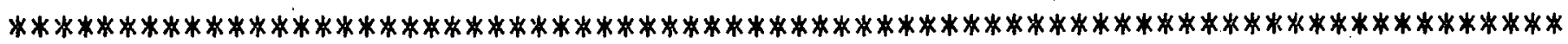

REQUIRED RATTO OF PROCESS HEAT/ELECTRICITY

$=\quad 2.3400$

REEQTRED PROCESS HEAT

$=302549056.0$ (KWH/YR)

REQUITED ELEECTRIC ENERGY

$=129294468.0 .(K W H / Y R)$

SUPPLEMENTAL ELECTRIC, ENIERGY PURCHASED

$=100710037.0$ (KWH/YR)

ASSUMED CAPACITY FACTOR

$=.4920$

ASSUMED STANDEY POWER FRACIIION

$=1.0000$

*************************************************************************************

ENEERG COONUERSION SYSTEM CHARACTERTZATION

WOOD-FIRED STEAM WITH BPT

**************************************************************************************

ACTUAL RATIO OF PROCESS HEAT/ELECTRICITY =

I.DEAL ENERGY UTTLIZATION FACTOR

$=\quad 10.58344$

SPECIFIC CAPITAL COST OF CONUERSION SYSTEM

$=\quad .9080$

INCR. LAEOR COST (INDUSTRY) (IST YEAR)

$=\quad 352.9070(\$ / K W Y)$

INCR. L.ABOR COST (UTTL.T.TY) (1ST YEAR)

$=98141.4492(\$)$

INCR L LAEOR COST (3RD PARTY) (1ST YEAR)

$=1.46591 .0254$ (\$)

********************************************************************************* 


\begin{tabular}{|c|c|c|c|}
\hline $\begin{array}{l}\text { DEBT ， EQUITY RATIO (INDUSTRY) } \\
\text { DERT } \\
\text { DE:ETT }\end{array}$ & $\begin{array}{l}= \\
=\end{array}$ & $\begin{array}{l}3.7000 \\
1.1 .000 \\
5.0000\end{array}$ & \\
\hline LIFE: OF PROJEC'T. & $=$ & 28 & (YEARS) \\
\hline LIFE OF INUESTMENT FOR TAX PURPOSES & $=$ & 28 & (YEARS.) \\
\hline INCOME: TAX RATES (FEDERAL. + STATE) & $=$ & .5060 & $(\% / 1.00)$ \\
\hline INTEREST RATE ON DEET & $=$ & .1000 & $(\% / Y R / 100)$ \\
\hline INUESTMENT TAX CREDIT RATE & $=$ & .2000 & $(\% / 100)$ \\
\hline ITCR UNDER SEPARATE GENERATION (INDUSTRY). & $=$ & .0000 & $(\% / 100)$ \\
\hline ITCR UNDER SEPARATE GENERATION (UTILITY) & $=$ & .1000 & $(\% / 100)$ \\
\hline PROPERTY TAX RATE (1ST YEAR) & $=$ & .0150 & $(\% / 100)$ \\
\hline INSURANCE RATE (1ST YEAR) & $=$ & .0150 & $(\% / 100)$ \\
\hline CHARGE FOR STANDEY POWER & $=$ & 69.0676 & $(\$ / K W)$ \\
\hline MAINTENANCE \& SUPPLIES COST FACTOR (1ST YR) & $=$ & .0375 & $(\% / 1.00)$ \\
\hline BOILER HEAT RATE (SEPARATE GENERATION) & $=$ & 3750.0000 & (ETU/KWH) \\
\hline CENTRAL STATION FIUS FAR HEAT RATE & $=$ & 9500.0000 & ( $\mathrm{BTU} / \mathrm{K} W H)$ \\
\hline TRANSMISSION LOSSES OF PURCHASED POWER & $=$ & .1000 & $(\% / 100)$. \\
\hline SPECIFIC CAPITAL. COST OF NEW UTILITY STATION & $v=$ & 1000.0000 & $(\$ / K W)$ \\
\hline PRICE OF PROCESS STEAM ( $1 S T$ YR) & $=$ & 5.4843 & $\left(\$ / 10^{\wedge} 6\right.$ ETU $)$ \\
\hline PRICE OF POWER AT CENTRAL STATION BUS BAR & $=$ & .01 .96 & $(\$ / K W H)$ \\
\hline PRICE OF POWER EOUGHT FROM UTILITY (IST YR) & $=$ & .0326 & $(\$ / K W H)$ \\
\hline PRICE OF POWER SOLD TO UTILITY (1ST YR) & $=$ & .0196 & $(\$ / K W H)$ \\
\hline PRICE OF FUEL (COGENERATION) & $=$ & 2.7415 & $\left(\$ / 10^{\wedge} 6\right.$ BTU $)$ \\
\hline PRICE OF FUEL, (SEP.GEN.: INDUSTRY) & $=$ & 2.9070 & $\left(\$ / 3.0^{\wedge} 6\right.$ ETU $)$ \\
\hline PRICE OF FUEL (SEP.GEN.: UTILITY ) & $=$ & 1.7894 & $\left(\$ / 10^{\wedge} G\right.$ ETU $)$ \\
\hline GENERAL INFLATION RATE: & $=$ & .0750 & $(\% / 100 / Y R)$ \\
\hline FUEL PRICE RELATIUE ESC. (COGENERATION FUEL) & $=$ & .0475 & $(\% / 100 / Y R)$ \\
\hline FUEL PRICE REL. ESC. (SEP.GEN. : INDUSTRY) & $=$ & .0468 & $(\% / 100 / Y R)$ \\
\hline FUEL PRICE REL. ESC. (SEP.GEN. : UTILITY) & $=$ & .0484 & $(\% / 100 / Y R)$ \\
\hline RELATIUE ESC. OF ELECTRICAL ENERGY COSTS & $=$ & .0360 & $(\% / 100 / Y R)$ \\
\hline RELATIUE ESC. OF PROCESS STEAM COSTS & $=$ & .0300 & $(\% / 100 / Y R)$ \\
\hline
\end{tabular}


INTEGRATED TEXTILE MILL

FOR INDUSTR IAL OWNERSHIP

INCKEMENTAL CAPITAL INUESTMENT

$=30550403(\$)$
$=\quad 5200068(\$)$

NET INCREMENTAL EQUITY CAPITAL INUESTMENT

\begin{tabular}{|c|c|}
\hline 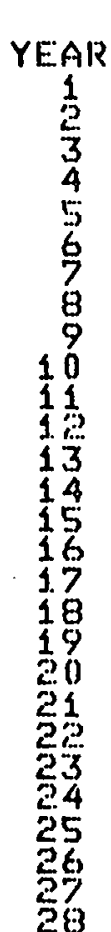 & 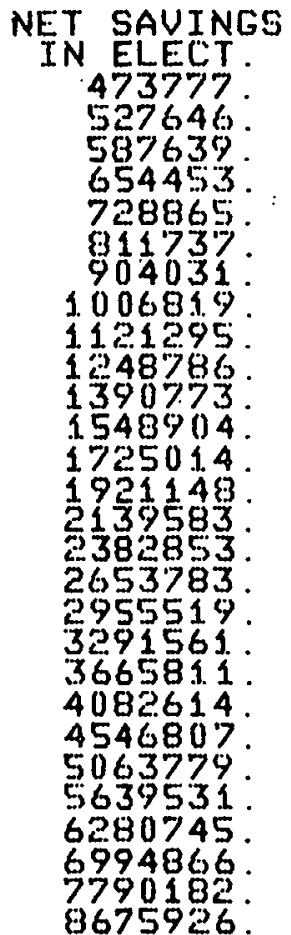 \\
\hline
\end{tabular}

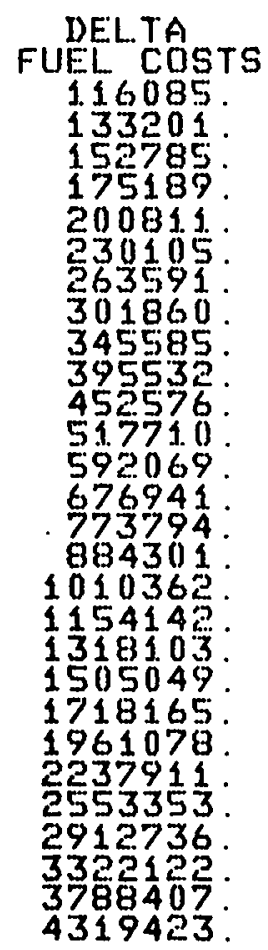

DE:LTA

0 AND M

1337065

1.437345

1545146

1661032

1785609 .

1919530

2063495

2218257 .

338462.

5563473

2755733

2962413.

3184594
3423439

3680196.

3956211.

45251896

4944789 .

5283398 .

5679652 .

6105626 .

6563548 .

7055814.

7585000

8153875
DE:LTA

PROP TAX

\& INSUR. 91651.2 985250 .

1059144 .

1138580 .

1223974 .

1315772 .

1. 414454 .

1520538 .

1634579

1757172.

5030632

2182930 .

2346649

2522648 .

2711846 .

2915235 .

3133877 .

3368918.

3621587.

3893206 .

4185196 .

4499086.

4836518 .

51.99256 .

5589201

6008390 .

6459020 .
TNCOME TAXES

ON SAUIINGS

$-3195169$.

-3220477 .

-3250 3207.

$-3323367$.

-3367667 .

$-3417533$

-3473335 .

$-3535474$

-3604377 .

-3764340 .

$-3856421$.

$-3957313$.

$-4067629$.

$-418802 \%$.

$-4319228$.

-4461999 .

$-4617180$.

$-4785682$

-...496849\%.

-51.66707 .

$-5381492$.

$-5614149$

-5866100 .

$-6138909$

$-6434314$.

-6754195 .

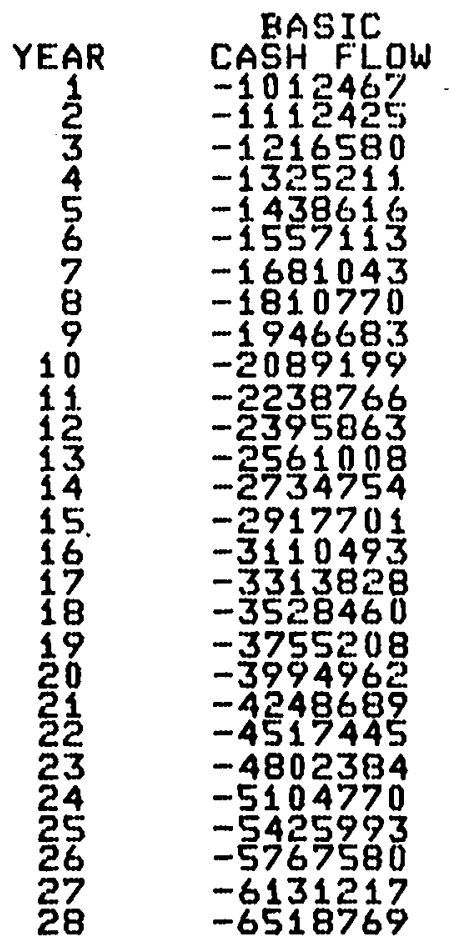

DISCOUNTED CASH FLOW RATE OF RETURN ON EQUITY(ROE) $=10 \%$

ANNUAL ENERGY SAUED UNDER COGENERATION $=297191.1406 \mathrm{MBTU} / \mathrm{YR} / \mathrm{C}-144$ 
INTEGRATED TEXTILE MILL

FOR UTILITY OWNERSHIP

INCREMENTAL CAPPTAL JNUESTMENT

$=\quad 20584909(\$)$
$=\quad 8822104(\$)$

NET INCREMENTAL EQUTTY CAPITAL. INUESTMENT

DELTA

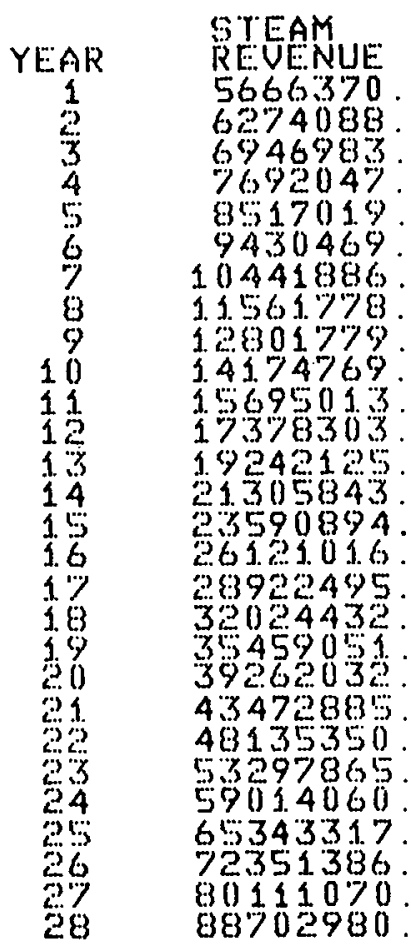

ELECT

RE:UENUE

2874343.

1869738 . 32.36168.

$2083327 . \quad 3643538$.

2319087 .

25832767

2876,428 .

3203478 .

3567713 .

3973362 .

442133

$49582 \% 1$.

5488615 .

$61126 \% 1$.

68076,81 .

7581715
844375

9403810

10473023 .

11663806

12989981.

14466941 .

16111933.

17943747 .

19983951.

22556126.

$24786,6,48$

276,04889

30743564
41. 021838

4648573

5199959

5854529 .

6591494

7421228.

8355407 .

9407179

10591342.

11924567 .

13425614 .

1515608 .

191.60565.

2572454

24087941.

57345244 .

30787386

34662810 .

39026055

43938522.

49469347 .

55696361 .

70607000
DELTA

918525.

987415

1061471 .

ij. 41081 .

1226662.

1318662 .

1417561 .

1. 523878 .

1638169 .

1761032.

1.893109

2035092.

2187724

5351803.

2528189

271.7803

2921638.

3140761

3376318

362554

3901.757.

$419438 \%$.

4508968

4837140 .

5210676 .

5601477 .

6021587.

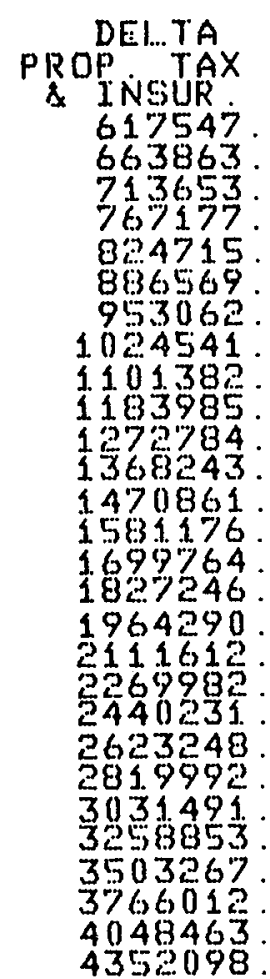

TAXESS 221071. 614358. 1080177. 1. 344599 1632618 1946372 2288167 2660492 3066018 $350761 \%$ $39883 \%$ 4511571 . 5080729
5699990. 6.372126 7102 (; 46. 7895291. 9686643 1. $0695 \% 32$.

11786071

14236355.

$156069 \% 3$ 17082079 18667231 .

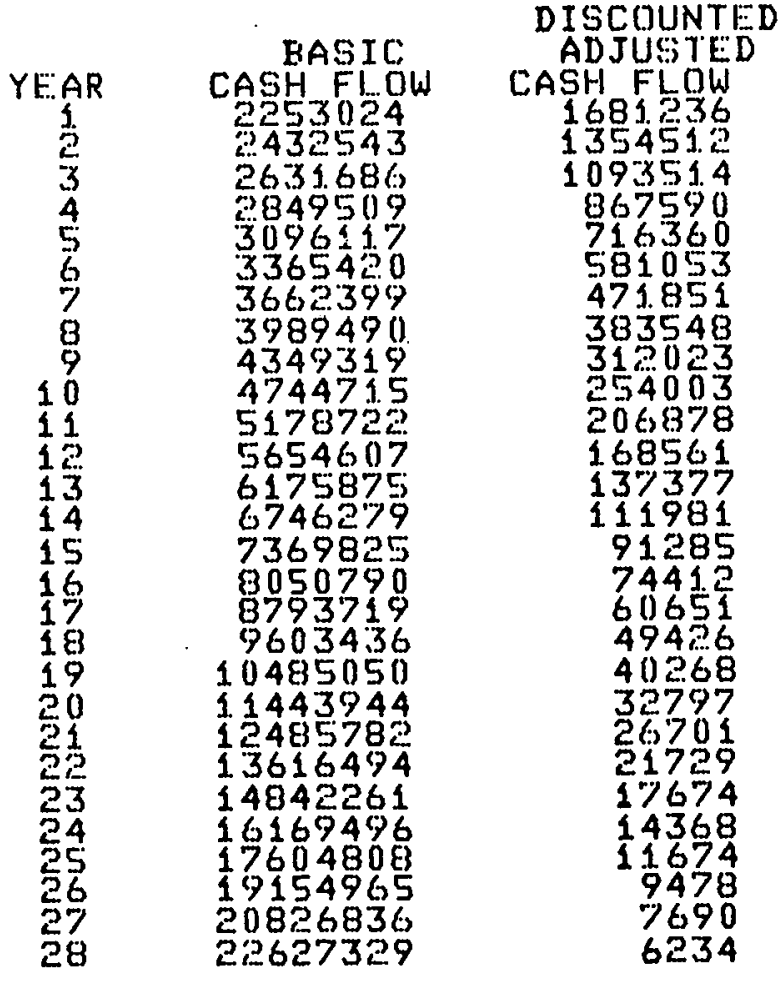

DISCOUNTED CASH FLOW RATE OF RETURN ON EQUITY(ROE) $=34.01 \%$ 
INTEGRATED TEXTILE MILL

FOR THIRD PARTY OWNERSHIP

CAP'T.TAL INUESTMENT

NIET EQUITY CAPITAL INUESTMENT

$=\quad 30550403(\$)$
$=\quad 4073387 \cdot(\$)$

DELTA

REVENUE:

473777
527646

567639

654453 .

728865

904031 .

1006819 .

1121295 .

1248786

1.548904 .

1725014 .

1.9211 .48 .

2139583

2382853

2653783

295551.9

3291561 .

3665813 .

4083261.4 .

4546807 .

$50637 \% 9$.

5639531 .

6280745 .

6994866.

7790182.

8675926.

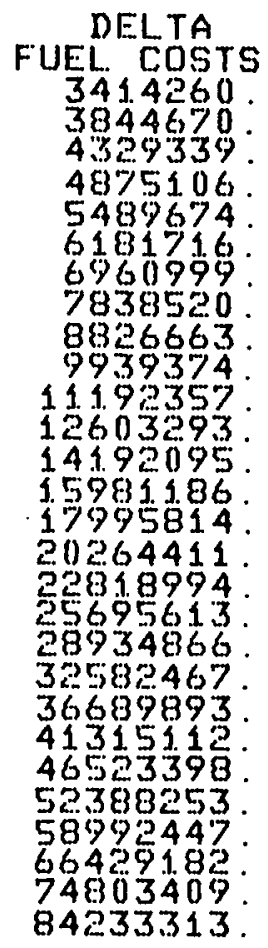

DELTA

1438822

1546734

$166273 \%$.

1787444 .

1924503.

2020536 .

5387076 .

2566107 .

2758565.

2965458 .

3187867.

3426957 :

3683979.

3960277
4257298

4576595 .

4919839 .

5288827.

$568548 \%$.

6191901 .

6570293

7592795 .

8162255.

9774424

1.0139943.
BASIC

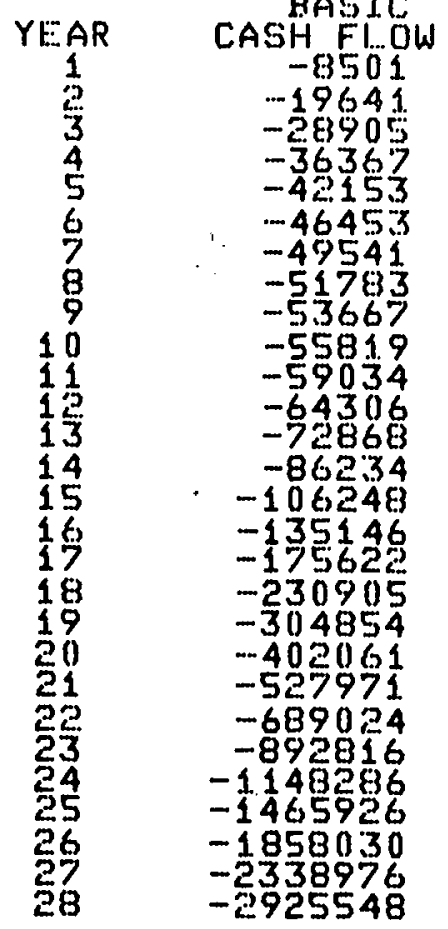

TAXE:S

PROP. TAX

\& INSUR

985350

1059144 .

1138580 .

1.223974.

1414454 .

j. 530538 .

1634579.

1888960.

2030632 .

$2182930^{\circ}$.

2346649

2522648 .

271.846 .

2915235.

3368918 .

3621587.

3893206.

4185196.

4499086.

4836518 .

5199256.

6008390 .

6459020 .
-2166813.

-2101348.

$-2033562$

-..1.9643.30

$-1892981$

$-1820311$

$-1746398$

$-1671620$

$-1596475$

$-1521604$

- 1447821

… 3376146 .

$-1.307841$

… 244456 .

-1187883

$-1140406$

-1104790 .

- - 1084341

$-1083012$

…1105:05

$-1157398$

-1245288
-1376966

-1561956 .

-1809837 .

- 2134391 .

- 549944

$-30736 \% 0$ 
TABLE C. 11-8

FUEL UTILIZATION - INTEGRATED TEXTILE MILL

Separate Generation

(MBtu/yr)

Natural Gas

011

Coal

Wood

Overa11
1134559

1471080

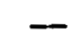

2605639
Cogeneration

(MBtu/yr)

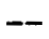

$-$

1063049

1245397

2308446
Savings (MBtu/yr)

1134559

408031

$-1245397$

297192

Percent Energy Savings $=11.4 \%$ 
Un _ J States

Department of Energy

Washington, DC 20585

Othicial Business

Penalty for Private Uso, $\$ 300$
Postage and Foes Paid

U.S. Department of Energy

DOE-360

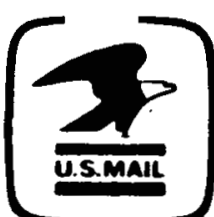

FIRST CLASS MAIL 